Marcos Gomes da Costa

N. ${ }^{\circ}$ USP 7124540

\title{
TUTELA DE URGÊNCIA \\ E Processo Arbitral
}

Dissertação apresentada à Banca Examinadora da Faculdade de Direito da Universidade de São Paulo como exigência parcial para obtenção do título de Mestre em Direito na área de concentração Direito Processual, sob a orientação do Prof. Dr. Paulo Henrique dos Santos Lucon

Faculdade de Direito da Universidade de São Paulo - USP

São Paulo - SP 
BANCA EXAMINADORA:

ORIENTADOR:

Prof. Dr. Paulo Henrique dos Santos Lucon 


\section{AGRADECIMENTOS}

Para a minha esposa Renata, meu amor, companheira inseparável, mãe de minhas filhas, minha inspiração diária, e que, certamente, foi quem possibilitou que esta dissertação fosse escrita, seja pelo constante incentivo, seja pela cobrança nas horas de preguiça, seja pela paciência nos momentos difíceis, seja pelos imprescindíveis passeios com as crianças nos finais de semana e feriados.

Para as minhas filhas Letícia e Fernanda, o amor que se tornou visível*, finalmente o papai terminou a sua "lição de casa".

Para os meus pais, Eduardo e Cleide, que me deram a vida, amor, educação e a tudo possibilitaram. Não há palavras para agradecê-los da maneira devida.

Para o meu orientador Paulo Lucon, por tudo o que me ensinou durante todo o processo de elaboração desta dissertação, pelo apoio irrestrito e, especialmente, pela confiança em mim depositada.

Para o Dr. Oswaldo Chade, exemplo de pessoa e de vida, com quem eu tenho o privilégio de conviver diariamente e com quem eu aprendo muito mais que Direito.

Para Oscar, Eliane, Reinaldo e Cleusa, algumas pessoas têm o infortúnio de não possuir pai e mãe, eu tenho o privilégio de ter três de cada.

Para todos os companheiros do escritório, pela amizade diária e pelo apoio para que esta dissertação pudesse ser finalizada.

E, finalmente, para os amigos Gláucia, Gustavo, João Paulo e Priscila, pelo tempo compartilhado na pós-graduação, pelo auxílio nos estudos e, sobretudo, pela amizade de sempre.

* Friedrich Novalis 


\section{ÍNDICE}

Capítulo I - Introdução 4

1. Apresentação e limitação do tema 4

2. Conceito de arbitragem e limites de sua utilização 8

Capítulo II - Retrospecto histórico da arbitragem 15

3. Breve histórico da arbitragem no mundo, sob a ótica da tutela de urgência 15

4. Histórico da arbitragem no Brasil, ainda sob a ótica da tutela de urgência 20

5. A Lei n. ${ }^{\circ}$ 9.307, de 23 de setembro de 199627

Capítulo III - Natureza jurídica da arbitragem e a sua importância na delimitação dos poderes do árbitro para conceder tutelas de urgência 31

6. Teoria publicista (ou processualista) 32

7. Teoria contratual (ou privatista) 34

8. Teoria mista (contratual-publicista) 35

9. Teoria autônoma 36

Capítulo IV - Jurisdição e os poderes jurisdicionais do árbitro 38

10. Flexibilização do conceito de jurisdição 38

11. Poderes jurisdicionais do árbitro 43

12. Relação entre o juízo arbitral e o juízo estatal 54

Capítulo V - Tutela de urgência na arbitragem $\quad 57$

13. Tutelas urgentes: breve histórico, distinção entre medida cautelar e $\begin{array}{ll}\text { tutela antecipada e sua aplicação para a arbitragem } & 57\end{array}$

14. Tempo e o processo: necessidade das tutelas de urgência 70

15. Cabimento das tutelas de urgência em arbitragem 77

Capítulo VI - Tutelas de urgência prévias à instituição da arbitragem 92

16. Cautelar prévia à instauração da arbitragem 102

16.1. Conexão, prevenção e competência 102

16.2. Requisitos da petição inicial 104

16.3. Prazo para a ação principal 106

16.4. O que ocorre com a medida cautelar deferida pelo juízo estatal e com os autos do processo após a instauração da arbitragem? 110

17. Procedimento pré-arbitral 117 
17.1. Necessidade de cognição da convenção de arbitragem

18. Tutela antecipada prévia à instauração da arbitragem

18.1. Prazo para a instituição da arbitragem

19. Revisão, pelo árbitro, das tutelas de urgência apreciadas pelo Judiciário

20. Medidas urgentes preparatórias em sede de arbitragem

Capítulo VII - Tutelas de urgência incidentais

21. Cautelar incidental

22. Pedido de antecipação de tutela incidental

Capítulo VIII - Concessão de tutela de urgência de ofício pelo árbitro

23. Impugnação da decisão do árbitro

24. Caução

25. Responsabilidade do beneficiário da medida e do árbitro

Capítulo X - Tutelas de urgência no processo arbitral e terceiros

Capítulo XI - Cumprimento das tutelas de urgência deferidas pelo árbitro

26. Nas arbitragens nacionais

27. Em arbitragens estrangeiras

Capítulo XII - Ação para suspender o processo arbitral ou estatal: Anti-suit injunction

Capítulo XIII - Conclusões

Capítulo XIV - Bibliografia

28. Resumo

29. Abstract 


\section{CAPÍTULO I \\ INTRODUCÃ̃O}

\section{APRESENTAČ̃̃o E LIMITAÇ̃̃o DO TEMA}

\section{A arbitragem é uma forma de resolução de conflitos em pleno} crescimento no Brasil ${ }^{1}$, tendo em vista que: (i) superou a desconfiança inicial das partes e dos operadores do Direito; (ii) teve a sua constitucionalidade reconhecida pelo Supremo Tribunal Federal ${ }^{2}$; e (iii) torna-se cada vez mais utilizada e abrangente, notadamente diante da morosidade e da falta de especificidade do Poder Judiciário ${ }^{3}$.

\footnotetext{
${ }^{1}$ MARCELO Muriel diz que "os dados disponíveis no website da CCI indicam um aumento significativo do número de procedimentos arbitrais instaurados por ou contra partes brasileiras. Como não poderia deixar de ser, o judiciário brasileiro também tem dado mostras de que está atento a esse movimento, e não tem se furtado a dar sua parcela de contribuição." (“A Arbitragem frente ao Judiciário Brasileiro". Revista Brasileira de Arbitragem, v. 1. São Paulo: IOB/CBAr, jan/mar de 2004, pp. 27/39). E mais: relatório conjunto da FGVCBAr aponta que, "de acordo com as estatísticas divulgadas pela CCI sobre o número de partes brasileiras em processos administrados por este órgão, o Brasil passou de 3 partes em 1996, ano de promulgação da lei de arbitragem, para 67 partes em 2006. Isso fez com que o Brasil se tornasse o $4^{\circ}$ país do mundo com mais partes envolvidas na CCI e o primeiro da América Latina. Em 2007, embora não ocupe mais o $4^{\circ}$ lugar, o país manteve um patamar elevado: 35 partes em novos casos, o que equivale ao $11^{\circ}$ lugar." (www.cbar.org.br /PDF/Relatorio_final_pesquisa_GV_CBAR.pdf. Acessado em 07/06/2012).

${ }^{2}$ Supremo Tribunal Federal, Pleno, Agravo Regimental em Sentença Estrangeira n. ${ }^{\circ}$ 5.206-7, j. 12/12/2001. Disponível em www.stf.jus.br. Acessado em 07/06/2012. Nesse sentido, FERNANDO DA FONSECA GAJARDONI aduz que "o Supremo Tribunal Federal, em sessão plenária do dia 12/12/2001, concluindo o julgamento do Agravo Regimental da Homologação de Sentença Estrangeira (Espanha) n 5.206, decidiu, por maioria de votos, pela constitucionalidade de todos os dispositivos da Lei de Arbitragem. Entendeu-se que a manifestação de vontade da parte na cláusula compromissória, quando da celebração do contrato, aliada à autorização legal dada ao juiz para que substitua a vontade da parte recalcitrante em firmar o compromisso, não ofende o artigo $5^{\circ}, \mathrm{XXXV}$, da Constituição Federal. Afinal, o preceito constitucional impede que se exclua, não que as partes livremente renunciem à jurisdição estatal, permitindo a apreciação extrajudicial da questão litigiosa. Portanto, não resta dúvida sobre a validade e eficácia plena de todos os dispositivos da Lei ${ }^{\circ}$ 9.307/96, sendo insustentável tese em contrário." "“A arbitragem nos tribunais estatais: 10 anos de jurisprudência". Revista do Advogado - Arbitragem e Mediação, ano XXVI, n. ${ }^{\circ}$ 87. São Paulo: AASP, setembro de 2006, pp. 52/60, p. 53). Aliás, a discussão acerca da constitucionalidade da arbitragem não é nova. Ao comentar esse tema, ainda sob a égide da Constituição anterior, WALDEMAR MARIZ DE OLIVEIRA JÚNIOR já defendia que "nem, tampouco, é correto dizer-se que o preceito do art. $153, \S 4^{\circ}$, da CF vedou a arbitragem no território nacional. A circunstância de a lei não poder excluir da apreciação do Poder Judiciário qualquer lesão de direito individual, não significa, em absoluto, que os litigantes, se assim o desejarem, portanto facultativa e optativamente, não poderão se utilizar da via jurisdicional, preferindo valer-se do juízo arbitral. O que a Lei Maior não permite, como, de resto, todas as Constituições anteriores, é que a lei, de forma imperativa, coercitiva, proíba o acesso ao Poder Judiciário. Se a lei processual, por exemplo, estabelecesse a obrigatoriedade da arbitragem para certos e determinados casos, aí, sim, o princípio constitucional teria sido ferido. Por isso mesmo é que o instituto, no Brasil, é simplesmente facultativo, exatamente porque, no instituto, prevalece a autonomia da vontade, de modo absoluto." (Participação e processo. GRINOVER, Ada Pellegrini; DINAMARCO, Cândido Rangel; WATANABE, Kazuo (coord.). São Paulo: RT, 1988, p. 313). Verifica-se que esse entendimento permanece aplicável e válido até os dias de hoje.

${ }^{3}$ CARLOS ALBERTO CARMONA anota que "escolhas políticas têm levado o legislador, de tempos em tempos, a voltar o olhar para soluções extrajudiciais de controvérsias. A crise do processo e a crise do Poder Judiciário - crises que vêm se agravando desde os anos 60 - são motor importante de propulsão das escolhas extrajudiciais de solução de litígios, ninguém duvida." (in YOSHIKAWA, Eduardo Henrique de Oliveira.
} 
O próprio Poder Judiciário brasileiro tem acompanhado a

evolução da arbitragem no Brasil, proferindo um grande número de decisões que refletem bom conhecimento sobre a matéria e que privilegiam as decisões arbitrais ${ }^{4}$.

Nessa esteira, é válida a citação de acórdão prolatado pelo Tribunal de Justiça de São Paulo, o qual enfatiza a importância de outros meios de solução de conflitos, tais como a arbitragem, garantindo a sua aplicação em casos concretos:

Execução Extrajudicial e Devido Processo Legal. São Paulo: Atlas, 2010, prefácio, p. xi). JOSÉ ROBERTO DOS SANTOS BEDAQUE também ressalta "a notória crise da justiça", dizendo que "a descrença no Poder Judiciário decorre fundamentalmente da má prestação do serviço a que ele se propõe" e que as circunstâncias que colaboram para esse estado de coisas são, dentre outras, "a insuficiência de juízes e funcionários do Poder Judiciário, a má distribuição da competência, a falta de estrutura adequada dos órgãos jurisdicionais." ("Estabilização das tutelas de urgência" in Estudos em homenagem a Ada Pellegrini Grinover. YARSHELL, Flávio Luiz; MORAES, Maurício Zanoide de (org.), São Paulo: DPJ, 2005, pp. 660/683, esp. pp. 676/677), o que também contribui para o crescimento de outros meios de solução de controvérsias, tais como a arbitragem. Há um julgado do Extinto 2. ${ }^{\circ}$ Tribunal de Alçada Civil de São Paulo que também destaca a relevância da arbitragem como alternativa à morosidade judicial: "A lei de arbitragem veio para subtrair do Poder Judiciário a apreciação destas reivindicações, mormente a considerar que o Judiciário brasileiro, como é cediço e de notório conhecimento, encontra-se soterrado, abarrotado, por pilhas e pilhas de demandas a serem resolvidas, o que certamente, motivou a instituição pelo legislador da Lei de Arbitragem, com o fim precípuo de simultaneamente, desafogar o Judiciário e oferecer uma alternativa ao jurisdicionado na solução de conflitos patrimoniais privados, observado o princípio da inafastabilidade da jurisdição estatal." (7. ${ }^{a}$ Câmara do Quarto Grupo, A.I. n. ${ }^{\circ}$ 0036712-87.2003.8.26.0000 - números anteriores 818.499/0-00 e 992.03.036712-2, Rel. Juiz Américo Angélico, j. 18/11/2003, maioria).

${ }^{4}$ Nesse sentido, acórdão do Ex-2. ${ }^{\circ}$ TACivSP: “A morosidade que assola o Poder Judiciário, impõe a aplicação, sempre que legal e constitucional, de vias alternativas, colimando a celeridade e praticidade às partes em conflito. A adoção do regramento das disposições do instituto da arbitragem, regidos pela lei 9.307/96, não agride os princípios constitucionais da inafastabilidade jurisdicional, tampouco do juiz natural, sua sentença (arbitral) produz, entre as partes e seus sucessores, os mesmos efeitos do 'decisum' prolatado pelo Judiciário e, sendo condenatório, é título executivo judicial. Em se tratando de direito disponível, e convencionado pelas partes quanto à forma de instituir a arbitragem, com a cláusula compromissória cheia, submeteram-se, assim, às normas do órgão ou entidade livremente escolhida. $O$ juízo arbitral não ofende o artigo $5^{\circ}$, inciso XXXV, da Constituição Federal, o que se exclui pela arbitragem (lei 9.307/96) é o acesso a via judicial, mas não à jurisdição. A solução do litígio, dar-se-á pela justiça arbitral e, não pela justiça comum. Nas duas, terse-á presente o exercício da atividade jurisdicional." (7. . Câmara do Quarto Grupo, Agravo n. ${ }^{\circ}$ 003671287.2003.8.26.0000 (n. ${ }^{\text {os }}$ anteriores 818.499/0 e 992.03.036712-2), Rel. Juiz Américo Angélico, j. 18/11/2003, maioria). SELMA M. FERREIRA LEMES salienta que a participação do Poder Judiciário tem sido decisiva para a consolidação da arbitragem, tanto por meio de decisões judiciais que confirmam a importância e a validade da arbitragem, tanto pela elaboração de estudos sobre o tema por parte de magistrados ("A arbitragem e a jurisprudência paulista" in Dez anos da lei de arbitragem - aspectos atuais e perspectivas para o instituto. Rio de Janeiro: Lumen Juris, 2007, pp. 171/182, p. 182). HAROLDO MALHEIROS DUClERC VERÇOSA também destacou a valorização da arbitragem pelo Judiciário no texto: "O Judiciário e a valorização da arbitragem" (www.migalhas.com.br/dePeso/16,MI160682,71043-O+Judiciario+e+a+valorizacao+da+arbitragem. Acesso em 01/08/2012). A importância da cooperação do Judiciário para o crescimento da arbitragem foi percebida também na França, tendo BRUNO OPPETIT enfatizado que "quanto aos juízes, muito têm contribuído para o sucesso da justiça arbitral, mantendo fiel colaboração, graças à assistência nunca recusada e ao espírito liberal que os inspira durante o controle das sentenças." (in Etudes offertes à Pierre Bellet. Paris: Litec, 1991, pp. 415/425, tradução de Clávio de Melo Valença Filho e Bruno Lemos. "Justiça Estatal e Justiça Arbitral". Revista Brasileira de Arbitragem, n. ${ }^{\circ}$ 25. São Paulo: IOB/CBAr, jan/mar de 2010, pp. 184/195, p. 191). 
"Em vista dos céleres avanços da vida em sociedade, e do agigantado aumento dos litígios entre as pessoas, não se pode furtar ao reconhecimento de que a administração da Justiça pelo Estado-Juiz tem revelado, além da morosidade que assola o Poder Judiciário, a alarmante dificuldade de se dar uma resposta adequada às necessidades que reclamam uma pronta solução de conflitos. Assim, à luz do inegável congestionamento da Justiça, imperioso se abdique das soluções tradicionais, na busca de novas fórmulas e novos caminhos tendentes à pacificação social, alvitrando a celeridade e praticidade aos litigantes. Daí avulta em importância, entre nós, o instituto da arbitragem, que deve ser sempre incentivado, desde que, é certo, não implique denegação de Justiça" .

Ainda a corroborar o indispensável e bom acolhimento do instituto da arbitragem pelo Poder Judiciário, cita-se a pesquisa feita pela Escola de Direito de São Paulo da Fundação Getúlio Vargas em conjunto com o Comitê Brasileiro de Arbitragem - CBAr, a qual apurou que, desde o início da vigência da Lei n. o 9.307/96 ("Lei de Arbitragem brasileira”, em vigor desde 23/11/1996) até o mês de fevereiro de 2008, somente trinta e três ações judiciais foram ajuizadas visando especificamente à invalidação da sentença arbitral pelo Poder Judiciário, tendo apenas quatorze delas sido acolhidas, com a anulação da decisão arbitral (de forma tecnicamente correta, segundo o estudo) ${ }^{6}$.

E, embora a arbitragem seja um meio de solução de conflitos notoriamente célere, em determinados casos, que envolvam relações jurídicas mais sensíveis ou situações de urgência, pode ser necessária a adoção de tutelas de urgência antes mesmo da instituição da arbitragem $^{7}$, ou após a sua instauração, para que seja

\footnotetext{
${ }^{5}$ TJ/SP, 31. ${ }^{a}$ Câm. Dir. Privado, Ap. c/ rev. n. ${ }^{\circ}$ 0083532-64.2009.8.26.0224, Rel. Des. Adilson de Araújo, j. 29/03/2011, v.u.. No mesmo sentido: TJ/SP, 5. ${ }^{a}$ Câm. Dir. Privado, A.I. n. ${ }^{\circ}$ 124.217-4, Rel. Des. Rodrigues de Carvalho, j. 16/09/1999, v.u.; TJ/SP, 35. ${ }^{a}$ Câm. Dir. Privado, A.I. n. ${ }^{o}$ 0293432-12.2011.8.26.0000, Rel. Des. Manoel Justino Bezerra Filho, j. 13/02/2012, v.u.; TJ/SP, 25. ${ }^{a}$ Câm. Dir. Privado, Apelação no $9060328-$ 93.2007.8.26.0000, Rel. Des. Vanderci Álvares, j. 23/11/2011, v.u.; TJ/GO, 4. ${ }^{a}$ Câm. Cível, Ap. Cível, n. ${ }^{\circ}$ 96.922-4/188, Rel. Des. Stenka I. Neto, j. 18/05/2006.

${ }^{6} \mathrm{http} / / / \mathrm{www}$. cbar.org.br/PDF/Pesquisa_GV-CBAr_relatorio_final_1_etapa_2fase_24.06.09.pdf. Acesso em 07/06/2012. Sobre o assunto, Modesto CARVAlHosA, citando estudo do World Justice Project (WJP), entidade que analisou o grau de segurança jurídica de 66 países quanto à arbitragem, confirma que o Brasil é o segundo colocado na América Latina, perdendo apenas para o Chile, bem como que, entre os BRIC, o levantamento apontou o Brasil como o primeiro (reportagem intitulada de "Judiciário incentiva a arbitragem", publicada no jornal "Valor Econômico", caderno "Legislação e Tributos", de 29/11/2011).

7 Nos termos do artigo 19 da Lei de Arbitragem brasileira, "considera-se instituída a arbitragem quando aceita a nomeação pelo árbitro, se for único, ou por todos, se forem vários". CARLOS AlBERTO CARMONA leciona que, desde 1973, "com a edição do novo Código de Processo Civil, que a matéria recebeu tratamento adequado. Neste diploma, o art. 1.085 (hoje revogado pela Lei de Arbitragem) dispunha que se considerava instituído o juízo arbitral 'tanto que aceita a nomeação pelo árbitro, quando apenas um, ou por todos, se forem vários'. A redação, melhorada, foi reproduzida pelo art. 19 da Lei, de forma que se pode hoje dizer, com tranquilidade, que só haverá litispendência (lide pendente) após a constituição do tribunal arbitral, o que
} 
resguardada a efetividade da tutela jurisdicional pleiteada no processo arbitral ou, ainda, para que seja garantido o próprio bem da vida nele discutido.

Surge, então, a necessidade de se pleitear, de se apreciar e de se efetivar tutelas de urgência em um processo arbitral (ou antes mesmo de sua instituição), ponto principal do trabalho.

Destarte, o tema deste trabalho se limitará às questões concernentes às tutelas de urgência antes e durante o processo arbitral (incluindo-se a forma como podem ser pleiteadas, apreciadas e efetivadas), bem como à interação entre os árbitros, o Poder Judiciário e também entre a Câmara de Arbitragem responsável pela condução do processo arbitral (no caso de arbitragem institucional).

Nessa esteira, o estudo seguirá as linhas basilares do Direito Processual Civil relativas aos pressupostos para a concessão de tutelas de urgência, por meio da análise dos requisitos processuais específicos no âmbito de uma arbitragem.

Para o desenvolvimento do trabalho, será feita uma breve análise histórica sobre a arbitragem, bem como acerca de sua natureza jurídica, com um enfoque específico às tutelas de urgência.

Igualmente, serão analisados os regulamentos dos principais centros de arbitragens pátrios e alienígenas, bem como a legislação nacional e estrangeira sobre o tema das tutelas de urgência em arbitragem.

Ainda nesse diapasão, como a Lei de Arbitragem brasileira autoriza que as partes escolham a lei material e também a lei processual que deverá reger uma determinada arbitragem $^{8}$, este trabalho considera a hipótese de serem aplicáveis subsidiariamente ao processo arbitral as regras do ordenamento jurídico pátrio 9

ocorrerá tão logo o árbitro único (ou o último dos árbitros do colégio) aceitar a indicação." (in Arbitragem e Processo: Um Comentário à Lei no 9.307/96, 3. a edição. São Paulo: Atlas, 2009, p. 278).

${ }^{8}$ Conforme o art. 21 da Lei n. ${ }^{\circ} 9.307 / 96:$ "a arbitragem obedecerá ao procedimento estabelecido pelas partes na convenção de arbitragem, que poderá reportar-se às regras de um órgão arbitral institucional ou entidade especializada, facultando-se, ainda, às partes delegar ao próprio árbitro, ou ao tribunal arbitral, regular o 
Essa será, portanto, a limitação do presente trabalho, que estudará as tutelas de urgência na arbitragem e os fenômenos processuais delas decorrentes, à luz da realidade dessa forma autônoma de solução de controvérsias, especialmente no que tange (i) às tutelas de urgência prévias à instauração da arbitragem (quando as partes já se comprometeram, por meio de cláusula compromissória ${ }^{10}$ ou de compromisso arbitral, a solucionar eventual lide por meio da arbitragem); (ii) às tutelas de urgência no curso de um processo arbitral; (iii) à efetivação das tutelas de urgência, a qual exige a utilização de força ("imperium" ou "poder de constrição"") e, por conseguinte, depende do auxílio e de interação com o Poder Judiciário ${ }^{12}$; (iv) à efetivação das tutelas de urgência proferidas em arbitragens estrangeiras; e (v) às anti-suit injunctions.

\section{CONCEITO DE ARBITRAGEM E LIMITES DE SUA UTILIZAĊ̃̃O}

A arbitragem pode ser conceituada como uma forma alternativa de resolução de $\operatorname{conflitos}^{13}$ que versem sobre direitos disponíveis, por meio da intervenção de terceiro, ou mesmo de terceiros, que são incumbidos nessa função de julgador em decorrência de convenção firmada pelas próprias partes com autonomia privada.

procedimento". Sobre o tema, ver: GARCEZ, José Maria Rossani. "Escolha da Lei Substantiva da Arbitragem". Revista de Arbitragem e Mediação, ano II, n. 4. São Paulo: RT, jan/mar de 2005, pp. 49/61.

${ }^{9}$ ALEXANDRE FREITAS CÂMARA esclarece que a lei regula apenas um procedimento a ser observado supletivamente, tendo em vista que, na arbitragem, a regra é que as partes fixem o procedimento a ser seguido na própria convenção arbitral. Acrescenta que "no caso da 'arbitragem institucional' as partes acabarão por observar um procedimento previamente estabelecido pela entidade arbitral a que voluntariamente se submetem", concluindo que "a preocupação do legislador ao regulamentar o procedimento arbitral foi, portanto, essencialmente supletiva.” (Arbitragem - Lei n. o 9.307/96, 5. a edição. R.J.: Lumen Juris, 2009, pp. 75/76).

10 “Art. $4 .^{\circ}$ A cláusula compromissória é a convenção através da qual as partes em um contrato comprometem-se a submeter à arbitragem os litígios que possam vir a surgir, relativamente a tal contrato".

${ }^{11}$ Cf. LEMES, Selma M. Ferreira. "A inteligência do art. 19 da Lei de Arbitragem (instituição da arbitragem) e as medidas cautelares preparatórias". Revista de Direito Bancário, do Mercado de Capitais e da Arbitragem, ano 6, n. ${ }^{\circ}$ 20. WALD, Arnoldo (coord.). São Paulo: RT, abril/junho de 2003, pp. 411/423, p. 418.

${ }^{12}$ Cf. GUERRERO, Luis Fernando. "Tutela de Urgência e Arbitragem" in Revista Brasileira de Arbitragem, n. ${ }^{\circ}$ 24. São Paulo: IOB/CBAr, out/nov/dez de 2009, pp. 22/44, p. 23.

${ }^{13}$ Nos E.U.A., na Inglaterra, no Canadá, na Austrália, dentre outros, a arbitragem é conhecida como uma $A D R$ ou alternative dispute resolution (trad. livre: resolução alternativa de disputa). Os outros dois principais meios alternativos de resolução de conflitos são a mediação e a conciliação. Nessa esteira, NEIL ANDREWS ensina que "the three main alternatives to civil litigation before the English courts are: (i) party-to-party negotiation leading to the settlement: this is the most common way in which a dispute or claim is terminated; (ii) mediation; (iii) arbitration." (trad. livre: "as três principais alternativas ao litígio civil perante às cortes Inglesas são: (i) negociação de parte-a-parte levando ao acordo: esse é o modo mais comum de se encerrar uma disputa ou demanda; (ii) mediação; (iii) arbitragem.”) (“Arbitration and mediation in England". Revista de Processo - RePro, ano 34, n. “ 175. São Paulo: RT, set. de 2009, pp. 107/129, p. 109). ADA PELLEGRINI GRINOVER também afirma que, "dentre as diversas formas alternativas de solução de conflitos, destacam-se a conciliação, a mediação e a arbitragem." ("Parecer - Arbitragem: ação anulatória e embargos do devedor". Revista Brasileira de Arbitragem, n. ${ }^{\circ}$ 18. São Paulo: IOB/CBAr, abr/jun de 2008, pp. 154/181, p. 157). 
Interpretando-se a Lei n. ${ }^{\circ}$ 9.307/96 em seu conjunto, a arbitragem pode ser definida, ainda, como um meio alternativo de solução de litígios civis ou comerciais, atuais ou futuros, sobre direitos patrimoniais disponíveis, por meio de árbitro ou árbitros privados, escolhidos pelas partes, cujas decisões produzem os mesmos efeitos jurídicos produzidos pelas sentenças proferidas pelos órgãos do Poder Judiciário ${ }^{14}$.

Chama-se de "forma alternativa", pois a jurisdição estatal, através do Poder Judiciário, é tida como o meio comum e ordinário de se solucionar um litígio em nosso país nos dias atuais ${ }^{15}$, embora alguns doutrinadores critiquem o termo “alternativo", tal como, por exemplo, CARLOS Alberto CARMONA ${ }^{16}$.

Nos termos do artigo $1 .^{\circ}$ da Lei de Arbitragem brasileira ${ }^{17}$, somente as pessoas capazes de $\operatorname{contratar}^{18}$ podem se valer da arbitragem e apenas para solucionar conflitos relacionados a direitos patrimoniais disponíveis.

\footnotetext{
${ }^{14}$ Um conceito bastante sintético de arbitragem é o do jurista francês MATTHIEU DE BOISSESÓN: "arbitragem é a instituição pela qual as partes confiam aos árbitros, livremente designados, a missão de resolver seus litígios." (in Droit francais de l'arbitrage: interne et international. Paris: GLN Joly, 1990, tradução livre).

${ }^{15}$ O Ministro GILMAR MENDES, em reportagem do jornal "Valor Econômico" de 29/11/2011, intitulada de "Judiciário incentiva a arbitragem", afirma que é necessária uma reforma na índole cultural brasileira e na mentalidade de juízes que tendem a achar que tudo deve ser resolvido na Justiça, enfatizando que "isso é um cacoete profissional que tende a ser vencido. É importante trabalharmos com meios alternativos". SÉRGIO CRUZ ARENHART também classifica a arbitragem como "forma alternativa de resolução dos conflitos, colocada ao lado da jurisdição tradicional." (in Breves observações sobre o procedimento arbitral. http://jus. com.br/revista/texto/7161/breves-observacoes-sobre-o-procedimento-arbitral. Acessado em 09/06/2012).

${ }^{16}$ CARLOS AlBERTO CARMONA conceitua a arbitragem como "uma técnica para a solução de controvérsias através da intervenção de uma ou mais pessoas que recebem seus poderes de uma convenção privada, decidindo com base nesta convenção sem intervenção do Estado, sendo a decisão destinada a assumir eficácia de sentença judicial." (Arbitragem e Processo..., p. 15). Em reportagem do jornal Valor Econômico de 29/11/2011, CARMONA afirma que a arbitragem não pode ser classificada como um meio alternativo, mas como a forma mais adequada para a resolução de conflitos societários, pois "o Judiciário não está preparado para julgar essas questões. Os juízes têm que resolver problemas que afetam a sociedade", sendo os árbitros mais especializados para decidir com propriedade esses tipos de conflito. Nessa linha, NEIL ANDREWS aduz que "o avanço das ADRs significa que o processo civil perante as cortes estão se tornando um sistema de último recurso, a ser perseguido somente quando as técnicas mais civilizadas e proporcionais de conciliação ou mediação tiverem falhado (...)" (Arbitration and mediation in England..., p. 108, tradução livre).

17 "Art. $1 .^{\circ}$ As pessoas capazes de contratar poderão valer-se da arbitragem para dirimir litígios relativos a direitos patrimoniais disponíveis".

${ }^{18}$ A capacidade civil está regulada nos arts. 1 a 10 do Código Civil. O art. 851 do CC reforça a necessidade da capacidade de contratar ao estatuir que "é admitido compromisso, judicial ou extrajudicial, para resolver litígios entre pessoas que podem contratar". Na argentina, somente as pessoas capazes de transacionar podem se valer da arbitragem, nos termos do artigo 738 do Código de Processo Civil e Comercial da Nação: "Capacidad - Art. 738. - Las personas que no pueden transigir no podrán comprometer en árbitros. Cuando la ley exija autorización judicial para realizar actos de disposición, también aquélla será necesaria para celebrar el compromiso. Otorgada la autorización, no se requerirá la aprobación judicial del laudo." (trad. livre: "Capacidade - Art. 738. - As pessoas que não podem transigir não poderão se submeter aos árbitros. Quando a lei exige autorização judicial para realizar atos de disposição, também aquela será necessária para celebrar o compromisso. Outorgada a autorização, não se exigirá a aprovação judicial do laudo.”).
} 
Diante disso, conflitos envolvendo questões outras que não patrimoniais $^{19}$, tais como questões de estado, de direito de família etc. não podem ser objeto de um processo arbitral ${ }^{20}$.

Por ser menos burocrática e mais célere que a justiça comum, bem como por possibilitar que as partes nomeiem experts para a solução de eventuais litígios, a arbitragem tende a ser muito utilizada para a solução de conflitos envolvendo questões comerciais de grande monta ${ }^{21}$ ou de disputas comerciais internacionais ${ }^{22}$. ${ }^{19}$ A justiça trabalhista não admite o uso da arbitragem para solucionar questões individuais de trabalho, sob o
argumento de que o Direito do Trabalho é composto de preceitos de ordem pública e dispositivos de ordem
cogente, que regulam direitos indisponíveis e, principalmente, em virtude do mau uso do instituto feito por
empregadores de má-fé, conforme os seguintes acórdãos: TRT-2. ${ }^{a}$ Região, Acórdão n. 20121027524 , Juiz
Relator Luiz Carlos Gomes Godói; Acórdão 20121017154, Juíza Relatora Mercia Tomazinho; Acórdão
20121004974 , Juíza Relatora Cândida Alves Leão; Acórdão 20121004257, Juíza Relatora Sônia Maria
Forster do Amaral; Acórdão 20120924204, Juiz Relator Sergio J. B. Junqueira Machado. O Tribunal
Superior do Trabalho também já se posicionou no sentido de que "a arbitragem não se compatibiliza com o
direito individual do trabalho, sendo possível sua adoção apenas para os conflitos coletivos.” (TST, 6. ${ }^{a}$ T.,
AIRR-227800-66.2006.5.02.0086, Rel. Min. Aloysio Corrêa da Veiga, j. 29/08/2012). No mesmo sentido: TST, RR-104100-20.2007.5.02.0021; E-RR-282000-61.2001.5.02.0033; E-ED-RR-79500-61.2006.5.05. 0028; RR-556-10.2010.5.09.0411; RR-217400-10.2007.5.02.0069; AIRR-259700-12.2009.5.09.0654; RR13100-51.2005.5.20.0006; RR-106500-58.2008.5.15.0005; RR-189900-66.2007.5.02.0263 e RR-11760008.2004.5.04.0732. Contudo, "em uma decisão ainda rara no Judiciário, a 76a Vara do Trabalho de São Paulo reconheceu a validade de uma cláusula arbitral presente em um contrato trabalhista entre um alto executivo do mercado de capitais e o BTG Pactual. (...) Nesse caso, o juiz Hélcio Luiz Adorno Júnior considerou que o documento foi firmado por um alto executivo de 'notável formação acadêmica' e 'expressivos vencimentos'. (...) Para a advogada Selma Lemes, especialista em arbitragem, a decisão é interessante porque o juiz aceita essa forma de resolução de conflitos considerando que não há um desequilíbrio entre as partes na relação de trabalho. 'No caso dos altos executivos fica claro que, por conta de toda a sua qualificação, há um alto nível de discernimento para negociar esses contratos e optar ou não pelos termos e condições estabelecidas'. No entanto, segundo ela, o Tribunal Superior do Trabalho ainda é resistente a esse entendimento, mesmo quando se trata de executivos." (matéria intitulada "Justiça aceita arbitragem em discussão trabalhista", publicada no jornal "Valor Econômico", caderno "Legislação e Tributos", de 15/02/2012).

${ }^{20} \mathrm{O}$ artigo 852 do CC reforça essa restrição, estatuindo que "é vedado compromisso para solução de questões de estado, de direito pessoal de família e de outras que não tenham caráter estritamente patrimonial".

${ }^{21}$ Acórdão do TJ/SP ressalta que as complexas e vultosas questões comerciais tendem a ser decididas por meio da arbitragem: "A morosidade que as normas processuais imprimem ao andamento dos processos, arrastando-os, seja pelo excesso de recursos, seja pelos permissivos legais tendentes a impedir cerceamento de defesa, retiraram, praticamente, do Poder Judiciário no âmbito empresarial, as grandes questões, que pela natureza do objeto em jogo exigem decisões céleres e imediatas. O mundo moderno, como se sabe, está cada vez mais ágil, mais comunicativo, com variação de câmbio, que não permite soluções demoradas aos conflitos de interesse. (...) Quanto às grandes causas, assim entendidas as de elevado valor, das empresas geralmente de porte, a globalização, que relativiza a soberania, pois que a lex mercatoria, trazendo um novo sentido de comunidade, rompendo com as fronteiras dos países, promoveu, como forma de solução aos litígios, a primeiro nível, a convenção de arbitragem." (TJ/SP, 5. ${ }^{a}$ Câmara de Direito Privado, A.I. n. ${ }^{\circ}$ 124.217-4/0, Rel. Des. Rodrigues de Carvalho, j. 16/09/1999, v.u.).

${ }^{22}$ PIERO BERNARDINI destaca que "o sucesso da arbitragem, notadamente no campo de transações transnacionais, é devido em grande parte ao fato de que ela constitui (...) um método eficiente de resolução de disputas comerciais. (...) Uma área que é suscetível de ser uma referência para arbitragens internacionais como um método eficiente de composição de disputas comerciais é aquela das medidas conservativas e provisórias. De fato, a crescente aceleração da vida econômica exige a proteção dos interesses legais e econômicos em tão curto espaço de tempo, mesmo que apenas provisoriamente, que a justiça arbitral pode ser vista como ideal para lidar com esse tipo de problema." (BERNARDINI, Piero. "The Powers of the Arbitrator". Conservatory 
Muito se discutiu, também, sobre a possibilidade de o Estado figurar, direta ou indiretamente, em uma arbitragem.

Quando representa e defende direitos indisponíveis de toda a coletividade, atuando na sua condição de entidade pública, o Estado não pode participar de uma arbitragem. No entanto, há sólido entendimento no sentido de que as sociedades de economia mista, as empresas estatais, as autarquias e os demais entes da Administração Pública podem participar de arbitragens que versem sobre assuntos ligados à atividade econômica em sentido estrito ou a atos de natureza contratual ou privada ${ }^{23}$. Nesse sentido, o Superior Tribunal de Justiça já decidiu que:

“(...) quando os contratos celebrados pela empresa estatal versem sobre atividade econômica em sentido estrito - isto é, serviços públicos de natureza industrial ou atividade econômica de produção ou comercialização

and Provisional Measures in International Arbitration. Paris: International Chamber of Commerce - ICC The International Court of Arbitration Publications, 1993, pp. 21/30, p. 21, tradução livre). Nessa mesma esteira, NEIL ANDREWS aponta que "um relatório de 2005 em Londres estatui que as companhias deram as seguintes razões para preferir a arbitragem comercial internacional ao invés dos processos judiciais: flexibilidade do procedimento, a privacidade do processo, a oportunidade de as partes selecionarem os árbitros, execução imediata da sentença (incluindo a execução nas jurisdições estrangeiras, pela aplicação da Convenção de Nova Iorque, 1958).” (Arbitration and mediation in England..., p. 114, tradução livre).

${ }^{23}$ Nesse diapasão: LEMES, Selma M. Ferreira. "Arbitragem na Concessão de Serviços Públicos - Arbitrabilidade Objetiva. Confidencialidade ou Publicidade Processual?” in Novos Rumos da Arbitragem no Brasil. GUILHERME, Luiz Fernando do Vale de Almeida (coord.). São Paulo: Fiuza, 2004, p. 368; Idem, Arbitragem na Administração Pública - fundamentos jurídicos e eficiência econômica. São Paulo: Quartier Latin, 2007, p. 93; CARMONA, Carlos Alberto. Arbitragem e Processo..., pp. 45/52; SUNDFELD, Carlos Ari; CÂMARA, Jacintho Arruda. "O cabimento da arbitragem nos contratos administrativos". Revista de Direito Administrativo, n. ${ }^{\circ}$ 248. São Paulo, mai/ago de 2008, pp. 117/126, p. 121; PINTO, José Emilio Nunes. “A arbitrabilidade de controvérsias nos contratos com o estado e empresas estatais" in Revista Brasileira de Arbitragem, n. ${ }^{\circ}$ 01. São Paulo: IOB/CBAr, jan./mar de 2004, p. 09; GRAU, Eros Roberto. “Arbitragem e contrato administrativo". Revista Trimestral de Direito Público, n. ${ }^{\circ} 32$, abr/jun de 2000, pp. 14/20, p. 15; Idem, "Da arbitrabilidade de litígios envolvendo sociedades de economia mista e da interpretação de cláusula compromissória”. Revista de Direito Bancário, do Mercado de Capitais e da Arbitragem, ano 5, vol. 18. WALD, Arnoldo (coord.). São Paulo: RT, 2003; SALLES, Carlos Alberto de. A Arbitragem na solução de controvérsias contratuais da administração pública. Tese de livre-docência defendida perante a Faculdade de Direito da Universidade de São Paulo em 2011; WALD, Arnoldo; CARNEIRO, Athos Gusmão; ALENCAR, Miguel Tostes de; e DOURADO, Ruy Janoni. "Da validade de convenção de arbitragem pactuada por sociedade de economia mista" in Revista de Direito Bancário, do Mercado de Capitais e da Arbitragem, ano 5, vol. 18. WALD, Arnoldo (coord.). São Paulo: RT, 2003; CORREIA, André de Luizi. Acórdão comentado: "Contrato de suprimento de gás canalizado entre a Petrobras e a CEG. Recusa da Petrobras em manter o suprimento de volumes não previstos em contrato. Arbitragem instaurada pela concessionária e ação judicial movida pelo Estado do Rio de Janeiro, ambas visando à manutenção do suprimento. Pedido de suspensão da ação, até a solução da questão pelo Tribunal Arbitral. Acórdão do TJRJ que indeferiu o pedido, sem, no entanto, negar a arbitrabilidade dos conflitos oriundos dos contratos de suprimento de gás. Petróleo Brasileiro S.A. (Petrobras) x Estado do Rio de Janeiro - AgIn 2008.002.05857 - TJRJ - rel. Des. Wagner Cinelli de Paula Freitas". Revista de Arbitragem e Mediação, ano 5, vol. 19. WALD, Arnoldo (coord.). São Paulo: RT, out/dez 2008; e ROMERO, Eduardo Silva. "International Arbitration involving State Parties. Observations on the applicable law in State Contract Arbitration" in Revista de Arbitragem e Mediação, vol. 6. WALD, Arnoldo (coord.). São Paulo: RT, 2005, pp. 176/195. 
de bens, suscetíveis de produzir renda e lucro -, os direitos e as obrigações deles decorrentes serão transacionáveis, disponíveis e, portanto, sujeitos à arbitragem. (...) Por outro lado, quando as atividades desenvolvidas pela empresa estatal decorram do poder de império da Administração Pública e, conseqüentemente, sua consecução esteja diretamente relacionada ao interesse público primário, estarão envolvidos direitos indisponíveis e, portanto, não-sujeitos à arbitragem" 24 .

Frise-se que há, inclusive, leis prevendo, expressamente, a possibilidade do uso da arbitragem pela Administração Pública para a solução de eventuais litígios, tais como: a Lei de Parceria Público-Privada ${ }^{25}$, a Lei de Concessão e Permissão de Serviços Públicos ${ }^{26}$, a Lei da Política Energética Nacional ${ }^{27}$, a Lei de Transportes Aquaviários e Terrestres $^{28}$ e a Lei de Transporte e Tratamento de Gás Natural ${ }^{29}$.

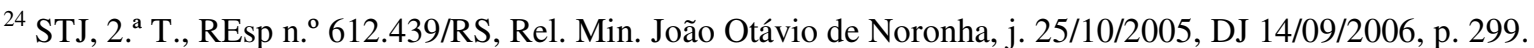
Nessa mesma linha: STJ, 1. ${ }^{a}$ Seção, MS 11.308/DF, Rel. Min. Luiz Fux, j. 09/04/2008; STJ, 2. ${ }^{a}$ Turma, REsp 606.345/RS, Rel. Min. João Otávio de Noronha, j. 17/05/2007; STF, Pleno, A.I. n. ${ }^{\circ}$ 52.191, Rel. Min. Bilac Pinto, RTJ 68/382 - Caso Lage; TJ/DF, Conselho Especial, M.S. n. ${ }^{\circ}$ 199800200366-9, Rel. Des. Nancy Andrighi, j. 18/05/1999, D.J. 18/08/1999. Destaca-se, ainda, o Recurso Especial n. ${ }^{\circ}$ 904.813/PR, por meio do qual o STJ decidiu que o fato de não haver previsão de arbitragem no edital de licitação ou no contrato celebrado entre as partes, não invalida o compromisso arbitral firmado posteriormente, considerando, pois, válido o compromisso arbitral firmado entre sociedade de economia mista e sociedade privada mesmo depois da celebração do contrato de licitação (STJ, 3. ${ }^{a}$ Turma, Rel. Min. Nancy Andrighi, j. 20/10/2011, v.u.).

${ }^{25}$ Lei n. ${ }^{\circ} 11.079$, de 30 de dezembro de 2004 - "Art. 11. O instrumento convocatório conterá minuta do contrato, indicará expressamente a submissão da licitação às normas desta Lei e observará, no que couber, os $\S \S 3^{\circ}$ e $4^{\circ}$ do art. 15 , os arts. 18,19 e 21 da Lei n. ${ }^{\circ} 8.987$, de 13 de fevereiro de 1995 , podendo ainda prever: (...) III - o emprego dos mecanismos privados de resolução de disputas, inclusive a arbitragem, a ser realizada no Brasil e em língua portuguesa, nos termos da Lei $n^{\circ}$ 9.307, de 23 de setembro de 1996, para dirimir conflitos decorrentes ou relacionados ao contrato".

${ }^{26}$ Lei n. ${ }^{\circ} 8.987$, de 13 de fevereiro de 1995: “Art. 23-A. O contrato de concessão poderá prever o emprego de mecanismos privados para resolução de disputas decorrentes ou relacionadas ao contrato, inclusive a arbitragem, a ser realizada no Brasil e em língua portuguesa, nos termos da Lei ${ }^{\circ}$ 9.307, de 23 de setembro de 1996" - Incluído pela Lei n ${ }^{\circ} 11.196$, de 2005.

${ }^{27}$ Lei $\mathrm{n}^{\circ}$ 9.478, de 06 de agosto 1997: “Art. 20. O regimento interno da ANP disporá sobre os procedimentos a serem adotados para a solução de conflitos entre agentes econômicos, e entre estes e usuários e consumidores, com ênfase na conciliação e no arbitramento" e "Art. 43. O contrato de concessão deverá refletir fielmente as condições do edital e da proposta vencedora e terá como cláusulas essenciais: (...) X - as regras sobre solução de controvérsias, relacionadas com o contrato e sua execução, inclusive a conciliação e a arbitragem internacional;".

${ }^{28}$ Lei n. ${ }^{\circ} 10.233$, de 05/06/2001: “Art. 35. O contrato de concessão deverá refletir fielmente as condições do edital e da proposta vencedora e terá como cláusulas essenciais as relativas a: (...) XVI - regras sobre solução de controvérsias relacionadas com o contrato e sua execução, inclusive a conciliação e a arbitragem;".

${ }^{29}$ Lei n. ${ }^{\circ} 11.909$, de 04 de março de 2009: "Art. 21. O contrato de concessão deverá refletir fielmente as condições do edital e da proposta vencedora e terá como cláusulas essenciais: (...) XI - as regras sobre solução de controvérsias relacionadas com o contrato e sua execução, inclusive a conciliação e a arbitragem; (...) Art. 24. A concessionária deverá: (...) III - submeter à aprovação da ANP a minuta de contrato padrão a ser celebrado com os carregadores, que deverá conter cláusula para resolução de eventuais divergências, podendo prever a convenção de arbitragem, nos termos da Lei $n^{\circ} 9.307$, de 23 de setembro de 1996; (...) Art. 48. Os contratos de comercialização de gás natural deverão conter cláusula para resolução de eventuais divergências, podendo, inclusive, prever a convenção de arbitragem, nos termos da Lei no 9.307, de 23 de setembro de 1996. Art. 49. As empresas públicas e as sociedades de economia mista, suas subsidiárias ou controladas, titulares de concessão ou autorização ficam autorizadas a aderir ao mecanismo e à convenção de arbitragem a que se refere o art. 48 desta Lei.". 
E, quanto ao tema deste trabalho, verifica-se ser possível a concessão de tutela de urgência mesmo em uma arbitragem envolvendo o Poder Público ${ }^{30}$.

Enfim, a arbitragem é um meio alternativo de solução de controvérsias, por meio do qual pessoas físicas ou jurídicas elegem um ou mais terceiros (um árbitro ou um colegiado de árbitros), seja por cláusula compromissória, seja por compromisso arbitral, para que decida(m) eventual litígio, atual ou futuro, envolvendo direitos patrimoniais disponíveis.

Ressalte-se que na Itália, na Argentina, na Alemanha, em Portugal, e na maioria dos demais países em que a arbitragem é aceita, também há restrições quanto às matérias que podem ser objeto de um processo arbitral.

Na Itália, o artigo 806 do Código de Processo Civil italiano, com a alteração introduzida pelo Decreto Legislativo n. ${ }^{\circ}$ 40, de 02 de fevereiro de 2006 (publicado em 15 de fevereiro de 2006), prevê que somente litígios envolvendo direitos disponíveis poderão ser objeto de uma arbitragem, dependendo, ainda, da inexistência de outras eventuais restrições estipuladas em lei. Referido artigo prevê, ainda, a possibilidade de arbitragens envolvendo direito do trabalho, desde que estabelecidas em contrato ou em acordo coletivo de trabalho ${ }^{31}$.

Na Argentina, o artigo 737 do Código de Processo Civil e Comercial da Nação exclui da arbitragem as matérias que não podem ser objeto de $\operatorname{transação~}^{32}$.

\footnotetext{
${ }^{30}$ Nesse sentido, ver: AMARAL, Paulo Osternack. "A concessão de medidas urgentes em processo arbitral envolvendo o poder público". Revista de Processo, ano 33, n. ${ }^{\circ}$ 157. São Paulo: RT, março/2008, pp. 18/50.

31 "Art. 806. (Controversie arbitrabili). Le parti possono far decidere da arbitri le controversie tra di loro insorte che non abbiano per oggetto diritti indisponibili, salvo espresso divieto di legge. Le controversie di cui all'articolo 409 possono essere decise da arbitri solo se previsto dalla legge o nei contratti o accordi collettivi di lavoro." (tradução livre: "Art. 806. (Controvérsia arbitral). As partes podem decidir arbitrar as controvérsias decorrentes entre elas que não tenham por objeto direito indisponível, salvo expressa proibição legal. As controvérsias referidas no artigo 409 podem ser decididas em arbitragem apenas se prevista por lei ou no contrato ou acordo coletivo de trabalho.").

${ }^{32}$ Eis os termos do referido dispositivo legal: "Cuestiones excluidas - Art. 737. - No podrán comprometerse en árbitros, bajo pena de nulidad, las cuestiones que no puedan ser objeto de transacción." (tradução livre: "Questões excluídas - Art. 737. - Não poderão ser submetidas aos árbitros, sob pena de nulidade, as questões que não podem ser objeto de transação.”).
} 
$\mathrm{Na}$ Alemanha, a regra é que apenas litígios envolvendo interesses econômicos estão sujeitos à arbitragem, não podendo a convenção arbitral, contudo, versar sobre arrendamentos residenciais na Alemanha, nos termos do § 1030, (1) a (3), do CPC alemão $(Z P O)^{33}$.

Por fim, em Portugal, qualquer litígio envolvendo direitos disponíveis ou transacionáveis pode ser solucionado por meio de arbitragem voluntária, com exceção dos conflitos que, por disposição legal, estejam submetidos obrigatoriamente à jurisdição estatal ou à arbitragem necessária, conforme o disposto no artigo 1. o, "1" e "2", da Lei n. ${ }^{\circ}$ 63, de 14 de dezembro de $2011^{34}$ (que entrou em vigor em 14 de março de 2012,

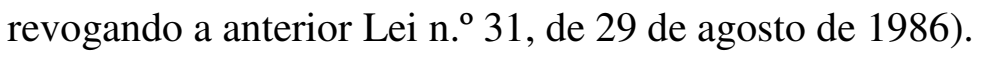

\section{Admite-se também em Portugal arbitragem envolvendo o}

Estado ou outros entes de direito público, desde que haja autorização por lei especial ou se a arbitragem versar sobre direito privado (artigo 1. ", "5", da Lei n. $\left.{ }^{\circ} 63 / 2011\right)^{35}$.

33 "Section 1030 Arbitrability (1) Any claim involving an economic interest ('vermögensrechtlicher Anspruch') can be the subject of an arbitration agreement. An arbitration agreement concerning claims not involving an economic interest shall have legal effect to the extent that the parties are entitled to conclude a settlement on the issue in dispute. (2) An arbitration agreement relating to disputes on the existence of a lease of residential accommodation within Germany shall be null and void. This does not apply to residential accommodation as specified in section 549 subs. 1 to 32 of the Civil Code. (3) Statutory provisions outside this Book by virtue of which certain disputes may not be submitted to arbitration, or may be submitted to arbitration only under certain conditions, remain unaffected." (tradução livre: "Seção 1030 Arbitrabilidade (1) Qualquer litígio envolvendo um interesse econômico ('vermögensrechtlicher Anspruch') pode ser objeto de uma convenção arbitral. Uma convenção arbitral relacionada a litígios que não envolvam um interesse econômico deve surtir efeitos legais até a extensão do que as partes estão autorizadas a decidir em um acordo sobre o tema em disputa. (2) Uma convenção arbitral relacionada a disputas sobre a existência de arrendamento de acomodação residencial na Alemanha será nula e inválida. Esse disposto não se aplica às acomodações residenciais especificadas na seção 549, itens 1 a 32 do Código Civil. (3) As previsões legais fora dessa Lei que regulam que determinados litígios não podem ser submetidos à arbitragem ou somente podem ser submetidos sob certas circunstâncias, permanecem válidas.”). Frise-se que, no Brasil, o artigo 89, inciso I, do CPC, também disciplina a competência exclusiva do Poder Judiciário para litígios relativos a bens imóveis situados no Brasil: "Art. 89. Compete à autoridade judiciária brasileira, com exclusão de qualquer outra: I - conhecer de ações relativas a imóveis situados no Brasil;”.

34 "Artigo 1. ${ }^{\circ}$ Convenção de arbitragem 1 - Desde que por lei especial não esteja submetido exclusivamente aos tribunais do Estado ou a arbitragem necessária, qualquer litígio respeitante a interesses de natureza patrimonial pode ser cometido pelas partes, mediante convenção de arbitragem, à decisão de árbitros. 2 - É também válida uma convenção de arbitragem relativa a litígios que não envolvam interesses de natureza patrimonial, desde que as partes possam celebrar transacção sobre o direito controvertido". Sobre as principais alterações trazidas pela nova lei de arbitragem em Portugal, ver: JÚDICE, José Miguel. "O Projecto de Nova Lei de Arbitragem Voluntária em Portugal” in Revista Brasileira de Arbitragem, n. 23. São Paulo: IOB/CBAr, jul/set de 2009, pp. 240/246.

35 “Art. 1. ${ }^{\circ}$ Convenção de Arbitragem 5 - O Estado e outras pessoas colectivas de direito público podem celebrar convenções de arbitragem, na medida em que para tanto estejam autorizados por lei ou se tais convenções tiverem por objecto litígios de direito privado". 


\section{CAPÍTULO II \\ RETROSPECTO HISTÓRICO DA ARBITRAGEM}

\section{BREVE HISTÓRICO DA ARBITRAGEM NO MUNDO, SOB A ÓTICA DA TUTELA DE URGÊNCIA}

Nos primórdios da civilização, os conflitos costumavam ser resolvidos pela utilização da força física, prevalecendo a vontade dos mais fortes sobre os mais fracos. Utilizava-se o que se denominou de "autotutela", em que cada pessoa protegia o seu próprio patrimônio, inclusive a sua vida, por meio do uso da força.

Nessa época, por óbvio, sequer se cogitava eventual tutela de urgência, tendo em vista a solução imediata do conflito pelas próprias partes envolvidas, na maior parte das vezes por meio da luta corporal e da vingança privada, não havendo declaração da existência de direitos ou a figura de um julgador.

Com a evolução da civilização, os litígios passaram a ser solucionados através da "autocomposição", por meio da qual as próprias partes litigantes negociavam um acordo para resolver o impasse criado entre elas.

Nessa esteira, era perfeitamente possível e, inclusive, desejável, a imediata entrega do bem da vida à parte tida como certa ou vencedora para a pronta solução do conflito. Mas não se tratava, no entanto, de uma tutela de urgência, mas, sim, da solução efetiva e imediata do litígio pelas próprias partes, inexistindo um processo propriamente dito para a discussão e solução da controvérsia.

Nessa época, como ainda não havia a figura do Estado e o seu poder de coerção, caso a avença não fosse cumprida, a parte prejudicada ainda precisaria se valer da "autotutela" para garantir o seu direito.

Com o passar do tempo, as civilizações primitivas buscaram nova forma amigável de solução de conflitos, a qual pode ser considerada como a origem da arbitragem, por meio da qual um terceiro imparcial e de confiança mútua das partes envolvidas era chamado para decidir o litígio. 
Esse terceiro, via de regra, era um ancião, ou um patriarca, ou um sábio da tribo ou da comunidade, que deveria decidir o conflito de acordo com as regras de experiência e com os costumes do grupo a que pertencia. Também poderia ser um sacerdote, o qual, sob a ótica das partes, tomaria a decisão acertada guiado pelas divindades e pela vontade dos Deuses.

Novamente aqui, a regra era a de que a decisão tomada pelo terceiro solucionava a controvérsia de forma imediata, não havendo necessidade de tutelas de urgência ou algo do gênero, notadamente levando-se em conta que as civilizações primitivas levavam uma vida muito mais simples que a atual, utilizando-se basicamente de uma economia de subsistência e de poucos escambos.

Pode-se afirmar, de qualquer maneira, que a origem da arbitragem, como meio de composição de litígios, é bem anterior à jurisdição pública ${ }^{36}$.

Foi na Grécia antiga que surgiu uma das primeiras figuras oficiais do árbitro. Como leciona EDUARDO LEMOS, eram freqüentes as soluções amigáveis das controvérsias na Grécia antiga por meio da arbitragem, a qual poderia ser a compromissória ou a obrigatória ${ }^{37}$.

Assim, nas Cidades-Estados, chamadas de polis, muitas vezes um terceiro era convocado para, após ouvir as partes, decidir o conflito de modo simples e direto. Os compromissos especificavam o objeto da controvérsia e o árbitro era indicado pelas próprias partes envolvidas.

A curiosidade fica por conta da publicidade da decisão arbitral, já havendo essa preocupação à época para assegurar a sua efetividade: assim que a

\footnotetext{
${ }^{36}$ Nesse sentido, FRANÇOIS DE MENTHON defende a idéia de que a arbitragem representou forma primitiva de Justiça, anterior à Justiça Pública (in Le rôle de l'arbitrage dans l'evolution judiciaire. Tese apresentada à Université de Paris - Faculté de Droit. Paris: Editions Spes, 1926). Em acórdão prolatado pelo Tribunal de Justiça de São Paulo, o Desembargador RoDRIGUES DE CARVALHO estatuiu que é "certo que a convenção de arbitragem não é coisa nova. Está, possivelmente, entre as mais antigas do mundo como solução de litígio." (TJ/SP, 5. ${ }^{a}$ Câm. Dir. Privado, A.I. n. ${ }^{\circ}$ 124.217-4/0, Rel. Des. Rodrigues de Carvalho, j. 16/09/1999, v.u.). Por fim, NEIL ANDREWS confirma que "a arbitragem é um tipo de resolução de conflito estabelecido há tempos." (tradução livre do texto original: "arbitration is a long-established type of dispute resolution." ANDREWS, Neil. Arbitration and mediation in England..., p. 108).

${ }^{37}$ LEMOS, Eduardo. Arbitragem \& Conciliação. Brasília: Editora Consulex, 2001.
} 
decisão arbitral era proferida, ela era gravada em placas de mármore ou de metal que eram afixadas nos templos das respectivas cidades para conhecimento de todo o povo ${ }^{38}$.

Em tal época, ainda não havia um processo complexo ou moroso. Pelo contrário, o árbitro deveria decidir o litígio de modo direto, motivo pelo qual, novamente, não são comuns relatos de tutelas de urgência. $\mathrm{O}$ sistema se equiparava muito mais ao da tutela da evidência, em que a parte que detinha o "direito evidente" recebia o provimento imediato.

É também da Grécia antiga o primeiro relato de utilização da cláusula compromissória arbitral. O Tratado de Paz firmado entre Atenas e Esparta, em aproximadamente 445 a.C., remetia às partes à via arbitral para a solução de eventual conflito oriundo de referido Tratado.

Contudo, a arbitragem veio mesmo a se consolidar em Roma, com a extensão dos poderes do magistrado ao árbitro.

No primeiro período do Direito Romano, as legis acciones em muito se assemelhavam às câmaras arbitrais ${ }^{39}$.

Ainda em Roma, a ordo judiciorum privatorum estabelecia que as questões cíveis deveriam ser primeiramente apresentadas perante o Magistrado no Tribunal para, depois, serem apresentadas diante de um árbitro particular (arbiter) escolhido pelas partes para julgar o processo $^{40}$.

Especialmente na fase do jus peregrinus, a arbitragem era utilizada para a solução de controvérsias com estrangeiros pelo praetor peregrinus ${ }^{41}$.

${ }^{38}$ Cf. OPORTO, Silvia Fazzinga; VASCONCELLOS, Fernando. Arbitragem Comercial Internacional. In http://sisnet.aduaneiras.com.br/lex/doutrinas/arquivos/080306t.pdf. Acessado em 02/06/2012.

${ }^{39}$ Cf. SZKLAROWSKY. Leon Frejda. Evolução histórica da arbitragem. In http://jus.com.br/revista/texto/ 6842/evolucao-historica-da-arbitragem. Acessado em 02/06/2012.

${ }^{40}$ Cf. SZKLAROWSKY. Leon Frejda. Evolução histórica da arbitragem. In http://jus.com.br/...

${ }^{41}$ Cf. OPORTO, Silvia Fazzinga; VASCONCELLOS, Fernando. Arbitragem Comercial Internacional... 
No período Justiniano, restou previsto que a parte vencedora na arbitragem poderia, em caso de recusa da outra em cumprir a decisão arbitral, postular a intervenção do magistrado para dar cumprimento à sentença arbitral, inclusive com a utilização de meios coercitivos. Instituiu-se, assim, uma actio in factum contra a parte que não executasse a decisão arbitral, no caso desta não ter sido impugnada nos dez dias posteriores à sua prolação ${ }^{42}$.

Ainda sobre o tema, AlFREDo BUZAID ensina que o Digesto previa, expressamente, o instituto da arbitragem ${ }^{43}$, podendo as partes celebrar compromissos, da mesma forma como o faziam perante a justiça comum, para que um terceiro, o árbitro, julgasse o conflito ${ }^{44}$. O julgamento (sententia) conferia a actio in factum ${ }^{45}$.

Nesse diapasão, tendo em vista que o processo romano já estabelecia providências semelhantes às nossas tutelas de urgência atuais, como se verá detalhadamente no "item 13" a seguir, tal como, por exemplo, o antigo processo do tipo interdital romano, em que o pretor antecipava a execução ou o mandamento no próprio processo cognitivo, independentemente de processo autônomo ${ }^{46}$, pode-se afirmar que no direito romano já se conheciam as tutelas de urgência e que estas poderiam ser deferidas pelo arbiter ou pelo pretor.

$\mathrm{Na}$ Idade Média, também era comum a utilização da arbitragem para a solução de conflitos entre nobres, cavaleiros, barões, proprietários feudais e, fundamentalmente, entre comerciantes ${ }^{47}$, assim como entre o Estado e a Igreja.

${ }^{42}$ Cf. OPORTO, Silvia Fazzinga; VASCONCELLOS, Fernando. Arbitragem Comercial Internacional...

${ }^{43}$ Cf. Digesto $15.1 .3, \S 11$, e, ainda, IV, 8,3

${ }^{44}$ BUZAID, Alfredo. Do Juízo Arbitral. in Separata da Revista da Faculdade de Direito da Universidade de São Paulo. Empresa Gráfica Revista dos Tribunais, 1960.

${ }^{45}$ Cf. SZKLAROWSKY. Leon Frejda. Evolução histórica da arbitragem. In http://jus.com.br/...

${ }^{46}$ Cf. BAPTISTA DA SILVA, Ovídio A. "A Antecipação de Tutela, na Recente Reforma Processual" in A Reforma do Código de Processo Civil. TEIXEIRA, Sálvio de Figueiredo (coord.). São Paulo: Saraiva, 1996, p. 136. Não é diferente a lição de JoÃo BATISTA LOPES, o qual também relembra que em Roma já "se conheciam instrumentos eficazes para a pronta proteção do direito como os interditos (interdicta), ordens expedidas pelo pretor, não como juiz, mas como autoridade investida de poder administrativo (imperium)." (LOPES, João Batista. “As 'antigas novidades' do processo civil brasileiro e a efetividade da jurisdição". Revista de Processo - RePro, ano 33, n. ${ }^{\circ}$ 157. São Paulo: RT, março de 2008, pp. 09/17).

${ }^{47}$ Cf. SZKLAROWSKY. Leon Frejda. Evolução histórica da arbitragem. In http://jus.com.br/... 
Silvia FAZZinga OpORTo e FERnando VAsconcellos, citando lição de GIANNI SCHIZZERROTO, afirmam que são cinco as causas para o desenvolvimento da arbitragem durante a Idade Média: (i) a ausência de leis; (ii) a falta de garantias jurisdicionais; (iii) a grande variedade de ordenamentos dos feudos; (iv) a fraqueza dos Estados; e (v) os conflitos entre Estado e Igreja ${ }^{48}$.

Aliás, o papel da Igreja Católica foi importante nessa fase, favorecendo soluções pacíficas de litígios entre fronteiras e também nas questões privadas. O Papa era considerado o árbitro supremo e os bispos também figuravam como árbitros, motivo pelo qual as penalidades aplicadas eram religiosas na maioria das vezes, tais como a excomunhão (vedação de a pessoa tomar sacramentos por toda a vida) e o interdito (proibindo-se o sacramento em determinada cidade, ou suspendendo o ofício da missa) ${ }^{49}$.

Não foram encontrados relatos de tutelas de urgência em arbitragens nesse período, em que o Estado era fraco e vigoravam muito mais as regras e as penalidades vislumbradas pela Igreja Católica.

Nos anos que se seguiram, com o fortalecimento dos Estados, a modernização do direito e a instauração do Poder Judiciário, a arbitragem acabou enfraquecida, notadamente diante da necessidade da homologação judicial da decisão arbitral ou da possibilidade de seu questionamento perante o juízo estatal, o que retirou por completo a sua eficácia e a sua celeridade, reduzindo significativamente a sua utilização.

No entanto, na Revolução Francesa de 1789, a Assembléia Constituinte adotou a arbitragem como o instrumento ideal de reação contra os abusos do antigo regime real ${ }^{50}$, o que impulsionou novamente a utilização desse instituto. Contudo, o seu uso não durou muito, tendo em vista as rigorosas formalidades impostas à arbitragem em 1806, as quais acabaram desestimulando a sua utilização ${ }^{51}$.

\footnotetext{
${ }^{48}$ Cf. OPORTO, Silvia Fazzinga; VASCONCELLOS, Fernando. Arbitragem Comercial Internacional...

${ }^{49}$ Cf. OPORTO, Silvia Fazzinga; VASCONCELLOS, Fernando. Arbitragem Comercial Internacional...

${ }^{50}$ BRUNO OPPETIT ensina que "os revolucionários editaram a Lei de 16-24 de agosto de 1790, cujo texto enunciava - provavelmente por ódio aos parlamentares do antigo regime e imbuídos do ideal de fraternidade entre os homens - que a arbitragem seria 'o meio mais razoável de se terminar uma contenda entre cidadãos' $\left(\right.$ art. $\left.1^{\circ}\right)$.” (OPPETIT, Bruno. Etudes offertes..., pp. 188/189).

${ }^{51}$ Cf. OPORTO, Silvia Fazzinga; VASCONCELLOS, Fernando. Arbitragem Comercial Internacional...
} 
Foi somente com a previsão legal da arbitragem pela Bélgica em 1876, com os seus atuais traços característicos, que o instituto ganhou novo impulso e acabou também se difundindo pelos demais países europeus e pelos E.U.A.

A arbitragem entre Estados ou entre particulares passou a se situar como uma alternativa à justiça estatal ou internacional ${ }^{52}$, inclusive com a possibilidade do deferimento de tutelas de urgência, como se verá detalhadamente a seguir.

Assim, paralelamente ao Poder Judiciário estatal, ressurgiu, definitivamente, o conceito atual de arbitragem.

\section{HISTÓRICO DA ARBITRAGEM NO BRASIL, AINDA SOB A ÓTICA DA TUTELA DE URGÊNCIA}

A arbitragem, como mecanismo alternativo de resolução de disputas comerciais e cíveis, foi prevista pela primeira vez no ordenamento jurídico brasileiro pelas Ordenações Filipinas ${ }^{53}$.

No Livro III das Ordenações Filipinas, os Títulos XVI e XVII regulavam, respectivamente, os "Juízes Árbitros” e os “Arbitradores”.

À época, era possível a interposição de recurso perante a justiça estatal contra a sentença proferida pelos juízes árbitros, mesmo que constasse expressamente do compromisso arbitral a cláusula de "não recorrer"

52 Cf. HERNANDES NETO, Antonio Marcos. "Noções Gerais de Arbitragem Comercial Internacional e sua Aplicação para Solução de Conflitos em Investimentos Estrangeiros" in Cadernos da Escola de Direito e Relações Internacionais - UniBrasil, n. ${ }^{\circ}$ 12, vol. 1. Curitiba, pp. 278/288.

${ }^{53}$ As Ordenações Afonsinas e Manuelinas também disciplinavam esse sistema de composição dos conflitos, mas somente vigoraram durante o período do Brasil-Colônia. Em acórdão sobre a arbitragem, o Desembargador RoDRIGUES DE CARVALHO relembra que "nosso País teve lei própria desde 1850, Decreto-Lei 737 e a Lei 556; a Lei n ${ }^{\circ}$ 1350, de 1866; a par das Ordenações (e da Constituição Imperial de 1824) que, por força da Lei da Boa Razão, vigeu até o Código Civil de 1916." (TJ/SP, 5. Câm. Dir. Privado, A.I. n. ${ }^{\circ}$ 124.217-4/0, Rel. Des. Rodrigues de Carvalho, j. 16/09/1999, v.u.).

${ }^{54}$ Redação original: "Posto que as partes compromettam em algum Juiz, ou Juizes arbitros, e se obriguem no compromisso star por sua determinação e sentença, e que della não possam appellar, nem aggravar, e o que o contrario fizer pague a outra parte certa pena, e ainda que no compromisso se diga, que paga a pena, ou não paga, fique sempre a sentença dos arbitros firme e valiosa; poderá a parte, que se sentir aggravada, sem embargo de tudo isto, appellar de sua sentença para os superiores, sem pagar a dita pena; e se os arbitros lhe denegarem a appellação, façam-lha dar os Juizes ordinarios (1). Porém, se os Juizes da appellação confirmarem a sentença dos arbitros, de que for appellado, pagará o appellante ao vencedor a pena conteúda no compromisso, que não se póde escusar de a pagar, pois prometteu não vir contra a sentença, e he achado 
A justificativa apresentada era a ausência de homologação da decisão dos juízes árbitros por parte do juiz ordinário, sendo possível a sua execução direta perante o juiz togado na ausência de recurso, nos termos da antiga lei:

"e se cada uma das partes não apelar em tempo devido da sentença dada pelos árbitros, tal sentença se dará à execução pelos Juízes ordinários, quer no compromisso fosse posta pena, quer não, assim como se daria à execução, sendo dada pelos Juízes ordinários"

Ressalte-se que, com relação ao tema deste trabalho, não havia previsão acerca da possibilidade de deferimento de tutelas de urgência pelos "Juízes Árbitros" nas Ordenações Filipinas ${ }^{56}$.

Posteriormente, a arbitragem passou a ser regida pela Constituição do Império de 1824, a qual previa a possibilidade de utilização da arbitragem para a solução de disputas entre nacionais e estrangeiros e, em seu artigo 160, estabelecia a utilização da arbitragem para a solução de ações de natureza civil ou penais civilmente intentadas: “Art. 160. Nas cíveis, e nas penais civilmente intentadas, poderão as Partes nomear Juízes Árbitros. Suas Sentenças serão executadas sem recurso, se assim o convencionarem as mesmas Partes"

Não havia, todavia, qualquer disposição sobre a possibilidade de o árbitro deferir tutela de urgência à época, tampouco foram encontrados exemplos acerca do tema no período do Império ${ }^{58}$.

que injustamente della appellou (2). E posto que as partes renunciem o beneficio desta Lei, tal renunciação será de nenhum efeito." (www.ci.uc.pt/ihti/proj/filipinas/13p578.htm. Acessado em 08/06/2012).

${ }^{55}$ Versão original: "e se cada huma das partes não appellar em tempo devido da sentença dada pelos arbitros, tal sentença se dará à execução pelos Juizes ordinários, quer no compromisso fosse posta pena, quer não, assi como se daria à execução, sendo dada pelos Juizes ordinários." (www.ci.uc.pt/ihti/proj/ filipinas/13p578.htm. Acessado em 08/06/2012).

${ }^{56}$ Aliás, nas Ordenações Filipinas não havia previsão de concessão de tutela de urgência, mas, na prática de foro, eram admitidas liminares nas ações possessórias, que eram sumárias, se intentadas dentro de ano e dia (Cf. MORAES E BARROS, Hamilton de. As liminares do mandado de segurança. Rio de Janeiro, 1963, p. 5) 57 JosÉ AUGUSTO DELGADO anota que "em ambiente puramente brasileiro, a arbitragem surgiu, pela primeira vez, na Constituição do Império, de 22/03/1824, em seu art. 160, (...)” (“Arbitragem no Brasil - evolução histórica e conceitual”. Arbitragem no Brasil - aspectos jurídicos relevantes. JOBIM, Eduardo; MACHADO, Rafael Bicca (coord.). São Paulo: Quartier Latin, 2008, pp. 221/247, esp. p. 229).

${ }^{58}$ PETRÔNIO R. G. MUNIZ narra caso antigo, mas que poderia perfeitamente ter ocorrido nos dias de hoje: durante o Império, em litígio em que eram partes o Almirante Lord Cochrane e o Brasil, a arbitragem, por eqüidade, para a solução do caso referente às "presas de guerra" durou 7 (sete) meses, enquanto a "Corte de 
Em 1831, a arbitragem passou a ser obrigatória para a resolução de controvérsias originadas de contratos de seguro e, em 1837, também passou a ser obrigatória para o deslinde dos conflitos envolvendo locação de serviços, através da Resolução n. ${ }^{\circ}$ 26/1831 e da Lei n. ${ }^{\circ}$ 108/1837, respectivamente.

Após, a arbitragem passou a ser regulada pelo Código Comercial $^{59}$ e pelo Regulamento 737 , ambos de $1850^{60}$.

O Código Comercial (Lei n. ${ }^{\circ}$ 556, de 25 de junho de 1850) também trazia alguns dispositivos que compeliam às partes a se valerem da arbitragem para a solução de determinados litígios específicos, tais como, por exemplo, os artigos 245 , 294, 348, 739, 783 e $846^{61}$. Contudo, essa obrigatoriedade da arbitragem não durou muito tempo, tendo sido abolida 16 (dezesseis) anos mais tarde pelo Decreto n. ${ }^{\circ} 3.900 / 1867^{62}$.

Presas" levou quase 50 (cinqüenta) anos para tentar a solução do conflito, sem êxito ("A arbitragem e a história naval brasileira” in Prática Jurídica, n. ${ }^{\circ} 26$. Brasília: Editora Consulex, maio de 2004).

59 No plano do Direito Comercial, algumas normas sobre arbitragem previstas no Código Comercial permaneceram em vigor até serem revogadas pelo Novo Código Civil (Lei n. ${ }^{\circ}$ 10.406/2002), como, por exemplo, o artigo 302, "5", que previa a possibilidade de se escolher árbitros para a solução de disputas acerca de "dúvidas sociais". Há regras de Direito Comercial previstas em normas extravagantes ainda em vigor, como, por exemplo, o artigo 129, § 2. ${ }^{\circ}$, da Lei das Sociedades por Ações (Lei n. ${ }^{\circ}$ 6.404/76), que prevê a possibilidade de instituição de arbitragem para a solução de impasse no caso de empate de votação em assembléia geral de acionistas.

${ }^{60}$ Nesse sentido: AZEVEDO, André Gomma de. “A arbitragem no Brasil após 5 anos da Lei no 9.307/96: novos desafios para a sua plena eficácia” in Estudos em arbitragem, mediação e negociação. AZEVEDO, André Gomma de (org.). Brasília: Brasília Jurídica, 2002, pp. 113/114.

61 “Art. 245 - Todas as questões que resultarem de contratos de locação mercantil serão decididas em juízo arbitral”; "Art. 294 - Todas as questões sociais que se suscitarem entre sócios durante a existência da sociedade ou companhia, sua liquidação ou partilha, serão decididas em juízo arbitral.”; "Art. 348 - Acabada a liquidação, e proposta a forma de divisão e partilha, e aprovada uma e outra pelos sócios liquidados, cessa toda e qualquer reclamação da parte destes, entre si reciprocamente e contra os liquidantes. O sócio que não aprovar a liquidação ou a partilha é obrigado a reclamar dentro de 10 (dez) dias depois desta lhe ser comunicada; pena de não poder mais ser admitido a reclamar, e de se julgar por boa a mesma liquidação e partilha. A reclamação que for apresentada em tempo, não se acordando sobre ela os interessados, será decidida por árbitros, dentro de outros 10 (dez) dias úteis; os quais o juiz de direito do comércio poderá prorrogar por mais 10 (dez) dias improrrogáveis."; "Art. 739 - As questões que se moverem sobre o pagamento de salvados, serão decididas por árbitros no lugar do distrito onde tiver acontecido o naufrágio.”; "Art. 783 - A regulação, repartição ou rateio das avarias grossas serão feitos por árbitros, nomeados por ambas as partes, as instâncias do capitão. Não se querendo as partes louvar, a nomeação de árbitros será feita pelo Tribunal do Comércio respectivo, ou pelo juiz de direito do comércio a que pertencer, nos lugares distantes do domicílio do mesmo tribunal.”; e “Art. 846 - Na segunda reunião dos credores, apresentados os pareceres da Comissão e Curador fiscal, e não se oferecendo duvida sobre a admissão dos créditos constantes da lista, e havidos por verificados para o fim tão somente de habilitar o credor para poder votar e ser votado, o Juiz comissário proporá à deliberação da reunião o projeto de concordata, se o falido o tiver apresentado. Porém se houver contestação sobre algum crédito, e não podendo o Juiz comissário conciliar as partes, se louvarão estas no mesmo ato em dois Juizes árbitros; os quais remeterão ao mesmo Juiz o seu parecer, dentro de cinco dias. Se os dois árbitros se não conformarem, o Juiz comissário dará vencimento com o seu voto àquela parte que lhe parecer, para o fim sobredito somente, e desta decisão arbitral não haverá recurso algum".

${ }^{62} \mathrm{O}$ art. 2. ${ }^{\circ}$ do Decreto n. 3.900 estabelecia, expressamente, que "o Juizo Arbitral será sempre voluntario". 
Do Regulamento 737, de 25 de novembro de 1850, pode-se destacar que, já em seu artigo 1. ${ }^{\circ}$, havia previsão explícita sobre a arbitragem, estipulando que o árbitro, ao julgar uma causa, deveria respeitar a legislação comercial em vigor ${ }^{63}$.

O seu art. 300 também estabelecia que a ação sobre seguros seria julgada pelo juízo arbitral, caso as partes assim o tivessem pactuado na apólice ${ }^{64}$.

Mas, sem sombra de dúvida, o tema mais relevante do Regulamento 737 para a arbitragem é o "Título VIII - Do Juízo Arbitral”, o qual trazia, em seu "Capítulo I", artigo 411, a distinção entre a arbitragem voluntária e a arbitragem necessária ${ }^{65}$, bem como a menção ao "compromisso arbitral".

Com base nesse título, os árbitros deveriam julgar de acordo com a legislação comercial e também com as cláusulas do compromisso.

E com o advento do Decreto n. 3.900 (de 26 de junho de 1867), o qual regulamentou o "juízo arbitral do comércio", o árbitro passou a ter a possibilidade de julgar por eqüidade, caso as partes assim o autorizassem ${ }^{66}$.

No entanto, foi também referido Decreto n. 3.900 que sujeitou, expressamente, a eficácia da cláusula compromissória à execução, pelas partes, de um novo e específico acordo nomeado de "compromisso".

Nos termos do artigo 3. ${ }^{\circ}$ do mencionado Decreto, "o Juízo Arbitral só pode ser instituído mediante o compromisso das partes", i.é, somente o compromisso era tido como instrumento hábil para afastar a jurisdição estatal, pois era nele

\footnotetext{
63 "Todo o Tribunal ou Juiz que conhecer dos negócios e causas commerciaes, todo o arbitro ou arbitrador, experto ou perito que tiver de decidir sobre objectos, actos, ou obrigações commerciaes, é obrigado a fazer applicação da legislação commercial aos casos occurrentes (art. 21 Tit. unico do Codigo Commercial)".

64 "Art. 300. A acção de seguros terá logar em Juizo arbitral, si as partes assim o estipularem na apolice (art. 667 \& 11 Codigo), ou por compromisso posterior".

65 "Art. 411. O Juizo arbitral ou é voluntario ou necessario: § $10^{\circ}$ É voluntario, quando é instituido por compromisso das partes; $\S 2 .^{\circ}$ É necessario, nos casos dos arts. 245, 294, 348, 739, 783 e 846 do Codigo Commercial, e em todos os mais, em que esta fórma de Juizo é pelo mesmo Codigo determinada".

66 "Art. 10. Além dos requisitos essenciaes do art. $8^{\circ}$ podem as partes acrescentar no compromisso as seguintes declarações: (...) $\$ 4 .^{\circ}$ Autorisação para os arbitros julgarem por equidade, independentemente das regras e fórmas do direito".
} 
que as partes descreveriam o objeto da lide e as regras a serem aplicadas para a sua solução, pouco importando a existência de cláusula compromissória arbitral.

Portanto, foi a partir do advento do Decreto n. 3.900 que a cláusula arbitral passou a ser considerada, salvo raras exceções, como mero pactum de compromittendo, dependendo do aperfeiçoamento do "compromisso", com os detalhes da questão controversa, para a sua execução ${ }^{67}$.

Isso, na prática, transformou a cláusula compromissória em verdadeira "cláusula morta", a qual possibilitaria, no máximo, a exigência de perdas e danos da parte faltosa pelo descumprimento da obrigação de firmar o compromisso ${ }^{68}$.

Com relação ao tema específico deste trabalho, nenhuma das leis supracitadas previa a possibilidade de o árbitro conceder tutelas de urgência em arbitragem, não havendo registro sobre o assunto que tenha sido encontrado em pesquisa.

Em seguida, a arbitragem passou a ser disciplinada pelo

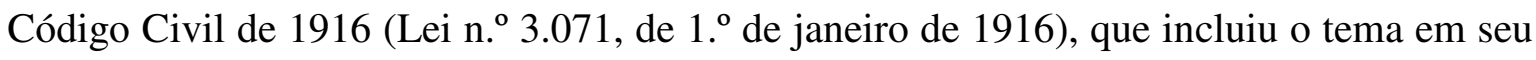
"Livro III - Do Direito das Obrigações", “Título II - Dos Efeitos das Obrigações", "Capítulo X - Do Compromisso", nos seus artigos 1037 a 1048, os quais nada diziam, todavia, a respeito da cláusula compromissória, tampouco acerca da possibilidade de o árbitro conceder tutelas de urgência.

Já no Código de Processo Civil de 1939 (Decreto-Lei n. ${ }^{\circ}$ 1.608, de 18 de setembro de 1939), a arbitragem foi trazida com destaque no "Livro IX Do Juízo Arbitral" em dezesseis artigos distribuídos em três capítulos específicos: "Disposições Gerais"; "Do Andamento da Causa e do Julgamento"; e "Da Homologação" (artigos 1031 a 1046).

Referido Codex, contudo, em linha com a corrente privatista da arbitragem, passou a exigir que a decisão arbitral fosse homologada pela justiça comum

\footnotetext{
${ }^{67}$ Nesse sentido: MARTINS, Pedro A. Batista. A arbitragem no Brasil. In www.tradutoresjuramentados. com/pbm/artigos/arbbra.pdf. Acessado em 09/06/2012.

${ }^{68}$ Com essa mesma opinião: MARTINS, Pedro A. Batista. A arbitragem no Brasil...
} 
para que pudesse produzir os seus efeitos ${ }^{69}$, o que impossibilitava a efetiva resolução dos litígios (ao menos de forma célere e eficaz).

Além disso, o CPC de 1939 também pecou pela falta absoluta de tratamento legal da cláusula compromissória.

Assim, passou a não ser mais suficiente a simples inserção de cláusula compromissória arbitral no contrato, pois era preciso, posteriormente, que fosse firmado o compromisso ${ }^{70} \mathrm{e}$, ainda mais, que depois da solução da controvérsia, as partes obtivessem do Poder Judiciário a homologação da decisão arbitral, o que trazia sérios e graves empecilhos para a utilização efetiva da arbitragem.

Também não havia previsão legal de concessão de tutelas de urgência pelo árbitro no CPC de 1939, tendo tal Código silenciado sobre o assunto.

O posterior Código de Processo Civil de 1973 (Lei n. ${ }^{\circ}$ 5.869, de 11 de janeiro de 1973) disciplinou a arbitragem por meio de seus artigos 1072 a 1102 (dispositivos esses que somente foram revogados pela Lei $n .^{\circ}$ 9.307/96).

Ele trazia capítulo específico sobre a arbitragem ("Capítulo XIV - Do Juízo Arbitral”), dividido em quatro Seções: "Seção I - Do Compromisso" (artigos 1072 a 1077); "Seção II - Dos Árbitros” (artigos 1078 a 1084); Seção III - Do Procedimento" (artigos 1085 a 1097); e "Seção IV - Da Homologação do Laudo" (artigos 1098 a 1102).

\footnotetext{
${ }^{69}$ Especialmente os seus artigos 1041 e 1042: “Art. 1.041. A execução da sentença arbitral dependerá de homologação" e "Art. 1.042. Será competente para a homologação do laudo arbitral o juiz a que, originariamente, competir o julgamento da causa".

70 Sobre o tema, seguem julgados da época do STF: “Cláusula compromissória (pactum de compromitendo) ainda não é o compromisso constitutivo do juízo arbitral, mas obrigação de o celebrar. Trata-se de uma obrigação de fazer, que se resolve em perdas e danos e que, como pacto de ordem privada, não torna incompetente o juiz natural das partes, se a ele recorrem." (RE n. ${ }^{\circ}$ 58.696/SP, 3. a T., Rel. Min. Luiz Gallotti, j. 02/06/1967, DJ 30/08/1967, p. 2625, v.u., RTJ Vol 42, p. 212); “Juízo arbitral. Diferença entre compromisso e cláusula compromissória. Extraordinário indeferido. Agravo não provido." (A.I. n. ${ }^{\circ}$ 28040Guanabara, 1. ${ }^{\text {T }}$., Rel. Min. Pedro Chaves, j. 30/05/1963, DJ 16/08/1963, p. 705, v.u., RTJ Vol 29, p. 263).
} 
Como destaque positivo, cumpre-se ressaltar que o CPC de 1973 trouxe regulamentação específica acerca da cláusula compromissória, mas, como destaque negativo, ele ainda exigia a homologação da sentença $\operatorname{arbitral}^{71}$.

Nesse sentido, em voto prolatado no agravo de instrumento n. ${ }^{\circ}$ 0036712-87.2003.8.26.0000, o juiz AMÉRICO ANGÉLICO relembra que a necessidade da homologação da decisão arbitral praticamente inviabilizava a utilização da arbitragem:

"Nos moldes de sua previsão anterior, disposta no artigo 1072 e ss. no Código de Processo Civil, tornou-se um instituto sem maior incidência na prática a arbitragem, justamente em função da circunstância de que era ordenado e vigiado pelo Estado, havendo sempre a necessidade de um pronunciamento judicial, através de sentença homologatória, para que o laudo arbitral adquirisse a qualidade de título executivo judicial, conforme previsão estatuída no inciso III do artigo 584 do Código de Processo Civil" ${ }^{172}$.

Tal Código passou a ter uma vivência harmônica com as disposições sobre arbitragem trazidas pelo Código Civil de 1916.

No que tange ao assunto específico deste trabalho, os artigos 1086 e 1087 do CPC de 1973 vedavam, expressamente, a concessão de medidas urgentes pelo(s) árbitro(s):

"Art. 1.086. O juízo arbitral pode tomar depoimento das partes, ouvir testemunhas e ordenar a realização de perícia. Mas lhe é defeso:

I - empregar medidas coercitivas, quer contra as partes, quer contra terceiros;

II - decretar medidas cautelares.

Art. 1.087. Quando for necessária a aplicação das medidas mencionadas nos números I e II do artigo antecedente, o juízo arbitral as solicitará à autoridade judiciária competente para a homologação do laudo" (grifamos).

Como último acontecimento, podemos apontar a Lei de Arbitragem brasileira atual, a conhecida Lei n. ${ }^{\circ}$ 9.307, de 23 de setembro de 1996.

\footnotetext{
71 “Art. 1.098. É competente para a homologação do laudo arbitral o juiz a que originalmente tocar o julgamento da causa".

${ }_{72}$ Extinto 2. ${ }^{\circ}$ TACiv-SP, 7. ${ }^{\mathrm{a}}$ Câmara do Quarto Grupo, A.I. n. ${ }^{\circ}$ 0036712-87.2003.8.26.0000 (números anteriores 818.499/0-00 e 992.03.036712-2), Rel. Juiz Américo Angélico, j. 18/11/2003, maioria.
} 


\section{A LEI N. ${ }^{\circ}$ 9.307, DE 23 DE SETEMBRO DE 1996}

Antes da promulgação da Lei n. ${ }^{\circ}$ 9.307/96, a arbitragem era pouco utilizada no Brasil e enfrentava resistência até mesmo dos operadores do direito, seja por tradição ${ }^{73}$, seja por questões culturais ${ }^{74}$.

A partir dessa lei, contudo, e como visto acima, a arbitragem passou a crescer e a ocupar lugar de maior destaque no direito pátrio, especialmente porque ela eliminou dois dos grandes obstáculos até então existentes na legislação brasileira para a efetiva utilização da arbitragem no país, quais sejam: a ausência de regulamentação da cláusula compromissória ${ }^{75}$ e a necessidade de homologação da sentença arbitral $^{76}$.

${ }^{73}$ CARlos Alberto CARMona, citando lição de Giovanni Verde, atesta que "[A] experiência tumultuosa destes últimos quarenta anos nos demonstra que a imagem do Estado onipotente e centralizador é um mito, que não pode (e talvez não mereça) ser cultivado. Deste mito faz parte a idéia de que a justiça deva ser administrada em via exclusiva pelos seus juízes." ("Arbitrato e giurisdizione", L'Arbitro secondo la legge 28/83. Napoli: Jovene Editore, 1985, pp. 161/182, especialmente p. 168, tradução livre) in CARMONA, Carlos Alberto. Arbitragem e Processo..., p. 26. BRUNO OPPETIT também enfatiza "a desconfiança do Estado, em relação a qualquer justiça que não seja a sua", citando entendimento de TROPLONG, no sentido de que "a arbitragem não caberia no horizonte do positivista: só há direito na lei e só os juízes podem aplicá-la; ao Estado pertence o monopólio da expressão jurídica." (OPPETIT, Bruno. Etudes offertes... pp. 188 e 189). Julian M. Lew, LoukAS A. Mistelis e Stefan Michael Kröll também anotam que, "historically, national courts were assertive of their jurisdiction over disputing parties before reaching a conclusion on the merits; this was considered an exclusive sovereign power." (trad. livre: "historicamente, as cortes estatais estavam asseguradas de sua jurisdição sobre partes litigantes antes de chegar a uma conclusão sobre o mérito; isso era considerado um poder soberano exclusivo.") (LEW, Julian M.; MISTELIS, Loukas A.; KRÖLL, Stefan Michael. Comparative International Commercial Arbitration. Haia, Londres, Nova Iorque: Kluwer Law International, 2003, pp. 585/625, esp. p. 587).

${ }^{74}$ PONTES DE MIRANDA afirmava que o juízo arbitral "é primitivo, regressivo mesmo, a que pretendem volver, por atração psíquica a momentos pré-estatais, os anarquistas de esquerda e os de alto capitalismo." (in Comentários ao Código de Processo Civil, Tomo XV. Rio de Janeiro: Forense, 1977, p. 344), também citado por CARMONA, Carlos Alberto. Arbitragem e Processo..., p. 1. Em acórdão prolatado pelo TJ/SP, o Desembargador RODRIGUES DE CARVALHO disse que: "certo é, também, que a arbitragem até então instituída em nossa lei (arts. 1037 a 1048, do Código Civil, e 1072 a 1102, do Código de Processo Civil), tirante algumas hipóteses de convenção estrangeira, raramente logrou êxito no Brasil. E isso, até por não ser próprio de nossa cultura." (TJ/SP, 5. ${ }^{\text {a }}{ }^{\text {C.D.Priv., A.I. n. }}{ }^{\circ}$ 124.217-4/0, Rel. Des. Rodrigues de Carvalho, j. 16/09/1999).

${ }^{75}$ Carlos Alberto Carmona anota que "antes do advento da Lei de Arbitragem, era corrente em nosso país a idéia de que a cláusula compromissória criava apenas uma obrigação de fazer, constituindo-se em pacto preliminar - como disse Clóvis Bevilaqua - 'cujo objeto é a realização de um compromisso, em dada emergência'. Generalizou-se também - antes da Lei - a idéia de que o pacto de compromittendo não teria efeito vinculativo, caracterizando-se como verdadeiro pactum nudum, de tal sorte que, na melhor das hipóteses, seu descumprimento geraria direito a indenização. A jurisprudência era pacífica sob a vigência do Código de Processo Civil de 1973 no sentido de negar à cláusula compromissória o efeito de impedir o acesso à justiça estatal. Conseqüentemente, só o compromisso constituía óbice à regular formação do processo e a cláusula compromissória (simples promessa, dependente de novo acordo dos contratantes) não impedia que as partes pleiteassem seus direitos perante as cortes estatais." (Arbitragem e processo..., p. 100). O acórdão prolatado no REsp n..$^{\circ}$ 616/RJ é um dos poucos acórdãos favoráveis ao efeito vinculante da cláusula compromissória antes da promulgação da Lei n. ${ }^{\circ}$ 9.307/96: "Cláusula de arbitragem em contrato internacional regras do Protocolo de Genebra de 1923. 1. Nos contratos internacionais submetidos ao Protocolo, a cláusula arbitral prescinde do ato subseqüente do compromisso e, por si só, é apta a instituir o 
Com efeito, a Lei de Arbitragem brasileira trouxe regramento claro e específico sobre a cláusula compromissória (artigos $3 .^{\circ}, 4 .^{\circ}, 5 .^{\circ}, 7 .^{\circ}$ e $\left.8 .^{\circ}\right)$, tendo, ainda, afastado à obrigatoriedade da homologação da decisão arbitral (artigo 18$)^{77}$.

Quanto ao principal assunto deste trabalho, a Lei de Arbitragem brasileira também inovou, possibilitando a concessão de tutelas de urgência pelo árbitro, conforme o disposto em seu artigo 22, § 4. ${ }^{\circ}$ :

“Art. 22. Poderá o árbitro ou o tribunal arbitral tomar o depoimento das partes, ouvir testemunhas e determinar a realização de perícias ou outras provas que julgar necessárias, mediante requerimento das partes ou de ofício. (...)

$\S 4^{\circ}$ Ressalvado o disposto no $\S 2^{\circ}$, havendo necessidade de medidas coercitivas ou cautelares, os árbitros poderão solicitá-las ao órgão do Poder Judiciário que seria, originariamente, competente para julgar a causa.”.

Embora tal dispositivo legal não tenha sido muito claro, o que gerou dúvidas quanto ao poder geral de cautela do árbitro no início da vigência da lei, como se verá detalhadamente no "item 15" a seguir, o fato é que já se pacificou o entendimento de que o árbitro pode conceder tutelas de urgência no processo arbitral.

Portanto, conclui-se que a Lei de Arbitragem brasileira, composta de 44 (quarenta e quatro) artigos, distribuídos em 7 (sete) capítulos, apesar de $\operatorname{tardia}^{78}$, trouxe inovações indispensáveis para a segura utilização da arbitragem no país.

juízo arbitral. 2. Esses contratos têm por fim eliminar as incertezas jurídicas, de modo que os figurantes se submetam, a respeito do direito, pretensão, ação ou exceção, à decisão dos árbi-tros, aplicando-se aos mesmos a regra do art. 244, do CPC, se a finalidade for atingida. 3. Recurso conhecido e provido." (STJ, 3. ${ }^{a}$ Turma, REsp n. ${ }^{\circ}$ 616/RJ, Relator originário: Min. Cláudio Santos, Relator para acórdão: Min. Gueiros Leite, j. 24/04/1990, maioria, RTJ 37/263). Referido acórdão certamente serviu de diretriz para a legislação ora vigente, tendo em vista que, utilizando-se das regras do Protocolo de Genebra de 1923 (o qual foi recepcionado pelo Brasil por meio do Decreto n. ${ }^{\circ}$ 21.187, de 22 de março de 1932), no sentido de não haver distinção entre cláusula compromissória e compromisso arbitral, acolheu e reconheceu a força vinculante da cláusula compromissória, entendendo ser possível a exclusão da jurisdição estatal para apreciar determinada questão de direito disponível somente frente à existência de cláusula compromissória arbitral em contrato comercial internacional, independentemente da posterior assinatura do compromisso arbitral.

${ }^{76}$ Nesse sentido: "Basicamente, eram dois os grandes obstáculos que a lei brasileira criava para a utilização da arbitragem: em primeiro, o legislador simplesmente ignorava a cláusula compromissória (o Código Civil de 1916 e o Código de Processo Civil de 1973 não exibiam qualquer dispositivo a esse respeito); ao depois, seguindo a tradição de nosso direito, exigia a homologação judicial do laudo arbitral." (CARMONA, Carlos Alberto. Arbitragem e Processo..., p. 4).

77 "Art. 18. O árbitro é juiz de fato e de direito, e a sentença que proferir não fica sujeita a recurso ou a homologação pelo Poder Judiciário". 
Ela tornou a arbitragem mais simples, objetiva e segura, eliminando a necessidade de homologação da decisão arbitral pelo Poder Judiciário, regulando a cláusula compromissória arbitral e possibilitando a concessão de tutelas de urgência pelo árbitro, fazendo com que o processo arbitral tenha menos pontos de encontro com o juízo estatal, sendo certo que, quanto mais a arbitragem venha a necessitar do Poder Judiciário, mais prejudicados ficam a celeridade e o sigilo dos atos ${ }^{79}$ (principais qualidades da arbitragem, juntamente com a especificidade do árbitro ${ }^{80}$ ), isto é, mais comprometido fica o próprio instituto da arbitragem ${ }^{81}$.

${ }^{78}$ Para se ter uma idéia da demora brasileira em regular de forma eficaz a arbitragem, verifica-se que a Convenção Interamericana sobre Arbitragem Comercial Internacional (subscrita pelo Brasil) é de 30 de janeiro de 1975. Igualmente, enquanto a Bélgica (em 1972), a França (em 1980), Portugal (em 1986), a Itália (em 1983) e a Espanha (em 1988) aboliram ou mitigaram as exigências de homologação da sentença arbitral, isso somente veio a ocorrer no Brasil em 1996, com a Lei n. ${ }^{0}$ 9.307/96 (Cf. CARMONA, Carlos Alberto. Arbitragem e Processo..., p. 5). Com relação às arbitragens para soluções de conflitos oriundos do comércio internacional, a burocracia e a lentidão legislativa no Brasil continuam emperrando a adoção de tratados e convenções sobre o tema. Como lembra LUIS FERNANDO GUERRERO, a Convenção de Viena sobre contratos de compra e venda internacional de mercadorias, que foi desenvolvida pela UNCITRAL (sigla em inglês para a "Comissão das Nações Unidas para o Direito Comercial Internacional”) e assinada em abril de 1980, ainda depende da atuação de nosso Congresso para a sua aprovação e para a sua aplicação expressa no Brasil, embora já tenha sido "aprovada por mais de 78 países, representativos de mais de $90 \%$ do comércio mundial e de $75 \%$ do comércio internacional brasileiro". Para suprir essa demora na aprovação da Convenção de Viena pelo Congresso brasileiro, "são cada vez mais comuns cláusulas compromissórias em contratos, abarcando empresas brasileiras, que indicam a Convenção de Viena como 'regra de direito' a ser utilizada para a solução de litígio em vez da lei nacional de cada uma das partes, que figura em uma relação de compra e venda internacional de mercadorias." (in "Convenção de Viena e a arbitragem", matéria publicada no jornal "Valor Econômico", caderno "Legislação e Tributos", de 15/06/2012).

${ }^{79}$ BRUNO OPPETIT destaca que "o tribunal arbitral não se submete ao princípio da publicidade; ao contrário, o segredo protege suas deliberações." (Etudes offertes..., p. 192). Isso porque, na França, o art. 1479 do Código de Processo Civil prevê, expressamente, o sigilo da decisão arbitral: "Arte. 1479. Les délibérations du tribunal arbitral sont secrètes." (trad. livre: "Art. 1479. As decisões do tribunal arbitral são secretas."). NEIL ANDREWS também pontifica que "arbitration does not embody the principle of publicity. This is because arbitration proceedings are not held in public but are instead confidential." (trad. livre: "a arbitragem não abarca o princípio da publicidade. Isso porque os processos arbitrais não correm em público, mas, ao revés, são confidenciais.") (Arbitration and mediation in England..., p. 111). JosÉ ANTÔNIO FICHTNER, SERGIO NELSON MANNHEIMER e ANDRÉ LUís MONTEIRO mencionam que, "inegavelmente, a confidencialidade na arbitragem é uma qualidade reconhecida internacionalmente. A Comissão das Nações Unidas para o Direito do Comércio Internacional, em suas Notes on Organizing Arbitral Proceedings, de 1996, reconhecem na primeira parte do item 31, que 'it is widely viewed that confidentiality is one of the advantageous and helpful features of arbitration'." ("Cinco pontos sobre a arbitragem no Projeto do novo Código de Processo Civil". Revista de Processo - RePro, ano 37, n. ${ }^{\circ}$ 205. São Paulo: RT, março de 2012, pp. 307/331, p. 321). O Projeto de Lei n. ${ }^{\circ}$ 8.046/2010, em trâmite na Câmara dos Deputados, que institui um novo CPC, contém previsão que preserva a confidencialidade da arbitragem no processo judicial: “Art. 164. Os atos processuais são públicos. Correm, todavia, em segredo de justiça os processos: (...) IV - que dizem respeito ao cumprimento de carta arbitral, desde que a confidencialidade estipulada na arbitragem seja comprovada perante o juízo".

${ }^{80}$ NEIL ANDREWS anota que a arbitragem "offers the benefits of ( $i$ ) confidentiality, (ii) consensual choice of arbitrator and (iii) selection of substantive norms, (iv) potential procedural flexibility, and (v) speedy enforcement of norms." (trad. livre: "oferece os benefícios da (i) confidencialidade, (ii) escolha consensual do árbitro e (iii) seleção das normas substantivas, (iv) potencial flexibilidade do procedimento, e (v) celeridade da execução das decisões.") (Arbitration and mediation in England..., p. 108). O autor ainda ressalta que os 
Não há dúvida, pois, de que a Lei n. ${ }^{0} 9.307 / 96^{82}$, instituiu uma nova visão sobre a arbitragem, possibilitando a efetiva utilização desse meio de solução de controvérsias no país em maior escala e com mais segurança, tanto por pessoas físicas, como jurídicas, para o fim de dirimir questões envolvendo direitos patrimoniais disponíveis.

árbitros não precisam ser advogados, podendo ser escolhidos pelas partes com base em sua especialidade, em seu conhecimento e na sua experiência (idem, p. 114).

${ }^{81}$ BRUNO OPPETIT alerta que a "freqüente utilização - da jurisdição estatal pela arbitragem - ameaça alterar a natureza profunda da justiça privada", bem como que o "vai e vem contínuo entre os recintos arbitrais e o palácio da justiça" deve ser corrigido. Caso contrário "tais desvios - cujos primeiros responsáveis são as partes e seus advogados -, pelos custos, pelo prolongamento dos procedimentos e complicações decorrentes, comprometerão a utilidade e a própria vocação da arbitragem.” (OPPETIT, Bruno. Etudes offertes..., p. 194). Corroborando esse entendimento, PAULO HOFFMAN ressalta "que essa intervenção [do Poder Judiciário na arbitragem] deve ser sempre residual e limitada a casos estritamente necessários, sob pena de aniquilar-se com o processo arbitral." (HOFFMAN, Paulo. "Arbitragem: algumas dúvidas processuais práticas quando o juízo estatal é chamado a intervir”. Arbitragem no Brasil - aspectos jurídicos relevantes. JOBIM, Eduardo; MACHADO, Rafael Bicca (coord.). São Paulo: Quartier Latin, 2008, pp. 301/326, p. 309).

${ }^{82}$ Ressalte-se que, dezesseis anos após o início da vigência da Lei de Arbitragem brasileira, o Senado Federal criou uma comissão especial para elaborar o anteprojeto de sua reforma, comissão essa que será presidida pelo Ministro LuIS FeliPE SALOMÃo e que será composta pelos juristas: MARCO MACIEL, JosÉ ANTÔNIO Fichtner, Caio Cesar Rocha, José Rogério Cruz e Tucci, Marcelo Rossi nobre, Francisco antunes Maciel Mussnich, Tatiana lacerda Prazeres, Adriana Braghetta, Carlos Alberto Carmona, Eleonora Coelho, Pedro Paulo Guerra de Medeiros, Silvia Rodrigues Pereira PACHIKOSKI e FRANCISCO MAIA NETO (www.migalhas.com.br/Quentes/17,MI168151,31047-Designada+ comissao+que+ira+elaborar+proposta+de+atualizacao+da+lei+de. Acessado em 03/12/2012). Na justificativa da proposta apresentada pelo Senador Renan Calheiros, ele afirmou que a arbitragem cresceu muito desde a sanção da Lei n. ${ }^{\circ}$ 9.307/96, bem como que as regras do instituto precisam ser atualizadas. O Ministro LUIS FELIPE SALOMÃo disse que o objetivo da comissão "é fortalecer a arbitragem como meio viável e célere de resolução de conflitos", lembrando que "por mais curioso que possa parecer, é o próprio Judiciário que vem fortalecendo e atualizando de forma indireta a Lei de Arbitragem. Os precedentes do STJ vêm no sentido de garantir a autonomia da decisão arbitral." (cf. www.stj.jus.br/portal_stj/publicacao/engine.wsp?tmp.area= 398\&tmp.texto=106824. Acessado em 04/09/2012). 


\title{
CAPÍTULO III
}

\section{NATUREZA JURÍDICA DA ARBITRAGEM E A SUA IMPORTÂNCIA NA DELIMITACÃO DOS PODERES DO ÁRBITRO PARA CONCEDER TUTELAS DE URGÊNCIA}

\begin{abstract}
Embora a natureza jurídica da arbitragem seja assunto já esgotado pela doutrina pátria ${ }^{83}$, faz-se relevante, para o presente trabalho, trazer um resumo das quatro correntes encontradas, bem como explicar em que medida a adoção de uma ou outra teoria repercutirá na delimitação dos poderes do árbitro para conceder tutelas de urgência em um processo arbitral.
\end{abstract}

De fato, ao longo do tempo, quatro foram as teorias desenvolvidas e sistematizadas acerca da natureza jurídica da arbitragem. São elas: (i) a teoria publicista ou processualista; (ii) a teoria contratual ou privatista; (iii) a teoria mista (contratual-publicista); e (iv) a teoria autônoma (esta, nem sempre mencionada).

Como se verá a seguir, a teoria publicista ou processualista adota a tese da jurisdicionalidade da arbitragem ${ }^{84}$, considerando que o árbitro recebe das partes o poder jurisdicional, ficando este subtraído ao juízo estatal ${ }^{85}$, o que possibilita ao árbitro a apreciação e a concessão de tutelas de urgência.

Por outro lado, aqueles que adotam a teoria contratual ou privatista, considerando, por conseguinte, que não há exercício de poderes jurisdicionais pelo(s) árbitro(s), muitas vezes são contrários à possibilidade de apreciação e de concessão

\footnotetext{
${ }^{83}$ Sobre o assunto, CARlos Alberto CARMona faz a seguinte crítica: "A verdade, porém, é que o debate [sobre a natureza jurídica da arbitragem] adquiriu um colorido excessivamente acadêmico e, pior, pouco prático, de sorte que não parece útil continuar a alimentar a celeuma. Não há tratado, manual, tese ou monografia - refiro-me agora à bibliografia nacional produzida nestes onze anos de vigência da Lei de Arbitragem - que não tenha desafiado o assunto, explorando filão que já se esgotara nas duas últimas décadas do século XX." (CARMONA, Carlos Alberto. Arbitragem e Processo..., p. 27).

${ }^{84}$ Cf. CARMONA, Carlos Alberto. Arbitragem e Processo..., p. 26.

85 “A convenção de arbitragem produz efeitos negativos e positivos. Enquanto pelo negativo subtrai poder jurisdicional ao juiz estatal, possibilita, pelo positivo, a outorga de tais poderes ao árbitro. Instaurada a instância arbitral, o árbitro é juiz de fato e de direito. Afasta-se o juiz estatal, não por falta de competência, mas, antes, por ausência de jurisdição." (VALENÇA FILHO, Clávio de Melo. "Sentença arbitral e juízo de execuções" in Revista do Advogado, n. ${ }^{\circ}$ 87, Ano XXVI. São Paulo: AASP, setembro de 2006, p. 36).
} 
de tutelas de urgência em um processo arbitral, sustentando a tese de que tais medidas somente poderiam ser apreciadas pelo Poder Judiciário.

Portanto, a relevância do presente capítulo reside no fato de este trabalho adotar a teoria publicista ou processualista da arbitragem, a qual considera que a arbitragem possui natureza jurisdicional, o que possibilita ao árbitro apreciar e conceder tutelas de urgência em um processo arbitral.

\section{TEORIA PUBLICISTA (OU PROCESSUALISTA)}

A teoria publicista ou processualista considera que a atividade dos árbitros é jurisdicional e derroga as regras de competência estatal, equiparando a sentença arbitral à sentença proferida pelo Poder Judiciário ${ }^{86}$.

${ }^{86}$ Cf. GUERRERO, Luis Fernando. Tutela de Urgência..., p. 28. Nesta obra, ele menciona quem aderiu à teoria publicista: desde o início, CARMONA, Carlos Alberto. Arbitragem e processo, 1. a edição. São Paulo: Malheiros, 1998, p. 32; MORTARA, Ludovico. Commentario del codice e della legge di procedura civile. Milano: Casa Editrice Dottor Francesco Vallardi, v. III, 1923, n. 34 ; LEMES, Selma M. Ferreira. "Os princípios jurídicos da Lei de Arbitragem" in Aspectos fundamentais da Lei de Arbitragem. MARTINS, Pedro A. Batista; LEMES, Selma M. Ferreira; CARMONA, Carlos Alberto (coord.). Rio de Janeiro: Forense, 1999, p. 107; e LA CHINA, Sergio. L'Arbitrato - Il Sistema e L'Esperienza. Milano: Giuffrè, 1995, p. 13. Ainda adotando a mesma teoria: CARMONA, Carlos Alberto. Arbitragem e Processo..., p. 26; VALENÇA FILHO, Clávio de Melo. Sentença arbitral e..., p. 36; PRADO, Vinícius de Andrade. "Medidas cautelares no procedimento arbitral" in Estudos em arbitragem, mediação e negociação. AZEVEDO, André Gomma de (org.). Brasília: Brasília Jurídica, 2002, p. 197; SIMÃO, José Fernando. "A natureza jurídica da arbitragem" in Novos Rumos da Arbitragem no Brasil. GUILHERME, Luiz Fernando do Vale de Almeida (coord.). São Paulo: Fiuza, 2004, p. 233; GIUSTI, Gilberto. "O árbitro e o juiz: da função jurisdicional do árbitro e do juiz" in Revista Brasileira de Arbitragem, n. ${ }^{\circ}$ 5, São Paulo: IOB/CBAr, 2005, pp. 07 e 09; BENETI, Sidnei. “Arbitragem e tutelas de urgência". Revista do Advogado - Arbitragem e Mediação, n. ${ }^{\circ}$ 87. São Paulo: AASP, setembro de 2006, p. 101; OPPETIT, Bruno. Etudes offertes..., p. 190; BOISSESÓN, Matthieu de. Droit francais de l'arbitrage: interne et international. Paris: GLN Joly, 1990, p. 06; MOTULSKY, Henry. La nature juridique de l'arbitrage. In Ecrits, t. II, Dalloz, 1974, p. 05; THEODORO JÚNIOR, Humberto. Curso de Direito Processual Civil, v. III, 34. ${ }^{a}$ edição. Rio de Janeiro: Forense, 2005, p. 330; FICHTNER, José Antônio; MANNHEIMER, Sergio Nelson; MONTEIRO, André Luís. Cinco pontos sobre a arbitragem..., p. 308; NERY JÚNIOR, Nelson. Código Brasileiro de Defesa do Consumidor comentados pelos Autores do Anteprojeto. [et al.], 8. a edição. Rio de Janeiro: Forense Universitária, 2004, pp. 357/358: "O que se exclui pelo compromisso arbitral é o acesso à via judicial, mas não à jurisdição. Não se poderá ir à justiça estatal, mas a lide será resolvida pela justiça arbitral. Em ambas há, por óbvio, a atividade jurisdicional.”; FIGUEIRA JÚNIOR, Joel Dias. Arbitragem, jurisdição e execução, 2. a edição. São Paulo: RT, 1999, p. 157: "podemos afirmar categoricamente que o juízo arbitral instituído pela Lei 9.307/96 apresenta natureza jurisdicional”. Ainda nesse sentido: “(...) em este equivalente jurisdiccional, que es el arbitraje, los árbitros no están sujetos a las misma normas que los jueces." (trad. livre: (...) em este equivalente jurisdicional, que é a arbitragem, os árbitros não estão sujeitos as mesmas normas que os juízes.) (CUESTA SAENZ, José Maria de la, "Introduccion al arbitraje de consumo". Revista de Derecho Privado, s/n. ${ }^{\circ}$, Madrid, Feb. 1997, pp. 122/123); e "En même temps que la réforme de 1980 reconnaissait en l'arbitrage une institution de caractère juridictionnel, (...)" (trad. livre: "ao mesmo tempo em que a reforma de 1980 reconheceu na arbitragem uma instituição de caráter jurisdicional, (...)") (NORMAND, Jacques. "Les mesures provisoires et l'arbitrage". Les mesures provisoires en droit belge, français et italien. VAN COMPERNOLLE, Jacques; TARZIA, Giuseppe (org.). Bruxelas: Bruylant, 1998, pp. 461/471, esp. p. 461). 
Os defensores dessa corrente partem da premissa não da vontade das partes, mas da vontade do legislador de fundamentar a arbitragem, defendendo a tese de que o Estado outorga ao árbitro, assim como outorga ao juiz, poderes para resolver conflitos ${ }^{87}$.

A nosso ver, no Brasil, o legislador fez uma clara e evidente opção pela teoria publicista (ou processualista) da arbitragem, nos termos, especialmente, dos artigos 18 e 31 da Lei n. ${ }^{\circ} 9.307 / 96^{88}$, os quais equiparam o árbitro ao juiz e estabelecem que a decisão proferida pelo árbitro produz os mesmos efeitos, entre as partes e seus sucessores, de uma sentença proferida pelo Poder Judiciário.

Há, inclusive, jurisprudência adotando a teoria da natureza publicista ou processualista da arbitragem, jurisprudência esta que encampa a tese de que há prestação jurisdicional pelo(s) árbitro(s) ${ }^{89}$.

Por essas razões, e com base na adequação do antigo conceito de jurisdição à realidade atual, como se verá no "item 10" abaixo, entende-se que a teoria publicista ou processualista é a que melhor define a natureza jurídica da arbitragem, adotando-se tal teoria, portanto, para este estudo, a qual permite a apreciação e a concessão

${ }^{87}$ Cf. BASILIO, Ana Tereza Palhares; FONTES, André R. C. "Notas introdutórias sobre a natureza jurídica da arbitragem" in Revista de Arbitragem e Mediação, ano 4, vol. 14. WALD, Arnoldo (coord.). São Paulo: RT, julho/setembro de 2007, pp. 48/51, p. 50.

88 "Art. 18. O árbitro é juiz de fato e de direito, e a sentença que proferir não fica sujeita a recurso ou a homologação pelo Poder Judiciário" e "Art. 31. A sentença arbitral produz, entre as partes e seus sucessores, os mesmos efeitos da sentença proferida pelos órgãos do Poder Judiciário e, sendo condenatória, constitui título executivo". Sobre o assunto, ver: CARMONA, Carlos Alberto. "Arbitragem e jurisdição" in Revista de Processo - RePro, n. ${ }^{\circ}$ 58. São Paulo: RT, 1990, pp. 33/40; e GUERRERO, Luis Fernando. “Arbitragem e jurisdição: premissa à homologação da sentença arbitral estrangeira” in Revista de Processo - RePro, ano 33, n. ${ }^{\circ}$ 159. São Paulo: RT, maio de 2008, pp. 09/34.

${ }^{89}$ Nesse diapasão: “A solução do litígio, dar-se-á pela justiça arbitral e, não pela justiça comum. Nas duas,

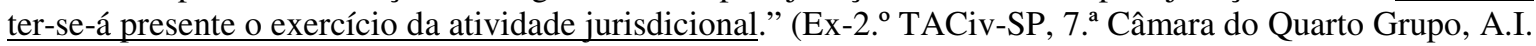
n. ${ }^{\circ}$ 0036712-87.2003.8.26.0000 - n. ${ }^{\text {os }}$ antigos 818.499/0-00 e 992.03.036712-2, Rel. Juiz Américo Angélico, j. 18/11/2003, maioria, grifamos); "Outrossim, como é consabido, a sentença arbitral produz entre as partes e seus sucessores, os mesmos efeitos da sentença proferida pelos órgãos do Poder Judiciário e, uma vez dotada de força condenatória, constitui título executivo, visto que, o que se exclui pela arbitragem (Lei $n^{\circ}$ 9.307/96) não é, propriamente, o acesso à jurisdição, mas, sim, à via judicial estatal. Portanto, a solução do litígio há de vir pela justiça arbitral e, não pelo Estado-Juiz (justiça estatal). Inegável, nada obstante, que nas duas hipóteses evidencia-se o exercício da atividade jurisdicional." (TJ/SP, 31. ${ }^{\mathrm{a}}$ Câm. Dir. Privado, Ap. c/ rev. n. ${ }^{\circ}$ 0083532-64.2009.8.26.0224, Rel. Des. ADILSON DE ARAÚJO, j. 29/03/2011, v.u., g.n.). E ainda: “Assim, os argumentos da doutrina favoráveis à jurisdicionalidade do procedimento arbitral revestem-se de coerência e racionalidade. Não há motivos para que se afaste o caráter jurisdicional dessa atividade." (STJ, 2. " Seção, CC 113.260-SP, voto da Min. Nancy Andrighi, g.n.); e “(...) não se negando, nos termos mesmo do voto, da Eminente Ministra Relatora, que a jurisdição arbitral seja também jurisdição, mas uma jurisdição que não é a jurisdição estatal, é a jurisdição convencional." (STJ, 2. ${ }^{a}$ Seção, CC 113.260-SP, voto do Min. Sidnei Beneti). 
de tutelas de urgência pelo árbitro, por entender que este possui a maior parte dos poderes jurisdicionais.

\section{TEORIA CONTRATUAL (OU PRIVATISTA)}

A teoria contratual ou privatista considera a arbitragem como criação da autonomia da vontade, associando-a a idéia de negócio jurídico e, mais especificamente, a um contrato, sendo, por conseguinte, de natureza privada ${ }^{90}$.

De acordo com os adeptos dessa teoria, não há exercício de poderes jurisdicionais pelos árbitros, tendo em vista que (i) estes não têm poder de imperium; (ii) não exercem atividades coercitivas e não são capazes de impor sanções; (iii) não atuariam a vontade concreta da lei (podem julgar por eqüidade) ${ }^{91}$; e, (iv) em muitas legislações, suas decisões dependem da homologação pelo Poder Judiciário local para que tenham eficácia ${ }^{92}$.

${ }^{90}$ Cf. BASILIO, Ana Tereza Palhares; FONTES, André R. C. Notas introdutórias sobre..., p. 49. Ainda: "Para os defensores da corrente privatista, entre eles, no estrangeiro, Saltore Satta, Carnelluti, Alfredo Rocco, Chiovenda, Elio Fazzalari e no Brasil, Cezar Fiúza, Cláudio Vianna de Lima entre outros, a opção pela utilização de árbitros seria um acordo, cujo objetivo é a renúncia à jurisdição e, via de consequiência, à ação, para solução de determinada controvérsia." (COUTINHO, Cristiane Maria Henrichs de Souza. Arbitragem e a Lei n. ${ }^{\circ} 9$ 307/96. Rio de Janeiro: Forense, 1999, p. 20).

${ }^{91}$ Cf. artigos 2..$^{\circ}$ e 11, inc. II, da Lei n. $.^{\circ} 9.307 / 96$. Em Portugal, o artigo 39. ", "1" da Lei n. ${ }^{\circ} 63 / 2011$ também autoriza o julgamento por eqüidade na arbitragem voluntária: "Artigo $39 .^{\circ}$ Direito aplicável; recurso à equidade; irrecorribilidade da decisão 1 - Os árbitros julgam segundo o direito constituído, a menos que as partes determinem, por acordo, que julguem segundo a equidade". E, em caso de julgamento por equiidade, não se autoriza qualquer recurso contra a decisão arbitral (art. 39. ., "4", da Lei n. ${ }^{\circ}$ 63/2011). NEIL ANDREWS aduz que, na Inglaterra, as partes também podem optar que a arbitragem seja julgada com base em "norms drawn from general principles of equity or religious law." (trad. livre: "normas advindas dos princípios gerais de equiidade ou leis religiosas.") (Arbitration and mediation in England..., p. 115).

92 Cf. GUERRERO, Luis Fernando. Tutela de Urgência..., p. 28. Adotando a teoria contratual ou privada: CHIOVENDA, Giuseppe. Istituzioni di diritto processuale civile, 1. ${ }^{a}$ edição. Napole: Jovene, 1928, p. 82; SATTA, Salvatore. Diritto processuale civile. 1. ${ }^{a}$ edição. Padova: Cedam, 1973, pp. 704/705; ZAVASCKI, Teori Albino. Comentários ao Código de Processo Civil, v. 8, 2. ${ }^{a}$ edição. São Paulo: RT, 2003, pp. 165/185; LIMA, Cláudio Vianna de. "Notícia da Arbitragem no Direito Positivo Brasileiro". Revista Forense, n. ${ }^{\circ} 34$, abr/jun de 1996, pp. $43 / 55$ p. 43; ARENHART, Sérgio Cruz. Breves observações...; MARINONI, Luiz Guilherme. Teoria Geral do Processo. São Paulo: RT, 2006, p. 147; e GOMES, Luiz Felipe Azevedo. A intervenção do Estado na arbitragem. Ajuris. Ano XXIV, s/n, março. Porto Alegre, 1997, p. 369. VINícIUS DE ANDRADE PRADO anota que "Chiovenda conferia à arbitragem natureza contratual ou privatista no sentido de que a lei resguardaria às partes o direito de deixar que a 'matéria lógica' fosse preparada sem o uso de poderes jurisdicionais. Acentuava-se tal posicionamento no pensamento de Chiovenda visto que a lei italiana exigia a homologação do laudo arbitral.” (PRADO, Vinícius de Andrade. Medidas cautelares..., p. 192). 
Para a teoria privatista, pois, a arbitragem seria estritamente contratual, considerada apenas fruto de um contrato firmado entre as partes, não tendo qualquer ligação com a jurisdição ${ }^{93}$.

Em razão disso, a maior parte dos defensores desta teoria entendem não ser possível que o árbitro aprecie e conceda tutelas de urgência em uma arbitragem, as quais devem ser sempre buscadas junto ao Poder Judiciário ${ }^{94}$.

\section{TEORIA MISTA (CONTRATUAL-PUBLICISTA)}

A teoria mista, como o próprio nome diz, adota parte dos fundamentos da teoria contratual e parte dos elementos da teoria publicista.

Fundamenta-se no posicionamento de que a arbitragem se desenvolve fora de um sistema jurídico, mas que ela estaria, de certa forma, vinculada à legislação do local de sua sede.

Além disso, considera que a arbitragem teria determinada dependência em relação ao sistema jurídico (e.g.: deve ser ao menos permitida pelo sistema), não sendo, contudo, inteiramente controlada pelo mesmo ${ }^{95}$.

\footnotetext{
93 BRUno OpPetit afirma que G. CORNu e J. FOYER, em sua obra Procédure civile (PUF, Coll., Thémis, 1958, p. 47), sustentam que "vista como o exercício de atributo da soberania, a priori, a função jurisdicional seria monopólio do Estado; a(s) justiça(s) privadas seria(m) apenas tolerada(s) pelo Estado. Dessa forma, haveria profunda diferença entre a natureza de ambas." (OPPETIT, Bruno. Etudes offertes... p. 188).

${ }^{94}$ Por todos, cite-se o magistério de SÉRGIO CRUZ ARENHART: “(...) a atividade arbitral não pode (...) ser tida como jurisdicional. Isso, obviamente, não retira desta atividade a sua importância ou reduz sua utilidade. (...) Logicamente, isso pode trazer reflexos, especialmente no que se refere à possibilidade de árbitros concederem medidas de urgência. Partindo-se da premissa acima lançada - do caráter não-jurisdicional da arbitragem - realmente resulta como indiscutível a conclusão de que não podem os árbitros exercer esse poder. Sempre deverá o interessado buscar tais medidas junto à jurisdição estatal, sendo claramente ineficaz qualquer decisão arbitral a este respeito. Às críticas que se podem formular a essa conclusão, pode-se responder com simples argumento prático: de que serve uma medida urgente concedida por um árbitro, se - ao menos na forma da legislação atual - deve ela ser concretizada dentro do Poder Judiciário? Note-se, nesse passo, que o Poder Judiciário, para realizar essa decisão provisória arbitral, utilizaria do processo de execução, indiscutivelmente inadequado para atender à urgência de qualquer situação. Mais que isso, é lógico que, ao submeter esta decisão arbitral ao Poder Judiciário, autoriza-se também este órgão a perquirir a legitimidade daquela decisão, seja porque se trata de decisão provisória arbitral - que não se revestiria da estabilidade natural da sentença arbitral - seja em razão da autorização contida no art. 32, da lei de arbitragem, combinada com o preceito descrito no art. 33, $\S 3^{\circ}$, da mesma lei." (ARENHART, Sérgio Cruz. Breves observações...).

${ }^{95}$ Cf. GUERRERO, Luis Fernando. Tutela de Urgência..., p. 29.
} 
De acordo com essa teoria, a arbitragem seria contratual na sua origem e jurisdicional no seu resultado ${ }^{96}$.

E, por possuir a arbitragem finalidade jurisdicional, os defensores dessa teoria também entendem que o árbitro possui poderes para apreciar e conceder tutelas de urgência no processo arbitral, notadamente se não houver qualquer vedação a respeito na cláusula compromissória ou no compromisso arbitral.

\section{TEORIA AUTÔNOMA}

Por fim, há também a teoria autônoma, aplicável em especial às arbitragens internacionais, em que não há ligação do procedimento arbitral com eventuais regras de quaisquer sistemas jurídicos ${ }^{97}$.

Para essa teoria, as arbitragens internacionais teriam fundamento e se desenvolveriam com base em regras próprias, adotadas pelas próprias partes da arbitragem, sem vinculação com qualquer sistema jurídico, seja com os sistemas jurídicos dos países das partes envolvidas, seja com o sistema jurídico do país da sede do órgão arbitral julgador.

Sob a ótica dessa teoria, a decisão arbitral é um ato autônomo, não vinculado a qualquer jurisdição.

\footnotetext{
96 Nessa esteira, SElma MARIA FERREIRA LEMES "ressalta ser ela (a arbitragem) contratual na fonte, mas jurisdicional no objeto.” (LEMES, Selma M. Ferreira. Arbitragem na Administração Pública..., pp. 60/61). Ainda: "Adota-se aqui, portanto, a teoria mista para explicar a arbitragem como um fenômeno contratual na origem, mas jurisdicional na sua essência de forma de solução de conflitos.” (GUERRERO, Luis Fernando. Tutela de Urgência..., p. 23). No direito estrangeiro, adotam tal teoria: CARNELUTTI, Francesco. Instituzioni del processo civile italiano, 5. ${ }^{\mathrm{a}}$ edição. Roma: Foro Italiano, 1956, p. 120; RUBINOSAMMARTANO, Mauro. Il Diritto dell'Arbitrato (Interno), 2. ${ }^{\text {a }}$ edição. Padova: Cedam, 1994. p. 28; e BERNARDINI, Piero. The Powers of the Arbitrator..., p. 29: “(...) even if the source of the arbitrator's powers is contractual, the latter's function is jurisdictional similarly to that of the state court." (trad. livre: “(...) mesmo se a origem dos poderes do árbitro é contratual, sua função final é jurisdicional, similarmente àquela da corte estatal.”).

${ }^{97}$ Cf. GUERRERO, Luis Fernando. Tutela de Urgência..., p. 29. Sobre essa teoria, ver ainda: DOLLINGER, Jacob; TIBURCIO, Carmen. Direito internacional privado - Arbitragem comercial internacional, 1. a edição. Rio de Janeiro: Renovar, 2003, pp. 96/97; DAVID, René. L'arbitrage Dans Le Commerce International, 1. ${ }^{a}$ edição. Paris: Económica, 1981, pp. 20/23; RUBELLIN-DEVICHI, Jacqueline L'Arbitrage. Nature Juridique. Droit Interne et Droit International Privé. Paris: LGDJ, 1965, p. 24; e LEW, Julian M.; MISTELIS, Loukas A.; KRÖLL, Stefan Michael. Comparative International..., pp. 81/82.
} 
Como as próprias partes acordariam as regras a serem adotadas na arbitragem, seria possível, com base nessa teoria, a outorga de poderes ao árbitro para a apreciação e a concessão de tutelas de urgência. 


\section{CAPÍTULO IV}

\section{JURISDIČ̃̃O E OS PODERES JURISDICIONAIS DO ÁRBITRO}

\section{FLEXIBILIZAÇÃO DO CONCEITO DE JURISDIÇÃO}

Como visto acima, este trabalho adota a teoria publicista ou processualista da arbitragem, sendo necessário, para tanto, tecer alguns comentários sobre a flexibilização e a adequação do conceito de jurisdição para a sua aplicação à arbitragem.

HUMBERTO THEODORO JÚNIOR, citando o ensinamento de ENRICO TUllio LiEBMAN, conceitua a jurisdição como "o poder que toca ao Estado de formular e de fazer atuar praticamente a regra jurídica concreta que, por força do direito vigente, disciplina uma determinada situação jurídica" ${ }^{, 98}$.

De acordo com os defensores da teoria contratual ou privatista, a arbitragem não possuiria jurisdicionalidade diante desse conceito tradicional de jurisdição, no sentido de que esta é uma das funções exercidas com exclusividade e unicamente pelo Estado, sendo os titulares dos interesses em litígio "substituídos pela figura do juiz estatal, que, de maneira imparcial, pacificará o conflito com Justiça" "99 , não sendo possível que particulares exerçam a jurisdição.

Nesse sentido, cite-se, por todos, Sergio Cruz Arenhart, o qual aduz não ser possível considerar a arbitragem como jurisdicional ${ }^{100}$, de acordo com as

\footnotetext{
${ }^{98}$ In Processo Cautelar, 18. ${ }^{\text {a }}$ edição. São Paulo: Livraria e Editora Universitária de Direito, 1999, p. 28.

${ }^{99}$ Cf. GUERRERO, Luis Fernando. Tutela de Urgência..., p. 29. Nessa mesma linha, AdA PELLEGRINI GRINOVER afirma que a jurisdição é "uma das funções do Estado, mediante a qual este se substitui aos titulares dos interesses em conflito para, imparcialmente, buscar a atuação da vontade do direito objetivo que rege a lide que lhe é apresentada em concreto para ser solucionada." (in Teoria Geral do Processo, 6. " edição - em cooperação com CINTRA, Antonio Carlos de Araújo; e DINAMARCO, Cândido Rangel. São Paulo: Malheiros, 1987, p. 83). Ainda nesse sentido: CARNEIRO, Athos Gusmão. Jurisdição e competência, 12. 'a edição. São Paulo: Saraiva, 2002. pp. 04/05.

100 "De toda exposição feita, ainda que de forma incompleta e sumária, resulta a constatação de que a atividade arbitral não pode, ao menos segundo as teorias de jurisdição que se costuma adotar atualmente, ser tida como jurisdicional.” (ARENHART, Sérgio Cruz. Breves observações sobre...).
} 
definições clássicas de jurisdição trazidas por Allorio ${ }^{101}$, CARNELUTTI ${ }^{102}$ e CHIOVENDA ${ }^{103}$.

Todavia, como bem enfatizam CARLOS AlBERTo CARMONA e LUIS FERNANDO GUERRERO, o enquadramento da arbitragem como atividade jurisdicional depende, de fato, seja dado um novo enfoque ao conceito de jurisdição, adequando-se a técnica à realidade e buscando-se uma visão mais ampla e teleológica da jurisdição, que, ao final, é a resolução dos conflitos e a pacificação social ${ }^{104}$.

Assim, se a jurisdição é tida como "poder" no plano da soberania nacional, "função" nos limites das atribuições do Estado e "atividade" no processo $^{105}$, pode-se concluir que a arbitragem possui todas essas qualidades ${ }^{106}$.

Isso porque se considerarmos a sentença como o elemento fundamental da jurisdição, pois é o que põe fim à controvérsia, sendo este o objetivo final

${ }^{101}$ Para o qual um ato somente pode ser considerado jurisdicional se se mostrar apto à produção da coisa julgada (ALLORIO, Enrico. Problemas de Derecho Procesal. Tradução de Santiago Sentis Melendo. Buenos Aires: Ediciones Jurídicas Europa América S.A., 1963. Tomo I. p. 437).

102 "Historicamente, a jurisdictio foi exatamente a manifestação do imperium (ou seja, do poder de mandato atribuído ao magistrado superior romano) que consistia em fixar regras jurídicas e que se distinguia, tanto do poder militar, quanto da coercitio; apenas devido a essa fixação de regras acontecia por meio do processo, o mesmo nome serviu por sua vez para designar o fim e o meio, e por conseguinte, nem tanto a função jurídica, quanto a função processual. Assim explica-se que se tenha acabado por chamar jurisdição a esta última, inclusive quando é execução." (CARNELUTTI, Francesco. Sistema de direito processual civil, v. I. Traduzido por Hiltomar Martins Oliveira. São Paulo: Classic Book, 2000, p. 223).

${ }^{103}$ Para o qual a jurisdição representa "a função do Estado que tem por escopo a atuação da vontade concreta da lei por meio da substituição, pela atividade de órgãos públicos, da atividade de particulares ou de outros órgãos públicos, já no afirmar a existência da vontade da lei, já no torná-la, praticamente, efetiva." (CHIOVENDA, Giuseppe. Instituições de direito processual civil. Vol. II. Trad. J. Guimarães Menegale. São Paulo: Saraiva, 1943, p. 11).

${ }^{104}$ Cf. CARMONA, Carlos Alberto. Arbitragem e Processo..., p. 26; e GUERRERO, Luis Fernando. Tutela de Urgência..., p. 29. Em prefácio de 1993, CÂNDIDO RANGEL DINAMARCO já afirmava que "justificava-se a rígida distinção entre arbitragem e jurisdição estatal, quando da jurisdição e do próprio sistema processual como um todo dizia-se que apenas tinham o mero e pobre escopo de atuação da vontade do direito ou de estabelecer a norma do caso concreto. Superada essa visão puramente jurídica do processo, todavia, e reconhecidos os escopos sociais e políticos muito mais nobres, cai por terra a premissa em que se legitimava a rígida distinção. Se o poder estatal é exercido, sub specie jurisdictionis, com o objetivo de pacificar pessoas e dirimir conflitos com justiça, e se afinal a arbitragem também visa a esse objetivo, boa parte do caminho está vencido, nessa caminhada em direção ao reconhecimento do caráter jurisdicional da arbitragem (ou, pelo menos, da grande aproximação dos institutos, em perspectiva teleológica)." (in CARMONA, Carlos Alberto. A arbitragem no processo civil brasileiro. São Paulo: Malheiros, 1993, prefácio).

${ }^{105}$ Cf. NEVES, Celso. Estrutura fundamental do processo civil. Rio de Janeiro: Forense, 1995, p. 28.

106 Cf. SILVA, João Paulo Hecker da. Tutela de Urgência e Tutela da Evidência nos Processos Societários. Tese de doutorado apresentada à Faculdade de Direito da Universidade de São Paulo - abril de 2012, p. 295. 
do Estado soberano ${ }^{107}$, já podemos verificar a presença de jurisdição na arbitragem, tanto que a sentença nela proferida não fica sujeita a recurso ou a homologação e também coloca fim à lide trazida aos árbitros, pacificando de forma definitiva o conflito social.

Além disso, os artigos 18, 26 e 31 da Lei de Arbitragem brasileira $^{108}$ e o artigo 475-N, IV, do $\mathrm{CPC}^{109}$ equiparam a sentença arbitral à sentença judicial $^{110}$, uma vez que ambas constituem título executivo judicial, bem como possuem os mesmos elementos e os mesmos efeitos, notadamente o de produzir coisa julgada ${ }^{111}$.

${ }^{107}$ Cf. PUCCI, Adriana Noemi. "Juiz \& Árbitro" in Aspectos Atuais da Arbitragem. Rio de Janeiro: Forense, 2001, p. 04.

108 "Art. 18. O árbitro é juiz de fato e de direito, e a sentença que proferir não fica sujeita a recurso ou a homologação pelo Poder Judiciário"; "Art. 26. São requisitos obrigatórios da sentença arbitral: I - o relatório, que conterá os nomes das partes e um resumo do litígio; II - os fundamentos da decisão, onde serão analisadas as questões de fato e de direito, mencionando-se, expressamente, se os árbitros julgaram por eqüidade; III - o dispositivo, em que os árbitros resolverão as questões que lhes forem submetidas e estabelecerão o prazo para o cumprimento da decisão, se for o caso; e IV - a data e o lugar em que foi proferida. Parágrafo único. A sentença arbitral será assinada pelo árbitro ou por todos os árbitros. Caberá ao presidente do tribunal arbitral, na hipótese de um ou alguns dos árbitros não poder ou não querer assinar a sentença, certificar tal fato"; e "Art. 31. A sentença arbitral produz, entre as partes e seus sucessores, os mesmo efeitos da sentença proferida pelos órgãos do Poder Judiciário e, sendo condenatória, constitui título executivo".

109 "Art. 475-N - São títulos executivos judiciais: (...) IV - a sentença arbitral;".

${ }^{110} \mathrm{Na}$ Alemanha, o § 1055 do CPC (ZPO) também equipara a sentença arbitral à sentença judicial: "Section 1055 - Effect of arbitral award. The arbitral award has the same effect between the parties as a final and binding court judgment." (tradução livre: "Seção 1055 - Efeito da sentença arbitral. A sentença arbitral gera o mesmo efeito entre as partes que uma decisão final e vinculante da Corte").

111 Conforme ensinamento de JOEL DIAS FIGUEIRA JÚNIOR in Arbitragem, jurisdição..., p. 156. Nesse diapasão, JOSÉ CARLOS BARBOSA MOREIRA afirma que a sentença arbitral "gera situação equiparável à da coisa julgada material." ("Estrutura da Sentença Arbitral" in Revista Síntese de Direito Civil e Processual Civil, n. ${ }^{\circ}$ 16. São Paulo, março/abril de 2002, pp. 05/12, p. 07). ANA CRISTINA AZEVEDo PonTES DE CARVALHO também aduz que "a equiparação entre a sentença estatal e a arbitral faz com que a segunda produza os mesmos efeitos da primeira (...) a decisão de mérito faz coisa julgada às partes entre as quais é dada (...)" (in "As inovações da Convenção de Nova Iorque de Arbitragem em face da Lei de Arbitragem brasileira". Arbitragem no Brasil - aspectos jurídicos relevantes. JOBIM, Eduardo; MACHADO, Rafael Bicca (coord.). São Paulo: Quartier Latin, 2008, pp. 45/72, p. 54). VINí́cIUS DE ANDRADE PRADO segue a mesma linha, dizendo que "a sentença arbitral faz coisa julgada e constitui título executivo judicial." (Medidas cautelares..., p. 192). Em sentido diametralmente oposto, SÉRGIO CRUZ ARENHART sustenta que "embora a sentença arbitral seja dotada de estabilidade entre as partes, é certo que ela não é, nem de longe, tão intensa como a coisa julgada", ressaltando, ainda, que "a lei de arbitragem autoriza, até mesmo, a discussão da sentença arbitral, dentro de certas circunstâncias, em juízo (arts. 31 a 33, da lei), o que indica que o fenômeno operado sobre aquela decisão não pode ser equiparado à coisa julgada", concluindo que, "em que pese o fato de que a arbitragem possui, em seu procedimento, a mesma forma declaratória exigida para caracterizar a jurisdição dentro dessa perspectiva, falta-lhe a tônica da coisa julgada." (ARENHART, Sérgio Cruz. Breves observações sobre...). Também pela ausência de coisa julgada da sentença arbitral: MARINONI, Luiz Guilherme; ARENHART, Sérgio Cruz. Processo de conhecimento, vol. II, $6{ }^{a}$ edição. São Paulo: RT, 2007, p. 763. Ainda nesse sentido, o Desembargador RODRIGUES DE CARVALHO "atribui à decisão do laudo arbitral não os efeitos da coisa julgada, mas sim os do ato jurídico perfeito, tornando estável o direito por ele declarado (direito adquirido)." (TJ/SP, 5. ${ }^{a}$ Câm. Dir. Privado, A.I. n. ${ }^{\circ}$ 124.217-4/0, Rel. Des. Rodrigues de Carvalho, j. 16/09/1999, v.u.). 
Outrossim, o fato de o legislador ter utilizado o termo "sentença arbitral", ao invés de "laudo arbitral", aproxima ainda mais os procedimentos arbitral e judicial, bem como reforça a vontade do legislador em conferir jurisdição ao árbitro, conforme enfatizam alguns doutrinadores ${ }^{112}$.

Ainda nessa linha, ressalte-se que a atividade exercida pelo árbitro é idêntica a atividade exercida pelo juiz de direito, sendo ambos "terceiros imparciais, que após a execução do processo de conhecimento, proferem uma decisão que é obrigatória para as partes envolvidas" ${ }^{\prime 13}$.

A verdade é que, embora muito tenha se discutido acerca da jurisdicionalidade da arbitragem no passado, mesmo quem defende a natureza contratual e privada do instituto não nega que a arbitragem se desenvolve com a garantia do devido processo legal e se encerra com ato que tem a mesma função da sentença judicial ${ }^{114}$.

Não se discute, igualmente, que a sentença arbitral torna-se definitiva, sendo vedado, inclusive, o recurso ao Poder Judiciário para a sua reforma de mérito, de maneira que não há dúvida de que a etapa anterior à formação da sentença arbitral reveste-se de caráter jurisdicional ${ }^{115}$.

Dessa forma, flexibilizando-se o conceito tradicional de jurisdição, notadamente a parte que a tem como atividade exclusiva do Estado ${ }^{116}$, e

112 Cf. FIGUEIRA JÚNIOR, Joel Dias. Arbitragem, jurisdição..., p. 154; e SIMÃO, José Fernando. A natureza jurídica..., p. 231.

${ }^{113}$ Cf. PUCCI, Adriana Noemi. Juiz \& Árbitro..., p. 07. No mesmo sentido, NeIL ANDREws leciona que "the award is binding on the parties. It can be recognised and enforced within the English or foreign legal systems under the New York Convention 1958, to which many nations are party." (trad. livre: "a sentença é vinculante para as partes. Ela pode ser reconhecida e executada nos sistemas legais inglês ou estrangeiros sob a Convenção de Nova Iorque de 1958, a qual foi subscrita por várias nações.") (Arbitration and mediation in England..., p. 110), mencionando, ainda, que a sentença arbitral torna-se res judicata (idem, p. 112).

${ }^{114}$ Cf. CARMONA, Carlos Alberto. Arbitragem e Processo..., p. 27.

${ }^{115}$ Cf. CARNEIRO, Athos Gusmão. "Arbitragem. Cláusula Compromissória. Cognição e Imperium. Medidas Cautelares e Antecipatórias. Civil Law e Common Law" in Revista Brasileira de Arbitragem, n. ${ }^{\circ}$ 3. São Paulo: IOB/CBAr, jul/set de 2004, pp. 42/59.

${ }^{116}$ Contrapondo a afirmação de que a jurisdição seria monopólio do Estado, BRUNO OPPETIT menciona "o argumento de que a atividade jurisdicional não é, em sua essência, estatal. Apenas o componente coercitivo da jurisdição é monopólio do Estado em seu respectivo território: 'De toda a forma, a sentença, uma vez proferida, escapa ao poder exclusivo do estado local, para se submeter ao da pluralidade de países nos quais a execução ou o reconhecimento são reclamados' (P. MAYER, L'autonomie de l'arbitre international dans l'appréciation de as propre compétence. Académie de droit international de La Haye, Recueil des cours, t. 217 (1989-V), n. 78, p. 402)." (Etudes offertes..., p. 192). Igualmente, HUMBERTO THEODORO JÚNIOR 
levando-se em consideração o tripé poder, função e atividade, como elementos caracterizadores da jurisdição ${ }^{117}$, é possível concluir que o árbitro possui poder jurisdicional ${ }^{118}$.

Tanto é que, como visto no "item 6" acima, boa parte da doutrina entende que a arbitragem, mesmo sendo uma forma alternativa e privada de solução de controvérsias, possui natureza jurisdicional.

Obviamente que a arbitragem e a justiça comum são duas formas distintas de jurisdição, diferenciadas tanto por sua origem ${ }^{119}$, como pelos órgãos que as exercem ${ }^{120}$, mas é evidente o caráter jurisdicional da arbitragem.

E ainda que assim não se entenda, não há como se negar que, por meio da Lei de Arbitragem brasileira (a qual, como adiantado na introdução deste

enfatiza que "o essencial para a configuração da prestação jurisdicional é que ela seja prestada, como emanação de autoridade, por um terceiro, e não por um dos sujeitos interessados na relação jurídica litigiosa. Essa moderna concepção presta-se a resolver até mesmo o problema de definir a natureza do juízo arbitral e, conseqüentemente, serve para reconhecer-lhe a integração na jurisdição, pois que é essencial para tanto, não é a qualidade do agente e sua ligação direta ao Poder Judiciário, mas o seu poder de impor, como terceiro, uma solução obrigatória para o conflito jurídico", e conclui afirmando que "onde uma vontade estranha e superior às partes tem força de proclamar (dizer) o direito, há juris dictio" (“Arbitragem e terceiros - litisconsórcio fora do pacto arbitral - outras intervenções de terceiros" in Reflexões sobre arbitragem: in memorian do Desembargador Cláudio Vianna de Lima. MARTINS, Pedro A. Batista; GARCEZ, José Maria Rossani (Coord.). São Paulo: LTr,, 2002, p. 241). Por fim, ADRIANA NOEMI PUCCI afirma que o termo "jurisdição" "provém do latim jurisdictio, e significa 'dição do direito' ”, razão pela qual ela entende que a arbitragem possui natureza jurisdicional, pois nela há a dicção do direito pelos árbitros (Juiz \& Árbitro..., p. 04).

117 ADA PELLEGRINI GRINOVER ensina que "a jurisdição é, ao mesmo tempo, um poder, uma função, e uma atividade. Como poder, é manifestação da própria soberania nacional, exercida pelos órgãos estatais competentes (no caso, pelos juízes). Como função, expressa o encargo que têm os órgãos estatais de promover a realização do direito, através do processo. E como atividade ela é a movimentação do juiz no processo, exercendo o poder e cumprindo a função que a lei lhe comete." (Teoria Geral do Processo..., p. 83).

${ }^{118}$ Cf. PRADO, Vinícius de Andrade. Medidas cautelares..., p. 188. CARMONA também confirma que "tanto o árbitro como o juiz exercem função, atividade e poder que caracterizam a jurisdição; tanto o árbitro como o juiz proferem decisões vinculativas para as partes; tanto o árbitro como o juiz julgam! Assim sendo, no momento em que o árbitro aceita o encargo, recebe das partes o poder de decidir um dado litígio, impondo, em caráter obrigatório e vinculativo, a solução para o caso concreto, caracterizando-se a substituição da vontade da partes pela do árbitro, que expressa e sintetiza a vontade da lei." (CARMONA, Carlos Alberto. "Das boas relações entre os juízes e os árbitros" in Revista do Advogado, n. ${ }^{\circ}$ 51. São Paulo: AASP, outubro de 1997, pp. 17/24, p. 19). Lecionando acerca das tendências atuais no direito processual sobre o conceito de jurisdição e a sua aproximação com o processo arbitral, EDUARDO SILVA DA SILVA aduz que "o instituto da jurisdição, portanto, teria sido redesenhado, pelos autores citados, pela presença destes dois elementos: um terceiro imparcial e o poder impositivo autoritário ou obrigatório (efeito vinculante da decisão). Ora, ambos os traços estão presentes na arbitragem, o que a aproxima da idéia de jurisdição." (SILVA, Eduardo Silva da. Arbitragem e direito de empresa. São Paulo: RT, 2003, p. 172).

${ }^{119}$ José CARLOS DE MAGAlHÃes relembra que a origem da jurisdição do juiz togado é pública e "emana direta ou indiretamente da Constituição, e a do árbitro é privada e deriva da vontade das partes, circunscritas às hipóteses previstas em lei" (MAGALHÃES, José Carlos de. "A tutela antecipada no processo arbitral" in

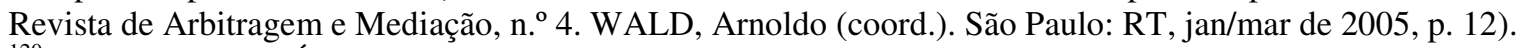
${ }^{120}$ Cf. FIGUEIRA JÚNIOR, Joel Dias. Arbitragem, jurisdição..., p. 154. 
trabalho, já foi declarada constitucional pelo Supremo Tribunal Federal) ${ }^{121}$, o Estado cedeu ao árbitro parte de seu poder de decidir uma lide ${ }^{122}$, sendo indispensável verificar quais os poderes jurisdicionais que foram outorgados por lei aos árbitros.

\section{$\underline{\text { 11. PODERES JURISDICIONAIS DO ÁRBITRO }}$}

O árbitro não possui todos os poderes que compõem a jurisdição estatal, mas apenas alguns deles, havendo um "fracionamento" da jurisdição no que tange à arbitragem e aos poderes do árbitro.

Nos termos da Lei de Arbitragem brasileira, o árbitro possui poderes de conhecer e de decidir uma causa, sendo imperioso concluir, por conseguinte, que o árbitro possui os poderes jurisdicionais de cognitio ou notio e de iudicium ${ }^{123}$.

Por outro lado, da simples leitura do artigo 24, caput, da Lei de Arbitragem brasileira ${ }^{124}$, verifica-se que o árbitro também possui o poder de documentação, que diz respeito ao registro dos atos processuais em autos ${ }^{125}$.

Resta examinar, por fim, se o árbitro possui os poderes jurisdicionais de coerção (coertio) e de execução (executio ou imperium), indispensável à efetivação das decisões arbitrais não adimplidas espontaneamente.

Nesse ponto, a doutrina é uníssona em afirmar que a resposta é negativa, uma vez que os poderes de coerção e de execução ("coertio" e "imperium" ou “poder de constrição”) são exclusivos do Estado.

\footnotetext{
${ }^{121}$ STF, Pleno, Agravo Regimental em Sentença Estrangeira n. ${ }^{\circ}$ 5.206-7, j. 12/12/2001. Ver "nota 2" acima. ${ }^{122}$ Cf. SIMÃO, José Fernando. A natureza jurídica..., p. 233.

123 JosÉ EDUARDo CARREIRA ALVIM aponta cinco componentes da jurisdição: (i) notio; (ii) vocatio; (iii) coertio; (iv) iudicium; e (v) executio. A notio é "a faculdade de conhecer certa causa, ou de ser regularmente investido da faculdade de decidir uma controvérsia, assim como de ordenar os atos respectivos, salvo a aplicação das leis de acordo com os diversos graus da jurisdição e da competência”, e o iudicium é o "direito de julgar e de pronunciar a sentença." (in Elementos de Teoria Geral do Processo, 7. a edição. Rio de Janeiro: Forense, 1997, p. 59).

124 “Art. 24. A decisão do árbitro ou dos árbitros será expressa em documento escrito”.

${ }^{125}$ Cf. PRADO, Vinícius de Andrade. Medidas cautelares..., p. 190.
} 
Corroborando esse entendimento: ADRIANA NOEMI PUCCI ${ }^{126}$, Alexandre Freitas CÂmara ${ }^{127}$, Bruno Oppetit ${ }^{128}$, Carlos Alberto Carmona ${ }^{129}$, Donaldo Armelin ${ }^{130}$, Gilberto Giusti ${ }^{131}$, José Antonio Fichtner e André Luís Monteiro $^{132}$, José EduARdo CARreira AlviM ${ }^{133}$, José MARIA RosSANi GARCEZ ${ }^{134}$, Luis FERnANDo Guerrero ${ }^{135}$, PAUlo Osternack Amaral ${ }^{136}$ e Vinícius DE ANdrade PRADO $^{137}$, dentre outros ${ }^{138}$, além da jurisprudência pátria ${ }^{139}$.

${ }^{126}$ In Juiz \& Árbitro..., p. 09.
127 "cabe ao árbitro conceder a medida cautelar, devendo ser solicitada ao juízo competente, tão-somente, a
atuação da mesma, já que o árbitro não pode usar a força para fazer cumprir suas decisões." (in Arbitragem...,
1997, pp. 83/84).
128 "o juiz arbitral não possui imperium: sua decisão transita em julgado, mas não tem força executória;", (OPPETIT, Bruno. Etudes offertes..., p. 192).

${ }_{129}$ In Arbitragem e Processo..., pp. 323/324.

130 "No plano doutrinário e jurisprudencial não existem discrepâncias de vulto a respeito da impossibilidade de inserção da arbitragem no âmbito da execução, até porque esta, em regra, não pode exigir a efetivação de atos de coerção, para os quais será necessária a atuação da força pública. No ordenamento jurídico nacional os atos coercitivos dessa natureza continuam restritos ao Poder Público, que mantém, nesse particular, o monopólio do uso legal da força pública para impor cumprimento dos comandos legais e jurisdicionais." ("Tutela de urgência e arbitragem". Tutelas de Urgência e Cautelares - Estudos em Homenagem a Ovídio A. Baptista da Silva. São Paulo: Saraiva, 2010, p. 362).

${ }_{131}$ "Foi, então, subtraído à arbitragem a aptidão de dispor da força para obter o cumprimento de atos e diligências do processo." (in O árbitro e o juiz..., p. 12).

132 "os árbitros, apesar de exercerem poder jurisdicional, não ostentam a mesma gama de poderes que detém o juízo estatal no exercício do seu mister. (...) o árbitro detém o ius cognitio, mas não o ius imperium, esse sim exclusividade do Estado, através do Poder Judiciário." ("Medidas urgentes no processo arbitral brasileiro". Revista Trimestral de Direito Civil, vol. 35. Rio de Janeiro: Padma, jul/set de 2008, pp. 43/73, p. 48).

133 "desses elementos, a jurisdição arbitral tem somente os dois primeiros (notio e vocatio) e o quarto (iudicium), faltando-lhe o terceiro (coertio) e o quinto (executio)." (in Tratado Geral da Arbitragem - Interno. Belo Horizonte: Mandamentos, 2000, p. 84). Ainda: "o árbitro dispõe da iurisdictio, que lhe permite fazer justiça em nome do Estado, mas não do imperium, que lhe garanta os poderes necessários para adentrar na esfera de liberdade das partes, executando suas próprias decisões." (CARREIRA ALVIM, José Eduardo. Comentários à Lei de Arbitragem, 2. edição, Rio de Janeiro: Lumen Juris, 2004, p. 127).

${ }^{134}$ Aos árbitros "falece o poder de imperium para decretar coativamente a execução de alguma cautelar", devendo o árbitro "valer-se para isto, caso necessário, do poder judiciário." ("Medidas cautelares e de antecipação de tutela na arbitragem" in Arbitragem doméstica e internacional: estudos em homenagem ao Prof. Theóphilo de Azeredo Santos. FERRAZ, Rafaella; MUNIZ, Joaquim de Paiva (coords.). Rio de Janeiro: Forense, 2008, pp. 213/230, especialmente p. 220).

135 "O árbitro não é dotado de coertio e executio." (in Arbitragem e jurisdição: premissa..., p. 14).

136 "Essas considerações deixam claro (...) a inviabilidade de o julgador privado impor atos de força, coerção (imperium) no processo arbitral, na medida em que tais providências constituem monopólio estatal" (AMARAL, Paulo Osternack. A concessão de medidas urgentes..., p. 29).

137 "carece ao árbitro o poder de coerção (coertiolexecutio) e, dessa maneira, haverá sempre a possibilidade de se necessitar do auxílio de um magistrado no que tange ao cumprimento de eventuais medidas cautelares ou até da sentença arbitral." (in Medidas cautelares..., p. 197).

${ }^{138} \mathrm{Na}$ doutrina estrangeira, destacam-se as lições de PIERO BERNARDINI: "However, when such protection requires the exercise of coercive powers, as in the case of conservatory and provisional measures, the coming again into play of the national judge as the only authority enjoying such powers is seen as unavoidable. (...) A further limitation, most frequently referred to by legal commentators, relates to the absence of coercive powers, the arbitrator being notoriously incapable of obtaining from a recalcitrant party the enforcement of a provisional and conservatory measure." (tradução livre: "Contudo, quando tal proteção requer o exercício de poderes coercitivos, como no caso de medidas conservativas ou provisórias, a participação novamente do juiz estatal como a única autoridade a gozar de tais poderes parece inevitável. (...) Outra limitação, referida com maior frequiência pelos doutrinadores, relaciona-se à falta de poderes 
No entanto, em uma análise mais profunda do poder de coerção, entendemos que o árbitro possui referido poder ao menos de maneira parcial, podendo determinar alguns atos de coerção, tal como, exempli gratia, fixar multa à parte contrária para o caso de descumprimento da tutela de urgência por ele deferida.

Isto é, o árbitro não possui poder de coerção para determinar, por exemplo, uma ordem de prisão ou a quebra do sigilo bancário, fiscal ou telefônico ${ }^{140}$, mas, a nosso ver, ele possui, sim, poder de coerção para fixar astreintes ${ }^{141}$ e algumas outras ordens que extrapolam a simples jurisdictio.

coercitivos, sendo o árbitro notoriamente incapaz de obter da parte recalcitrante o cumprimento forçado da medida provisória e conservativa.") (The Powers of the Arbitrator..., p. 21); e de JULIAN M. LEW, LOUKAS A. MISTELIS e STEFAN MICHAEL KRÖLL: "Where enforcement is necessary it has to be effected by state courts." (tradução livre: "Quando a execução é necessária ela deve ser efetivada pelo juízo estatal”) (Comparative International..., p. 609).

139 “(...) ao Juízo Arbitral não se concedeu poder de coerção, reservado à jurisdição Estatal. (...) não obstante tivessem as partes se comprometido a submeter à arbitragem os litígios que pudessem surgir em decorrência de compra e venda de imóvel acordada, o fato é que o juízo arbitral tem sua atuação limitada às ações que demandam o processo de conhecimento, na medida em que resolvida a questão levada à sua apreciação, não tem o poder de coerção, sendo necessária a jurisdição estatal para tornar efetivo o comando expresso na decisão do árbitro, reconhecida como título executivo judicial, (...)" (TJ/RJ, 8. ${ }^{a}$ Câmara Cível, Apelação n. ${ }^{\circ}$ 0005398-73.2003.8.19.0209 (2004.001.07596), ACi n. ${ }^{0}$ 7596/2004, Rel. Des. Adriano Celso Guimarães, j. 25/01/2005, v.u.); "Medida cautelar de sustação de protesto - Contrato elegendo a via arbitral - Alegação de incompetência do Juízo Comum para apreciação da questão - Ausência de poder de coerção do juízo arbitral - Medida cautelar admissível de conhecimento pelo Poder Judiciário - Recurso improvido" (TJ/SP, 38. Câm. de Direito Privado, A.I. n. ${ }^{\circ}$ 0069506-20.2010.8.26.0000 - antigo n. ${ }^{\circ}$ 990.10.069506-1, Rel. Des. Souza Lopes, j. 04/08/2010, v.u.); “(...) Como é cediço, ao Juízo Arbitral falta a coerção estatal para o cumprimento de seus julgados, tanto que formam título executivo exatamente para que à parte refratária, que concordou em se submeter ao julgamento, seja imposta, perante a justiça comum, a prestação a que foi condenada. Portanto, não está entre suas funções promover a execução de suas decisões. (...)" (STJ, CC 111.230-DF, decisão monocrática do Min. Rel. Aldir Passarinho Filho, de 01/07/2010, publicada no DJe de 02/08/2010); "Evidentemente, a competência do juízo arbitral se limita ao deferimento da cautelar, estando impedido de dar cumprimento às medidas de natureza coercitiva, as quais, havendo resistência da parte em acolher a determinação do(s) árbitro(s), deverão ser executadas pelo Poder Judiciário, a quem se reserva o poder de imperium." (STJ, 3. ${ }^{a}$ Turma, REsp n. ${ }^{\circ}$ 1.297.974-RJ, Rel. Min. Nancy Andrighi, j. 12/06/2012, v.u.); “o árbitro não detém poder coercitivo direto, não podendo impor, contra a vontade do devedor, restrições a seu patrimônio." (STJ, 3. ${ }^{a}$ Turma, REsp n. ${ }^{\circ}$ 944.917/SP, Rel. Min. Nancy Andrighi, DJe de 03/10/2008).

${ }^{140}$ Cf. HOFFMAN, Paulo. Arbitragem: algumas dúvidas..., p. 317.

${ }^{141}$ Nessa esteira, ClÁvio DE MELO VALENÇA FILHO aduz que "a transferência de poder jurisdictio da esfera pública à privada não implica, todavia, transferência de imperium, ao menos não em sua forma pura, de força organizada, dita imperium merum. Sim, o árbitro tem poderes para realizar certos atos de cunho mandamental que decerto extrapolam a simples jurisdictio: impor astreintes ou multas para o caso de sua ordem ou sentença não ser voluntariamente adimplida. Não pode, por outro lado, distribuir força organizada, espécie de tutela reservada a órgãos do Estado. Em suma: a jurisdição que se autoriza transferir do Estado ao privado não implica atos de execução compulsória. $\mathrm{O}$ efeito negativo da convenção de arbitragem não opera em relação ao juízo estatal de execuções. À parte interessada na execução da sentença arbitral cabe recorrer à espada da justiça estatal, única habilitada à constrição patrimonial.” (Sentença arbitral e..., pp. 36/37, g.n.). PEDRO A. BATISTA MARTINS também entende ser possível que os árbitros estabeleçam penalidades à parte renitente, tal como as astreintes (MARTINS, Pedro A. Batista. "Da Ausência de Poderes Coercitivos e Cautelares do Árbitro" in Aspectos fundamentais da Lei de Arbitragem. MARTINS, Pedro A. Batista; LEMES, Selma M. Ferreira; CARMONA, Carlos Alberto (coord.). Rio de Janeiro: Forense, 1999, p. 367). 
Dentre atos de natureza nitidamente coercitiva, entendemos ser possível que o árbitro profira decisões liminares determinando (i) anotação em registro imobiliário; (ii) busca e apreensão; (iii) astreintes; (iv) exibição de documentos etc. ${ }^{142}$

Julian M. Lew, Loukas A. Mistelis e Stefan Michael KRÖLL anotam que, em arbitragens internacionais, também é possível a adoção de tutelas de urgência de caráter coercitivo pelo(s) árbitro(s) ${ }^{143}$, tais como medidas para assegurar a futura execução (“measures to secure enforcement"), seja por meio de depósito, arresto ou outras garantias ${ }^{144}$, mencionando, a título de exemplo, o artigo 25.1 (a) e (b) do regulamento da The London Court of International Arbitration - LCIA ${ }^{145}$ e os artigos 37 (1) e 38 (1) do regulamento da Nederlands Arbitrage Instituut - NAI ${ }^{146}$, os quais prevêem a

${ }^{142}$ Nesse sentido: "4.4. Pode o árbitro, antes de se socorrer da intervenção estatal, aplicar as penas do art. 461? Sem dúvida! Os arts. 461 e 461-A do CPC colocam à disposição do juiz a possibilidade de decretar medidas, principalmente a multa e a busca e apreensão, como forma de forçar a parte a cumprir sua obrigação. Assim, antes de socorrer-se da força estatal, pode e deve o árbitro utilizar meios sub-rogatórios de imposição de vontade da parte renitente, (...)" (HOFFMAN, Paulo. Arbitragem: algumas dúvidas..., p. 315).

${ }^{143}$ Julian M. LEW, LouKAS A. Mistelis e STEFAN M. KRÖLl ressaltam ainda que o regulamento da CCI e outros regulamentos de centros internarcionais de arbitragem outorgam ao tribunal arbitral poderes para conceder quaisquer medidas provisórias que ele entender apropriado (Comparative International..., p. 598).

144 "Medidas para garantir a execução. Enquanto a arbitragem está em curso uma parte pode tentar frustrar o seu objetivo ou a efetividade da decisão final por meio da transferência de bens além do alcance da outra parte ou do tribunal. Quando uma parte estiver preocupada com que isso ocorra, ela pode buscar o seqüestro da propriedade em disputa, ou a penhora de bens da parte. Além disso, a situação financeira de uma das partes pode gerar dúvida razoável que ela ainda será capaz de cumprir quaisquer das obrigações pecuniárias determinadas na sentença. Em tal caso, será necessário o fornecimento da caução adequada na forma de um depósito bancário ou de uma garantia." (Comparative International..., pp. 596/597, trad. livre). Na França e na Bélgica, como se verá a seguir, a legislação proíbe, expressamente, a concessão de arrestos, penhoras e outras medidas ligadas a garantias judiciais pelo árbitro, por serem atos privativos do Estado. Por isso, BRUNO OPPETIT leciona que "o juiz arbitral (...) não pode ordenar certas medidas cautelares ou conservatórias, a exemplo das penhoras;” (OPPETIT, Bruno. Etudes offertes..., p. 192).

145 “Artigo 25. Medidas Liminares e Conservativas. 25.1 O Tribunal Arbitral terá o poder, a não ser que as partes tenham acordado de outra forma por escrito, mediante o pedido de qualquer das partes: (a) para ordenar qualquer réu de pedido ou de pedido contraposto para fornecer caução/garantia de toda ou de parte do valor em litígio, por meio de depósito ou de garantia bancária ou de qualquer outra forma e nos termos que o Tribunal Arbitral entender apropriados. Referidos termos podem incluir o fornecimento pelo autor ou pelo reconvinte de uma contra-indenização, caucionada de tal maneira que o Tribunal Arbitral considerar apropriado para garantir quaisquer custos ou perdas incorridos pelo réu no fornecimento da caução/garantia. $\mathrm{O}$ valor de quaisquer custos ou perdas pagáveis por esta contra-indenização poderá ser determinado pelo Tribunal Arbitral em uma ou mais decisões; (b) para ordenar a preservação, o armazenamento, a venda ou outra disposição de qualquer propriedade ou coisa sob a posse da parte e relacionada ao objeto da arbitragem;" (tradução livre - original em www.lcia.org/Dispute_Resolution_Services/LCIA_Arbitration_ Rules.aspx. Acessado em 17/11/2012).

146 “Artigo 37 - 1. (...) Isso inclui a autoridade para ordenar o fornecimento de caução/garantia em favor da parte que a pleiteia, em uma forma a ser determinada pelo tribunal arbitral, com relação ao pedido ou pedido contraposto, bem como com relação aos custos relacionados ao mérito da arbitragem. Artigo 38 - 1. Sem prejuízo do poder previsto no Artigo 37, o tribunal arbitral, a pedido de uma parte, em qualquer momento do processo, pode provisoriamente tomar qualquer decisão ou tomar qualquer medida com relação ao objeto da disputa que ele entender útil ou necessária. Essa autoridade inclui a autoridade para ordenar o fornecimento de caução/garantia, como mencionado na segunda parte do primeiro parágrafo do Artigo 37." (trad. livre). 
possibilidade de o árbitro exigir liminarmente um depósito a ser feito pela parte para a garantia da futura decisão.

Todavia, o árbitro não terá poderes para executar coativamente a sua decisão, o que, mesmo assim, não o impede de proferi-la.

Caso a parte contrária não cumpra a ordem espontaneamente, a execução da decisão arbitral poderá ser feita perante o Poder Judiciário ${ }^{147}$.

Em suma, embora grande parte da doutrina afirme, de maneira genérica, que o árbitro carece de poderes coercitivos, a realidade é que ele detem, sim, poderes (limitados, é verdade) para decretar determinadas tutelas coercitivas, não detendo, por outro lado, poderes para executá-las a força. Por conta disso, a efetivação forçada das tutelas de caráter coercitivo que forem deferidas pelo(s) árbitro(s) deverá ser buscada exclusivamente perante a jurisdição estatal ${ }^{148}$.

Ainda com relação aos poderes coercitivos do árbitro, é válida a menção da 2. a fase da pesquisa "Arbitragem e Poder Judiciário", da Escola de Direito de São Paulo da Fundação Getúlio Vargas em conjunto com o Comitê Brasileiro de Arbitragem - CBAr, coordenada por LuIS FERNANDo GUERRERo e VERA CECÍliA Monteiro DE BArros, a qual, no 4. ${ }^{\circ}$ Tema - "Execução e Cumprimento da Sentença Arbitral", apurou a existência de quatro acórdãos discutindo a possibilidade de os árbitros

\footnotetext{
${ }^{147}$ Nesse diapasão, Pedro A. BAtista Martins ensina que "as decisões do árbitro que deferirem medidas que necessitarem de ato ou imposição complementar (v.g. anotação em registro imobiliário; constituição de fiel depositário; arresto; busca e apreensão), deverão autorizar a parte interessada a buscar o juízo ordinário para confirmação e/ou execução das medidas requeridas, fundamentando-as de modo preciso e objetivo." (Da Ausência de Poderes Coercitivos..., pp. 361/362). Igualmente, PAUlo HofFMAN sustenta que, "caso haja a necessidade de o árbitro impor medidas coercitivas, poderá valer-se da cooperação do juiz estatal" (Arbitragem: algumas dúvidas..., p. 308), bem como que "atos de força ou expropriação tendentes à efetivação dessas medidas, especialmente se envolverem terceiros não participantes do juízo arbitral, dependerão sempre da intervenção estatal, se não cumpridos voluntariamente.” (Idem, p. 315).

${ }^{148}$ Sobre o tema, SÉRGIO BERMUDES aduz "que aos árbitros, ou árbitro, falta apenas a competência para a efetivação da medida coercitiva, quando ela depender do uso da força. Neste caso só resta ao tribunal arbitral pedir ao juiz togado a providência que assegure o efeito prático da medida determinada. A lei, portanto, é peremptória ao proibir a execução de medidas coercitivas de força pelo tribunal arbitral; não porém a decretação delas. O juiz arbitral as decreta. O togado as executa mediante a solicitação daquele" ("Medidas coercitivas e cautelares no processo arbitral" in Reflexões sobre arbitragem: in memoriam do Desembargador Cláudio Vianna de Lima. MARTINS, Pedro A. Batista; GARCEZ, José Maria Rossani (Coord.). São Paulo: LTr., 2002, pp. 276/282, esp. p. 279).
} 
"proferirem certas decisões que determinam ou autorizam atos a serem praticados pelas partes, como por exemplo, a determinação de desocupação de um imóvel" ${ }^{149}$.

Nessa pesquisa, foi mencionado acórdão prolatado pelo

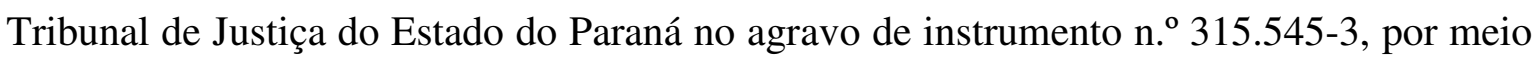
do qual foi reformada decisão de Primeiro Grau que deixou de determinar o cumprimento de sentença arbitral que havia ordenado a desocupação de imóvel locado, sob o argumento de que o árbitro não poderia determinar ordem de despejo ${ }^{150}$.

Confirmou-se, assim, a possibilidade de o árbitro conceder tutela condenando o locatário a desocupar o imóvel locado em prazo a ser fixado na arbitragem, sendo certo que essa tutela poderia ser concedida em caráter de urgência, dependendo das circunstâncias fáticas e dos termos do contrato.

Outro acórdão citado na pesquisa acima é o de nº $0020103-$ 24.2003.8.19.0000 (2003.002.18187), prolatado pelo Tribunal de Justiça do Estado do Rio de Janeiro em sede de agravo de instrumento, por meio do qual foi reformada decisão de Primeira Instância que havia determinado a incidência de multa para o cumprimento de

\footnotetext{
${ }^{149}$ www.cbar.org.br/PDF/Execucao_e_Cumprimento_da_Sentenca_Arbitral.pdf. Acessado em 08/07/2012.

150 "É de se ver que o caso vertente traz uma pactuação por mediação arbitral; portanto, pode-se extrair que ambas as partes igualmente concordaram em se utilizar da arbitragem como meio de solucionar a pendência, haja vista que a competência do Tribunal Arbitral decorre de cláusula compromissória inserida em contrato (fls. 32 TJ/PR). No dia 04 de julho de 2005, foi proferida sentença arbitral que condenou a agravada ao pagamento dos aluguéis vencidos desde 30.11.2004 até o dia da efetiva desocupação do imóvel, além de outros encargos, como também determinou a desocupação do imóvel no prazo de 15 (quinze) dias após o recebimento da sentença, o que não ocorreu. Embora ciente da sentença arbitral, a agravada-ré não atendeu ao contido nos artigos 30 e 33 da Lei 9.307/96, quedando-se inerte. Nestes autos, não há qualquer prova de que a decisão arbitral foi impugnada. Em sede de execução de título judicial, pediu-se que o imóvel fosse desocupado para que, em seguida, fossem executados os valores do débito locatício por quantia certa. Ao despachar, a MM. Juíza da $13^{\text {a }}$ Vara Cível considerou que a Lei ${ }^{\circ}$ 9.307/96, em seu art. 31, somente constitui como título executivo a sentença condenatória e que, no presente caso, a Justiça Arbitral teria proferido uma sentença arbitral mista, ou seja, apenas a execução por quantia certa poderia ser objeto da execução. Portanto, indeferiu o pedido de expedição de mandado de desocupação do imóvel pela agravada. (...) Destarte, tendo a Ação de Execução e a obrigação de fazer (desocupação do imóvel) a mesma causa de pedir, seja ela remota ou próxima, é de se reconhecer a vinculação dos pedidos na sentença arbitral. Assim, a sentença arbitral não deveria ser recepcionada como uma sentença mista. Portanto, a sentença arbitral consolidou-se em título executivo judicial, nos termos do artigo 584, inciso VI, do Código de Processo Civil, ensejando o procedimento executivo preconizado no artigo 632 do referido código. Desse modo, a desocupação de imóvel faz parte das condenações arroladas na sentença arbitral, que, como título executivo, deve ser acolhida

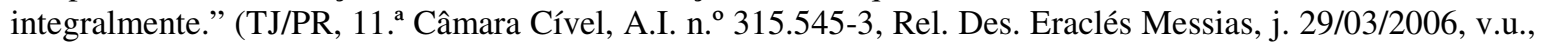
http://portal.tjpr.jus.br/jurisprudencia/j/1472068/Acórdão-315545-3. Acessado em 08/07/2012).
} 
obrigação de fazer constante de decisão arbitral, sem que tal decisão arbitral tivesse fixado aludida multa ao condenar a parte na obrigação de fazer ${ }^{151}$.

Reconheceu-se em referido acórdão, a contrario sensu, a possibilidade de o árbitro fixar multa em caso de descumprimento de obrigação de fazer.

Com relação a esse acórdão, entendemos que houve excesso de rigor por parte do Tribunal de Justiça do Rio de Janeiro, pois a relação entre o juízo estatal e o juízo arbitral deve ser sempre de cooperação (conforme o "item 12" abaixo), especialmente em sede de cumprimento da decisão arbitral.

Assim, se a decisão arbitral que condenou a parte em obrigação de fazer não foi cumprida espontaneamente pela parte vencida, como deveria, e teve de ser executada perante o juízo estatal, é possível que este, ao revés do que restou decidido no acórdão supracitado, fixe astreintes para forçar o cumprimento da decisão arbitral ${ }^{152}$.

Entendemos ser possível, inclusive, a majoração de eventual multa fixada na decisão arbitral pelo juízo estatal, na hipótese de a parte renitente manterse inerte quanto ao cumprimento da decisão arbitral executada na justiça comum, tendo em vista que o objetivo da multa é exercer pressão sobre a vontade do devedor para que este resolva adimplir a obrigação que lhe incumbe ${ }^{153}$.

151 “A sentença proferida no Juízo arbitral se encontra por cópia a fls. 126/128 e dela não consta qualquer multa para a hipótese de descumprimento ou atraso no seu cumprimento. Por tais considerações, dá-se provimento parcial ao recurso para cancelar a multa que extrapola os limites do título executivo." (TJ/RJ, 1. ${ }^{a}$ Câmara Cível, A.I. n. ${ }^{\circ}$ 0020103-24.2003.8.19.0000 - 2003.002.18187, Rel. Des. Valéria G. da Silva Maron, j. 10/02/2004, v.u., http://srv85.tjrj.jus.br/ConsultaDocGedWeb/faces/ResourceLoader.jsp?idDocumento=0003303D838A6862364967C38264E192E0121970C31B5819. Acessado em 08/07/2012. Essa decisão foi comentada por LAURO DA GAMA E SOUZA JÚNIOR na Revista de Arbitragem e Mediação, n. ${ }^{\circ} 4$. São Paulo: RT, janeiro/março de 2005, pp. 262/266).

${ }^{152}$ Nesse sentido, o parágrafo $5 .^{\circ}$ do artigo 461 do CPC estabelece que o juiz pode, inclusive de ofício, fixar multa ou determinar outras medidas em caso de descumprimento de obrigação de fazer: "§ $5^{\circ}$ Para a efetivação da tutela específica ou a obtenção do resultado prático equivalente, poderá o juiz, de ofício ou a requerimento, determinar as medidas necessárias, tais como a imposição de multa por tempo de atraso, busca e apreensão, remoção de pessoas e coisas, desfazimento de obras e impedimento de atividade nociva, se necessário com requisição de força policial”. E tendo em vista que a execução forçada de qualquer decisão arbitral se dará sempre perante a justiça estatal, referido dispositivo legal é perfeitamente aplicável.

${ }^{153}$ Aplicar-se-ia ao caso, subsidiariamente, o parágrafo $6^{\circ}{ }^{\circ}$ do artigo 461 do CPC: "\$ $6^{\circ} \mathrm{O}$ juiz poderá, de ofício, modificar o valor ou a periodicidade da multa, caso verifique que se tornou insuficiente ou excessiva". 
Portanto, embora o juízo estatal não possa rever o mérito da decisão proferida em sede de arbitragem, ele tem o poder-dever de cooperar com o juízo arbitral no cumprimento de referida decisão, motivo pelo qual entendemos ser plenamente possível, nessa linha de cooperação, a fixação das astreintes pelo juízo estatal, pois este é, na qualidade de detentor do monopólio do imperium, o condutor da execução forçada da decisão arbitral.

A pesquisa supracitada ainda fez referência ao acórdão proferido pelo Tribunal de Justiça do Estado de São Paulo que negou provimento ao agravo de instrumento n. ${ }^{\circ}$ 0114241-80.2006.8.26.0000, mantendo decisão proferida em sede de execução que deferiu o cumprimento de medidas coercitivas determinadas por sentença arbitral condenatória, tais como a juntada de certidões imobiliárias em nome das sociedades comerciais e dos sócios remanescentes, ofício à CIRETRAN para bloqueio de alienação de veículos em nome das pessoas físicas e jurídicas etc. ${ }^{154}$.

Em outro julgado do Tribunal de Justiça de São Paulo, foi declarada a perda do objeto do agravo de instrumento n. ${ }^{\circ}$ 0305397-55.2009.8.26.0000, que havia sido interposto contra decisão liminar proferida pela justiça comum, tendo em vista que referida liminar foi confirmada e mantida pelos árbitros, após ter sido instaurada a $\operatorname{arbitragem~}^{155}$.

Ressalte-se que, nesse caso, o Exmo. Desembargador Relator HERALDO DE OliveIRA explicou que "estava decidindo o recurso com os seguintes fundamentos", e expôs toda a fundamentação jurídica no sentido de dar parcial provimento ao agravo, para afastar a incidência de multa que havia sido imposta à parte agravante, mas, diante da notícia da instauração da arbitragem e da manutenção integral, pelos

\footnotetext{
154 "Vale salientar que é admissível o requerimento do autor, ora apelado, para determinar, de acordo com o 'Convênio Bacen Jud', o bloqueio on line de recursos depositados em estabelecimentos bancários, bloqueio dos bens imóveis constantes das certidões imobiliárias, bem como ofício à CIRETRAN, para bloqueio de alienações de veículos das pessoas físicas e jurídicas indicadas no laudo arbitral. Outrossim, a decisão agravada não merece reparos animada na determinação da sentença arbitral de que a 'execução recairá sobre todo o patrimônio disponível dos devedores, deferindo-se medidas cautelares e demais meios necessários para assegurar o pagamento da obrigação, a serem promovidos perante o Juízo de Direito que deferiu o compromisso arbitral' (fl. 58), bem como nos arts. 615, III, combinado com o art. 797, do CPC." (TJ/SP, 5. ${ }^{\text {a }}$ Câmara de Direito Privado, A.I. n. ${ }^{\circ}$ 0114241-80.2006.8.26.0000 - n. ${ }^{\text {os }}$ antigos 994.06.114241-0 e 433.0104/3-00, Rel. Des. Silvério Ribeiro, j. 22/03/2006, v.u.).

${ }^{155} \mathrm{TJ} / \mathrm{SP}, 13{ }^{a}{ }^{a}$ Câmara de Direito Privado, A.I. n. ${ }^{\circ}$ 0305397-55.2009.8.26.0000 (antigo n. ${ }^{\circ}$ 990.09.305397-7), Rel. Des. Heraldo de Oliveira, j. 28/04/2010, v.u.
} 
árbitros, da decisão liminar que havia sido deferida pelo juiz monocrático, o Desembargador pontificou "que prevalece a decisão proferida pelo Tribunal Arbitral, competente para dirimir o litígio entre as partes, por força de cláusula contratual, e assim ficam prejudicadas as razões do agravo de instrumento".

E embora os árbitros tenham apenas confirmado a decisão liminar anteriormente deferida por juízo comum, em referida decisão houve a imposição de multas diárias e de outras obrigações de fazer de caráter nitidamente coercitivo ${ }^{156}$, não tendo sido reformada pelo Tribunal de Justiça de São Paulo, que declarou a perda do objeto do agravo, por entender ser o juízo arbitral o competente para decidir o pedido de tutela de urgência da forma que melhor lhe aprouvesse, aceitando, inclusive, as medidas de caráter coercitivo, tal como a multa diária mantida em arbitragem.

Assim, ao se analisar os poderes do árbitro e os elementos da jurisdição, depreende-se que o árbitro tem o poder de conhecimento (cognitio), o poder de documentação, o poder de julgamento (iudicium), mas possui o poder de coerção (coertio) de forma restrita e não possui o poder de execução forçada (executio ${ }^{157}$, uma vez que ele não tem o poder de império para fazer valer coativamente as suas decisões.

\footnotetext{
${ }^{156}$ Eis os termos da decisão liminar arbitral que prevaleceu: "41. Pelos motivos e razões acima elencados, decide o Tribunal Arbitral, por unanimidade: (a) reconhecer, com fundamento no art. $8^{\circ}$, $\S$ único da Lei n. 9.307/96, a jurisdição deste Tribunal Arbitral, determinando o prosseguimento do presente procedimento, devidamente administrado pela Câmara de Mediação e Arbitragem de São Paulo, na forma do seu Regulamento; (b) manter integralmente a decisão liminar proferida pelo MM. Juízo da 25a Vara Cível do Foro Central da Comarca de São Paulo, para que a Fundação Uniplac: (i) se abstenha de cobrar e receber todos os créditos negociados; (ii) envie, mensalmente, à Requerente, até o dia 05 de cada mês, os arquivos completos de atualização mensal, tal como determinado na cláusula $8^{a}$ do Contrato, sob pena de ser garantido à Requerente a possibilidade de diligenciar junto à sede da Instituição de Ensino, ora Requerida, para elaborar o relatório mensal; (iii) comunique aos alunos, cujas mensalidades foram negociadas através do Contrato, que o pagamento das mensalidades deverá se dar através dos boletos de pagamento emitidos pela Requerente, o que deverá ocorrer mediante correspondências, avisos fixados na tesouraria, sem prejuízo de comunicações pelos mesmos meios e quantidades dos enviados pela Instituição de Ensino, ora Requerida, em sentido contrário. Caso descumpridas quaisquer das determinações, ficam mantidas as multas fixadas judicialmente, quais sejam, em relação ao item (i), R\$ 1.000,00 para cada violação do preceito, e aos itens (ii) e (iii), $\mathrm{R} \$ 10.000,00$ para cada dia de atraso. Permanece a Requerente obrigada a depositar na conta judicial os valores eventualmente recebidos diretamente, nos termos da decisão liminar original do Exmo. Dr. Samuel Francisco Mourão Neto, datada de 02 de outubro de 2009, até ulterior deliberação; (c) indeferir, até segunda ordem, se for o caso, o levantamento de quaisquer valores bloqueados judicialmente por parte da Requerente, ressalvada a possibilidade de revisão desta decisão caso seja oferecida caução idônea, nos termos acima descritos; (d) indeferir o levantamento de quaisquer valores bloqueados judicialmente por parte da Requerida Uniplac; (e) indeferir o pedido da Uniplac no sentido de cobrar diretamente dos alunos as mensalidades e matrículas que tenham sido objeto de cessão no Contrato".

${ }^{157}$ Com relação ao tema, é interessante o magistério de GILBERTO GIUSTI, no sentido de que não há como se afirmar que o árbitro nunca exerce o poder da executio, tendo em vista que os provimentos declaratórios ou constitutivos proferidos em arbitragem "não dependem de um processo de execução posterior, sujeitando-se
} 
É nesse particular, portanto, que se fraciona a jurisdição arbitral, sem que isso possa lhe trazer qualquer prejuízo ou nulidade, apenas por lhe faltar o coertio integral e o imperium/executio, que são componentes privativos do Estado ${ }^{158}$.

Ressalte-se, por oportuno, que a falta de imperium não afeta o caráter jurisdicional da arbitragem, tendo em vista que o próprio Estado "coloca à sua disposição a coerção que detém para que o laudo seja respeitado e cumprido"159.

Nessa esteira, recorda-se que (i) os juízes trabalhistas também não têm poderes para decretar prisões; (ii) os juízes dos antigos juizados de pequenas causas não possuíam competência para executar as suas sentenças antes da alteração legislativa de 1993; e, (iii) no Tribunal do Júri, há participação de particulares para decidir a questão ${ }^{160}$, sem que se cogite a ausência de jurisdição nesses casos ${ }^{161}$.

as partes automaticamente ao resultado (...) já que o provimento surte efeito vinculante e imediato no plano da realização da pretensão." (GIUSTI, Gilberto. O árbitro e o juiz..., p. 13), valendo-se ressaltar que, em caso de cumprimento espontâneo da sentença arbitral condenatória, também se verifica a sua capacidade executória e, portanto, a presença da executio na arbitragem.

${ }^{158}$ Cf. MARTINS, Pedro A. Batista Martins. Da Ausência de Poderes Coercitivos..., p. 361. Nessa mesma esteira, cite-se voto vencedor proferido pelo juiz MIGUEL CUCINELLI: "apesar de o cumprimento das decisões ter de ser feito pelo Poder Judiciário, o único que detém o poder para impor medidas coercitivas, isso não significa que o procedimento cautelar ou especial não tenha sido contemplado pela lei que instituiu a arbitragem no Brasil. Esse é o preciso comando que se extrai da leitura do art. $22, \S 4^{\circ}$, da Lei n. ${ }^{\circ} 9.307$, de 23 de setembro de 1996." (Ex-2. ${ }^{\circ}$ TACiv-SP, 7. ${ }^{a}$ Câm. do Quarto Grupo, A.I. n. ${ }^{\circ}$ 0036712-87.2003.8.26.0000 (números anteriores 818.499/0-00 e 992.03.036712-2), Rel. designado Juiz Américo Angélico, j. 18/11/2003, maioria). Em Portugal, o árbitro também é competente para conceder as tutelas de urgência, todavia, assim como no Brasil, não possui poderes para executá-las, devendo buscar o imperium junto ao juízo estatal, nos termos do artigo 27. ${ }^{\circ}$ da Lei n. ${ }^{\circ}$ 63/2011. O mesmo ocorre na Alemanha, conforme o art. 1041 (2) da ZPO.

${ }^{159}$ MORAIS, Jose Luis Bolzan de. Mediação e Arbitragem: alternativas à jurisdição! Porto Alegre: Livraria do Advogado, 1999, p. 196. Na Inglaterra ocorre o mesmo, podendo a decisão arbitral ser executada perante o juízo estatal (cf. ANDREWS, Neil. Arbitration and mediation in England..., p. 117).

160 "Muitas vezes, o Estado, com respaldo constitucional, integra o particular no cumprimento da função jurisdicional, como, por exemplo, no Tribunal do Júri, em que seus veredictos são expressão da própria autoridade estatal." (CARREIRA ALVIM, José Eduardo. Tratado Geral da Arbitragem..., p. 55).

${ }^{161}$ Conforme lição de JoÃo PAUlo HeCKER DA SILVA: "a dúvida reside na confusão entre o exercício do poder com o exercício da força, já que equivocadamente se toma atos de força como aqueles inerentes ao exercício da jurisdição. Não é essa a melhor interpretação porque apesar de o árbitro não poder decretar prisões, os juízes trabalhistas também não possuem tais poderes; apesar de o árbitro não poder executar suas decisões efetuando constrições sobre bem alheio, os juízes dos antigos juizados de pequenas causas, que não possuíam competência para execução de suas sentenças antes da alteração legislativa de 1993 (art. 40 da Lei n. 7.244/84), também não tinham. A alegação de que a participação do particular no cumprimento da função jurisdicional também não retira da arbitragem seu caráter jurisdicional não prevalece porque isso sempre ocorreu com o Tribunal do Júri, muito embora nunca se tenha suscitado ausência de jurisdição nesses casos. Vale notar que a competência do Tribunal do Júri é absoluta e, portanto, a participação do particular é obrigatória para o exercício da jurisdição. Assim, percebe-se que em todos os exemplos dados, nunca se cogitou a ausência de jurisdição desses juízes de direito." (Tutela de Urgência e Tutela..., pp. 295/296). Em igual sentido: CARMONA, Carlos Alberto. Das boas relações entre os juízes..., p. 19. 
Pedro A. Batista Martins, um dos co-autores da Lei de Arbitragem brasileira, esclarece que essa posição conservadora (ausência de poder de imperium por parte do árbitro) foi adotada para se evitar possíveis obstáculos na tramitação e para a aprovação de referida lei ${ }^{162}$.

Quanto ao assunto, como a própria legislação reservou privativamente ao Estado o poder de imperium, tal poder não pode ser concedido aos árbitros pelas partes na convenção de arbitragem, sob pena de ofensa à ordem pública ${ }^{163}$.

Resta claro e evidente, pois, o poder cognitivo do árbitro para apreciar e julgar os pedidos de concessão de tutelas de urgência em sede de arbitragem (cognitio e iudicium), e, por outro lado, a impossibilidade de o árbitro (julgador privado) impor, por meio de atos de força (imperium), as suas determinações, na medida em que tal providência constitui monopólio estatal ${ }^{164}$.

Desse modo, considerando-se que a jurisdição é una e o poder de decisão, na arbitragem, é concedido por lei ao árbitro, inevitável concluir que o poder de imperium deve ser buscado junto ao Poder Judiciário, tendo em vista que, na

\footnotetext{
${ }^{162}$ Da Ausência de Poderes Coercitivos..., p. 361. Contudo, para ele, "seria um avanço significativo, a causar enorme polêmica, se ao árbitro fosse dado o componente jurisdicional da coerção (ainda privativo do Estado) e, assim, pudesse impor suas próprias determinações cautelares e coercitivas.” (idem, p. 357). CARLOS A. CARMONA também anota que a comissão relatora do anteprojeto da Lei de Arbitragem pensou em conceder poder de imperium aos árbitros, "mas acabou concluindo que não havia ainda (corria o ano de 1991!) cultura arbitral sólida que pudesse escudar uma providência tão inovadora." (Arbitragem e Processo..., p. 324). PAULO HOFFMAN sugere que a legislação deve ser alterada, conferindo-se poder de imperium ao árbitro, dizendo que "o procedimento arbitral não deve ficar manco e dependente do Poder Judiciário", bem como que "deve o árbitro ter poderes para cumprir e executar suas decisões, desafogando e separando ainda mais jurisdição estatal de jurisdição privada." (Arbitragem: algumas dúvidas..., p. 316). Sobre os poucos exemplos de execução extrajudicial previstos em lei no Brasil, ver: YOSHIKAWA, Eduardo Henrique de Oliveira. Execução Extrajudicial e Devido Processo Legal. São Paulo: Atlas, 2010.

${ }^{163}$ JOSÉ ANTONIO FICHTNER e ANDRÉ LUís MONTEIRO aduzem que a atuação arbitral se desenvolve nos limites do que foi deliberado na convenção de arbitragem, "na qual não se permite em hipótese alguma outorgar ao árbitro poderes típicos de execução em sentido lato." (Medidas urgentes no processo..., p. 47). Nas arbitragens internacionais, contudo, isso seria possível. JULIAN M. LEW, LOUKAS A. MisTELIS e STEFAN M. KRÖLL aduzem que as partes podem outorgar poderes de coerção ao(s) árbitro(s): "unless specifically agreed by the parties, a tribunal lacks the power to enforce its measures and cannot impose penalties for non-compliance." (trad. livre: "ao menos que especificamente acordado pelas partes, um tribunal arbitral não possui poderes para executas suas medidas e não pode impor penalidades pela ausência de cumprimento.") (Comparative International..., p. 593). Ainda sobre o tema, CARLOS AlBERTO CARMONA aponta que a Ley de Arbitraje e Mediación do Equador (de 1997), privilegiando o princípio da autonomia, faculta às partes concederem aos árbitros poderes para executar as medidas cautelares decretadas, valendo-se do concurso da estrutura estatal (in Arbitragem e Processo..., p. 323).

${ }^{164}$ Cf. TALAMINI, Eduardo. Tutela relativa aos deveres de fazer e de não fazer: e sua extensão aos deveres de entrega de coisa (CPC, arts. 461 e 461-A; CDC art. 84), 2. ${ }^{a}$ edição. São Paulo: RT, 2003 p. 459.
} 
realidade, arbitragem e Judiciário compõem um mesmo sistema ${ }^{165}$, com um único objetivo comum: a busca pela pacificação de conflitos.

Exatamente por isso, seria ingênuo pensar que a arbitragem poderia sobreviver sem o auxílio e o suporte do Poder Judiciário nos termos da lei atual ${ }^{166}$, pois o poder de imperium deve, obrigatoriamente, ser buscado perante o juiz estatal.

\section{RELAČ̃̃o ENTRE O JUÍZO ARBITRAL E O JUÍZO ESTATAL}

Surge, então, a dúvida de como se dá a relação entre o juízo arbitral e o estatal.

Há duas correntes com relação ao tema: a primeira, que sugere uma relação de subordinação do árbitro ao juiz estatal; e a segunda, que nos parece sem dúvida a mais correta, que parte da idéia de cooperação entre juiz togado e árbitro.

E não deve haver dúvida de que o Poder Judiciário é órgão de cooperação, de suporte e de assistência às atividades do juízo arbitral, não sendo aquele

${ }^{165}$ Cf. PRADO, Vinícius de Andrade. Medidas cautelares..., p. 193.

166 Cf. MARTINS, Pedro A. Batista Martins. Da Ausência de Poderes Coercitivos..., p. 370. Igualmente, SIDNEI BENETI aduz que "a arbitragem, que vem a auxiliar a jurisdição estatal, aliviando-lhe a carga de trabalho na composição das massas de lide, não pode prescindir totalmente desta, da jurisdição estatal, para efetivar-se e consolidar-se", constatando que a jurisdição convencional (arbitragem) e a jurisdição estatal não podem "viver uma sem a outra." (Arbitragem e tutelas de urgência..., p. 101). SABRINA RIBAS BOLFER também aponta "que o juiz estatal possui papel primordial no funcionamento e desenvolvimento da arbitragem" e que, "sem ele, a arbitragem não poderia se desenvolver, e as decisões do árbitro não se tornariam executáveis (...) porque é o juiz estatal quem concede força coercitiva à arbitragem.” (BOLFER, Sabrina Ribas. Anti-suit injuctions e Arbitragem Comercial Internacional. Dissertação de mestrado apresentada à Faculdade de Direito da Pontifícia Universidade Católica do Paraná em julho de 2005, p. 02). Lecionando sobre a relação entre a justiça estatal e a justiça arbitral, BRUNO OPPETIT salienta que "a complementaridade entre ambas vem à tona cada vez que há necessidade de se dirigir aos tribunais estaduais para requerer apoio à instauração de um tribunal arbitral, para obter medida conservatória ou, ainda, para tornar a sentença executória ou requerer-lhe a anulação.” (in Etudes offertes..., p. 193). NEIL ANDREWS, citando decisão de LORD HOFFMANN na Câmara dos Lordes (House of Lords), diz que “(...) Arbitration cannot be sef-sustaining. It needs the support of the courts (...)” (tradução livre: “(...) A arbitragem não pode ser auto-sustentável. Ela necessita do apoio das cortes (...)”.) (Arbitration and mediation in England..., p. 128). Por fim, PIERO BERNARDINI, falando sobre a arbitragem internacional, sustenta que "if it wants to remain an efficient mechanism of disputes resolution, has to accept a degree of intervention from the national judge in complementing the arbitrator's functions." (tradução livre: "se ela [a arbitragem] quer permanecer um mecanismo eficiente de resolução de disputas, ela tem que aceitar um nível de intervenção do juiz togado em complementar as funções do árbitro.”) (The Powers of the Arbitrator..., p. 22). 
órgão de interferência ou de fiscalização da justiça privada, não possuindo o juiz togado poderes para revisar ou para se imiscuir no processo conduzido pelos árbitros ${ }^{167}$.

A arbitragem e o Poder Judiciário devem ser vistos como órgãos de realização da justiça com funções complementares, e não concorrentes ${ }^{168}$.

É de uma clareza solar que a Lei de Arbitragem brasileira instituiu um regime de cooperação, e não de subordinação, entre o árbitro e o órgão judicial, tanto que ela prevê, em diversas situações, essa atividade de cooperação do Judiciário com o árbitro, como, por exemplo, (i) para a execução específica da cláusula compromissória (art. 7. ${ }^{\circ}$ ); (ii) para a nomeação de árbitro para completar o Tribunal Arbitral (art. 13. ${ }^{\circ}, \S 2 .^{\circ}$ ); (iii) para a nomeação de árbitro substituto (art. 16, § 2. ${ }^{\circ}$ ); (iv) para a condução coercitiva de testemunhas (art. $\left.22, \S 44^{\circ}\right)^{169}$ etc..

${ }^{167}$ Nesse sentido: MARTINS, Pedro A. Batista Martins. Da Ausência de Poderes Coercitivos..., pp. 369/370. Igualmente: "Desta maneira, encontrando-se uma arbitragem em andamento, a regra geral está na falta de competência do Judiciário para imiscuir-se no procedimento." (VERÇOSA, Haroldo Malheiros Duclerc. O Judiciário e a valorização...). Ainda: "Convencionada essa via para a resolução da controvérsia, as partes afastam consensualmente a intervenção do Poder Judiciário, que fica impedido de intervir no mérito do litígio." (AMARAL, Paulo Osternack. A concessão de medidas urgentes..., p. 23).

${ }^{168}$ Nessa linha: "é preciso assimilar o entendimento de que os órgãos judiciais e privados de realização da justiça têm funções complementares e não concorrentes. Essa cultura é fundamental para a boa prática e regular condução do processo arbitral." (MARTINS, Pedro A. Batista Martins. Da Ausência de Poderes Coercitivos..., p. 370). Ainda: "esse relacionamento entre os órgãos do Poder Judiciário e os órgãos arbitrais deve ser marcado pelo sentimento de cooperação, pelo estado de prontidão e, principalmente, pela consciência do múnus público exercido. (...) os juízos estatais e os árbitros deverão cooperar em busca do fim comum: a composição da lide." (FICHTNER, José Antonio; MONTEIRO, André Luís. Medidas urgentes no processo..., p. 50).

${ }^{169}$ Em Portugal, o artigo 38. ", “1”, da Lei n. ${ }^{\circ}$ 63/2011, também prevê a hipótese de o Poder Judiciário colaborar com o juízo arbitral quanto à produção da prova, in verbis: "Artigo $38 .^{\circ}$ Solicitação aos tribunais estaduais na obtenção de provas 1 - Quando a prova a produzir dependa da vontade de uma das partes ou de terceiros e estes recusem a sua colaboração, uma parte, com a prévia autorização do tribunal arbitral, pode solicitar ao tribunal estadual competente que a prova seja produzida perante ele, sendo os seus resultados remetidos ao tribunal arbitral". Na Alemanha, há previsão similar de colaboração do Poder Judiciário para a instrução do processo arbitral, conforme o § 1050 do CPC (ZPO): "Section 1050 - Court assistance in taking evidence and other judicial acts The arbitral tribunal or a party with the approval of the arbitral tribunal may request from a court assistance in taking evidence or performance of other judicial acts which the arbitral tribunal is not empowered to carry out. Unless it regards the application as inadmissible, the court shall execute the request according to its rules on taking evidence or other judicial acts. The arbitrators are entitled to participate in any judicial taking of evidence and to ask questions." (trad. livre: "Seção 1050 Assistência da Corte para a produção de provas e para outros atos judiciais. O tribunal arbitral ou a parte, com a aprovação do tribunal arbitral, poderão requerer à Corte assistência para a produção de provas ou para efetivar outros atos judiciais para os quais o tribunal arbitral não possui poderes. A não ser que a Corte considere o pedido inadmissível, a Corte deverá executar o pedido de acordo com suas regras de produção de provas ou dos demais atos judiciais. Os árbitros poderão participar de qualquer ato judicial para produção de provas e fazer perguntas.”). Na França, também há previsão de auxílio do Poder Judiciário à arbitragem, conforme o disposto no art. 1460 do Código de Processo Civil francês: "Arte. 1460. Le juge d'appui est saisi soit par une partie, soit par le tribunal arbitral ou l'un de ses membres. La demande est formée, instruite et jugée comme en matière de référé." (trad. livre: "Art. 1460. O pedido para o juiz agir em apoio à arbitragem 
Dessa feita, resta evidente que a relação entre o árbitro e o juiz togado é de cooperação, e não de subordinação ${ }^{170}$.

Admitir o contrário seria o mesmo que não aceitar a validade da arbitragem, questão essa que, como visto no capítulo introdutório, já foi dirimida pelo Supremo Tribunal Federal.

pode ser feito por uma parte, pelo tribunal arbitral ou por um de seus membros. Essa ação deve ser formada, instruída e julgada como matéria de liminar-urgência). Na Suíça, o artigo 184 (2) da Lei Federal Suíça de Direito Privado Internacional segue a mesma linha, prevendo o auxílio do juiz togado para a produção de provas em arbitragem: "Art. 184 - Taking of evidence - (...) 2. If the assistance of the judicial or administrative authorities of the State is needed to take evidence, the arbitral tribunal or, with the consent of the arbitral tribunal, a party may request the assistance of the judge at the seat of the arbitral tribunal who shall apply his own law." (trad. livre: "Art. 184 - Produção de provas - (...) 2. Se o auxílio da autoridade judicial ou administrativa do Estado é necessária para a produção de provas, o tribunal arbitral ou, com o consenso do tribunal arbitral, a parte pode requerer a assistência do juiz na sede do tribunal arbitral, o qual deverá aplicar a sua própria lei."). Por fim, NEIL ANDREWS ensina que, na Inglaterra, "to compel prospective witnesses to appear before the arbitrator or to produce other evidence, a party to arbitration must ultimately invoke the court's coercitive machinery. For this purpose, the 1996 Act enables a party to arbitration, with the arbitrator's permission, to 'use the same court procedures as are available in relation to legal proceedings to secure the attendance before the [arbitral] tribunal of a witness'." (trad. livre: "para compelir a testemunha em perspectiva a aparecer perante o árbitro ou para produzir outras provas, a parte da arbitragem deve ao final invocar o maquinário coercitivo da corte. Para esse propósito, a Lei de 1996 permite que a parte de uma arbitragem, com a autorização do árbitro, 'utilize os mesmos procedimentos das cortes disponíveis em relação aos procedimentos legais para garantir o comparecimento de uma testemunha perante o tribunal [arbitral]".") (Arbitration and mediation in England..., p. 117).

${ }^{170}$ Nesse exato sentido: "O Judiciário precisa enxergar e considerar a arbitragem como aliada na luta pela efetividade da jurisdição [art $5^{\circ}, \mathrm{XXXV}$, da CF], o que reclama respeito à sua autonomia, sem, no entanto, prejudicar a atuação paralela do Estado-juiz, quando essa atividade for harmônica e produtiva aos objetivos perseguidos pelas partes e para a própria sociedade." (TJ/SP, 4. ${ }^{a}$ Câm. Dir. Privado, MC n. ${ }^{\circ} 9036737-$ 05.2007.8.26.0000 - n. ${ }^{\circ}$ antigo 494.408-4/6, Rel. Des. Enio Zuliani, j. 28/06/2007, v.u.). Na Itália, assim como em outros sistemas jurídicos, a atividade do juízo estatal também é de colaboração com a arbitragem, nos termos da lição de LAURA SALVANESCHI: “Or, à l'instar d'autres systèmes de droit positif, en droit italien, l'on observe une collaboration accrue entre le juge étatique et es arbitres." (trad. livre: "No entanto, assim como em outros sistemas de direito positivo, no direito italiano, observa-se uma colaboração acentuada entre o juiz estatal e os árbitros.") (SALVANESCHI, Laura. "Mesures provisoires et arbitrage en droit italien". Les mesures provisoires en droit belge, français et italien, VAN COMPERNOLLE, Jacques; TARZIA, Giuseppe (org.). Bruxelas: Bruylant, 1998, pp. 447/460, p. 455). 


\section{CAPÍTULO V \\ TUTELA DE URGÊNCIA NA ARBITRAGEM}

13. TUTELAS URGENTES: BREVE HISTÓRICO, DISTINČ̃̃O ENTRE MEDIDA CAUTELAR E TUTELA ANTECIPADA E SUA APLICAĊ̃̃O PARA A ARBITRAGEM

Conforme sustenta José Roberto dos SANTOS BedAque, é possível se estabelecer uma comparação entre as tutelas de urgência atuais e os interditos do processo romano ${ }^{171}$.

Isso porque, já nos interditos do direito romano, era possível a obtenção de ordem liminar, até mesmo sem a presença da parte contrária e mediante cognição sumária das alegações do autor (sendo os direitos obrigacionais, tais como pedidos de indenização, por outro lado, amparados pela actio, com juízo privado).

Nesse sentido, Carlos Alberto Alvaro de Oliveira ensina que o conceito de sumariedade era trabalhado de duas formas no direito romano: pela técnica da exposição sumária dos fatos por parte do autor ou pela técnica da cognição sumária do juiz, ressaltando o jurista que a cognição sumária sempre se revela em essência a mesma, "atuando mediante limitações na investigação da evidência prima facie"172.

No direito romano antigo, portanto, já eram conhecidas a cognição sumária e a antecipação dos efeitos da tutela ${ }^{173}$.

\footnotetext{
${ }^{171}$ BEDAQUE, José Roberto dos Santos. Tutela cautelar e tutela antecipada: tutelas sumárias e de urgência (tentativa de sistematização), 5. ${ }^{a}$ edição. São Paulo: Malheiros, 2009, p. 30. GALENO LACERDA também leciona que os interditos romanos podem ser apontados como os precursores das medidas urgentes, lembrando, igualmente, que medidas dessa natureza foram previstas no Codex Iuris Canonici (Cânone 1672) e nos Códigos Sardos de 1854 e 1859 ("Tutela Antecipatória e Tutela Interdital". Estudos de Direito Processual e Homenagem a Luiz Machado Guimarães. BARBOSA MOREIRA, José Carlos (coord.), 1. ${ }^{a}$ edição. Rio de Janeiro: Forense, 1977, p. 187).

${ }_{172}^{17}$ Comentários ao Código de Processo Civil, Vol. VIII, T. II, 8. a edição. Rio de Janeiro: Forense, 2007, p. 4.

${ }^{173} \mathrm{Cf}$. BEDAQUE, José Roberto dos Santos. Tutela cautelar e tutela antecipada..., pp. 30/31. BEDAQUE ainda lembra "a existência de doze exemplos de tutelas dessa natureza, dez nas Pandectas e dois nos Códigos de 231 e 331 d.C", apontando também como antecedentes da moderna tutela cautelar a manus iniectio e a pignoris capio. Nessa linha, C. A. ALVARO DE OliveIRA ressalta que "desde o direito romano, registra a história do direito processual casos de tutela de conhecimento em que se permite, até por cognição prima facie, a interferência no mundo fático, com antecipação de efeitos materiais. É o que demonstra Briegleb, jurista e historiador alemão do século XIX, professor do grande Adolph Wach, indicando, em sua magistral
} 
Ainda quanto ao assunto, OvíDIO A. BAPTISTA DA Silva aduz que a tutela de urgência instituída pelo artigo 273 do Código de Processo Civil é semelhante ao antigo processo do tipo interdital romano, em que o pretor antecipava a execução ou o mandamento no próprio processo cognitivo, independentemente de processo autônomo, superando a rígida separação entre conhecimento e execução ${ }^{174}$.

Não há dúvida, pois, de que os interditos romanos podem ser indicados como antecessores das tutelas de urgência, "pois se assemelham às liminares atuais, contendo ordem de tutela provisória"175.

No direito pátrio moderno, antes mesmo da atual redação dada ao artigo 273 do Código de Processo Civil pela Lei n. ${ }^{\circ}$ 8.952, de 13 de dezembro de 1994 (que instituiu expressamente a possibilidade da antecipação de tutela de forma genérica), já era prevista a possibilidade de antecipação da tutela jurisdicional em certas hipóteses, conforme exemplos citados por EdUARDo HenRIQUe DE OLIVEIRA YoshiKAwA: “a execução provisória das sentenças condenatórias (art. 588, na redação originária do CPC; atualmente art. 475-O) e as liminares em ações possessórias de 'força nova' (art. 928) e em mandado de segurança (na legislação revogada, art. $7^{\circ}$, II, da Lei $\mathrm{n}^{\mathrm{o}} 1.533 / 51$; atualmente art. $7^{\mathrm{o}}$, III, da Lei $\left.\mathrm{n}^{\mathrm{o}} 12.016 / 2009\right)^{, 176}$.

Admitia-se também, em alguns casos, o uso do processo cautelar (que tem como objetivo proteger a eficácia do processo - caráter conservativo ou

obra sobre processo sumário, 12 exemplos dessa espécie, 10 nas Pandetas - sendo nove de Ulpiano e um de Paulo - e dois nos Códigos, respectivamente, de 213 e 331 d.C." (in Comentários ao Código de..., p. 01).

${ }^{174}$ Cf. BAPTISTA DA SILVA, Ovídio A. "A Antecipação de Tutela, na Recente Reforma Processual” in A Reforma do Código de Processo Civil. TEIXEIRA, Sálvio de Figueiredo (coord.). São Paulo: Saraiva, 1996, p. 136. Não é diferente a lição de JoÃo BATISTA LOPES, o qual também relembra que em Roma já "se conheciam instrumentos eficazes para a pronta proteção do direito como os interditos (interdicta), ordens expedidas pelo pretor, não como juiz, mas como autoridade investida de poder administrativo (imperium)." (LOPES, João Batista. "As 'antigas novidades' do processo civil brasileiro e a efetividade da jurisdição". Revista de Processo - RePro, ano 33, n. ${ }^{\circ}$ 157. São Paulo: RT, março de 2008, pp. 09/17). Quanto à unidade do processo cautelar, LIEBMAN diz que há atividade de cognição e de execução na tutela cautelar: (i) de cognição, por decidir se está presente ou não a condição para o deferimento da medida cautelar pleiteada; (ii) de execução, por colocar em prática a medida cautelar deferida, concluindo que as principais razões da unidade do processo cautelar são a sua instrumentalidade e a impossibilidade de se distinguir um processo de conhecimento e um processo de execução (LIEBMAN, Enrico Tullio. "Unità del processo cautelare". Problemi del processo civile. Napoli: Morano, 1962, pp. 104/110).

${ }_{175}$ Cf. BEDAQUE, José Roberto dos Santos. Tutela cautelar e tutela antecipada..., p. 32.

176 YOSHIKAWA, Eduardo Henrique de Oliveira. "Limites à Possibilidade de Antecipação da Tutela Jurisdicional de Ofício" in Revista Dialética de Direito Processual, n. ${ }^{\circ}$ 104. São Paulo: Dialética, 2011, pp. 24/43, p. 26. 
assecuratório) para tutelar o próprio direito material pleiteado em juízo, de forma provisória, até a decisão final, para o fim de se evitar os efeitos maléficos do tempo sobre o direito da parte (a exemplo do que já havia ocorrido antes na Itália quanto à aplicação do artigo 700 do Codice de Procedura Civile $)^{177}$.

E o aumento do uso dos provimentos cautelares de forma satisfativa ou visando a tutelar o direito material pleiteado em juízo, possibilitou ao legislador disciplinar, de forma expressa, as tutelas de urgência antecipatórias do mérito da causa, o que foi feito por meio da Lei n. ${ }^{\circ} 8.952$, de 13 de dezembro de $1994^{178}$.

Quanto às tutelas de urgência ${ }^{179}$ atuais, é sabido que, tanto na prática forense, como na Academia, distingue-se a medida cautelar da tutela antecipada ${ }^{180}$.

De fato, doutrina e jurisprudência apontam, pacífica e amplamente, as diferenças existentes entre os dois institutos, pontificando, em linhas

${ }^{177}$ Cf. YOSHIKAWA, Eduardo Henrique de Oliveira. Limites à Possibilidade de..., p. 27.

${ }^{178}$ FLÁVIO LUIZ YARSHELL enfatiza que a autonomia conceitual da "tutela antecipada" também constituiu garantia do sistema processual contra a denegação de justiça pelos juízes, os quais, muitas vezes, indeferiam medidas cautelares satisfativas urgentes sob o argumento de que elas seriam incompatíveis com a tutela cautelar ("Antecipação de Tutela Específica nas Obrigações de Declaração de Vontade, no Sistema do CPC" in Aspectos Polêmicos da Antecipação de Tutela. WAMBIER, Teresa Arruda Alvim (coord.). São Paulo: RT, 1997, p. 172, nota 1), conforme, por exemplo, o seguinte acórdão do STJ: "Processual Civil - Ação cautelar - Garantia e eficácia do processo principal. I - Não têm as medidas cautelares a função de proteger o direito da parte mas, tão só, de garantir a eficácia e a utilidade do processo principal ante a iminência de situação de perigo ou risco da parte que venha a sair vitoriosa no julgamento da lide. II - Pedido indeferido." (STJ, 3. ${ }^{a}$ Turma, Pet 324/SP, Rel. Min. Waldemar Zveiter, j. 25/08/1992, DJ 16/11/1992, p. 21.132, RSTJ 43/213). PAUlo OSTERNACK AMARAL ainda lembra que "o motivo determinante para a inclusão da antecipação de tutela no ordenamento pátrio foi, indubitavelmente, por consistir na principal alternativa para se restabelecer a distribuição isonômica do ônus do tempo do processo entre as partes litigantes." (in A concessão de medidas urgentes..., p. 25).

179 JOSÉ ROBERTO DOS SANTOS BEDAQUE anota que "a expressão 'tutela de urgência' está consagrada pela doutrina." (Tutela cautelar e tutela antecipada..., p. 166). Lívio GOELLNER GORON também ensina que "a doutrina brasileira reservou a expressão 'tutela de urgência' apenas às tutelas sumárias provisórias, ou seja, às medidas cautelares e antecipatórias”, mas faz críticas à expressão, dizendo que o seu uso corrente não seria inteiramente correto, pois ela também poderia se aplicar às tutelas sumárias autônomas, especialmente porque "a idéia de 'urgência' é suficientemente ampla para abarcar tanto o perigo de um dano aferido em concreto como a valoração abstrata do tipo de causa ou da situação processual que resultou na redistribuição, em favor do autor, do ônus do tempo no processo", ficando "evidenciada a insuficiência da expressão "tutelas de urgência' para diferenciar os provimentos cautelares e antecipatórios das medidas autônomas". Conclui adotando a expressão "tutelas provisórias de urgência" como sendo a expressão mais correta para tanto ("Repensando as Tutelas de Urgência e as Fronteiras entre Medidas Cautelares e Antecipatórias". Revista Dialética de Direito Processual, n. ${ }^{\circ}$ 103. São Paulo: Dialética, 2011, pp. 67/87, esp. pp. 74/76).

${ }^{180}$ No processo brasileiro, a dualidade das tutelas de urgência surgiu, substancialmente, das reformas dos anos 1990, com a nova redação dada aos artigos 273 e 461 do CPC, as quais prestigiaram a doutrina que considerava superado o entendimento de CALAMANDREI no sentido de que a antecipação e a conservação são funções de um mesmo gênero de tutela provisória (cf. GORON, Lívio Goellner. Repensando as Tutelas de Urgência..., p. 78). 
gerais, que os provimentos cautelares são medidas instrumentais ao processo, que visam a assegurar a utilidade de seu provimento final, enquanto a antecipação da tutela, por sua vez, tem como escopo antecipar a entrega do próprio bem da vida pretendido, oferecendo ao demandante, desde logo, no todo ou em parte, aquilo que pretende obter como resultado final do processo ${ }^{181}$.

Por todos, cite-se a lição de CÂNDIDO RANGEL DinAMARCO, no sentido de que as tutelas jurisdicionais antecipadas são "as medidas que oferecem ao sujeito, desde logo, a fruição integral ou parcial do próprio bem ou situação pela qual litiga", enquanto as medidas cautelares são "as medidas destinadas a proteger o processo em sua eficácia ou na qualidade de seu produto final" ${ }^{\prime 182}$.

Não obstante as diferenças conceituais acima apontadas, os provimentos cautelares e as antecipações de tutela fundadas no inciso I do artigo 273 do

${ }^{181}$ Cf. SILVA, João Paulo Hecker da. Tutela de Urgência e Tutela..., p. 74. Embora se deva dizer que, muitas vezes, há dúvida objetiva acerca da natureza da tutela pretendida e embora "havia - como ainda há numerosas medidas satisfativas compartilhando de espaço no recinto do "processo cautelar'." (GORON, Lívio Goellner. Repensando as Tutelas de Urgência..., p. 78), tal como a exibição judicial de documento (CPC, art. 844, II). C. A. AlvARo DE OliveIRA faz menção aos "falsos procedimentos cautelares" previstos no CPC, por implicarem, na verdade, antecipação de tutela, citando, a título de exemplo, os alimentos provisionais disciplinados pelo art. 852 do CPC e dizendo que a parte não precisará ingressar com dois processos autônomos e distintos, podendo se valer da antecipação da tutela no processo principal (Comentários ao Código de..., p. 25). O contrário também ocorre, sendo comum o ajuizamento de ação cautelar para a sustação de um protesto, quando a sustação do protesto nada mais é do que a antecipação dos efeitos do provimento final da ação que visa à declaração de inexigibilidade do título em discussão.

182 DINAMARCO, Cândido Rangel. Instituições de Direito Processual Civil, vol. I. São Paulo: Malheiros, 2001, p. 161. ENRICO TULLIO LIEBMAN também ensina que a tutela cautelar, ao contrário da tutela de conhecimento, não visa a um resultado útil imediato, mas serve apenas para garantir um resultado útil futuro, salientando que a função puramente instrumental da cognição no processo cautelar encontra a sua explicação naquilo que é o seu objeto: o de garantir o resultado do processo principal (Unità del processo cautelare..., pp. 104/110). FERRUCIO TOMMASEO, por sua vez, ressalta a finalidade satisfativa da tutela de urgência antecipatória, o que permite reconhecer nela uma forma de tutela sumária não cautelar de direitos subjetivos (I Provvedimenti d'Urgenza. Padova: Cedam, 1983, p. 123). DonAldo ARMELIN diz que a diferença entre a tutela cautelar e a tutela antecipada "resulta dos respectivos escopos", "acautelar na primeira e satisfazer na segunda." (Tutela de urgência e arbitragem..., p. 366). JOSÉ JOAQUIM CALMON DE PASSOS aduz que antecipar a tutela "significa, necessariamente, deferir essa tutela que só deferível seria após o trânsito em julgado da decisão, num momento outro qualquer precedente ao do trânsito em julgado da decisão", ressaltando que "pouco importa se liminarmente ou no curso do feito, pouco importa que no primeiro ou no segundo grau etc., se a tutela é deferida antes do trânsito em julgado da decisão, houve antecipação." (Comentários ao Código de Processo Civil, V. III, 8. a edição. Rio de Janeiro: Forense, 2001, p. 16). Por fím, Lívio GoELLNER GORON afirma que "certa diferenciação entre as medidas cautelares e antecipatórias é real e deixa perceber-se com nitidez. (...) a tutela antecipatória importa na satisfação provisória do próprio direito, enquanto a tutela cautelar tem caráter conservativo. (...) Também é verdade que os efeitos do provimento cautelar caracterizam-se pela efemeridade - jamais podem tornar-se definitivos. Já os efeitos provisórios da tutela antecipatória podem aspirar à permanência mediante a sua confirmação pela sentença de mérito." (Repensando as Tutelas de Urgência..., p. 79). 
Código de Processo Civil ${ }^{183}$ têm um evidente elemento comum, capaz de integrá-las em um único gênero: o gênero das tutelas de urgência, do qual elas seriam espécies.

Isso porque os dois institutos (a medida cautelar e a tutela antecipada) têm como objetivo comum neutralizar ou, ao menos, minorar os efeitos prejudiciais do decurso do tempo sobre os direitos ${ }^{184}$.

Além disso, as duas tutelas de urgência supracitadas também têm em comum a sumariedade na cognição ${ }^{185}$ e a provisoriedade da decisão que a defere ${ }^{186}$

Tanto para a concessão da antecipação da tutela prevista no inciso I do artigo 273 do CPC, como para o deferimento do provimento cautelar, a lei não exige que o julgador se paute por critérios de certeza, mas, sim, por critérios de probabilidade (CPC, art. 273 - verossimilhança da alegação e CPC, art. 814 - fumus boni juris), sendo certo, ainda, que quaisquer dessas medidas dependem da futura confirmação

${ }^{183}$ Que fique claro que a tutela antecipada ora mencionada é aquela fundada no inciso I do artigo 273 do Código de Processo Civil, o qual prevê a possibilidade de antecipação dos efeitos da tutela para se evitar dano irreparável ou de difícil reparação. As tutelas antecipadas previstas no inciso II e no $§ 66^{\circ}$ desse mesmo artigo não se tratam, por óbvio, de tutelas de urgência, mas de formas de sumarização do processo.

${ }_{184}$ Cf. DINAMARCO, Cândido Rangel. Instituições de Direito..., vol. I, p. 161. Igualmente: MONIZ DE ARAGÃO, Egas Dirceu. "Alterações no Código de Processo Civil: tutela antecipada, perícia" in Reforma do Código de Processo Civil. TEIXEIRA, Sálvio de Figueiredo (coord.). São Paulo: Saraiva, 1996, p. 236. Ainda: "a realidade é que todas as medidas provisórias de urgência respondem ao mesmo propósito de assegurar a utilidade da prestação jurisdicional. (...) E, sob esse ângulo finalístico, ambas - tutela cautelar e tutela antecipatória - atuam no sentido de prevenir o dano." (GORON, Lívio Goellner. Repensando as Tutelas de Urgência..., pp. 80/81); e "Não há dúvida, portanto, de que tanto a tutela cautelar típica quanto a antecipatória têm como função precípua prevenir o dano, pois ambas estão vinculadas à urgência. Nas duas hipóteses, mostra-se manifesta essa finalidade.” (OLIVEIRA, C. A. Alvaro de. Comentários ao Código de..., pp. 10/20). ${ }^{185}$ DONALDO ARMELIN sustenta que "por tutelas de urgência é possível entender aquelas vinculadas a uma cognição e procedimentos sumários, que permitem a prestação jurisdicional com a celeridade indispensável ao fim a que se destina." (Tutela de urgência e arbitragem..., p. 363). C. A. Alvaro DE OliveIRA anota que HANS KARL BRIEGLEB, já em 1859, distinguiu a mera simplificação formal do processo da sumariedade material, destacando que "o processo verdadeiramente sumário caracteriza-se pela incompletude material da causa cognitio" e que a cognição incompleta e não exauriente das tutelas de urgência é denominada de prima facie. (Comentários ao Código de..., pp. 18/19).

${ }_{186}$ Tanto o provimento cautelar, como a tutela antecipada, "supõem uma providência definitiva posterior, da qual buscam assegurar o resultado efetivo. (...) Daí decorre que as medidas provisórias de urgência podem ser revogadas ou modificadas a qualquer tempo pelo juiz." (GORON, Lívio Goellner. Repensando as Tutelas de Urgência..., pp. 81/82). Em igual sentido: "Por isso mesmo, tanto a providência cautelar em sentido estrito quanto a antecipatória podem ser modificadas ou revogadas a qualquer tempo e não dispensam a prolação de sentença quanto ao direito principal (...)" (OLIVEIRA, C. A. Alvaro de. Comentários ao Código de..., p. 10). PIERO BERNARDINI diz que, não importa sua natureza, as medidas conservativas e provisórias: "a) são temporárias por sua natureza, sendo seus efeitos limitados pelo propósito de assegurar uma proteção específica até a prolação da decisão final (portanto, seu nome 'provisória'); b) gozam de certeza limitada, considerando que são concedidas por meio de cognição sumária; c) são limitadas pelo objeto do litígio, tendo em vista que sua finalidade não pode exceder aquela da proteção legal pleiteada pela parte como tutela final de mérito." (in The Powers of the Arbitrator..., p. 23, tradução livre). 
por sentença de mérito para se estabilizar ${ }^{187}$, sendo revogáveis a qualquer tempo e em qualquer grau de jurisdição ${ }^{188}$.

CÂNDIDO RANGEl DinAmarco, bem percebendo a semelhança entre a tutela jurisdicional antecipada fundada no inciso I do artigo 273 do CPC e a tutela cautelar, afirma textualmente que são institutos "intimamente ligados, como irmãos gêmeos quase siameses"189, ressaltando que a comunhão de objetivos é um elemento muito mais significativo do que às diferenças existentes entre tais institutos ${ }^{190}$ e concluindo que "são duas categorias de um gênero só, o das medidas urgentes"191.

${ }^{187}$ Ressalte-se que o Projeto de Lei n. ${ }^{\circ} 8.046 / 2010$, em trâmite na Câmara dos Deputados, que institui um novo CPC, prevê a estabilização da tutela de urgência não impugnada. Eis os termos do art. 281: "Não sendo contestado o pedido, os fatos alegados pelo requerente presumir-se-ão aceitos pelo requerido como verdadeiros, caso em que o juiz decidirá dentro de cinco dias. (...) $§ 2^{\circ}$ Concedida a medida em caráter liminar e não havendo impugnação, após sua efetivação integral, o juiz extinguirá o processo, conservando a sua eficácia". Na hipótese de o novo CPC ser aprovado dessa forma, com a estabilização sugerida, haveria alteração até mesmo da natureza do instituto, perdendo as tutelas de urgência a sua característica de provisoriedade e assumindo uma condição de tutela sumária não cautelar (e, verificada a preclusão, ela se tornaria imutável, adquirindo estabilidade). LuIGI PAOLO COMOGLIO, CoRRADO FERRI e Michele TARUfFo ensinam que, na Itália, de uma forma geral, o provimento antecipatório é revogável e modificável, nos termos dos artigos 177, commi 1-2, e 178, comma 1, do CPC italiano. Como exceção, eles citam o exemplo da condenação em pagamento de quantia certa não contestada, em que o artigo 186-bis do CPC italiano prevê, expressamente, que a ordem antecipada de pagamento (no caso de ausência de contestação) constitui título executivo imediato, o qual conserva a sua eficácia mesmo no caso de posterior extinção do processo. Nesse caso, há a estabilização do julgamento antecipado na condenação de pagar quantia certa (in Lezioni sul processo civile. Bologna: Il Mulino, 1998, pp. 683/695). PAUlo HenRIQUE DOS SANTOS LuCON lembra que em outros ordenamentos jurídicos há previsão específica de tutela antecipada definitiva, citando os référés belga, francês e luxemburguês e a tutela antecipada italiana em alguns casos, ao deixar de impor o exame definitivo do mérito (in Eficácia das decisões e execução provisória. São Paulo: RT, 2000). Em sua obra "Estabilização das tutelas de urgência", BEDAQUE também traz sugestão de alteração do artigo 273 do CPC para prever a estabilização da tutela antecipada em determinados casos (BEDAQUE, José Roberto dos Santos. "Estabilização das tutelas de urgência". Estudos em homenagem a Ada Pellegrini Grinover, Flávio Luiz Yarshell e Maurício Zanoide de Moraes (org.), São Paulo: DPJ, 2005, pp. 660/683).

${ }^{188}$ Cf. artigos $273,4^{\circ} .^{\circ}$ e 807 , caput, do CPC. O artigo 283 do projeto do novo CPC (P.L. n. ${ }^{\circ} 8.046 / 2010$ ) também traz previsão similar: "Art. 283. As medidas conservam a sua eficácia na pendência do processo em que esteja veiculado o pedido principal, mas podem, a qualquer tempo, ser revogadas ou modificadas, em decisão fundamentada, exceto quando um ou mais dos pedidos cumulados ou parcela deles mostrar-se incontroverso, caso em que a solução será definitiva".

${ }^{189}$ DINAMARCO, Cândido Rangel. "O Regime jurídico das medidas urgentes" in A nova era do processo civil. São Paulo: Malheiros, 2003, p. 36. Em outra magistral obra, DINAMARCO afirma que a antecipação da tutela jurisdicional e a tutela cautelar são "dois irmãos quase gêmeos (ou dois gêmeos quase univitelinos)" (in A reforma da reforma. São Paulo: Malheiros, 2002, p. 90). Lívio GOELLNER GORON, corroborando esse entendimento, aduz que "irmanam-se as duas espécies", pois, "do ponto de vista teleológico, faz sentido conceber a existência de apenas um instituto processual, que conjuga as funções "estática" (a conservação de uma situação de fato até a superveniência da tutela principal) e 'dinâmica' (referente à possível antecipação do conteúdo da tutela definitiva)", destacando, igualmente, que "a unidade revela-se ainda no plano estrutural, porque ambas as espécies revestem-se da natureza de tutelas provisórias e instrumentais", razão pela qual "não é desarrazoada a convergência das tutelas cautelar e antecipatória sob a mesma categoria processual." (Repensando as Tutelas de Urgência..., pp. 80, 81 e 84).

${ }^{190}$ DINAMARCO aduz que "comparando-os, percebe-se que essa comunhão de objetivos é um elemento muito mais significativo e perceptível que as diferenças entre eles, tanto que em inúmeros casos continua sendo equivocadamente afirmada ou pressuposta a natureza cautelar de certos provimentos que na realidade 
A reforçar a semelhança entre a tutela antecipada fundada no inciso I do artigo 273 do CPC e a medida cautelar, deve ser mencionada a inserção do parágrafo $7 .^{\circ}$ ao referido artigo 273 do CPC, pela Lei n. ${ }^{\circ} 10.444$, de 07 de maio de 2002.

Com efeito, mencionado parágrafo $7 .^{\circ}$ do artigo 273 do CPC prevê, expressamente, a fungibilidade da tutela antecipada para medida cautelar, ao estatuir que "se o autor, a título de antecipação de tutela, requerer providência de natureza cautelar, poderá o juiz, quando presentes os respectivos pressupostos, deferir a medida cautelar em caráter incidental do processo ajuizado".

E a melhor doutrina pátria defende que essa fungibilidade é de "mão dupla", servindo tanto para a substituição do pedido de antecipação da tutela por um provimento cautelar, como para a substituição do pedido de provimento cautelar por uma tutela antecipada ${ }^{192}$.

cautelares não são - é o caso, em primeiro lugar, da sustação de protesto e dos alimentos provisionais. Chega-se ao ponto de, numa postura fútil e pueril, dizer que alguma medida só pode ser considerada se for pedida a título de cautelar, mas não, se pedida como antecipação de tutela jurisdicional - como se uma coisa fosse o que se diz que ela é e não o que é realmente, ou se a manipulação do nomen juris fosse suficiente para alterar a natureza das coisas. Assim, sendo tão intimamente ligados esses dois institutos, ao menos por analogia devem ser aplicados à tutela jurisdicional antecipada muitos dos dispositivos destinados diretamente à tutela cautelar" (O Regime jurídico das medidas..., p. 36). Por essas mesmas razões, BARBosA MOREIRA considera "excessiva" a preocupação da doutrina em distinguir as funções de conservação e de antecipação, sustentando ser mais relevante a pesquisa dos seus elementos comuns do que "a busca metafísica dos fatores que a distinguem." (BARBOSA MOREIRA, José Carlos. "Tutela de Urgência e Efetividade do Direito" in Temas de direito processual, 8. ${ }^{a}$ Série. São Paulo: Saraiva, 2004, pp. 89/105, p. 100).

${ }^{191}$ Cf. DINAMARCO, Cândido Rangel. A reforma da reforma. São Paulo: Malheiros, 2002, p. 90. BeDAQUE também ensina que ambos os provimentos, "os antecipatórios e os conservativos, pertencem à mesma categoria de provimentos sumários, instrumentais e provisórios. Têm, pois, estrutura e finalidade idênticas." (Tutela cautelar e tutela antecipada..., p. 166). Nessa mesma linha, HUMBERTO THEODORO JÚNIOR assevera que "ambas as tutelas pertencem a um só gênero, o das tutelas de urgência." (Tutela jurisdicional de urgência - Medidas cautelares e antecipatórias. Rio de Janeiro: América Jurídica, 2001, pp. 20/21). Por fim, C. A. ALVARO DE OLIVEIRA também afirma que as tutelas cautelares e antecipatórias compartilham a mesma função e a mesma estrutura, mas não o mesmo efeito jurídico. Diz que "o efeito jurídico, que aproxima a tutela antecipatória do verbo satisfazer e a cautelar do verbo assegurar, é que realmente as diferencia, impedindo possam ser consideradas da mesma espécie", ressalvando, "todavia, embora não da mesma espécie, tutela cautelar e antecipatória compartilham do mesmo gênero, gênero esse destinado à prevenção do dano ao provável direito da parte, mediante ordens e mandamentos que interfiram desde logo no plano sensível". Conclui entendendo ser bastante adequado, no terreno terminológico, "falar-se em tutela de urgência, a exemplo da elaboração doutrinária italiana." (Comentários ao Código de..., pp. 23/24).

${ }_{192}$ DINAMARCO diz que "a redação do novo $\S 7^{\circ}$ do art. 273 não é suficientemente clara, porque dá a impressão de que somente autorizaria o juiz a receber como cautelar uma demanda proposta com o título de antecipação, e não o contrário. Essa impressão é falsa, porque é inerente a toda fungibilidade a possibilidade de intercâmbio recíproco, em todos os sentidos imagináveis. Não há fungibilidade em mão única de direção. Já é geralmente aceito, diante disso, que o novo dispositivo autoriza o juiz, amplamente, a receber qualquer pedido de tutela urgente, enquadrando-o na categoria que entender adequada, ainda que o demandante haja errado ao qualificar o que é cautelar como antecipação, ou o que é antecipação como cautelar." (DINAMARCO, Cândido Rangel. O Regime jurídico das medidas ..., pp. 60/61). BEDAQUE também aduz 
Diante dessa fungibilidade das tutelas de urgência (cautelares ou antecipatórias), o juiz poderá conceder a medida mais adequada à situação dos autos, independentemente de eventual equívoco do requerente ao deduzir o pedido ${ }^{193}$.

Aliás, o acréscimo do parágrafo $7 .^{\circ}$ ao artigo 273 do Código de Processo Civil sequer era necessário para a aplicação da fungibilidade e no "duplo sentido vetorial", pois esta decorre da própria lógica do sistema ${ }^{194}$. Por meio de uma interpretação teleológica e sistemática dos dispositivos que regulam as tutelas de urgência, verifica-se que essa fungibilidade já era plausível antes mesmo da reforma que acresceu o parágrafo 7. $^{\circ}$ ao artigo 273 do Código de Processo Civil ${ }^{195}$.

A tese da mão dupla da fungibilidade também foi encampada pela jurisprudência pátria, inclusive pela jurisprudência dos Tribunais Superiores. A Exma. Ministra NANCY ANDRIGHI, em voto proferido em 11/10/2011, ressaltou que "o $\S 7^{\circ}$ do art. 273 do CPC, acrescido pela Lei $\mathrm{n}^{\circ} 10.444 / 02$, reestruturou a sistemática de concessão

que, "embora o legislador refira-se somente à possibilidade de substituição da tutela antecipada por cautelar, não pode haver dúvida de que a fungibilidade opera nas duas direções, sendo possível conceder tutela antecipada em lugar de cautelar." (BEDAQUE, José Roberto dos Santos. Código de Processo Civil Interpretado. MARCATO, Antônio Carlos (coord.). São Paulo: Atlas, 2004, p. 808).

${ }^{193}$ Cf. BEDAQUE, José Roberto dos Santos. Código de Processo Civil Interpretado..., pp. 807/808. Para HUMBERTO THEODORO JÚNIOR, as tutelas de urgência foram "concebidas para conjurar o perigo de dano pela demora do processo e, em muitos casos haverá uma certa dificuldade em descobrir, com rigor, a qual das duas espécies pertence a providência que, in concreto, se vai adotar para contornar o periculum in mora. Para ater-se ao rigor técnico classificatório, o juiz pode correr o risco de denegar a tutela de urgência somente por uma questão formal, deixando assim o litigante privado da efetividade do processo, preocupação tão cara à ciência do direito processual contemporâneo. Com efeito, não é nesse rumo que se orienta esse ramo da ciência jurídica. É reiterado o entendimento de que não é pelo rótulo, mas pelo pedido de tutela formulado, que se deve admitir ou não seu processamento em juízo; assim como é pacífico que não se anula procedimento algum simplesmente por escolha errônea de forma." (Tutela jurisdicional de urgência..., pp. 20/21). Na mesma linha, C. A. AlVARO DE OlIVEIRA afirma que "a constatação da identidade funcional das duas tutelas, com seu enquadramento como espécies do mesmo gênero, acarreta várias consequiências práticas", ressaltando que "uma das mais importantes é a impossibilidade de o juiz extinguir o processo sem julgamento do mérito, se por mero equívoco a parte denominou a antecipação de cautelar, ou vice-versa. (...) Incide, pois, o princípio da fungibilidade, agora adotado de modo expresso pelo $\S 7^{\circ}$ do art. 273 (acrescido pela Lei ${ }^{\circ}$ 10.444/2002)." (Comentários ao Código de..., p. 24).

${ }^{194}$ Nesse sentido, BEDAQUE afirma que "esse duplo sentido vetorial entre as medidas urgentes sequer necessitaria estar previsto em lei, pois decorre da própria lógica do sistema das tutelas provisórias e instrumentais" (BEDAQUE, José Roberto dos Santos. Tutela cautelar e tutela antecipada..., p. 418), ressaltando que a expressão "duplo sentido vetorial entre as medidas urgentes" é de DINAMARCO.

${ }^{195}$ Ao falar sobre o "duplo sentido vetorial" dessa fungibilidade, DINAMARCO sustenta que "mesmo sem o novo parágrafo do art. 273, o juiz já estaria autorizado a dar a sua própria qualificação jurídica aos fatos narrados pelo autor - e isso se aplica indiferentemente a todas as espécies de processos e aos pedidos que neles se deduzem (processo de conhecimento ou cautelar, pedido de cautela ou de antecipação etc). Esse parágrafo tem porém a virtude de ser explícito e específico, abrindo caminho à exorcização do fantasma da radical distinção entre medidas cautelares e antecipatórias." (A reforma da reforma..., p. 94). 
das tutelas provisórias de urgência, autorizando que seja incidentalmente concedida tutela cautelar no âmbito do processo principal"196.

E, nos termos do magistério de José RoBerTo dos SANTOS BEDAQUE, a adoção da fungibilidade "constitui demonstração inequívoca da identidade substancial entre as modalidades de tutela de urgência e provisória", indicando "a necessidade de aproximação das espécies de tutela sumária, urgente e provisória, a fim de que todas recebam o mesmo tratamento jurídico" ${ }^{\text {197. }}$.

Nesse diapasão, cumpre-se mencionar que o Projeto de Lei do Senado n. ${ }^{\circ}$ 166, de 2010 (agora Projeto de Lei n. ${ }^{\circ}$ 8.046/2010, em trâmite na Câmara dos Deputados), que institui um novo Código de Processo Civil, prevê a extinção do livro das ações cautelares, regulando as tutelas de urgência em um só título, juntamente com as tutelas da evidência ${ }^{198}$, o que também demonstra o viés sistemático para a criação de um

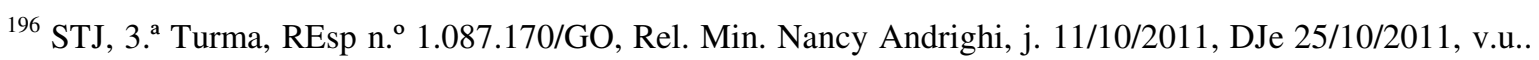
No mesmo sentido: AgRg no REsp n. ${ }^{\circ}$ 1.213.000/RS; REsp n. ${ }^{\circ} 222.251 / \mathrm{CE}$; REsp n. ${ }^{\circ}$ 206.221/SP; REsp n. ${ }^{\circ}$

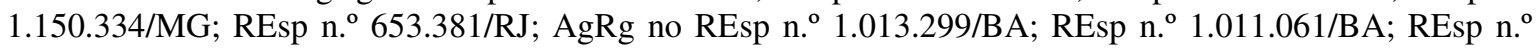
889.886/RJ; e REsp n. ${ }^{\circ}$ 686.209/RS.

${ }^{197}$ BEDAQUE, José Roberto dos Santos. Tutela cautelar e tutela antecipada..., p. 419.

198 Trata-se do "Título IX - Tutela de Urgência e Tutela da Evidência", versando a "Seção II", "Da tutela de urgência cautelar e satisfativa". Consta da "exposição de motivos" do anteprojeto do Novo Código de Processo Civil que "o Novo CPC agora deixa clara a possibilidade de concessão de tutela de urgência e de tutela à evidência. Considerou-se conveniente esclarecer de forma expressa que a resposta do Poder Judiciário deve ser rápida não só em situações em que a urgência decorre do risco de eficácia do processo e do eventual perecimento do próprio direito. Também em hipóteses em que as alegações da parte se revelam de juridicidade ostensiva deve a tutela ser antecipadamente (total ou parcialmente) concedida, independentemente de periculum in mora, por não haver razão relevante para a espera, até porque, via de regra, a demora do processo gera agravamento do dano. Ambas essas espécies de tutela vêm disciplinadas na Parte Geral, tendo também desaparecido o livro das Ações Cautelares. A tutela de urgência e da evidência podem ser requeridas antes ou no curso do procedimento em que se pleiteia a providência principal. Não tendo havido resistência à liminar concedida, o juiz, depois da efetivação da medida, extinguirá o processo, conservando-se a eficácia da medida concedida, sem que a situação fique protegida pela coisa julgada. Impugnada a medida, o pedido principal deve ser apresentado nos mesmos autos em que tiver sido formulado o pedido de urgência. As opções procedimentais acima descritas exemplificam sobremaneira a concessão da tutela cautelar ou antecipatória, do ponto de vista procedimental." (www.senado.gov.br/senado/novocpc/pdf/Anteprojeto.pdf. Acessado em 05/06/2011). As principais alterações propostas no projeto quanto às tutelas de urgência foram assim elencadas por JOÃO PAULO HECKER DA SILVA: “(i) As tutelas antecipadas e cautelares, como gêneros das medidas urgentes, foram disciplinadas sob um regime único das tutelas de urgência, cujo tratamento em termos de procedimento e requisitos foi unificado e previsto no Código de Processo Civil em um único local, o da Parte Geral (excluiu-se, portanto, o livro das ações cautelares); (ii) Os requisitos para deferimento das tutelas da urgência foram unificados e definidos como sendo a 'plausibilidade do direito' e o 'risco de dano irreparável ou de difícil reparação'; (iii) Criou-se a figura da tutela da evidência, com a prescindibilidade do requisito da urgência ('risco de dano irreparável ou de difícil reparação') em determinadas hipóteses de 'plausibilidade do direito' pré-definidas: abuso do direito de defesa ou propósito protelatório; pedido incontroverso, com solução definitiva sobre ele; prova documental irrefutável contra a qual o réu não oponha prova inequívoca; matéria de direito com jurisprudência definida em recursos repetitivos ou súmula vinculante (única hipótese de deferimento sem a oitiva do réu); (iv) O requerimento das medidas urgentes foi 
único gênero de tutelas de urgência (ao invés da dicotomia existente atualmente entre tutela antecipada e medida cautelar).

Saliente-se que, no Direito português, há previsão semelhante no artigo 381..$^{\circ}$ do seu Código de Processo Civil, o qual prevê que, em havendo fundado receio de dano irreparável ou de difícil reparação, a parte tem o direito de pleitear a medida conservatória ou antecipatória mais adequada ao caso ${ }^{199}$.

Na Itália, a doutrina da tutela antecipatória desenvolveu-se a partir da interpretação e da aplicação do artigo 700 do CPC italiano ${ }^{200}$, o qual reza que:

"Fora dos casos regulados nas seções precedentes deste capítulo, quem tem fundado motivo de temer que durante o tempo necessário para fazer valer o seu direito em via ordinária, este seja ameaçado por um prejuízo iminente e irreparável, pode pedir ao juiz os provimentos de urgência, que pareçam,

previsto em seus caráteres preparatório e incidental (antes ou no curso do procedimento), sem pagamento de custas extras àquelas em que se pleiteia a providência principal; (v) Previu-se a autorização para o juiz conceder medidas de urgência de ofício em determinadas hipóteses (sem apontar exatamente quais seriam), a faculdade de o juiz exigir caução (salvo em caso de hipossuficiência econômica) e a possibilidade de o juiz revogar as medidas de urgência em decisão fundamentada; (vi) A prioridade de tramitação nas demandas em que tenham sido deferidas medidas de urgência foi definida, em acréscimo aos demais motivos de tramitação preferencial previstos em lei; (vii) O projeto de estabilização da medida urgente foi expressamente incorporado, de modo que a medida urgente será mantida desde que ausente a impugnação da parte contrária. Assim, os efeitos da medida urgente perduram até que ela seja questionada por demanda autônoma. Nesses casos, a situação não ficará protegida pela coisa julgada, salvo se houver decisão de mérito nessa referida demanda autônoma; (viii) Havendo impugnação da medida urgente, previu-se que o pedido principal deverá ser apresentado nos mesmos autos; (ix) Não tendo havido resistência pelo réu, previu-se a hipótese de o juiz extinguir o processo depois da efetivação da medida urgente, conservando-se sua eficácia sem que a situação fique protegida pela coisa julgada. Assim, os efeitos da medida urgente perduram até que ela seja questionada por demanda autônoma." (cf. SILVA, João Paulo Hecker da. Tutela de Urgência e Tutela...,. pp. 27/28).

${ }^{199}$ Conforme lição de GIUSEPPE TARZIA, no direito português, uma fórmula similar é prevista no artigo 381 . $^{\circ}$ do CPC, o qual preceitua que "sempre que alguém mostre fundado receio de que outrem cause lesão grave e dificilmente reparável ao seu direito, pode requerer a providência conservatória ou antecipatória concretamente adequada a assegurar a efetividade do direito ameaçado." ("Medidas cautelares atípicas: uma análise comparativa". LUCON, Paulo Henrique dos Santos (trad.). Revista de Processo - RePro, n. ${ }^{\circ}$ 99. São Paulo: RT, jul/set de 2000, pp. 206/222). Ainda conforme o magistério de GIUSEPPE TARZIA, na Alemanha, na França, na Suíça, na Bélgica, na Áustria, na Grécia, na Itália e na Espanha também prevalece o entendimento de que uma medida urgente pode antecipar os efeitos da sentença definitiva, se necessário o for, outorgando à parte, sob o ponto de vista dos efeitos, a mesma tutela que receberia se vitoriosa ao final de um processo ordinário. (TARZIA, Giuseppe. "Considerazioni Comparative sulle Misure Provisiorie nel Processo Civile" in Rivista di Diritto Processuale, n. ${ }^{2}$. Padova: Cedam, abril/junho de 1985, pp. 245/246).

${ }^{200}$ Confira-se, nesse sentido: I procedimenti cautelari, a cura di Giuseppe Tarzia. Padova: Cedam, 1990, notadamente pp. 159 e ss.; e Il nuovo processo cautelare, a cura di Giuseppe Tarzia. Padova: Cedam, 1993, especialmente pp. 175 ss.; e a doutrina citada nessas obras (TARZIA, Giuseppe. Medidas cautelares atípicas..., pp. 206/222). Ainda acerca da consolidação da tutela antecipada no artigo 700 do CPC italiano, ver: TOMMASEO, Ferrucio. I provvedimenti d'urgenza. Struttura e limiti della tutela antecipatória. Padova: Cedam, 1983. 
segundo as circunstâncias, mais idôneos a assegurar provisoriamente os efeitos da decisão sobre o mérito" (tradução livre) ${ }^{201}$.

Assim como a doutrina portuguesa e italiana adotam o gênero dos provimentos de urgência, o Projeto de Lei no Senado n. ${ }^{\circ}$ 166, de 2010 (agora Projeto de Lei n. ${ }^{\circ}$ 8.046/2010, em trâmite na Câmara dos Deputados) também prevê um novo Código de Processo Civil com um capítulo único para as tutelas de urgência, distinguindoas entre tutelas de urgência cautelar e satisfativa ${ }^{202}$.

Portanto, se mesmo no processo civil (o qual é sujeito a muito mais formalismos e ao princípio da adequação mais rigoroso) as medidas cautelares e as tutelas antecipadas são fungíveis, sendo irrelevantes para o deslinde do caso concreto as diferenças ontológicas existentes entre elas, com muito mais razão essa mesma diretriz deve ser adotada na arbitragem ${ }^{203}$.

A arbitragem, como visto acima, é um meio alternativo de solução de controvérsias, a qual tem como principais características a celeridade, a especificidade e a ausência de formalismo excessivo.

Por conta dessas características, faz ainda mais sentido se adotar, para a arbitragem, o gênero das "tutelas de urgência", ao invés das espécies provimento cautelar e tutela antecipada, notadamente porque, como já mencionado acima, o processo arbitral não está vinculado ao ordenamento jurídico processual nacional.

\footnotetext{
${ }^{201}$ Redação original: “Art. 700. Fuori dei casi regolati nelle precedenti sezioni di questo capo, chi ha fondato motivo di temere che durante il tempo occorrente per far valere il suo diritto in via ordinaria, questo sia minacciato da un pregiudizio imminente e irreparabile, puo' chiedere con ricorso al giudice i provvedimenti d'urgenza, che appaiono, secondo le circostanze, piu' idonei ad assicurare provvisoriamente gli effetti della decisione sul merito".

${ }^{202}$ Eis os termos do art. 269 do P.L. n. ${ }^{\text {o } 8.046 / 2010: ~ " A ~ t u t e l a ~ d e ~ u r g e ̂ n c i a ~ e ~ a ~ t u t e l a ~ d a ~ e v i d e ̂ n c i a ~ p o d e m ~ s e r ~}$ requeridas antes ou no curso do processo, sejam essas medidas de natureza satisfativa ou cautelar. $\S 1^{\circ}$ São medidas satisfativas as que visam a antecipar ao autor, no todo ou em parte, os efeitos da tutela pretendida. $\S 2^{\circ}$ São medidas cautelares as que visam a afastar riscos e assegurar o resultado útil do processo". Já as atuais tutelas antecipadas fundadas no inciso II e no parágrafo $6 .^{\circ}$ do artigo 273 do CPC passarão a ser chamadas de "tutela da evidência", nos termos do artigo 278, incisos I a IV, do P.L. n. ${ }^{\circ}$ 8.046/2010.

${ }^{203}$ Cf. SILVA, João Paulo Hecker da. Tutela de Urgência e Tutela..., pp. 76 e 299.
} 
Já se pacificou o entendimento de que as partes são livres para adotar as regras que entenderem convenientes para o deslinde da controvérsia ${ }^{204}$, devendo zelar, tão somente, para que não sejam violados os princípios do contraditório, do devido processo legal, da igualdade das partes, da imparcialidade do árbitro e de seu livre convencimento, bem como para que não haja ofensa à ordem pública ${ }^{205}$.

Além disso, não devem ser aplicadas de forma indiscriminada ao processo arbitral as regras do processo comum, sabidamente formalistas e morosas.

\footnotetext{
${ }^{204}$ Nesse sentido: "Uma das principais características da arbitragem é a flexibilidade do processo (art. 21 da Lei de Arbitragem) que deixa a cargo das partes e do árbitro estipularem as regras do procedimento." (TJ/SP, 35. ${ }^{a}$ Câm. Dir. Privado, A.I. n. ${ }^{\circ}$ 0293432-12.2011.8.26.0000, Rel. Des. Manoel Justino Bezerra Filho, j. 13/02/2012, v.u.). Sobre o tema: CARMONA, Carlos Alberto. "Flexibilização do Procedimento Arbitral". Revista Brasileira de Arbitragem, n. ${ }^{\circ}$ 24. São Paulo: IOB/CBAr, out/nov/dez 2009, pp. 07/21; e MONTORO, Marcos André Franco. Flexibilidade do procedimento arbitral. Tese de doutorado apresentada à Faculdade de Direito da Universidade de São Paulo em 2010. Na França, o artigo 1464 do CPC francês estabelece que a arbitragem não deve seguir obrigatoriamente as regras de direito processual, devendo apenas respeitar alguns princípios fundamentais: "Arte. 1464. A moins que les parties n'en soient convenues autrement, le tribunal arbitral détermine la procédure arbitrale sans être tenu de suivre les règles établies pour les tribunaux étatiques. Toutefois, sont toujours applicables les principes directeurs du procès énoncés aux articles 4 à 10, au premier alinéa de l'article 11, aux deuxième et troisième alinéas de l'article 12 et aux articles 13 à 21, 23 et 23-1." (trad. livre: "A não ser que as partes tenham pactuado de outra forma, o tribunal arbitral determinará o procedimento arbitral, sem ser obrigado a seguir as regras estabelecidas para os tribunais estatais. Todavia, são sempre aplicáveis os princípios fundamentais do processo estabelecidos nos artigos 4 a 10, no primeiro parágrafo do artigo 11, no segundo e no terceiro parágrafos do artigo 12 e nos artigos 13 a 21 e 23-1"). O mesmo ocorre na Espanha: “(...) los árbitros no están sujetos a las misma normas que los jueces. El proceso arbitral se rige por lo dispuesto por las partes o por las normas establecidas por el ente que administra el arbitraje." (trad. livre: (...) os árbitros não estão sujeitos às mesmas normas que os juízes. O processo arbitral se rege pela disposição das partes ou pelas normas estabelecidas pelo ente que administra a arbitragem.) (CUESTA SAENZ, José Maria de la, "Introduccion al arbitraje de consumo" in Revista de Derecho Privado, s/n. ${ }^{\circ}$, Madrid, Feb. 1997, pp. 122/123). No direito paraguaio também é possível a escolha do procedimento aplicável à arbitragem, conforme ensina CARLOS A. FILARTIGA LACROIX: "El arbitraje se ha utilizado desde los tiempos mas remotos para resolucion de conflictos, siendo para muchos autores la justicia que mas se acerca al ideal ya que surge de un acuerdo entre las partes, priorizandose la autonomia de la voluntad, sobre todos los aspectos del proceso: desde la eleccion de los arbitros hasta el procedimiento a ser utilizado." (trad. livre: "A arbitragem é utilizada desde os tempos mais remotos para a resolução de conflitos, sendo para muitos autores a justiça que mais se aproxima da ideal já que surge de um acordo entre as partes, priorizando-se a autonomia da vontade sobre todos os aspectos do processo: desde a eleição dos árbitros até o procedimento a ser utilizado.”) (LACROIX, Carlos A. Filartiga. El primer arbitraje, www.cacb.org.br /.../El\%20Primer\%20 Arbitraje.doc. Acessado em 08/06/2012. A FINRA (Financial Industry Regulatory Authority), que é a maior agência independente reguladora de empresas que negociam valores mobiliários nos E.U.A., lançou um projeto piloto, em 02/07/2012, que dá mais flexibilidade em arbitragens envolvendo negócios com valores mobiliários de US\$ 10 milhões ou mais. A presidente da unidade de soluções de conflito da FINRA, a Sra. Linda Fienberg, confirmou que o programa vai permitir que as partes de litígios de valores vultosos possam moldar sua própria arbitragem (conforme notícia da agência Reuters publicada em 12/06/2012 e republicada no informativo Migalhas de 13/06/2012). Por fim, na Inglaterra, a legislação permite que as partes adotem a lei inglesa, um sistema legal estrangeiro, o julgamento por eqüidade ou com base em leis religiosas (cf. ANDREWS, Neil. Arbitration and mediation in England..., pp. 114/115), podendo as partes, ainda, elaborarem um procedimento específico (tailor-made) para o caso (idem, p. 115).

${ }^{205}$ Cf. CARMONA, Carlos Alberto. Arbitragem e Processo..., p. 289.
} 
Pelo contrário, as eventuais lacunas do procedimento adotado pelas partes ou previsto no regulamento da instituição arbitral não deverão, obrigatoriamente, ser preenchidas pelos dispositivos do Código de Processo Civil, podendo ser resolvidas pelo(s) próprio(s) árbitro(s), com base em princípios gerais do processo ${ }^{206}$.

Desse modo, ao se depararem com a necessidade de tutelas de urgência em um processo arbitral, os árbitros não estarão vinculados aos dispositivos do Código de Processo Civil, especialmente se tais disposições acarretarem risco ao bem da vida tutelado ou risco de ineficácia do provimento final.

Em suma, apesar de a tutela antecipada fundada no inciso I do artigo 273 do CPC e o provimento cautelar serem institutos distintos, eles podem ser considerados do mesmo gênero, qual seja: das "tutelas de urgência", notadamente para o processo arbitral, que é despido do rigor formal presente em nosso ordenamento processual e para o qual a própria Lei de Arbitragem brasileira permite a estipulação de regras próprias pelas partes ou pelos árbitros.

\footnotetext{
${ }^{206}$ CARlos Alberto CARMONA aduz que "a advertência é importante, pois é comum a invocação no procedimento arbitral de preceitos típicos do procedimento comum, reportando-se por vezes alguma das partes a determinadas regras da lei processual. A Lei de Arbitragem não contém norma que determine o emprego subsidiário da lei processual para suprir omissões no procedimento utilizado pelas partes. Assim, não há razão para impor ao árbitro, no eventual preenchimento de lacunas procedimentais, regras do Código." (Arbitragem e Processo..., pp. 292/293). No mesmo sentido, Clávio DE MElo VALENÇA FILHO sustenta que "o árbitro não está adstrito às prescrições de Código de Processo Civil algum, brasileiro ou estrangeiro" ("Tutela Judicial de Urgência e a Lide Objeto da Convenção de Arbitragem”. Revista Brasileira de Arbitragem, n. ${ }^{\circ} 7$. São Paulo: IOB Thomson, jul/set de 2005, pp. 07/29, p. 22). De forma mais incisiva, HAROLDO MALHEIROS DuClerC VerÇOSA aduz que "jogar o Código de Processo Civil no colo dos árbitros e exigir deles uma plena obediência àquele diploma legal significaria reduzir enormemente a utilidade da arbitragem, tornando-a excessivamente rígida, demorada, e quase tão onerosa para os interessados quanto o recurso ao Judiciário." ("Doze anos da Lei de Arbitragem: alguns aspectos ainda relevantes" in Aspectos da Arbitragem Institucional - 12 anos da Lei 9.307/1996. VERÇOSA, Haroldo Malheiros Duclerc (coord.), São Paulo: Malheiros, 2008, p. 26). José Antonio Fichtner, SERgio Nelson MANnheimer e ANDRÉ Luís Monteiro também anotam que "a doutrina dominante considera que não se aplica o Código de Processo Civil na arbitragem, salvo na hipótese de escolha pelas próprias partes na convenção de arbitragem." (Cinco pontos sobre a arbitragem..., p. 309). HUMBERTO THEODORO JÚNIOR tem opinião distinta, defendendo a aplicação supletiva do CPC ao processo arbitral (in Arbitragem e terceiros..., p. 248). Na doutrina alienígena, ELIO FAZZALARI também defende a aplicação supletiva do Código de Processo Civil ao processo arbitral, restringindo tal aplicação, no entanto, às regras referentes ao atendimento do contraditório e àquelas compatíveis com a função privada do árbitro e com a sua falta de poderes coercitivos (L'Arbitrato. Torino: UTET, 1997, p. 56).
} 


\title{
14. TEMPO E O PROCESSO: NECESSIDADE DAS TUTELAS DE URGÊNCIA
}

Com relação às tutelas de urgência em si, tema que será desenvolvido sob a ótica do processo arbitral, é sabido que as discussões acerca da concessão de uma tutela jurisdicional justa e tempestiva, bem como sobre a necessidade da aceleração do processo, têm sido destaque no Brasil e no restante do mundo ${ }^{207}$.

Aliás, é antiga a preocupação com a razoável duração do processo. Já dizia o processualista uruguaio EDUARDo COUTURE, nos anos 50, que "no processo, o tempo é mais que ouro: é justiça; quem dispõe dele tem em sua mão a carta do triunfo; quem não puder esperar sabe-se de antemão que está derrotado"208.

Também dos anos 50 209, a Convenção Européia para Salvaguarda dos Direitos do Homem e das Liberdades Fundamentais já trazia em seu artigo 6.", "1", que:

\begin{abstract}
"toda pessoa tem direito a que sua causa seja examinada eqüitativa e publicamente num prazo razoável, por um tribunal independente e imparcial instituído por lei, que decidirá sobre seus direitos e obrigações civis ou sobre o andamento de qualquer acusação em matéria penal contra ela dirigida" (grifos nossos).
\end{abstract}

\footnotetext{
${ }^{207}$ PIERO BERNARDINI aduz que "ours is an increasingly litigious society. The demand, therefore, is always more for an efficient administration of justice, which means also timely justice ('justice delayed is justice denied', as it is correctly stated)." (tradução livre: "nossa sociedade é cada vez mais litigiosa. A demanda, portanto, é sempre mais para uma administração eficiente da justiça, que também significa justiça tempestiva ('justiça atrasada é justiça negada', como é corretamente apontado)." (The Powers of the Arbitrator..., p. 21). ${ }^{208}$ COUTURE, Juan Eduardo. Fundamentos del derecho procesal civil. Buenos Aires: Depalma editor, 1958. Aliás, em 1921, Rui BARBOSA, em sua célebre "Oração aos Moços", já dizia que "justiça atrasada não é justiça, senão injustiça qualificada e manifesta. Porque a dilação ilegal nas mãos do julgador contraria o direito escrito das partes, e, assim, as lesa no patrimônio, honra e liberdade." (www.casaruibarbosa.gov.br/ dados/DOC/artigos/rui_barbosa/FCRB_RuiBarbosa_Oracao_aos_mocos.pdf. Acessado em 09/07/2011). NoÉ AzEVEDO, em discurso como paraninfo da Turma de 1938 da Faculdade de Direito de São Paulo, já ressaltava que "o serviço não rende, os processos não andam, a Justiça é desesperadoramente demorada (...) nomeiem-se, portanto, mais juízes, faça-se melhor distribuição das causas, e, fatalmente, se há de aumentar e melhorar a produção, produzindo-se, se não aceleradamente, pelo menos com uma rapidez compatível com a aceleração da vida contemporânea." (www.migalhas.com.br/Quentes/17,MI89503,101048-Crise+no+Judicia rio+um+tema+recorrente). C. A. AlvARo DE Oliveira também ensina que "já se acentuara, aliás, no início do século XX, essa vocação do processo, considerado um mal social ('social Übel', expressão de Frederico, o Grande), um fenômeno doentio, a ser suprimido da maneira mais rápida possível, mormente porque sua freqüente repetição representa autêntico perigo para a sociedade.” (Comentários ao Código de..., p. 5).

${ }^{209}$ Subscrita em 04 de novembro de 1950, em Roma.
} 
O esforço da doutrina processual para tentar minorar os prejuízos causados por aquilo que FRANCESCO CARNELUTTI chamou de "tempo-inimigo",210 no processo é, de fato, antigo, mas, ainda assim, continua atual e premente ${ }^{211}$.

Nesse sentido, DinAMARCO anota que "o tempo às vezes é inimigo dos direitos e o seu decurso pode lesá-los de modo irreparável ou ao menos comprometê-los insuportavelmente (Carnelutti)"212.

O processo, como forma de solução de conflitos que se exterioriza por uma seqüência de atos processuais, é dinâmico e, por conseguinte, tem o fator tempo como um de seus elementos característicos naturais.

\section{Com efeito, não existe processo que não consuma ao menos} algum tempo ${ }^{213}$, razão pela qual se pode afirmar, sem qualquer dúvida, que o tempo é um dos componentes indissociáveis do processo ${ }^{214}$.

${ }^{210}$ In Diritto e Processo. Napoli: Morano Editore, 1958, n. ${ }^{\circ} 232$, pp. 353/355. Em outra magistral obra, CARNELUTTI também afirmou que "el valor que el tiempo tiene en el proceso es inmenso y, em grand parte desconocido. No sería demasiado atrevido parangonar el tiempo a un enemigo contra el cual el juez lucha sin descanso". (CARNELUTTI, Francesco. Derecho Procesal Civil y Penal. Buenos Aires: Ediciones Jurídicas, 1971, p. 412 - trad. livre: "O valor que o tempo tem no processo é imenso e, em grande parte desconhecido. Não seria atrevido demais comparar o tempo a um inimigo contra o qual o juiz luta sem descanso.”). Na doutrina pátria, confira-se, por todos: CRUZ E TUCCI, José Rogério. Tempo e processo: uma análise empírica das repercussões do tempo na fenomenologia processual (civil e penal). São Paulo: RT, 1997. Nessa obra, José ROGÉRIO CRUZ E TUCCI aborda as complexas relações entre o tempo e o processo, analisando os fatores determinantes da lentidão na administração da justiça e as suas conseqüências para as partes e para a sociedade.

${ }^{211}$ Cf. SILVA, João Paulo Hecker da. Tutela de Urgência e Tutela..., pp. 292/293.

${ }^{212}$ DINAMARCO, Cândido Rangel. Instituições de Direito..., vol. I, p. 160.

${ }^{213}$ HUMBERTO THEODORO JÚNIOR lembra que "o provimento judicial definitivo não pode ser ministrado instantaneamente. A composição do conflito de interesses, através do processo, só é atingida mediante a sequiência de vários atos essenciais que ensejam a plena defesa dos interesses das partes e propiciam ao julgador a formação do convencimento acerca da melhor solução da lide, extraído do contato com as partes e com os demais elementos do processo. De tal sorte, entre a interposição da demanda e a providência judicial satisfativa do direito de ação (sentença ou ato executivo), medeia necessariamente certo espaço de tempo, que pode ser maior ou menor, conforme a natureza do procedimento e a complexidade do caso concreto." (THEODORO JÚNIOR, Humberto. Processo Cautelar..., pp. 41/42).

${ }^{214}$ Sobre o tema, ITALO ANDOLINA menciona a dupla perspectiva da relação tempo-processo, citando que existe tanto o tempo no processo (o tempo que organiza o fluir interno do processo), como o processo no tempo (a sintonia entre o processo e sua realidade externa, que garante a coerência entre a tutela resultante do processo e os fatos mutáveis da realidade). ("Il Tempo e Il Processo". Revista de Processo - RePro, n. ${ }^{\circ} 176$. São Paulo: RT, outubro de 2009, pp. 261 e 274). 
E diante do fator tempo (que não é eliminável, uma vez que é inerente a qualquer processo) surge o conflito entre celeridade-efetividade e segurança jurídica $^{215}$ ou a dicotomia entre far presto e far bene ${ }^{216}$.

A doutrina processual pátria é uníssona no sentido de que a excessiva duração do processo ofende a garantia do devido processo legal, bem como que o processo só cumpre a sua função quando permite a concessão, ao titular da pretensão, da tutela a que este faz jus, em tempo de efetivamente preservar o seu direito, tendo em vista a evidente e íntima relação entre a efetividade da tutela jurisdicional e a duração temporal do processo $^{217}$.

Por isso mesmo, é assente na doutrina hodierna que o papel do direito processual é o de fazer atuar as normas de direito substancial da maneira mais efetiva possível e no menor espaço de tempo, pois não há dúvida de que a efetividade do processo está intimamente ligada, dentre outras coisas, ao seu tempo de duração ${ }^{218}$

Por conta disso, quando se pensa em efetividade, deve-se ter em mente um processo que cumpra o papel que lhe é destinado (qual seja: conceder a tutela a quem tiver razão) no menor tempo possível.

${ }^{215}$ Cf. YOSHIKAWA, Eduardo Henrique de Oliveira. Limites à Possibilidade de..., p. 27. Sobre o tema, LÍvio GoEllner Goron, citando as lições de ANDrea Proto PiSANI, LuIZ GuILHERME MARINONI e TEORI ALBINO ZAVASCKI, anota que "enquanto a cognição exauriente - cuja essência reside na realização do contraditório sob forma plena e antecipada - persegue essa (sempre relativa) certeza, privilegiando o valor da segurança, a cognição sumária exprime-se pelos juízos de verossimilhança e se presta à salvaguarda da efetividade da jurisdição." (Repensando as Tutelas de Urgência..., p. 72).

216 Expressão de CARLO FURNO mencionada por: LUCON, Paulo Henrique dos Santos in Eficácia das decisões e execução provisória. São Paulo: RT, 2000, p. 181.

${ }^{217}$ Cf. LUCON, Paulo Henrique dos Santos. Duração razoável e informatização do processo judicial. Vitória: Panóptica, ano 1, n. ${ }^{\circ}$ 8, maio/junho 2007, pp. 368/384. Disponível em: www.panoptica.org/maio_junto2007/ N.8_016_Lucon.p.368-384.pdf. Acessado em 03/07/2011. Nessa obra, LUCON ainda aduz que “a prestação jurisdicional intempestiva de nada ou pouco adianta para a parte que tem razão, constituindo verdadeira denegação de justiça; como efeito secundário e reflexo, a demora do processo desprestigia o Poder Judiciário e desvaloriza todos os envolvidos na realização do direito (juízes, promotores de justiça, procuradores e advogados). O processo com duração excessiva, além de ser fonte de angústia, tem efeitos sociais graves, já que as pessoas se vêem desestimuladas a cumprir a lei, quando sabem que outras a descumprem reiteradamente e obtêm manifestas vantagens, das mais diversas naturezas" (Idem, p. 369). Nessa mesma esteira, LUIS GUILHERME MARINONI afirma que "a problemática da efetividade do processo está ligada ao fator tempo, pois não são raras as vezes que a demora do processo acaba por não permitir a tutela efetiva do direito." (in Efetividade do processo e tutela de urgência. Porto Alegre: Fabris, 1994, p. 37).

${ }^{218}$ Cf. LUCON, Paulo Henrique dos Santos. Duração razoável e informatização..., p. 368. 
Pode-se dizer que deve ser acrescida à máxima chiovendiana, no sentido de que "o processo deve dar à parte que tem o direito, na medida do que for praticamente possível, tudo aquilo, e exatamente aquilo que ela tem o direito de receber", a expressão "dentro de prazo razoável e de forma tempestiva",219.

Especialmente com relação aos processos de cognição plena, ANDREA PROTO PISANI aponta dois obstáculos à efetividade da jurisdição.

O primeiro deles é o fato de o processo não impedir o dano, pois, normalmente, a parte somente busca a tutela jurisdicional quando a violação ao direito já ocorreu. Nesse caso, o processo poderá impedir que a violação continue, mas não poderá eliminar de imediato a violação ocorrida. E mais: muitas vezes não poderá evitar o dano em si, mas somente ressarcir a parte prejudicada pelo dano sofrido ${ }^{220}$.

O segundo, e mais grave obstáculo, é a própria duração do processo de cognição plena, que é um claro impedimento à efetividade da tutela jurisdicional. Um processo de cognição plena, em que é assegurada de forma completa a garantia ao contraditório, costuma consumir bastante tempo. Como conseqüência da longa duração do processo de cognição plena, até que seja obtida uma sentença final executável, a parte poderá sofrer um prejuízo irreparável ${ }^{221}$. É o que ENRICO FINZI chamou de "dano marginal" que a duração do processo causa ou ajuda a causar à parte ${ }^{222}$.

\footnotetext{
${ }^{219}$ Nessa linha, C. A. Alvaro DE OliveIRA aduz que o valor da efetividade dá nova vida a recomendação de GIUSEPPE CHIOVENDA, lançada há mais de 100 anos, e tantas vezes repetidas: "Il processo deve dare per quanto è possible praticamente a chi ha um diritto tutto quello e próprio quello ch'egli ha diritto di conseguire." (Comentários ao Código de..., p. 05, nota 15). No entanto, também deve ser ressaltada a preocupação de LUIGI PAOlo COMOGLIO, CORRADO FERRI e Michele TARUFFO com relação ao risco da sumarização excessiva do processo de cognição em Primeiro Grau, devendo haver um equilíbrio entre os interesses em contraste (segurança e celeridade) (COMOGLIO, Luigi Paolo; FERRI, Corrado; TARUFFO, Michele. Lezioni sul processo civile. Bologna: Il Mulino, 1998, pp. 683/695). Igualmente, JOSÉ ROBERTO DOS SANTOS BEDAQUE alerta que "a efetividade do processo não pode ser buscada a qualquer custo, com sacrifício de garantias fundamentais de uma das partes", pois "técnicas processuais desse tipo desconsideram a própria isonomia constitucional", sendo preciso dotar o processo de celeridade, sem abrir mão do valor segurança (Estabilização das tutelas de urgência..., p. 683).

220 "i primi ostacoli derivano dalla circostanza di fatto che non vi è istantaneità fra il momento del sorgere del diritto, quello della sua violazione e quello infine del ricorso alla tutela giurisdizionale." (tradução livre: "o primeiro obstáculo advém da circunstância de fato de que não há proximidade entre o momento do surgimento do direito, quando da sua violação, e quando finalmente se recorre à tutela jurisdicional".) (PROTO PISANI, Andrea. Lezioni di diritto processuale civile. 3. a edição. Napoli: Jovene, 1999, p. 630).

221 "la seconda specie di ostacoli che può operare contro l'effettività della tutela giurisdizionale è costituita dagli ostacoli derivanti della durata del processo (o dei processi) a cognizione piena" (tradução livre: "a segunda espécie de obstáculo que pode trabalhar contra a efetividade da tutela jurisdicional é constituída
} 
PROTO PISANI chega a mencionar que o processo de cognição plena padece de uma lentidão patológica ${ }^{223}$, cabendo ao ordenamento jurídico possibilitar uma intervenção para o fim de neutralizar esse prejuízo advindo da demora, sendo tal intervenção necessária para se garantir a efetividade do direito de ação e da tutela jurisdicional a quem tem razão, trazendo o autor diversos exemplos desses remédios previstos na legislação italiana, dentre eles as medidas cautelares e antecipatórias.

Independentemente do tipo de processo, o fato é que a nova tendência imediatista da sociedade moderna e o maior dinamismo das atividades humanas assumiram particular importância no problema do tempo necessário para o término do processo e para a solução definitiva dos $\operatorname{conflitos}^{224}$.

Evidencia-se essa mobilização em prol da celeridade no processo civil moderno, o qual não mais se presta somente para propiciar o simples acesso ao procedimento comum ordinário, destinado, em sua essência, a tutelar de forma repressiva os danos já ocorridos ${ }^{225}$, mas deve ter como objetivo a prestação de uma tutela jurisdicional acertada, adequada e tempestiva ao cidadão, atuando como "instrumento de realização da dignidade da pessoa humana e não como rito perpetuador de injustiças"226.

Nessa esteira, PAUlo HENRIQUE dOS SANTOS LUCON ressalta que "a presteza da atividade jurisdicional constitui aspecto fundamental para o acesso à justiça", lembrando, ainda, que o processo não pode servir de fonte de vantagens, de qualquer natureza que seja, para a parte que não possui razão ${ }^{227}$.

daqueles obstáculos derivados da duração do processo (ou dos processos) de cognição plena.”) (PROTO PISANI, Andrea. Lezioni di diritto processuale..., p. 631).

${ }^{222}$ A expressão "dano marginal" decorrente da lentidão do processo é atribuída por PIERo CALAMANDREI (in Introduzione allo studio sistemático dei provvedimenti cautelari. Opere Giuridiche, Morano, 1983, n. 8, p. 173) a ENRICO FINZI. De fato, em sua obra Questioni controverse in tema di esecuzione provvisoria, p. II/50, FINZI define o periculum in mora como "quel danno marginale, che non vi sarebbe se non nella ipotesi di ritardo nella esecuzione, e che scompare con la esecuzione provvisoria." (trad. livre: "o dano marginal, que haveria apenas na hipótese de atraso na execução, e que desaparece com a execução provisória.").

223 "lentezza patologica dei processi a cognizione piena". Lezioni di diritto processuale..., p. 633.

${ }^{224}$ Cf. BARBOSA MOREIRA, José Carlos. Tutela de Urgência e Efetividade..., p. 91. C. A. ALvaro DE OLIVEIRA também ressalta as "reais necessidades da sociedade atual", bem como a "corrente sócio-cultural melhor afinada para a realização efetiva dos direitos." (Comentários ao Código de..., p. 05).

${ }^{225}$ Cf. AMARAL, Paulo Osternack. A concessão de medidas urgentes..., p. 20.

${ }^{226}$ NALINI, José Renato. Ética Geral e Profissional, São Paulo: RT, 1997, p. 243.

${ }^{227}$ LUCON, Paulo Henrique dos Santos. Eficácia das decisões e execução..., p. 172. 
O processo não pode mais se distanciar do objetivo para o qual foi concebido, qual seja: realizar o direito material mediante a implementação do “acesso à ordem jurídica justa”, na consagrada expressão de KAZUO WATANABE ${ }^{228}$.

Exatamente por conta disso é que as reformas havidas nos últimos anos no Código de Processo Civil visaram, primordialmente, à aceleração do processo e a encurtar a entrega da prestação jurisdicional final (e.g.: artigos 273, 285-A, $475, \S 3 .^{\circ}, 518, \S 1 .^{\circ}, 544, \S \S 3 .^{\circ}$ e $4 .^{\circ}$ e 557 do CPC). Enfim, visam à celeridade ${ }^{229}$.

Até mesmo na Constituição Federal foi inserido no artigo 5. ${ }^{\circ}$ o inciso LXXVIII, o qual estipula que "a todos, no âmbito judicial e administrativo, são assegurados a razoável duração do processo e os meios que garantam a celeridade de sua tramitação" 230 .

A razoável duração do processo, embora a nosso ver já estivesse implícita nas garantias de acesso à justiça e do devido processo legal, foi alçada, expressamente, a uma garantia fundamental, tanto individual, como coletiva, inserindo-se no denominado "Direito Constitucional Processual, consubstanciado num conjunto de normas processuais contidas no texto constitucional"231.

O Projeto de Lei do Senado n. ${ }^{\circ}$ 166, de 2010 (agora Projeto de Lei n. ${ }^{\circ}$ 8.046/10, na Câmara dos Deputados), que reforma o Código de Processo Civil, a par das diversas críticas relativas à sua elaboração, também objetiva dar maior celeridade aos processos, conforme narrado pelo Ministro LUIZ FUX na audiência pública realizada no Tribunal de Justiça do Estado de São Paulo em 26/03/2010 e conforme consta de carta por ele elaborada disponível no website do Senado ${ }^{232}$.

\footnotetext{
228 "Assistência judiciária e o juizado de pequenas causas" in Juizado especial de pequenas causas (Lei 7.244, de 7 de novembro de 1984). WATANABE, Kazuo (coord.). São Paulo: RT, 1985, p. 161.

${ }^{229}$ C. A. Alvaro DE OliveIRA anota que "razões semelhantes justificam o inaudito elastecimento da tutela cautelar em nossa época, assim como a concepção de remédios jurisdicionais de índole provisória, autônomos ou não, com caráter antecipatório e satisfativo do pretendido direito.” (Comentários ao Código..., p. 05). ${ }^{230}$ Por meio da E.C. n. ${ }^{\circ} 45$, de 2004, que consagrou o artigo $8^{\circ}$, "1", do Pacto de San José da Costa Rica.

${ }^{231}$ Cf. LUCON, Paulo Henrique dos Santos. Duração razoável e informatização..., p. 372.

232 "Esse o desafio da comissão: resgatar a crença no judiciário e tornar realidade a promessa constitucional de uma justiça pronta e célere. (...) O tempo não nos fez medrar e de pronto a Comissão enfrentou a tormentosa questão da morosidade judicial. Queremos justiça!!! Prestem-na com presteza; dizem os cidadãos". In www.senado.gov.br/sf/senado/novocpc/pdf/anteprojeto.pdf. Acessado em 19/06/2010.
} 
Enfim, da inevitável duração de um processo é que surge a necessidade das tutelas de urgência, que não podem aguardar, muitas vezes, sequer a citação da parte contrária (ou, no caso deste trabalho, sequer a instauração do juízo arbitral ou o término da arbitragem), sob pena de dano grave ou de difícil reparação à parte, ou, até mesmo, de perecimento do bem da vida em questão.

Portanto, as tutelas de urgência surgiram para contornar a dificuldade que era trazida pela ausência de efetividade das tutelas jurisdicionais deferidas de forma intempestiva, as quais poderiam sujeitar à parte a um processo e a uma sentença praticamente inúteis $^{233}$.

Elas trazem um efeito relevante que é o de redistribuir os ônus do tempo da duração do processo entre as partes, colocando em situação mais favorável a parte que possui o melhor direito prima facie $^{234}$.

Em se tratando de um processo em trâmite perante o Poder Judiciário, a fim de se evitar um dano irreparável ou de difícil reparação, ou para garantir o resultado útil e prático do processo durante o inevitável tempo (ainda que mínimo) que ele deverá tramitar, o juiz tem à sua disposição as medidas cautelares (artigos 798 e seguintes do CPC) e a possibilidade de antecipação da tutela (artigo 273 do CPC).

E assim como no processo judicial, não há dúvida de que, no processo arbitral, ou antes mesmo de sua instauração, também haverá situações em que será necessário tomar providências urgentes para garantir a eficácia do provimento arbitral ou, até mesmo, para preservar o bem da vida em discussão, diante dos prejuízos que o tempo de duração do processo poderá causar ao direito da parte ${ }^{235}$.

${ }^{233}$ Cf. YOSHIKAWA, Eduardo Henrique de Oliveira. Limites à Possibilidade de..., p. 27. Lívio GoELLNER GORON também destaca as tutelas urgentes "como mecanismos importantes para o enfrentamento da crise de efetividade do processo." (in Repensando as Tutelas de Urgência..., p. 67).

${ }^{234} \mathrm{Na}$ doutrina estrangeira, também é destacada a melhor distribuição dos ônus da duração do processo pelas tutelas de urgência: "The effect of such measures is to distribute the risk for the duration of the main action between the parties, shifting it from the party applying for the interim measures to the other party." (tradução livre: "o efeito de tais medidas é o de distribuir o risco da duração da ação principal entre as partes, transferindo-o da parte que pleiteia a medida liminar para a outra parte." (LEW, Julian M.; MISTELIS, Loukas A.; KRÖLL, Stefan M. Comparative International..., p. 585).

${ }^{235}$ Criticando o formalismo excessivo presente em muitas arbitragens atualmente, PIERO BERNARDINI aponta a importância crescente das tutelas de urgência no processo arbitral, dizendo que: "created and developed as 
E são essas tutelas de urgência em um processo arbitral, ou antes de tal processo ser instaurado, que serão tratadas a seguir.

\section{CABIMENTO DAS TUTELAS DE URGÊNCIA EM ARBITRAGEM}

Como visto no "item 4" acima, as tutelas de urgência na arbitragem já eram reguladas antes mesmo do advento da Lei n. ${ }^{\circ} 9.307 / 96$. Isso porque os artigos 1.086 e 1.087 do Código de Processo Civil traziam regramento específico sobre o assunto, vedando, expressamente, a decretação de "medidas cautelares e coercitivas" pelo juízo arbitral, nos seguintes termos:

"Art. 1.086. O juízo arbitral pode tomar depoimento das partes, ouvir testemunhas e ordenar a realização de perícia. Mas lhe é defeso:

I - empregar medidas coercitivas, quer contra as partes, quer contra terceiros;

II - decretar medidas cautelares.

Art. 1.087. Quando for necessária a aplicação das medidas mencionadas nos números I e II do artigo antecedente, o juízo arbitral as solicitará à autoridade judiciária competente para a homologação do laudo".

Embora referidos artigos previssem a impossibilidade de o

árbitro decretar "medidas cautelares", parte da doutrina já defendia, à época, a possibilidade de o árbitro conceder tutelas de urgência ${ }^{236}$.

a mechanism destined to avoid the intricacies of national rules of procedure in favor of a more flexible and fair conduct of the proceedings, it is increasingly becoming subject to the same procedural constraints of a proceeding before a state court. This explains why even the party to an arbitration tends to make use of all available delay and obstructive tatics in order to avoid a result which perceives will be contrary to its interest. This, in turn, increases the need also for the claimant in arbitration to look for conservatory and provisional measures which will ensure that the pecuniary obligations eventually imposed upon the party by the award will find at such time sufficient assets out of which to be satisfied." (tradução livre: "Criada e desenvolvida como um mecanismo destinado a evitar as intrincadas regras de processo civil em favor de um procedimento mais flexível e fácil de ser conduzido, a arbitragem está cada vez mais se tornando sujeita ao mesmo procedimento restritivo de um processo perante o juízo estatal. Isso explica porque até a parte de uma arbitragem tende a fazer uso de todas as táticas de obstrução e protelação para evitar um resultado que ela percebe que será contrário ao seu interesse. Isso, por sua vez, aumenta também a necessidade de a parte de uma arbitragem buscar medidas conservativas e provisórias, as quais garantirão que as eventuais obrigações pecuniárias impostas a outra parte pela sentença arbitral encontrarão, quando esta for proferida, bens suficientes para a sua satisfação.”) (in The Powers of the Arbitrator..., p. 22).

${ }^{236}$ Tal como: CARMONA, Carlos Alberto. A Arbitragem no processo civil brasileiro. São Paulo: Malheiros, 1993, pp. 108/109. O mesmo autor ainda afirmou que, "em realidade, a lei processual de então, revogada em boa hora pela Lei $9.307 / 96$, foi infeliz ao dispor que ao árbitro seria defeso decretar medidas cautelares, já que o dispositivo visava proibir a execução (rectius: cumprimento) da medida cautelar." (in Arbitragem e Processo..., p. 323). 
Mesmo com a entrada em vigor da Lei de Arbitragem brasileira, a questão acerca do cabimento ou não de tutelas de urgência persistiu no início, uma vez que o artigo $22, \S 4 .^{\circ}$, da Lei n. ${ }^{\circ}$ 9.307/96, que trata das medidas urgentes no processo arbitral, não possui uma redação clara e precisa sobre o assunto. Eis os termos do aludido dispositivo legal:

"Art. 22. Poderá o árbitro ou o tribunal arbitral tomar o depoimento das partes, ouvir testemunhas e determinar a realização de perícias ou outras provas que julgar necessárias, mediante requerimento das partes ou de ofício.

(...)

$\S 4 .^{\circ}$ Ressalvado o disposto no $\S 2 .^{\circ}$, havendo necessidade de medidas coercitivas ou cautelares, os árbitros poderão solicitá-las ao órgão do Poder Judiciário que seria, originariamente, competente para julgar a causa".

Em virtude da linguagem indireta e obscura desse dispositivo legal $^{237}$, logo após o início da vigência da Lei de Arbitragem brasileira, parte da doutrina sustentou a impossibilidade de o árbitro deferir tutelas de urgência ${ }^{238}$, ou que tal poder estaria vinculado à disposição expressa na convenção de $\operatorname{arbitragem}^{239}$.

Abra-se um parêntese: com relação à redação do aludido artigo, segundo Pedro A. BAtista MARTins, um dos co-autores do projeto da referida lei, tal dispositivo não foi claro de forma proposital, para evitar que maiores polêmicas tumultuassem ou retardassem ainda mais a promulgação da Lei de Arbitragem ${ }^{240}$. Nessa mesma esteira, Carlos Alberto CARmona, outro dos co-autores da Lei de Arbitragem

237 JoSÉ MARIA ROSSANI GARCEZ observa que “a lei brasileira de arbitragem, objeto de tantos e tão merecidos elogios, no que diz respeito a medidas cautelares não andou, todavia, muito bem, em termos redacionais, cometendo um engano, embora tautológico, ao dispor de uma forma que a melhor e mais lógica interpretação teria que, na verdade, transformar para tornar funcional ou mais funcional." (Medidas cautelares e de antecipação..., p. 219).

${ }^{238}$ Tais como: FURTADO, Paulo; BULOS, Uladi L. A Lei de Arbitragem Comentada. São Paulo: Saraiva, 1997, p. 93; ARENHART, Sérgio Cruz. Breves observações sobre...; e THEODORO JÚNIOR, Humberto. "A arbitragem como meio de solução de controvérsias". Revista Forense, n. ${ }^{o}$ 353. Rio de Janeiro: Forense, jan/fev de 2001, pp. 107/116. JOÃO ROBERTO PARIZATTO também sustenta que o árbitro não possui poderes para apreciar e deferir tutelas de urgência, afirmando que "não tendo o árbitro jurisdição, é defeso a este tomar qualquer medida coercitiva ou cautelar.” (Arbitragem: Comentários à Lei 9.307, de 23-9-96. São Paulo: Editora de Direito, 1997, p. 82).

239 Tal como: CARNEIRO, Paulo Cezar Pinheiro. "Aspectos processuais da nova lei de arbitragem” in Arbitragem - lei brasileira e praxe internacional, 2. ${ }^{a}$ edição. CASELLA, Paulo Borba (coord.). São Paulo: LTr, 1999, p. 311.

${ }^{240}$ Da Ausência de Poderes Coercitivos..., pp. 357/358. Nesse sentido: PITOMBO, Eleonora Coelho. “Arbitragem e o Poder Judiciário: Aspectos Relevantes" in GUILHERME, Luiz Fernando do Vale de Almeida (coord.). Aspectos práticos da arbitragem. São Paulo: Quartier Latin, 2006, pp. 105/124, esp. pp. 110/111. 
brasileira, afirma que, ainda que "de modo elíptico", a lei prevê o poder dos árbitros de conceder tutelas de urgência ${ }^{241}$. Fecha-se o parêntese.

E embora a redação do art. $22, \S 4 .^{\circ}$, da Lei n. ${ }^{\circ}$ 9.307/96 induza à conclusão de que somente seria possível a concessão de medidas cautelares (conservativas) no processo arbitral, não é esse o entendimento majoritário na doutrina.

Passados mais de dezesseis anos da entrada em vigor da Lei de Arbitragem brasileira, a doutrina pátria já se posicionou a favor do poder cautelar do árbitro $^{242}$, incluindo a possibilidade de concessão da antecipação dos efeitos da tutela ${ }^{243}$.

Até mesmo porque não faria sentido os árbitros (i) serem considerados juízes de fato e de direito (cf. artigo 18 da Lei n. ${ }^{\circ}$ 9.307/96); (ii) proferirem sentença que não está sujeita a recurso ou homologação do Poder Judiciário (cf. artigo 18 da Lei n. ${ }^{\circ}$ 9.307/96); (iii) prolatarem sentença que produz os mesmos efeitos da sentença proferida pelos órgãos do Poder Judiciário, constituindo título executivo judicial, se condenatória (cf. artigo 31 da Lei de Arbitragem brasileira e artigo 475-N, IV, do CPC), e não terem poderes para proferir tutelas de urgência necessárias à eficácia de sua decisão ${ }^{244}$.

${ }^{241}$ Cf. CARMONA, Carlos Alberto. Arbitragem e Processo. ..., p. 323.

242 “(...) não devem restar dúvidas de que as cautelares devem ser analisadas e concedidas pelos árbitros.” (GARCEZ, José Maria Rossani. Medidas cautelares e de antecipação..., pp. 220 e 222). Ainda: CARMONA, Carlos Alberto. Arbitragem e Processo..., p. 323; FICHTNER, José Antonio; e MONTEIRO, André Luís. Medidas urgentes no processo..., p. 51; CÂMARA, Alexandre Freitas. Arbitragem..., p. 93; ARMELIN, Donaldo. Tutela de urgência e arbitragem..., p. 376. BERMUDES, Sérgio. Medidas coercitivas e cautelares..., p. 278; AMARAL, Paulo Osternack. A concessão de medidas urgentes..., p. 28, dentre outros.

${ }^{243}$ Admitindo a concessão de tutela antecipada em arbitragem: CARMONA, Carlos Alberto, Arbitragem e Processo..., p. 329; Idem, “Árbitros e Juízes: guerra ou paz?”. Aspectos Fundamentais da Lei de Arbitragem. MARTINS, Pedro A. Batista; LEMES, Selma M. Ferreira; CARMONA, Carlos Alberto (coord.). Rio de Janeiro: Forense, 1999, pp. 432/433; TALAMINI, Eduardo. Tutela relativa aos deveres de fazer e de não fazer; e sua extensão aos deveres de entrega de coisa, 2. ${ }^{a}$ edição. São Paulo: RT, 2003, p. 459; COSTA, Nilton César Antunes da. Poderes do Árbitro. São Paulo: RT, 2002, p. 110; FIGUEIRA JR., Joel Dias. Arbitragem, jurisdição..., p. 221; CARNEIRO, Athos Gusmão. Arbitragem. Cláusula Compromissória...; CÂMARA, Alexandre Freitas. Arbitragem..., p. 107 (o autor ainda menciona que, após a entrada em vigor da Lei de Arbitragem brasileira, CARREIRA ALVIM também adotou esse entendimento em seu Tratado Geral da Arbitragem, pp. 396/405); VALENÇA FILHO, Clávio de Melo. Tutela judicial de urgência e a lide..., p. 14; ARMELIN, Donaldo. "Arbitragem. Antecipação dos efeitos da tutela. Ação de instituição de arbitragem procedente. Eficácia imediata, embora pendente apelação sem efeito suspensivo. Competência do Tribunal Arbitral para a concessão de antecipação dos efeitos da tutela" in Revista de Arbitragem e Mediação, vol. 6. WALD, Arnoldo (coord.). São Paulo: RT, jul/set de 2005, pp. 217/227, esp. pp. 224/225; Idem. Tutela de

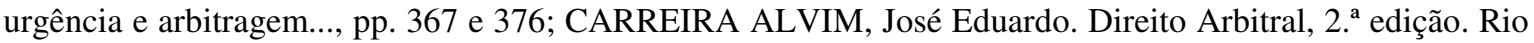
de Janeiro: Forense, 2004, p. 336; FICHTNER, José Antonio; MONTEIRO, André Luís. Medidas urgentes no processo..., pp. 60/62; e AMARAL, Paulo Osternack. A concessão de medidas urgentes..., p. 28.

${ }^{244}$ Nesse diapasão, SÉRGIO BERMUDES leciona que "não faria sentido poderem os árbitros proferir sentença produtora (por certo, dentro dos limites subjetivos e objetivos da coisa julgada) dos mesmos efeitos da 
Nem mesmo a ausência do poder de coerção integral e do poder de imperium pode ser visto como um obstáculo ao poder do árbitro de apreciar e de conceder tutelas de urgência, pois, como visto no "item 11" acima, tais poderes podem ser buscados em caráter de cooperação junto ao Poder Judiciário ${ }^{245}$.

\section{Por todos, cite-se a lição de CARlos Alberto CARMONA no} sentido de que, "havendo necessidade de tutela cautelar, a parte interessada na concessão da medida deverá dirigir-se ao árbitro (e não ao juiz togado), formulando seu pedido fundamentadamente" 246 , e que será o árbitro quem, considerando estarem comprovados os requisitos do fumus boni iuris e do periculum in mora, deverá conceder a medida cautelar.

CARMONA ainda aduz que não vê "obstáculo para que o árbitro também possa, instado pela parte interessada, antecipar tutela" ${ }^{247}$, esclarecendo que “se apenas o árbitro está autorizado a proferir o provimento final, toca também a ele - e apenas a ele - decidir se antecipará ou não algum, alguns ou todos os efeitos que sua decisão irá produzir!"248.

sentença proferida pelos órgãos do Poder Judiciário (art. 31), consistente, quando condenatória, num título executivo judicial (CPC, art. 585, III), sem que pudessem determinar providências assecuratórias da eficácia desses julgados. Por isso, há que se entender que os árbitros, posto que algo insuficiente a lei quanto à explicação desse aspecto, dispõem do poder cautelar necessário à garantia da eficácia de suas decisões." (Medidas coercitivas e cautelares..., p. 278). Nessa mesma linha, José EdUARDo CARREIRA AlviM aduz que "vincular o juízo arbitral ao juízo togado, na eventualidade da necessidade de medidas coercitivas ou cautelares, além de nada acrescentar em termos de proteção aos direitos constitucionais, presta-se a restringir os poderes jurisdicionais do árbitro, pondo toda a arbitragem na dependência de uma justiça sabiamente lenta, e que não tem condições de dar respostas satisfatórias às necessidades imediatas das partes interessadas." (Direito arbitral, 2. ${ }^{a}$ edição. Rio de Janeiro: Forense, 2004, pp. 335/336).

${ }^{245}$ Nessa esteira, cite-se voto proferido pelo juiz MIGUEL CUCINELLI: "apesar de o cumprimento das decisões ter de ser feito pelo Poder Judiciário, o único que detém o poder para impor medidas coercitivas, isso não significa que o procedimento cautelar ou especial não tenha sido contemplado pela lei que instituiu a arbitragem no Brasil. Esse é o preciso comando que se extrai da leitura do art. $22, \S 4^{\circ}$, da Lei n. ${ }^{\circ} 9.307$, de 23 de setembro de 1996." (Ex-2. ${ }^{\circ}$ TACiv-SP, 7. ${ }^{a}$ Câm. do Quarto Grupo, A.I. n. ${ }^{\circ}$ 0036712-87.2003.8.26.0000 (números anteriores 818.499/0-00 e 992.03.036712-2), Rel. designado Juiz Américo Angélico, j. 18/11/03).

${ }^{246}$ CARMONA, Carlos Alberto. Arbitragem e Processo..., p. 323.

${ }^{247}$ CARMONA, Carlos Alberto. Arbitragem e Processo..., p. 329.

${ }^{248}$ CARMONA, Carlos Alberto. Arbitragem e Processo..., p. 330. No direito estrangeiro, PIERO BERNARDINI ressalta que "nothing seems to prevent the arbitrator from being recognized as having the powers to order conservatory and provisional measures. Those legal systems which still provide that such powers are exclusively vested in state courts either reflect the old climate of mistrust for arbitration or hold an incorrect view of state courts' jurisdictional prerogatives." (trad. livre: "nada parece evitar que o árbitro possa ser reconhecido como detentor de poderes para ordenar medidas conservativas e provisórias. Aqueles sistemas legais que ainda prevêem que tais poderes são exclusivos das cortes estatais ou refletem o antigo clima de desconfiança com relação à arbitragem ou possuem uma visão incorreta das prerrogativas jurisdicionais das cortes estatais.") (The Powers of the Arbitrator..., p. 29). Nessa mesma linha: "The relief sought in the principal action is frequently insufficient to protect effectively the rights or interest of the alleged innocent party. Due to the time gap between commencement of the proceedings and the substantive hearing, the 
E não há sequer necessidade de a convenção de arbitragem prever, expressamente, poderes específicos para que os árbitros possam conceder tutelas de urgência, pois tais poderes decorrem da sistemática da Lei de Arbitragem brasileira e da própria investidura dos árbitros pelas partes para solucionarem o litígio ${ }^{249}$.

Como visto acima, ao árbitro é outorgada a jurisdição (ainda que privada), recebendo este os poderes para apreciar e julgar o conflito existente entre as partes, sendo inerente aos próprios poderes jurisdicionais recebidos pelo árbitro o poder geral de cautela e o poder de antecipar a tutela. Apenas o poder de imperium é reservado em caráter de exclusividade ao Estado.

subject-matter or necessary evidence may disappear; by the time the final relief is to be granted irreparable and noncompensatory harm may occur. One party may frustrate the rights of the other party and make enforcement impossible by dissipating or placing beyond reach assets or the subject-matter in issue. In these situations one of the parties may seek to protect its rights or property by some appropriate interim measures." (trad. livre: "O remédio buscado na ação principal freqüentemente é insuficiente para proteger efetivamente os direitos ou o interesse da parte tida como inocente. Devido ao lapso de tempo entre o começo do processo e a audiência principal, o objeto relevante ou a prova necessária pode desaparecer; Até a decisão final ser proferida, um dano irreparável e incompensável pode ocorrer. Uma parte pode frustrar os direitos da outra e tornar inviável a efetivação da decisão através da dissipação ou da ocultação de bens ou do objeto em disputa. Nessas situações, uma das partes poderá buscar proteger os seus direitos ou propriedades por meio das medidas liminares apropriadas.”) (LEW, Julian M.; MISTELIS, Loukas A.; KRÖLL, Stefan M. Comparative International..., p. 585).

${ }^{249}$ Nessa esteira, CARMONA anota que "(...) é do árbitro a competência para decidir demanda cautelar encetada por qualquer dos litigantes acerca de matéria sujeita à decisão arbitral. E para configurar tal competência não é preciso encontrar na convenção arbitral poderes expressos para proferir decisão que diga respeito à tutelar cautelar. Insisto neste ponto: se as partes concederam poderes ao árbitro para resolver suas pendências acerca de um determinado contrato, para solucionar uma disputa entre sócios de determinada companhia, para estabelecer a responsabilidade pela prática de dado ato, estes poderes também envolvem os decorrentes da tutela cautelar (eventual e instrumental)", bem como que "não haverá necessidade de encontrar na convenção de arbitragem autorização para que os árbitros antecipem tutela, pois tal autorização é implícita: as partes investem os árbitros de poderes para resolver todas as questões controvertidas que as envolvem, cabendo aos julgadores - juízes que são - zelar pela justa solução do litígio, adotando todas as providências necessárias ao pleno exercício do poder jurisdicional que lhes foi concedido pelos contendentes" (Arbitragem e Processo..., pp. 325 e 330). Não é diferente o entendimento de PEDRo A. BATISTA MARTins: “(...) quando os compromitentes firmam o compromisso, derrogando a jurisdição estatal, conferem ao árbitro a competência e o poder para resolver todas as questões atinentes à espécie, assumindo este o dever de zelar para que as partes não sejam prejudicadas nos seus direitos, o que inclui, obviamente, a competência para determinar medidas cautelares e coercitivas." (Da ausência de poderes coercitivos..., pp. 357/382). Em sentido contrário apenas com relação à possibilidade de antecipação de tutela pelo árbitro, JOSÉ CARLOS DE MAGALHÃES diz que "se a convenção dispuser sobre a matéria e omitir autorização para o juízo arbitral deferir a tutela antecipada é porque não quiseram as partes conferir-lhe esse poder." (A tutela antecipada no..., p. 15). JOSÉ MARIA ROSSANI GARCEZ também aduz que somente é possível a antecipação da tutela pelo árbitro se houver previsão expressa na convenção arbitral (Medidas cautelares e de antecipação..., p. 224). Por fim, PAULO CEZAR PINHEIRO CARNEIRO afirma que, nos casos em que não haja outorga expressa de poderes aos árbitros para a análise de medidas urgentes, estas poderão ser demandadas perante o Poder Judiciário, independente de convenção arbitral pré-existente (Aspectos processuais da nova lei..., p. 311). 
Há, contudo, entendimento de renomados juristas no sentido de que as partes possuiriam a faculdade de excluir do árbitro o poder para conceder tutelas de urgência. SIDNEI BENETI, por exemplo, afirma que "nada impede que na convenção de arbitragem estipulem as partes que eventuais medidas cautelares, se necessárias, sejam diretamente pleiteadas ao juiz togado"250.

\section{Em sentido diametralmente oposto, ALEXANDRE FREITAS}

CÂMARA nega essa possibilidade, aduzindo que "proibir a concessão de tutela antecipada pelo árbitro, principalmente nos casos de direitos em perigo (tutela de segurança), seria, a meu sentir, contrário ao princípio, norteador do sistema jurídico brasileiro, de acesso à ordem jurídica justa" ${ }^{251}$.

Não é diferente o entendimento de NILTON CÉSAR ANTUNES DA $\operatorname{COSTA}^{252}$ e de ARISTÓTELES ATHENIENSE ${ }^{253}$, que também reputam ser inviável que a convenção de arbitragem exclua previamente a possibilidade de o árbitro conceder tutelas de urgência no processo arbitral.

${ }^{250}$ BENETI, Sidnei. Arbitragem e tutelas de urgência..., p. 103. No mesmo sentido: CARMONA, Carlos Alberto. Arbitragem e Processo..., p. 326; MONTORO, Marcos André Franco. Flexibilidade do procedimento arbitral. Tese de doutorado apresentada à Faculdade de Direito da Universidade de São Paulo, 2010, p. 375; CARREIRA ALVIM, José Eduardo. Direito Arbitral, 2. ${ }^{a}$ ed. Rio de Janeiro: Forense, 2004, p. 341; PRADO, Vinícius de Andrade. Medidas cautelares..., p. 198; e AYOUB, Luiz Roberto. Arbitragem: o acesso à justiça e a efetividade do processo. Rio de Janeiro: Lumen Juris, 2005, p. 81. Na doutrina estrangeira, PIERO BERNARDINI também aduz que as partes podem limitar os poderes cautelares do árbitro ou exclui-los, podendo, ainda, excluir a competência concorrente do Judiciário (nos países em que há essa competência concorrente): "the parties are in principle at liberty: $i$ ) to define the scope of such measures in their contract by mentioning the type of measures or by excluding some of then; ii) to exclude the arbitrator's powers when they are provided by the applicable procedural law (as in the case of art. 183 of the LIPL [da Suíça]; iii) to provide for the exclusion of the otherwise concurrent jurisdiction of the national judge (which seems possible in the French and Swiss legal systems but not under the English 1950 Arbitration Act);" (tradução livre: "as partes, em princípio, são livres: i) para definir o escopo de tais medidas em seu contrato, mencionando os tipos de medidas cabíveis ou excluindo algumas delas; ii) para excluir os poderes do árbitro quando eles são outorgados pela lei processual aplicável (como no caso do art. 183 da LIPL [da Suíça]); iii) para estabelecer a exclusão de eventual jurisdição concorrente do juízo estatal (o que parece possível nos sistemas legais da França e da Suíça, mas não perante o Arbitration Act inglês de 1950);”) (Power of the Arbitrator..., p. 27). Julian M. LEW, LOUKAS A. Mistelis e STEFAN M. KRÖLl seguem a mesma linha, estatuindo que "under most laws and rules party autonomy generally determines the types of measures the arbitration tribunal can order." (tradução livre: "sob a maioria das leis e regulamentos a autonomia das partes geralmente determina os tipos de medidas que o tribunal arbitral pode conceder.”) (Comparative International..., p. 594).

${ }^{251}$ CÂMARA, Alexandre Freitas. Arbitragem..., p. 107. Valendo ressaltar que a expressão "ordem jurídica justa" é de KAZUO WATANABE.

${ }^{252}$ In Poderes do Árbitro. São Paulo: RT, 2002, p. 111.

${ }^{253}$ In "As medidas coercitivas no juízo arbitral”. Revista de Direito Bancário, do Mercado de Capitais e da Arbitragem, vol. 19. WALD. Arnoldo (coord.). São Paulo: RT, jan/mar de 2003, pp. 313/316, esp. p. 314. 
Além de não admitir que a convenção das partes exclua a possibilidade de o árbitro conceder tutelas de urgência, JOEL DiAS FIGUEIRA JÚNIOR sustenta, ainda, que "tal convenção será absolutamente nula por afrontar o direito constitucional de acesso à jurisdição estatal ou privada" ${ }^{254}$.

Concordamos com esse entendimento, pois o poder geral de cautela do árbitro (incluindo o poder de conceder a antecipação dos efeitos da tutela) é inerente à própria jurisdição $\operatorname{arbitral}^{255}$, isto é, quando as partes concedem ao árbitro poderes para solucionar uma controvérsia, concedem também a ele o poder geral de cautela e o poder de antecipar os efeitos da tutela final indispensáveis, muitas vezes, ao pleno exercício da jurisdição arbitral.

De fato, seria ilógico pensar que as partes, ao optarem pela solução de uma disputa por meio da arbitragem, pudessem resolver seus litígios perante um árbitro com poderes limitados ${ }^{256}$.

Ademais, não se mostra cabível, tampouco produtivo, no curso de uma arbitragem, ter dois poderes (duas jurisdições nesse caso) um decidindo sobre o mérito da questão e o outro de forma provisória ${ }^{257}$.

\footnotetext{
${ }^{254}$ In Arbitragem, jurisdição..., pp. 224/225. Sobre o tema das nulidades, ver: LACERDA, Galeno. Despacho saneador, 3. ${ }^{a}$ edição. Porto Alegre: Fabris, 1990; CALMON DE PASSOS, José Joaquim. Esboço de uma teoria das nulidades aplicada às nulidades processuais. Rio de Janeiro: Forense, 2002; e BEDAQUE, José Roberto dos Santos. "Nulidade processual e instrumentalidade do processo". Revista de Processo - RePro, n. ${ }^{\circ}$ 60. São Paulo: RT, outubro/dezembro de 1990, pp. 31/43.

${ }^{255}$ PIERO BERNARDINI menciona que há doutrinadores que entendem que o poder geral de cautela é inerente às funções e à autoridade do árbitro, citando HOELLERING ("The authority of arbitrators to grant interim relief comes from their inherent powers to conduct the arbitral proceedings" - trad. livre: "A autoridade dos árbitros para deferir liminares advém de seus poderes inerentes para conduzir o processo arbitral" - "Interim measures and arbitration: the situation in the U.S.", trabalho apresentado na reunião conjunta da A.I.S.A. e da I.C.C.A. em Bolonha em 19/04/1991, p. 03) e MENDEZ, Ramos. "Arbitrage international et mesures conservatoires". Rev. Arb., 1985, p. 56 (in The Powers of the Arbitrator..., p. 22). JULIAN M. LEW, LOUKAS A. Mistelis e StefAn Michael KRÖLl também tratam desse tema: "a questão que surge é se o tribunal arbitral possui um poder inerente para tanto [para conceder tutelas de urgência]. Tal poder foi assumido por diversos tribunais arbitrais sob as regras da CCI de 1988 que não continham qualquer poder expresso. O raciocínio para essa visão é que pela convenção de arbitragem as partes outorgam ao tribunal os poderes necessários para resolver sua disputa. Isso também inclui o poder para ordenar qualquer medida provisória que seja necessária para resguardar os direitos das partes e a eficiência do poder de decisão do tribunal arbitral." (Comparative International..., pp. 592/593, tradução livre).

${ }^{256}$ Cf. SILVA, João Paulo Hecker da. Tutela de Urgência e Tutela..., p. 297. Em igual sentido: “entendemos que nem mesmo as partes poderiam decidir pela impossibilidade de o árbitro apreciar medidas de urgência, discordando do argumento que alega que isso estaria no poder de disponibilidade das partes. (...) não se pode optar por 'meia' jurisdição arbitral” (HOFFMAN, Paulo. Arbitragem: algumas dúvidas..., p. 311).
} 
Se o árbitro é quem vai decidir o mérito da questão, não nos parece plausível que as partes possam retirar daquele o poder de apreciar e de conceder tutelas de urgência ${ }^{258}$, especialmente porque, em muitos casos, a decisão liminar pode ser fundamental ao próprio mérito da causa ${ }^{259}$.

Imagine-se, por exemplo, a hipótese de o árbitro entender ser necessária uma tutela de urgência para resguardar o direito da parte, mas não poder concedê-la, ante a retirada desses poderes pela convenção de arbitragem. A parte, então, pleiteia essa tutela de urgência diretamente perante a justiça estatal, mas esta indefere o seu pedido. A situação ficaria sem solução, talvez até mesmo impossibilitando o árbitro de julgar referida arbitragem, diante do perecimento do direito da parte, o que violaria, sem sombra de dúvida, a jurisdição concedida ao árbitro pelas partes.

Esse problema aumenta ainda mais em se tratando de pedido de antecipação de tutela, o qual envolve uma análise, ainda que sumária, do próprio mérito da causa. Relegar essa análise ao juízo estatal, e não ao árbitro, parece de todo sem sentido, uma vez que será este quem analisará de forma definitiva a questão.

Aliás, o fato de a tutela de urgência ser provisória, podendo ser reformada ou modificada a qualquer tempo, também acarreta a impossibilidade de o poder geral de cautela ficar a cargo do Poder Judiciário, e não do árbitro, pois é este quem conduzirá o processo arbitral e a sua instrução.

257 Cf. SILVA, João Paulo Hecker da. Tutela de Urgência e Tutela..., p. 298. Sobre o tema, JOEL DIAS FIGUEIRA JÚNIOR afirma que "o juízo arbitral é soberano, e somente o árbitro ou o colégio é que, por maioria ou unanimidade, possui jurisdição privada e competência para decidir acerca do pedido de concessão de providência acautelatória, antecipatório ou inibitório" e que, "desde que instaurado o juízo arbitral, inexiste possibilidade jurídica de o interessado dirigir qualquer desses requerimentos ao juiz togado que seria competente, originariamente, se fosse o caso, para conhecer da lide principal.” (Arbitragem, jurisdição..., p. 221).

${ }^{258}$ PAULO HOFFMAN, corroborando esse entendimento, diz que, "se o mérito será decidido pelo árbitro, toda e qualquer situação que envolva o litígio, igualmente, deve ser de competência exclusiva dele." (in Arbitragem: algumas dúvidas..., p. 311). Igualmente, JOSÉ MARIA ROSSANI GARCEZ aduz que "o posicionamento ideal na prática e quanto à doutrina dominante é o de que as medidas cautelares, em litígios que sejam resolvidos por arbitragem, sejam da alçada dos próprios árbitros, pois são eles que virão posteriormente a julgar a causa em sede arbitral, e assim poderão avaliar, in limine, os pressupostos do fumus boni juris e periculum in mora, com análise contrabalanceada do periculum in inverso" (Medidas cautelares e de antecipação..., pp. 216/217). ${ }^{259}$ Nesse sentido, Julian M. LEW, LOUKAS A. Mistelis e STEFAN MiCHAEL KröLl afirmam que "interim measures often actually decide the dispute" (tradução livre: "medidas liminares na realidade decidem a disputa com frequiência.") (Comparative International..., p. 621). 
Na prática, a outorga do poder cautelar e de antecipar tutela ao juízo estatal também traria problemas de difícil solução. Por exemplo, o árbitro, a rigor, ficaria obrigado a informar ao juiz togado acerca de toda nova prova produzida no processo arbitral, para que o magistrado, então titular do poder geral de cautela, pudesse verificar a pertinência da reforma ou da manutenção da decisão liminar (já que esta pode ser revista a qualquer tempo, especialmente diante de novas provas). Essa situação sui generis atrasaria e atravancaria o regular andamento do processo arbitral, aumentando, inevitavelmente, os pontos de contato entre justiça arbitral e justiça estatal, algo totalmente incabível e que deve ser evitado, sob pena de inviabilização da própria arbitragem ${ }^{260}$.

A autonomia da vontade das partes não pode chegar ao ponto de dividir a jurisdição arbitral (quanto ao mérito, a jurisdição seria arbitral, e quanto às tutelas de urgência, que também envolvem a análise do mérito, ainda que de forma sumária, a jurisdição seria estatal ${ }^{261}$, pois o poder do árbitro para apreciar e conceder tutelas de urgência decorre da própria Lei de Arbitragem ${ }^{262}$, bem como do conceito constitucional de jurisdição, a qual é outorgada ao árbitro pelas partes quando optam pela arbitragem $^{263}$.

\footnotetext{
${ }^{260}$ Vale aqui nova menção à lição de BRUNO OPPETrT, no sentido de que a "freqüente utilização - da jurisdição estatal pela arbitragem - ameaça alterar a natureza profunda da justiça privada", bem como que o "vai e vem contínuo entre os recintos arbitrais e o palácio da justiça" deve ser corrigido. Caso contrário "tais desvios - cujos primeiros responsáveis são as partes e seus advogados -, pelos custos, pelo prolongamento dos procedimentos e complicações decorrentes, comprometerão a utilidade e a própria vocação da arbitragem." (OPPETIT, Bruno. Etudes offertes..., p. 194).

${ }^{261}$ MANUEla CoRReia Botelho COLOMBO salienta que "a autonomia das partes não é absoluta, já que a própria lei estabelece parâmetros para a instituição do procedimento arbitral." ("Medidas de Urgência no Processo Arbitral Brasileiro" in Revista de Processo - RePro, ano 35, n. ${ }^{\circ}$ 183. São Paulo: RT, maio de 2010, pp. 257/287, especificamente p. 266).

${ }^{262}$ Nesse sentido, o voto prolatado pela Min. NANCY ANDRIGHI no REsp n. ${ }^{\circ}$ 1.297.974-RJ: "A competência do Tribunal Arbitral para processar e julgar pedido cautelar formulado pelas partes encontra-se pacificada na doutrina e na jurisprudência, visto que o poder é inerente ao compromisso arbitral, estando expressamente

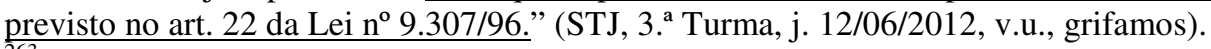

${ }^{263}$ Conforme lição de ClÁVIO DE MELo VAlençA FILHO, "a convenção de arbitragem (...) subtrai poder jurisdicional ao juiz estatal" e "outorga de tais poderes ao árbitro. Instaurada a instância arbitral, o árbitro é juiz de fato e de direito. Afasta-se o juiz estatal, não por falta de competência, mas, antes, por ausência de jurisdição." (Sentença arbitral e..., p. 36). Nesse mesmo sentido, a jurisprudência do TJ/SP, no sentido de não se tratar de questão de competência, mas de jurisdição: "note-se que, em rigor, não se deve falar em competência, pois que de competência não se trata. O que há é renúncia à via jurisdicional que, entretanto, não fica excluída a manifestar-se sobre a validade do ato." (TJ/SP, 5. ${ }^{a}$ Câmara de Direito Privado, A.I. n. ${ }^{\circ}$ 124.217-4/0, Rel. Des. Rodrigues de Carvalho, j. 16/09/1999, v.u.); e "a questão trazida não trata, pois, de regra de competência, mas de indagar se há renúncia à via jurisdicional para submissão da questão litigiosa ao juízo arbitral convencionado." (TJ/SP, 5. ${ }^{a}$ Câmara de Direito Privado, Apelação cível com revisão n. ${ }^{\circ}$ 0123750-69.2005.8.26.0000 - n. ${ }^{\circ}$ antigo 431.916-4/3-00, Rel. Des. Silvério Ribeiro, j. 11/06/2008, v.u.).
} 
Caso tudo fosse permitido, em nome do princípio da autonomia da vontade das partes, poderia se aceitar, por exemplo, uma convenção de arbitragem em que os árbitros, por consenso das partes, não pudessem produzir provas para solucionar a lide (aceitar-se-ia, pois, a exclusão dos poderes instrutórios do árbitro).

Por óbvio, uma convenção arbitral nesse sentido seria nula de pleno direito ${ }^{264}$, assim como entendemos ser nula também a convenção de arbitragem que exclui dos árbitros os poderes para apreciar e conceder tutelas de urgência, uma vez que, em ambos os casos, a jurisdição arbitral estaria sendo ceifada de sua plenitude ${ }^{265}$.

Entender que o poder dos árbitros para apreciar e conceder tutelas de urgência possa ficar ao livre arbítrio das partes é negar vigência ao artigo 22 , $\S 4 .^{\circ}$, da Lei n. ${ }^{\circ} 9.307 / 96$, cuja regra se encontra fundada nos princípios gerais do processo civil, dentre os quais o da efetividade ${ }^{266}$.

Assim, conclui-se ser perfeitamente possível a concessão de tutelas de urgência em um processo arbitral, sendo dos árbitros o poder para apreciar e deferir tanto o provimento cautelar, como a tutela antecipada, quando a arbitragem já estiver instituída ${ }^{267}$.

Nos ordenamentos jurídicos estrangeiros, há basicamente três

$\operatorname{posições~distintas~}^{268}$.

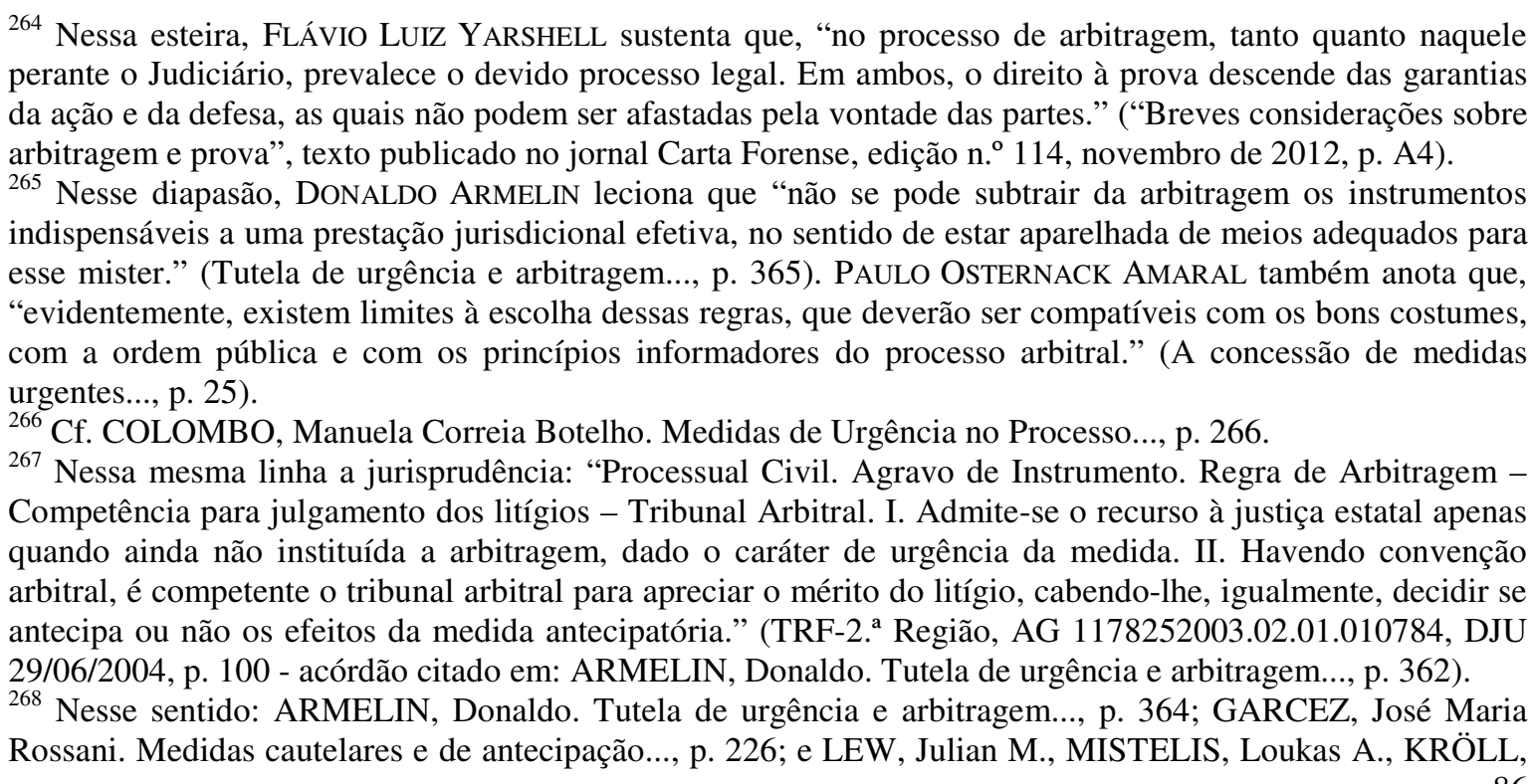


A primeira, dos países que reservam ao Estado o poder de apreciar e determinar tutelas de urgência, vedando a sua concessão em sede de arbitragem (como, por exemplo, a Argentina - artigo 753 do Código de Processo Civil e Comercial da Nação ${ }^{269}$, a Itália - artigo 818 do Código de Processo Civil italiano ${ }^{270}$ e a Áustria - art. 589 do Código de Processo Civil austríaco ${ }^{271}$ ). Até mesmo por isso a doutrina desses países é no sentido da inexistência de poder cautelar do árbitro ${ }^{272}$.

Stefan Michael. Comparative International..., pp. 587/590. Ainda sobre o tema, PEDRO A. BATISTA MARTins (in Da Ausência de Poderes Coercitivos..., p. 362), menciona a conclusão de PIERo BERNARDINI, em sua obra "The Powers of the Arbitrator" in Conservatory and Provisional Measures in International Arbitration. Paris: ICC Publishing, 1993, pp. 23/24, nos seguintes termos: “A posição de sistemas nacionais no que tange à relação entre medidas conservativas e provisórias e os poderes dos árbitros pode ser dividida em três categorias gerais: 1) Há sistemas nacionais que excluem os poderes do árbitro para ordenar tais medidas, reservando-os exclusivamente ao juízo estatal. (...) 2) Outros sistemas nacionais conferem os poderes em questão ao árbitro ou aceitam que eles sejam exercidos pelo árbitro. (...) 3) Há sistemas nacionais que permitem que as partes confiram esses relevantes poderes ao árbitro, seja na convenção de arbitragem ou em outro tempo do litígio." (tradução livre).

269 “Art. 753. - Los árbitros no podrán decretar medidas compulsorias, ni de ejecución, deberán requerirlas al juez y éste deberá prestar el auxilio de su jurisdicción para la más rápida y eficaz sustanciación del proceso arbitral." (tradução livre: "Os árbitros não poderão decretar medidas compulsórias, nem de execução, deverão requerê-las ao juiz e este deverá prestar o auxílio de sua jurisdição para a mais rápida e eficaz condução do processo arbitral.").

${ }^{270}$ Eis o teor do artigo 818 do Código de Processo Civil italiano, com a nova redação dada pelo Decreto Legislativo n. ${ }^{\circ}$ 40, de 02 de fevereiro de 2006 (publicado em 15 de fevereiro de 2006): “Art. 818. (Provvedimenti cautelari) Gli arbitri non possono concedere sequestri, ne' altri provvedimenti cautelari, salva diversa disposizione di legge." (tradução livre: “Art. 818. (Provimentos cautelares) Os árbitros não podem conceder seqüestro, nem outro provimento cautelar, salvo diversa disposição de lei”).

${ }^{271}$ Cf. BERNARDINI, Piero. The Powers of the Arbitrator..., p. 23.

${ }^{272}$ PALACIO, Lino Enrique. Manual de Derecho Procesal Civil, vol. II. Abeledo-Perrot, 1990, pp. 506 e 547; LA CHINA, Sergio. L'Arbitrato - Il Sistema e L'Esperienza. Milano: Giuffrè, 1995, pp. 97/98; PROTO PISANI, Andrea. Lezioni di diritto processuale civile. Jovene, 1994, p. 861; SATTA, Salvatore. Direito processual civil, vol. II. Borsoi, tradução de Luiz Autuori, 1973, p. 779; GONNET, Gabriella Rampazzo. Commentario breve al Codice di Procedura Civile, 3. ${ }^{a}$ edição. CARPI, Federico; e TARUFFO, Michele (coords.). Padova: Cedam, 1994, p. 1.559; e AULETTA, Ferruccio. "Cognizione sommaria e giudizio arbitrale". Diritto dell'arbitrato (a cura di Giovanni Verde). Torino: Giappichelli, pp. 493/508, esp. p. 493. FERRUCCIO AULETTA esclarece que a ausência do poder geral de cautela do árbitro na Itália é justificada pela carência de jus imperii por parte do árbitro (Idem, p. 497). LAURA SALVANESCHI também anota que o art. 818 do CPC italiano veda ao árbitro ordenar seqüestro, arresto ou qualquer outra medida provisória, sustentando que esse é um traço particular da arbitragem italiana, advindo da ausência de poder de império do árbitro (Mesures provisoires et arbitrage... pp. 447 e 460). Com relação às tutelas de urgência em arbitragens estrangeiras, LAURA SALVANESCHI aduz que há duas correntes na Itália: a primeira, que entende que o art. 669-quinquies se aplica às abitragens nacionais e estrangeiras, razão pela qual somente o juiz estatal pode conceder medidas urgentes; e a segunda, que entende que o art. 669-quinquies se aplica apenas às arbitragens internas, podendo o árbitro conceder tutelas de urgência em uma arbitragem estrangeira, ressalvando a jurista que, "comme nous l'avons déjà rappelé, ces deux interprétations soient l'une et l'autre acceptables d'un point de vue littéral, je crois qu'il est plus correct de considérer que l'article 669quinquies du C. proc. civ. régit toutes situations de compétence en matière de juridiction provisoire lorsque le litige est soumis à l'arbitrage, ceci sans aucune distinction entre l'arbitrage étranger et l'arbitrage de droit interne." (trad. livre: "como já foi mencionado anteriormente, essas duas interpretações são uma e outra aceitáveis do ponto de vista literal, eu acredito que é mais correto considerar que o artigo 669quinquies do C. proc. civ. governa todas situações de competência em matéria de jurisdição provisória quando o litígio for submetido à arbitragem, isso sem qualquer distinção entre arbitragem estrangeira e arbitragem de direito interno.”) (idem, p. 449). 
A segunda, dos países que conferem aos árbitros o poder de apreciar e conceder tutelas de urgência (e.g., a Alemanha - § 1041, (1), do CPC ${ }^{273}$ - embora haja competência concorrente da justiça estatal - $§ 1033$ do $\mathrm{CPC}^{274}$; a Bélgica - art. 1696, "1", do Código Judiciário belga ${ }^{275}$, com exceção de medidas conservativas, tais como o arresto; a Suíça - art. 183, "1”, da Lei Federal Suíça de Direito Privado Internacional ${ }^{276}$; a França - art. 1468 do Código de Processo Civil francês, com exceção de arresto (apreensões conservativas) e garantias judiciais ${ }^{277}$; Portugal - arts. $20 .^{\circ}$ a $29 .^{\circ}$ da Lei

273 "Section 1041 - Interim measures of protection (1) Unless otherwise agreed by the parties, the arbitral tribunal may, at the request of a party, order such interim measures of protection as the arbitral tribunal may consider necessary in respect of the subject-matter of the dispute. The arbitral tribunal may require any party to provide appropriate security in connection with such measure." (trad. livre: "Seção 1041 - Medidas provisórias de proteção. (1) A não ser que as partes tenham pactuado de outra forma, o tribunal arbitral poderá, a pedido da parte, ordenar tais medidas provisórias de proteção caso o tribunal arbitral as considere necessárias com relação ao objeto da disputa. O tribunal arbitral poderá requerer a qualquer das partes que preste a caução apropriada com relação a tal medida.”). Na Alemanha, a regulamentação do instituto da arbitragem voluntária é feita pelos artigos 1025 a 1066 do ZPO (CPC alemão), na versão que entrou em vigor em 1. ${ }^{\circ}$ de janeiro de 1998, não havendo lei específica sobre o tema.

274 "Section 1033 - Arbitration agreement and interim measures by court. It is not incompatible with an arbitration agreement for a court to grant, before or during arbitral proceedings, an interim measure of protection relating to the subject-matter of the arbitration upon request of a party." (trad. livre: "Seção 1033 - Convenção arbitral e medidas provisórias pela Corte. Não é incompatível com uma convenção arbitral a Corte conceder, antes ou durante o procedimento arbitral, uma medida provisória de proteção relativa ao objeto da arbitragem mediante pedido da parte.").

275 “Art. 1696. 1. Sans préjudice de l'application de l'article 1679, le tribunal arbitral peut ordonner des mesures provisoires et conservatoires à la demande d'une partie, à l'exception d'une saisie conservatoire." (tradução livre: “Art. 1696. Sem prejuízo da aplicação do artigo 1679, o tribunal arbitral pode ordenar medidas provisórias e conservativas a pedido de uma parte, com exceção de uma apreensão conservativa.").

276 "Art. 183. Mesures provisionnelles et mesures conservatoires. 1 Sauf convention contraire, le tribunal arbitral peut ordonner des mesures provisionnelles ou des mesures conservatoires à la demande d'une partie." (tradução livre: "Art. 183. Medidas provisórias e medidas conservativas. 1. Salvo convenção em contrário, o tribunal arbitral pode ordenar as medidas provisórias ou as medidas conservativas a pedido de uma parte.").

277 “Arte. 1468. Le tribunal arbitral peut ordonner aux parties, dans les conditions qu'il détermine et au besoin à peine d'astreinte, toute mesure conservatoire ou provisoire qu'il juge opportune. Toutefois, la juridiction de l'Etat est seule compétente pour ordonner des saisies conservatoires et sûretés judiciaires. Le tribunal arbitral peut modifier ou compléter la mesure provisoire ou conservatoire qu'il a ordonnée." (trad. livre: “Art. 1468. O tribunal arbitral pode ordenar às partes, nas condições que determinar e se necessário sob pena de multa, todas as medidas conservativas ou provisórias que julgar oportunas. No entanto, a jurisdição do Estado é a única competente para ordenar apreensões conservativas (penhora/arresto) e garantias judiciais. O tribunal arbitral pode modificar ou complementar a medida provisória ou conservativa que concedeu."). Sobre o tema, JACQUES NORMAND ensina que "uma distinção se impõe entre as medidas puramente conservativas, destinadas a salvaguardar os interesses pendentes até o resultado da disputa, e as apreensões e registros conservativos, destinados a garantir a posterior execução de um título executivo que o credor não tem de imediato", dizendo que o árbitro possui competência para as primeiras, enquando somente o juiz estatal pode apreciar as segundas (Les mesures provisoires et l'arbitrage..., pp. 465/466, trad. livre). JACQUES NORMAND ainda menciona a competência concorrente do juízo estatal para a apreciação de tutelas de urgência na França: "sempre se admitiu que o juiz das liminares ("juge des référés") pudesse conceder medidas urgentes, tanto antes da constituição do tribunal arbitral, como durante, no processo que se instaurou perante ele, a fim de tomar todas as medidas conservativas que a urgência impõe. Justifica-se essa competência pelo caráter de ordem pública da competência estatal em caso de urgência." (idem, p. 462, tradução livre). 
n. ${ }^{\circ} 63 / 2011^{278}$, havendo competência concorrente da justiça estatal, conforme o disposto no artigo 29. . " “1”, da Lei n. ${ }^{\circ} 63 / 2011^{279}$, dentre outros ${ }^{280}$ ).

E a terceira, dos países que autorizam as partes a conceder aos árbitros, se assim o desejarem, poderes para apreciar e conceder tutelas de urgência ${ }^{281}$ (como, por exemplo, na Holanda, em que o árbitro não possui poderes para apreciar e conceder tutelas de urgência, salvo se concedido pelas partes na convenção $\operatorname{arbitral~}^{282}$. Na Inglaterra, a competência do árbitro para medidas urgentes é presumida em determinadas hipóteses ligadas à condução do processo, em especial o security for cost $\mathrm{e}$ a proteção dos meios de provas - artigo 38 (3), (4) e (6) do Arbitration Act de 1996. Mas, para as tutelas

\footnotetext{
278 Destacando-se os artigos 20.', “1”, e 22. ", “1”: “Artigo 20. Providências cautelares decretadas pelo tribunal arbitral. 1 - Salvo estipulação em contrário, o tribunal arbitral pode, a pedido de uma parte e ouvida a parte contrária, decretar as providências cautelares que considere necessárias em relação ao objecto do litígio." e "Artigo 22. ${ }^{\circ}$ Requerimento de ordens preliminares; requisitos. 1 - Salvo havendo acordo em sentido diferente, qualquer das partes pode pedir que seja decretada uma providência cautelar e, simultaneamente, requerer que seja dirigida à outra parte uma ordem preliminar, sem prévia audiência dela, para que não seja frustrada a finalidade da providência cautelar solicitada". JosÉ MIGUEL JÚDICE anota que essa é matéria "totalmente inovatória em Portugal", pois a lei anterior (Lei n. ${ }^{\circ} 31 / 86$ ) nada dispunha sobre o tema ("O Projecto de Nova Lei de Arbitragem Voluntária em Portugal”. Revista Brasileira de Arbitragem, n. ${ }^{\circ} 23$. São Paulo: IOB/CBAr, jul/set de 2009, pp. 240/246, p, 243).

279 “Artigo 29..$^{\circ}$ Providências cautelares decretadas por um tribunal estadual. 1 - Os tribunais estaduais têm poder para decretar providências cautelares na dependência de processos arbitrais, independentemente do lugar em que estes decorram, nos mesmos termos em que o podem fazer relativamente aos processos que corram perante os tribunais estaduais".

${ }^{280} \mathrm{Na}$ Cidade-Estado de Hong Kong, a nova "Hong Kong Arbitration Ordinance (Cap. 609)" ("Lei de Arbitragem de Hong Kong - Capítulo 609”), em vigor desde 01/06/2011, estabelece em sua parte 6 ("Interim measures and preliminary orders" - tradução livre: "Medidas liminares e ordens preliminares"), divisão 1 ("Interim measures" - tradução livre: "medidas liminares"), seção 35 ("Article 17 of UNCITRAL Model Law [Power of arbitral tribunal to order interim measures]" - tradução livre: "Artigo 17 da Lei Modelo da UNCITRAL [Poder do tribunal arbitral para conceder medidas liminares]"), que o artigo 17 da Lei Modelo da UNCITRAL se aplica a todas as arbitragens, nacionais ou internacionais: "(1) Article 17 of the UNCITRAL Model Law, the text of which is set out below, has effect: 'Article 17. Power of arbitral tribunal to order interim measures (1) Unless otherwise agreed by the parties, the arbitral tribunal may, at the request of a party, grant interim measures'.” (tradução livre: “(1) Artigo 17 da Lei Modelo da UNCITRAL, o texto citado abaixo está em vigor: 'Artigo 17. Poder do tribunal arbitral para conceder medidas liminares (1) A não ser que as partes tenham pactuado de outra forma, o tribunal arbitral pode, a pedido de uma parte, conceder medidas liminares"). FERRUCCIO AULETTA aponta que, na Espanha, o artigo 23 da Lei n. ${ }^{\circ}$ 60/2003, em vigor desde 27/03/2004, concede poder cautelar ao tribunal arbitral, concorrente com aquele da autoridade judiciária (in Cognizione sommaria e giudizio..., p. 498).

${ }^{281}$ FERRUCCIO AULETTA anota que "è opzione frequente di permettere alle parti il conferimento agli arbitri del potere suppletivo di emanare provvedimenti cautelari (...)" (tradução livre: "é opção freqüente permitir que as partes confiram aos árbitros o poder supletivo de conceder provimentos cautelares.") (Cognizione sommaria e giudizio..., p. 498).

${ }^{282}$ Cf. COSTA. Almir Alegres. Competência dos Tribunais Arbitrais com relação a medidas coercivas e cautelares. www.viajus.com.br/viajus.php?pagina=artigos\&id=1905\&idAreaSel=15\&seeArt=yes. Acessado em 09/09/2012.
} 
de urgência em geral, faz-se necessário que as partes outorguem o poder cautelar ao(s) árbitro(s), nos termos do artigo 39, (1) e (4), do Arbitration Act de $1996^{283}$ ).

José Augusto DelgAdo salienta que vários países, seguindo uma tendência moderna, incorporaram em sua legislação interna a Lei Modelo da UNCITRAL (“United Nations Commission on International Trade Law” - Comissão das Nações Unidas para o Direito Comercial Internacional), na sua íntegra ou em grande parte, para regular as arbitragens internacionais, citando como exemplo: o Canadá, o Chipre, a Rússia, a Austrália, a Bulgária, o México, a Escócia, o Peru, a Nigéria, a Tunísia, a Ucrânia, o Egito, Hong-Kong, Cingapura e diversos estados dos Estados Unidos da América ${ }^{284}$, sendo certo que o artigo 17, (1), da referida Lei Modelo da UNCITRAL autoriza a concessão de tutelas de urgência pelo(s) árbitro(s), a não ser que pactuado de outra forma pelas partes ${ }^{285}$.

Diante disso, nas arbitragens internacionais, caberá ao árbitro analisar se as regras eleitas pelas partes contemplam o poder do árbitro para apreciar e deferir tutelas de urgência. Em sendo positiva a resposta, o árbitro deverá verificar, ainda, se referido poder não conflita com as regras de direito do país local onde eventual medida urgente deverá ser executada ${ }^{286}$.

283 "Power to make provisional awards. 39. (1) The parties are free to agree that the tribunal shall have power to order on a provisional basis any relief which it would have power to grant in a final award. (...) (4) Unless the parties agree to confer such power on the tribunal, the tribunal has no such power." (trad. livre: "Poder para conceder medidas provisórias. 39. (1) As partes são livres para acordar que o tribunal terá poder para ordenar, de forma provisória, qualquer medida que ele teria poder para conceder na decisão final. (...) (4) A não ser que as partes concordem em conferir tal poder ao tribunal, o tribunal não tem referido poder."). Como ensina NEIL ANDREWS, o Arbitration Act 1996 da Inglaterra é baseado na Lei Modelo da UNCITRAL, especialmente quanto a sua estrutura, mas cobre muito mais facetas da arbitragem do que a Lei Modelo. O autor salienta ainda que, de acordo com o Arbitration Act 1996, o árbitro não possui poder cautelar, a não ser que as partes tenham outorgado, expressamente, tal poder ao árbitro, mas que os árbitros podem proferir sentenças parciais antes da sentença final (Arbitration and mediation in England..., pp. 115/117).

${ }^{284}$ In Arbitragem no Brasil - evolução..., p. 244.

285 "Chapter IV A. Interim measures and preliminary orders (As adopted by the Commission at its thirtyninth session, in 2006). Section 1. Interim measures. Article 17. Power of arbitral tribunal to order interim measures (1) Unless otherwise agreed by the parties, the arbitral tribunal may, at the request of a party, grant interim measures." (tradução livre: "Capítulo IV A. Medidas liminares e ordens preliminares (Como adotado pela Comissão em sua trigésima nona sessão, em 2006) Seção 1. Medidas liminares. Artigo 17. Poder do tribunal arbitral para ordenar medidas liminares (1) A não ser que as partes tenham pactuado de outra forma, o tribunal arbitral pode, a pedido de uma parte, conceder medidas liminares".) (www.uncitral.org/pdf/english/texts/arbitration/ml-arb/07-86998_Ebook.pdf. Acessado em 22/12/2012).

${ }^{286}$ Cf. BERNARDINI, Piero. The Powers of the Arbitrator..., pp. 22/23: "Accordingly, the arbitrator will first have to determine wheter the applicable rules of procedure, be they the rules of a national system or those of an arbitral institution ot those specifically made by the parties, contemplate such powers. Then, assuming a positive answer, it will have to verify that the powers so conferred do not conflict with the mandatory rules of the place where the requested measure is to be enforced." (trad. livre: "Nesse sentido, o árbitro deverá primeiro determinar se as regras de procedimento aplicáveis, sejam elas regras de um sistema 
STEFAN MiCHAEL KRÖLL ressaltam que os regulamentos das principais câmaras arbitrais internacionais prevêem a possibilidade de o árbitro apreciar e deferir tutelas de urgência ${ }^{287}$, tal como o artigo 26 das Regras de Arbitragem da UNCITRAL ${ }^{288}$ e o artigo 28 do regulamento de arbitragem e de ADR da Câmara do Comércio Internacional - CCI (International Chamber of Commerce - ICC $)^{289}$, mencionando ainda os dois principais requisitos para a concessão de tutelas de urgência em arbitragens internacionais:

\begin{abstract}
"A prática da arbitragem internacional sugere que há pelo menos dois requisitos relevantes largamente aceitos para a concessão de medida liminar pelos tribunais arbitrais: o não pré-julgamento do caso, e o risco de dano irreparável ou substancial que não poderá ser compensado ante os prejuízos"290.
\end{abstract}

nacional ou aquelas de uma instituição arbitral ou aquelas especificamente criadas pelas partes, contemplam tais poderes. Depois, assumindo a resposta positiva, ele deverá verificar se os poderes conferidos não conflitam com as regras obrigatórias do local onde a medida pleiteada deverá ser executada.”). JULIAN M. LEW, LOUKAS A. MisTELIS e STEFAN MICHAEL KRÖLL também ressaltam a importância das regras adotadas pelas partes na arbitragem e da legislação do país onde a tutela de urgência será executada: "Generally, the power to order interim relief depends on the authority of the tribunal as agreed by the parties. This may be done expressly in the arbitration agreement or by the choice of arbitration rules which allow arbitrators to order such relief." (trad. livre: "Geralmente, o poder para conceder tutelas de urgência depende da autoridade do tribunal definida pelas partes. Isso pode ser feito expressamente na convenção de arbitragem ou pela escolha das regras de arbitragem que autorizem os árbitros a conceder tais medidas.") e "These measures may also be influenced by the relevant national legal systems involved in each arbitration." (trad. livre: "Essas medidas também poderão ser influenciadas pelas legislações nacionais envolvidas em cada arbitragem.") (Comparative International..., pp. 586/587 e 585), ressaltando, no entanto, que nem sempre a limitação da lei local é aplicada em arbitragens internacionais, citando a possibilidade de uma medida de "congelamento de bens" prevista na Inglaterra ser aplicada em uma arbitragem internacional com sede na Alemanha (local em que essa medida não pode ser aplicada pelo juízo estatal) (Idem, p. 594).

${ }^{287}$ Cf. LEW, Julian M., MISTELIS, Loukas A., KRÖLL, Stefan M. Comparative International..., p. 590. PIERO BERNARDINI também menciona alguns exemplos, tais como: os artigos 13.1, 15.1 e 15.2 do regulamento da London Court of International Arbitration de 01/01/1985; o artigo 22 do regulamento de arbitragens internacionais da American Arbitration Association de 01/03/1991; o artigo 26 do regulamento da Inter-American Commercial Arbitration Comission de 01/04/1982; o artigo 37 do regulamento da The Netherlands Arbitration Institute de 01/12/1986; e o artigo 28 do regulamento de arbitragem da Zurich Chamber of Commerce de 1989 (in The Powers of the Arbitrator..., pp. 24/26).

288 "Interim measures - Article 26 - 1. The arbitral tribunal may, at the request of a party, grant interim measures." (tradução livre: "Medidas liminares - Artigo 26 - 1. O tribunal arbitral pode, a pedido de uma parte, conceder medidas liminares.").

289 "Artigo 28 - Medidas cautelares e provisórias - 1. A menos que as partes tenham convencionado diferentemente, o tribunal arbitral poderá, tão logo esteja na posse dos autos, e a pedido de uma das partes, determinar a adoção de qualquer medida cautelar ou provisória que julgar apropriada. $\mathrm{O}$ tribunal arbitral poderá subordinar tal medida à apresentação de garantias pela parte solicitante. A medida que for adotada tomará a forma de ordem procedimental devidamente fundamentada, ou a forma de uma sentença arbitral, conforme o tribunal arbitral considerar adequado".

${ }^{290}$ In Comparative International..., p. 603, tradução livre - trecho original: "International arbitration practice suggests there are at least two widely agreed substantive requirements for the granting of interim relief by arbitration tribunals: no pre-judgment of the case, and the threat of irreparable or substantial harm which cannot be compensated for by damages". 


\title{
CAPÍTULO VI \\ TUTELAS DE URGÊNCIA PRÉVIAS À INSTITUIC̃̃̃O DA ARBITRAGEM
}

\begin{abstract}
Como visto no "item 1", o artigo 19 da Lei de Arbitragem estabelece, expressamente, que a arbitragem somente é instituída quando o árbitro aceita a nomeação (se for único) ou quando o último dos árbitros indicados aceita a nomeação (quando há mais de um árbitro).
\end{abstract}

Assim, embora a arbitragem seja uma forma de resolução de controvérsias que tem como uma de suas principais vantagens a celeridade (juntamente com a especificidade e o sigilo $)^{291}$, certamente haverá casos em que as partes poderão necessitar de uma tutela de urgência antes mesmo de instituída a arbitragem, ou seja, durante o lapso de tempo entre a violação do direito e a aceitação do encargo pelo(s) árbitro(s).

Até mesmo porque a própria instauração da arbitragem poderá levar um tempo razoável em determinados casos, seja em virtude de uma cláusula compromissória vazia, seja por conta da recusa do árbitro em aceitar o encargo, seja em razão de eventual impugnação do árbitro indicado por qualquer das partes etc. ${ }^{292}$.

Nessa hipótese, a parte estará diante de uma situação complexa e sui generis, na qual a cláusula compromissória ou o compromisso arbitral ${ }^{293}$

\footnotetext{
${ }^{291}$ PAULO HOFFMAN confirma que "muitas são as vantagens para quem opta pela arbitragem, devendo-se destacar, principalmente, a maior celeridade das decisões, com especialidade do árbitro, a preservação (confidencialidade) da questão em discussão e de eventuais segredos pessoais ou profissionais que o cercam, além da menor litigiosidade entre as partes que já consentiram por um processo arbitral e tendem a se conformar com a decisão." (in Arbitragem: algumas dúvidas..., p. 307).

${ }^{292}$ Nessa esteira: “(...) a arbitragem, na forma pela qual se desenvolve, exige, em regra, um segmento de tempo razoável para que o juízo arbitral seja instituído. Entre a propositura da arbitragem e a sua instituição pode mediar um segmento cronológico maior ou menor, que não depende da iniciativa da parte demandante. Com efeito, a Lei n. 9.307/96 considera instituída a arbitragem quando os árbitros aceitam o encargo, o que pode demandar meses, considerando a possibilidade de um ou mais deles declinarem da indicação, dentre outros fatos potencialmente hábeis a enseja a procrastinação dessa instituição.” (ARMELIN, Donaldo. Tutela de urgência e arbitragem..., p. 363).

${ }^{293}$ Quanto ao compromisso arbitral, é válida a advertência de CARMONA, no sentido de que "a existência de um compromisso arbitral não significa que a arbitragem já esteja instituída, pois os árbitros - que não estão obrigados a firmar o compromisso - podem ainda não ter aceito o encargo e a arbitragem só está instituída quando os árbitros aceita a função (art. 19 da Lei)!” (Arbitragem e Processo..., p. 328, nota 57).
} 
derroga a jurisdição estatal (CPC, artigos 267, VII, e 301, IX), mas ainda não há um juízo arbitral regularmente instituído para apreciar a tutela de urgência que se fizer necessária.

Quando isso ocorrer (e houver a necessidade de uma tutela de urgência para evitar dano irreparável ou de difícil reparação, ou, até mesmo, para antecipar a entrega do bem da vida em jogo), a doutrina é unânime no sentido de que caberá ao Poder Judiciário apreciar a medida urgente que se fizer necessária ${ }^{294}$ (salvo se houver previsão de procedimento pré-arbitral, como detalhado abaixo).

Isso porque, enquanto não instituído o juízo arbitral, não pode haver um "vácuo de jurisdição", especialmente diante de situações em que haja risco de dano irreparável ou de difícil reparação para a esfera jurídica de uma das partes que pactuaram a cláusula compromissória ou o compromisso arbitral ${ }^{295}$.

A jurisprudência também já pacificou esse entendimento, citando-se, dentre outros, os seguintes acórdãos:

"DIREITO PROCESSUAL CIVIL. ARBITRAGEM. MEDIDA CAUTELAR. COMPETÊNCIA. JUÍZO ARBITRAL NÃO CONSTITUÍDO.

1. O Tribunal Arbitral é competente para processar e julgar pedido cautelar formulado pelas partes, limitando-se, porém, ao deferimento da tutela, estando impedido de dar cumprimento às medidas de natureza coercitiva, as

\footnotetext{
${ }^{294}$ Nesse sentido: CARMONA, Carlos Alberto. Arbitragem e Processo..., pp. 326/327; Idem, Das boas relações entre juízes..., p. 23; LEMES, Selma M. Ferreira. A inteligência do art. 19 da Lei de Arbitragem..., pp. 420 e 421; Idem. "Medidas cautelares prévias à instituição da arbitragem - Logos Engenharia S/A x Construtora Gomes Lonrenço Ltda. AgIn 1.0024.08.074006-1/001(1), TJMG, rel. Des. Márcia de Paoli Balbino". Revista de Arbitragem e Mediação, ano 6, vol. 20. São Paulo: RT, jan/mar de 2009, p. 231; MARTINS, Pedro A. Batista. Da ausência de poderes coercitivos..., p. 357; MUNIZ, Petrônio R. G. "A tutela antecipada no procedimento pré-arbitral". Arbitragem - Estudos em Homenagem ao Prof. Guido Fernando Silva Soares, In Memorian. LEMES, Selma M. Ferreira; CARMONA, Carlos Alberto; MARTINS, Pedro Batista (coord.). São Paulo: Atlas, 2007, p. 285; GARCEZ, José Maria Rossani. Medidas cautelares e de antecipação..., p. 214; FIGUEIRA JR, Joel Dias. Arbitragem, jurisdição..., p. 224; COSTA, Nilton César Antunes da. Poderes do Árbitro..., p. 107; ARMELIN, Donaldo. Tutela de urgência e arbitragem..., p. 368; GAJARDONI, Fernando da Fonseca. A arbitragem nos tribunais..., p. 59; VERÇOSA, Haroldo Malheiros Duclerc. O Judiciário e a valorização...; AMARAL, Paulo Osternack. A concessão de medidas urgentes..., pp. 31/32; e HOFFMAN, Paulo. Arbitragem: algumas dúvidas..., p. 310. Na doutrina estrangeira, PIERO BERNARDINI ensina que "a primeira limitação da arbitragem se origina do fato de que quando um litígio surge ainda não há um tribunal arbitral para o qual a parte possa fazer um pedido para obter uma medida conservativa e provisória, a qual freqüentemente se faz necessária precisamente no momento em que a decisão de se iniciar o litígio é tomada. Recorrer à justiça estatal nesse caso é inevitável." (The Powers of the Arbitrator..., p. 21, tradução livre). Na mesma esteira: LEW, Julian M.; MISTELIS, Loukas A.; KRÖLL, Stefan Michael. Comparative International..., p. 615.

${ }^{295}$ Cf. ARMELIN, Donaldo. Tutela de urgência e arbitragem..., pp. 364 e 367.
} 
quais, havendo resistência da parte em acolher a determinação do(s) árbitro(s), deverão ser executadas pelo Poder Judiciário, a quem se reserva o poder de imperium.

2. Na pendência da constituição do Tribunal Arbitral, admite-se que a parte se socorra do Poder Judiciário, por intermédio de medida de natureza cautelar, para assegurar o resultado útil da arbitragem.

3. Superadas as circunstâncias temporárias que justificavam a intervenção contingencial do Poder Judiciário e considerando que a celebração do compromisso arbitral implica, como regra, a derrogação da jurisdição estatal, os autos devem ser prontamente encaminhados ao juízo arbitral, para que este assuma o processamento da ação e, se for o caso, reaprecie a tutela conferida, mantendo, alterando ou revogando a respectiva decisão.

4. Em situações nas quais o juízo arbitral esteja momentaneamente impedido de se manifestar, desatende-se provisoriamente as regras de competência, submetendo-se o pedido de tutela cautelar ao juízo estatal; mas essa competência é precária e não se prorroga, subsistindo apenas para a análise do pedido liminar.

5. Recurso especial provido." (STJ, 3. a Turma, REsp n. ${ }^{\circ}$ 1.297.974-RJ, Rel. Min. Nancy Andrighi, j. 12/06/2012, v.u.).

"Agravo de Instrumento - Medida cautelar - Liminar deferida para suspensão dos efeitos de cláusula do acordo de acionistas. O r. despacho hostilizado não viola a Lei 9.307/96, porquanto a agravada não tinha outra alternativa senão socorrer-se do Poder Judiciário, uma vez que a arbitragem ainda não havia sido instituída, o que, como é notório, depende de inúmeras providências e demanda tempo - $\mathrm{O}$ próprio regulamento da Corte Internacional de Arbitragem - CCI, eleito pelas partes, permite o acesso ao Judiciário em determinadas circunstâncias, inclusive medidas cautelares ou provisórias - Recurso desprovido." (TJ/SP, 9. ${ }^{a}$ Câm. Dir. Privado, A.I. n. ${ }^{\circ}$ 384.896.4/4-00, Rel. Des. Sérgio Gomes, j. 03/05/2005, v.u. $)^{296}$.

\footnotetext{
${ }^{296}$ Nesse sentido: TJ/SP, 13. ${ }^{\text {a }}$ Câm. Dir. Privado, A.I. n. ${ }^{\circ}$ 990.09.305397-7, Rel. Des. Heraldo de Oliveira, j. 28/04/2010, v.u.; TJ/SP, 25. a Câm. Dir. Privado, Apelação n. ${ }^{\circ}$ 9184314-84.2007.8.26.0000, Rel. Des. Vanderci Álvares, j. 23/11/2011; TJ/SP, 4. ${ }^{a}$ Câm. Dir. Privado, MC n. ${ }^{\circ}$ 9036737-05.2007.8.26.0000 n. $^{\circ}$ antigo 494.408-4/6, Rel. Des. Enio Zuliani, j. 28/06/2007, v.u.; TJ/SP, 1. ${ }^{a}$ Câm. Dir. Privado, A.I. n. ${ }^{\circ}$ 0027677-40.2002.8.26.0000 - n. ${ }^{\circ}$ antigo 240.062-4/8-00, Rel. Des. Elliot Akel, j. 27/08/2002, v.u.; TJ/SP, 30. ${ }^{a}$ Câm. Dir. Privado, A.I. n. ${ }^{\circ}$ 0112844-10.2011.8.26.0000, Rel. designado Des. Lino Machado, j. 27/07/2011, maioria; TJ/SP, 9. ${ }^{a}$ Câm. Dir. Privado, A.I. n. ${ }^{\circ}$ 0009379-82.2011.8.26.0000, Rel. Des. José Luiz Gavião de Almeida, j. 09/08/2011, maioria; TJ/SP, 17. ${ }^{a}$ Câm. Dir. Privado, Apelação n. ${ }^{\circ}$ 017344507.2010.8.26.0100, Rel. Des. Erson T. Oliveira, j. 27/07/2011, v.u.; TJ/SP, 4. ${ }^{a}$ Câm. Dir. Privado, Apelação n. ${ }^{\circ}$ 524.752.4/7-00, Rel. Des. Francisco Loureiro, j. 30/07/2009, v.u.; TJ/SP, 1. ${ }^{a}$ Câm. Dir. Privado, A.I. n. ${ }^{\circ}$ 0031883-82.2011.8.26.0000, Rel. Des. De Santi Ribeiro, j. 02/08/2011, v.u.; TJ/SP, 1. ${ }^{a}$ Câm. Dir. Privado, A.I. n. ${ }^{\circ}$ 0076752-33.2011.8.26.0000, Rel. Des. De Santi Ribeiro, j. 02/08/2011, v.u.; TJ/SP, 27. ${ }^{a}$ Câm. Dir. Privado, A.I. n. ${ }^{\circ}$ 990.09.328659-9, Rel. Des. Emanuel Oliveira, j. 02/03/2010, v.u. (revogando a liminar, pois ausentes os requisitos legais, mas admitindo a tutela de urgência perante o Poder Judiciário antes de instaurada a arbitragem); TJ/SP, 25. ${ }^{a}$ Câm. Dir. Privado, A.I. n. ${ }^{\circ}$ 992.09.083161-5, Rel. Des. Amorim Cantuária, j. 17/11/2009, v.u.; TJ/SP, 31. ${ }^{a}$ Câm. Dir. Privado, A.I. n. ${ }^{\circ}$ 1.081.240-0/3, Rel. Des. Armando Toledo; TJ/SP, 5. ${ }^{a}$ Câm. Dir. Privado, A.I. n. ${ }^{\circ}$ 614.006-4/4-00, Rel. designado Des. Roberto Mac Cracken, j. 18/02/2009, maioria (extinguindo a ação cautelar, em virtude da celebração do compromisso arbitral, mas admitindo a tutela de urgência perante o Judiciário antes de instaurada a arbitragem - bem fundamentado); TJ/SP, 5. ${ }^{a}$ Câm. Dir. Privado, Apelação cível com revisão n. ${ }^{\circ}$ 0123750-69.2005.8.26.0000 - n. ${ }^{\circ}$ antigo 431.916-4/3-00, Rel. Des. Silvério Ribeiro, j. 11/06/2008, v.u.; TJ/MG, 3. ${ }^{a}$ Câmara Cível, A.I. n. ${ }^{\circ}$ 0273072-3, Rel. Des. Edilson Fernandes, j. 24/02/1999, v.u.; TJ/RJ, 2. ${ }^{a}$ Câm. Cível, Ap. n. ${ }^{\circ}$ 0120862-27.2002.8.19.0001
} 
Dessa maneira, não obstante as partes tenham optado pela arbitragem para a solução de eventual lide (por meio de cláusula compromissória ou de compromisso arbitral), as tutelas de urgência poderão ser apreciadas pelo Poder Judiciário enquanto não instituída a arbitragem ${ }^{297}$.

Mencione-se, por todos, o magistério de JOSÉ EDUARDO CARreira Alvim, no sentido de que "a doutrina tem admitido o recurso à justiça estatal quando ainda não instituída a arbitragem, dado o caráter urgente da medida, e porque para a instituição do juízo arbitral 'são necessários vários passos, caminhos, assinaturas de documentos', não podendo a parte interessada esperar" ${ }^{298}$.

A doutrina nacional fundamenta essa possibilidade no art. 5. XXXV, da Constituição ${ }^{299}$, o qual prevê o princípio da inafastabilidade da jurisdição, bem como no fato de que mesmo o juízo incompetente pode apreciar tutelas de urgência ${ }^{300}$.

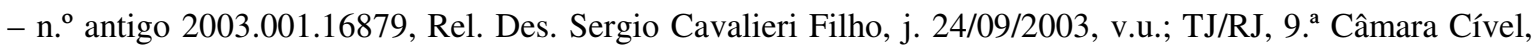
Apelação n. ${ }^{\circ}$ 0025600-50.8.19.0001 - n. ${ }^{\circ}$ antigo 2003.001.01004, Rel. Des. Ruyz Athayde Alcântara de Carvalho, j. 15/04/2003, v.u.; TJ/RJ, Ap. cível n. ${ }^{\circ}$ 2003.001.16879; TJ/MG, AI n. ${ }^{\circ}$ 2.0000.00.410533-5/000; STJ, 3. ${ }^{a}$ Turma, AgRg na MC n. ${ }^{\circ}$ 19.226/MS, Rel. para acórdão Min. Nancy Andrighi, j. 21/06/2012.

${ }^{297} \mathrm{Na}$ França, o Código de Processo Civil francês, já com as alterações trazidas pelo Decreto n. $.^{\circ} .011-48$, de 13 de janeiro de 2011, prevê, expressamente, em seu artigo 1449, a possibilidade de a parte pleitear uma tutela de urgência perante o Poder Judiciário enquanto não instituída a arbitragem: "Arte. 1449. L'existence d'une convention d'arbitrage ne fait pas obstacle, tant que le tribunal arbitral n'est pas constitué, à ce qu'une partie saisisse une juridiction de l'Etat aux fins d'obtenir une mesure d'instruction ou une mesure provisoire ou conservatoire. Sous réserve des dispositions régissant les saisies conservatoires et les sûretés judiciaires, la demande est portée devant le président du tribunal de grande instance ou de commerce, qui statue sur les mesures d'instruction dans les conditions prévues à l'article 145 et, en cas d'urgence, sur les mesures provisoires ou conservatoires sollicitées par les parties à la convention d'arbitrage." (trad. livre: "Art. 1449. A existência de uma convenção de arbitragem não impede, enquanto o tribunal arbitral não estiver constituído, que uma das partes pleiteie uma jurisdição do Estado para o fim de obter uma medida de instrução ou uma medida provisória ou conservativa. Sem prejuízo das disposições que regem as apreensões conservativas e as garantias judiciais, a demanda deve ser ajuizada perante o presidente do tribunal de grande instância ou do comércio, que deverá decidir sobre as medidas de instrução de acordo com as regras previstas no artigo 145 e, no caso de urgência, sobre as medidas provisórias ou conservativas solicitadas pelas partes da convenção de arbitragem.”). Quanto ao tema, JOSÉ MARIA ROSSANI GARCEZ, citando trabalho de GÉRARD PLUYETTE, anota que "a maioria dos casos verificados na França quanto à concessão de medidas cautelares em arbitragens, dá-se na fase pré-arbitral e poucas vezes durante o procedimento arbitral. E a maioria dessas medidas tem o objetivo de preservar uma situação ou conservar ativos, ou prover garantias e preparar para a execução da sentença arbitral. Os precedentes judiciais nesses casos requerem, necessariamente, a existência dos pressupostos de urgência ou a situação de risco." (Medidas cautelares e de antecipação..., p. 227).

${ }^{298}$ CARREIRA ALVIM, José Eduardo. Direito Arbitral, 2. a edição. Rio de Janeiro: Forense, 2004, p. 335.

${ }^{299}$ ARMELIN, Donaldo. Tutela de urgência e arbitragem..., p. 368; BENETI, Sidnei. Arbitragem e tutelas de urgência..., p. 106; e AMARAL, Paulo Osternack. A concessão de medidas urgentes..., p. 32.

300 CARMONA, por exemplo, suscita o princípio do direito luso-brasileiro segundo o qual quando est periculum in mora incompetentia non attenditur, concluindo que "as regras de competência podem ser desprezadas se houver algum obstáculo que impeça a parte necessitada de tutela emergencial de ter acesso ao juízo originariamente competente, o que aconteceria na hipótese de a parte interessada não poder requerer a medida cautelar ao árbitro (como deveria) pelo simples fato de não ter sido ainda instituída a arbitragem" 
Com relação ao assunto, é válida a menção da lição de Clávio de Melo Valença Filho, para o qual o problema da concessão de tutelas de urgência antes da instituição da arbitragem não tem relação com a idéia de "competência". Segundo ele, "não poucos operadores insistem em localizar a questão no plano da competência, quando, de fato, o problema é pré-processual, de jurisdição", sustentando haver "subtração" e "restituição" da jurisdição ao(s) árbitro(s) ${ }^{301}$.

De qualquer forma, deparando-se a parte com a necessidade de uma tutela de urgência antes de ser instaurada a arbitragem, ela poderá ajuizar ação pleiteando tal medida perante o órgão do Poder Judiciário que seria originariamente competente para julgar a causa.

Por se tratar de uma ação perante o Poder Judiciário, ela será disciplinada pelo Código de Processo Civil, como se verá detalhadamente a seguir, sendo perfeitamente possível, e até mesmo recomendável, a exigência da prestação de caução pela parte para que a tutela de urgência pré-arbitral seja deferida e efetivada pelo juízo estatal $^{302}$.

E caso a solução do litígio por meio da arbitragem esteja prevista em uma cláusula compromissória vazia e se faça necessário o ajuizamento da ação judicial regulada pelo artigo $7 .^{\circ}$ da Lei de Arbitragem brasileira ${ }^{303}$, ante a recusa da parte contrária em firmar o compromisso arbitral, entendemos ser possível a cumulação do pedido de tutela de urgência ao processo de instauração forçada da arbitragem, notadamente se o periculum in mora não permitir a análise final de referida demanda sem o prejuízo do direito a ser tutelado liminarmente.

(CARMONA, Carlos Alberto. Arbitragem e Processo..., p. 327). Em igual sentido: HOFFMAN, Paulo. Arbitragem: algumas dúvidas..., p. 310.

${ }^{301}$ VALENÇA FILHO, Clávio de Melo. Tutela judicial de urgência e a lide..., p. 10.

${ }^{302}$ Nesse diapasão, DONALDO ARMELIN sustenta que a tutela cautelar pré-arbitral pode ser condicionada "à prestação de uma caução, que garanta ao requerido o ressarcimento de eventuais prejuízos decorrentes da efetivação da liminar. Trata-se da denominada contracautela, que estabelece uma situação de relativo equilíbrio entre as partes litigantes nessa tela pré-arbitral, assegurando o retorno ao status quo anterior à efetivação da liminar ou o ressarcimento dos prejuízos dela resultantes, se improcedente a cautelar que propiciou a liminar antecipatória." (Tutela de urgência e arbitragem..., p. 372).

303 “Art. $7^{\mathbf{0}}$ Existindo cláusula compromissória e havendo resistência quanto à instituição da arbitragem, poderá a parte interessada requerer a citação da outra parte para comparecer em juízo a fim de lavrar-se o compromisso, designando o juiz audiência especial para tal fim". 
Nessa hipótese, até mesmo em respeito ao princípio da economia processual, um mesmo juiz togado analisaria a tutela de urgência pré-arbitral e a cláusula compromissória vazia, fixando os termos do compromisso arbitral a ser firmado pelas partes e a ser seguido na futura arbitragem.

A reforçar o cabimento da tutela de urgência prévia à instituição da arbitragem perante o Poder Judiciário, cumpre-se salientar que algumas câmaras arbitrais trazem em seus regulamentos previsão específica autorizando o acesso ao Poder Judiciário em determinadas circunstâncias, inclusive, para a obtenção de medidas cautelares ou antecipatórias ${ }^{304}$.

Nessa mesma linha, JosÉ MARIA RosSANI GARCEZ relembra que o artigo 9. ${ }^{\circ}$ da Lei-Modelo da Comissão das Nações Unidas para o Desenvolvimento

\footnotetext{
${ }^{304}$ Exemplo disso é o artigo 28.2 do novo regulamento da Corte Internacional de Arbitragem da Câmara de Comércio Internacional - CCI: “Artigo 28.2. As partes poderão, antes da remessa dos autos ao tribunal arbitral e posteriormente, em circunstâncias apropriadas, requerer a qualquer autoridade judicial competente que ordene as medidas cautelares ou provisórias pertinentes. $\mathrm{O}$ requerimento feito por uma das partes a uma autoridade judicial para obter tais medidas, ou a execução de medidas similares ordenadas por um tribunal arbitral, não será considerado como infração ou renúncia à convenção de arbitragem e não comprometerá a competência do tribunal arbitral a este título. Quaisquer pedidos ou medidas adotadas pela autoridade judicial deverão ser notificados sem demora à Secretaria, devendo esta informar o tribunal arbitral." (www.iccwbo. org/WorkArea/DownloadAsset.aspx?id=2147489112. Acessado em 03/11/2012). Esclarece-se que o art. 28.2 do novo regulamento da CCI, em vigor a partir de 2012, repetiu a redação do art. 23.2 do antigo regulamento. Em igual sentido: o artigo 8.9 da SP Arbitral: "8.9 O tribunal arbitral poderá determinar medidas coercitivas ou cautelares e, quando necessário requererá auxílio à autoridade judicial competente para a execução da referida medida. Se ainda não instalado o tribunal arbitral, as partes poderão requerer tais medidas à autoridade judicial competente, devendo, neste caso, dar ciência imediata à Câmara. Referida providência não representará renúncia à arbitragem." (www.sparbitral.com/pdf/regulamento_da_arbitragem.pdf. Acesso em 15/06/11); o artigo 9.2 da CAMARB - Câmara de Arbitragem Empresarial: "9.2 Enquanto não instalado o Tribunal Arbitral, as partes poderão requerer medidas cautelares ou antecipatórias de mérito à autoridade judicial competente. Neste caso, a parte deverá, imediatamente, dar ciência do pedido à CAMARB. O Tribunal Arbitral, tão logo constituído, poderá reapreciar o pedido da parte, ratificando ou modificando, no todo ou em parte, a medida deferida pela autoridade judicial." (www.camarb.com.br/imagensdin/areasdinamicas/ arquivos/63_Regulamento_camarb.pdf. Acessado em 15/06/2011); o artigo 8.2 do regulamento em vigor a partir de 2012 do Centro de Arbitragem e Mediação da Câmara de Comércio Brasil-Canadá: "8.2. Havendo urgência, quando ainda não instituído o Tribunal Arbitral, as partes poderão requerer medidas cautelares ou coercitivas à autoridade judicial competente, se outra forma não houver sido expressamente estipulada por elas. Nesse caso, a parte deverá dar ciência ao CAM/CCBC das decisões.” (www.ccbc.org.br/default.asp? categoria=2\&subcategoria=Regulamento\%202012\#8. Acessado em 22/09/2012). Frise-se que o artigo 9.18 do regulamento que vigorou de 1998 a 2011 do Centro de Arbitragem e Mediação da Câmara de Comércio Brasil-Canadá também fazia menção ao possível auxílio do Poder Judiciário quanto às tutelas de urgência: “9.18. O Tribunal Arbitral adotará as medidas necessárias e convenientes para o correto desenvolvimento do procedimento e, quando oportuno, requererá à autoridade judiciária competente a adoção de medidas cautelares e coercitivas." (www.ccbc.org.br/arbitragem.asp?subcategoria=regulamento\%20portugues. Acesso em 11/06/2011). Por fim, o art. 5.1.3, in fine, da Câmara de Arbitragem do Mercado-CAM: "5.1.3 (...) Caso contrário, a parte deverá requerer diretamente ao Poder Judiciário as medidas conservatórias necessárias à prevenção de dano irreparável ou de difícil reparação, e tal proceder não será considerado renúncia à arbitragem." (www.camaradomercado.com.br/InstDownload/nova-regulamentacao.pdf. Acesso em 03/11/2012).
} 
do Comércio Internacional (UNCITRAL) sobre Arbitragem Comercial Internacional também estabelece "não ser incompatível com uma convenção de arbitragem uma parte requerer uma medida provisória de proteção (an interim measure of protection) a um tribunal, antes ou durante o processo arbitral, bem como a concessão dessa medida pelo tribunal", autorizando, dessa forma, a busca da tutela de urgência pré-arbitral perante o Poder Judiciário local ${ }^{305}$.

Esclarece-se, por oportuno, que o fato de uma parte se valer do Poder Judiciário para obter uma tutela de urgência, enquanto não instaurada a arbitragem, não significa, de forma alguma, renúncia à jurisdição arbitral ${ }^{306}$.

305 GARCEZ, José Maria Rossani. Medidas cautelares e de antecipação..., p. 214. O autor ainda afirma que "essa mesma estipulação faz parte de diversas legislações arbitrais e de regras de instituições sobre a arbitragem como fórmula de solução de conflitos", citando, por exemplo, o artigo 26 do Regulamento de Arbitragem da UNCITRAL (Idem, p. 215) e o artigo 23 das regras de arbitragem da Câmara de Comércio Internacional - CCI e da American Arbitration Association - AAA (Idem, pp. 217/218).

${ }^{306}$ Alguns centros de arbitragem trazem essa ressalva em seus regulamentos. Nessa esteira, o artigo 28.2 do regulamento da Corte Internacional de Arbitragem da Câmara de Comércio Internacional - CCI: "Artigo 28.2. (...) O requerimento feito por uma das partes a uma autoridade judicial para obter tais medidas, ou a execução de medidas similares ordenadas por um tribunal arbitral, não será considerado como infração ou renúncia à convenção de arbitragem e não comprometerá a competência do Tribunal Arbitral a este título. (...)" (www.iccwbo.org/WorkArea/DownloadAsset.aspx?id=2147489112. Acesso em 03/11/2012); o art. 8.9 da SP Arbitral: "8.9 (...) Se ainda não instalado o tribunal arbitral, as partes poderão requerer tais medidas à autoridade judicial competente, devendo, neste caso, dar ciência imediata à Câmara. Referida providência não representará renúncia à arbitragem." (www.sparbitral.com/pdf/regulamento_da_arbitragem.pdf. Acesso em 15/06/2011); o art. 8.2.2 do regulamento em vigor a partir de 2012 do Centro de Arbitragem e Mediação da Câmara de Comércio Brasil-Canadá: "8.2.2. O requerimento feito por uma das partes a uma autoridade judicial para obter tais medidas, ou a execução de medidas similares ordenadas por um Tribunal Arbitral, não serão considerados como infração ou renúncia à convenção de arbitragem e não comprometerão a competência do Tribunal Arbitral." (www.ccbc.org.br/default.asp?categoria=2\&subcategoria=Regulamento \%202012\#8. Acessado em 22/09/2012); e o art. 5.1.3 do regulamento da Câmara de Arbitragem do MercadoCAM: "5.1.3 O Árbitro de Apoio somente poderá ser acionado se a convenção de arbitragem contiver previsão expressa quanto à sua atuação. Caso contrário, a parte deverá requerer diretamente ao Poder Judiciário as medidas conservatórias necessárias à prevenção de dano irreparável ou de difícil reparação, e tal proceder não será considerado renúncia à arbitragem." (www.camaradomercado.com.br/InstDownload/novaregulamentacao.pdf. Acessado em 03/11/2012). Na Bélgica, o artigo 1679, “2”, do Código Judiciário belga também prevê a competência do Poder Judiciário para apreciação de medidas urgentes, sem que isso implique renúncia à arbitragem: “Art. 1679. (...) 2. Une demande en justice tendant à des mesures conservatoires ou provisoires n'est pas incompatible avec la convention d'arbitrage et n'implique pas renonciation à celleci." (tradução livre: “Art. 1679. (...) 2. Uma ação na justiça visando a medidas conservativas ou provisórias não é incompatível com a convenção de arbitragem e não implica à renúncia da mesma.”). JOSÉ MARIA ROSSANI GARCEZ também cita o artigo 26 (3) do Regulamento de Arbitragem da UNCITRAL, o qual dispõe que "3. A request for interim measures addressed by any party to a judicial authority shall not be deemed incompatible with the agreement to arbitrate, or as a waiver of that agreement." (tradução do autor: "uma solicitação de medida provisória dirigida por uma parte a uma autoridade judicial não será incompatível nem representará renúncia da parte em relação à convenção de arbitragem.") (Medidas cautelares e de antecipação..., pp. 215/216). Frise-se que, após a revisão do regulamento em 2010, referida regra encontra-se reproduzida no artigo 26 (9) atualmente. Por fim, JULIAN M. LEW, LOUKAS A. MisTELIS e STEFAN MiCHAEL KRÖLL confirmam que "an application to state courts for interim relief should not be considered a waiver of the right to arbitrate." (tradução livre: "o pedido para uma corte estatal de uma liminar não pode ser considerado uma renúncia ao direito de arbitrar.") (Comparative International..., p. 620). 
Nesse caso, a convenção de arbitragem (seja a cláusula compromissória, seja o compromisso arbitral) permanecerá válida, podendo o árbitro, inclusive, quando instaurada a arbitragem, reapreciar o pedido de concessão de tutela de urgência e revisar a decisão proferida pelo juiz estatal, como se verá no “item 19” abaixo.

Em sentido contrário, cite-se acórdão do Tribunal de Justiça do Estado de São Paulo que, ao analisar agravo de instrumento interposto em ação cautelar de sustação de protesto, pontificou que: "cumpre ressaltar, ademais, que a matéria concernente à convenção de arbitragem não é de ordem pública e que no caso em análise pode-se dizer que, ao propor a presente medida cautelar, a agravada abriu mão do direito à arbitragem, aceitando que o Poder Judiciário julgasse a demanda”307.

Não podemos concordar com essa assertiva, uma vez que, como visto acima, o acesso ao Poder Judiciário muitas vezes é a única opção da parte para obter uma tutela de urgência enquanto não instituída a arbitragem.

A própria sustação de um protesto (objeto do acórdão citado), que na maioria das vezes tem de ser pleiteada pela parte em no máximo quarenta e oito horas (prazo normalmente informado nas notificações enviadas pelos cartórios de protesto), é um exemplo de uma tutela de urgência que dificilmente será discutida diretamente em sede de arbitragem ${ }^{308}$ (a não ser de forma incidental, em um processo arbitral já em curso), tendo em vista ser pouco provável a instituição de uma arbitragem em menos de quarenta e oito horas (uma vez que a instauração da arbitragem depende de procedimentos burocráticos, especialmente a indicação e a aceitação do encargo pelo[s] árbitro[s]).

Assim, a utilização do Poder Judiciário pela parte para obter uma tutela de urgência antes da instituição da arbitragem não pode ser considerada como renúncia à jurisdição arbitral.

${ }^{307} \mathrm{TJ} / \mathrm{SP}$, 37. ${ }^{\text {a }}$ Câmara de Direito Privado, Agravo de Instrumento n. ${ }^{\circ}$ 0284092-78.2010.8.26.0000, Relator Desembargador Luis Fernando Lodi, julgado em 26/05/2011, v.u.

${ }^{308}$ De qualquer forma, cumpre-se salientar, nos termos da lição de DONALDO ARMELIN, que "cautelares, que impõem a sustação de protesto ou a proibição de registro de ata de assembléia de sociedade por ações, não carecem de força pública e podem ser concedidas pelos árbitros independentemente de qualquer atuação da jurisdição estatal." (Tutela de urgência e arbitragem..., p. 365). 
Somente se a parte ajuizar a ação principal perante o Poder Judiciário e a outra parte, ao ser convocada para se defender, não opuser a exceção da convenção de arbitragem, é que poderá ser reconhecida a "concordância tácita com a revogação do compromisso",309.

Ressalte-se, ainda, que a tutela de urgência pré-arbitral somente poderá ser pleiteada perante o Poder Judiciário, como o próprio nome sugere, antes da instituição da arbitragem.

Caso a arbitragem já esteja devidamente instaurada, a parte não poderá se valer do Poder Judiciário, devendo dirigir o pedido de tutela de urgência diretamente ao(s) árbitro(s), pois, nesse caso, toda e qualquer medida urgente incidental somente poderá ser apreciada pela jurisdição privada arbitral ${ }^{310}$.

De fato, tendo as partes optado pela arbitragem, renunciando à resolução do conflito pelo Poder Judiciário, após a sua instauração, toda e qualquer matéria relativa à controvérsia deverá ser decidida pelo(s) árbitro(s), tanto o mérito, como as tutelas de urgência, motivo pelo qual "a parte interessada não poderá requerer a medida de urgência diretamente ao Poder Judiciário", já que não se admite "indevidas incursões de um juízo na jurisdição do outro"311.

${ }^{309}$ Cf. DIDIER JR., Fredie. Curso de Direito Processual Civil, 7. a edição. Salvador: Jus Podivum, 2007, p. 502. Nesse mesmo sentido, alertando que o juízo estatal não pode conhecer de ofício a convenção de arbitragem (nos termos do artigo 301, § 4. ${ }^{\circ}$, do CPC: "Art. 301. Compete-lhe, porém, antes de discutir o mérito, alegar: (...) IX - convenção de arbitragem; (...) $§ 4^{\circ}$ Com exceção do compromisso arbitral, o juiz conhecerá de ofício da matéria enumerada neste artigo."), DONALDO ARMELIN diz que se impõe "à parte sua alegação tempestiva, sob pena de se configurar, na sua omissão, verdadeira renúncia à arbitragem pactuada." (Tutela de urgência e arbitragem..., p. 361).

${ }^{310}$ Frise-se que a legislação brasileira prevê a jurisdição exclusiva do juízo arbitral para apreciação de tutelas de urgência incidentais à arbitragem (arts. $1 .^{\circ}, 3 .^{\circ}, 4 .^{\circ}, 9 .^{\circ}$ da Lei n. ${ }^{\circ} 9.307 / 96$ e arts. 86, 267, VII, 301, IX, do CPC). Nesse sentido, a lição de PEDRo A. BATISTA MARTINS: “(...) quando os compromitentes firmam o compromisso, derrogando a jurisdição estatal, conferem ao árbitro a competência e o poder para resolver todas as questões atinentes à espécie, assumindo este o dever de zelar para que as partes não sejam prejudicadas nos seus direitos, o que inclui, obviamente, a competência para determinar medidas cautelares e coercitivas" (Da ausência de poderes coercitivos..., p. 358). O STJ também já firmou o entendimento de que a existência de convenção de arbitragem é causa de extinção do processo sem o julgamento do mérito, nos termos do art. 267, VII, do CPC: REsp 712.566/RJ, 3. ${ }^{a}$ Turma, Rel. Min. Nancy Andrighi, DJ de 05/09/2005; REsp 606.345/RS, 2. ${ }^{a}$ Turma, Rel. Min. João Otávio de Noronha, DJ de 08/06/2007; e REsp 933.371/RJ, 1. ${ }^{a}$ Turma, Rel. Min. Arnaldo Esteves Lima, DJe de 20/10/2010. Em outros países, no entanto, há competência concorrente do juízo estatal para a apreciação das tutelas de urgência, tais como na Alemanha ( $\$ 1033$ da ZPO) e em Portugal (artigo 29. ., "1", da Lei n.. 63/2011).

${ }^{311}$ Cf. FICHTNER, José Antonio; MONTEIRO, André Luís. Medidas urgentes no processo..., p. 54. Nesse mesmo diapasão, HUMBERTO THEODORO JÚNIOR salienta que "não é dado à parte dirigir-se diretamente ao 
A única exceção a essa regra é a hipótese de uma tutela de urgência que não poderia aguardar sequer um dia e não se faz possível a reunião do(s) árbitro(s) em tempo hábil, por motivos pessoais ou profissionais.

Por exemplo, as partes iniciam um processo arbitral para discutir o custeio de uma intervenção cirúrgica e, depois de instaurada a arbitragem com um único árbitro, este se encontra inacessível em viagem ao exterior por um período razoavelmente longo, e referida intervenção cirúrgica passa a ser de extrema urgência, em virtude de alguma mudança no estado de saúde da parte.

Nesse caso, diante da impossibilidade de o árbitro analisar a tutela de urgência, a parte está autorizada a se valer do Poder Judiciário para a sua apreciação, até mesmo para se evitar o perecimento do direito da parte e para que não sejam violados princípios constitucionais básicos de acesso à justiça e de apreciação de lesão ou ameaça a direito ${ }^{312}$.

Esse seria o único caso em que se admitiria a tutela urgente de maneira incidental perante o Poder Judiciário, não se tratando, no entanto, de uma tutela de urgência pré-arbitral, mas, sim, de uma medida urgente pós-arbitral, dirigida ao Poder Judiciário em razão de circunstâncias fáticas raras, mas que podem ocorrer, cabendo a reapreciação da medida pelo(s) árbitro(s) a posteriori.

juiz togado para requerer-lhe medida preventiva a ser aplicada sobre os direitos e bens disputados no procedimento extrajudicial" (Curso de Direito Processual Civil. Vol. III, 34. ${ }^{a}$ ed. RJ: Forense, 2005, p. 326).

312 Nesse mesmo sentido, PEDRO A. BATISTA MARTins diz que "duas exceções podem ocorrer: a primeira, quando a medida se faça necessária antes da instituição da arbitragem, e, a segunda, após constituído o juízo arbitral, o remédio legal seja imperativo e impossível a reunião dos árbitros, em tempo hábil, de modo a garantir a eficácia da medida requerida. Contudo, em ambos os casos, é forçoso comprovar a urgência do provimento legal." (MARTINS, Pedro A. Batista. "Apontamentos sobre a arbitragem no Brasil" in Revista do Advogado, n. ${ }^{\circ}$ 51. São Paulo: AASP, out/1997, p. 45). Igualmente, CARMONA afirma que "existe ainda outra circunstância que autoriza o acesso à Justiça Estatal, mesmo após a instituição da arbitragem, para a obtenção da tutela de urgência. Imagine-se uma situação de emergência ocorrida durante feriado local, tornando impossível o acesso aos árbitros: diante da impossibilidade de a parte dirigir-se aos árbitros, volto a invocar o velho princípio do direito luso-brasileiro (quando est periculum in mora incompetentia non attenditur) para permitir o acesso aos órgãos jurisdicionais estatais;" (Arbitragem e Processo..., p. 328, negrito no original). CLÁVIO DE MELO VALENÇA FILHO também aduz que "é possível que o árbitro tenha sido suspensa a instância arbitral, que esteja doente, ausente ou viajando, ou simplesmente que a eficácia da medida requeira jurisdictio sobre terceiros não vinculados ou imperium merum. Ora, a urgência da situação em perigo pode não comportar a delonga de uma tutela de urgência híbrida, distribuída em duas etapas: uma de cognitio, perante o árbitro, e outra de executio, perante o juiz estatal. Deve, em casos tais, intervir o juízo estatal de urgência." (Tutela judicial de urgência e a lide..., p. 17). 
E uma vez verificado o cabimento das tutelas de urgência pré-arbitrais perante o Poder Judiciário, enquanto não instituída a arbitragem, não resta dúvida de que é possível se pleitear tanto um provimento cautelar, como uma tutela antecipada, como se verá a seguir.

\section{CAUTELAR PRÉVIA À INSTAURAÇÃo dA ARBITRAGEM}

A ação cautelar pré-arbitral perante o Poder Judiciário deverá sempre anteceder à instauração da arbitragem, devendo, por conseguinte, ser de natureza preparatória $^{313}$.

Isso porque, como visto acima, ela somente se justifica na hipótese de a arbitragem ainda não estar instituída, ocasião em que não poderá haver, na expressão de DONALDO ARMELIN, um "vácuo de jurisdição"314, devendo ser assegurado à parte o direito de evitar o perecimento do bem da vida a ser tutelado e de garantir o resultado prático da futura arbitragem a ser instaurada.

\subsection{CONEXÃO, PREVENĊ̃̃O E COMPETÊNCIA}

Há, no entanto, uma exceção a essa regra. A ação cautelar pré-arbitral poderá ter natureza incidental se já estiver em curso a ação judicial prevista no artigo 7. $^{\circ}$ da Lei de Arbitragem brasileira, visando à lavratura do compromisso arbitral pela parte renitente perante o Poder Judiciário.

Nessa hipótese, surgindo a necessidade da tutela cautelar durante o trâmite da ação judicial prevista no artigo $7 .^{\circ}$ da Lei n. ${ }^{\circ} 9.307 / 96$, a ação cautelar deverá ser distribuída incidentalmente àquela, por conexão.

A conexão nesse caso é evidente, pois há nítida prejudicialidade do resultado da ação para a lavratura do compromisso arbitral relativamente à ação

\footnotetext{
${ }^{313}$ Nesse sentido: "Assim, desde logo impende ressaltar que esse tipo de tutela cautelar exige, como medida necessariamente precedente da instituição da arbitragem, ser decorrente da propositura de uma ação cautelar antecedente, de natureza preparatória. Deveras, para ser pré-arbitral a pretensão à tutela cautelar deve anteceder tal instituição.” (ARMELIN, Donaldo. Tutela de urgência e arbitragem..., p. 371).

314 Tutela de urgência e arbitragem..., p. 364.
} 
cautelar a ser ajuizada pela parte interessada, tendo em vista que, na hipótese de a ação prevista no art. $7 .^{\circ}$ da Lei de Arbitragem ser julgada procedente, com a lavratura judicial do compromisso arbitral, o árbitro passará a ser o único responsável pelo julgamento da ação cautelar ajuizada perante o juízo estatal ${ }^{315}$.

Assim, tendo ambas as ações (a para a lavratura do compromisso arbitral e a cautelar) a mesma causa de pedir remota (qual seja: o litígio que deverá ser solucionado, ou não, em arbitragem), e diante da evidente prejudicialidade do resultado da primeira ação com relação à segunda, elas devem ser reunidas, nos termos do artigo 103 do Código de Processo Civil ${ }^{316}$.

E o juízo estatal que já tiver despachado e estiver conduzindo a ação prevista no artigo $7 .^{\circ}$ da Lei de Arbitragem estará prevento para a apreciação da ação cautelar pré-arbitral (CPC, artigo 106) $)^{317}$, o que faz com que, necessariamente, esta seja distribuída incidentalmente àquela.

Igualmente, o ajuizamento de uma ação cautelar pré-arbitral perante o juízo estatal, visando à obtenção de uma tutela de urgência antes da instituição da

\footnotetext{
315 Nessa esteira: "Em se tratando da ação prevista no art. $7^{\circ}$ da Lei n. 9.307/96, direcionada à lavratura de compromisso, quando a tanto insuficiente a convenção de arbitragem, a sua pendência propiciará à parte interessada em evitar o risco de dano irreparável ou de difícil reparação a possibilidade de ajuizar ação cautelar incidental àquela já pendente. Deveras, não se justifica a propositura de ação cautelar antecedente, quando já se questiona a respeito da celebração de compromisso, em ação de natureza constitutiva necessariamente ajuizada em face do réu renitente na sua celebração. A prejudicialidade do resultado dessa ação relativamente à cautelar é suficiente para a atrair para esse processo, no qual ela assumirá a natureza de cautelar incidental.”(DONALDO ARMELIN, Tutela de urgência e arbitragem..., p. 371).

316 “Art. 103. Reputam-se conexas duas ou mais ações, quando lhes for comum o objeto ou a causa de pedir". Quanto ao tema, PATRÍCIA MiRANDA PIZZOL leciona que "há conexão quando "há um nexo, um elo (...) um vínculo que entrelaça duas ou mais ações' (Moacyr Amaral Santos, Primeiras linhas de direito processual civil, v.1, p. 257), ou seja, uma ação se liga a outra de tal modo que a decisão de uma causa possa influir na da outra, produzindo julgamentos que se conciliem. (...) Registre-se, ainda, que um dos objetivos da reunião dos processos, na hipótese de conexão, é exatamente evitar julgados que sejam logicamente incompatíveis (razão de ordem pública), e outro é a possibilidade de economia processual (economia de tempo e dinheiro)", ressaltando, ainda, que "há conexão quando duas ou mais ações são análogas, ou seja, têm em comum um de seus elementos (objeto, causa de pedir, partes)." (PIZZOL, Patrícia Miranda. Código de Processo Civil Interpretado. MARCATO, Antônio Carlos (coord.). São Paulo: Atlas, 2004, p. 294).

317 "Art. 106. Correndo em separado ações conexas perante juízes que têm a mesma competência territorial, considera-se prevento aquele que despachou em primeiro lugar". Com relação à prevenção, "torna-se prevento o juízo (vara) ou o próprio juiz (havendo dois ou mais juízes com a mesma competência numa mesma vara, como ocorre, por exemplo, nas varas cíveis do foro central) segundo um dos critérios indicados (...) citação - art. 219 do CPC - ou despacho inicial - art. 106 do CPC." (PIZZOL, Patrícia Miranda. Código de Processo Civil Interpretado..., p. 305).
} 
arbitragem, tornará referido juízo prevento para uma eventual futura ação de anulação da decisão $\operatorname{arbitral}^{318}$.

Não havendo conexão ou prevenção, a ação cautelar prévia à arbitragem será livremente distribuída perante o juízo estatal que seria originariamente competente para julgar o feito.

E tratando-se de uma ação cautelar perante o Poder Judiciário, ainda que preparatória à futura arbitragem, aplicam-se a tal feito as regras de fixação de competência previstas no Código de Processo Civil, o que significa reconhecer a possibilidade de questionamento da competência absoluta ou relativa do juízo estatal ao qual o processo foi distribuído para processar e decidir a tutela cautelar, enquanto não instaurada a arbitragem ${ }^{319}$.

\subsection{REQUISITOS DA PETIÇÃO INICIAL}

Nessa mesma linha, como eventual medida cautelar prévia à instauração da arbitragem deverá ser pleiteada em ação perante a justiça comum, aplicamse a aludido processo os requisitos da petição inicial previstos no artigo 801 do CPC $^{320}$.

Isto é, a parte deverá indicar: (i) a autoridade judiciária a que for dirigida a inicial (CPC, art. 801, inc. I), exprimindo o requisito da competência; (ii) a qualificação das partes (CPC, art. 801, inc. II), para identificar os sujeitos do processo cautelar; (iii) a lide e respectivo fundamento da ação principal (CPC, art. 801, inc. III), para que o magistrado possa aferir a instrumentalidade da medida cautelar; (iv) a exposição

\footnotetext{
${ }^{318}$ Nesse diapasão, FERNANDO DA FONSECA GAJARDONI aduz que "a parte deve requerer diretamente ao Juiz competente para o conhecimento da causa (o da sede do juízo arbitral) a medida (agora sim com prevenção para a futura ação de nulidade do art. 32/33, da LA)." (in A arbitragem nos tribunais..., p. 59).

${ }^{319}$ Cf. ARMELIN, Donaldo. Tutela de urgência e arbitragem..., p. 371, o qual reconhece "a possibilidade de questionamento, na tela judicial, da competência absoluta ou relativa para processar e decidir o feito cautelar, enquanto não se institui a arbitragem." (Idem, p. 371). Tratando da ação prevista no art. 7. ${ }^{\circ}$ da Lei de Arbitragem brasileira, mas em lição que também se aplica perfeitamente à ação cautelar pré-arbitral perante o juízo estatal, CARMONA também sustenta que, "de fato, nada impedirá que o réu argúa, como é óbvio, a incompetência absoluta do juízo." (Arbitragem e processo..., p. 159).

${ }^{320}$ Quanto ao tema, DONALDO ARMELIN afirma que, "como cautelar antecedente, a pré-arbitral deve ser ajuizada mediante uma petição que reflita o adimplemento dos requisitos do art. 801 do CPC, em especial a lide arbitral e seu fundamento, bem como a exposição sumária do direito ameaçado e do receio de lesão deste." (in Tutela de urgência e arbitragem..., p. 371).
} 
sumária do direito ameaçado e o receio de lesão (CPC, art. 801, inc. IV), para demonstrar o fumus boni iuris e o periculum in mora; e (v) as provas que pretende produzir (CPC, art. 801, inc. V), porquanto os procedimentos cautelares são sumários, sem fase de saneamento em que seria possível a especificação de provas $^{321}$.

Especificamente com relação à indicação da lide e da ação principal (CPC, art. 801, inc. III), cumpre à parte autora informar ao juízo estatal que a ação cautelar é preparatória de futura arbitragem a ser instaurada perante o juízo arbitral previsto na convenção de arbitragem $^{322}$.

Tal fato é de extrema relevância, porque poderá afetar, inclusive, o conhecimento da ação cautelar pré-arbitral.

Pode ocorrer de o autor deixar de informar a existência da convenção de arbitragem ao juízo estatal, aduzindo que irá ajuizar, dentro do prazo legal, uma ação principal perante o próprio juízo comum.

Se isso acontecer, conforme lição de CARLOS Alberto CARMONA, duas serão as providências que o juiz togado poderá tomar. A primeira, na hipótese de haver cláusula compromissória arbitral no contrato em discussão, o juiz deverá decretar a inépcia da petição inicial da ação cautelar pré-arbitral, pois já saberá de antemão que a ação principal indicada pela parte não terá êxito, uma vez que a cláusula compromissória pode ser conhecida de ofício pelo magistrado. A segunda, na hipótese de o

\footnotetext{
${ }^{321}$ Cf. PAULA, Paulo Afonso Garrido de. Código de Processo Civil Interpretado..., pp. 2.233/2.334.

${ }^{322}$ Nesse sentido, DONALDO ARMELIN anota que "a inicial da cautelar deve retratar com clareza a pretensão a ser veiculada na arbitragem. Só assim poderá o magistrado aferir a existência do periculum in mora e do fumus boni iuris." (Tutela de urgência e arbitragem..., pp. 371/372). Não é diferente o entendimento de CARlos AlBerto CARMona, o qual observa "que na hipótese de ser manejada cautela antecedente, não haverá ação principal a ser promovida perante o juiz estatal (art. 806 do Código de Processo Civil). De fato, considerando-se que o autor da ação cautelar já tenha informado ao juiz togado de que está promovendo a demanda antecedente perante juízo incompetente por conta da urgência, o magistrado, se entender presentes os requisitos para a concessão da medida cautelar, concederá a tutela emergencial, remetendo as partes à via arbitral;" (Arbitragem e Processo..., p. 327). Exemplo prático é a ação cautelar de arrolamento de bens n. ${ }^{\circ}$ 0112066-05.2009.8.26.0002 (002.09.112066-1), que tramitou perante o MM. Juízo da 4. . Vara Cível do Foro Regional de Santo Amaro-SP, Comarca da Capital do Estado de São Paulo, por meio da qual a parte autora requereu o arrombamento da sede de empresa da qual era sócia e havia sido abandonada pela outra sócia, para que fosse feito o arrolamento dos bens lá constantes em caráter de urgência, informando, expressamente, na petição inicial, que aludida ação cautelar era preparatória de futura arbitragem a ser instaurada perante o Centro de Arbitragem e Mediação da Câmara de Comércio Brasil-Canadá, nos termos da cláusula compromissória arbitral existente no contrato firmado entre as partes.
} 
juiz verificar a existência de compromisso arbitral, cuja existência depende de alegação pelo réu (CPC, art. 301, IX, § 4. ${ }^{\circ}$ ), o juiz deverá determinar a citação da parte contrária, a qual poderá suscitar em sua defesa a existência da convenção arbitral (que impedirá o conhecimento da ação principal indicada pelo autor e acarretará a extinção da própria ação cautelar) ou nada dizer, aceitando a jurisdição estatal para a ação cautelar (o que não significa a renúncia à arbitragem para a ação principal) $)^{323}$.

A petição inicial da ação cautelar pré-arbitral também deverá observar os demais requisitos formais previstos na legislação processual, devendo ser formulada em peça escrita, a qual deverá ser “instruída com os documentos indispensáveis à propositura da ação, (...) a saber: instrumento de mandato (art. 37) e aqueles que servem à comprovação de fatos que arrimam a pretensão cautelar" ${ }^{324}$, podendo o réu, em sua defesa, argüir "defeito de representação do autor, entre outros pressupostos processuais"

\subsection{PRAZO PARA A AČ̃̃o PRINCIPAL}

Ainda tendo em vista a aplicação das regras do Código de Processo Civil à ação cautelar prévia à instituição da arbitragem perante o Poder Judiciário, doutrina e jurisprudência pátrias também sustentam que se aplica ao caso o disposto no artigo 806 do Estatuto Processual ${ }^{326}$, segundo o qual "cabe à parte propor a ação, no prazo

${ }^{323}$ Cf. CARMONA, Carlos Alberto. Arbitragem e Processo..., p. 328.

${ }_{324}^{324}$ Cf. PAULA, Paulo Afonso Garrido de. Código de Processo Civil Interpretado..., p. 2.233.

${ }^{325}$ Cf. CARMONA, Carlos Alberto. Arbitragem e Processo..., p. 159.

${ }^{326}$ Nesse sentido, JOEL DIAS FIGUEIRA JÚNIOR afirma que "nas hipóteses de cautelares preparatórias aforadas perante a jurisdição pública, o processo acautelatório rege-se integralmente pelas normas insculpidas no Livro III do CPC, o que importa, entre outros aspectos, dizer que o juízo arbitral deverá ser instaurado no prazo de 30 dias contados da efetivação da medida (art. 806)." (Arbitragem, jurisdição..., p. 224). MANUELA CORREIA BOTELHO COLOMBO também diz que "não se pode olvidar que o ordenamento processual brasileiro exige a propositura da ação principal no prazo de até 30 dias a contar da efetivação da medida cautelar preparatória (art. 806 do CPC)." (Medidas de Urgência no Processo..., p. 269). Na mesma linha: ARMELIN, Donaldo. Tutela de urgência e arbitragem..., p. 372; LEMES, Selma M. Ferreira. A inteligência do art. 19 da Lei de Arbitragem..., pp. 421 e 422; OLIVEIRA, Carlos Alberto Alvaro de. Comentários ao Código de..., p. 25; HOFFMAN, Paulo. Arbitragem: algumas dúvidas..., p. 320; dentre outros. Na jurisprudência: STJ, 2. ${ }^{\text {a Turma, REsp n. }}{ }^{\circ}$ 606.345/RS, Rel. Min. João Otávio de Noronha, j. 17/05/2007, DJ 08/06/2007, p. 240, v.u., que trata da extinção de ação cautelar preparatória por ofensa à cláusula compromissória e por descumprimento do prazo previsto no artigo 806 do CPC. Em igual sentido: "Processo Civil. Juízo arbitral. Cláusula compromissória. Extinção do processo. Art. 267, VII, do CPC. Sociedade de economia mista. Direitos disponíveis. Extinção da ação cautelar preparatória por inobservância do prazo legal para a proposição da ação principal. 1. Cláusula compromissória é o ato por meio do qual as partes contratantes formalizam seu desejo de submeter à arbitragem eventuais divergências ou litígios passíveis de ocorrer ao longo da execução da avença. Efetuado o ajuste, que só pode ocorrer em hipóteses envolvendo direitos disponíveis, ficam os contratantes vinculados à solução extrajudicial da pendência. 2. A eleição da cláusula 
de trinta dias, contados da data da efetivação da medida cautelar, quando esta for concedida em procedimento preparatório"327.

Ressalte-se, contudo, que, como a ação principal não será dirigida ao juízo estatal, mas, sim, ao juízo arbitral (será a própria arbitragem), a doutrina majoritária entende que o prazo de trinta dias deve ser interpretado de forma distinta da corriqueiramente havida na justiça estatal, fazendo-se necessária uma "interpretação construtiva a respeito" ${ }^{, 328}$.

Com efeito, não se poderá exigir da parte a instituição da arbitragem no prazo legal de trinta dias, contados da efetivação da medida cautelar, pois, como visto acima, a instauração da arbitragem depende da aceitação do encargo pelo(s) árbitro(s) (nos termos do artigo 19 da Lei de Arbitragem), ato que poderá levar muito mais do que trinta dias em virtude de motivos alheios à vontade da parte (e.g.: impugnação da nomeação do árbitro, recusa do árbitro etc.), não podendo a parte, por conseguinte, ser prejudicada por conta disso.

Assim, como a instituição propriamente dita da arbitragem foge ao controle das partes, caberá ao beneficiário do provimento cautelar pré-arbitral comprovar, dentro do prazo legal de trinta dias previsto no artigo 806 do CPC, apenas e tão-somente que tomou as providências necessárias para dar início à arbitragem ${ }^{329}$.

A dúvida que surge, então, é o que deve ser interpretado como "providências para dar início à arbitragem”.

compromissória é causa de extinção do processo sem julgamento do mérito, nos termos do art. 267, inciso VII, do Código de Processo Civil. (...) 4. Recurso especial parcialmente provido.” (STJ, 2. ${ }^{\mathrm{a}}$ T., REsp n. ${ }^{\circ}$ 612.439/RS, Rel. Min. João Otávio de Noronha, j. 25/10/2005, v.u., grifos nossos).

${ }^{327}$ Cf. FIGUEIRA JR, Joel Dias. Arbitragem, jurisdição..., p. 224.

${ }^{328}$ Cf. ARMELIN, Donaldo. Tutela de urgência e arbitragem..., p. 372.

${ }^{329}$ Não é diferente a lição de DONALDO ARMELIN, para o qual "a matéria, em se tratando de cautelar préarbitral, exige uma interpretação construtiva a respeito", tendo em vista que "a instituição da arbitragem não depende apenas da iniciativa do seu proponente", bem como que "o prazo de trinta dias fixado na lei processual pode desvendar-se exíguo para a instituição da arbitragem", concluindo que "aforada a cautelar pré-arbitral e deferida a medida liminar nela pleiteada, sendo esta efetivada, o requerente da medida terá o prazo de trinta dias a contar dessa efetivação para propor o início da arbitragem e assim se forrar da sanção prevista no art. 811, III, do CPC." (Tutela de urgência e arbitragem..., pp. 372/373). 
A doutrina não é uníssona quanto ao tema. Para alguns doutrinadores, o início da arbitragem deve ser entendido como a comunicação enviada pela parte interessada à(s) parte(s) contrária(s) noticiando a sua intenção de iniciar o processo arbitral $^{330}$. Para outros, o início da arbitragem deve ser considerado como o simples peticionamento à câmara arbitral eleita pelas partes informando acerca da intenção de dar início à arbitragem, nos casos de arbitragens institucionais ${ }^{331}$.

Adotamos neste trabalho a posição de CARLOS AlBerto CARMONA, no sentido de que:

“caberá ao autor, portanto, no prazo de 30 (trinta) dias contados na forma do art. 806 já referido, demonstrar que tomou as medidas necessárias para a instituição da arbitragem. A prova a que está adstrito o autor, sob pena de cessação da eficácia da medida cautelar (art. 808, I, Código de Processo Civil) é no sentido de que tomou as providências tendentes à nomeação do painel de árbitros (notificação à parte contrária na arbitragem ad hoc, notificação ao órgão arbitral institucional na arbitragem administrada), não sendo exigível que no trintídio demonstre o requerente que os árbitros aceitaram o encargo (ou seja, que a arbitragem está instituída)"332.

De qualquer forma, para se evitar eventuais percalços na prática, a recomendação é a de que a parte tome todas as medidas possíveis para o início da arbitragem: seja apresentando o pedido expresso perante a câmara arbitral eleita, seja enviando notificação à(s) parte(s) contrária(s) acerca de sua intenção de dar início à

\footnotetext{
${ }^{330}$ Por todos, cite-se o entendimento de DONALDO ARMELIN: “a melhor solução a respeito é a de fixar na data da propositura da arbitragem, com a consequente comunicação à parte contrária da intenção de a iniciar, pelo requerente da medida cautelar." (in Tutela de urgência e arbitragem..., p. 372).

${ }^{331}$ Nesse sentido: "A doutrina se inclina no sentido de que a simples solicitação de instauração da arbitragem deve ser considerada como o início da arbitragem." (COLOMBO, Manuela Correia Botelho. Medidas de Urgência no Processo..., p. 269); e “(...) com a sistemática introduzida pela convenção de arbitragem, a cláusula compromissória também tem o condão de instituí-la e, desta feita, surgida a controvérsia, o primeiro ato que exterioriza a intenção de constituí-la, tal como a propositura da demanda arbitral perante a instituição arbitral eleita pelas partes para administrar a arbitragem, a toda evidência, é considerada como data do início da arbitragem. (...) em homenagem a lógica e a boa hermenêutica haveremos de concluir que os efeitos práticos da arbitragem iniciam e se projetam na fase inicial, desde a propositura da demanda de arbitragem." (LEMES, Selma M. Ferreira. A inteligência do art. 19 da Lei de Arbitragem..., p. 417). J. E. CARREIRA ALVIM, mencionando lição de MAURO RUBINO-SAMMARTANO, também afirma que, por analogia ao processo judicial, o pedido de instituição da arbitragem deve ser considerado como o seu início, diferenciando a "constituição da arbitragem" do "início do procedimento arbitral" e sustentando que "quanto à primeira, como existe a nomeação do árbitro e a sua aceitação, só a partir desta pode-se falar na constituição da arbitragem. Mas, se este é o elemento essencial para fins do procedimento arbitral, não é necessariamente o seu início. Nada impede tenha o procedimento arbitral início antes da aceitação da nomeação do árbitro, como depois da constituição da arbitragem.” (in Tratado Geral da Arbitragem..., p. 117).

${ }^{332}$ CARMONA, Carlos Alberto. Arbitragem e Processo..., p. 327.
} 
arbitragem, seja tomando qualquer outra medida efetiva que transpareça a sua vontade clara de iniciar o processo arbitral dentro do prazo de trinta dias da efetivação da liminar.

Na hipótese de cláusula compromissória vazia, caso a parte contrária se recuse a assinar o compromisso arbitral após ter sido devidamente notificada para tanto, caberá à parte que se valeu da cautelar pré-arbitral ajuizar a ação prevista no art. $7^{\circ}$ da Lei n. ${ }^{\circ}$ 9.307/96 dentro desse prazo de trinta dias, comprovando, assim, que tomou as medidas cabíveis para a instituição do processo arbitral dentro do prazo legal ${ }^{333}$, sob pena de extinção da cautelar pré-arbitral ${ }^{334}$.

No direito estrangeiro, o Código de Processo Civil italiano possui previsão similar em seu artigo 669-octies, o qual prevê que a parte que se valeu de uma ação cautelar perante o Poder Judiciário, também deve dar início à arbitragem dentro do prazo legal ${ }^{335}$.

\footnotetext{
${ }^{333}$ Nessa esteira: "Negando-se a parte ex adversa em instituir a arbitragem, o interessado deverá ajuizar perante o Estado-juiz, no trintídio legal, a demanda estatuída nos arts. $6^{\circ}$ e $7^{\circ}$ da Lei n ${ }^{\circ} 9307 / 96$, conforme o caso concreto." (FIGUEIRA JÚNIOR, Joel Dias. Arbitragem, jurisdição..., p. 224); e “(...) caso a cláusula compromissória seja vazia, o atendimento à exigência contida no art. 806 do CPC se aperfeiçoará no momento em que a parte interessada manifestar à outra parte sua intenção de dar início à arbitragem, por via postal ou por outro meio qualquer de comunicação, mediante comprovação de recebimento, convocando-a para firmar o compromisso arbitral (art. 6. ${ }^{\circ}$ da Lei 9.307/96). Não comparecendo a parte convocada, ou não havendo consenso, a parte interessada deverá intentar perante o Poder Judiciário a demanda de que trata o art. 7. ${ }^{\circ}$ da Lei de Arbitragem, cuja sentença de procedência valerá como compromisso (art. 7. ${ }^{\circ}$ ).” (AMARAL, Paulo Osternack. A concessão de medidas urgentes..., p. 35).

${ }^{334}$ Nesse sentido, a jurisprudência: "Processo Civil - Arbitragem - Cláusula compromissória - Extinção do processo - Art. 267, VII, do CPC - Admissibilidade - As partes firmaram termo de prestação de contas e quitação e a autora atribuiu ao réu abuso no depósito dos cheques que lhe foram entregues e no posterior encaminhamento dessas ordens de pagamento ao cartório de protesto, por não ter observado as obrigações que lhe foram impostas no mesmo documento - Documento que contém cláusula vazia de compromisso arbitral - Réu nunca pretendeu discutir o contrato, apenas cobrar em cartório de protesto os cheques impagos, emitidos em decorrência daquela avença - Não precisava manifestar à autora sua intenção de dar início à arbitragem, pois o seu comportamento não estava sob o domínio normativo do art. $6^{\circ}$ da Lei 9.307, de 23-91996 - O que restava à autora, ante a existência de 'cláusula vazia' na avença, era o uso de medida judicial com o objetivo único de ver instituída a arbitragem (cumprimento específico da cláusula compromissória vazia), ou a instituição forçada da arbitragem, como previsto no art. $7^{\circ}$ do mesmo diploma - Não podia, ao contrário, mover ação declaratória de inexigibilidade de títulos de crédito c. c. indenização por danos materiais e morais - Existência de anterior ação cautelar de sustação de protesto - Irrelevância - Obtenção de liminar de sustação de protesto em ação cautelar não impedia a autora de solicitar o concurso do Poder Judiciário para a instituição da arbitragem e nesta, se acolhida a pretensão deduzida, poderia ser convalidada aquela - Cautelar não era óbice à medida prevista no art. $7^{\circ}$ da Lei 9.307 - Cláusula compromissória funciona como o impedimento ao exercício do direito de ação, tornando a parte carecedora da ação por ausência da condição de possibilidade jurídica do respectivo exercício - Recurso desprovido." (TJ/SP, 20. ${ }^{a}$ Câm. Dir. Privado, Apelação n. ${ }^{\circ}$ 999.843/6, Rel. Des. Álvaro Torres Júnior, j. 23/06/2008, v.u., grifamos).

335 "Art. 669-octies (...) Nel caso in cui la controversia sia oggetto di compromesso o di clausola compromissoria, la parte, nei termini di cui ai commi precedenti, deve notificare all'altra un atto nel quale dichiara la propria intenzione di promuovere il procedimento arbitrale, propone la domanda e procede, per quanto le spetta, alla nomina degli arbitri." (trad. livre: "Art. 669-oitavo (...) No caso em que a controvérsia
} 
E, conforme anota SERGio LA ChINA, a legislação italiana prevê, expressamente, que o processo arbitral se intaura no momento da "domanda d'arbitrato", ou seja, no momento em que uma das partes promove a arbitragem, sendo essa a providência que deve ser tomada para o cumprimento do prazo $^{336}$.

Por fim, Ferruccio Auletta esclarece que, na Itália, a competência para declarar a ineficácia da medida cautelar em virtude da violação do prazo para o início da ação principal é do juiz que concedeu a medida ${ }^{337}$, entendimento esse aplicável ao Brasil, mas somente até a instituição da arbitragem, quando passa a ser do(s) árbitro(s) esse mister.

\subsection{O QUE OCORRE COM A MEDIDA CAUTELAR DEFERIDA PELO JUÍZO ESTATAL E COM}

\section{OS AUTOS DO PROCESSO APÓS A INSTAURAÇÃO DA ARBITRAGEM?}

Outra questão que deve ser tratada é o que deve acontecer com a tutela cautelar concedida pelo juiz togado e com os próprios autos da ação cautelar pré-arbitral após a instituição da arbitragem?

Primeiramente, esclarece-se que a tutela cautelar pré-arbitral deferida pela justiça comum não perde o seu objeto ou a sua eficácia ${ }^{338}$, tampouco deve ser automaticamente revogada pelo juízo togado, pela simples instauração da arbitragem.

seja objeto de compromisso ou de cláusula compromissória, a parte, nos termos dos números anteriores, deve notificar a outra de um ato no qual declarou a própria intenção de promover o procedimento arbitral, propor a demanda e proceder, enquanto espera, à nomeação dos árbitros.”). LAURA SALVANESCHI esclarece que a parte deve dar início a arbitragem no prazo de trinta dias (Mesures provisoires et arbitrage..., p. 450).

${ }^{336}$ L'Arbitrato..., p. 77. FERRUCCIO AULETTA alerta que o prazo deve ser cumprido "pena l'inefficacia della misura cautelare" (trad. livre: "sob pena de ineficácia da medida cautelar"), mencionando, ainda, outras hipóteses em que há a revogação do provimento cautelar: "a) 'se la parte che [...] aveva richiesto [la misura provvisoria] non presenta domanda di esecutorietà in Italia [...] del lodo arbitrale entro i termini eventualmente previsti a pena di decadenza dalla legge o dalle convenzioni internazionali’, b) se [è] pronunciat[o] lodo arbitrale che dichiari [...] inesistente il diritto per il quale il provvedimento era stato concesso' (art. 669-novies, ultimo comma, c.p.c.)" (trad. livre: “a) 'se a parte que [...] havia pleiteado [a medida provisória] não apresenta ação de execução na Itália [...] do laudo arbitral até o término eventulmente previsto da pena de decadência da lei ou da convenção internacional', b) 'se [é] proferid[o] laudo arbitral declarando inexistente o direito pelo qual o provimento foi concedido'.”) (AULETTA, Ferruccio. "Cognizione sommaria e giudizio arbitrale". Diritto dell'arbitrato (a cura di Giovanni Verde). Torino: Giappichelli, pp. 493/508, pp. 494 e 495). LAURA SALVANESCHI também menciona esses dois exemplos de caducidade da tutela de urgência arbitral na Itália (Mesures provisoires et arbitrage..., p. 451).

${ }^{337}$ AULETTA, Ferruccio. Cognizione sommaria e giudizio..., p. 497.

${ }^{338}$ Conforme o seguinte julgado do TJ/RJ: "Nesse caso, a toda evidência, a medida cautelar deferida pela justiça comum, e ainda por uma questão de lógica, não perderá o seu objeto uma vez instaurado o tribunal 
Tal advertência parece óbvia e desnecessária, mas diante da falta de regulamentação específica e de entendimentos divergentes, ela se torna relevante.

Por exemplo, em caso prático, o juízo da 47. ${ }^{a}$ Vara Cível da Comarca da Capital do Estado do Rio de Janeiro deferiu medida cautelar pré-arbitral em favor da parte autora nos autos da ação cautelar inominada n. ${ }^{\circ}$ 0178164-38.2007.8.19.0001 (2007.001.173951-7). Por se tratar de ação cautelar pré-arbitral perante o Poder Judiciário, a decisão liminar é recorrível por meio de agravo de instrumento, nos termos dos arts. 522 e seguintes do CPC. A parte contrária, então, interpôs agravo de instrumento contra aludida decisão, sendo certo que, durante o trâmite de referido recurso, foi instituída a arbitragem. E o Tribunal de Justiça do Rio de Janeiro, ao analisar o agravo de instrumento em questão, por meio de decisão monocrática proferida pelo Desembargador MARCOS ALCINO DE AZEVEDO TORRES, houve por bem revogar a tutela cautelar pré-arbitral, pelo simples fato de a arbitragem já ter sido instaurada, sustentando que a questão deveria ser submetida aos árbitros. Eis os termos desse decisum, in verbis:

“(...) Se de fato o Poder Estatal está impedido de exercer jurisdição na discussão envolvendo as partes, como parece estar, não faz sentido manter a decisão proferida, pois deverá a agravada buscar a medida cautelar que entende ter direito naquele Tribunal (ou deveria já ter buscado, uma vez que instaurado o Tribunal Arbitral desde maio deste ano). Assim, sem adentrar na questão de fundo, por incompetente este Tribunal, dou provimento liminar ao recurso nos termos do artigo 557 do CPC, para cassar a decisão proferida. I-se." (TJ/RJ, 3. . Câm. Cível, A.I. n. ${ }^{\circ}$ 0028379-68.2008.8.19.0000 - antigo n. ${ }^{\circ}$ 2008.002.19589, D.O. 11/08/2008, origem: medida cautelar inominada n. ${ }^{\circ}$ 0178164-38.2007.8.19.0001 - antigo n. ${ }^{\circ}$ 2007.001.173951-7).

Com todo o respeito, não podemos concordar com essa decisão, pois o Tribunal de Justiça do Rio de Janeiro não poderia ter cassado a tutela cautelar única e tão-somente pelo fato de a arbitragem já ter sido instaurada quando da apreciação do recurso. A nosso ver, o TJ/RJ deveria apenas ter reconhecido a sua ausência de jurisdição para apreciar o pedido liminar em sede de agravo de instrumento, tendo em vista a instituição da arbitragem (como o fez), e ter remetido a questão para a apreciação

arbitral. Pelo contrário, deverá prosseguir para garantir a eficácia da decisão a ser proferida pelos árbitros, salvo se por eles for determinada alguma medida de idêntica eficácia. Se assim não se entender, perderá todo e qualquer sentido a procura da justiça comum antes da instauração do juízo arbitral, e as decisões deste poderão se tornar ineficazes." (TJ/RJ, 2. ${ }^{a}$ Câmara Cível, Apelação n. ${ }^{\circ}$ 0120862-27.2002.8.19.0001 - n. ${ }^{\circ}$ antigo 2003.001.16879, Rel. Des. Sergio Cavalieri Filho, j. 24/09/2003, v.u.). 
dos árbitros, os quais, após a instauração da arbitragem, são os únicos com poderes jurisdicionais para determinar a manutenção ou a revogação da liminar.

Assim, uma vez instituída a arbitragem, a tutela cautelar eventualmente concedida pela justiça estatal não perderá o seu objeto ou a sua eficácia, devendo os autos da ação cautelar pré-arbitral serem remetidos ao juízo arbitral, o qual, como se verá detalhadamente no "item 19" abaixo, deverá reapreciar a questão, mantendo, reformando ou revogando o provimento cautelar deferido pelo juízo estatal.

E o ideal é que o juízo comum envie os próprios autos da ação cautelar ao juízo arbitral, para que este possa reapreciar e analisar o pedido liminar da melhor forma possível, bem como para que o(s) árbitro(s) possa(m) analisar o mérito da ação cautelar (que não mais poderá ser apreciado pelo juiz togado).

Anote-se que esse tema (remessa dos autos da ação cautelar pré-arbitral ao juízo arbitral) é pouco tratado pela doutrina, sendo ligeiramente mais rica a jurisprudência sobre o assunto. De qualquer forma, o entendimento majoritário encontrado tanto na doutrina como na jurisprudência pátrias é no sentido de que o juiz togado deve remeter os próprios autos da ação cautelar pré-arbitral ao juízo arbitral assim que instituída a arbitragem ${ }^{339}$.

${ }^{339}$ Nessa esteira: “(...) nesses casos, à exceção da medida cautelar de antecipação de provas (art. 846 do CPC), que se esgota com a simples produção, os demais provimentos cautelares ou de urgência deverão, após concedidos pela Jurisdição Estatal (arrestos, seqüestros, etc.), ser ratificados pelo juízo arbitral a se instaurar, remetendo-lhe o juiz os autos tão logo tenha ciência da aceitação da nomeação pelos árbitros, preservando-se, assim, a competência plena da Jurisdição privada sobre o litígio." (GAJARDONI, Fernando da Fonseca. A arbitragem nos tribunais..., p. 59, grifamos). Igualmente: "Agravo inominado em agravo de instrumento Ação cautelar inominada preparatória - Cláusula arbitral - Ajuizamento no juízo estadual - Possibilidade Indeferimento da medida - Agravo de instrumento - Efeito ativo concedido - Ciência da posterior instauração do juízo arbitral - Incompetência superveniente da Justiça Estatal - Remessa dos autos ao arbitro para manutenção ou não da tutela concedida. (...) Nesses casos, admite-se que o requerimento seja feito diretamente ao Juiz togado competente para o conhecimento da causa, sujeitando-se, todavia, à ratificação pelo Juízo Arbitral, assim que instaurado, remetendo-lhe os autos, de forma a preservar a competência plena da Jurisdição privada sobre o litígio.” (TJ/MG, 14. ${ }^{a}$ Câmara Cível, Ag. Inst. n. ${ }^{\circ}$ 1.0024.07.600275-7/002, Rel. Des. Elias Camilo, j. 17/01/2008, v.u., grifamos); “Ação cautelar inominada preparatória - Cláusula arbitral Ajuizamento da ação no Juízo Estadual - Possibilidade - Deferimento da medida - Posterior ajuizamento do procedimento arbitral - Remessa dos autos ao arbitro para manutenção ou não da tutela concedida. Sendo a medida cautelar aviada antes de instaurada a arbitragem é cabível ao juízo estatal a concessão da medida perseguida, devendo, contudo, serem os autos remetidos ao juízo arbitral para que o mesmo aprecie a manutenção ou não da tutela concedida assim que iniciado o procedimento arbitral. De ofício, determinaram a remessa dos autos ao juízo arbitral para manutenção ou não da tutela concedida." (TJ/MG, 12. ${ }^{a}$ Câm. Cível, A.I. n. ${ }^{\circ}$ 1.0480.06.083392-2/001, Rel. Des. Domingos Coelho, j. 14/02/07, grifos nossos); "Superadas as circunstâncias temporárias que justificavam a intervenção contingencial do Poder Judiciário e considerando 
Há entendimento, no entanto, de que o juízo comum deva remeter apenas cópia do processo ao juízo arbitral, devendo este, se entender ser o caso, pleitear ao juiz togado a extinção da ação cautelar que se encontra em trâmite perante o Poder Judiciário.

Contudo, essa linha de pensamento apenas burocratiza o processo, gerando atos que se tornariam desnecessários e que se resolveriam com a simples remessa dos próprios autos da ação cautelar pré-arbitral pelo juízo estatal ao juízo arbitral, sendo esta, portanto, a solução mais célere, direta e acertada, pois evita, inclusive, eventual usurpação de jurisdição entre os juízos comum e arbitral ${ }^{340}$.

E mesmo que a tutela cautelar prévia à instituição da arbitragem tenha caráter satisfativo e já tiver sido cumprida perante o juízo estatal, ainda assim os autos deverão ser remetidos ao juízo arbitral, após a sua instauração, para a ratificação ou não da liminar, sendo certo que, em caso de sua reforma ou revogação, a parte que se favoreceu da medida urgente deverá ressarcir a parte contrária dos prejuízos por ela sofridos, como se verá no "item 25 " abaixo ${ }^{341}$.

que a celebração do compromisso arbitral implica, como regra, a derrogação da jurisdição estatal, os autos devem ser prontamente encaminhados ao juízo arbitral, para que este assuma o processamento da ação e, se for o caso, reaprecie a tutela conferida, mantendo, alterando ou revogando a respectiva decisão." (STJ, 3. ${ }^{\text {a }}$ Turma, REsp n. ${ }^{\circ}$ 1.297.974-RJ, Rel. Min. Nancy Andrighi, j. 12/06/2012, v.u., grifamos). Ainda: STJ, 3. ${ }^{a}$ Turma, AgRg na MC n. ${ }^{\circ}$ 19.226/MS, Rel. para acórdão Min. Nancy Andrighi, j. 21/06/2012, maioria.

${ }^{340}$ Nesse mesmo sentido, cumpre-se transcrever trecho do voto prolatado pela Ministra NANCY ANDRIGHI no REsp n. ${ }^{\circ}$ 1.297.974/RJ: "Há quem sustente que o Poder Judiciário deve encaminhar apenas cópia do processo para apreciação do juízo arbitral que, entendendo pelo não cabimento da tutela concedida, deverá requerer ao Juiz a extinção da medida cautelar. (...) Sou adepta, porém, da desburocratização do processo, sendo certo que o procedimento acima sugerido implicaria necessariamente na realização de uma série de atos que, na prática, terão o mesmo efeito da remessa direta dos próprios autos da ação cautelar para o juízo arbitral. Sendo assim, me parece suficiente que o Juiz, ao encaminhar os autos ao árbitro, consigne a ressalva de que sua decisão foi concedida em caráter precário, estando sujeita a ratificação pelo juízo arbitral, sob pena de perder eficácia. Com isso, e sem que haja qualquer usurpação de competência ou conflito de jurisdição, evitase a prática de atos inúteis e o prolongamento desnecessário do processo." (STJ, 3. ${ }^{a}$ T., j. 12/06/2012, v.u.).

${ }^{341}$ Nessa esteira, a jurisprudência do TJ/SP: "Bem móvel. Cana-de-açúcar. Compra e venda. Ação cautelar para buscar e apreender o produto objeto de venda. Existência de cláusula estipulando juízo arbitral. Previsão contratual possibilitando ajuizamento de ação judicial visando a tutelas emergenciais. 1. A previsão contratual de juízo arbitral não impede a parte de promover ação judicial visando tutelas de emergência, máxime quando o próprio contrato traz exceção, possibilitando à parte valer-se do judiciário para obter providência urgente. 2 . O caráter satisfativo da medida cautelar, que se consumou com a entrega liminar do produto, não impede a apreciação do mérito pelo juízo arbitral, conforme previsto no contrato. 3 . Deram provimento ao recurso da autora, prejudicado o da ré." (TJ/SP, 25. ${ }^{a}$ Câmara de Direito Privado, Apelação n. ${ }^{\circ}$ 9184314-84.2007.8.26.0000, Rel. Des. Vanderci Álvares, j. 23/11/2011). 
Quanto ao recurso contra a decisão proferida na ação cautelar pré-arbitral que estiver pendente de julgamento perante um Tribunal, este deverá ser julgado prejudicado se a arbitragem for instituída antes de seu julgamento, com a remessa dos autos ao juízo arbitral.

Isso porque, assim que instaurado o juízo arbitral, cessa a jurisdição do juízo estatal com relação ao provimento cautelar pré-arbitral, mesmo que de um Tribunal, devendo este também remeter à questão (e os autos do processo) para a análise do(s) árbitro(s) assim que a arbitragem for instituída ${ }^{342}$.

Nessa linha, o Tribunal de Justiça de São Paulo julgou prejudicado o recurso de agravo de instrumento n. $^{\circ}$ 0305397-55.2009.8.26.0000 (antigo n. ${ }^{\circ}$ 990.09.305397-7), que havia sido interposto contra decisão liminar pré-arbitral deferida em Primeira Instância, tendo em vista a instauração do juízo arbitral e a confirmação da tutela cautelar por este ${ }^{343}$.

Frise-se que, nesse caso, o Desembargador Relator HERALDO DE OLIVEIRA chegou a transcrever o voto que havia preparado para julgar o recurso no mérito, mencionando, inclusive, que daria parcial provimento ao agravo de instrumento, para afastar a multa que havia sido imputada pela decisão liminar de Primeiro Grau, mas julgou prejudicado o recurso, aduzindo que a tutela cautelar somente poderia ser apreciada pelo juízo arbitral, uma vez que já instaurado à época do julgamento, mencionando, ainda, que o juízo arbitral já havia mantido a decisão liminar na íntegra, como informado pelas partes no processo, não mais podendo o Poder Judiciário apreciar a matéria.

Em sentido contrário, a demonstrar que a jurisprudência ainda não é pacífica sobre o assunto, o mesmo Tribunal de Justiça de São Paulo conheceu e deu parcial provimento ao agravo de instrumento n. ${ }^{\circ}$ 0002754-71.2007.8.26.0000 (antigo n. ${ }^{\circ}$ 1.106.614-0/8), para reformar parcialmente tutela cautelar pré-arbitral, mesmo tendo a

\footnotetext{
${ }^{342}$ Nessa mesma linha: "Após instituída a arbitragem (com a aceitação do encargos pelos árbitros), cessa a competência do juiz estatal, impondo-se a remessa dos autos (e do eventual agravo de instrumento porventura interposto) ao juízo arbitral.” (AMARAL, Paulo Osternack. A concessão de medidas urgentes..., p. 32, g.n.). ${ }^{343} \mathrm{TJ} / \mathrm{SP}, 13{ }^{\mathrm{a}}{ }^{\mathrm{C}}$ Câmara de Direito Privado, A.I. n. ${ }^{\circ}$ 0305397-55.2009.8.26.0000 (antigo n. ${ }^{\circ}$ 990.09.305397-7), Rel. Des. Heraldo de Oliveira, j. 28/04/2010, v.u.. Em igual sentido: TJ/SP, 6. ${ }^{a}$ Câm. Dir. Privado, A.I. n. ${ }^{\circ}$ 990.10.049607-7, Rel. Des. Vito Guglielmi, j. 08/04/2010, v.u.; TJ/SP, 8. ${ }^{a}$ Câm. Dir. Privado, Apelação n. ${ }^{\circ}$ 0004935-07.2010.8.26.0011, Rel. Des. Salles Rossi, j. 19/10/2011, v.u..
} 
parte agravada suscitado a incompetência superveniente do juízo estatal em virtude da instauração do juízo arbitral ${ }^{344}$.

Entendemos, com a devida vênia, que esse v. acórdão violou a Lei de Arbitragem brasileira, pois, uma vez instituída a arbitragem, somente os árbitros possuem poderes jurisdicionais para apreciar as tutelas de urgência, razão pela qual o Tribunal de Justiça de São Paulo deveria ter reconhecido a ausência de jurisdição para a apreciação da liminar, ter julgado prejudicado o recurso de agravo e ter remetido a questão (e os autos do processo) para o juízo arbitral já instaurado.

Esse, inclusive, é o entendimento do Superior Tribunal de Justiça, o qual, por meio do recurso especial n. ${ }^{\circ} 1.297 .974 / R J$, relatado pela Ministra NANCY ANDRIGHI, já decidiu nesse mesmo sentido ${ }^{345}$.

Com efeito, nesse caso prático analisado pelo STJ, o juízo monocrático conheceu e julgou improcedente ação cautelar pré-arbitral, tendo a parte vencida interposto recurso de apelação ao Tribunal de Justiça do Rio de Janeiro. Antes do julgamento do apelo, as partes instituíram arbitragem para solucionar o conflito, o que foi informado ao TJ/RJ. Este, no entanto, decidiu que a cláusula compromissória constante do acordo de acionistas firmado entre as partes, instituindo o juízo arbitral para a solução da lide, seria "relativa em relação às medidas de caráter urgente por vontade das próprias

344 "Bem móvel/Semovente. Medida cautelar. Formação de painel arbitral. Incompetência superveniente do D. Juízo Estatal. Extinção do processo sem resolução do mérito. Descabimento. Preliminar rejeitada". Trecho do acórdão: "Quanto à preliminar, entendo que, apesar de inegável a existência de painel arbitral já instaurado para dirimir os litígios oriundos do contrato de fornecimento estipulado entre as partes, não há a incompetência da jurisdição que atende ao princípio da sua inafastabilidade, previsto no inciso XXXV, artigo $5^{\circ}$, da Constituição Federal, especialmente quanto às medidas de urgência, como o caso dos autos. Portanto, rejeita-se a preliminar de incompetência do Juízo Estatal." (TJ/SP, 31. . Câm. Dir. Privado, A.I. n. ${ }^{\circ} 0002754-$ 71.2007.8.26.0000, antigo n. ${ }^{\circ}$ 1.106.614-0/8, Rel. Des. Armando Toledo, j. 05/06/2007, v.u.).

${ }^{345}$ Conforme a seguinte ementa: "DIREITO PROCESSUAL CIVIL. ARBITRAGEM. MEDIDA CAUTELAR. COMPETÊNCIA. JUÍZO ARBITRAL NÃO CONSTITUÍDO. (...) 2. Na pendência da constituição do Tribunal Arbitral, admite-se que a parte se socorra do Poder Judiciário, por intermédio de medida de natureza cautelar, para assegurar o resultado útil da arbitragem. 3. Superadas as circunstâncias temporárias que justificavam a intervenção contingencial do Poder Judiciário e considerando que a celebração do compromisso arbitral implica, como regra, a derrogação da jurisdição estatal, os autos devem ser prontamente encaminhados ao juízo arbitral, para que este assuma o processamento da ação e, se for o caso, reaprecie a tutela conferida, mantendo, alterando ou revogando a respectiva decisão. 4. Em situações nas quais o juízo arbitral esteja momentaneamente impedido de se manifestar, desatende-se provisoriamente as regras de competência, submetendo-se o pedido de tutela cautelar ao juízo estatal; mas essa competência é precária e não se prorroga, subsistindo apenas para a análise do pedido liminar. 5. Recurso especial provido." (STJ, 3. ${ }^{\text {a }}$ Turma, REsp n. ${ }^{\circ}$ 1.297.974-RJ, Rel. Min. Nancy Andrighi, j. 12/06/2012, v.u.). 
partes, não retirando dos contratantes, portanto, a faculdade de buscar a solução dessas questões pela via judicial, sob pena de violação do pacta sunt servanda e do acesso ao Poder Judiciário", o que deu azo à interposição de recurso especial pela parte prejudicada.

O STJ, então, ao analisar o REsp n. ${ }^{\circ} 1.297 .974 / \mathrm{RJ}$, por meio do voto relator da Ministra NANCY ANDRIGHI, deixou claro que: (i) a competência do juízo comum para a apreciação da tutela cautelar pré-arbitral é precária e subsiste apenas para a análise do pedido liminar, cessando assim que é instituída a arbitragem; (ii) a apreciação do pedido liminar pelo juízo estatal não prorroga a sua competência para a apreciação do mérito da ação cautelar pré-arbitral, ainda que já tenha sido proferida sentença em primeira instância; e (iii) os autos da ação cautelar prévia à instituição da arbitragem devem ser remetidos ao juízo arbitral assim que instaurada a arbitragem, motivo pelo qual o TJ/RJ deveria ter julgado prejudicado o recurso de apelação, uma vez que não possuía mais poderes para apreciar a questão ${ }^{346}$.

Em igual sentido, Carlos Alberto Carmona ensina que "a competência do juiz togado, portanto, ficará adstrita (...) apenas à análise da medida emergencial, passando a direção do processo na sequência aos árbitros, tão logo seja instituída a arbitragem (ou seja, tão logo os árbitros aceitem o encargo)"347.

\footnotetext{
${ }^{346}$ Destacam-se os seguintes trechos do acórdão: "Cinge-se a lide a determinar os limites da competência dos juízos estatal e arbitral para apreciação de medidas cautelares tendo por objeto questão sujeita a arbitragem, presente a peculiaridade de que, no ato de ajuizamento da ação judicial, ainda não havia a constituição do Tribunal Arbitral, formado somente após a prolação da sentença, mas antes do julgamento da apelação. (...) a questão posta a desate nestes autos vai além, exigindo que se defina se o juízo estatal é competente para prosseguir no processamento da medida cautelar depois que o Tribunal Arbitral é formalmente instituído. Nessa situação, superadas as circunstâncias temporárias que justificavam a intervenção contingencial do Poder Judiciário e considerando que a celebração do compromisso arbitral implica, como regra, a derrogação da jurisdição estatal, é razoável que os autos sejam prontamente encaminhados ao juízo arbitral, para que este assuma o processamento da ação e, se for o caso, reaprecie a tutela conferida, mantendo, alterando ou revogando a respectiva decisão. (...) Seja como for, o entendimento do TJ/RJ, de que a competência do Juízo Arbitral "é relativa em relação às medidas de caráter urgente por vontade das próprias partes" (fl. 1.567, eSTJ) deve ser visto com reservas. Na realidade, em situações nas quais o juízo arbitral esteja momentaneamente impedido de se manifestar, desatende-se provisoriamente as regras de competência, submetendo-se o pedido de tutela cautelar ao juízo estatal; mas essa competência é precária e não se prorroga, subsistindo apenas para a análise do pedido liminar. Na hipótese específica dos autos, o Juiz de primeiro grau de jurisdição indeferiu a liminar e julgou o pedido cautelar improcedente, sendo que, no julgamento da apelação pelo TJ/RJ, momento em que houve a concessão da tutela, o Tribunal Arbitral já estava devidamente instituído. A rigor, portanto, o Tribunal Estatal já era incompetente, de sorte que sequer deveria ter julgado o recurso." (negritos no original).

${ }^{347}$ In Arbitragem e processo..., p. 327. Em igual sentido, HAROLDO MALHEIROS DUClerR VerÇOSA aduz que "esta intervenção do Judiciário é provisória, não sendo ela substitutiva da competência dos árbitros." (O Judiciário e a valorização...).
} 
Portanto, com relação à ação cautelar pré-arbitral, não importando se o processo se encontra em Primeiro Grau ou em um Tribunal, os autos deverão ser remetidos ao juízo arbitral assim que instituída a arbitragem, para que o(s) árbitro(s) possa(m) reapreciar o pedido liminar e julgar a ação cautelar no mérito.

\section{PROCEDIMENTO PRÉ-ARBITRAL}

Outra possibilidade mencionada pela doutrina para solucionar o problema da apreciação de tutelas de urgência antes da instituição da arbitragem é o chamado "procedimento pré-arbitral".

Por meio desse procedimento, as partes poderão, na própria convenção de arbitragem (seja na cláusula compromissória, seja no compromisso arbitral), excluir do Poder Judiciário inclusive a apreciação das tutelas de urgência, atribuindo tal encargo, antes da instituição da arbitragem, a um árbitro especial ou a um órgão arbitral específico $^{348}$.

Algumas câmaras arbitrais adotam regulamentos próprios voltados às tutelas de urgência pré-arbitrais, nos quais há previsão da imediata nomeação

\footnotetext{
${ }^{348}$ Corroborando esse entendimento: "E também que, mesmo antes de se instaurar o procedimento arbitral, uma medida cautelar possa ser emitida não pelo judiciário nem propriamente pelo árbitro ou árbitros aos quais caberá analisar o mérito da arbitragem, mas dentro de um mesmo contexto, das mesmas regras, com auxílio de entidade administradora da arbitragem, por alguém, um tipo de árbitro, especialmente nomeado pelas partes." (GARCEZ, José Maria Rossani. Medidas cautelares e de antecipação..., p. 214). Ainda: PITOMBO, Eleonora Coelho. Arbitragem e o Poder Judiciário..., p. 109; e ARMELIN, Donaldo. Tutela de urgência e arbitragem..., p. 365. No direito estrangeiro, o artigo 484 do Código de Processo Civil francês traz disposição semelhante: “Arte. 484 - L'ordonnance de référé est une décision provisoire rendue à la demande d'une partie, l'autre présente ou appelée, dans les cas où la loi confère à un juge qui n'est pas saisi du principal le pouvoir d'ordonner immédiatement les mesures nécessaires." (tradução livre: "a ordem liminar é uma decisão provisória proferida a pedido de uma parte, outro presente ou recorrente, quando o caso ou a lei confere a um juiz que não participa do principal o poder de ordenar imediatamente as medidas necessárias."). JULIAN M. LEW, LOUKAS A. MISTELIS e STEFAN MICHAEL KRÖLL também afirmam que "parties can agree to preclude a national court from granting interim measures" e que "the ICC pre-arbitration référé procedure can also be seen as an exclusion of court jurisdiction" (tradução livre: "as partes podem acordar em impedir uma corte nacional de deferir medidas liminares" e que "o procedimentopré-arbitral da CCI também pode ser visto como uma exclusão da jurisdição estatal”) (Comparative International..., p. 619). Na frança, conforme lição de JACQUES NORMAND, quando a tutela de urgência é puramente conservativa, não implicando a garantia de futura execução, "a competência do juiz de liminares ("juge de référés") no caso de urgência não é, ao contrário do ensinado antes, considerada de ordem pública. A convenção de arbitragem pode excluir, explícita ou implicitamente (por referência a um regulamento de arbitragem), todos os recursos ao juiz estatal de liminares." (Les mesures provisoires et l'arbitrage..., p. 466).
} 
de um terceiro, o qual terá poderes para analisar e conceder medidas urgentes antes da instauração da arbitragem definitiva ${ }^{349}$. Exemplos delas são:

(i) A American Arbitration Association - AAA, que criou as "Emergency Measures of Protection" (tradução livre: "Medidas Emergenciais de Proteção"), as quais prevêem a nomeação, em um dia útil, de um árbitro emergencial único selecionado de um painel especial de árbitros emergenciais da $A A A$ para tutelas de urgência que se fizerem necessárias antes da constituição do painel arbitral definitivo ${ }^{350}$.

${ }^{349}$ Cf. PITOMBO, Eleonora Coelho. Arbitragem e o Poder Judiciário..., p. 109.

350 "Medidas Emergenciais de Proteção - Artigo 37 - 1. A não ser que as partes acordem de outra forma, as disposições deste Artigo 37 aplicam-se a arbitragens conduzidas sob cláusulas compromissórias ou compromissos pactuados a partir de 01/05/2006. 2. Um parte que necessitar de uma medida emergencial antes da constituição do tribunal deverá notificar o administrador e todas as outras partes por escrito da natureza da medida buscada e das razões porque referida medida é requerida de forma emergencial. O pedido também deverá trazer as razões pelas quais a parte tem direito a tal medida. Referida notificação pode ser feita por $e$ mail, fac-símile, transmissão ou qualquer outro meio confiável, mas deve trazer uma declaração certificando que todas as outras partes foram notificadas ou uma explicação acerca dos passos tomados de boa-fé para notificar as outras partes. 3 . Em um dia útil do recebimento da notificação prevista no parágrafo 2 , o administrador nomeará um único árbitro emergencial de um painel especial de árbitros emergenciais designado para decidir pedidos de urgência. Antes de aceitar a nomeação, o árbitro emergencial indicado deverá revelar ao administrador qualquer circunstância possível a causar dúvidas justificáveis com relação à independência e à imparcialidade do árbitro. Qualquer impugnação à nomeação do árbitro emergencial deve ser feita no prazo de um dia útil da comunicação feita pelo administrador às partes acerca da nomeação do árbitro emergencial e das circunstâncias reveladas. 4. O árbitro emergencial deverá o quanto antes, mas de qualquer forma em no máximo dois dias úteis a partir de sua nomeação, estabelecer um cronograma para a apreciação do pedido da tutela de urgência. Aludido cronograma deverá possibilitar uma oportunidade razoável para que todas as partes sejam ouvidas, mas pode prever que esse procedimento seja feito por telefone, conferência ou razões escritas como alternativas à uma audiência formal. $\mathrm{O}$ árbitro emergencial deverá ter a autoridade investida ao tribunal arbitral nos termos do artigo 15, incluindo a autoridade para decidir sobre a sua própria jurisdição e deverá resolver qualquer questão relativa à aplicação deste artigo 37 ao caso. 5. O árbitro emergencial deverá ter o poder para conceder ou deferir qualquer medida liminar ou conservativa que ele entenda necessária, incluindo medida liminar e medidas para a proteção ou conservação de bens. Quaisquer dessas medidas podem ser deferidas por decisão liminar ou por ordem de alívio emergencial. $\mathrm{O}$ árbitro emergencial deverá fundamentar sua decisão em qualquer dos casos. $\mathrm{O}$ árbitro emergencial pode modificar ou revogar a decisão liminar ou a ordem de alívio emergencial por uma boa causa demonstrada. 6. O árbitro emergencial não deverá ter mais qualquer poder para agir após a instituição do tribunal arbitral. Uma vez que o tribunal arbitral estiver constituído, o tribunal pode reconsiderar, revisar ou revogar a decisão liminar ou a ordem de alívio emergencial proferida pelo árbitro emergencial. O árbitro emergencial não pode servir de membro do tribunal arbitral, a não ser que as partes acordem de outra maneira. Qualquer decisão liminar ou ordem de alívio emergencial pode ser condicionada a prestação de caução apropriada pela parte que busca tal medida. 8 . O pedido de medidas liminares endereçado pela parte à autoridade judicial não deverá ser tido como incompatível com este Artigo 37 ou com a convenção de arbitragem ou como renúncia ao direito de arbitrar. Se o administrador for solicitado pela autoridade judicial para nomear um 'mestre especial' para considerar e se reportar sobre um pedido de medida urgente, o administrador deverá proceder da forma prevista no Parágrafo 2 deste artigo e a referência feita ao 'árbitro emergencial' deverá ser lida como 'mestre especial', exceto que o 'mestre especial' deverá proferir um relatório e não uma decisão liminar. 9. Os custos associados aos pedidos de medidas emergenciais deverão ser inicialmente distribuídos pelo árbitro emergencial ou pelo 'mestre especial', ficando sujeitos ao poder do tribunal arbitral de determinar ao final a distribuição de tais custos" (tradução livre de www.adr.org/aaa/ faces/rules/searchrules/rulesdetail?doc. Acessado em 17/11/2012). Mesmo antes desse novo regulamento (em vigor desde 01/06/2009), a AAA - American Arbitration Association possuía anteriormente disposição similar nas "optional rules for emergency measures of protection" (tradução livre: "regras opcionais para medidas 
(ii) A WIPO - World Intellectual Property Organization (“OMPI - Organização Mundial de Propriedade Intelectual"), que também possui um regulamento próprio para o procedimento pré-arbitral, denominado de "WIPO - Emergency Relief Rules" (tradução livre: “OMPI - Regras de Medidas Emergenciais"). Referido regulamento somente pode ser aplicado em uma arbitragem se devidamente aceito pelas partes, possuindo dois procedimentos distintos: o primeiro, com a participação de todas as partes; e o segundo, que corre inaudita altera parte. Em ambos os casos, um árbitro emergencial nomeado de um painel de árbitros da própria WIPO deverá decidir a tutela de urgência de forma bastante célere ${ }^{351}$; e

(iii) A Corte Internacional de Arbitragem da CCI, a qual possui um regulamento específico desde 01/01/1990 352 e prevê um procedimento pré-arbitral no artigo 29 do seu novo

emergenciais de proteção"), compostas pelos seguintes itens: "O-1. Applicability" (tradução livre: "Aplicabilidade"); "O-2. Appointment of Emergency Arbitrator" (tradução livre: "Indicação do Árbitro Emergencial"); "O-3. Schedule" (tradução livre: "Cronograma"); "O-4. Interim Award" (tradução livre: "Decisão Liminar"); e "O-5. Constitution of the Panel" (tradução livre: "Instituição do Painel Arbitral”) (www.adr.org/sp.asp?id=22440\#O2. Acessado em 15/06/2011).

${ }^{351}$ Cf. LEW, Julian M., MISTELIS, Loukas A., KRÖLL, Stefan M. Comparative International..., p. 593. Eis os termos do Artigo XIII das Regras de Medidas Emergenciais da WIPO: "Artigo XIII (a) Em circunstâncias excepcionais, quando a notificação do Réu possa envolver um risco real de que o objeto do Processo possa perecer, o Autor pode entregar ou transmr o pedido de liminar ao Centro sem o seu envio à parte contrária. (b) $\mathrm{O}$ pedido de liminar entregue ou transmitido na forma do parágrafo (a) deve, adicionalmente aos requisitos exigidos pelo Artigo IV, indicar as razões pelas quais a notificação à parte contrária envolveria um risco real do objeto do Processo perecer. (c) Quando satisfeito o requisito de que a notificação à parte contrária envolveria um risco real do objeto do Processo perecer, o Árbitro Emergencial pode ouvir o Autor e proceder à decisão na ausência do Réu. Referida decisão deverá estar sujeita à condição de que a decisão, bem como a documentação que o Árbitro Emergencial considerar apropriada, seja entregue ao Réu da maneira e dentro do prazo determinado pelo Árbitro Emergencial, de forma a possibilitar que o Réu seja ouvido sobre o assunto. (d) As regras deste Anexo devem ser aplicadas mutatis mutandis a qualquer processo regido por este artigo, entendendo-se que as normas relativas a uma sentença deverão também se aplicar a uma ordem proferida sob este Artigo por um Árbitro Emergencial.” (tradução livre).

${ }^{352} \mathrm{O}$ antigo "Reglement de référé pré-arbitral" ou "Regulamento de Procedimento Cautelar Pré-Arbitral", nos termos do seu art. 1.1., estabelecia "um procedimento denominado 'procedimento cautelar pré-arbitral', que prevê a nomeação imediata de uma pessoa ('Terceiro Ordenador'), investida de poderes para ordenar determinadas medidas antes que seja provocado o tribunal arbitral ou estatal competente para decidir o mérito da controvérsia (a 'Jurisdição Competente')." (www.iccwbo.org/uploadedFiles/Court/Arbitration/ other/rules_pre_arbitral_portuguese.pdf. Acessado em 15/06/2011). Nos termos do artigo 2.1 desse antigo regulamento, o árbitro emergencial, chamado de "terceiro ordenador", tinha poderes para: "a) ordenar quaisquer medidas conservatórias ou reparatórias que se revistam de caráter de urgência, seja a fim de prevenir um dano iminente ou um prejuízo irreparável, e, dessa forma, resguardar quaisquer direitos ou bens de uma das partes; b) ordenar que uma das partes efetue, à outra ou a terceiro, o pagamento do que lhe é devido; c) ordenar a uma das partes que tome toda medida que deva ser adotada em virtude do contrato firmado entre as partes, inclusive a assinatura ou entrega de qualquer documento, ou a intervenção de uma das partes no sentido de fazer assinar ou entregar um documento; d) ordenar a prática de qualquer medida necessária à conservação ou produção de provas". Por fim, nos termos do artigo 2.3, esse terceiro ordenador não poderia ser o futuro árbitro: “2.3. Salvo estipulação em contrário, o Terceiro Ordenador nomeado nos termos deste Regulamento não pode exercer a função de árbitro em qualquer procedimento ulterior entre as partes, nem em qualquer outro procedimento em que uma questão ou problema idêntico ou conexo àqueles suscitados no procedimento cautelar pré-arbitral possa ser levantado". Sobre esse antigo procedimento, ver: 


\author{
"Regulamento de Arbitragem e de ADR", em vigor desde $2012^{353}$. Aludido procedimento é \\ similar aos descritos acima, também prevendo a nomeação de um árbitro de emergência \\ que decidirá o pedido de tutela de urgência.
}

Conforme ressaltou Petrônio R. G. Muniz, o procedimento pré-arbitral da CCI passou por seu maior teste no recurso de anulação de decisão préarbitral interposto por Société Nationale des Pétroles du Congo e République de Congo contra Total Fina Elf E\&P Congo (TEP Congo), tendo a Cour d'Appel de Paris mantido a validade da tutela de urgência pré-arbitral deferida, sob o argumento de que "as partes tendo conferido a um terceiro a missão de proferir uma decisão que elas entre si contratual e previamente tornaram obrigatória, à mesma (decisão) devem submeter-se como matéria contratual" ${ }^{\prime 354}$.

LIMA, Leandro Rigueira Rennó. "O Procedimento Cautelar Pré-Arbitral da CCI”. Revista Brasileira de Arbitragem, n. ${ }^{\circ}$ 18. São Paulo: IOB/CBAr, abr/mai/jun de 2008, pp. 60/79.

353 “Artigo 29 - Árbitro de emergência - 1 A parte que necessitar de uma medida urgente cautelar ou provisória que não possa aguardar a constituição de um tribunal arbitral ('medidas urgentes') poderá requerer tais medidas nos termos das Regras sobre o Ấrbitro de Emergência dispostas no Apêndice V. Tal solicitação só será aceita se recebida pela Secretaria antes da transmissão dos autos ao tribunal arbitral nos termos do artigo 16 e independentemente do fato de a parte que requerer a medida já ter apresentado seu Requerimento de Arbitragem. 2 A decisão do árbitro de emergência tomará a forma de uma ordem. As partes se comprometem a cumprir qualquer ordem proferida pelo árbitro de emergência. $3 \mathrm{~A}$ ordem do árbitro de emergência não vinculará o tribunal arbitral no que tange a qualquer questão, tema ou controvérsia determinada em tal ordem. O tribunal arbitral poderá alterar, revogar ou anular uma ordem ou qualquer modificação a uma ordem proferida pelo árbitro de emergência. $4 \mathrm{O}$ tribunal arbitral decidirá qualquer pedido ou demanda das partes relativo ao procedimento do árbitro de emergência, inclusive a realocação dos custos de tal procedimento e qualquer demanda relativa a ou em conexão com o cumprimento ou não da ordem. 5 Os artigos 29(1)-29(4) e as Regras sobre o Árbitro de Emergência previstas no Apêndice V (coletivamente as 'Disposições sobre o Árbitro de Emergência') serão aplicáveis apenas às partes signatárias, ou seus sucessores, da convenção de arbitragem, que preveja a aplicação do Regulamento e invocada para o requerimento da medida. 6 As Disposições sobre o Árbitro de Emergência não são aplicáveis quando: a) a convenção de arbitragem que preveja a aplicação do Regulamento foi concluída antes da data de entrada em vigor do Regulamento; b) as partes tiverem convencionado excluir a aplicação das Disposições sobre o Árbitro de Emergência; ou c) as partes tiverem convencionado a aplicação de algum outro procedimento pré-arbitral o qual preveja a possibilidade de concessão de medidas cautelares, provisórias ou similares. 7 As Disposições sobre o Árbitro de Emergência não têm a finalidade de impedir que qualquer parte requeira medidas cautelares ou provisórias urgentes a qualquer autoridade judicial competente a qualquer momento antes de solicitar tais medidas e, em circustâncias apropriadas, até mesmo depois de tal solicitação, nos termos do Regulamento. Qualquer requerimento de tais medidas a uma autoridade judicial competente não será considerado como infração ou renúncia à convenção de arbitragem. Quaisquer pedidos e medidas adotadas pela autoridade judicial deverão ser notificados sem demora à Secretaria" (www.iccwbo.org/WorkArea/Download Asset.aspx?id=2147489112. Acessado em 17/11/2012). No Regulamento de Arbitragem e de ADR da CCI ainda consta o "Apêndice V - Regras sobre o árbitro de emergência", divido nos seguintes artigos: "Artigo $1^{\circ}$ Solicitação de Medidas Urgentes"; "Artigo 2. " Nomeação do árbitro de emergência; transmissão dos autos"; "Artigo 3. ${ }^{\circ}$ Impugnação de um árbitro de emergência"; "Artigo 4. ${ }^{\circ}$ Sede dos procedimentos do árbitro de emergência"; "Artigo 5. Procedimento"; "Artigo 6. ${ }^{\circ}$ Ordem"; "Artigo 7. ${ }^{\circ}$ Custos do procedimento do árbitro de emergência"; e "Artigo 8..$^{\circ}$ Regra geral", os quais regulam exatamente o procedimento a ser seguido para o pedido da tutela de urgência.

${ }^{354}$ Cf. MUNIZ, Petrônio R. G. A tutela antecipada no procedimento..., pp. 299/300. 
José MARIA RoSSANI GARCEZ ainda lembra que, nos termos do regulamento da CCI, a utilização do procedimento pré-arbitral não interfere na competência dos árbitros para julgar o mérito da controvérsia ${ }^{355}$.

No Brasil, encontramos a previsão do procedimento préarbitral no regulamento da Câmara de Arbitragem do Mercado - CAM, o qual prevê a nomeação de um "árbitro de apoio" pelo Presidente da CAM para apreciar pedidos de medidas conservativas ou reparatórias de urgência antes da instituição da arbitragem. Referido árbitro de apoio intimará a parte contrária para se manifestar no prazo de quarenta e oito horas ou decidirá a questão inaudita altera parte, quando não houver tempo para a oitiva da parte contrária sem prejuízo da eficácia da medida ${ }^{356}$.

Outra menção da doutrina sobre o assunto é que o "árbitro emergencial", ou o "árbitro de apoio", ou o "terceiro ordenador", responsável pela apreciação da tutela de urgência pré-arbitral, não poderá participar do tribunal arbitral a ser posteriormente constituído, evitando-se, assim, qualquer alegação de imparcialidade ${ }^{357}$.

355 In Medidas cautelares e de antecipação..., p. 219. Nesse mesmo sentido: "os poderes do Terceiro Ordenador de nenhum modo interferem com a jurisdição estatal ou arbitral." (LOBO, Carlos Augusto da Silveira. "O procedimento cautelar pré-arbitral da CCI”. Arbitragem doméstica e internacional. FERRAZ, Rafaella; MUNIZ, Joaquim de Paiva (coord.). Rio de Janeiro: Forense, 2008, pp.55/63, p. 59).

356 "5.1 Medidas de Urgência antes de constituído o Tribunal Arbitral. Caso ainda não tenha sido constituído o Tribunal Arbitral, e se façam necessárias medidas conservatórias ou reparatórias revestidas de caráter de urgência, a fim de prevenir dano iminente ou prejuízo irreparável, a questão poderá ser submetida ao Presidente da Câmara de Arbitragem, que nomeará um integrante do Corpo de Árbitros da Câmara de Arbitragem como árbitro de apoio, cuja função será deliberar sobre a medida de urgência, a qual vigerá até que o Tribunal Arbitral decida sobre a matéria ('Árbitro de Apoio'). Na indicação do Árbitro de Apoio será observado o disposto no art. 13, § $6^{\circ}$ da Lei n ${ }^{\circ}$ 9.307, de 23.9.1996. 5.1.1 O Árbitro de Apoio deverá decidir sobre a medida de urgência após ouvir a parte contrária, que será notificada para manifestar-se no prazo de 48 (quarenta e oito) horas. A medida de urgência poderá ser determinada sem a oitiva da parte contrária, quando for indispensável para a sua eficácia, devendo o árbitro ordenar sua notificação imediata acerca do conteúdo da decisão. 5.1.2 O Árbitro de Apoio que vier a decidir a questão fará jus ao recebimento de remuneração específica, a ser fixada pelo Presidente da Câmara de Arbitragem, observando a Tabela de Custas, e adiantada pela parte que requereu a medida, não podendo o Árbitro de Apoio compor o Tribunal Arbitral que decidirá de forma definitiva a controvérsia, nem qualquer outro que envolva questão conexa. 5.1.3 O Árbitro de Apoio somente poderá ser acionado se a convenção de arbitragem contiver previsão expressa quanto à sua atuação. Caso contrário, a parte deverá requerer diretamente ao Poder Judiciário as medidas conservatórias necessárias à prevenção de dano irreparável ou de difícil reparação, e tal proceder não será considerado renúncia à arbitragem. 5.1.4 A decisão proferida pelo Árbitro de Apoio ou pelo Poder Judiciário poderá ser mantida ou reformulada pelo Tribunal Arbitral a ser constituído." (www.camaradomercado.com.br/InstDownload/nova-regulamentacao.pdf. Acessado em 03/11/2012).

357 Cf. PITOMBO, Eleonora Coelho. Arbitragem e o Poder Judiciário..., p. 109. Também nesse sentido: HANOTIAU, Bernard. "A experiência da cautelar pré-arbitral na CCI”. Revista de Direito Bancário, do Mercado de Capitais, da Arbitragem, ano 5, n. ${ }^{\circ}$ 17. WALD, Arnoldo (coord.). São Paulo: RT, jul/set de 2002, pp. 325/328. Ainda quanto ao tema, o artigo 37 (6) do "International Dispute Resolution Procedures (Including Mediation and Arbitration Rules)" (Procedimento para Resolução de Disputas Internacionais - 
Diante da celeridade do procedimento pré-arbitral, em que um único árbitro deverá analisar uma tutela de urgência em um curto período de tempo, é recomendável que seja exigida caução da parte beneficiada para o deferimento da liminar.

Nessa esteira, frise-se que o artigo 37 (7) do "International Dispute Resolution Procedures (Including Mediation and Arbitration Rules)" (Procedimento para Resolução de Disputas Internacionais - Incluindo Regras de Mediação e Arbitragem) da American Arbitration Association - AAA condiciona o deferimento de uma tutela de urgência de emergência à caução pela parte beneficiada ${ }^{358}$.

Enfim, o procedimento pré-arbitral consiste em se atribuir previamente a um terceiro, por meio de cláusula compromissória ou do compromisso arbitral, a competência para decidir, em caráter provisório, a tutela de urgência que a ele for submetida, cabendo ao juízo arbitral definitivo, após a sua devida instituição, confirmar ou revogar tal decisão.

A grande vantagem do procedimento pré-arbitral com relação à tutela de urgência prévia à instituição da arbitragem perante o Poder Judiciário é que a decisão que aprecia a medida urgente será proferida por um árbitro da própria câmara arbitral que será responsável pela condução da futura arbitragem, tratando-se de pessoa

Incluindo Regras de Mediação e Arbitragem) da AAA - American Arbitration Association proíbe a participação do árbitro emergencial no painel arbitral, a não ser que as partes decidam de outra forma: "Emergency Measures of Protection - Article 37 (...) 6. The emergency arbitrator shall have no further power to act after the tribunal is constituted. Once the tribunal has been constituted, the tribunal may reconsider, modify or vacate the interim award or order of emergency relief issued by the emergency arbitrator. The emergency arbitrator may not serve as a member of the tribunal unless the parties agree otherwise." (trad. livre: "Medidas de Proteção de Emergência - Artigo 37 (...) 6. O árbitro emergencial não deverá ter mais qualquer poder para atuar após a instituição do tribunal arbitral. Uma vez constituído, o tribunal arbitral poderá reconsiderar, modificar ou revogar a medida provisória ou ordem de alívio de emergência proferida pelo árbitro emergencial. $\mathrm{O}$ árbitro emergencial não poderá servir como um membro do tribunal arbitral a não ser que as partes concordem com isso."). (www.adr.org/aaa/faces/rules/searchrules/ rulesdetail?doc. Acessado em 27/10/2012). No mesmo sentido, o artigo 5.1.2 do regulamento da Câmara de Arbitragem do Mercado-CAM: "5.1.2 O Árbitro de Apoio que vier a decidir a questão fará jus ao recebimento de remuneração específica, a ser fixada pelo Presidente da Câmara de Arbitragem, observando a Tabela de Custas, e adiantada pela parte que requereu a medida, não podendo o Árbitro de Apoio compor o Tribunal Arbitral que decidirá de forma definitiva a controvérsia, nem qualquer outro que envolva questão conexa." (www.camaradomercado. com.br/InstDownload/nova-regulamentacao.pdf. Acesso em 03/11/2012).

${ }^{358}$ Eis os termos desse artigo: "Emergency Measures of Protection - Article 37 (...) 7. Any interim award or order of emergency relief may be conditioned on provision by the party seeking such relief of appropriate security." (trad. livre: "Medidas de Proteção de Emergência - Artigo 37 (...) 7. Qualquer medida provisória ou ordem de alívio de emergência deve ser condicionada ao fornecimento da garantia apropriada pela parte interessada.") (www.adr.org/aaa/faces/rules/searchrules/rulesdetail?doc. Acessado em 27/10/2012). 
com expertise no assunto e habituado com o processo arbitral, o que faz com que referida decisão seja menos apta à posterior revisão pelos árbitros do que uma decisão proferida de forma urgente e precária pelo juízo comum (o qual, muitas vezes, sequer tem condições de apreciar todos os argumentos e os documentos trazidos pela parte, diante do volume de trabalho diário) $)^{359}$.

Esse procedimento pré-arbitral é pouco utilizado no Brasil, uma vez que a maioria das câmaras arbitrais pátrias, notadamente as de maior renome, não possuem regulamento específico, preferindo, ao invés disso, ressalvar a competência do Poder Judiciário para a apreciação e a concessão das tutelas de urgência antes da instituição da arbitragem ${ }^{360}$.

Isso não quer dizer que tal procedimento pré-arbitral não seja autorizado no Brasil ${ }^{361}$. Muito pelo contrário, como as partes já possuem a faculdade de renunciar à jurisdição estatal por meio da escolha da arbitragem, é perfeitamente possível que elas estabeleçam as regras para a adoção de um procedimento pré-arbitral por meio de cláusula compromissória ou de compromisso arbitral, até mesmo porque, como bem assevera CARlos Augusto da Silveira Lobo, nem sempre a arbitragem é capaz de prover a tempo a tutela de urgência pretendida ${ }^{362}$.

\footnotetext{
${ }^{359}$ Nesse diapasão: "Outra consideração (...) poderia enfatizar a conveniência da concessão de liminares em cautelares antes de se ter constituído o procedimento arbitral por árbitros ou figuras com outra denominação, mas nomeadas pelas partes para esses efeitos. É o simples fato de que a arbitragem ocorrerá e a medida cautelar anterior poderá ser cassada ou ter de ser cassada ao curso do procedimento da arbitragem, colocando numa posição mais frágil ou problemática a cautelar quando esta for concedida pelo poder judiciário anteriormente à instauração do processo arbitral. Por isso a criatividade dos juristas e contratualistas em nível internacional criou a figura da cautelar pré-arbitral, a ser concedida, no mesmo hábitat, por experts da mesma ambiência, de acordo com as regras da mesma entidade que administrará a arbitragem." (GARCEZ, José Maria Rossani. Medidas cautelares e de antecipação..., p. 220); e "O juízo estatal, embora possa propiciar liminares em curtíssimo prazo, freqüentemente conduz o exame da matéria a juiz ou tribunal não familiarizado com os aspectos técnicos ou com as especialidades do objeto do contrato, capaz de inteirar-se dos fatos a ponto de bem decidir sobre a medida a ser determinada, no curto tempo que ela requer para ter eficácia." (LOBO, Carlos Augusto da Silveira. O procedimento cautelar pré-arbitral da CCI..., p. 56).

${ }^{360}$ Conforme exemplos trazidos na "nota 304" acima.

361 Em sentido oposto, há acórdão do TJ/SP pontificando que "não é aceitável que as partes ajustem previamente a exclusão das medidas cautelares urgentes da apreciação do juízo estatal." (5. Câm. Dir. Privado, Apelação cível com revisão n. ${ }^{\circ}$ 0123750-69.2005.8.26.0000 - n. ${ }^{\circ}$ antigo 431.916-4/3-00, Rel. Des. Silvério Ribeiro, j. 11/06/2008, v.u.). Contudo, referido acórdão não faz menção expressa ao procedimento pré-arbitral, sendo certo, ainda, que esse decisum estava reformando decisão monocrática que julgou extinta ação cautelar em virtude da existência de cláusula compromissória e, portanto, estava reforçando a impossibilidade de a parte ficar sem qualquer opção quando necessita de uma tutela de urgência e a arbitragem ainda não está instaurada.

${ }^{362}$ LOBO, Carlos Augusto da Silveira. O procedimento cautelar pré-arbitral da CCI..., p. 56.
} 
Deve-se ressaltar, apenas, que tal procedimento pré-arbitral deve ter sido expressamente aceito e regulado pelas partes, uma vez que, no silêncio, prevalece o direito de elas se socorrerem ao Poder Judiciário ${ }^{363}$.

\subsection{NECESSIDADE DE COGNIÇÃO DA CONVENČ̃̃ DE ARBITRAGEM}

Como visto acima, para que o procedimento pré-arbitral possa ser utilizado pelas partes, é preciso que ele esteja devidamente previsto na convenção de arbitragem firmada entre elas.

No Brasil, a convenção de arbitragem deverá, obrigatoriamente, ser estipulada por escrito para que tenha validade ${ }^{364}$.

A exigência de a convenção de arbitragem ser escrita também existe na Alemanha ${ }^{365}$, na Itália ${ }^{366}$, em Portugal ${ }^{367}$, na França ${ }^{368}$, na Inglaterra ${ }^{369}$ e na Argentina $^{370}$, dentre outros ${ }^{371}$.

\footnotetext{
${ }^{363}$ No mesmo sentido: PITOMBO, Eleonora Coelho. Arbitragem e o Poder Judiciário..., pp. 109/110. O artigo 5.1.3 do regulamento da Câmara de Arbitragem do Mercado-CAM, ressalta a necessidade da expressa anuência das partes com relação ao procedimento pré-arbitral: "5.1.3 O Árbitro de Apoio somente poderá ser acionado se a convenção de arbitragem contiver previsão expressa quanto à sua atuação. Caso contrário, a parte deverá requerer diretamente ao Poder Judiciário as medidas conservatórias necessárias à prevenção de dano irreparável ou de difícil reparação, e tal proceder não será considerado renúncia à arbitragem." (www.camaradomercado.com.br/InstDownload/nova-regulamentacao.pdf. Acessado em 03/11/2012).

${ }^{364}$ Em nosso país, a arbitragem poderá ser convencionada por cláusula compromissória ou por compromisso arbitral. Nos termos do parágrafo $1 .^{\circ}$ do artigo $4 .^{\circ}$ da Lei n..$^{\circ}$ 9.307/96, a clásula compromissória deverá ser escrita para que seja válida: “Art. $4^{\circ}$ (...) $\S 1^{\circ}$ A cláusula compromissória deve ser estipulada por escrito, podendo estar inserta no próprio contrato ou em documento apartado que a ele se refira". Nesse sentido, por todos, cite-se a lição de ALEXANDRE FREITAS CÂMARA: "a cláusula compromissória deve ter forma escrita, podendo constar do próprio contrato a que se refere ou de ato separado que a ele faça menção." (in Arbitragem..., p. 24). O mesmo ocorre com o compromisso arbitral, que pode ser judicial ou extrajudicial, nos termos do artigo 9. ${ }^{\circ}$ da Lei de Arbitragem: “Art. $9^{\circ} \mathrm{O}$ compromisso arbitral é a convenção através da qual as partes submetem um litígio à arbitragem de uma ou mais pessoas, podendo ser judicial ou extrajudicial. $\S 1^{\circ} \mathrm{O}$ compromisso arbitral judicial celebrar-se-á por termo nos autos, perante o juízo ou tribunal, onde tem curso a demanda. $\S 2^{\circ} \mathrm{O}$ compromisso arbitral extrajudicial será celebrado por escrito particular, assinado por duas testemunhas, ou por instrumento público".

${ }^{365} \mathrm{Na}$ Alemanha, a convenção de arbitragem deve ser escrita e pode estar contida em um contrato ou em cartas, telegramas, fax etc.: "Section 1031 - Form of arbitration agreement (1) The arbitration agreement shall be contained either in a document signed by the parties or in an exchange of letters, telefaxes, telegrams or other means of telecommunication which provide a record of the agreement." (tradução livre: "Seção 1031 - Forma da convenção arbitral (1) A convenção arbitral pode estar contida tanto em um documento assinado pelas partes como em uma troca de carta, faxes, telegramas ou qualquer outro meio de telecomunicação que forneça o registro da convenção.”).

${ }^{366} \mathrm{Na}$ Itália, a convenção arbitral também deve ser escrita: “Art. 807. (Compromesso) Il compromesso deve, a pena di nullita', essere fatto per iscritto e determinare l'oggetto della controversia. La forma scritta s'intende rispettata anche quando la volonta' delle parti e' espressa per telegrafo, telescrivente, telefacsimile
} 
o messaggio telematico nel rispetto della normativa, anche regolamentare, concernente la trasmissione e la ricezione dei documenti teletrasmessi." (tradução livre: “Art. 807. (Compromisso) O compromisso deve, sob pena de nulidade, ser feito por escrito e determinar o objeto da controvérsia. A forma escrita se entende respeitada inclusive quando a vontade das partes é expressa por telégrafo, telex, fax ou mensagem eletrônica, respeitadas as normas, e também regulamentos, concernentes à transmissão e recepção de documentos teletransmitidos". O artigo 669-octies equipara a cláusula compromissória ao compromisso arbitral, ao estatuir que: "Art. 669-octies. (Provvedimento di accoglimento) (...) Nel caso in cui la controversia sia oggetto di compromesso o di clausola compromissoria, la parte, nei termini di cui ai commi precedenti, deve notificare all'altra un atto nel quale dichiara la propria intenzione di promuovere il procedimento arbitrale, propone la domanda e procede, per quanto le spetta, alla nomina degli arbitri." (trad. livre: "Art. 669-oitavo (Procedimento de acolhimento) No caso em que a controvérsia seja objeto de compromisso ou de cláusula compromissória, a parte, nos termos dos artigos precedentes, deve notificar a outra parte por meio de um ato no qual declara a própria intenção de promover o procedimento arbitral, propõe a demanda e procede, no que lhe disser respeito, à nomeação dos árbitros.").

${ }^{367}$ Em Portugal, o artigo 2..$^{\circ}$ da Lei n. ${ }^{\circ}$ 63/2011 também prevê a forma escrita da convenção de arbitragem: “Artigo 2. ${ }^{\circ}$ Requisitos da convenção de arbitragem; sua revogação 1 - A convenção de arbitragem deve adoptar forma escrita. 2 - A exigência de forma escrita tem-se por satisfeita quando a convenção conste de documento escrito assinado pelas partes, troca de cartas, telegramas, telefaxes ou outros meios de telecomunicação de que fique prova escrita, incluindo meios electrónicos de comunicação. 3 - Considera-se que a exigência de forma escrita da convenção de arbitragem está satisfeita quando esta conste de suporte electrónico, magnético, óptico, ou de outro tipo, que ofereça as mesmas garantias de fidedignidade, inteligibilidade e conservação".

${ }^{368} \mathrm{Na}$ França, antes da reforma de 2011, os arts. 1442 a 1446 do Código de Processo Civil francês regulavam a cláusula compromissória: “Arte. 1442 (Créé par Décret 81-500 1981-05-12 arte. 5 JORF 14 mai 1981 rectificatif JORF 21 mai 1981) La clause compromissoire est la convention par laquelle les parties à un contrat s'éngagement à soumettre à l'arbitrage les litiges qui pourraient naître relativement à ce contrat." (trad. livre: "Art. 1442 (Decreto n. ${ }^{\circ} 81-500$ de 12 de maio de 1981, Diário Oficial de 14 de maio de 1981, emenda JORF de 21 de maio de 1981) A cláusula compromissória é a convenção por meio da qual as partes de um contrato se comprometem a submeter à arbitragem os litígios que possam surgir relativos ao contrato.”); “Arte. 1443 (Créé par Décret 81-500 1981-05-12 arte. 5 JORF 14 mai 1981 rectificatif JORF 21 mai 1981) La clause compromissoire doit, à peine de nullité, être stipulée par écrit dans la convention principale ou dans un document auquel celle-ci si se réfère. Sous la même sanction, la clause compromissoire doit, soit designer le ou les arbitres, soit prévoir les modalités de leur désignation." (trad. livre: “Art. 1443 (Decreto n. ${ }^{\circ}$ 81-500 de 12 de maio de 1981, Diário Oficial de 14 de maio de 1981, emenda JORF de 21 de maio de 1981) A cláusula compromissória deve, sob pena de nulidade, ser estipulada por escrito no contrato principal ou em um documento que se refere àquele. Sob a mesma pena, a cláusula compromissória deve, ou indicar o ou os árbitros, ou prever os meios de sua designação."; (...) "Arte. 1446 (Créé par Décret 81-500 1981-05-12 arte. 5 JORF 14 mai 1981 rectificatif JORF 21 mai 1981) Lorsqu'elle est nulle, la clause compromissoire est réputée non écrite." (trad. livre: Art. 1446 (Decreto n. ${ }^{\circ}$ 81-500 de 12 de maio de 1981, Diário Oficial de 14 de maio de 1981, emenda JORF de 21 de maio de 1981) Se for nula, a cláusula compromissória será considerada não escrita.”). Após o Decreto n. ${ }^{\circ}$ 2011-48, de 13 de janeiro de 2011, a arbitragem passou a ser regulada pelos artigos 1442 a 1527 do Código de Processo Civil francês, tendo o artigo 1442 equiparado a cláusula compromissória ao compromisso arbitral: "Arte. 1442. La convention d'arbitrage prend la forme d'une clause compromissoire ou d'un compromis. La clause compromissoire est la convention par laquelle les parties à un ou plusieurs contrats s'engagent à soumettre à l'arbitrage les litiges qui pourraient naître relativement à ce ou à ces contrats. Le compromis est la convention par laquelle les parties à un litige né soumettent celui-ci à l'arbitrage." (trad. livre: "Art. 1442. A convenção de arbitragem pode ser na forma de uma cláusula compromissória ou de um compromisso arbitral. A cláusula compromissória é a convenção por meio da qual as partes de um ou mais contratos se comprometem a submeter à arbitragem os litígios que possam surgir relativos ao ou aos contratos. O compromisso arbitral é a convenção por meio da qual as partes de um litígio submetem-no à arbitragem."). O artigo 1443 manteve a necessidade da convenção arbitral por escrito: “Arte. 1443. A peine de nullité, la convention d'arbitrage est écrite. Elle peut résulter d'un échange d'écrits ou d'un document auquel il est fait référence dans la convention principale." (trad. livre: "Art. 1443. Sob pena de nulidade, a convenção de arbitragem deve ser escrita. Ela pode resultar de uma troca de comunicações por escrito ou de um documento que faça referência ao contrato principal.”).

${ }^{369}$ NEIL ANDREWS ensina que "the English Arbitration Act 1996 requires the arbitration agreement to be in writing." (trad. livre: "a Lei de Arbitragem Inglesa de 1996 exige que a convenção de arbitragem seja por escrito.”) (Arbitration and mediation in England..., p. 112), citando a seção 3 do Arbitration Act 1996. 
Nesse diapasão, certamente será mais comum que o procedimento pré-arbitral esteja previsto em uma cláusula compromissória do que em um compromisso arbitral. Isso porque é mais fácil e lógico que as partes convencionem a adoção do procedimento pré-arbitral por meio de cláusula compromissória (prevendo a resolução de eventual futuro conflito por meio da arbitragem e do procedimento préarbitral - para as tutelas de urgência que se fizerem necessárias), do que firmem um compromisso arbitral prevendo a imediata adoção do procedimento pré-arbitral quando já se encontram em litígio e já necessitam de uma tutela de urgência.

E estando o procedimento pré-arbitral previsto em uma cláusula compromissória, esta deverá ser cheia, estabelecendo de forma detalhada e completa o procedimento pré-arbitral a ser seguido, ou adotando um procedimento préarbitral já existente de alguma câmara de arbitragem ${ }^{372}$, uma vez que a cláusula compromissória vazia praticamente impossibilita a adoção do procedimento pré-arbitral pelas partes, as quais ainda precisarão pactuar as regras da futura arbitragem.

\footnotetext{
370 “Art. 736. (...) La sujeción a juicio arbitral puede ser convenida en el contrato o en un acto posterior. (...) Forma del Compromiso. Art. 739. El compromiso deberá formalizarse por escritura pública o instrumento privado, o por acta extendida ante el juez de la causa, o ante aquél a quien hubiese correspondido su conocimiento." (trad. livre: "Art. 736. (...) A sujeição ao juízo arbitral pode ser convencionada no contrato ou em um ato posterior (...) Forma do Compromisso. Art. 739. O compromisso deverá ser formalizado por escritura pública ou instrumento privado, ou por ata assinada perante o juiz da causa, ou perante aquele a quem teve correspondido seu conhecimento.").

${ }^{371}$ A convenção de Nova Iorque, que dispõe sobre o reconhecimento e a execução de sentenças arbitrais estrangeiras, também prevê a convenção de arbitragem (cláusula compromissória ou compromisso arbitral) por escrito: "Artigo II - 1. Cada Estado signatário deverá reconhecer o acordo escrito pelo qual as partes se comprometem a submeter à arbitragem todas as divergências que tenham surgido ou que possam vir a surgir entre si no que diz respeito a um relacionamento jurídico definido, seja ele contratual ou não, com relação a uma matéria passível de solução mediante arbitragem. 2. Entender-se-á por 'acordo escrito' uma cláusula arbitral inserida em contrato ou acordo de arbitragem, firmado pelas partes ou contido em troca de cartas ou telegramas. 3. O tribunal de um Estado signatário, quando de posse de ação sobre matéria com relação à qual as partes tenham estabelecido acordo nos termos do presente artigo, a pedido de uma delas, encaminhará as partes à arbitragem, a menos que constate que tal acordo é nulo e sem efeitos, inoperante ou inexeqüível. Convenção de Nova Iorque". CARMONA anota que esse "Tratado adotou o conceito de convenção arbitral", bem como que "a regra formal que o Tratado de Nova Iorque estabelece para a convenção de arbitragem reside apenas na necessidade de ser o compromisso ou a cláusula celebrada por escrito", podendo a convenção arbitral ser pactuada por meio de cartas ou telegramas, não havendo a obrigatoriedade da assinatura de instrumento contratual pelas partes (in Arbitragem e Processo..., p. 98).

${ }^{372}$ Nesse sentido: "De tal cláusula [compromissória] pode constar a referência às regras de alguma entidade especializada em arbitragem, ou a algum órgão arbitral institucional, caso em que a arbitragem deverá ser instituída de acordo com essas regras." (CÂ̂MARA, Alexandre Freitas. Arbitragem..., p. 25). Quanto ao procedimento pré-arbitral da CCI, CARlos Augusto da Silveira Lobo anota que, "no preâmbulo do Regulamento, a CCI recomenda a adoção de uma cláusula padrão, prevendo o Procedimento Cautelar PréArbitral da CCI." (O procedimento cautelar pré-arbitral da CCI..., p. 57).
} 
Quanto ao tema, lembra-se que a cláusula compromissória guarda plena autonomia em relação ao contrato ou ao documento em que estiver inserida (artigo 8. ${ }^{\circ}$, caput, da Lei de Arbitragem) ${ }^{373}$, permanecendo válida ainda que o contrato ou o documento seja considerado nulo ${ }^{374}$.

Ainda quanto ao tema, cumpre ao(s) próprio(s) árbitro(s) decidir(em) acerca da validade da cláusula compromissória ${ }^{375}$ (artigo 8..$^{\circ}$ § único, da Lei de Arbitragem - princípio da kompetenz-kompetenz $)^{376}$.

373 “Art. $8^{\circ}$ A cláusula compromissória é autônoma em relação ao contrato em que estiver inserta, de tal sorte

que a nulidade deste não implica, necessariamente, a nulidade da cláusula compromissória".
${ }_{374}$ Nesse sentido, por todos, CARLOS ALBERTO CARMONA confirma que "a cláusula compromissória recebe da Lei natural autonomia em relação ao contrato onde eventualmente vier inserida. E é natural que assim seja, até porque a nulidade (ou anulabilidade) do contrato poderá ser submetida à decisão dos árbitros, tudo a pressupor a separação da cláusula do restante do contrato." (Arbitragem e Processo..., p. 173). Na Alemanha, a cláusula compromissória também possui autonomia, nos termos do § 1040, (1), in fine, da ZPO: "For that purpose, an arbitration clause which forms part of a contract shall be treated as an agreement independent of the other terms of the contract." (trad. livre: "Para esse propósito, uma cláusula compromissória arbitral que faz parte de um contrato deve ser considerada como um acordo independente dos outros termos do contrato."). O mesmo ocorre na Itália, nos termos do art. 808, in fine, do CPC italiano: "Art. 808. (Clausola compromissoria) (...) La validitá della clausola compromissoria deve essere valutata in modo autonomo rispetto al contratto al quale si riferisce; tuttavia, il potere di stipulare il contratto comprende il potere di convenire la clausola compromissoria." (trad. livre: “Art. 808. (Cláusula compromissória) (...) A validade da cláusula compromissória deve ser avaliada de modo autônomo em respeito ao contrato a que se refere; todavia, o poder de pactuar o contrato compreende o poder de concordar com a cláusula compromissória.”). $\mathrm{Na}$ França, a reforma de 2011 manteve a autonomia da cláusula compromissória: "Arte. 1447. La convention d'arbitrage est indépendante du contrat auquel elle se rapporte. Elle n'est pás affectée par l'inefficacité de celui-ci. Lorsqu'elle est nulle, la clause compromissoire est réputée non écrite." (tradução livre: Art. 1447. A convenção de arbitragem é independente do contrato a que se refere. Ela não será afetada se tal contrato for nulo. Se for nula, a cláusula compromissória será considerada não escrita"). Na Inglaterra, "a cláusula arbitral poderá ser válida mesmo se o contrato principal não for." (ANDREWS, Neil. Arbitration and mediation in England..., p. 112, tradução livre). Por fim, em Portugal, é reconhecida igualmente a autonomia da cláusula compromissória pelo art. 18. ", "2" e "3", da Lei n. ${ }^{\circ}$ 63/2011: "Artigo 18. ${ }^{\circ}$ Competência do tribunal arbitral para se pronunciar sobre a sua competência (...) 2 - Para os efeitos do disposto no número anterior, uma cláusula compromissória que faça parte de um contrato é considerada como um acordo independente das demais cláusulas do mesmo. 3 - A decisão do tribunal arbitral que considere nulo o contrato não implica, só por si, a nulidade da cláusula compromissória".

${ }_{375}$ Nesse sentido: CARMONA, Carlos Alberto. Arbitragem e Processo..., p. 175.

376 "Art. 8. ${ }^{\circ}$ (...) Parágrafo único. Caberá ao árbitro decidir de ofício, ou por provocação das partes, as questões acerca da existência, validade e eficácia da convenção de arbitragem e do contrato que contenha a cláusula compromissória”. Foi na Alemanha que surgiu o princípio da kompetenz-kompetenz, o qual estatui que o árbitro é competente para apreciar a validade da convenção arbitral, hoje previsto no § 1040, (1), da ZPO: "Section 1040 Competence of arbitral tribunal to rule on its jurisdiction (1) The arbitral tribunal may rule on its own jurisdiction and in this connection on the existence or validity of the arbitration agreement. For that purpose, an arbitration clause which forms part of a contract shall be treated as an agreement independent of the other terms of the contract." (trad. livre: "Seção 1040 - Competência do tribunal arbitral para decidir sobre sua jurisdição. (1) $\mathrm{O}$ tribunal arbitral poderá decidir sobre a sua própria jurisdição e sobre a existência e validade da convenção arbitral. Para esse propósito, uma cláusula compromissória arbitral que faz parte de um contrato deve ser considerada como um acordo independente dos outros termos do contrato."). Na França, também é dos árbitros a competência para decidir sobre o seu poder jurisdicional: "Arte. 1465. Le tribunal arbitral est seul compétent pour statuer sur les contestations relatives à son pouvoir juridictionnel." (trad. livre: Art. 1465. O tribunal arbitral é o único competente para decidir as objeções relativas ao seu poder jurisdicional.”). O mesmo ocorre em Portugal, onde o árbitro é competente para analisar a 
Assim, caberá ao árbitro emergencial, de apoio ou ao terceiro ordenador, responsável pela apreciação da tutela de urgência pré-arbitral, verificar a regularidade da convenção de arbitragem, analisando (i) se esta prevê o procedimento préarbitral, (ii) se tal procedimento foi devidamente aceito e regulado pelas partes, (iii) se as partes foram regularmente representadas ao pacturem a convenção de arbitragem etc. ${ }^{377}$.

Por exemplo, se uma cláusula compromissória prevendo o procedimento pré-arbitral estiver contida em um contrato de adesão, o árbitro emergencial deverá atentar se foram cumpridos os requisitos específicos previstos no parágrafo $2 .^{\circ}$ do artigo $4 .^{\circ}$ da Lei de Arbitragem brasileira ${ }^{378}$.

E caso o árbitro emergencial, o árbitro de apoio ou o terceiro ordenador verifique a existência de alguma irregularidade na convenção de arbitragem, ele não poderá analisar e conduzir o procedimento pré-arbitral, por ausência de poderes jurisdicionais, evitando-se, assim, a futura anulação da decisão arbitral de urgência ${ }^{379}$.

regularidade da convenção de arbitragem, conforme o disposto no art. 18. o, “1”, da Lei n. ${ }^{\text {o } 63 / 2011: ~ " C a p i ́ t u l o ~}$ III - Da competência do tribunal arbitral. Artigo $18 .^{\circ}$ Competência do tribunal arbitral para se pronunciar sobre a sua competência. 1 - O tribunal arbitral pode decidir sobre a sua própria competência, mesmo que para esse fim seja necessário apreciar a existência, a validade ou a eficácia da convenção de arbitragem ou do contrato em que ela se insira, ou a aplicabilidade da referida convenção". Na Inglaterra, "o árbitro pode, ele mesmo, decidir se a cláusula arbitral relevante é válida, e se ela confere autoridade ao mesmo para decidir a presente referência arbitral." (ANDREWS, Neil. Arbitration and mediation in England..., p. 112, trad. livre).

377 Nessa linha, Julian M. LEW, LOUKAS A. Mistelis e STEFAN MiCHAEL KRÖLl lecionam que: "The arbitration tribunal must at least have prime facie jurisdiction in the main action. Otherwise it also lacks jurisdiction to order the interim relief." (tradução livre: "O tribunal arbitral deverá ao menos ter jurisdição prima facie para a ação principal. Caso contrário, ele não terá jurisdição para conceder a medida liminar.”) (Comparative International..., p. 609).

378 “Art. $4^{\circ}(\ldots) \S 2^{\circ}$ Nos contratos de adesão, a cláusula compromissória só terá eficácia se o aderente tomar a iniciativa de instituir a arbitragem ou concordar, expressamente, com a sua instituição, desde que por escrito em documento anexo ou em negrito, com a assinatura ou visto especialmente para essa cláusula". Na Alemanha, também há o cuidado com os contratos de adesão e com o consumidor (que, via de regra, é quem adere a tais contratos): "Section 1031. (5) Arbitration agreements to which a consumer is a party must be contained in a document which has been personally signed by the parties. The written form pursuant to subsection 1 may be substituted by electronic form pursuant to section 126 a of the Civil Code ('Bürgerliches Gesetzbuch-BGB'). No agreements other than those referring to the arbitral proceedings may be contained in such a document or electronic document; this shall not apply in the case of a notarial certification" (trad. livre: "Seção 1031. (5) Convenções de arbitragem das quais um consumidor seja parte devem estar contidas em um documento pessoalmente assinado pelas partes. A forma escrita prevista na subseção 1 poderá ser substituída pela forma eletrônica conforme a seção 126 a do Código Civil ('Bürgerliches Gesetzbuch $B G B^{\prime}$ '). Nenhuma outra convenção que não aquela que se refere ao procedimento arbitral poderá estar contida em referido documento ou arquivo eletrônico; essa regra não será aplicada em caso de certificação notarial"). O mesmo ocorre na Inglaterra, conforme o disposto nos artigos 89 a 91 do Arbitration Act de 1996.

${ }^{379}$ Em caso interessante, o juízo da 4. ${ }^{\text {a }}$ Vara Cível da Comarca de Barueri-SP anulou sentença arbitral por entender haver falha na convenção de arbitragem, a qual teria sido assinada por procurador sem poderes específicos para tanto, mesmo tendo o árbitro considerado válida a convenção de arbitragem pela aplicação da teoria da aparência (autos n. ${ }^{\circ}$ 068.01.2011.012802-6). 
Ainda com relação à cláusula compromissória, esclarece-se, por oportuno, que nos termos da Súmula 485 do STJ: “A Lei de Arbitragem aplica-se aos contratos que contenham cláusula arbitral, ainda que celebrados antes da sua edição” ${ }^{\text {380 }}$.

Dessa feita, mesmo que a cláusula compromissória prevendo a utilização do procedimento pré-arbitral esteja contida em contrato ou em documento firmado antes da entrada em vigor da Lei n. ${ }^{\circ}$ 9.307/96, ela será vinculante e aplicar-se-ão ao caso as disposições da Lei de Arbitragem brasileira ${ }^{381}$.

\section{TUTELA ANTECIPADA PRÉVIA À INSTAURAČ̃̃o DA ARBITRAGEM}

Com relação especificamente à antecipação da tutela préarbitral, há poucos trabalhos que enfrentam a fundo o tema.

De fato, embora no plano doutrinário alguns autores se manifestem favoravelmente à concessão da tutela antecipada pré-arbitral, a maioria deles não se aprofunda na questão, deixando de enfrentar os principais problemas ligados ao assunto, quais sejam: o eventual pré-julgamento do litígio pelo Poder Judiciário e o

\footnotetext{
${ }^{380}$ Publicada no Diário da Justiça eletrônico de 01/08/2012. Essa súmula veio confirmar o entendimento esposado pelo STJ no REsp 712.566RJ (3. ${ }^{a}$ Turma, Rel. Min. Nancy Andrighi, DJ 05/09/2005), na SEC 507/EX (Corte Especial, Rel. Min. Gilson Dipp, DJ 13/11/2006), nos EDcl na SEC 507/GB (Corte Especial, Rel. Min. Gilson Dipp, DJ 05/02/2007), na SEC 349/JP (Corte Especial, Rel. Min. Eliana Calmon, j. 21/03/2007, DJ 21/05/2007, p. 528 - "As disposições da Lei 9.307/96 têm incidência imediata nos contratos celebrados antecedentemente, se neles estiver inserida a cláusula arbitral" e "a arbitragem é instituto eminentemente processual, razão pela qual a lei que regula o instituto aplica-se de imediato aos feitos pendentes e a fortiori aos que ainda não se iniciaram" - voto-vista do Min. Luiz Fux), na SEC 839/EX (Corte Especial, Rel. Min. Cesar Asfor Rocha, DJ 13/08/2007), na SEC 831/FR (Corte Especial, Rel. Min. Arnaldo Esteves Lima, DJ 19/11/2007), no AgRg na MC n. ${ }^{\circ}$ 14.130-RJ (1. ${ }^{a}$ Turma, Rel. Min. Denise Arruda, j. 07/10/2008) e no REsp 934.771 (4. ${ }^{a}$ Turma, Rel. Min. Luis Felipe Salomão, j. 25/05/2010, v.u.). No mesmo sentido o entendimento do STF na SEC 5.847-1 (Rel. Min. Maurício Corrêa, DJ 17/12/1999).

${ }^{381} \mathrm{Na}$ Alemanha, a lei prevê o oposto, no sentido de que a efetividade da convenção arbitral firmada antes da entrada em vigor das novas regras (01/01/1998) deverá ser verificada com base na lei anterior: "Transitional provisions - Section 1. Arbitral proceedings - (1) The effectiveness of arbitration agreements that have been concluded prior to the entry into force of this Act, shall be determined according to the law previously in force." (trad. livre: "Regras de transição - Seção 1 - Procedimentos arbitrais. (1) A efetividade da convenção arbitral concluída antes da entrada em vigor deste Ato deverá ser apurada de acordo com a lei previamente em vigor.”). Os itens (2) a (4) desse artigo prevêem que a lei anterior também se aplica às arbitragens em curso, aos processos judiciais em curso que estavam discutindo uma arbitragem e aos acordos arbitrais já concluídos, que aguardam execução. Em Portugal, as disposições transitórias da nova Lei de Arbitragem Voluntária - Lei n. ${ }^{\circ}$ 63, de 14/12/2011, previstas no artigo 4., "1" a "4", também estabelecem que as novas regras somente se aplicam aos processos arbitrais iniciados após a sua vigência (art. 4. . , "1"), ou a arbitragens em curso desde que as partes concordem expressamente (art. 4. ", "2"), garantindo a eficácia da convenção de arbitragem com base na lei anterior (Lei n. . 31/86), especialmente o direito aos recursos (art. 4. o, "3").
} 
descompasso cronológico relativo à antecipação de tutela de processo arbitral ainda não iniciado ou instaurado ${ }^{382}$.

Isso porque, em tese, considerando-se os exatos termos do artigo 273, inciso I, do CPC, não seria possível o pedido de antecipação de tutela sem que o processo arbitral, em que o pedido principal deve ser formulado e analisado, esteja devidamente instituído e em curso ${ }^{383}$.

Em outras palavras: somente com a arbitragem já em trâmite, e com os pedidos já formulados pelas partes em suas razões iniciais, é que seria possível se falar em antecipação, parcial ou total, de um dos pedidos aduzidos no processo arbitral.

Contudo, tendo em vista as peculiaridades envolvendo a instituição de uma arbitragem e, especialmente, em se tratando de uma medida indispensável para evitar o perecimento do direito da parte, deve-se abrir uma exceção e se aceitar que o pedido de antecipação de tutela seja feito em procedimento autônomo, em outros autos, que não os da própria arbitragem (pois ainda não instituída), perante o juízo estatal.

Nesse sentido, José Roberto dos SANTOs Bedaque admite, expressamente, o pedido de antecipação de efeitos da tutela em processo autônomo, em lição que se aplica perfeitamente à hipótese em questão (pedido de antecipação de tutela em processo autônomo perante a justiça comum, diante da impossibilidade de se instituir com a celeridade necessária a arbitragem):

"Também não se pode afastar, de forma absoluta, como pretendem alguns, a possibilidade de a antecipação de efeitos da sentença final ser requerida em procedimento autônomo, antecedente ao pedido de tutela cognitiva. Situações haverá que tornarão admissível e até necessária a adoção dessa

\footnotetext{
${ }^{382}$ Cf. ARMELIN, Donaldo. Tutela de urgência e arbitragem..., p. 374. Por exemplo, PETRÔNIO R. G. MUNIZ escreveu interessante artigo sobre o tema, mas, em seu trabalho, ele se reporta quase que exclusivamente ao procedimento pré-arbitral previsto no regulamento da CCI, deixando de enfrentar a questão à luz da Lei n. ${ }^{\circ}$ 9.307/96 (MUNIZ, Petrônio R. G. A tutela antecipada no procedimento..., pp. 285/302).

${ }^{383}$ Nessa mesma esteira, DONALDO ARMELIN confirma que "não haveria como antecipar os efeitos de um provimento arbitral e emergente de arbitragem ainda não instituída e que, portanto, não tem ainda definida perante o árbitro ou tribunal arbitral a pretensão a ser em face dele formulada. A dicção do art. 273 , I, do CPC reporta-se a uma antecipação, total ou parcial, dos efeitos da tutela pretendida no pedido inicial. Se inexistente ainda esse pedido, porque não proposta ou instituída a arbitragem, não haveria como conceder essa antecipação pré-arbitral." (Tutela de urgência e arbitragem..., p. 369).
} 
técnica, para evitar lesão irreparável ao direito e completa inutilidade da tutela a ser requerida" ${ }^{384}$.

Portanto, deve-se privilegiar, nesse caso, o direito ameaçado da parte e os princípios da efetividade e da instrumentalidade, em detrimento da técnica processual pura e do formalismo exacerbado ${ }^{385}$.

Não são poucos os casos, no dia-a-dia forense, em que se verifica a necessidade de se fazer "vista grossa" à formalidade processual para se evitar o perecimento do direito da parte ${ }^{386}$.

Exemplo clássico é o da sustação de um protesto. Embora tal pedido seja verdadeira antecipação dos efeitos da sentença final acerca da inexigibilidade do título encaminhado a protesto, ele é corriqueiramente deduzido em processo autônomo (equivocadamente chamado de "ação cautelar de sustação de protesto"), especialmente porque, na maioria das vezes, a parte não possui tempo hábil, tampouco a documentação necessária para o ajuizamento da ação principal com pedido de antecipação de tutela ${ }^{387}$.

\footnotetext{
${ }^{384}$ Tutela cautelar e tutela antecipada..., p. 316. Nessa obra, BEDAQUE cita outro exemplo prático em que a tutela antecipada é pleiteada em procedimento autônomo, e não nos próprios autos, qual seja: quando a necessidade da antecipação da tutela surge após a prolação da sentença, mas os autos ainda estão em Primeiro Grau. Nesse caso, a parte deve dirigir petição ao Tribunal, instruída com as peças necessárias, para pleitear a tutela antecipada diretamente ao Tribunal ad quem (Idem, p. 316).

${ }^{385}$ Em igual sentido, DONALDO ARMELIN anota que "a necessidade de preservar um direito ameaçado deverá prevalecer relativamente à técnica processual, que não permite a concessão antecipada de efeitos decorrentes de uma pretensão a ser veiculada em processo não iniciado, a despeito de estarem presentes os pressupostos para a sua concessão." (Tutela de urgência e arbitragem..., p. 370). Profícuo defensor da instrumentalidade das formas e da efetividade, BEDAQUE segue a mesma linha, sustentando que "o aspecto formal em nada influi na natureza da tutela. (...) Além do mais, não se pode excluir definitivamente seja a antecipação requerida em procedimento autônomo. Desde que necessária a utilização dessa técnica em determinada situação concreta, a fim de assegurar a efetividade da tutela, deve ser admitida", concluindo que "questões meramente formais não podem obstar à realização de valores constitucionalmente garantidos." (Tutela cautelar e tutela antecipada..., pp. 316/317).

${ }^{386}$ Aqui, vale ser citada, uma vez mais, a lição de HUMBERTO THEODORO JÚNIOR, para quem o julgador deve se preocupar mais com o direito e com a efetividade do que com o rigor técnico: "[as tutelas de urgência foram] concebidas para conjurar o perigo de dano pela demora do processo e, em muitos casos haverá uma certa dificuldade em descobrir, com rigor, a qual das duas espécies pertence a providência que, in concreto, se vai adotar para contornar o periculum in mora. Para ater-se ao rigor técnico classificatório, o juiz pode correr o risco de denegar a tutela de urgência somente por uma questão formal, deixando assim o litigante privado da efetividade do processo, preocupação tão cara à ciência do direito processual contemporâneo. Com efeito, não é nesse rumo que se orienta esse ramo da ciência jurídica. É reiterado o entendimento de que não é pelo rótulo, mas pelo pedido de tutela formulado, que se deve admitir ou não seu processamento em juízo; assim como é pacífico que não se anula procedimento algum simplesmente por escolha errônea de forma." (Tutela jurisdicional de urgência..., pp. 20/21).

${ }^{387}$ BEDAQUE também cita esse exemplo, mencionando que "o pedido de sustação de protesto, que tem nítido caráter antecipatório de efeitos do futuro provimento sobre a invalidade da cambial, pode ser pleiteado de
} 
Em outras situações extremas, admite-se o ajuizamento de ação cautelar perante o Superior Tribunal de Justiça para se obter efeito suspensivo a recurso especial sequer interposto, ou que sequer foi recebido.

Esses são alguns exemplos em que a efetividade e a necessidade de se evitar o perecimento de um direito prevalecem sobre o formalismo.

A própria fungibilidade entre os provimentos cautelares e as antecipações de tutela autoriza o ajuizamento de uma ação autônoma, perante o juízo estatal, enquanto não instituída a arbitragem, visando à obtenção de uma tutela antecipada, podendo tal procedimento ser considerado de natureza cautelar preparatória.

Uma solução pragmática para a questão é a simples remessa dos autos em foi feito o pedido de antecipação de tutela perante o juízo estatal para o juízo arbitral, assim que este for instaurado, prosseguindo a arbitragem nos mesmos autos que se encontravam na justiça comum e em que foi deduzido o pedido de tutela antecipada ${ }^{388}$.

Um dos poucos a tratar sobre o tema, DONALDO ARMELIN sustenta ser perfeitamente possível a antecipação da tutela pré-arbitral, notadamente nos

forma autônoma, pois muitas vezes a parte interessada ainda não possui todos os elementos necessários para a propositura da demanda principal." (Tutela cautelar e tutela antecipada..., p. 316).

${ }^{388}$ Nesse sentido, a jurisprudência do TJ/MG: "Agravo inominado em agravo de instrumento - Ação cautelar inominada preparatória - Cláusula arbitral - Ajuizamento no juízo estadual - Possibilidade - Indeferimento da medida - Agravo de instrumento - Efeito ativo concedido - Ciência da posterior instauração do juízo arbitral Incompetência superveniente da Justiça Estatal - Remessa dos autos ao arbitro para manutenção ou não da tutela concedida. É da competência plena do juízo arbitral, ao qual se submete o exame da causa, a cognição sobre a oportunidade da medida antecipatória ou acautelatória, ficando apenas sua execução afeta ao juiz estatal, mediante seu poder de coertio e executio, caso a parte resista em cumpri-la espontaneamente. Hipótese excepcional, que enseja a competência do juízo estatal, todavia, é quando, antes da instauração do Juízo Arbitral, com a aceitação da nomeação pelo árbitro, haja necessidade de alguma dessas medidas cautelares ou de urgência. Nesses casos, admite-se que o requerimento seja feito diretamente ao Juiz togado competente para o conhecimento da causa, sujeitando-se, todavia, à ratificação pelo Juízo Arbitral, assim que instaurado, remetendo-lhe os autos, de forma a preservar a competência plena da Jurisdição privada sobre o litígio.” (TJ/MG, 14. ${ }^{a}$ Câm. Cível, Ag. n. ${ }^{\circ}$ 1.0024.07.600275-7/002, Rel. Des. Elias Camilo, j. 17/01/2008, v.u.); “Ação cautelar inominada preparatória - Cláusula arbitral - Ajuizamento da ação no Juízo Estadual Possibilidade - Deferimento da medida - Posterior ajuizamento do procedimento arbitral - Remessa dos autos ao arbitro para manutenção ou não da tutela concedida. Sendo a medida cautelar aviada antes de instaurada a arbitragem é cabível ao juízo estatal a concessão da medida perseguida, devendo, contudo, serem os autos remetidos ao juízo arbitral para que o mesmo aprecie a manutenção ou não da tutela concedida assim que iniciado o procedimento arbitral. De ofício, determinaram a remessa dos autos ao juízo arbitral para manutenção ou não da tutela concedida." (TJ/MG, 12. ${ }^{a}$ Câm. Cível, A.I. n. ${ }^{\circ}$ 1.0480.06.083392-2/001, Rel. Des. Domingos Coelho, j. 14/02/2007, v.u.). 
casos que envolvam o direito à vida (exemplo: prestação pecuniária a ser solicitada em arbitragem para uma cirurgia indispensável à saúde $)^{389}$.

Nessas hipóteses, citando o magistério de BEDAQUE, o mencionado jurista aduz que antecipação da tutela estará dotada de "tônus cautelar", equiparando essa tutela de urgência à antiga e questionada cautelar satisfativa ${ }^{390}$.

Quanto à questão do pré-julgamento da lide que seria de competência do juízo arbitral, quando da apreciação da tutela de urgência pré-arbitral pelo Poder Judiciário, é fato que o Poder Judiciário poderá, eventualmente, antecipar matéria que seria objeto da arbitragem para a apreciação do pedido ${ }^{391}$.

Por exemplo, ao apreciar eventual pedido de antecipação de tutela pré-arbitral, o Poder Judiciário poderá reconhecer a prescrição ou a decadência do direito argüido, ou qualquer outra matéria de ordem pública, cognoscível de ofício ${ }^{392}$.

De qualquer modo, conforme alerta DonALDO ARMELIN, esse "reconhecimento somente produzirá efeitos inerentes à coisa julgada se e quando reconhecidos na arbitragem futura pelos árbitros que nela atuarem"393.

Por essa razão, pode-se afirmar que a antecipação de tutela pré-arbitral deve ser uma exceção, cabível somente nas hipóteses em que haja real e efetivo

\footnotetext{
389 “Como não seria admissível esse vazio de jurisdição, evidenciam-se casos excepcionais, nos quais o risco de dano irreparável se mostre, notadamente quando a antecipação de tutela embora direcionada a direitos disponíveis está conotada a direitos indisponíveis e de superior posição na constelação daqueles que integram o universo jurídico, como é o caso do direito à vida, dependente de uma prestação pecuniária a ser reclamada na arbitragem." (Tutela de urgência e arbitragem..., p. 374).

${ }^{390}$ In Tutela de urgência e arbitragem..., pp. 374/375.

391 JACQUES NORMAND, ao falar sobre os problemas do "référé-provision" (previsão de liminar) perante o juiz estatal, ressalta "que cet aspect particulier du référé implique, par hypothèse, un examen et un appréciation du litige au fond." (trad. livre: "que esse aspecto particular da liminar implica, por hipótese, um exame e uma apreciação do mérito do litígio.”) (Les mesures provisoires et l'arbitrage..., p. 467).

${ }^{392}$ Em sentido contrário, cumpre-se mencionar voto prolatado pela Ministra NANCY ANDRIGHI no Agravo Regimental na Medida cautelar n. ${ }^{\circ}$ 19.226/MS, no qual se pontificou que, "ainda que, na pendência da constituição do Tribunal Arbitral, se admita que a parte se socorra do Poder Judiciário, por intermédio de medida de natureza cautelar, para assegurar o resultado útil da arbitragem, sua atuação ficará limitada à apreciação da tutela de urgência, sendo vedada a incursão no mérito da controvérsia.” (STJ, 3. ${ }^{a}$ Turma, AgRg na MC n. ${ }^{\circ}$ 19.226/MS, Rel. para acórdão Min. Nancy Andrighi, j. 21/06/2012, maioria).

${ }^{393}$ in Tutela de urgência e arbitragem..., pp. 375/376.
} 
risco de perecimento do bem da vida a ser tutelado na arbitragem, sendo plausível e viável, também, a exigência de caução para o seu deferimento ${ }^{394}$.

Em precedentes jurisprudenciais sobre o tema, o Poder Judiciário, ante a urgência da tutela antecipada pleiteada, deferiu a medida liminar, deixando claro, no entanto, que o mérito do litígio deve ser posteriormente apreciado e decidido em sede de arbitragem, a ser obrigatoriamente instaurada pela parte ${ }^{395}$.

\section{$\underline{\text { 18.1. Prazo Para a INSTITUIČ̃̃o da ARBitragem }}$}

A parte que se beneficiou da tutela antecipada pré-arbitral perante o juízo estatal não poderá se manter inerte após a efetivação da medida.

Aplicam-se, aqui, as mesmas regras expostas no "item 16.3" acima, relativo ao prazo para a propositura da arbitragem após a efetivação da medida cautelar pré-arbitral.

Assim, a parte deverá, igualmente, no prazo legal de trinta dias previsto no artigo 806 do CPC (e aplicado analogicamente à hipótese), propor o início

\footnotetext{
${ }^{394}$ Conforme a lição de DONALDO ARMELIN: "Viável será também a possibilidade de exigir caução para o deferimento da antecipação." (Tutela de urgência e arbitragem..., p. 375).

${ }^{395}$ Ementa: "Bem móvel. Cana-de-açúcar. Compra e venda. Ação cautelar para buscar e apreender o produto objeto de venda. Existência de cláusula estipulando juízo arbitral. Previsão contratual possibilitando ajuizamento de ação judicial visando a tutelas emergenciais. 1. A previsão contratual de juízo arbitral não impede a parte de promover ação judicial visando tutelas de emergência, máxime quando o próprio contrato traz exceção, possibilitando à parte valer-se do judiciário para obter providência urgente. 2 . O caráter satisfativo da medida cautelar, que se consumou com a entrega liminar do produto, não impede a apreciação do mérito pelo juízo arbitral, conforme previsto no contrato. 3. Deram provimento ao recurso da autora, prejudicado o da ré". Trecho do voto: "O caráter satisfativo desta ação cautelar, visto que a entrega da canade-açucar já se efetivou com a concessão da liminar, não impede a discussão da controvérsia - a respeito do direito da compradora recorrente à obtenção do produto da ré apelada - pelo juízo arbitral por elas instituído no contrato. E essa discussão, sim, deve ser submetida ao juízo arbitral, em observância estrita ao contrato." (TJ/SP, 25. ${ }^{a}$ Câm. Dir. Privado, Apelação n. ${ }^{\circ}$ 9184314-84.2007.8.26.0000, Rel. Des. Vanderci Álvares, j. 23/11/2011). Ainda: “(...) Embora prevista a instauração de arbitragem, enquanto não instaurada, as partes podem valer-se do Poder Judiciário para obtenção de medida cautelar, ainda que implique antecipação de tutela, sob pena, de assim não sendo, a parte prejudicada não ter tutela jurisdicional à sua disposição (art. $5^{\circ}$, XXXV, CR) (...)” (TJ/SP, 30. ${ }^{a}$ Câm. Dir. Privado, A.I. n. ${ }^{\circ}$ 0112844-10.2011.8.26.0000, Rel. designado Des. Lino Machado, j. 27/07/2011, maioria).
} 
da arbitragem para confirmar ou não a tutela que foi provisoriamente antecipada perante o Poder Judiciário $^{396}$.

É sabido que a legislação pátria não prevê qualquer prazo para a propositura da ação principal nas hipóteses de antecipação de tutela, mas isso se dá, de forma óbvia, porque a tutela antecipada é pleiteada, em regra, nos próprios autos.

Dessa forma, tendo em vista a necessidade de o pedido de antecipação de tutela pré-arbitral ser feito em procedimento autônomo perante o juízo estatal, entendemos ser aplicável ao caso, de forma analógica, o artigo 806 do $\mathrm{CPC}^{397}$.

A parte contrária, que sofreu os efeitos da antecipação da tutela pré-arbitral, também poderá tomar as providências para a instituição da arbitragem, tendo em vista, especialmente, que a decisão proferida pelo juízo estatal poderá ser revista pelo(s) árbitro(s), como se verá a seguir.

\section{REVISÃO, PELO ÁRBITRO, DAS TUTELAS DE URGÊNCIA APRECIADAS PELO JUDICIÁRIO}

A doutrina nacional é praticamente unânime no sentido de ser possível (e mais: de ser até mesmo um dever) o árbitro revisar a decisão provisória e precária proferida pelo Poder Judiciário que apreciou o pedido de tutela de urgência préarbitral, assim que a arbitragem for regularmente instaurada, tendo o juízo arbitral poder

\footnotetext{
${ }^{396}$ PAULO HOFFMAN também afirma "que o prazo do art. 806, nesses casos, valerá qualquer que tenha sido a natureza da tutela concedida, isto é, cautelar, antecipatória etc." (Arbitragem: algumas dúvidas..., p. 320).

${ }^{397}$ Conforme o ensinamento de DONALDO ARMELIN: "Aceitando essa possibilidade, é de se exigir a adoção de um prazo para a incoação da arbitragem, sob pena de extinção dos efeitos da antecipação, tal como sucede com a tutela cautelar pré-arbitral. Evidentemente, não há, nas hipóteses legais de antecipação de tutela, qualquer imposição condicionante de sua manutenção no processo no qual se efetivou. A razão dessa omissão legislativa é óbvia. A antecipação de tutela ocorre no bojo do próprio processo no qual ela é concedida, diferentemente, portanto, do que sucede com a cautelar preparatória ou antecedente. À míngua de qualquer disposição legal sobre a matéria, parece razoável que, admitida a antecipação de tutela pré-arbitral, deverá ser proposta a arbitragem no prazo de trinta dias, tal como sucede com o art. 806 do CPC" e "(...) à míngua de disciplina processual própria, tornam-se aplicáveis a ela determinadas regras atinentes à cautelar pré-arbitral. Assim é que a inicial veiculadora do pedido de antecipação deve deixar patente o pedido a ser formulado na arbitragem a ser incoada. (...) Deferida e efetivada a antecipação dos efeitos da tutela, não poderá restar esse resultado à mercê da vontade de seu requerente em propor a arbitragem. Razoável será impor-lhe um prazo para a iniciação da arbitragem, o que, aliás, poderá ser providenciado pela contraparte prejudicada com essa antecipação.", defendendo, ainda, a imposição do prazo de 30 (trinta) dias previsto no art. 806 do CPC "ao requerente da antecipação dos efeitos da arbitragem futura." (in Tutela de urgência e arbitragem..., pp. 370 e 375 ).
} 
para "manter, alterar ou revogar a medida cautelar deferida pelo juiz togado", sendo esse entendimento "matéria assente na jurisprudência (ApCiv 2007.001.47555, 18. ${ }^{a}$ Câm. Cív., TJRJ; ApCiv 999.843/6, 20. a Câm. Direito Privado do TJSP, j. 23.06.2008; AgIn 02730723, 3. ${ }^{\text {a }}$ Câm. Cív. do TAMG, v.u., j. 24.02.1999 etc.) ${ }^{\text {’398. }}$

CARMONA também leciona que a tutela de urgência préarbitral apreciada pelo Poder Judiciário "será novamente analisada pelos árbitros tão logo seja instituída a arbitragem, para manter, modificar ou cassar a decisão judicial”399, sendo válida, ainda, a menção do magistério de PEDro A. BAtista Martins, no sentido de que, “instituída a arbitragem, nasce a jurisdição arbitral, em toda a sua plenitude, cabendo ao árbitro manter, alterar ou cassar a liminar concedida pela justiça comum, agora incompetente (melhor, sem jurisdição!) para apreciar as questões envolvendo o objeto da demanda e aquilo que lhe é acessório"400.

${ }^{398}$ Cf. LEMES, Selma M. Ferreira. Medidas cautelares prévias à instituição..., p. 250. MANUELA CORREIA Botelho COLOMBo também aduz que "tão logo seja o tribunal arbitral instituído, a medida cautelar preparatória apreciada será remetida ao tribunal arbitral, para que este a modifique ou a mantenha, conforme o caso." (in Medidas de Urgência no Processo..., p. 268). Não é diferente a lição de DonALDO ARMELIN: "a cautelar pré-arbitral tem sua disciplina definida no CPC, mas sempre submetida ao crivo do juízo arbitral, que mantém sua competência para ratificar ou não o decidido ou efetivado na tela judicial." (in Tutela de urgência e arbitragem..., p. 372) e "o princípio básico que governa a antecipação pré-arbitral dos efeitos decorrentes da arbitragem a ser instituída é o da prevalência das decisões que a respeito forem prolatadas pelos árbitros após essa instituição.” (Idem, p. 376). HAROLDO MALHEIROS DUCLERC VERÇOSA ressalta que, "uma vez instalada a arbitragem, os árbitros decidirão autonomamente a respeito, confirmando ou não a liminar concedida, vindo a estabelecer o caminho adequado de acordo com a cláusula compromissória e os termos da avença celebrada entre as partes." (O Judiciário e a valorização...). Ainda no mesmo sentido: GARCEZ, José Maria Rossani. Medidas cautelares e de antecipação..., p. 220; AMARAL, Paulo Osternack. A concessão de medidas urgentes..., p. 34; e HOFFMAN, Paulo. Arbitragem: algumas dúvidas..., p. 310. No direito estrangeiro, Julian M. LEW, LOUKAS A. Mistelis e STEFAN MiChAEL KröLl sustentam que "arbitrators should have the final word and be allowed to overrule, release or vary interim measures ordered by state courts." (trad. livre: "os árbitros devem ter a palavra final e ser permitidos a revogar, reformar ou modificar as medidas liminares ordenadas pela corte estatal.”) (Comparative International..., p. 624).

${ }^{399}$ CARMONA, Carlos Alberto. Arbitragem e Processo..., p. 330.

${ }^{400}$ Apontamentos sobre a Lei de Arbitragem. Rio de Janeiro: Forense, 2008, p. 247. Em igual sentido a lição de FERNANDO FONSECA GAJARDONI: "Entretanto, nesses casos, à exceção da medida cautelar de antecipação de provas (art. 846 do CPC), que se esgota com a simples produção, os demais provimentos cautelares ou de urgência deverão, após concedidos pela Jurisdição Estatal (arrestos, seqüestros, etc.), ser ratificados pelo juízo arbitral a se instaurar, remetendo-lhe o juiz os autos tão logo tenha ciência da aceitação da nomeação pelos árbitros, preservando-se, assim, a competência plena da Jurisdição privada sobre o litígio. Entendendo o juízo arbitral ser impertinente ou desnecessária a medida, poderá, simplesmente, cassá-la, sem que haja problema algum de âmbito processual, posto que as cautelares em geral não fazem coisa julgada material, bem como, as concedidas liminarmente, podem ser cassadas a qualquer tempo ("Aspectos fundamentais de processo arbitral e pontos de contato com a jurisdição estatal', Revista de Processo, n. 106, pp. 202/203).” (in A arbitragem nos tribunais..., p. 59). 
Em sentido contrário, LuIZ RoBERTO AyOuB ${ }^{401}$, ARNOLdO WALD $^{402}$ e JOEL DIAS FIGUEIRA JÚNIOR ${ }^{403}$ sustentam que não seria possível o árbitro rever a decisão proferida pelo Poder Judiciário ao apreciar a tutela de urgência pré-arbitral, sob os argumentos da soberania do Poder Judiciário e da força da coisa julgada material.

Não nos parece, com todo o respeito e acatamento, que esses argumentos se sustentem.

A uma, pois não há a alegada soberania do Poder Judiciário sobre o juízo arbitral. Tal corrente já se encontra superada há tempos, vingando hoje o posicionamento no sentido de que a relação entre o árbitro e o juízo estatal é a de cooperação, e não a de subordinação ${ }^{404}$.

A duas, pois não há que se falar em coisa julgada da decisão que aprecia tutela de urgência, tendo em vista que essa, como é sabido, sequer se estabiliza, sendo revogável a qualquer tempo e em qualquer grau de jurisdição ${ }^{405}$.

\footnotetext{
${ }^{401}$ Arbitragem: o acesso à justiça e a efetividade do processo, 1. ${ }^{\text {a }}$ ed. Rio de Janeiro: Lumen Juris, 2005.

402 "o tribunal arbitral é incompetente para extinguir a medida cautelar concedida pelo juiz antes ou durante o curso da arbitragem" ("Novos rumos para a arbitragem no Brasil". Revista de Direito Bancário, do Mercado de Capitais e da Arbitragem, vol. 14. São Paulo: RT, out/dez de 2001, pp. 321/356, p. 351).

${ }^{403}$ Segundo JOEL DIAS FIGUEIRA JÚNIOR, "tratando-se de cautelar preparatória, o interessado formula a sua pretensão diretamente ao Estado-juiz que seria competente, se fosse o caso, para conhecer da ação principal (art. 800, CPC), tramitando o feito de acordo com o rito (genérico ou específico) do próprio Código de Processo Civil, sem que o árbitro possa, quando instaurado posteriormente o juízo privado, revogar ou modificar a providência acautelatória concedida ou denegada. (...) E assim deve ser porque a soberania das decisões do Poder Judiciário se sobrepõe à instauração posterior de jurisdição paraestatal ou, ainda, porque os litigantes não firmaram compromisso arbitral que viabilizasse a propositura de ação cautelar perante o árbitro ou tribunal arbitral. Em outros termos, não há como questionar a tutela acautelatória concedida ou rejeitada pelo Estado-juiz por força da coisa julgada decorrente da decisão proferida em ação acessória preparatória." (in Arbitragem, jurisdição..., p. 234).

${ }^{404}$ Como visto no "item 12" acima. Pedro A. Batista Martins também esclarece que "é o Poder Judiciário órgão de cooperação, de suporte às atividades do juízo arbitral", até mesmo porque "o Judiciário não é órgão de interferência ou fiscalização da justiça privada ou veículo de interferência no processo levado a efeito pelos árbitros." (Da Ausência de Poderes Coercitivos... pp. 369/370).

${ }^{405}$ Quanto ao tema, FERNANDO DA FONSECA GAJARDONI aduz que, "entendendo o juízo arbitral ser impertinente ou desnecessária a medida, poderá, simplesmente, cassá-la, sem que haja problema algum de âmbito processual, posto que as cautelares em geral não fazem coisa julgada material, bem como, as concedidas liminarmente, podem ser cassadas a qualquer tempo (Aspectos fundamentais de processo arbitral e pontos de contato com a jurisdição estatal. Revista de Processo n. 106, p. 202/203)." (GAJARDONI, Fernando da Fonseca. A arbitragem nos tribunais..., p. 59). Em igual sentido, PAULO OsTERNACK AMARAL afirma que “(...) se a provisoriedade é inerente à própria essência da medida urgente, nada mais adequado e coerente que o julgador investido de jurisdição para dirimir a controvérsia de forma definitiva e irrecorrível possa também decidir acerca da manutenção da medida urgente (concedida ou negada) proferida pelo juiz estatal." (A concessão de medidas urgentes..., p. 34).
} 
Aliás, como visto acima, as principais características das tutelas de urgência são a sumariedade da cognição e a sua provisoriedade, sendo pacífico que elas dependem de futura confirmação por sentença de mérito para se estabilizar e fazer coisa julgada, o que derruba por completo o argumento supra.

A três, pois sustentar o contrário seria o mesmo que admitir que uma decisão pré-arbitral de urgência proferida em caráter precário e provisório pelo Poder Judiciário definiria o destino do processo e limitaria a jurisdição arbitral, uma vez que o árbitro, então, não poderia decidir o mérito de forma distinta, sob pena de, em o fazendo, modificar ou revisar a decisão anteriormente proferida pelo juiz togado ${ }^{406}$.

A nosso ver, até mesmo eventual sentença proferida em ação cautelar pré-arbitral pode ser revista e alterada pelos árbitros, ainda que tal sentença tenha restado irrecorrida no juízo estatal ou reconhecido alguma matéria de ordem pública (tal como, por exemplo, a prescrição, agora cognoscível de ofício pelo juiz), considerando que a controvérsia analisada é de competência (melhor: de jurisdição) dos árbitros ${ }^{407}$.

É óbvio que, nesses casos, haverá certo desconforto por parte do juiz togado em efetivar uma tutela de urgência deferida pelo árbitro e que havia sido anteriormente rejeitada por ele. Mas isso ocorre no dia-a-dia forense, em que o Tribunal ad quem pode reformar as decisões dos juízes de primeiro grau e estes são obrigados a cumprir as decisões prolatadas pelo Tribunal, mesmo sem concordar com as mesmas ${ }^{408}$.

Frise-se, por oportuno, que algumas das câmaras arbitrais prevêem, expressamente, em seus regulamentos, a possibilidade de revisão e modificação

\footnotetext{
${ }^{406}$ Cf. AMARAL, Paulo Osternack. A concessão de medidas urgentes..., p. 34.

${ }^{407}$ Nessa mesma linha, a lição de DONALDO ARMELIN: "O mesmo, de resto, sucede com o reconhecimento pelo juiz, na cautelar pré-arbitral, da prescrição ou decadência do direito do requerente, tal como o autoriza o art. 810 do CPC, agora, no que concerne à prescrição, independentemente de requerimento na parte, na medida em que esta passou a ser matéria de ordem pública adstrita à livre apreciação do Judiciário. Destarte, a sentença na cautelar que reconhecer qualquer desses fenômenos jurídicos não se torna inapreciável na arbitragem, não gerando preclusão em detrimento da jurisdição arbitral. Da mesma forma a sentença final e irrecorrida na ação cautelar pré-arbitral não inibe os árbitros de a reexaminar, considerando que essa matéria, salvo convenção das partes em contrário, remanesce sob a competência do árbitro ou tribunal arbitral. Assim, mesmo que se reconheça a possibilidade de o processo cautelar gerar coisa julgada material, o que é admitido por corrente minoritária na doutrina, as decisões nele prolatadas - em se tratando de cautelar pré-arbitral poderão ser revistas no decorrer da arbitragem." (in Tutela de urgência e arbitragem..., p. 373).

${ }^{408}$ Em igual sentido: HOFFMAN, Paulo. Arbitragem: algumas dúvidas..., pp. 310/311.
} 
das decisões proferidas pelo juízo estatal acerca de tutelas de urgência pré-arbitrais, quando da instituição da arbitragem ${ }^{409}$.

Portanto, acompanhando a posição majoritária, entendemos ser perfeitamente possível que, após instituída a arbitragem, o árbitro reveja e reaprecie a decisão proferida pelo Poder Judiciário acerca da tutela de urgência pré-arbitral, mantendo, alterando ou revogando referida decisão, com o que coaduna a jurisprudência hodierna ${ }^{410}$.

${ }^{409}$ Tal como o artigo 9.2 da CAMARB - Câmara de Arbitragem Empresarial: "9.2 Enquanto não instalado o Tribunal Arbitral, as partes poderão requerer medidas cautelares ou antecipatórias de mérito à autoridade judicial competente. Neste caso, a parte deverá, imediatamente, dar ciência do pedido à CAMARB. O Tribunal Arbitral, tão logo constituído, poderá reapreciar o pedido da parte, ratificando ou modificando, no todo ou em parte, a medida deferida pela autoridade judicial." (www.camarb.com.br/imagensdin/areasdina micas/arquivos/63_Regulamento_camarb.pdf. Acessado em 15/06/2011); o artigo 8.2.1 do regulamento em vigor a partir de 2012 do Centro de Arbitragem e Mediação da Câmara de Comércio Brasil-Canadá: "8.2.1. Assim que instituído o Tribunal Arbitral, caberá a ele manter, modificar ou revogar a medida concedida anteriormente." (www.ccbc.org.br/default.asp?categoria=2\&subcategoria=Regulamento\%202012\#8. Acesso em 22/09/2012); e o art. 5.1.4 do regulamento da Câmara de Arbitragem do Mercado-CAM: "5.1.4 A decisão proferida pelo Árbitro de Apoio ou pelo Poder Judiciário poderá ser mantida ou reformulada pelo Tribunal Arbitral a ser constituído." (www.camaradomercado.com.br/InstDownload/nova-regulamentacao.pdf. Acesso em 03/11/2012).

410 "Nessa situação, superadas as circunstâncias temporárias que justificavam a intervenção contingencial do Poder Judiciário e considerando que a celebração do compromisso arbitral implica, como regra, a derrogação da jurisdição estatal, é razoável que os autos sejam prontamente encaminhados ao juízo arbitral, para que este assuma o processamento da ação e, se for o caso, reaprecie a tutela conferida, mantendo, alterando ou revogando a respectiva decisão" (STJ, 3. ${ }^{a}$ Turma, REsp n. ${ }^{\circ}$ 1.297.974-RJ, Rel. Min. Nancy Andrighi, j. 12/06/2012, v.u., grifos nossos); "Agravo inominado em agravo de instrumento - Ação cautelar inominada preparatória - Cláusula arbitral - Ajuizamento no juízo estadual - Possibilidade - Indeferimento da medida Agravo de instrumento - Efeito ativo concedido - Ciência da posterior instauração do juízo arbitral Incompetência superveniente da Justiça Estatal - Remessa dos autos ao arbitro para manutenção ou não da tutela concedida. É da competência plena do juízo arbitral, ao qual se submete o exame da causa, a cognição sobre a oportunidade da medida antecipatória ou acautelatória, ficando apenas sua execução afeta ao juiz estatal, mediante seu poder de coertio e executio, caso a parte resista em cumpri-la espontaneamente. Hipótese excepcional, que enseja a competência do juízo estatal, todavia, é quando, antes da instauração do Juízo Arbitral, com a aceitação da nomeação pelo árbitro, haja necessidade de alguma dessas medidas cautelares ou de urgência. Nesses casos, admite-se que o requerimento seja feito diretamente ao Juiz togado competente para o conhecimento da causa, sujeitando-se, todavia, à ratificação pelo Juízo Arbitral, assim que instaurado, remetendo-lhe os autos, de forma a preservar a competência plena da Jurisdição privada sobre o litígio.” (TJ/MG, 14. ${ }^{a}$ Câm. Cível, Ag. n. ${ }^{\circ}$ 1.0024.07.600275-7/002, Rel. Des. Elias Camilo, j. 17/01/2008, v.u., g.n.); “Ação cautelar inominada preparatória - Cláusula arbitral - Ajuizamento da ação no Juízo Estadual - Possibilidade - Deferimento da medida - Posterior ajuizamento do procedimento arbitral - Remessa dos autos ao arbitro para manutenção ou não da tutela concedida. Sendo a medida cautelar aviada antes de instaurada a arbitragem é cabível ao juízo estatal a concessão da medida perseguida, devendo, contudo, serem os autos remetidos ao juízo arbitral para que o mesmo aprecie a manutenção ou não da tutela concedida assim que iniciado o procedimento arbitral. De ofício, determinaram a remessa dos autos ao juízo arbitral para manutenção ou não da tutela concedida." (TJ/MG, 12. ${ }^{a}$ Câm. Cível, A.I. n. ${ }^{\circ}$ 1.0480.06.083392-2/001, Rel. Des. Domingos Coelho, j. 14/02/2007, v.u., grifos nossos); “Ao contrário, se o juízo arbitral entender cabível a manutenção da tutela jurisdicional, ou não, é questão que só cabe a ele decidir, pois é o juiz de fato e de direito eleito para dirimir a questão principal (art. 18 da Lei $\mathrm{n}^{\circ}$ 9307/96). (...) Urge esclarecer, por fim, que ao órgão jurisdicional não cabe a apreciação do mérito da demanda, tendo em vista que, uma vez convencionada a arbitragem, esta, por si só, veda a apreciação meritória pelo Poder Judiciário." (TJ/SP, 5. a Câm. Dir. Privado, Apelação cível com revisão n. ${ }^{\circ}$ 0123750-69.2005.8.26.0000 - n. ${ }^{\circ}$ antigo 431.916-4/3-00, Rel. Des. Silvério Ribeiro, j. 11/06/2008, v.u., g.n.). Ainda: TJ/SP, 13. ${ }^{a}$ C.D.Priv., A.I. n. ${ }^{\circ}$ 0305397-55.2009.8.26.0000 (antigo n. ${ }^{\circ}$ 990.09.305397-7), Rel. Des. Heraldo de Oliveira, j. 28/04/2010, v.u. 


\section{MEDIDAS URGENTES PREPARATÓRIAS EM SEDE DE ARBITRAGEM}

É perfeitamente possível a instauração de uma arbitragem cautelar preparatória, tal como, por exemplo, para a exibição de documentos ou para a produção antecipada de prova, especialmente se houver consenso entre as partes e estas já tiverem optado, por meio de cláusula compromissória ou de compromisso arbitral, pela solução do litígio por meio de arbitragem ${ }^{411}$.

Nesse caso, conforme leciona Flávio LUIZ YARSHELL, duas serão as opções: ou se confirma, posteriormente, a instauração da arbitragem com os árbitros que participaram da arbitragem cautelar preparatória; ou, diversamente, não se confirma $^{412}$.

Isso porque, especialmente com relação à exibição cautelar de documentos e a produção antecipada de provas, já se decidiu, inclusive quando tramitam no Poder Judiciário, que tais feitos podem ter caráter satisfativo ${ }^{413}$. Isto é, quando satisfativas as medidas, não se exige a propositura de uma ação principal caso os documentos exibidos cautelarmente ou a prova produzida de forma antecipada demonstrem a desnecessidade da ação pretendida.

Nada impede, igualmente, que as partes interessadas na produção antecipada de uma prova instaurem uma arbitragem cujo objeto seja única e exclusivamente a produção e a homologação de tal prova, comprometendo-se a resolver eventual litígio posterior, se necessário, também por meio de arbitragem ${ }^{414}$.

\footnotetext{
${ }^{411}$ Sobre o tema, ver: YARSHELL, Flávio Luiz. "Brevíssimas notas a respeito da produção antecipada da prova na arbitragem". Revista de Arbitragem e Mediação, ano 4, vol. 14. WALD, Arnoldo (coord.). São Paulo: RT, julho/setembro de 2007, pp. 52/56.

${ }^{412}$ YARSHELL, Flávio Luiz. Brevíssimas notas a respeito..., p. 56.

${ }^{413}$ Nesse sentido: "MEDIDA CAUTELAR - Exibição de documentos - Extratos bancários - Interesse de agir - Ocorrência - Possibilidade de ajuizamento de ação cautelar de exibição de documentos com caráter satisfativo e desvinculada de propositura de ação principal (...)" (TJ/SP, 17. a Câmara de Direito Privado, Apelação n. ${ }^{\circ}$ 9115245-28.2008.8.26.0000, Rel. Des. Paulo Pastore Filho, j. 27/06/2012); "Medida Cautelar Produção antecipada de prova - Medida conservativa de direito - Não incidência do prazo previsto no art. 806 do CPC - Sentença de natureza homologatória (...)" (TJ/SP, 28. ${ }^{a}$ Câmara de Direito Privado, Apelação n. ${ }^{\circ}$ 9060248-32.2007.8.26.0000, Rel. Des. Mello Pinto, j. 15/05/2012); “Agravo de Instrumento. Ação cautelar de exibição de documento. Natureza satisfativa (...)" (Ex-2. ${ }^{\circ}$ TACiv-SP, 29. ${ }^{a}$ Câmara do Quinto Grupo, A.I. n. ${ }^{\circ}$ 0070535-47.2006.8.26.0000, Rel. Des. Pereira Calças, j. 06/12/2006).

${ }^{414}$ Sobre a existência de um direito autônomo das partes de produzir provas, ver: YARSHELL, Flávio Luiz. Antecipação da prova sem o requisito da urgência e direito autônomo à prova. São Paulo: Malheiros, 2009.
} 
No entanto, havendo urgência na produção da prova e ainda não se encontrando instaurada a arbitragem, a parte poderá se valer do Poder Judiciário para produzi-la, mesmo que exista cláusula compromissória arbitral no contrato a que diz respeito tal prova ${ }^{415}$.

Nas arbitragens internacionais, as medidas para a preservação das provas ("measures for the preservation of evidence") também são admitidas ${ }^{416}$.

\section{Nesse sentido, Julian M. Lew, Loukas A. Mistelis e}

STEFAN MiCHAEL KRÖLL apontam as diversas circunstâncias em que isso pode se dar nas arbitragens internacionais, em lição perfeitamente aplicável às arbitragens pátrias:

"Provas cruciais para a determinação de assuntos relevantes podem precisar
ser preservadas ou realizadas em um estágio anterior do processo. Um
exemplo é quando a qualidade de mercadorias devem ser determinadas
antes delas serem vendidas ou delas perecerem, ou quando uma testemunha
fundamental está terminalmente doente. Quando o direito a resultados de
um contrato de pesquisa e desenvolvimento estão em jogo, ou quando o
contrato de venda e compra prevê que a compra do negócio ou o preço de
compra deve ser calculado de acordo com os resultados da companhia, e a
informação relevante, ou os papéis financeiros e contábeis, precisam ser
preservados"417.

${ }^{415}$ Nesse mesmo diapasão, cite-se trecho de acórdão do TJ/SP: "Não parece incompatível com a convivência amistosa entre juízes e árbitros o processamento, pelos primeiros, de uma prova de engenharia, por ser trabalho técnico supervisionado por razões formais e que se esgota com a conclusão dos peritos. O Juiz nada decide, apenas verifica se a prova pericial observou os ditames legais e entrega a prova para que as partes façam uso, inclusive nos tribunais arbitrais. Não existe perigo de subtrair competência definida pelo contrato, justamente porque a prova que se pretende realizar será útil para futura decisão dos árbitros, em sendo instituída a arbitragem." (TJ/SP, 4. ${ }^{a}$ Câm. Dir. Privado, MC n. ${ }^{\circ}$ 9036737-05.2007.8.26.0000 - n. ${ }^{\circ}$ antigo 494.408-4/6, Rel. Des. Enio Zuliani, j. 28/06/2007, v.u.).

${ }^{416}$ Nessa esteira: "It is undisputed that tribunals can take appropriate measures to preserve evidence under most laws or rules. Some of them even allow such measures either under a general rule or in a special provision. Even when express references are lacking these measures will generally be admissible as they usually concern the subject matter of the dispute as required by the narrower provisions of the arbitration rules." (trad. livre: "É indiscutível que tribunais arbitrais possam tomar medidas apropriadas para preservar provas sob a maioria das leis e regulamentos. Alguns deles autorizam essas medidas ou sob uma regra geral ou em uma regra especial. Até mesmo quando não há previsão expressa essas medidas serão geralmente admitidas, tendo em vista que elas dizem respeito ao objeto da disputa como exigido pelas disposições mais estreitas das regras de arbitragem.") (LEW, Julian M.; MISTELIS, Loukas A.; KRÖLL, Stefan Michael. Comparative International..., p. 595).

${ }^{417}$ In Comparative International..., pp. 594/595, tradução livre do original: "Evidence crucial for the determination of the substantive issues may need to be preserved or taken at an early stage of the proceedings. An example is where the quality of goods must be determined before the goods are either sold or perish, or where a crucial witness is terminally ill. Where entitlement to the results of a research and development contract are at stake, or where the sale and purchase agreement which provides for the buy out or purchase price to be calculated according to the financial results of the company, the relevant data, or financial and accounting papers, may need to be preserved". 
Ainda quanto ao tema das medidas cautelares preparatórias, LAURA SALVANESCHI aponta que, na Itália, não é possível a produção antecipada de provas (instrução in futurum) pelo juízo arbitral ${ }^{418}$. Segundo ela, isso se dá em virtude de impossibilidades estruturais advindas da legislação italiana, especialmente por conta da equiparação da ação cautelar de produção antecipada de provas a uma medida provisória, a qual, nos termos do artigo 818 do CPC italiano, não pode ser concedida pelos árbitros ${ }^{419}$.

${ }^{418}$ SALVANESCHI, Laura. Mesures provisoires et arbitrage..., pp. 452/456.

419 "Ce premier écueil, d'ordre structurel, commande de conclure à impossibilité de conférer l'instruction in futurum du litige aux arbitres, lorsque ceux-ci ne sont pas encore saisis du fond de la demande. D'autres ont relayé cette conclusion déduite des impossibilités structurelles, par un raisonnement de texte fondé sur l'assimilation de la mesure d'instruction ad futurum aux mesures provisoires, qui, on l'a vu, sont exclues de la compétence des arbitres par l'article 818 du C. de proc. Civ." (trad. livre: "O primeiro obstáculo, de ordem estrutural, comanda a concluir a impossibilidade de se conferir a instrução in futurum aos árbitros, quando eles ainda não adentraram no mérito da demanda. Outros têm repetido essa conclusão deduzida das impossibilidades estruturais, por uma interpretação de texto baseada na assimilação da medida de instrução ad futurum para medidas provisórias, as quais, como visto, são excluídas da competência dos árbitros pelo artigo 818 do C. proc. civ.”) (SALVANESCHI, Laura. Mesures provisoires et arbitrage..., pp. 452/453). A autora menciona outros juristas com o mesmo entendimento, dentre eles: RICCI, Edoardo F. La prova nell'arbitrato rituale. Milão, 1974, pp. 60/70; e ANDRIOLI, V. Commentario al codice di procedura civile, IV. Napoli, 1964, sub. Art. 818 do C.P.C., p. 851. 


\section{CAPÍTULO VII \\ TUTELAS DE URGÊNCIA INCIDENTAIS}

Embora a arbitragem seja um meio de resolução de conflitos sabidamente mais célere que a justiça comum, ainda assim haverá ocasiões em que, certamente, far-se-á necessária a adoção de tutelas de urgência para assegurar a efetividade do processo arbitral ou para garantir o próprio bem da vida em discussão ${ }^{420}$.

Será necessária, portanto, a apreciação e a concessão de provimentos cautelares ou de antecipação de tutela incidentais pelo(s) árbitro(s), temas que serão analisados a seguir.

\section{CAUTELAR INCIDENTAL}

$\mathrm{Na}$ justiça estatal, o processo cautelar deve ter procedimento autônomo, autuado em apartado. Quando incidental, a medida cautelar é pleiteada em ação distribuída por dependência ao juízo do processo principal, conforme rezam os artigos 796, segunda parte, e 800, primeira parte, do Código de Processo Civil ${ }^{421}$.

Já no juízo arbitral, diferentemente, não há a necessidade da instauração de um novo processo para o pedido de concessão de medida cautelar incidental. Basta que a parte interessada na referida medida cautelar incidental faça o pedido por meio de petição endereçada ao(s) árbitro(s) da arbitragem já em curso ${ }^{422}$.

Como visto acima, a arbitragem prescinde de formalismos excessivos, sendo possível, pois, a adoção de um procedimento mais informal, direto e célere para o pleito de medidas cautelares incidentais em um processo arbitral.

\footnotetext{
${ }^{420}$ Nessa esteira, MANUEla CORREIa Botelho Colombo alerta que "por vezes a celeridade inerente ao procedimento arbitral não é suficiente para tutelar adequadamente o direito material afirmado pela parte, de modo que se faz necessária a adoção de medidas de urgência.” (Medidas de Urgência no Processo..., p. 258). ${ }^{421}$ Cf. OLIVEIRA, Carlos Alberto Alvaro de. Comentários ao Código de..., p. 24.

${ }^{422}$ O projeto do novo CPC (P.L. n. ${ }^{\circ}$ 8.046/2010) traz disposição semelhante: “Art. 272. A tutela de urgência e a tutela da evidência serão requeridas ao juiz da causa e, quando antecedentes, ao juízo competente para conhecer do pedido principal. Parágrafo único. Nas ações e nos recursos pendentes no tribunal, perante este será a medida requerida".
} 
Se a medida cautelar em questão for de extrema urgência, não podendo aguardar sequer a manifestação da parte contrária ${ }^{423}$, ou na hipótese de haver fundado receio de que a parte contrária possa impedir a efetivação do provimento cautelar, caso tome conhecimento de seu conteúdo, o árbitro poderá apreciar o pedido inaudita altera parte ${ }^{424}$, hipótese em que o contraditório será postergado, mas deverá ser garantido, com a oitiva da parte contrária a posteriori ${ }^{425}$.

${ }^{423}$ Quanto ao tema, interessante é a lição de JOÃo PAULO HECKER DA SILVA acerca da "fabricação" do periculum in mora, sustentando que "alguns expedientes são conhecidos no foro e constituem litigância de má-fé", sendo a demora intencional na realização do pedido nos autos uma delas, "considerando a circunstância de que o fato lesivo é conhecido pela parte requerente da medida urgente já há algum tempo". Destaca o autor, pois, que "é relevante essa investigação da data da ciência do ato que se pretende impugnar em juízo, já que, se conhecido há tempos", nada justificaria o pedido liminar feito "à véspera de uma assembléia geral ou da assinatura de um contrato". Concluindo que se o julgador "identificar que houve a 'fabricação' do periculum in mora, deve indeferir a medida urgente inaudita altera parte e relegar a reapreciação da medida depois da manifestação da parte contrária." (Tutela de Urgência e Tutela..., p. 98).

${ }^{424}$ Essa é a dicção do art. 804 do CPC: "É lícito ao juiz conceder liminarmente ou após justificação prévia a medida cautelar, sem ouvir o réu, quando verificar que este, sendo citado, poderá torná-la ineficaz; caso em que poderá determinar que o requerente preste caução real ou fidejussória de ressarcir os danos que o requerido possa vir a sofrer". Esse também é o entendimento do STJ: "A concessão de liminar inaudita altera parte se justifica quando a demora no provimento possa acarretar prejuízos ao requerente ou ineficácia de seu provimento final. Ademais, a providência não impõe restrição ao princípio do contraditório, mas tão-somente posterga no tempo a oitiva da parte contrária." (STJ, 1. ${ }^{a}$ Turma, AgRg na MC 8810/AL, Relatora Ministra Denise Arruda, j. 28/09/2004, DJ 22/11/2004, p. 264). No mesmo sentido: RMS 335-0/CE. Em Portugal, a própria Lei de Arbitragem Voluntária (Lei n. ${ }^{\circ}$ 63/2011) prevê em seu artigo 22. ., "1" e "2", a possibilidade de tutelas de urgência sem a oitiva da parte contrária, na hipótese de risco de frustração da medida: "Artigo 22. Requerimento de ordens preliminares; requisitos 1 - Salvo havendo acordo em sentido diferente, qualquer das partes pode pedir que seja decretada uma providência cautelar e, simultaneamente, requerer que seja dirigida à outra parte uma ordem preliminar, sem prévia audiência dela, para que não seja frustrada a finalidade da providência cautelar solicitada. 2 - O tribunal arbitral pode emitir a ordem preliminar requerida, desde que considere que a prévia revelação do pedido de providência cautelar à parte contra a qual ela se dirige cria 0 risco de a finalidade daquela providência ser frustrada". O Artigo XIII das Regras de Medidas Emergenciais da OMPI - Organização Mundial de Propriedade Intelectual ("WIPO Emergency Relief Rules") também prevê um procedimento pré-arbitral inaudita altera parte.

${ }_{425}$ Falando sobre o justo processo de execução, GIUSEPPE TARZIA também sustenta a possibilidade de o contraditório ser postergado em certos casos: "E peraltro un contraddittorio destinato a completarsi eventualmente, in forma piena, nelle opposizioni, secondo quella tecnica del 'contraddittorio differito o eventuale' (o, come altrove si è detto, della 'inversione del contenzioso') cui a ragione si è riconosciuta piena legittimità, sia prima che dopo la riforma costituzionale." (trad. livre: "É também um contraditório destinado a complementar-se eventualmente, de forma plena, na oposição, segundo a técnica do 'contraditório diferido ou eventual' (ou, como já dito em outra parte, da 'inversão do contencioso'), cuja razão se é reconhecida plena legitimidade, seja antes ou depois da reforma constitucional") e "Come la nuova garanzia costituzionale non esclude la pronuncia di provvedimenti giurisdizionali inaudita altera parte, purché il contraddittorio successivo, con pienezza di effetti, sia adeguatamente assicurato" (trad. livre: "como a nova garantia constitucional não exclui o deferimento do provimento jurisdicional inaudita altera parte, desde que o contraditório sucessivo, com plenitude de efeitos, seja adequadamente assegurado.") (Il Giusto Processo di Esecuzione. Rivista di Diritto Processuale. 2001, pp. 329/350, p. 335). 
Caso contrário, em respeito ao princípio do contraditório, o árbitro deverá intimar a parte contrária para que se manifeste, para, somente depois, apreciar o pedido cautelar incidental ${ }^{426}$.

Isso porque, como aduz GIUSEPPE TARZIA, o mérito mais significativo do contraditório é o de garantir a igualdade das partes no processo ${ }^{427}$ (a "paridade de armas", tão difundida pela doutrina italiana), cumprindo-se ressaltar, também, a lição de ELIO FAZZALARI, no sentido de que deve ser garantida a participação igualitária das partes no processo ${ }^{428}$.

${ }^{426}$ Nessa esteira, JOÃo PAULO HECKER DA SILVA afirma que o princípio do contraditório "impõe ao magistrado o dever de ouvir as partes antes de decidir" e que, desse modo, "não pode o juiz decidir tendo ouvido apenas uma das partes", uma vez que "a regra de vedação à surpresa no processo vale não só para autor e réu, mas para um ou outro isoladamente também" (Tutela de Urgência e Tutela..., p. 94. Ainda quanto ao tema, o Projeto de Lei do Senado n. ${ }^{\circ}$ 166, de 2010 (agora P.L. n. ${ }^{\circ}$ 8.046/2010, em trâmite na Câmara dos Deputados), que altera o Código de Processo Civil, prevê em seu artigo 10 que "o juiz não pode decidir, em grau algum de jurisdição, com base em fundamento a respeito do qual não se tenha dado às partes oportunidade de se manifestar, ainda que se trate de matéria sobre a qual tenha que decidir de ofício", ressalvando o parágrafo único, no entanto, que "o disposto no caput não se aplica aos casos de tutela de urgência e nas hipóteses do art. 307". Na doutrina estrangeira, PIERO BERNARDINI questiona a legalidade da concessão de uma tutela de urgência sem a oitiva da parte contrária em arbitragem, dizendo que "uma segunda limitação deve-se ao fato de que uma medida desse tipo, para ser efetiva, é frequientemente deferida pelo juízo estatal inaudita altera parte, um procedimento que parece estar em contraste com o princípio do devido processo/contraditório que o árbitro deve respeitar. (...) Deve-se verificar se a urgência, que normalmente caracteriza o pedido de tais medidas, permite uma ordem inaudita altera parte, sujeita ao direito da outra parte de defender posteriormente o seu caso e de pleitear a reversão da ordem. A validade legal dessa solução é duvidosa considerando-se que, ao contrário do processo no juízo estatal, não há recurso cabível contra a decisão do árbitro. Ademais, na ausência de cumprimento voluntário da decisão liminar arbitral pela parte adversa, o juízo estatal ao qual se faz necessário pedir auxílio para a execução da decisão arbitral pode considerar tal ordem ineficaz em virtude da violação ao princípio do devido processo/contraditório.") (The Powers of the Arbitrator..., pp. 21 e 27, trad. livre). Julian M. Lew, LoukAS A. Mistelis e STEFAN M. KRÖLL também ressaltam que a concessão de medidas urgentes inaudita altera parte em arbitragens internacionais é assunto controvertido, especialmente diante da ausência de recurso cabível (Comparative International..., p. 606), afirmando que não há obstáculos para que a outra parte seja ouvida pelo árbitro, ainda que de modo informal e a qualquer hora. Mas admitem em casos excepcionais a concessão de tutela de urgência sem a prévia oitiva da parte contrária, desde que a parte seja ouvida logo após (Idem, pp. 606/607).

${ }^{427}$ TARZIA, Giuseppe. "O contraditório no processo executivo". Revista de Processo - RePro, ano 7, n. 28 (tradução de Thereza Celina de Arruda Alvim). São Paulo: RT, out/dez de 1982, pp. 55/85, p. 56.

428 "O contraditório, estrutura dialética do procedimento, consiste na participação dos destinatários dos efeitos do ato final à fase preparatória do mesmo; na simétrica paridade das suas posições; na mútua implicação das suas atividades (destinadas, respectivamente, a promover e a impedir a promulgação da disposição); na importância das mesmas pelo autor da disposição: de modo que cada contraditor possa exercer um conjunto - conspícuo ou modesto não importa - de escolhas, de reações, de controles, e deva sofrer os controles e as reações dos outros, e que o autor do ato deva considerar os resultados. Imagine, por exemplo, a fase que precede uma sentença civil de condenação e na qual se recolhem os elementos com base nos quais o juiz deverá emanar esta sentença ou recusá-la: a ela participam aquele que é destinado a ser o beneficiário da condenação e aquele que é destinado a sofrê-la, em contraditório entre si, ou seja, desenvolvendo atividades, simétricas entre si, destinadas a fornecer ao juiz - que não poderá não considerálas - elementos a favor e contra a emanação. (...) Há processo quando em uma ou mais fases do iter de formação de um ato é observada a participação não só - e obviamente - do seu autor, mas também dos destinatários dos seus efeitos, em contraditório, de modo que eles possam desenvolver atividades que o autor do ato deve considerar; e cujos resultados ele pode não responder, mas não ignorar" (FAZZALARI, Elio. 
Ressalte-se que o periculum in mora que não possibilita nem mesmo a oitiva da parte contrária é mais comum em processos em trâmite perante a justiça comum, notadamente quando a medida cautelar está sendo buscada em ação cautelar preparatória e o pedido é deduzido na petição inicial. Nessas hipóteses, para que seja garantido o exercício do contraditório à parte contrária, a parte requerente deverá aguardar a ordem de citação da contraparte, a expedição de mandado de citação, a nomeação de oficial de justiça, a contratação de advogado pela parte contrária, o prazo mínimo de defesa (cinco dias para as ações cautelares - art. 802, caput, do CPC) etc.

Já em uma arbitragem, como esta é instituída com a aceitação do encargo pelo(s) árbitro(s) (cf. artigo 19 da Lei n. ${ }^{\circ}$ 9.307/96), ocasião em que as partes já estão, em regra, representadas por advogados, tanto a medida cautelar pleiteada nas razões iniciais, como o provimento cautelar pedido incidentalmente, poderá ser facilmente informado à parte contrária através de um simples e-mail (ou de qualquer outro meio de correspondência expressa) ao seu advogado.

Será mais comum na arbitragem, portanto, a concessão de medida cautelar inaudita altera parte na hipótese de fundado receio de que a parte contrária, ciente do conteúdo do pedido, possa tomar providências para impedir a sua efetivação, tendo em vista que, para a cautelar requerida incidentalmente ao processo arbitral já em curso, será medida simples, do ponto de vista prático, efetivar a oitiva da parte contrária, que já está representada por advogado constituído nos autos.

E uma vez apreciada a medida cautelar incidental pelo árbitro, deferida esta ou não, a instrução do processo arbitral deverá ser feita de maneira conjunta, de forma a aproveitar tanto o pedido principal, como o pedido cautelar incidental. Isso já é feito, atualmente, nos processos perante a justiça comum ${ }^{429}$. E assim se dá para se evitar a duplicação inútil de atividade, em atenção ao princípio da economia processual, e,

Istituzioni di Diritto Processuale, 7. a edição. Padova: Cedam, 1994 - tradução de Edna Luiza Nobre Galvão in Princípio do Contraditório, texto elaborado em 10/1999, http://jus.com.br/revista/texto/819/principio-docontraditorio/2. Acessado em 03/11/2012).

${ }^{429}$ C. A. Alvaro DE OliveIRA aponta que "nada obstante a letra da lei, a prática judiciária brasileira vem optando geralmente pela desnecessidade de investigação probatória em separado da pretensão cautelar, tendo se tornado moeda corrente a instrução conjunta nos próprios autos do processo principal, com prolação de uma única sentença, que resolva as duas lides." (Comentários ao Código de..., p. 25). 
especialmente, tendo em vista a corriqueira similitude fática da matéria tratada tanto no pedido principal como no pedido cautelar incidental ${ }^{430}$.

Uma diferença significativa da medida cautelar incidental pleiteada perante o juízo arbitral com relação à medida requerida perante o juízo estatal é que a decisão do árbitro que concede ou indefere o provimento cautelar não fica sujeita a recurso, tendo em vista a ausência de previsão na Lei de Arbitragem brasileira ${ }^{431}$. Isso dificilmente ocorre nos processos judiciais, em que, normalmente, uma das partes recorre da decisão interlocutória que concede ou não o provimento cautelar ${ }^{432}$.

Tal diferença torna ainda mais relevante, na arbitragem, a provisoriedade das tutelas de urgência e a própria instrução do processo arbitral. Isso porque, como é notório, na justiça comum, dificilmente um julgador revisa ou altera a sua decisão quanto ao provimento cautelar, mesmo após a instrução do processo ${ }^{433}$. E, a nosso ver, um dos motivos para isso ocorrer é, exatamente, o fato de a decisão de primeiro grau já ter sido, na maioria das vezes, confirmada ou reformada pelo Tribunal ad quem antes mesmo do término da instrução do processo. Assim, há certo "comodismo" do julgador em não reapreciar o provimento cautelar, especialmente porque este, em regra, já foi confirmado ou revisado em grau de recurso. Mas, na arbitragem, como não há recurso cabível contra a decisão que concede ou não uma medida cautelar, caberá à parte trazer os elementos necessários, em sede de instrução do processo arbitral, para possibilitar eventual revisão da decisão pelo(s) árbitro(s), tendo em vista que o provimento cautelar é passível de revisão a qualquer tempo diante de novos fatos e de novas evidências.

E ante a ausência de recurso cabível, a decisão arbitral liminar deverá ser imediatamente cumprida pela parte, sob pena de ser executada perante a justiça estatal, conforme será detalhadamente explicado no "item 26" abaixo.

\footnotetext{
${ }^{430}$ Cf. OLIVEIRA, Carlos Alberto Alvaro de. Comentários ao Código de..., p. 25.

${ }^{431}$ Embora as partes possam pactuar eventual recurso na convenção de arbitragem, fato que é raro.

432 "Por outro lado, no sistema jurídico brasileiro, concedida a liminar, a discussão usualmente se transfere ao segundo grau de jurisdição, pela possibilidade de imediato agravo de instrumento ou de impetração de mandado de segurança, ambos também aparelhados com provimento liminar." (OLIVEIRA, Carlos Alberto Alvaro de. Comentários ao Código de..., p. 25).

${ }^{433}$ Nesse diapasão, C. A. Alvaro DE OliveIRA menciona que "raros, aliás, os casos de revogação ou de alteração da cautela liminarmente deferida, imperando a lei da inércia e de manutenção do novo status quo." (Comentários ao Código de..., p. 25).
} 
A sentença arbitral que apreciar os pedidos principais das partes também deverá confirmar, modificar ou revogar a decisão relativa à cautelar incidental, uma vez que, como visto acima, os provimentos cautelares têm como uma de suas principais características a provisoriedade, dependendo de decisão futura para a sua confirmação.

E se forem instauradas duas arbitragens para a apreciação do mesmo pedido cautelar perante câmaras arbitrais distintas? As partes terão de se valer do Poder Judiciário para verificar a correta interpretação da convenção arbitral, não cabendo conflito de competência ao Superior Tribunal de Justiça ${ }^{434}$.

\section{PEDIdO DE ANTECIPACÃo de TUTELA INCIDENTAL}

Assim como dito com relação à medida cautelar incidental, o pedido de antecipação de tutela incidental também somente poderá ser apreciado sem a prévia oitiva da parte contrária caso o periculum in mora seja tamanho que não permita essa providência ${ }^{435}$ ou quando houver fundado receio de que a parte contrária possa evitar a efetivação da tutela se dela tiver conhecimento.

Caso contrário, é obrigatória a oitiva da parte contrária pelo árbitro antes da apreciação do pedido de tutela antecipada, em respeito, especialmente, ao princípio do contraditório (art. $21, \S 2 .^{\text {o }}$, da Lei n. $\left..^{\circ} 9.307 / 96\right)^{436}$.

${ }^{434}$ Cf. STJ, 2. ${ }^{a}$ Seção, CC 113.260/SP, Rel. p/acórdão Min. João Otávio de Noronha, j. 08/09/2010, maioria.

${ }^{435}$ Quanto à ausência de tempo hábil para a efetivação do contraditório, JOÃo PAULO HECKER DA SILVA aduz que, "para que essa situação se configure, o tempo de operacionalização da manifestação da parte contrária deve inviabilizar a tutela do prejuízo ou do ilícito em tempo e modo.” (Tutela de Urgência e Tutela..., p. 97).

${ }^{436}$ Nesse sentido, PAULO HENRIQUE DOS SANTOS LUCON adverte que "a concessão da tutela antecipada sem a observância do contraditório deve ser sempre medida excepcional, já que a ciência dos atos e termos do processo é fundamental para a legitimação do procedimento", ressaltando, ainda, que "evitar injustificáveis diferenças de tratamento impõe aos pedidos de tutela antecipada a observância do contraditório sempre que não houver prejuízo em decorrência da bilateralidade do processo." (in Eficácia das decisões e execução..., pp. 238 e 258). JOSÉ CARLOS DE MAGALHÃES defende que a antecipação de tutela na arbitragem somente pode ser deferida após a oitiva da parte contrária, salvo disposição expressa em contrário na convenção de arbitragem: "Há que se fazer, ainda, uma distinção entre a tutela antecipada no processo judicial e a eventualmente admitida na arbitragem. É que, podendo o juiz deferi-la sem a audiência da parte contrária, essa possibilidade não se verifica na arbitragem, que tem, como requisito indispensável, o contraditório (art. 21, $\S 2^{\circ}$, da Lei $n^{\circ} 9.307 / 96$ ). Embora também no processo judiciário o contraditório seja princípio essencial, a lei processual faculta ao juiz, em determinados casos, tomar decisões sem audiência da outra parte, como ocorre em medidas cautelares, mas apenas nos casos autorizados por lei (art. 797 do CPC). No processo arbitral, salvo se a convenção autorizar - no processo judicial é a lei que autoriza - a tutela antecipada somente poderá ser concedida após audiência da parte contrária. A concessão da medida liminarmente, todavia, se 
Ou seja, o contraditório somente poderá ser diferido em casos excepcionais, exempli gratia: quando o perigo na demora for extremo, tal como quando a parte necessita de uma intervenção cirúrgica urgente que já foi negada extrajudicialmente, ou quando houver fundado receio de que a parte contrária, caso fique ciente do conteúdo do pedido de antecipação de tutela, possa tomar alguma providência para impedir a sua efetivação.

Da mesma forma que ocorre com a medida cautelar incidental, o perigo na demora que não admite sequer a oitiva da parte contrária, em regra, é mais comum de ocorrer em um processo judicial, especialmente quando o pedido de antecipação de tutela é deduzido na petição inicial e, para que seja garantido o exercício do contraditório, faz-se necessária uma logística mais complexa, que inclui a citação da parte contrária e, para tanto, a expedição de mandado de citação, a nomeação de oficial de justiça, aguardar o prazo de defesa da parte etc.

Em uma arbitragem, como esta é instaurada apenas com a aceitação da nomeação pelo(s) árbitro(s), nos termos do artigo 19 da Lei n. ${ }^{\circ}$ 9.307/96, o pedido de antecipação de tutela feito nas razões iniciais ou incidentalmente poderá ser prontamente levado ao conhecimento da parte contrária por meio de e-mail, de fax ou de carta ao próprio advogado da contraparte, a qual já estará representada na arbitragem.

Diante disso, é mais comum em arbitragem a antecipação de tutela inaudita altera parte nos casos em que há fundado receio de que a parte contrária possa impedir a sua efetivação se tomar ciência do conteúdo do pedido.

Na justiça comum, a tutela antecipada pode ser pleiteada e analisada a qualquer tempo e em qualquer grau de jurisdição, dependendo apenas da demonstração de seus requisitos ${ }^{437}$.

assim previsto na convenção arbitral, não implica descumprimento do contraditório, pois a parte afetada deverá pronunciar-se sobre ela, devendo ser-lhe assegurado esse direito." (MAGALHÃES, José Carlos de. A tutela antecipada no..., pp. 11 e ss.).

${ }^{437}$ C. A. ALVARO DE OLIVEIRA confirma que a concessão da antecipação da tutela "pode ser deferida initio litis, sob a forma de provimento liminar, ou em momento posterior e até quando da prolação da sentença de primeiro grau ou no julgamento de algum recurso em grau superior de jurisdição, nos próprios autos do processo de conhecimento." (in Comentários ao Código de..., p. 25). 
$\mathrm{Na}$ arbitragem, como não há recurso cabível contra a sentença arbitral, nos termos do artigo 18 da Lei de Arbitragem brasileira, o árbitro somente poderá apreciar eventual pedido de antecipação de tutela até a prolação da sentença, ocasião em que se encerra a sua jurisdição.

De qualquer forma, frente a qualquer prova ou fato novos, o árbitro poderá revisar a sua decisão, diante da provisoriedade da tutela antecipada. 


\section{CAPÍTULO VIII \\ CONCESSÃO DE TUTELA DE URGÊNCIA DE OFÍCIO PELO ÁRBITRO}

A regra em nosso ordenamento jurídico é que qualquer tutela jurisdicional, inclusive uma tutela de urgência, somente é deferida em favor da parte mediante pedido expresso da mesma.

\section{Como anota Eduardo Henrique de Oliveira YoshiKawa,} o artigo 2. ${ }^{\circ}$ do Código de Processo Civil veda o exercício da jurisdição sem provocação, em respeito ao princípio dispositivo, sendo projeções ou conseqüências do ônus de demandar as regras previstas nos artigos 128 e 460 do mesmo Codex ${ }^{438}$.

Assim, é da parte o ônus processual ${ }^{439}$ de ingressar em juízo, bem como o ônus processual de pleitear eventual tutela de urgência. A parte não é obrigada a tanto, mas possui essa faculdade que pode ser exercida em prol de seu próprio interesse.

Até mesmo para o início da execução provisória ou do cumprimento definitivo da sentença (situações em que já há, inclusive, o reconhecimento do direito da parte - provisório, na primeira, e definitivo, na segunda), a legislação pátria também exige a provocação do interessado, nos termos dos artigos 475-O, I, e 475-J, § 5. , $^{\circ}$ do CPC, respectivamente, proibindo o juiz de agir de ofício nesses casos.

A regra, portanto, é a de que as tutelas de urgência, sejam elas provimentos cautelares ou tutelas antecipadas, apenas podem ser deferidas se houver pedido expresso da parte, valendo-se citar a sempre valiosa lição de CÂNDIDO RANGEL

\footnotetext{
${ }^{438}$ YOSHIKAWA, Eduardo Henrique de Oliveira. Limites à Possibilidade de..., pp. 31/32. BEDAQUE também relembra que "a regra da inércia representa conquista da ciência moderna, pois visa a assegurar o afastamento do juiz dos interesses em conflito, retirando-lhe os poderes de iniciativa." (BEDAQUE, José Roberto dos Santos. Tutela cautelar e tutela antecipada..., p. 413).

439 "A idéia de ônus que é ínsita à maioria dos atos que as partes praticam no processo, traz consigo, necessariamente, a de princípio dispositivo. De fato, se a parte pode escolher exercer determinada atividade ou não, é porque o princípio dispositivo inspira essa posição jurídica por ela ocupada.” (SICA, Heitor Vitor Mendonça. Preclusão Processual Civil, 2. edição. São Paulo: Atlas, 2008, p. 276).
} 


\section{DiNAMARCO no sentido de que "o titular da pretensão insatisfeita é o melhor juiz da conveniência e oportunidade de postular meios para a satisfação"440.}

Todavia, em algumas situações extraordinárias, o juiz pode, de ofício, determinar a adoção de provimentos cautelares ou de medidas coercitivas, conforme previsto na legislação ${ }^{441}$ e já pacificado pela jurisprudência pátrias ${ }^{442}$.

${ }^{440}$ DINAMARCO, Cândido Rangel. A Reforma do Código de Processo Civil, 5. a edição. São Paulo: Malheiros, 2001, p. 149.

${ }^{441}$ O Código de Processo Civil traz, em diversos artigos, medidas que podem ser tomadas de ofício pelo Juiz: "Art. 15. É defeso às partes e seus advogados empregar expressões injuriosas nos escritos apresentados no processo, cabendo ao juiz, de ofício ou a requerimento do ofendido, mandar riscá-las."; "Art. 18. O juiz ou tribunal, de ofício ou a requerimento, condenará o litigante de má-fé a pagar multa não excedente a um por cento sobre o valor da causa e a indenizar a parte contrária dos prejuízos que esta sofreu, mais os honorários advocatícios e todas as despesas que efetuou.”; “Art. 105. Havendo conexão ou continência, o juiz, de ofício ou a requerimento de qualquer das partes, pode ordenar a reunião de ações propostas em separado, a fim de que sejam decididas simultaneamente."; “Art. 130. Caberá ao juiz, de ofício ou a requerimento da parte, determinar as provas necessárias à instrução do processo, indeferindo as diligências inúteis ou meramente protelatórias."; "Art. 195. O advogado deve restituir os autos no prazo legal. Não o fazendo, mandará o juiz, de ofício, riscar o que neles houver escrito e desentranhar as alegações e documentos que apresentar."; "Art. 342. O juiz pode, de ofício, em qualquer estado do processo, determinar o comparecimento pessoal das partes, a fim de interrogá-las sobre os fatos da causa."; "Art. 382. O juiz pode, de ofício, ordenar à parte a exibição parcial dos livros e documentos, extraindo-se deles a suma que interessar ao litígio, bem como reproduções autenticadas."; "Art. 418. O juiz pode ordenar, de ofício ou a requerimento da parte: I - a inquiriçã̃o de testemunhas referidas nas declarações da parte ou das testemunhas; II - a acareação de duas ou mais testemunhas ou de alguma delas com a parte, quando, sobre fato determinado, que possa influir na decisão da causa, divergirem as suas declarações.”; "Art. 437. O juiz poderá determinar, de ofício ou a requerimento da parte, a realização de nova perícia, quando a matéria não lhe parecer suficientemente esclarecida."; "Art. 440. O juiz, de ofício ou a requerimento da parte, pode, em qualquer fase do processo, inspecionar pessoas ou coisas, a fim de se esclarecer sobre fato, que interesse à decisão da causa."; "Art. 461. $\mathrm{Na}$ ação que tenha por objeto o cumprimento de obrigação de fazer ou não fazer, o juiz concederá a tutela específica da obrigação ou, se procedente o pedido, determinará providências que assegurem o resultado prático equivalente ao do adimplemento. (...) $\S 3^{\circ}$ Sendo relevante o fundamento da demanda e havendo justificado receio de ineficácia do provimento final, é lícito ao juiz conceder a tutela liminarmente ou mediante justificação prévia, citado o réu. A medida liminar poderá ser revogada ou modificada, a qualquer tempo, em decisão fundamentada. $\S 4^{\circ} \mathrm{O}$ juiz poderá, na hipótese do parágrafo anterior ou na sentença, impor multa diária ao réu, independentemente de pedido do autor, se for suficiente ou compatível com a obrigação, fixando-lhe prazo razoável para o cumprimento do preceito. $\S 5^{\circ}$ Para a efetivação da tutela específica ou a obtenção do resultado prático equivalente, poderá o juiz, de ofício ou a requerimento, determinar as medidas necessárias, tais como a imposição de multa por tempo de atraso, busca e apreensão, remoção de pessoas e coisas, desfazimento de obras e impedimento de atividade nociva, se necessário com requisição de força policial. $\S 6^{\circ} \mathrm{O}$ juiz poderá, de ofício, modificar o valor ou a periodicidade da multa, caso verifique que se tornou insuficiente ou excessiva."; "Art. 805. A medida cautelar poderá ser substituída, de ofício ou a requerimento de qualquer das partes, pela prestação de caução ou outra garantia menos gravosa para o requerido, sempre que adequada e suficiente para evitar a lesão ou repará-la integralmente.”; "Art. 989. O juiz determinará, de ofício, que se inicie o inventário, se nenhuma das pessoas mencionadas nos artigos antecedentes o requerer no prazo legal."; "Art. 1.107. Os interessados podem produzir as provas destinadas a demonstrar as suas alegações; mas ao juiz é licito investigar livremente os fatos e ordenar de ofício a realização de quaisquer provas.".

${ }^{442}$ Por exemplo, pode o Juiz, de ofício, fixar astreintes para forçar o cumprimento de obrigação de fazer: "Processual Civil. Recurso Especial. Execução de fazer. Descumprimento. Astreintes. Aplicação contra a Fazenda Pública. Possibilidade. Multa. Termo Final. Cumprimento Integral. Agravo desprovido. I - Esta Corte Superior tem jurisprudência firmada no sentido de que, em se tratando de obrigação de fazer, é permitido ao Juiz, de ofício ou a requerimento da parte, a imposição de multa cominatória ao devedor 
Com efeito, há casos em que o bem jurídico, seja pela sua natureza, seja pela sua relevância, pode ser tutelado de ofício pelo juiz, para evitar o seu perecimento ou para evitar o risco de inutilidade do provimento jurisdicional.

Citem-se, por exemplo, os direitos indisponíveis, os quais, pela sua natureza, afastam o princípio dispositivo, ao menos em toda a sua plenitude, de modo a autorizar o julgador a tomar providências urgentes, de ofício, independente de pedido da parte, caso se façam necessárias durante o curso do processo ${ }^{443}$.

Sem sombra de dúvida, não pode um juiz deixar de apreciar e evitar, inclusive de ofício, eventual risco ao direito à vida, à saúde ou a qualquer outro direito indisponível dessa magnitude.

Quanto às medidas cautelares, o artigo 797 do Código de Processo Civil deixa claro que o poder geral de cautela do julgador o autoriza a conceder provimentos cautelares de ofício em determinadas hipóteses, ao estabelecer que "só em casos excepcionais, expressamente autorizados por lei, determinará o juiz medidas cautelares sem a audiência das partes" ${ }^{\prime 44}$.

A redação desse artigo, evidentemente, não foi das mais felizes ao estatuir que "só em casos excepcionais" e "expressamente autorizados por lei" é que o juiz poderia deferir a tutela cautelar sem a audiência das partes. Isso porque as duas situações mencionadas são claramente excludentes entre si: ou o caso é excepcional, ou ele está expressamente autorizado por lei. Se uma hipótese está prevista em lei, por óbvio que não há que se falar em sua “excepcionalidade”, por força da própria prescrição legal.

(astreintes), mesmo que seja contra a Fazenda Pública. Não há razão para se estabelecer exceção onde o legislador não o fez. (...)" (STJ, 5. a Turma, AgRg no REsp n. ${ }^{\circ}$ 1.213.061/RS, Rel. Min. Gilson Dipp, j. 17/02/11, DJe 09/03/11, v.u.). Nesse sentido: AgRg no Ag 1.040.411, Min. Herman Benjamin, j. 02/10/08; REsp 1.063.902, Min. Francisco Falcão, j. 19/08/08; REsp 723.016, Min. Franciulli Netto, j. 04/08/05. Ainda deferindo, de ofício, liminar em agravo de instrumento, para suspender execução indevida: TJ/SP, 23. ${ }^{a}$ Câm. Dir. Privado, A.I. n. ${ }^{\circ}$ 0075352-47.2012.8.26.0000, Rel. Des. Rizzatto Nunes, j. 16/05/2012. E deferindo, de ofício, liminar para que seja afixada informação relevante à coletividade em praças de pedágio: TJ/SP, 1. ${ }^{\text {a }}$ Câm. Dir. Público, A.I. n. ${ }^{\circ}$ 0237898-20.2010.8.26.0000, Rel. Des. Castilho Barbosa, j. 14/12/2010.

443 DONALDO ARMELIN anota que "a tutela de urgência pode versar direitos indisponíveis, cuja proteção não pode restar indissociavelmente vinculada à iniciativa da parte.” (Tutela de urgência e arbitragem..., p. 369).

444 Nesse sentido, BEDAQUE leciona que "o legislador processual, rompendo com o dogma da inércia da jurisdição, permite ao juiz conceder tutela cautelar de ofício. Tal possibilidade encontra fundamento no art. 797 do Código de Processo Civil.” (in Tutela cautelar e tutela antecipada..., p. 412). 
Nas palavras de Egas Dirceu Moniz de Aragão, “não se trata de 'casos excepcionais' e 'expressamente autorizados por lei' e sim de 'casos excepcionais' ou "expressamente autorizados por lei'., 445.

Dessa feita, a medida cautelar apenas poderá ser concedida ex officio, sem provocação da parte, nos casos em que houver expressa autorização legal (e.g., as medidas acautelatórias previstas no artigo 888 do $\mathrm{CPC}^{446}$ ou as astreintes e outras medidas coercitivas previstas no artigo $461, \S 5 .^{\circ}$, do $\mathrm{CPC}^{447}$ ) ou nos casos excepcionais envolvendo direitos indisponíveis ou outros direitos dessa mesma relevância ${ }^{448}$.

Resta, pois, analisar a "excepcionalidade" citada pelo próprio ordenamento jurídico e de que forma ela deve ser interpretada.

\section{Mais uma vez citando-se a lição de EDUARDo HENRIQUE DE}

OLIVEIRA YoshiKAWA, não há dúvida de que o reconhecimento de tal "excepcionalidade" não fica ao livre arbítrio do juiz ${ }^{449}$, mas decorre do próprio sistema, residindo precisamente na indisponibilidade do direito ${ }^{450}$.

${ }^{445}$ MONIZ DE ARAGÃO, Egas Dirceu. "Medidas Cautelares Inominadas" in Revista Brasileira de Direito Processual, n. ${ }^{\circ}$ 57. Rio de Janeiro: Forense, janeiro/março, 1998, pp. 33/90, esp. p. 41. O Projeto do novo CPC (P.L. n. ${ }^{\circ}$ 8.046/2010, em trâmite na Câmara dos Deputados) corrige esse equívoco: "Art. 277. Em casos excepcionais ou expressamente autorizados por lei, o juiz poderá conceder medidas de urgência de ofício".

446 "Art. 888. O juiz poderá ordenar ou autorizar, na pendência da ação principal ou antes de sua propositura: I - obras de conservação em coisa litigiosa ou judicialmente apreendida; II - a entrega de bens de uso pessoal do cônjuge e dos filhos; III - a posse provisória dos filhos, nos casos de separação judicial ou anulação de casamento; IV - o afastamento do menor autorizado a contrair casamento contra a vontade dos pais; V - o depósito de menores ou incapazes castigados imoderadamente por seus pais, tutores ou curadores, ou por eles induzidos à prática de atos contrários à lei ou à moral; VI - o afastamento temporário de um dos cônjuges da morada do casal; VII - a guarda e a educação dos filhos, regulado o direito de visita que, no interesse da criança ou do adolescente, pode, a critério do juiz, ser extensivo a cada um dos avós; VIII - a interdição ou a demolição de prédio para resguardar a saúde, a segurança ou outro interesse público". Sobre tais medidas, ver: OLIVEIRA, C. A. Alvaro de. Comentários ao Código de..., pp. 26/30, que considera que o legislador optou por defender os direitos nelas contidas por meio de processo especial sumário e não-cautelar (p. 28).

447 “Art. 461. (...) § $5^{\circ}$ Para a efetivação da tutela específica ou a obtenção do resultado prático equivalente, poderá o juiz, de ofício ou a requerimento, determinar as medidas necessárias, tais como a imposição de multa por tempo de atraso, busca e apreensão, remoção de pessoas e coisas, desfazimento de obras e impedimento de atividade nociva, se necessário com requisição de força policial".

${ }_{448}$ Em interessante exemplo, EduARDo HenRique DE OliveIRA YoshiKaWA anota que "os direitos individuais homogêneos, enquanto 'atomizados' podem ser objeto de disposição pelos seus titulares, mas uma vez aglutinados, 'molecularizados', tornam-se indisponíveis por aquele que atua como representante da classe/substituto processual." (Limites à Possibilidade de..., p. 35).

${ }^{449}$ Nesse sentido, é válida a citação de acórdãos revogando liminares concedidas ex officio em: (i) ação de exibição de documentos - TJ/SP, 2. ${ }^{a}$ Câm. Dir. Privado, A.I. n. ${ }^{\circ}$ 102.898-4/5, Rel. Des. J. Roberto Bedran, j. 30/03/1999; e (ii) ação declaratória de inexigibilidade de títulos - TJ/SP, A.I. n. ${ }^{\circ}$ 361.104-4/3-00.

${ }_{450}$ Cf. YOSHIKAWA, Eduardo Henrique de Oliveira. Limites à Possibilidade de..., pp. 36/37. Corroborando esse entendimento, JOSÉ JOAQUIM CALMON DE PASSOS anota que "versando, contudo, o processo principal 
Já quanto à possibilidade da concessão de tutela antecipada de ofício, a questão é ainda mais complexa. A doutrina e a jurisprudência, de forma geral, não admitem a antecipação dos efeitos da tutela de ofício, tendo em vista que o próprio artigo 273 do CPC condiciona tal providência ao "requerimento da parte"451.

\section{Contudo, nos termos da lição de José Roberto DOS SANTOS}

BEDAQUE, não se pode excluir situações excepcionais em que o magistrado verifique a necessidade da antecipação de tutela e que, embora presentes os requisitos legais necessários para tanto, a parte não pleiteou a medida, sendo a atuação ex officio do juiz o único meio de preservar a utilidade do resultado do processo ${ }^{452}$.

Nessas hipóteses excepcionalíssimas, e que envolvam direitos indisponíveis, a doutrina ${ }^{453}$ e a jurisprudência ${ }^{454}$ admitem a tutela antecipada de ofício.

sobre direito indisponível, afastada, desse modo, a possibilidade de disporem os interessados sobre o objeto do litígio e se por força disso se deferiu ao juiz poderes extraordinários (no sentido de poderes que extrapolam os que comumente lhe são reconhecidos) quer no tocante à prova, quer no tocante à conclusão do procedimento ou no pertinente ao objeto do litígio, por força do princípio da instrumentalidade, tais poderes se comunicam também ao processo cautelar e nele autorizam iniciativas de ofício do magistrado." (Comentários ao Código de Processo Civil, Tomo I, Vol. X. São Paulo: RT, 1984, p. 84).

${ }^{451}$ Sobre o tema, são citadas as lições de DONALDO ARMELIN: "No que concerne à tutela antecipatória, a dicção do art. 273, caput, do CPC refere-se claramente à exigência de requerimento da parte para a concessão da antecipação dos efeitos do pedido veiculado na inicial." (Tutela de urgência e arbitragem..., p. 369); e de BEDAQUE: "Seria admissível a antecipação de tutela de ofício? A resposta genérica é negativa. O legislador condiciona a medida ao pedido da parte (art. 273)." (in Tutela cautelar e tutela antecipada..., pp. 412); e os seguintes julgados: "Embargos de declaração. Omissão. Condenação em indenização por dano moral. Sentença que concedeu a tutela antecipada de ofício, para exigir o pagamento imediato da indenização, sob pena de multa cominatória diária, como pressuposto do recebimento de recurso pelas rés. Sentença teratológica. A antecipação de tutela tem de ser requerida pela parte (art. 273 do CPC) (...)" (TJ/SP, 1. ${ }^{a}$ Câm. Dir. Privado, Emb. Dec. n. ${ }^{\circ}$ 9191320-11.2008.8.26.0000, Rel. Des. Paulo Eduardo Razuk, j. 17/04/2012); e "Agravo de Instrumento. Tutela antecipada concedida de ofício. Impossibilidade. Necessidade de requerimento da parte. Inteligência do art. 273, caput, do CPC. Recurso provido.” (TJ/SP, 21. . Câm. Dir. Privado, A.I. n. ${ }^{\circ}$ 0122035-79.2011.8.26.0000, Rel. Des. Virgilio de Oliveira Junior, j. 19/10/2011).

${ }^{452}$ BEDAQUE, José Roberto dos Santos. Tutela cautelar e tutela antecipada..., p. 413.

${ }^{453}$ Para justificar a tutela antecipada de ofício, BEDAQUE aduz que, "ainda que dúvida possa existir quanto à possibilidade de antecipação de tutela ex officio, a situação regulada pelo art. 273 tem, em tudo e por tudo, natureza cautelar. Rege-se, pois, pelas regras dessa modalidade de tutela. Nessa linha de pensamento, não há por que afastar a incidência do art. 798." (Tutela cautelar e tutela antecipada..., p. 416). Ainda sobre o tema, BARBOSA MOREIRA anota que a timidez de alguns advogados tem exigido dos magistrados, "sobretudo nos Juizados Especiais Cíveis e nas causas de família, a desprezar a letra da lei e decretar de ofício a antecipação da tutela, em casos nos quais encontra base sólida a convicção da imprescindibilidade da medida." (BARBOSA MOREIRA, José Carlos. "As reformas do Código de Processo Civil: condições de uma avaliação objetiva”. Temas de direito processual, 6. ${ }^{\text {a }}$ série. São Paulo: Saraiva, 1997, p. 89). Mencionando os princípios que regem o processo cautelar na Itália, GIUSEPPE TARZIA recorda que vige plenamente no direito italiano o princípio da demanda, reafirmado pela lei (art. 669 bis et seq. do CPC italiano) para todas as providências cautelares. Em virtude de tal princípio, o autor entende que não seria possível a antecipação da tutela de ofício na Itália, pois o juiz estaria adstrito ao pedido do autor. Já em Portugal, TARZIA destaca que a fórmula é diversa, havendo previsão legal no sentido de que "o tribunal não está adstrito à providência concretamente requerida" (art. 392, § 3..$^{\circ}$ ), o que autorizaria, em tese, o juiz a conceder de ofício uma medida 
Dentro dessa linha, levando-se em conta que o árbitro é o juiz de fato e de direito de um processo arbitral (artigo 18 da Lei de Arbitragem brasileira), consideramos ser perfeitamente possível e admissível a concessão de tutelas de urgência de ofício também por parte do árbitro ${ }^{455}$.

Ressalva-se, no entanto, a necessidade de se respeitar a excepcionalidade acima mencionada, sob pena de ofensa ao devido processo legal, à ordem pública e a própria imparcialidade do árbitro.

Ressalva-se, igualmente (e por óbvio), que o árbitro somente poderá deferir uma tutela de urgência de ofício de forma incidental e após ter aceitado o encargo de árbitro, tendo em vista que, antes disso, ele não possui poderes jurisdicionais ${ }^{456}$.

antecipatória (in "Medidas cautelares atípicas: uma análise comparativa". LUCON, Paulo Henrique dos Santos (trad.). Revista de Processo - RePro, n. ${ }^{\circ}$ 99. São Paulo: RT, jul/set de 2000, pp. 206/222).

${ }^{454}$ Conforme os seguintes julgados: "Tutela antecipada. Declaratória de nulidade c.c. indenização por danos morais. Decisão 'extra-petita'. Inocorrência. Inexistência de pedido do agravado acerca da suspensão dos descontos em conta corrente. Irrelevância. Cabível a concessão da tutela antecipada, de ofício, ante a existência de fundado receio de lesão grave ao direito do agravado. Inteligência dos arts. 798 e 126, ambos do CPC. Decisão mantida. Agravo improvido." (TJ/SP, 24. ${ }^{a}$ Câm. Dir. Privado, A.I. n. ${ }^{\circ}$ 900279897.2008.8.26.0000 - n. ${ }^{\text {os }}$ antigos: 7.240.186-8/00 e 991.08.025158-8, Rel. Des. Salles Vieira, j. 24/04/2008, v.u., grifamos); e "Previdência. União Estável. Requisito temporal. (...) 3. Em tal hipótese, a própria existência dos filhos não pode deixar de ser considerada para afastar o requisito temporal. Apelação provida em parte, com deferimento de tutela antecipada, de ofício." (TJ/SP, 3. ${ }^{a}$ Câm. Dir. Público, Apelação n. ${ }^{\circ}$ 9151793-86.2007.8.26.0000 - n. ${ }^{\text {s }}$ antigos: 6807985900, 994.07.048337-5, Rel. Des. Laerte Sampaio, j. 30/10/2007, v.u., grifos nossos).

${ }^{455}$ Corroborando essa tese, PEDRo A. BATista Martins afirma que "na adoção de medidas cautelares e coercitivas não fica o árbitro a depender de requerimento das partes, podendo ser elas solicitadas ex officio, se assim entender o julgador após ter tomado conhecimento de algum fato relevante." (Da Ausência de Poderes Coercitivos..., p. 372). PAUlo CEZAR PINHEIRO CARNEIRO também sustenta que "nada impede que o próprio árbitro, de ofício, solicite ao juiz que seria competente para o julgamento da causa as medidas cautelares que ele entenda indispensáveis para garantir a efetividade da própria arbitragem enquanto procedimento análogo ao judicial." (Aspectos processuais da nova lei..., p. 311). Em sentido oposto, BELIZÁRIO ANTÔNIO DE LACERDA defende a impossibilidade da apreciação e da concessão de tutelas de urgência pelo árbitro, especialmente ex officio: "significa que nem o árbitro nem o tribunal arbitral poderá tomar qualquer medida cautelar ou coercitiva dentro do processo, quer a requerimento das partes, quer de ofício, pois tais medidas são privativas do Poder Judiciário, que somente quando solicitado comprovadamente pelo juízo arbitral, poderá a esse emprestar colaboração para o bom desate da causa." (Comentários à lei de arbitragem. Belo Horizonte: Del Rey, 1998, p. 82). JosÉ EduARdo CARREIRA AlviM, por sua vez, adota posição intermediária, lecionando que "relativamente às medidas cautelares, pode o árbitro conceder de ofício aquelas que, nos termos, do art. 797 do Código de Processo Civil, possam igualmente ser concedidas pelos juízes. Em todas as demais hipóteses, inclusive quanto às medidas cautelares inominadas (art. 798 do CPC), não se admite procedimento de ofício, devendo o árbitro aguardar a iniciativa da parte interessada (princípio da iniciativa ou princípio da demanda)" (Direito Arbitral..., p. 339).

${ }^{456}$ Nesse mesmo sentido: VILELA, Marcelo Dias Gonçalves. "Reflexões sobre a Tutela Cautelar na Arbitragem" in Revista Brasileira de Arbitragem, n. ${ }^{\circ}$ 7. São Paulo: IOB Thomson, jul/set de 2005, pp. 30/44, especialmente p. 36, o qual também concorda que "é inegável que o árbitro tem poder jurisdicional para conceder medida cautelar independentemente de requerimento da parte." (idem, ibidem). 
Ainda quanto ao tema, cumpre-se frisar que a possibilidade de atuação de ofício do árbitro é ainda mais limitada se comparada com a atuação de ofício do juiz em um processo judicial. Isso porque, como visto no "item 2" acima, os direitos indisponíveis não podem ser objeto de uma arbitragem, o que reduz consideravelmente as hipóteses em que se admite uma atuação ex officio do árbitro (pois, na maioria das vezes, é a indisponibilidade do direito que permite a atuação de ofício do julgador).

Mas isso não impede, de forma alguma, a atuação de ofício do(s) árbitro(s) em processos arbitrais que, embora versem, no plano primário, sobre um direito disponível, estejam ligados, no plano secundário, a um direito indisponível. A título de exemplo, pode ser citado um processo arbitral por meio do qual se cobra apenas uma quantia pecuniária (direito disponível), mas que tal quantia é indispensável para o custeio de uma cirurgia médica imprescindível para a saúde da parte litigante (direito à vida indisponível). Nessa hipótese, sem sombra de dúvida, poderá haver eventual atuação de ofício do(s) árbitro(s).

Quanto às medidas coercitivas para a instrução do processo, assim como o juiz, o árbitro também poderá tomá-las de ofício, em virtude de seu poderdever de instrução do processo. Poderá o árbitro, de ofício, (i) determinar as provas que entender necessárias para a instrução da arbitragem (CPC, art. 130); (ii) determinar o comparecimento pessoal das partes, em qualquer estado do processo, para prestar esclarecimentos sobre os fatos da causa (CPC, art. 342); (iii) ordenar a exibição de livros e documentos que interessarem ao litígio (CPC, art. 382); (iv) ordenar a inquirição de testemunhas referidas nas declarações das partes ou das testemunhas (CPC, art. 418, I) etc.

Todavia, como já visto no "item 11" acima, tendo em vista que o árbitro não possui o poder de imperium para conduzir coercitivamente uma testemunha ou para buscar e apreender livros e documentos, na hipótese de renitência da parte ou da testemunha em cumprir tais determinações, o árbitro poderá, de ofício, requerer a execução de tais providências coercitivas junto ao Poder Judiciário ${ }^{457}$.

\footnotetext{
${ }^{457}$ Nessa esteira, JosÉ EdUARdo CARREIRA AlVIM leciona que “o árbitro tem a iniciativa de determinar quaisquer medidas coercitivas relacionadas com a instrução do processo, só que se valendo do órgão do Poder Judiciário, se houver resistência ao seu cumprimento." (Direito Arbitral..., p. 339). Ainda sobre o tema, CARlos Alberto CARMONA ensina que "havendo injustificável resistência da testemunha convocada a
} 
No plano das arbitragens internacionais, essa atuação de ofício é ainda mais limitada e restrita, tendo em vista que os regulamentos das principais câmaras de arbitragem internacionais vinculam a concessão de eventual tutela de urgência ao pedido expresso da parte ${ }^{458}$.

Julian M. LeW, LouKas A. Mistelis e Stefan M. KRÖll também salientam esse ponto, ressalvando, no entanto, que o regulamento do International Centre for Settlement of Investment Disputes - ICSID traz uma exceção a essa regra geral, autorizando expressamente a concessão de tutelas de urgência de ofício pelos árbitros ${ }^{459}$.

depor, caberá ao árbitro solicitar a colaboração do Poder Judiciário. O árbitro, por simples ofício, instruído com a cópia da convenção de arbitragem (que demonstra sua investidura), informará o juiz togado de sua decisão acerca da necessidade de ouvir a testemunha renitente, solicitando condução coercitiva." (Arbitragem e Processo..., pp. 317/318).

${ }^{458}$ Como o artigo 26 do Regulamento de Arbitragem da UNCITRAL: "Interim measures - Article 26 - 1. The arbitral tribunal may, at the request of a party, grant interim measures." (trad. livre: "Medidas liminares Artigo 26 - 1. O tribunal arbitral pode, a pedido de uma parte, conceder medidas liminares." - grifamos); o art. 28.1 do regulamento de arbitragem e de ADR da Câmara do Comércio Internacional - CCI (International Chamber of Commerce - ICC): "Artigo 28 - Medidas cautelares e provisórias - 1. A menos que as partes tenham convencionado diferentemente, o tribunal arbitral poderá, tão logo esteja na posse dos autos, $\underline{\text { e a }}$ pedido de uma das partes, determinar a adoção de qualquer medida cautelar ou provisória que julgar apropriada. O tribunal arbitral poderá subordinar tal medida à apresentação de garantias pela parte solicitante. A medida que for adotada tomará a forma de ordem procedimental devidamente fundamentada, ou a forma de uma sentença arbitral, conforme o tribunal arbitral considerar adequado." (grifamos); e o artigo 21.1 do regulamento de resolução de disputas internacionais da AAA - American Arbitration Association: "1. At the request of any party, the tribunal may take whatever interim measures it deems necessary, including injunctive relief and measures for the protection or conservation of property." (trad. livre: "A pedido de qualquer das partes, o tribunal arbitral poderá conceder quaisquer medidas liminares que ele entender necessárias, incluindo remédios liminares e medidas para a proteção ou conservação de bens." - g.n.). PIERO BERNARDINI ainda sustenta que as partes podem limitar o poder cautelar do árbitro ao pedido expresso das partes, dizendo que as partes são livres "para estabelecer que o árbitro somente pode utilizar seus poderes cautelares em resposta a um pedido feito pela parte (...)" (The Powers of the Arbitrator..., p. 27, trad. livre).

${ }^{459}$ In Comparative International..., p. 605 . Eis os termos do artigo 39 (3) do regulamento da ICSID: "Rule 39 Provisional Measures (...) (3) The Tribunal may also recommend provisional measures on its own initiative or recommend measures other than those specified in a request. It may at any time modify or revoke its recommendations". (tradução livre: "Regra 39 - Medidas provisórias (...) (3) O Tribunal também pode recomendar medidas provisórias por iniciativa própria ou recomendar outras medidas além daquelas especificadas em um pedido. Ele pode a qualquer tempo modificar ou revogar as suas recomendações.”) (https://icsid.worldbank.org/ICSID/StaticFiles/basicdoc/CRR_English-final.pdf. Acessado em 17/11/2012). 


\section{CAPÍTULO IX}

\section{REVISÃO DAS TUTELAS DE URGÊNCIA DEFERIDAS PELO ÁRBITRO}

\section{IMPUGNACC̃̃O DA DECISÃO DO ÁRBITRO}

A decisão proferida pelo(s) árbitro(s) que aprecia uma tutela de urgência, concedendo-a ou a indeferindo, em regra, não pode ser impugnada por meio de recurso, tendo em vista a ausência de previsão na Lei de Arbitragem brasileira ${ }^{460}$.

Com relação às arbitragens institucionais, os regulamentos da grande maioria das câmaras arbitrais pátrias prevêem somente a possibilidade da oposição de embargos de declaração ${ }^{461}$, os quais, como sabido, não possuem efeitos infringentes (embora possam, eventualmente, modificar a decisão) ${ }^{462}$.

\footnotetext{
${ }^{460} \mathrm{Na}$ Argentina, a decisão do árbitro é recorrível, a não ser que as partes tenham aberto mão do direito de recorrer, nos termos dos artigos 758 e 760 do Código de Processo Civil e Comercial da Nação: "Recursos Art. 758. - Contra la sentencia arbitral podrán interponerse los recursos admisibles respecto de las sentencias de los jueces, si no hubiesen sido renunciados en el compromiso." (tradução livre: "Recursos Art. 758. - Contra a sentença arbitral poderão interpor os recursos admissíveis a respeito das sentenças dos juízes, se não houverem sido renunciados no compromisso."); e "Renuncia de recursos. Aclaratoria, Nulidad - Art. 760. - Si los recursos hubieren sido renunciados, se denegarán sin sustanciación alguna. La renuncia de los recursos no obstará, sin embargo, a la admisibilidad del de aclaratoria y de nulidad, fundado en falta esencial del procedimiento, en haber fallado los árbitros fuera del plazo, o sobre puntos no comprometidos. En este último caso, la nulidad será parcial si el pronunciamiento fuere divisible. Este recurso se resolverá sin sustanciación alguna, con la sola vista del expediente." (trad. livre: "Renúncia de recursos. Aclaratória. Nulidade - Art. 760. - Se os recursos houverem sido renunciados, serão denegados sem fundamentação alguma. A renúncia aos recursos não obstará, sem embargo, a admissibilidade da aclaratória e da nulidade, fundada em vício essencial do procedimento, em haver falado os árbitros fora de prazo, ou sobre pontos não envolvidos. Neste último caso, a nulidade será parcial se o pronunciamento foi divisível. Este recurso será resolvido sem fundamentação alguma, apenas com a vista de expediente.”). É competente para apreciar o recurso o Tribunal hierarquicamente superior ao juiz que teria decidido a causa apreciada em arbitragem, salvo se no compromisso as partes pactuarem que o recurso será apreciado por árbitros, nos termos do art. 763 do Código de Processo Civil e Comercial da Nação. Em Portugal, "a sentença do tribunal arbitral que decidir sobre uma ordem preliminar ou providência cautelar e a sentença do tribunal estadual que decidir sobre o reconhecimento ou execução coerciva de uma providência cautelar de um tribunal arbitral não são susceptíveis de recurso." (art. 27. ., "4", da Lei n. . 63/2011). Na França, o artigo 1489 do Código de Processo Civil francês também prevê que não cabe recurso contra a decisão do árbitro, salvo estipulação em contrário das partes: "Arte. 1489. La sentence n'est pas susceptible d'appel sauf volonté contraire des parties." (trad. livre: "Art. 1489. A sentença não é passível de recurso, salvo vontade contrária das partes.”).

${ }^{461}$ Nesse sentido, o art. 10.6 do regulamento do Centro de Arbitragem de Mediação da Câmara de Comércio Brasil-Canadá: "10.6. As partes poderão, no prazo de 15 (quinze) dias contados da data do recebimento da sentença arbitral, requerer esclarecimentos sobre contradição, omissão ou obscuridade, mediante petição dirigida ao Tribunal Arbitral." (www.ccbc.org.br/default.asp?categoria=2\&subcategoria=Regulamento $\% 202012$ \#10. Acessado em 03/11/2012); o art. 10.8 do regulamento da Câmara de Arbitragem Empresarial-Brasil CAMARB: "10.8. Na hipótese de erro material, omissão, obscuridade, dúvida ou contradição da sentença arbitral, as partes terão o prazo de cinco dias, contado da data de recebimento da sentença, para formular
} 
Um dos poucos a tratar do assunto, JOEL DiAS FIGUEIRA

JÚNIOR ressalva, no entanto, que a decisão arbitral de urgência poderá ser objeto de recurso se as partes fizerem constar da convenção de arbitragem essa possibilidade ${ }^{463}$.

Nessa linha, as partes poderão pactuar na convenção de arbitragem que eventual decisão arbitral que apreciar pedido de tutela de urgência poderá ser reapreciada, por exemplo, por um colegiado de árbitros que não participam do processo arbitral no qual o decisum foi proferido ou pelo presidente da câmara arbitral na qual a arbitragem está em curso.

Afora essa hipótese específica e rara ${ }^{464}$, a decisão arbitral de urgência somente poderá ser impugnada judicialmente ${ }^{465}$ : (i) por meio da ação prevista no

pedidos de esclarecimentos." (www.camarb.com.br/imagensdin/areasdinamicas/arquivos/84_Regulamento_ camarb.pdf. Acessado em 03/11/2012); o artigo 7.7 do regulamento da Câmara de Arbitragem do MercadoCAM: "7.7 Pedido de Esclarecimento. No prazo de 15 (quinze) dias a contar do recebimento da cópia da decisão, a parte interessada poderá solicitar ao Tribunal Arbitral que: i) corrija erro material da sentença arbitral; e/ou ii) esclareça alguma obscuridade, dúvida ou contradição da sentença arbitral, ou se pronuncie sobre ponto a respeito do qual deveria ter se manifestado." (www.camaradomercado.com.br/InstDownload/ nova-regulamentacao.pdf. Acessado em 03/11/2012). O regulamento da Corte Internacional de Arbitragem da Câmara de Comércio Internacional - CCI também prevê a possibilidade de correção de erros materiais ou omissões, conforme o disposto em seu artigo 35.

${ }^{462}$ Conforme o seguinte julgado: “A obtenção de efeitos infringentes, como pretende a Embargante, somente é possível, excepcionalmente, nos casos em que, reconhecida a existência de um dos defeitos elencados nos incisos do mencionado art. 535, a alteração do julgado seja consequência inarredável da correção do referido vício; bem como nas hipóteses de erro material ou equívoco manifesto, que, por si sós, sejam suficientes para a inversão do julgado.” (STJ, Terceira Seção, EDcl no MS n. ${ }^{\circ}$ 11.760/DF, Rel. Min. Laurita Vaz, j. 27/09/06, DJ 30/10/2006, p. 238, v.u.).

463 “(...) a decisão interlocutória concessiva da tutela cautelar, antecipatória ou inibitória proferida em sede privada é irrecorrível, salvo estipulação em contrário na convenção de arbitragem (...)” (FIGUEIRA JÚNIOR, Joel Dias. Arbitragem, jurisdição..., p. 225). Tratando da sentença arbitral, mas em lição aplicável à decisão arbitral liminar, CARMONA também afirma que "a decisão tomada pelos árbitros não fica sujeita a recurso, a não ser que as partes, na convenção de arbitragem, estabeleçam uma modalidade interna de revisão do laudo", bem como que "não se impede (...) que os contratantes estabeleçam, dentro do próprio procedimento arbitral, os recursos que entenderem necessários.” (Arbitragem e Processo..., p. 270).

${ }^{464}$ Não vemos sentido em as partes convencionarem a possibilidade de recurso em uma arbitragem, pois isso vulneraria uma de suas principais vantagens: a celeridade. Além disso, aumentaria os custos para as partes (na maioria das câmaras de arbitragem os árbitros cobram por hora e há cobranças de taxas mensais de manutenção do processo) e desafiaria a própria lógica do juízo arbitral, pois quem decide a questão já é, em regra, um especialista. Quanto ao tema, CARLOS ALBERTO CARMONA anota que "a experiência internacional revela que não é usual a previsão de duplo grau de jurisdição em sede arbitral, já que tal previsão acabaria por aumentar tanto a duração do processo como os seus custos.” (in Arbitragem e Processo..., p. 270).

${ }^{465}$ ADA PELLEGRINI GRINOVER confirma “(...) que o ordenamento abre espaço para alguma forma de controle estatal das decisões proferidas no seio da arbitragem", ressaltando, no entanto, que "fíca substraído ao Poder Judiciário o conhecimento do mérito - e respectivas questões de fato e de direito - da controvérsia." ("Parecer - Arbitragem: ação anulatória e embargos do devedor". Revista Brasileira de Arbitragem, n. ${ }^{\circ}$ 18. São Paulo: IOB/CBAr, abr/jun de 2008, pp. 154/181, p. 163). 
artigo 33, caput, da Lei n. ${ }^{\circ} 9.307 / 96^{466}$, ou (ii) por meio de impugnação ao cumprimento da decisão $^{467}$, caso esta não tenha sido espontaneamente cumprida e a parte beneficiada pela tutela de urgência tenha buscado a sua execução perante a justiça comum. Em qualquer das hipóteses, a decisão arbitral de urgência somente poderá ser contestada se estiver eivada de alguma das nulidades previstas no artigo 32 da mesma $1 \mathrm{e}^{468}$, não podendo a parte vencida, de forma alguma, desafiar o mérito da decisão ${ }^{469}$.

466 “Art. 33. A parte interessada poderá pleitear ao órgão do Poder Judiciário competente a decretação da nulidade da sentença arbitral, nos casos previstos nesta Lei”. Nessa esteira, ARISTÓTELES ATHENIENSE também aduz que as decisões provisórias proferidas pelo juízo arbitral poderão se sujeitar à ação anulatória perante o Poder Judiciário (in As medidas coercitivas no juízo..., p. 314). Ainda sobre o tema: GRINOVER, Ada Pellegrini. "Parecer - Arbitragem: ação anulatória e embargos do devedor". Revista Brasileira de Arbitragem, n. ${ }^{\circ}$ 18. São Paulo: IOB/CBAr, abr/jun de 2008, pp. 154/181.

${ }^{467}$ Embora o $§ 3 .^{\circ}$ do artigo 33 estabeleça a hipótese de anulação da decisão arbitral por meio de embargos do devedor: "\$ $3^{\circ}$ A decretação da nulidade da sentença arbitral também poderá ser argüida mediante ação de embargos do devedor, conforme o art. 741 e seguintes do Código de Processo Civil, se houver execução judicial", esclarece-se que a Lei n. ${ }^{\circ} 11.232$, de 22 de dezembro de 2005, alterou a forma de impugnação da execução de título judicial, estabelecendo que o agora cumprimento de sentença somente poderá ser objeto de impugnação (art. 475-L do CPC), e não mais de embargos do devedor (os quais ficaram restritos à Fazenda Pública e às execuções de títulos extrajudiciais - cf. alterações trazidas ao CPC pela Lei n. ${ }^{\circ} 11.382$, de 2006).

468 “Art. 32. É nula a sentença arbitral se: I - for nulo o compromisso; II - emanou de quem não podia ser árbitro; III - não contiver os requisitos do art. 26 desta Lei; IV - for proferida fora dos limites da convenção de arbitragem; V - não decidir todo o litígio submetido à arbitragem; VI - comprovado que foi proferida por prevaricação, concussão ou corrupção passiva; VII - proferida fora do prazo, respeitado o disposto no art. 12 , inciso III, desta Lei; e VIII - forem desrespeitados os princípios de que trata o art. $21, \S 2^{\circ}$, desta Lei'. Nesse sentido: “(...) a decisão interlocutória concessiva da tutela cautelar, antecipatória ou inibitória proferida em sede privada é irrecorrível, salvo (...) se estiver eivada de nulidade, por alguns dos motivos assinalados no art. 32 da Lei 9.307/96, procedendo-se da mesma forma que as hipóteses de anulação de sentença arbitral." (FIGUEIRA JÚNIOR, Joel Dias. Arbitragem, jurisdição..., pp. 225/226). Na Alemanha, o § 1059, (1) a (5), da $Z P O$ traz as hipóteses em que a decisão arbitral poderá ser questionada perante a justiça estatal. Dentre elas, há também a previsão de ofensa a ordem pública (“ordre public”) - §1059, (2), “2”, “b”. Em Portugal, também são restritas as hipótese de anulação da decisão arbitral: “Artigo 46. Pedido de anulação 1 - Salvo se as partes tiverem acordado em sentido diferente, ao abrigo do n. 4 do artigo $39 .^{\circ}$, a impugnação de uma sentença arbitral perante um tribunal estadual só pode revestir a forma de pedido de anulação, nos termos do disposto no presente artigo". Na Itália, nos termos dos artigos 827 a 831 de seu Código de Processo Civil, a decisão arbitral pode ser impugnada "per nullitá, per revocazione e per opposizione di terzo" (trad. livre: por nulidade, por revogação e por oposição de terceiro). Na França, por sua vez, o artigo 1492 do CPC francês traz as razões pelas quais uma decisão arbitral pode ser anulada.

${ }^{469}$ Nessa esteira, a jurisprudência: "Consoante o art. 31 da referida Lei, a sentença arbitral produz os mesmos efeitos da sentença judicial só que, no entanto, não se sujeita a recurso nem a homologação do Poder Judiciário (art. 18 da Lei de Arbitragem). A sentença arbitral é portanto, soberana e irrecorrível e deste modo, não pode ser revista nem mesmo pelo Poder Judiciário; o Poder Judiciário apenas poderá rever, em caráter excepcional, os aspectos formais relativos ao procedimento adotado no julgamento arbitral, nas hipótese de nulidade, taxativamente previstas no art. 32 da Lei de Arbitragem." (TJ/SP, 35. ${ }^{\text {a }}$ Câm. Dir. Privado, A.I. n. ${ }^{\circ}$ 0293432-12.2011.8.26.0000, Rel. Des. Manoel Justino Bezerra Filho, j. 13/02/2012, v.u.); “Como maneira de prestígio da função arbitral e estímulo a sua utilização como meio alternativo extrajudicial de resolução de conflitos, o Poder Judiciário apenas pode rever aspectos formais relativos ao procedimento adotado no julgamento arbitral, além de eventuais nulidades no decisum e ferimentos à ordem jurídico-constitucional, consoante rol do art. 32 da Lei 9.307/96. No mais, a sentença arbitral é soberana e inatacável.” (TJ/SP, 8. ${ }^{a}$ Câm. Dir. Privado, A.I. n. ${ }^{\circ}$ 0516363-59.2010.8.26.0000 - antigo n. ${ }^{\circ}$ 990.10.516363-7, Rel. Des. Theodureto Camargo, j. 09/02/2011, v.u.); "Não é possível a análise do mérito da sentença arbitral pelo Poder Judiciário, sendo, contudo, viável a apreciação de eventual nulidade no procedimento arbitral.” (STJ, 3. ${ }^{a}$ Turma, REsp 693.219/PR Rel. Min. Nancy Andrighi, j. 19/04/2005, v.u.). Ainda: TJ/SP, 27. ${ }^{a}$ Câm. Dir.

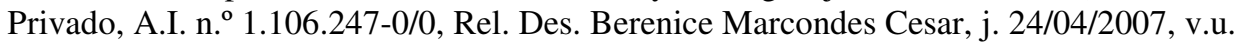




\section{Aplicam-se as normas do Código de Processo Civil tanto à} ação prevista no artigo 33, caput, da Lei de Arbitragem, como à impugnação ao cumprimento da decisão, por se tratar de objeções que tramitarão perante o juízo comum.

A regra é que a execução da decisão arbitral não se suspende, mesmo se contestada por impugnação ou por ação visando à decretação de nulidade (anulação) da decisão arbitral perante o Poder Judiciário. Embora seja possível, em caso de decisão arbitral teratológica ou, ainda, de dano grave e irreversível pelo cumprimento da decisão, a concessão de efeito suspensivo à impugnação ou o deferimento de tutela antecipada na ação de nulidade (anulação) para o fim de suspender os efeitos da decisão arbitral de urgência.

No entanto, assim como ocorre hoje nos cumprimentos de decisões judiciais, a suspensão da execução deve ser sempre a exceção ${ }^{470}$.

\footnotetext{
${ }^{470}$ Nesse diapasão: "Bem móvel - Ação de anulação de sentença arbitral - Pedido de tutela antecipada para sustar os efeitos da sentença arbitral - Impossibilidade de liminar - Sentença arbitral, em princípio válida e eficaz - Presunção de ausência de nulidades - Inexistência de verossimilhança capaz de autorizar a concessão da tutela - Decisão reformada - Em tese, para fins de tutela antecipada, inexiste prova inequívoca com verossimilhança de alegações capaz de justificar a concessão de tutela antecipada para suspender os efeitos de uma sentença arbitral. Em favor da sentença arbitral já repousa a presunção de validade, ou seja, de não ocorrência de nulidades, até porque as partes caminharam até final decisão sob a égide do juízo arbitral por eles mesmos eleito. Somente em casos teratológicos, de evidente nulidade é que se justificaria a concessão de tutela antecipada para sustar os efeitos da sentença arbitral. Ademais, manter a liminar concedida seria obrigar uma das partes a permanecer jungida a um contrato que não mais lhe interessa, o que seria descabido, até porque se a ação principal vier a ser julgada procedente, a parte que descumpriu o contrato de forma acaso ilícita responderá por perdas e danos, se for o caso. - Recurso de agravo de instrumento provido, prejudicado o julgamento do agravo regimental". Trecho do acórdão: "Somente em casos teratológicos, de evidente nulidade é que se justificaria a concessão da tutela antecipada requerida." (TJ/SP, 35. ${ }^{a}$ Câm. Dir. Privado, A.I. n. ${ }^{\circ}$ 0293432-12.2011.8.26.0000, Rel. Des. Manoel Justino Bezerra Filho, j. 13/02/2012, v.u.); "PROCESSO CIVIL - Impugnação ao cumprimento de sentença (arbitral) - Pedido de efeito suspensivo Ausência dos pressupostos legais (...) Em relação à Ação Ordinária de Nulidade de Sentença Arbitral noticiada pela recorrente, o mero ajuizamento não autoriza a pronta suspensão do curso da execução, sob pena de negar eficácia ao título executivo." (TJ/SP, 4. ${ }^{a}$ Câm. Dir. Privado, A.I. 0096051-93.2011.8.26.0000, Rel. Des. Francisco Loureiro, j. 30/06/2011, v.u.); "Tutela antecipada - Suspensão da eficácia executória da sentença arbitral - Impossibilidade diante da ausência de verossimilhança das alegações e do direito do credor de promover o cumprimento de sentença em relação à decisão arbitral (CPC, art. 585, § $\left.1^{\circ}\right)$ - Decisão mantida - Recurso desprovido." (TJ/SP, 8. ${ }^{a}$ Câm. Dir. Privado, A.I. n. ${ }^{\circ}$ 0516363-59.2010.8.26.0000 - antigo n. ${ }^{\circ}$ 990.10.516363-7, Rel. Des. Theodureto Camargo, j. 09/02/2011, v.u.); "Ação declaratoria de nulidade de sentença arbitral, com pedido de antecipação de tutela, cc. obrigação de fazer - Concessão de efeito ativo ao recurso de apelação interposto pela Agravante, a fim de suspender a eficácia da sentença arbitral proferida Impossibilidade - Arts. 475-R cc. 585, § $1^{\circ}$, ambos do CPC, impedem que o ajuizamento de ação discutindo o título executivo obste o direito do credor de promover o cumprimento de sentença em relação à decisão arbitral - Recurso da autora não provido.” (TJ/SP, 27. ${ }^{a}$ Câm. Dir. Privado, A.I. n. ${ }^{\circ}$ 1.106.247-0/0, Rel. Des. Berenice Marcondes Cesar, j. 24/04/2007, v.u.).
} 


\section{CAUCC̃̃o}

O Código de Processo Civil pátrio, em diversos de seus dispositivos, prevê a prestação de caução pela parte beneficiária para o deferimento ou para o cumprimento de uma tutela de urgência, bem como para a efetivação de atos de execução ou de posse, a fim de que a parte contrária possa ser ressarcida dos prejuízos eventualmente causados por tais medidas, na hipótese de sua futura revogação.

São exemplos disso os artigos 475-M, § 1. ${ }^{\circ}, 475-\mathrm{O}, \mathrm{III}, 690$, 739-A, § 1. ${ }^{\circ}, 745, \S 2 .^{\circ}, 799,804,805,816$, II, 819, II, 824, II, 826 a 838, 925 do CPC, dentre outros.

Dessa forma, assim como ocorre em um processo judicial ${ }^{471}$, poderá o árbitro determinar que a parte beneficiária preste caução a fim de que uma tutela de urgência seja deferida em seu favor no processo arbitral ${ }^{472}$.

Esclarece-se que a caução não é obrigatória para o deferimento de uma tutela de urgência, sendo uma faculdade do árbitro exigi-la ou não ${ }^{473}$.

\footnotetext{
${ }^{471}$ Nesse diapasão, a jurisprudência do STJ: “A exigência, pelo juízo, de prestação de garantia idônea para a concessão da requerida sustação do protesto, encontra respaldo na legislação de regência." (STJ, 4. ${ }^{a}$ Turma, AgRg-MC 1727/SP, Rel. Min. Sálvio de Figueiredo Teixeira, j. 25/04/2000, DJ 05/06/2000, p. 160, v.u.).

${ }^{472}$ O Projeto de Lei n. ${ }^{\circ}$ 8.046/2010, em trâmite na Câmara dos Deputados, que prevê um novo CPC, também traz previsão de caução para a concessão de tutelas de urgência: “Art. 276 (...) Parágrafo único. Na concessão liminar da tutela de urgência, o juiz poderá exigir caução real ou fidejussória idônea para ressarcir os danos que o requerido possa vir a sofrer, ressalvada a impossibilidade da parte economicamente hipossuficiente".

${ }^{473}$ Quanto ao tema, a jurisprudência do STJ já pacificou que "no âmbito do poder geral de cautela do Juiz está a faculdade de exigir caução como contra cautela, bem como indeferir pedido de substituição do seqüiestro de bens por depósito em dinheiro." (3. ${ }^{a}$ Turma, REsp n. ${ }^{\circ}$ 141.434/ES, Rel. Min. Waldemar Zveiter, j. 03/12/1998, v.u.), bem como que "a determinação de prestação de caução real ou fidejussória, para a concessão de liminar em sustação de protesto, não é exigível em todos os casos, podendo ser dispensada pelo

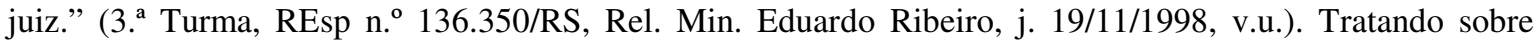
arbitragens internacionais, PIERO BERNARDINI entende que as partes, nesses casos, podem vincular a concessão de eventual tutela de urgência pelo árbitro à prestação de caução, ensinando que as partes são livres "para estabelecer que o deferimento de quaisquer medidas desse tipo pelo árbitro fique sujeita à prestação da caução apropriada pela parte requerente (...)" (The Powers of the Arbitrator..., p. 27, tradução livre). Quanto ao tema, os regulamentos de algumas câmaras de arbitragem internacionais prevêem a possibilidade de o árbitro exigir a prestação de caução para o deferimento de tutelas de urgência, tais como o artigo 28.1 do regulamento de arbitragem e de ADR da Câmara do Comércio Internacional - CCI (International Chamber of Commerce - ICC): “(...) O tribunal arbitral poderá subordinar tal medida à apresentação de garantias pela parte solicitante."; e o artigo 26 (6) das Regras de Arbitragem da UNCITRAL: "6. The arbitral tribunal may require the party requesting an interim measure to provide appropriate security in connection with the measure." (trad. livre: "6. O tribunal arbitral pode exigir que a parte que pleiteia uma medida liminar preste a caução apropriada em relação à medida.”).
} 
No entanto, nas situações em que a concessão da tutela de urgência envolva evidente risco patrimonial à parte contrária, ou mesmo risco de irreversibilidade da medida ${ }^{474}$, é recomendável que o árbitro exija a prestação de caução pela parte beneficiada.

Por exemplo, caso a decisão arbitral de urgência envolva o levantamento de valores ou a prática de qualquer outro ato que importe alienação de patrimônio ou do qual possa resultar dano grave ou de difícil reparação à parte contrária, entendemos ser necessária a fixação de caução pelo árbitro para que referida decisão possa ser efetivada ${ }^{475}$.

E na hipótese de o árbitro não ter fixado referida caução, entendemos que o juiz togado poderá fazê-lo quando do cumprimento judicial de mencionada decisão arbitral, para evitar que a parte contrária não seja devidamente ressarcida na hipótese de reforma da decisão liminar ${ }^{476}$.

\footnotetext{
${ }^{474}$ De acordo com PAULO HENRIQUe DOS SANTOS LUCON, é possível mitigar o requisito da irreversibilidade do provimento antecipado, uma vez que, "apesar do limite imposto pelo $\S 2^{\circ}$ do art. 273 , consistente no 'perigo da irreversibilidade', nada impede que em determinadas situações excepcionais a tutela antecipada produza efeitos irreversíveis (p. ex., alimentos provisionais)". Por conta disso, "a irreversibilidade não pode atuar como um limite intransponível à técnica da antecipação, seja na tutela antecipada, seja na execução provisória da sentença”. Como ensina LUCON, o juiz deve sopesar os diferentes pesos dos valores que estão em jogo, pendendo para a irreversibilidade quando o valor em jogo for mais valioso ou mais importante de acordo com os possíveis danos a serem causados a cada uma das partes. Assim, por exemplo, entre se deferir o custeio de uma cirurgia pelo plano de saúde por meio de tutela antecipada para preservar o bem da vida ou se indeferir esse pedido para resguardar o interesse econômico do plano de saúde, pesa muito mais, sem dúvida, o direito à vida. A irreversibilidade, pois, deve ser analisada por mais de um ângulo, levando-se em conta qual o maior risco: do demandante ou do demandado. A técnica da antecipação é a do equilíbrio entre a situação desfavorável temida pelo demandante da medida e a situação desfavorável imposta ao demandado (juízo do mal maior-quem sofrerá mais). (Eficácia das decisões e execução provisória. São Paulo: RT, 2000). O artigo 387. ., "2", do CPC português reflete essa preocupação do "mal maior - quem sofrerá mais", preceituando que: "Artigo 387. ${ }^{\circ}$ Deferimento e substituição da providência (Alterado pelo Decreto-Lei n. ${ }^{\circ}$ 180/96, de 25 de Setembro) (...) 2 - A providência pode, não obstante, ser recusada pelo tribunal, quando o prejuízo dela resultante para o requerido exceda consideravelmente o dano que com ela o requerente pretende evitar".

${ }^{475}$ CARLOS Alberto AlVARO DE Oliveira confirma que "se a antecipação compreender o levantamento de depósito em dinheiro e a prática de atos que importem alienação de propriedade ou dos quais possa resultar grave dano à contraparte, deverá ser prestada caução suficiente e idônea, arbitrada de plano pelo juiz e prestada nos próprios autos do processo (aplicação analógica do art. 475-O, III, Lei n 11.232, de 2005)." (Comentários ao Código de..., p. 07). Na mesma linha, LuCON leciona que, "sempre que se afigurar possível, deve o juiz exigir caução do demandante para autorizar a transferência de domínio, a fim de garantir o ressarcimento de eventual prejuízo sofrido pelo demandado no caso de cessação ou revogação da tutela antecipada", ressalvando, todavia, que a caução não pode ser requisito para a concessão da antecipação dos efeitos da tutela, a não ser que esta seja irreversível, ocasião em que a caução torna-se obrigatória - seria uma contracautela processual (in Eficácia das decisões e execução provisória. São Paulo: RT, 2000).

${ }^{476}$ Em Portugal, há previsão expressa nesse sentido na Lei de Arbitragem Voluntária (Lei n.o 63/2011), nos termos do seu artigo 27. ", "3": "Artigo 27. ${ }^{\circ}$ Reconhecimento ou execução coerciva (...) 3 - O tribunal estadual ao qual for pedido o reconhecimento ou a execução coerciva da providência pode, se o considerar conve-
} 
Outra hipótese de caução é aquela prevista no artigo 805 do CPC, a qual permite que o réu preste caução ou outra garantia menos gravosa em substituição à tutela de urgência. Eis os termos do artigo 805 do CPC:

"A medida cautelar poderá ser substituída, de ofício ou a requerimento de qualquer das partes, pela prestação de caução ou outra garantia menos gravosa para o requerido, sempre que adequada e suficiente para evitar a lesão ou repará-la integralmente" ${ }^{, 477}$.

PAulo Afonso Garrido de PAula aponta que "é desse dispositivo, primordialmente, que se extrai a característica da instrumentalidade do processo cautelar genuíno", pois ele possibilita a concessão da medida cautelar adequada para impedir a lesão ao direito da outra parte, "aquela cuja instrumentalidade afigura-se estritamente concorde com o desiderato de proteção ao bem jurídico perseguido no processo principal" ${ }^{\text {478 }}$.

Dessa forma, assim como ocorre em um processo judicial, o(s) árbitro(s) também poderá(ão) substituir a tutela de urgência concedida a uma parte por caução ou outra garantia menos gravosa a ser prestada pela parte adversa na arbitragem.

Com isso, restará respeitado o critério do menor gravame, admitindo-se a substituição, troca ou modificação da tutela de urgência mais onerosa pela caução ou garantia menos gravosa ${ }^{479}$.

niente, ordenar à parte requerente que preste caução adequada, se o tribunal arbitral não tiver já tomado uma decisão sobre essa matéria ou se tal decisão for necessária para proteger os interesses de terceiros". O artigo 24. ${ }^{\circ}$, "2", da Lei n. ${ }^{\circ}$ 63/2011, também autoriza o próprio tribunal arbitral a fixar caução: "Artigo 24. ${ }^{\circ}$ Modificação, suspensão e revogação; prestação de caução (...) 2 - O tribunal arbitral pode exigir à parte que solicita o decretamento de uma providência cautelar a prestação de caução adequada".

477 O Projeto de Lei n. ${ }^{\circ}$ 8.046/2010, em trâmite na Câmara dos Deputados, que institui um novo CPC, traz previsão semelhante: “Art. 270. (...) Parágrafo único. A medida de urgência poderá ser substituída, de ofício ou a requerimento de qualquer das partes, pela prestação de caução ou outra garantia menos gravosa para o requerido, sempre que adequada e suficiente para evitar a lesão ou repará-la integralmente". O Código de Processo Civil português também: “Artigo 387. ${ }^{\circ}$ Deferimento e substituição da providência (Alterado pelo Decreto-Lei n. ${ }^{\circ}$ 180/96, de 25 de Setembro) (...) 3 - A providência decretada pode ser substituída por caução adequada, a pedido do requerido, sempre que a caução oferecida, ouvido o requerente, se mostre suficiente para prevenir a lesão ou repará-la integralmente. 4 - A substituição por caução não prejudica o direito de recorrer do despacho que haja ordenado a providência substituída, nem a faculdade de contra esta deduzir oposição, nos termos do artigo seguinte".

${ }^{478}$ PAULA, Paulo Afonso Garrido de. Código de Processo Civil Interpretado..., p. 2.246.

${ }^{479}$ Nessa linha, PAUlo AFOnso GARRIDO DE PAUlA aduz que: “(...) sempre sobre o critério do menor gravame, de sorte que o transtorno à cidadela jurídica do requerido não assuma proporções maiores do que 
Ressalte-se, por fim, que a parte requerente deverá ser informada e ouvida acerca da substituição da medida, mesmo sendo sabido que a substituição poderá ser feita pelo julgador independentemente de provocação da parte requerente, uma vez que a execução da liminar corre por conta e risco desta. Com isso, ou seja, com a oitiva da parte requerente sobre a troca da medida, restará afastada qualquer ilação sobre a sua eventual irresponsabilidade pela execução da liminar ${ }^{480}$.

\section{RESPONSABILIDADE DO BENEFICIÁRIO DA MEDIDA E DO ÁRBITRO}

Nos termos do artigo 811 do $\mathrm{CPC}^{481}$, a responsabilidade do beneficiário de uma medida cautelar que é posteriormente revogada é objetiva.

Em outras situações similares, tais como na execução ou na execução provisória, nosso sistema também imputa a responsabilidade objetiva ao beneficiário da medida reformada, nos termos dos artigos $475-\mathrm{O}$, I e II, e 574 do $\mathrm{CPC}^{482}$.

E, conforme lição de CÂNDIDO RANGEL DinAMARCO, a responsabilidade objetiva prevista no art. 811 do CPC também se aplica, analogicamente, às tutelas antecipadas, mesmo tendo o art. 273 do CPC silenciado sobre o assunto, tendo em vista que tanto o provimento cautelar, como a antecipação de tutela pertencem ao

aquela causada em razão do eventual acolhimento do pedido formulado na ação principal." (in Código de Processo Civil Interpretado..., p. 2.246).

${ }^{480}$ Cf. PAULA, Paulo Afonso Garrido de. Código de Processo Civil Interpretado..., p. 2.246.

481 “Art. 811. Sem prejuízo do disposto no art. 16, o requerente do procedimento cautelar responde ao requerido pelo prejuízo que lhe causar a execução da medida: I - se a sentença no processo principal lhe for desfavorável; II - se, obtida liminarmente a medida no caso do art. 804 deste Código, não promover a citação do requerido dentro em 5 (cinco) dias; III - se ocorrer a cessação da eficácia da medida, em qualquer dos casos previstos no art. 808, deste Código; IV - se o juiz acolher, no procedimento cautelar, a alegação de decadência ou de prescrição do direito do autor (art. 810). Parágrafo único. A indenização será liquidada nos autos do procedimento cautelar". O P.L. n. ${ }^{\circ}$ 8.046/2010, em trâmite na Câmara dos Deputados, que institui um novo CPC, também possui disposição semelhante: “Art. 274. Independentemente da reparação por dano processual, o requerente responde ao requerido pelo prejuízo que lhe causar a efetivação da medida, se: I - a sentença no processo principal lhe for desfavorável; II - obtida liminarmente a medida em caráter antecedente, não promover a citação do requerido dentro de cinco dias; III - ocorrer a cessação da eficácia da medida em qualquer dos casos legais; IV - o juiz acolher a alegação de decadência, ou da prescrição da pretensão do autor. Parágrafo único. A indenização será liquidada nos autos em que a medida tiver sido concedida".

482 “Art. 475-O. A execução provisória da sentença far-se-á, no que couber, do mesmo modo que a definitiva, observadas as seguintes normas: I - corre por iniciativa, conta e responsabilidade do exeqüente, que se obriga, se a sentença for reformada, a reparar os danos que o executado haja sofrido; II - fica sem efeito, sobrevindo acórdão que modifique ou anule a sentença objeto da execução, restituindo-se as partes ao estado anterior e liquidados eventuais prejuízos nos mesmos autos, por arbitramento;"; e "Art. 574. O credor ressarcirá ao devedor os danos que este sofreu, quando a sentença, passada em julgado, declarar inexistente, no todo ou em parte, a obrigação, que deu lugar à execução”. 
mesmo gênero das "tutelas de urgência" (como visto no "item 13" acima), as quais trazem consigo os mesmos riscos inerentes à sumariedade de sua cognição, não sendo plausível, portanto, se instituir a responsabilidade objetiva do beneficiário de um provimento cautelar e não fazer o mesmo com relação ao favorecido por uma antecipação de tutela ${ }^{483}$.

Dessa forma, o beneficiário da tutela de urgência, qualquer que seja ela, será objetivamente responsável pelos efetivos prejuízos causados à parte contrária em caso de reforma da decisão que havia concedido, a priori, a medida urgente em seu favor ${ }^{484}$. Regra essa aplicável também à arbitragem.

Diz-se "efetivos prejuízos", pois, embora a responsabilidade do beneficiário da tutela de urgência seja objetiva, caberá a outra parte comprovar a efetiva ocorrência dos danos que lhes foram causados em virtude da efetivação da tutela de urgência, uma vez que não há responsabilidade sem prejuízo. Desse modo, caso a efetivação da tutela de urgência não tenha causado qualquer dano à parte contrária, nenhuma indenização será devida ${ }^{485}$.

\footnotetext{
${ }^{483}$ CÂNDIDO RANGEL DiNAMARCO sustenta que, "se a efetivação da medida urgente houver causado dano, é natural que por ele responda aquele que requerera tal medida e dela se beneficiara. Na disciplina da tutela antecipada o Código de Processo Civil nada diz sobre essa responsabilidade, o que mais uma vez gera a necessidade de um lavor interpretativo capaz de, mediante remissão ao que está disposto quanto às medidas cautelares, conduzir a resultados satisfatórios. Se essas duas espécies de medidas urgentes são igualmente portadoras dos mesmos riscos inerentes à superficialidade da instrução em que se baseiam, seria ilegítimo instituir a responsabilidade objetiva do beneficiário de medidas cautelares e negar igual tratamento em caso de antecipação tutelar. Por isso, ao art. 811 do Código de Processo Civil, inserido no livro regente do processo cautelar, deve ser atribuída eficácia de estabelecer que o requerente de medida urgente responde ao requerido pelo prejuízo que lhe causar a execução da medida. Tanto quanto ali se estabelece em relação à tutela cautelar, também no tocante às antecipações essa responsabilidade é objetiva, o que dispensa o elemento subjetivo e faz ser suficiente a efetividade do dano e da causalidade entre a medida e este, dispensando-se o lesado de qualquer prova do dolo ou culpa do beneficiário da medida." (O Regime jurídico das medidas..., pp. 60/61).

${ }^{484}$ Nesse diapasão, TÉRCIO CHIAVASSA diz que "o direito processual pátrio, ao contrário do lusitano, acolheu a teoria da responsabilidade objetiva para indenização que será devida por aquele que, com o auxílio do Estado, fez atuar uma tutela de urgência e desse ato tenha surgido um dano para a parte, sem que haja necessidade de se perquirir sobre a culpa ou o dolo daquele que dela se aproveitou" (Tutelas de Urgência Cassadas: a Recomposição do Dano. São Paulo: Quartier Latin, 2004, p. 116). PAULO AFONSO GARRIDO DE PAULA também confirma que, "a exemplo do que fez com a execução provisória (CPC, art. 588), o legislador prescreve hipótese de responsabilidade objetiva para o requerente da medida cautelar que a obtém mas não consegue validar o direito que alegava ter ou que deixa de atentar para as condições excepcionais que possibilitaram sua concessão." (Código de Processo Civil Interpretado..., p. 2.258). Em sentido contrário, pela responsabilidade subjetiva da parte: BAPTISTA DA SILVA, Ovídio A. "Antecipação de Tutela e Responsabilidade Objetiva". Revista dos Tribunais, n. ${ }^{\circ}$ 748. São Paulo: RT, fevereiro de 1998, pp. 32/46.

${ }^{485}$ Nesse sentido, CARLOS ROBERTO GONÇALVES ensina que "sem a prova do dano, ninguém pode ser responsabilizado civilmente", ressaltando que "ainda mesmo que haja violação de um dever jurídico, e que tenha existido culpa e até mesmo dolo por parte do infrator, nenhuma indenização será devida, uma vez que
} 
Em oportuna lição, LUCON ressalta que, caso seja reformada a decisão que concedeu a tutela de urgência e ela tenha sido executada com a cobrança de multa diária (astreintes), o valor recebido pela parte favorecida a título de multa também deverá ser devolvido à parte contrária, por força da responsabilidade objetiva do demandante e para se evitar enriquecimento sem causa. Nesse caso, LuCON explica que, como não há no sistema brasileiro o "contempt of court" e a multa não é destinada ao Estado, mas, sim, à parte, o valor pago a título de multa também deve retornar ao patrimônio do demandado ${ }^{486}$.

Mesmo na hipótese de concessão de tutela de urgência de ofício, a própria parte será responsável pelos prejuízos causados pela efetivação da medida, uma vez que, como visto acima, a parte demandante responde objetivamente pelos prejuízos causados por processo por si ajuizado, nos termos do CPC.

Todavia, os árbitros ou o tribunal arbitral também poderão ser responsabilizados, especialmente nos casos em que a parte que não pleiteou a tutela de urgência noticiar ao juízo arbitral que não tem interesse na medida, mas apenas na tutela jurisdicional de mérito, para ter certeza de que seu direito é válido (minorando o risco de a decisão favorável deferida em tutela de urgência ser revertida ao final).

E não há razão para essa sistemática processual do processo judicial perante a justiça estatal não ser aplicada, também, ao processo arbitral ${ }^{487}$.

Caso não haja qualquer previsão distinta no regulamento escolhido pelas partes na arbitragem, e por meio de uma interpretação sistemática das próprias tutelas de urgência (e da potencialidade danosa que trazem consigo, uma vez que, na maioria das vezes, são deferidas inaudita altera parte e com base em cognição sumária), aplicar-se-á, sim, a responsabilidade objetiva prevista em nosso ordenamento processual civil também aos processos arbitrais.

não se tenha verificado prejuízo. A inexistência de dano é óbice à pretensão de uma reparação, aliás sem

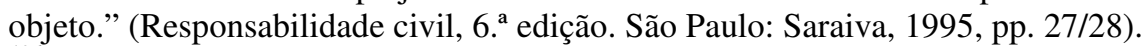

${ }^{486}$ in Eficácia das decisões e execução provisória. São Paulo: RT, 2000.

${ }^{487}$ Cf. SILVA, João Paulo Hecker. Tutela de Urgência e Tutela..., p. 319. 
Assim, a parte beneficiária de uma tutela de urgência que for posteriormente revogada pelo árbitro ou painel arbitral responderá objetivamente pelos prejuízos efetivamente causados a outra parte por conta de referida medida urgente ${ }^{488}$.

Ressalte-se, por oportuno, que, se a decisão que houver concedido a tutela de urgência for revogada, modificada ou reformada, as partes deverão ser restituídas ao status quo ante, sendo possível a liquidação dos prejuízos causados à parte contrária nos próprios autos da arbitragem. Isto é, caso o árbitro, quando da sentença final, revogue, modifique ou reforme a decisão liminar anterior, deverá fixar nessa sentença final, por arbitramento, em favor da parte contrária, a indenização pelos prejuízos causados pela medida urgente ${ }^{489}$.

Quanto à eventual responsabilidade do(s) árbitro(s), também se aplicam subsidiariamente as regras previstas em nosso ordenamento jurídico relativas à responsabilidade do juiz, especialmente porque, conforme o disposto no artigo 18 da Lei de Arbitragem brasileira, o árbitro é legalmente considerado "juiz de fato e de direito".

${ }^{488} \mathrm{O} \S 1041$, (4), do CPC alemão (ZPO) prevê regra bastante similar, estabelecendo que: "Section 1041 Interim measures of protection (4) If a measure ordered under subsection 1 proves to have been unjustified from the outset, the party who obtained its enforcement is obliged to compensate the other party for damage resulting from the enforcement of such measure or from his providing security in order to avoid enforcement. This claim may be put forward in the pending arbitral proceedings." (trad. livre: "Seção 1041 - Medidas interinas de proteção (4) Se a medida ordenada com fundamento na subseção 1 for tida como injustificada desde o início, a parte que obteve sua execução é obrigada a compensar a outra parte dos prejuízos advindos da execução de tal medida ou da caução fornecida para evitar a execução. Esse pedido pode ser feito no procedimento arbitral pendente.”). Em Portugal, a Lei de Arbitragem Voluntária (Lei n. ${ }^{\circ}$ 63/2011) também prevê a responsabilidade objetiva do beneficiário da medida urgente, conforme o disposto em seu artigo $26 .^{\circ}$ : "Responsabilidade do requerente. A parte que solicite o decretamento de uma providência cautelar ou requeira a emissão de uma ordem preliminar é responsável por quaisquer custos ou prejuízos causados à outra parte por tal providência ou ordem, caso o tribunal arbitral venha mais tarde a decidir que, nas circunstâncias anteriormente existentes, a providência ou a ordem preliminar não deveria ter sido decretada ou ordenada. O tribunal arbitral pode, neste último caso, condenar a parte requerente no pagamento da correspondente indenização em qualquer estado do processo". O artigo 26 (8) das Regras de Arbitragem da UNCITRAL segue a mesma linha: "8. The party requesting an interim measure may be liable for any costs and damages caused by the measure to any party if the arbitral tribunal later determines that, in the circumstances then prevailing, the measure should not have been granted. The arbitral tribunal may award such costs and damages at any point during the proceedings." (tradução livre: "8. A parte requerente de uma medida liminar será responsável por quaisquer custos e prejuízos causados pela medida a qualquer parte se o tribunal arbitral posteriormente determinar que, nas circunstâncias então em vigor, a medida não deveria ter sido concedida. O tribunal arbitral pode determinar tais custos e prejuízos a qualquer tempo durante o processo arbitral.").

${ }^{489}$ Nesse sentido, C. A. Alvaro DE OllveIRA afirma que, nas hipóteses de modificação, revogação ou anulação da tutela de urgência, "as partes serão restituídas ao estado anterior e liquidados eventuais prejuízos nos mesmos autos, por arbitramento (aplicação analógica do disposto no art. 475-O, II, Lei $\mathrm{n}^{\circ} 11.232$, de 2005). Claro que se a decisão for revogada, modificada ou anulada apenas em parte, somente nessa parte ficarão sem efeito a tutela antecipada e sua efetivação (aplicação analógica do art. 475-O, $\S 1^{\circ}$, Lei n ${ }^{\circ} 11.232$, de 2005)." (Comentários ao Código de..., p. 7). 
Nos termos do artigo 133 do Código de Processo Civil ${ }^{490}$, o juiz responde pelos danos causados às partes quando procede com dolo ou má-fé ${ }^{491}$.

Portanto, se o árbitro agir com dolo ou má-fé (e.g., se receber valores de uma das partes para decidir em seu favor, se decidir com base em interesse pessoal ou profissional em favor de uma das partes etc.), com a intenção de prejudicar qualquer das partes de uma arbitragem, violando, por conseguinte, os deveres prescritos nos artigos $13, \S 6 .^{\circ}$, e $14, \S 1 .^{\circ}$, da Lei de Arbitragem brasileira ${ }^{492}$, não há dúvida de que ele também responderá pelos prejuízos causados às partes ${ }^{493}$.

Ou seja, se o árbitro receber propina de uma das partes para deferir determinada tutela de urgência, ele certamente será responsável pelos prejuízos causados à parte contrária em virtude de aludida medida.

Uma diferença com relação à responsabilidade do juiz e à responsabilidade do árbitro quando agem com dolo ou má-fé é que, com relação aos

\footnotetext{
490 "Art. 133. Responderá por perdas e danos o juiz, quando: I - no exercício de suas funções, proceder com dolo ou fraude; II - recusar, omitir ou retardar, sem justo motivo, providência que deva ordenar de ofício, ou a requerimento da parte. Parágrafo único. Reputar-se-ão verificadas as hipóteses previstas no noำ II só depois que a parte, por intermédio do escrivão, requerer ao juiz que determine a providência e este não lhe atender o pedido dentro de 10 (dez) dias".

${ }^{491}$ JOSÉ ROBERTO DOS SANTOS BEDAQUE anota que "como qualquer pessoa, o juiz pode ser autor de ato ilícito, agindo no exercício de suas funções. Se o fizer, responderá pelas respectivas perdas e danos. Mas aqui verifica-se uma peculiaridade. A responsabilidade aquiliana do juiz somente ocorre se ele agir com dolo ou fraude, isto é, com intenção de prejudicar alguém." (Código de Processo Civil Interpretado..., p. 371).

492 "Art. 13. (...) $\S 6^{\circ}$ No desempenho de sua função, o árbitro deverá proceder com imparcialidade, independência, competência, diligência e discrição."; "Art. 14. Estão impedidos de funcionar como árbitros as pessoas que tenham, com as partes ou com o litígio que lhes for submetido, algumas das relações que caracterizam os casos de impedimento ou suspeição de juízes, aplicando-se-lhes, no que couber, os mesmos deveres e responsabilidades, conforme previsto no Código de Processo Civil. $\S 1^{\circ}$ As pessoas indicadas para funcionar como árbitro têm o dever de revelar, antes da aceitação da função, qualquer fato que denote dúvida justificada quanto à sua imparcialidade e independência".

${ }^{493} \mathrm{Na}$ Argentina, os artigos 745 e 756 do Código de Processo Civil e Comercial da Nação também regulam a responsabilidade do árbitro, estatuindo que "Desempeño de Los Arbitros - Art. 745. - La aceptación de los árbitros dará derecho a las partes para compelerlos a que cumplan con su cometido, bajo pena de responder por daños y perjuicios." (tradução livre: "Desempenho dos Árbitros - Art. 745. - A aceitação dos árbitros dará direito às partes para compeli-los a cumprir com suas obrigações, sob pena de responder por danos e prejuízos.") e que "Responsabilidad de Los Arbitros - Art. 756. - Los árbitros que, sin causa justificada, no pronunciaren el laudo dentro del plazo, carecerán de derecho a honorarios. Serán asimismo responsables por los daños y perjuicios." (tradução livre: Responsabilidade dos árbitros - Art. 756. - Os árbitros que, sem causa justificada, não proferirem o laudo dentro do prazo, perderão o direito a honorários. Serão assim mesmo responsáveis pelos danos e prejuízos"). Na Itália, a responsabilidade dos árbitros está prevista no artigo 813-ter do Código de Processo Civil italiano, havendo previsão expressa de responsabilidade quando o árbitro age com dolo ou culpa grave, podendo a ação de responsabilidade ser proposta pela parte ainda enquanto pendente o processo arbitral.
} 
prejuízos causados pelo juiz, o Estado também responde solidariamente por referidos prejuízos e de forma objetiva ${ }^{494}$, nos termos dos artigos $5 .^{\circ}$, LXXV, e $37, \S 6 .^{\circ}$, da Constituição Federal ${ }^{495}$. Quanto ao árbitro, somente ele responderá pelos prejuízos causados por atos eivados de dolo ou de má-fé ou, se se tratar de uma arbitragem institucional, conduzida perante alguma Câmara Arbitral, esta também responderá pelos prejuízos, mas não objetivamente, pois subsistirá a necessidade da comprovação do elemento subjetivo do "dolo ou má-fé" do árbitro ou da violação de quaisquer dos deveres estatuídos nos artigos $13, \S 6 .^{\circ}$, e $14, \S 1$. $^{\circ}$ da Lei n. ${ }^{\circ} 9.307 / 96$.

Ainda quanto ao assunto, se a arbitragem contar com mais de um árbitro, somente aquele(s) que comprovadamente agir(em) com dolo ou má-fé pode(m) ser responsabilizado(s) de pronto.

Por exemplo, em uma arbitragem que conta com três árbitros, dois deles receberam vantagens financeiras de uma das partes para conceder uma tutela de urgência em seu favor, não tendo o terceiro árbitro sequer sido procurado por referida parte. Evidente que este último árbitro, que não recebeu qualquer valor indevido, não poderá ser responsabilizado de plano, especialmente se proferiu decisão divergente (pode a tutela de urgência, sem dúvida, ser concedida por maioria em um processo arbitral, assim como ocorre em segunda instância na justiça estatal).

No entanto, se referido árbitro tiver acompanhado a decisão dos árbitros corrompidos, ele também poderá ser eventualmente responsabilizado se ficar demonstrada a violação aos deveres de "competência e diligência" (art. 13, § 6. ${ }^{\circ}$, da Lei n. ${ }^{\circ}$ 9.307/96). Ou seja, comprovando-se que a decisão proferida pelos árbitros corrompidos era teratológica, absurda mesmo, o árbitro imparcial que acompanhou aludida decisão também responderá pelos prejuízos causados, em virtude da violação aos deveres supracitados de “competência e diligência”, expressamente previstos na Lei de Arbitragem brasileira.

\footnotetext{
494 Nesse sentido, José Roberto dos SANTOS BedAQUe leciona que o artigo 133 do CPC "trata da responsabilidade pessoal do juiz, o que não obsta eventual obrigação do Estado, independentemente do elemento subjetivo (CF, art. 37, § 6º." (Código de Processo Civil Interpretado..., p. 371).

495 “Ar. 5. (...) LXXV - o Estado indenizará o condenado por erro judiciário, assim como o que ficar preso além do tempo fixado na sentença;”; “Art. 37. (...) $§ 6^{\circ}$ - As pessoas jurídicas de direito público e as de direito privado prestadoras de serviços públicos responderão pelos danos que seus agentes, nessa qualidade, causarem a terceiros, assegurado o direito de regresso contra o responsável nos casos de dolo ou culpa".
} 
Fazendo-se aqui uma analogia entre a responsabilidade de vários árbitros com a responsabilidade de diversos administradores de uma sociedade anônima, aplicar-se-ia à hipótese o $\S 1 .^{\circ}$ do art. 158 da Lei n. ${ }^{\circ} 6.404 / 76$, o qual dispõe que:

"§ $1^{\circ} \mathrm{O}$ administrador não é responsável por atos ilícitos de outros administradores, salvo se com eles for conivente, se negligenciar em descobri-los ou se, deles tendo conhecimento, deixar de agir para impedir a sua prática. Exime-se de responsabilidade o administrador dissidente que faça consignar sua divergência em ata de reunião do órgão de administração ou, não sendo possível, dela dê ciência imediata e por escrito ao órgão da administração, no conselho fiscal, se em funcionamento, ou à assembléia-geral".

Utilizando-se dessa mesma e coerente lógica, o árbitro que não foi corrompido apenas poderia ser responsabilizado: (i) se foi conivente; (ii) se foi negligente (exemplo de negligência seria a concordância com uma decisão claramente teratológica); ou (iii) se deixou de impedir a prática do ilícito, se dele tomou conhecimento.

Outro ponto que também deve ser aqui tratado é a eventual responsabilidade do árbitro ou do painel de árbitros pela revogação judicial da decisão arbitral que havia deferido eventual tutela de urgência.

Como visto no "item 23" acima, tendo em vista que não cabe recurso contra a decisão do(s) árbitro(s) que concede uma tutela de urgência, a parte somente poderá impugná-la perante a justiça estatal, seja por meio de ação para declarar a nulidade (anulação) da decisão arbitral, seja por meio de impugnação ao cumprimento da decisão arbitral, não podendo, no entanto, discutir o mérito da decisão arbitral, mas apenas as matérias descritas no artigo 32 da Lei de Arbitragem brasileira.

E o mencionado artigo 32 da Lei de Arbitragem prevê as seguintes hipóteses de nulidade da decisão arbitral, in verbis:

“Art. 32. É nula a sentença arbitral se:

I - for nulo o compromisso;

II - emanou de quem não podia ser árbitro;

III - não contiver os requisitos do art. 26 desta Lei;

IV - for proferida fora dos limites da convenção de arbitragem;

V - não decidir todo o litígio submetido à arbitragem; 
VI - comprovado que foi proferida por prevaricação, concussão ou corrupção passiva;

VII - proferida fora do prazo, respeitado o disposto no art. 12, inciso III, desta Lei; e

VIII - forem desrespeitados os princípios de que trata o art. $21, \S 2^{\circ}$, desta Lei”.

De plano, verifica-se que o(s) árbitro(s) responde(m) pessoalmente pelos prejuízos causados às partes no caso de anulação judicial de sua decisão com base no inciso VI do artigo 32, qual seja: decisão "proferida por prevaricação, concussão ou corrupção passiva", com base nos argumentos acima expostos, tendo em vista que se enquadra na hipótese já tratada de decisão proferida com dolo ou má-fé.

A responsabilidade do(s) árbitro(s), nesse caso, será tanto civil como criminal, pois, nos termos do artigo 17 da Lei de Arbitragem brasileira ${ }^{496}$, o árbitro é equiparado a um funcionário público no exercício ou em razão de suas funções ${ }^{497}$.

Com relação à responsabilidade do(s) árbitro(s) pela anulação da decisão arbitral fundada nos demais incisos do artigo 32 da Lei n. ${ }^{\circ}$ 9.307/96, esta decorre do dever contratual do(s) árbitro(s) para com as partes de proferir uma decisão válida, isto é, decorreria da culpa do(s) árbitro(s) em não cumprir referido dever.

E, conforme destaca Jõ̃o PAUlo HeCKER DA SILVA ${ }^{498}$, há duas situações distintas quanto à responsabilidade do(s) árbitro(s) em caso de anulação da decisão arbitral: uma quando a anulação está fundada nos incisos III, IV ou V do artigo 32 da Lei de Arbitragem, e outra quando a anulação se dá com base nos incisos I, II, VI, VII ou VIII desse mesmo dispositivo legal.

Isso porque, apesar de em todas as hipóteses a decisão arbitral restar anulada, perdendo, de pleno direito, qualquer eficácia, no caso de anulação da decisão arbitral com base nos incisos III, IV ou V do artigo 32, a própria Lei de

\footnotetext{
496 “Art. 17. Os árbitros, quando no exercício de suas funções ou em razão delas, ficam equiparados aos funcionários públicos, para os efeitos da legislação penal”.

${ }^{497}$ Corroborando esse entendimento: "Nesse caso, é evidente a responsabilidade não só civil como criminal, já que o árbitro, no desempenho de suas funções, é comparado a funcionário público.” (SILVA, João Paulo Hecker da. Tutela de Urgência e Tutela..., p. 320); "Tal é a importância do árbitro, que é equiparado a funcionário público, notadamente para fins penais.” (HOFFMAN, Paulo. Arbitragem: algumas dúvidas..., p. 309).

498 Tutela de Urgência e Tutela..., pp. 320/321.
} 
Arbitragem determina seja proferida nova decisão em sede de arbitragem (art. 33, § 2. ${ }^{\circ}$, II), o que não ocorre em caso de anulação da decisão arbitral fundada nos demais incisos I, II, VI, VII ou VIII (art. 33, § 2. ${ }^{\circ}$, I), em que a decisão arbitral é anulada e se encerra a

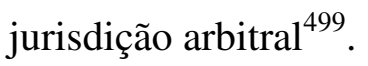

Assim, quando a decisão arbitral é anulada com base nos incisos I, II, VI, VII ou VIII do artigo 32 da Lei de Arbitragem brasileira, o árbitro ou o painel de árbitros é civilmente responsável pelos prejuízos advindos da tutela de urgência que havia deferido, incluindo-se também a obrigação de ressarcir às partes as custas, as despesas, os honorários do(s) árbitro(s) e do advogado, devidamente atualizados, em virtude do encerramento da jurisdição arbitral.

Por outro lado, quando a anulação da decisão arbitral se dá com fulcro nos incisos III, IV ou V do artigo 32 da Lei n. ${ }^{\circ}$ 9.307/96, a responsabilidade do árbitro ou do painel arbitral fica restrita à prolação de nova decisão arbitral, sanando os vícios indicados na decisão judicial (obrigação de fazer), sob pena de, não o fazendo, aí sim, se converter essa obrigação em perdas e danos, com a responsabilização do(s) árbitro(s) no pagamento de compensação pecuniária ${ }^{500}$.

\footnotetext{
${ }^{499}$ Eis os termos do art. 33, § 2. ${ }^{\circ}$, I e II, da Lei n. ${ }^{\circ}$ 9.307/96: "Art. 33. A parte interessada poderá pleitear ao órgão do Poder Judiciário competente a decretação da nulidade da sentença arbitral, nos casos previstos nesta Lei. (...) $\S 2^{\circ}$ A sentença que julgar procedente o pedido: I - decretará a nulidade da sentença arbitral, nos casos do art. 32, incisos I, II, VI, VII e VIII; II - determinará que o árbitro ou o tribunal arbitral profira novo laudo, nas demais hipóteses".

${ }^{500}$ Nesse diapasão: "evidentemente que, se não cumprida a tutela específica no tempo e modo definidos em lei ou pela sentença judicial, tal descumprimento poderá ensejar a conversão da obrigação de fazer do árbitro ou Tribunal Arbitral em pagamento dos valores pagos pelas partes a título de custas, despesas e honorários de árbitro, além dos lucros cessantes e das perdas e danos causadas." (SILVA, João Paulo Hecker da. Tutela de Urgência e Tutela..., p. 321).
} 


\section{CAPÍTULOX - TUTELAS DE URGÊNCIA NO PROCESSO ARBITRAL E TERCEIROS}

Outro assunto relevante, em se tratando de tutelas de urgência em arbitragem, diz respeito ao envolvimento de eventuais terceiros.

\section{Como ensina EugÊnia C. G. DE Jesus Zerbini, "é inques-} tionável que as raízes da arbitragem estão plantadas na vontade das partes" ${ }^{, 501}$, razão pela qual estas só podem ser obrigadas a arbitrar seus litígios de comum acordo ${ }^{502}$.

Por conta disso, não é possível compelir quem não tenha firmado a convenção de arbitragem (cláusula compromissória ou compromisso arbitral) a participar de uma arbitragem ou a se sujeitar aos seus efeitos, sendo vedado ao(s) árbitro(s) conceder tutelas de urgência que envolvam bens ou direitos de terceiros, que não participam da arbitragem ${ }^{503}$.

Nesse mesmo diapasão, AdA PELLEGRINI GRINOVER leciona que, em decorrência do princípio do devido processo legal e seus corolários, aplica-se à arbitragem a conhecida regra de direito processual de que a decisão proferida em um processo não deve atingir terceiros ${ }^{504}$.

${ }^{501}$ ZERBINI, Eugênia C. G. de Jesus. "Cláusulas arbitrais: transferência e vinculação de terceiros à arbitragem". Arbitragem no Brasil - Aspectos jurídicos relevantes. JOBIM, Eduardo; MACHADO, Rafael Bicca (coord.). São Paulo: Quartier Latin, 2008, pp. 141/151, p. 142.

${ }^{502}$ Quanto ao tema, PAULO HOFFMAN afirma que "a arbitragem é facultativa e pode ser eleita pelas partes interessadas, mas nunca ser imposta legalmente.” (in Arbitragem: algumas dúvidas..., p. 307). Igualmente, CARMONA anota que, no Brasil, a opção pela arbitragem é sempre voluntária, pois não existe arbitragem obrigatória em nosso país (foi abolida em 1866), ressalvando, no entanto, que em Portugal e na Costa Rica a solução arbitral é obrigatória para determinadas matérias (in Arbitragem e Processo..., p. 36).

${ }^{503}$ Nesse sentido, BERNARD HANOTIAU relembra que o "consenso é a base da arbitragem e, em geral, uma corte judicial ou um tribunal arbitral irão se recusar a tratar uma pessoa ou entidade como uma parte do contrato ou, ao menos, da cláusula arbitral se ela não tiver expressa ou implicitamente consentido com isso; um fato que na maioria - mas não em todos - os casos será expressado pela assinatura da pessoa ou entidade envolvida no documento contratual." (HANOTIAU, Bernard. Complex Arbitrations. The Hague: Kluwer Law, 2005, p. 32, tradução livre). Nessa mesma linha: "não é possível compelir quem não seja parte na convenção de arbitragem a comparecer perante o tribunal arbitral, exceto se aceito alguns desses expedientes aleatórios que, de modo laborioso, a prática tenta implementar" (OPPETIT, Bruno. Etudes offertes..., p. 192). ${ }^{504}$ GRINOVER, Ada Pellegrini. "Parecer - Arbitragem e Litisconsórcio Necessário". Revista Brasileira de Arbitragem, n. ${ }^{\circ}$ 10. São Paulo: IOB/CBAr, jul/set 2006, pp. 07/38, p. 13. PIERO BERNARDINI também ensina que “(...) os poderes do árbitro são limitados pela convenção de arbitragem e não podem ser exercidos contra pessoas que não são partes de tal convenção. Com efeito, um árbitro jamais poderá ordenar medidas conservativas e provisórias que necessitariam que uma terceira parte seja envolvida para a sua execução." (The Powers of the Arbitratos..., pp. 21/22, trad. livre). Igualmente, Julian M. LEW, LOUKAS A. MisTELIS e 
Todavia, especialmente nas arbitragens internacionais, diversas teorias foram desenvolvidas ao longo do tempo acerca da suposta possibilidade da extensão da convenção de arbitragem a terceiros interessados ou envolvidos em determinadas situações.

Dentre elas, destacam-se: (i) a teoria do grupo de companhias ("group of companies doctrine"), desenvolvida a partir do precedente "Dow Chemical vs Isover Saint Gobain" (ICC interim award n. ${ }^{\circ} 4131$, de 1982); (ii) a teoria da desconsideração da pessoa jurídica (conhecida na doutrina internacional como "disregard of the legal entity", "piercing the corporate veil" ou como teoria do "alter ego"); (iii) a teoria do consenso tácito ("implied consent"); (iv) a teoria da agência ou representação ("agencyrepresentation"); (v) da sucessão; (vi) da cessão de direitos ("universal or individual transfers"); (vii) do terceiro beneficiário e de garantidores ("third-party beneficiaries and guarantee clauses"); ou, ainda, (viii) a teoria de raiz anglo-americana denominada de "estoppel" ou "equitable estoppel",505.

De acordo com tais teorias e com os motivos específicos de cada uma delas, um terceiro poderia ser incluído em uma arbitragem ou ser atingido por uma decisão arbitral, mesmo não tendo firmado a convenção de arbitragem.

No Brasil, contudo, referidas teorias ainda são vistas com desconfiança, exigindo-se, por cautela, o consenso inequívoco da parte para que esta figure em uma arbitragem e para que esteja sujeita aos efeitos da decisão arbitral.

STEFAN MiCHAEL KRÖLL ressaltam que "limites importantes aos poderes dos árbitros de conceder medidas liminares advêm diretamente da natureza consensual de sua autoridade. Um tribunal arbitral não pode ordenar obrigações de fazer ou de não fazer a terceiras partes que não participam da arbitragem. Quaisquer dessa medidas que podem estar disponíveis para as cortes estatais não podem ser deferidas por um tribunal arbitral." (Comparative International..., p. 593, tradução livre).

${ }^{505}$ Sobre cada uma dessas teorias, ver: CAPRASSE, Olivier. "A arbitragem e os grupos de sociedades". Revista de Direito Bancário, do Mercado de Capitais e da Arbitragem, ano 6, n. ${ }^{\circ}$ 21. WALD, Arnoldo (coord.). São Paulo: RT, julho/setembro de 2003, pp. 339/386; SILVA, João Marçal Rodrigues Martins da. “A Extensão dos Efeitos da Cláusula de Arbitragem para Partes Não Signatárias”. Monografia apresentada à Faculdade de Direito da Pontifícia Universidade Católica do Rio de Janeiro em 2012 (www.maxwell.lambda. ele.puc-rio.br/16779/16779.PDF. Acessado em 18/11/2012); e ZERBINI, Eugênia C. G. de Jesus. "Cláusulas arbitrais: transferência e vinculação de terceiros à arbitragem”. Arbitragem no Brasil - Aspectos jurídicos relevantes. JOBIM, Eduardo; MACHADO, Rafael Bicca (coord.). SP: Quartier Latin, 2008, pp. 141/151. 
Nessa esteira, refutando a aplicação da teoria do grupo de companhias em nosso país, CARLOS AlBerto CARMONA afirma que o consentimento dos interessados é essencial, devendo ser cabal, claro e inequívoco, não podendo ser deduzido, imaginado, intuído ou estendido, notadamente porque a convenção arbitral produz efeitos contundentes (afastar a jurisdição estatal), concluindo que "mesmo que o árbitro perceba confusão patrimonial entre sociedades do mesmo grupo, não creio possível a inclusão na arbitragem de sociedade que não tenha celebrado o compromisso arbitral"506.

Gustavo TePedino, por sua vez, ressalta a possibilidade de o Poder Judiciário também controlar e analisar a validade da cláusula compromissória com relação a terceiros, especialmente quando há abusos em sua aceitação, tais como em um autocontrato ou na assinatura por mandato sem poderes específicos para tanto ${ }^{507}$.

A jurisprudência pátria sobre o tema, embora ainda escassa, também segue a mesma linha, sendo válida a menção de sentença proferida pelo juízo da 4. ${ }^{a}$ Vara Cível da Comarca de Barueri-SP, nos autos n. ${ }^{\circ}$ 068.01.2011.012802-6, por meio da qual referido juízo anulou sentença arbitral por inexistência de cláusula compromissória válida, entendendo a juíza da causa que não seria possível a extensão da arbitragem para terceiros com base na teoria da aparência ${ }^{508}$.

Ou seja, a doutrina e a jurisprudência brasileiras se inclinam para o entendimento de que a arbitragem não pode ser imposta sem que haja o consenso

${ }^{506}$ In Arbitragem e Processo..., p. 83.

507 "diante da ausência de outorga de poder expresso e especial para a celebração de cláusula arbitral e da falta de ratificação de tal cláusula pelos mandantes, aliada à expressa discordância quanto à instauração da arbitragem, não há que se falar em vinculação dos mandantes à jurisdição arbitral." (TEPEDINO, Gustavo. "Invalidade da Cláusula Compromissória e seu Controle (também) pela Jurisdição Estatal". Arbitragem no Brasil - Aspectos jurídicos relevantes. JOBIM, Eduardo; MACHADO, Rafael Bicca (Coord.). São Paulo: Quartier Latin, 2008, pp. 153/173, p. 168).

${ }^{508}$ No mesmo sentido dessa sentença: "(é indispensável que exista) clara e inequívoca demonstração de que as partes manifestaram sua intenção de submeter o litígio à arbitragem, sob pena de, na ausência de tal manifestação de vontade, a sentença arbitral não ser reconhecida pela justiça estatal brasileira." (LIMA, Flávio Pereira; MIRANDA, Daniel Calhman. "A Extensão da Cláusula Compromissória a Partes Não Signatárias no Direito Brasileiro”. Arbitragem no Brasil, volume I. São Paulo: Impressão Régia, 2010, pp. 13/26, p. 18). Na apelação n. ${ }^{\circ} 9193203-03.2002 .8 .26 .0000$ (n. ${ }^{\text {os }}$ antigos: 267.450-4/6-00, 994.02.0603920 - Rel. Des. Constança Gonzaga, j. 24/05/2006, v.u.), a 7. ${ }^{a}$ Câmara de Direito Privado do Tribunal de Justiça de São Paulo negou provimento ao recurso de apelação interposto, considerando a recorrente parte legítima para figurar no pólo passivo da ação de instituição de arbitragem e do próprio processo arbitral, mesmo não tendo a parte assinado o contrato do qual constava a clásula compromissória. Nesse caso, no entanto, o TJ/SP entendeu que houve o consenso inequívoco da parte quanto ao contrato e quanto à cláusula compromissória em outros documentos que não o contrato no qual estava contida a cláusula compromissória. 
inequívoco das partes para submeter o litígio ao juízo arbitral, não podendo as decisões arbitrais de urgência, por conseguinte, atingir terceiros ${ }^{509}$.

Isso não significa, entretanto, que o árbitro não possa conceder tutelas de urgência que envolvam providências simples a serem tomadas por órgãos públicos ou privados (terceiros), tais como, por exemplo, uma anotação em registro imobiliário ou a retirada do nome da parte de um cadastro de inadimplentes.

O único inconveniente, nessas hipóteses, será a recusa do órgão em cumprir a decisão arbitral, ocasião em que se fará necessário o auxílio do Poder Judiciário, ante a ausência de poder de imperium do árbitro para executar forçadamente a sua decisão ${ }^{510}$.

E caso uma decisão arbitral de urgência venha a atingir, de alguma forma, bens ou direitos de terceiro, este terá de se valer do mesmo remédio previsto para a hipótese similar em processos judiciais, qual seja: dos embargos de terceiro, a serem opostos perante o juiz togado.

Isso porque o terceiro não é parte na arbitragem, não podendo peticionar ou deduzir pedidos no processo arbitral, notadamente porque o árbitro não possui jurisdição para a análise de pedidos de terceiros.

\footnotetext{
${ }^{509}$ Nesse sentido, HuMBERTO THEODORO JÚNIOR entende que, "em função de sua origem contratual, a jurisdição arbitral não pode ir além do negócio jurídico que motivou a sua implantação, nem pode envolver senão as partes que o convencionaram. O árbitro, que sustenta sua função sobre a vontade das partes litigantes, mostra-se sem poder em relação a terceiros, ou seja, aqueles que não participaram do negócio instituir do juízo arbitral." (Arbitragem e terceiros..., p. 243), dentre outros. Na Itália, o artigo 816-quinquies do CPC estabelece que o terceiro apenas pode ser incluído na arbitragem com o seu consenso e com o consenso das partes e dos árbitros: "Art. 816-quinquies. (Intervento di terzi e successione nel diritto controverso) L'intervento volontario o la chiamata in arbitrato di un terzo sono ammessi solo con l'accordo del terzo e delle parti e con il consenso degli arbitri." (trad. livre: "Art. 816-quinto (Intervenção de terceiro e sucessão no direito controverso) A intervenção voluntária ou o chamamento de um terceiro em arbitragem são permitidos somente com a concordância do terceiro e das partes e com o consenso dos árbitros.").

${ }_{510}$ Nesse exato sentido, PeDro A. BATISTA MARTINS aponta que "as decisões do árbitro que deferirem medidas que necessitarem de ato ou imposição complementar (v.g. anotação em registro imobiliário; constituição de fiel depositário; arresto; busca e apreensão), deverão autorizar a parte interessada a buscar o juízo ordinário para confirmação e/ou execução das medidas requeridas, fundamentando-as de modo preciso e objetivo." (MARTINS, Pedro A. Batista. Da Ausência de Poderes Coercitivos..., pp. 361/362).
} 
Dessa forma, o terceiro eventualmente prejudicado pela decisão arbitral de urgência poderá impugná-la judicialmente por meio de embargos de terceiro, os quais certamente suscitarão a ausência de jurisdição do(s) árbitro(s) para atingir bens de uma parte que não participa da arbitragem, ou seja, em decisão proferida fora dos limites da convenção de arbitragem (cf. artigo 32, IV, da Lei de Arbitragem brasileira) ${ }^{511}$.

511 “Art. 32. É nula a sentença arbitral se: (...) IV - for proferida fora dos limites da convenção de arbitragem;”. Na França, o terceiro prejudicado também pode pleitear em juízo a anulação da decisão arbitral que lhe afetar, nos termos do art. 1501 do CPC francês: "Arte. 1501. La sentence arbitrale peut être frappée de tierce opposition devant la juridiction qui eût été compétente à défaut d'arbitrage, sous réserve des dispositions du premier alinéa de l'article 588." (tradução livre: “Art. 1501. A sentença arbitral pode ser impugnada por oposição de terceiro perante à jurisdição que seria competente se não houvesse a arbitragem, ficando sujeita às disposição da primeira alínea do artigo 588.”). 


\section{CAPÍTULO XI}

\section{CUMPRIMENTO DAS TUTELAS DE URGÊNCIA DEFERIDAS PELO ÁRBITRO}

\section{NAS ARBITRAGENS NACIONAIS}

Não há, na Lei de Arbitragem ou na legislação brasileira, regramento sobre a forma de como deve se dar a execução (rectius: cumprimento) da tutela de urgência deferida em arbitragem.

E, em virtude da ausência de regras específicas, ainda pairam dúvidas e questionamentos acerca do modo por meio do qual a tutela de urgência concedida no processo arbitral deve ser executada.

Primeiramente, pode ser que haja o cumprimento espontâneo pela própria parte contra a qual a tutela de urgência foi imposta. Caso isso ocorra, a medida urgente terá sido efetivada pela parte vencida e o juízo arbitral não terá que tomar qualquer outra providência ${ }^{512}$.

Quanto ao tema, é interessante a lição de PEDRO A. BATISTA MARTINS, no sentido de que a parte deve considerar que, se não cumprir espontaneamente a decisão liminar do(s) árbitro(s), isso provavelmente será levado em conta na apreciação do mérito ${ }^{513}$.

\footnotetext{
${ }^{512}$ SÉRGIO BERMUDES afirma que "muitas vezes, basta ao juízo decretar uma providência, para que, dócil, a parte a cumpra." (in Medidas coercitivas e cautelares..., p. 279).

513 “(...) o descumprimento de providência determinada pelo juízo privado será sempre sopesado e levado em consideração quando do julgamento do mérito da questão. Certamente, esse juízo de reflexão não é o que desejará a parte que apresenta-se como prejudicada frente a situação controvertida e busca obter a confirmação dos seus direitos, justamente, perante os julgadores que determinaram a medida que restou por ela inadimplida." (Da Ausência de Poderes Coercitivos..., p. 367). PIERO BERNARDINI também ressalta esse ponto: "tem sido corretamente ressaltado que a falta de poderes coercitivos do árbitro não torna a sua ordem ausente de significância prática, tendo em vista que, dentre outras considerações, será levado em conta, no momento da decisão final, o comportamento da parte recalcitrante." (The Powers of the Arbitrator..., p. 27, nota 34, trad. livre). NEIL ANDREWS também anota que o árbitro "pode extrair inferências contrárias do ato de não cumprimento." (Arbitration and mediation in England..., p. 116, trad. livre). Ainda quanto ao tema, o regulamento do Centro de Arbitragem e Mediação da Câmara de Comércio Brasil-Canadá prevê uma punição para a parte que deixar de cumprir uma decisão arbitral: "11.2. Na hipótese de descumprimento da sentença arbitral a parte prejudicada poderá comunicar o fato ao $\mathrm{CAM} / \mathrm{CBC}$, para que o divulgue a outras
} 
PIERO BERNARDINI ressalta, ainda, que as tutelas de urgência ordenadas pelo árbitro nem sempre exigem execução forçada, mencionando "o caso, por exemplo, de uma ordem autorizando uma parte a realizar um certo ato, ${ }^{, 514}$.

Nessas hipóteses (de cumprimento espontâneo da decisão arbitral de urgência pela parte ou de ausência da necessidade de execução da medida), o Poder Judiciário sequer intervirá na relação ${ }^{515}$, pois não haverá a necessidade de utilização do poder de imperium para fazer valer a decisão.

O auxílio por parte do Poder Judiciário somente será necessário se a parte contra a qual a tutela de urgência foi dirigida se recusar a cumpri-la espontaneamente, ocasião em que haverá a necessidade de utilização de força e de meios coercitivos, os quais, como visto acima, são exclusivos do Poder Judiciário ${ }^{516}$.

Nesse caso, em que há a recusa da parte em cumprir por livre e espontânea vontade a tutela de urgência imposta pelos árbitros, é que a decisão deverá ser executada perante o juízo comum ${ }^{517}$, surgindo a dúvida de como deverá ocorrer o pedido

instituições arbitrais e às câmaras de comércio ou entidades análogas, no País ou no exterior." (www.ccbc. org.br/default.asp?categoria=2\&subcategoria=Regulamento\%202012\#8. Acessado em 03/11/2012).

${ }^{514}$ The Powers of the Arbitrator..., p. 27.

${ }^{515}$ Cf. AMARAL, Paulo Osternack. A concessão de medidas urgentes..., p. 29. José ANTONIO FICHTNER, SERGIO NELSON MANNHEIMER e ANDRÉ LUís MONTEIRO também apontam que "concedida a medida e cumprida voluntariamente pela parte contrária, tudo se resolve na própria seara arbitral." (Cinco pontos sobre a arbitragem..., p. 317).

${ }^{516}$ Nessa esteira: "o socorro ao Poder Judiciário se dará no caso da parte à qual se dirige a medida negar-se a cumpri-la espontaneamente, fazendo-se necessária a utilização de força ou coerção que, como se sabe, é de exercício privativo do Estado.” (PITOMBO, Eleonora Coelho. Arbitragem e o Poder Judiciário..., p. 111). PIERO BERNARDINI também anota que "(...) most of the measures which may be ordered by the arbitrator require, if not voluntarily complied with, the assistance of the state court to be enforced." (trad. livre: “(...) a maioria das medidas que podem ser concedidas pelo árbitro exige, se não cumprida voluntariamente, a assistência do juízo estatal para ser executada.") (The Powers of the Arbitrator..., p. 27).

517 Nesse diapasão: "Sem embargo da força executória das decisões obtidas pela arbitragem, é perante o Poder Judiciário que se processará o cumprimento da referida sentença, consoante a regra do art. 475-P, III, do CPC." (TJ/SP, 8. ${ }^{a}$ Câm. Dir. Privado, A.I. n. ${ }^{\circ}$ 0013020-78.2011.8.26.000, Rel. Des. Ribeiro da Silva, j. 19/10/2011, v.u.). Assim como no Brasil, em Portugal o árbitro também é competente para conceder as tutelas de urgência, mas não possui poderes para executá-las, devendo buscar o imperium junto ao juízo estatal, nos termos do artigo 27. ', “1”, da Lei n. ${ }^{\circ}$ 63/2011: “Artigo 27. ${ }^{\circ}$ Reconhecimento ou execução coerciva 1 - Uma providência cautelar decretada por um tribunal arbitral é obrigatória para as partes e, a menos que o tribunal arbitral tenha decidido de outro modo, pode ser coercivamente executada mediante pedido dirigido ao tribunal estadual competente, independentemente de a arbitragem em que aquela foi decretada ter lugar no estrangeiro, sem prejuízo do disposto no artigo 28.”. Na suíça, nos termos do art. 183 , (2), da Lei Federal Suíça de Direito Privado Internacional, a decisão liminar arbitral que não é cumprida pela parte também deve ser executada perante a justiça estatal: "Art. 183 - Provisional and protective measures (...) 2. If the party concerned does not comply voluntarily, the arbitral tribunal may request the assistance of the judge with jurisdiction who shall apply his own law." (tradução livre: "Art. 183 - Medidas provisórias e 
de auxílio do(s) árbitro(s), ou do tribunal arbitral, ou da instituição arbitral, ou da própria parte favorecida pela liminar ${ }^{518}$ ao Poder Judiciário para a efetivação da medida urgente.

E apesar de a Lei de Arbitragem não ter se manifestado a esse respeito, e mesmo não havendo regramento específico sobre o assunto, a maioria dos doutrinadores entende que tal pedido, se oriundo do(s) árbitro(s), ou do tribunal arbitral, ou da instituição arbitral, deve ser feito mediante simples comunicação entre juízos, "como no caso de uma carta precatória",519.

Por todos, cite-se Carlos Alberto Carmona, para o qual essa comunicação se dará mediante a simples expedição de ofício pela corte arbitral ao juízo estatal, solicitando o cumprimento, com a utilização de força ou coerção, da tutela de urgência deferida no processo arbitral ${ }^{520}$.

conservativas - (...) 2. Se a parte em questão não cumprir voluntariamente a decisão, o tribunal arbitral pode requerer a assistência do juiz com jurisdição, o qual deverá aplicar a sua própria lei.”).

518 Nessa esteira, José Antonio Fichtner, SERgio Nelson MANNHEIMER e André Luís Monteiro esclarecem que "embora essa competência para solicitar o apoio do Poder Judiciário, em princípio, seja do árbitro, do tribunal arbitral ou da instituição arbitral, nos termos literais do mencionado $\S 4 .^{\circ}$ do art. 22 da Lei 9.307/96, nada impede que a parte interessada, havendo urgência ou qualquer outra justificativa, também apresente o requerimento diretamente ao Poder Judiciário", dizendo que "a parte interessada poderá tomar diretamente a iniciativa, nada justificando uma exclusividade absoluta do árbitro em estabelecer esse contato com o juiz togado." (Cinco pontos sobre a arbitragem..., p. 317). Pedro A. BATISTA MARTins também diz que, "determinado expressamente pelo árbitro o remédio cautelar ou coercitivo pleiteado, poderá o interessado dirigir-se ao Judiciário para buscar o ato judicial de deferimento da imposição da medida, munido da decisão do julgador privado que autorizou a providência." (in Da Ausência de Poderes Coercitivos..., p. 365). Em sentido contrário, PAULO HOFFMAN pontifica que "será sempre o árbitro quem formulará o requerimento perante o Poder Judiciário, (...)” (Arbitragem: algumas dúvidas..., p. 319).

${ }^{519}$ Cf. PITOMBO, Eleonora Coelho. Arbitragem e o Poder Judiciário..., p. 112. Em igual sentido, SIDNEI BENETI aduz que "a efetivação da cautelar ou da antecipação da tutela arbitral caracteriza a cooperação jurisdicional (entre ambas as jurisdições), à moda do que ocorre com as cartas precatória ou rogatória, (...)" (Arbitragem e tutelas de urgência..., p. 105).

520 “O árbitro dirigir-se-á ao juiz por meio de ofício, instruído com cópia da convenção de arbitragem e do adendo de que trata o art. 19, parágrafo único, da Lei de Arbitragem, se existir. Enquanto não houver regulamentação para os trâmites necessários ao cumprimento da solicitação do concurso do juiz togado, o melhor método será o da distribuição do ofício a um dos juízos cíveis competentes para o ato." (in Arbitragem e Processo..., p. 325). O autor reiterou esse entendimento em outra obra: "afirmo, portanto, que o árbitro sendo necessário o concurso do Poder Judiciário - dirigir-se-á ao juiz togado por mero ofício, sem necessidade de qualquer fórmula fantasiosa, comprovando sua investidura (apresentará cópia do compromisso ou do documento que contém a cláusula compromissória) e é o quanto basta!" (in “O processo arbitral”. Revista de Arbitragem e Mediação, vol. 1. WALD, Arnoldo (coord.). São Paulo: RT, jan/abr 2004, pp. 21/31, p. 30). No mesmo sentido, PAULO OSTERNACK AMARAL afirma que "como ainda não há regulamentação a propósito dos trâmites atinentes aos atos de cooperação entre árbitro e o juiz togado, entende-se, sistematicamente, que a solicitação de efetivação das medidas concedidas pelo árbitro será feita por meio de ofício." (A concessão de medidas urgentes..., p. 29). Não é diferente a lição de ClÁVIO DE MELO VALENÇA FILHO, para o qual “o pedido de colaboração deve ser encaminhado ao juiz estatal na forma de ofício instruído com cópia da convenção e do contrato de arbitragem, como se fora uma precatória." (Tutela judicial de urgência e a lide..., p. 28). SIDNEI BENETI também leciona que "o instrumento da 'solicitação' é um ofício de requisição expedido pelo árbitro ao juízo estatal competente, (...)” (Arbitragem e tutelas de urgência..., p. 105). Por fim, ANDRÉ 
LUIS FERNANDO GUERRERO, confirmando que são comuns as decisões no Judiciário brasileiro que recebem solicitações de árbitros e as cumprem, seguindo os princípios estabelecidos na Lei de Arbitragem ${ }^{521}$, traz um exemplo prático do Estado do Mato Grosso:

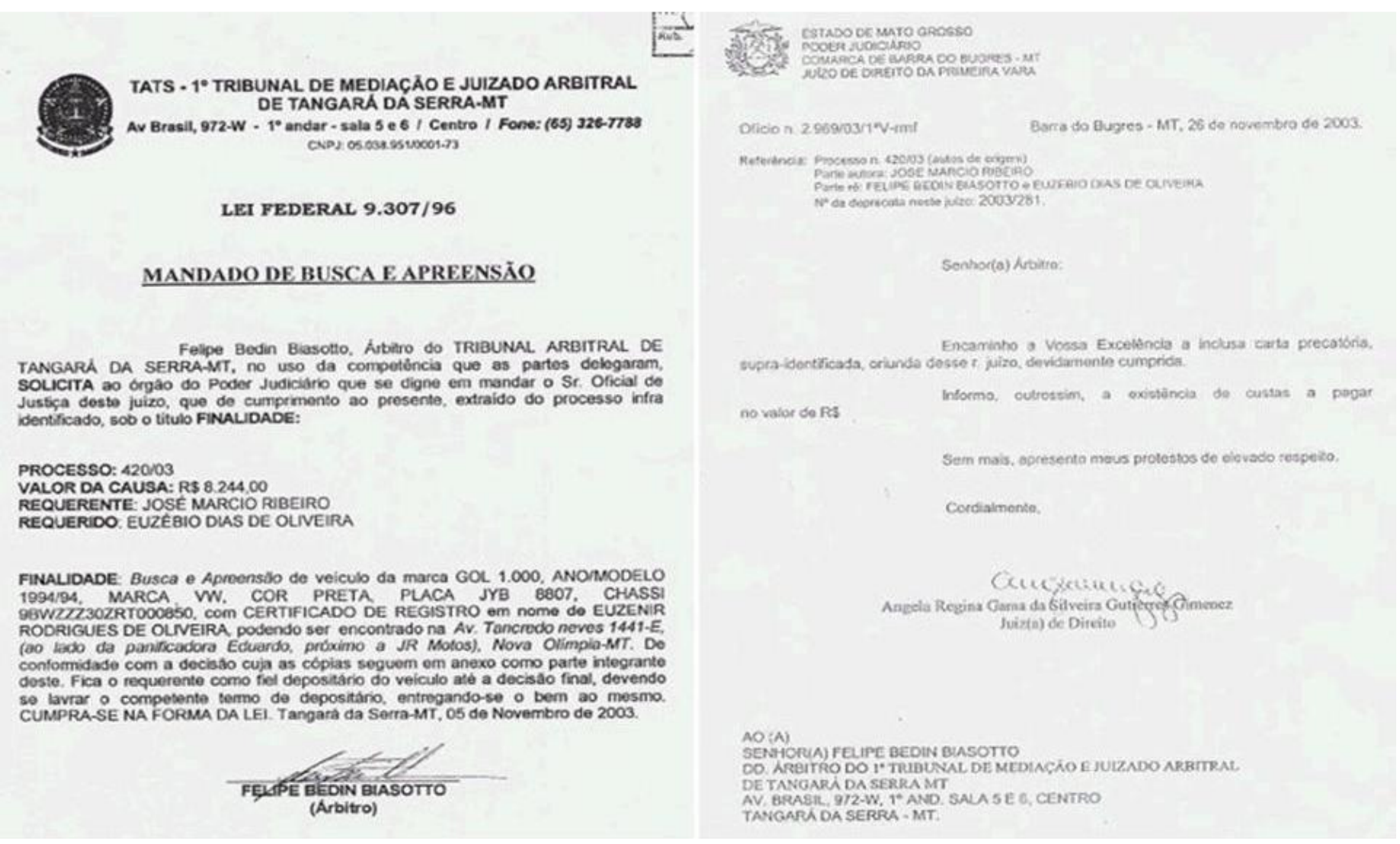

Outro exemplo prático é a comunicação abaixo havida através de simples ofícios trocados entre o Centro de Arbitragem e Mediação da Câmara de Comércio Brasil-Canadá e o juízo da 5. ${ }^{a}$ Vara Cível do Foro Regional de Pinheiros-SP:

LUís MonTEIRO e JoSÉ ANTONIO FICHTNER aduzem que "a solicitação de auxílio ao Poder Judiciário será encaminhada pelo árbitro por mero ofício", tratando-se de "procedimento semelhante à comunicação entre juízos (v.g., cartas precatórias)", "que não se confunde com um ato postulatório da parte interessada." (in Medidas urgentes no processo..., p. 55).

${ }^{521}$ GUERRERO, Luis Fernando. Tutela de Urgência..., p. 38. 

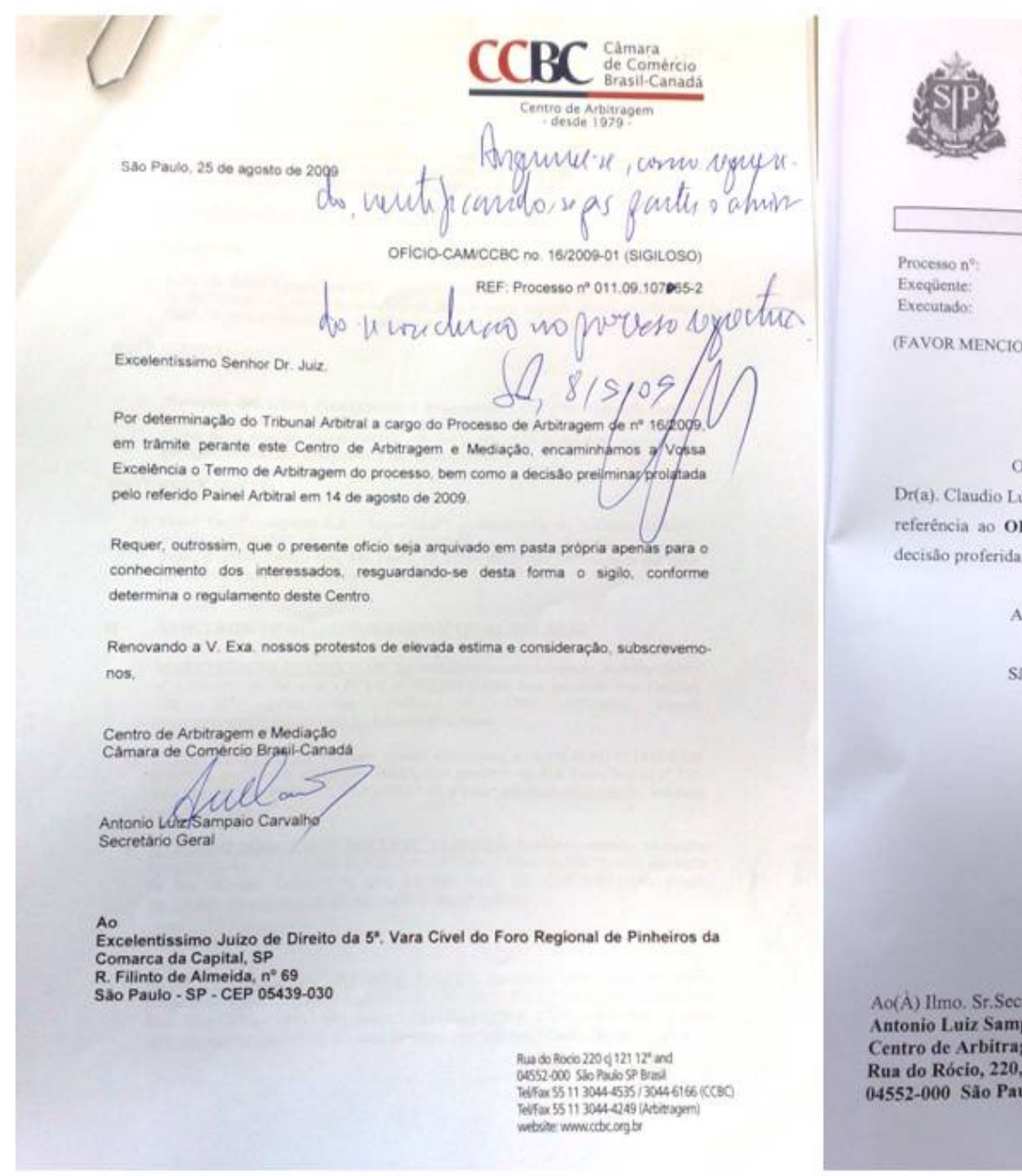

TRIBUNAL DE JUSTICAA DO ESTADO DE SÃO PAULO COMARCA DE São PAULO S"VARA RIVET XI - PINHEIROS 5" VARA CIVEL.

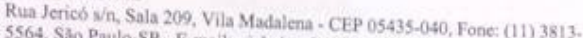
5564, S3o Paulo-SP - E-mail: pinheiros5cvatisp poy br

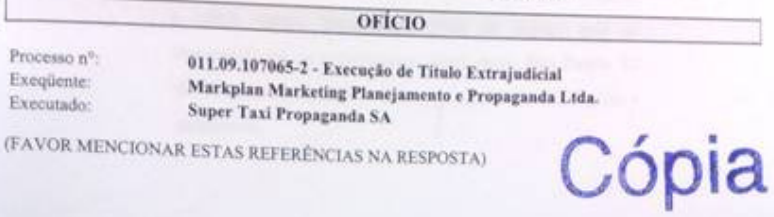

O(A) MM. Juiz(a) de Direito do(a) 5" Vara Civel do Foro Regional XI - Pinheiros, Dr(a). Claudio Luiz Bueno de Godoy, pelo presente, expedido nos autos da açho em epigrafe e em referéncia ao OFIC10-CAM/CCBC a* 16/2009-01, encaminha a Vossa Senhoria cópia da decisłlo proferida nestes autos para as providéncias cabiveis.

Atenciosamente.

S.̆o Paulo, 03 de dezembro de 2009

Não se trata, pois, de ação a ser ajuizada pelo(s) árbitro(s) ou pelo tribunal arbitral ${ }^{522}$, nem de processo em que seja exercida atividade jurisdicional ${ }^{523}$, tendo em vista que o árbitro já decidiu a questão e apenas apresenta mera solicitação de cooperação ao juízo estatal, tal como uma carta precatória.

\footnotetext{
${ }^{522}$ Nesse sentido: "Em absoluto o requerimento de intervenção do Poder Judiciário feito pelo árbitro pode ser considerado como ação, daí por que não se fala em nenhum outro instituto inerente e conseqüente a uma demanda judicial, tal como sentença, citação, coisa julgada e, também, contraditório e ampla defesa, porque o árbitro já decidiu e somente vem a juízo solicitar cooperação, como se fosse expedida uma carta precatória." (HOFFMAN, Paulo. Arbitragem: algumas dúvidas..., pp. 317/318).

${ }_{523}$ Corroborando essa tese: "Parece-nos que tal requerimento deve ser como uma carta precatória. Não se trata de processo em que seja exercida atividade jurisdicional, seja voluntária, quanto menos contenciosa (afastado, portanto, qualquer tipo de contraditório). A jurisdição foi exercida pelo árbitro quando da determinação do ato de força. $\mathrm{O}$ ato subseqüente, ou seja, mero 'cumpra-se' do juiz estatal no requerimento de execução da medida, somente é necessário em razão do árbitro, particular que é, não ter o aparato policial/administrativo à sua mercê." (GAJARDONI, Fernando da Fonseca. "Aspectos fundamentais de processo arbitral e pontos de contato com a jurisdição estatal". Revista de Processo - RePro, ano 27, n. 106. São Paulo: RT, abril/junho de 2002, pp. 189/216, p. 201).
} 
No entanto, caso a própria parte interessada tome a iniciativa de iniciar o contato com o juiz togado, ela deverá fazê-lo por meio de petição, a qual deverá ser instruída com as peças referidas no artigo 475-O, § 3. ${ }^{\circ}$, incisos I a V, do CPC, além, é claro, da cópia da convenção de arbitragem e da comprovação de que o(s) árbitro(s) que proferiu(iram) a decisão aceitou(aram) o encargo, seguindo o procedimento de uma execução provisória.

Tal petição deverá ser distribuída para uma das varas que seriam competentes para julgar a questão posta na arbitragem, determinando o juiz togado sorteado o cumprimento da decisão arbitral de urgência pela parte renitente.

Uma vez recebida essa comunicação do árbitro ou da parte pelo juízo estatal, este não poderá questionar o mérito da decisão que deferiu a tutela de urgência em arbitragem, devendo fazê-la cumprir, em atenção à indispensável boa relação entre juiz togado e árbitro.

Saliente-se que, embora o juiz estatal não possa intervir para modificar o mérito da decisão proferida pelo(s) árbitro(s) (o que configuraria uma arbitrariedade por parte do Poder Judiciário e o colocaria em posição de superioridade em relação aos árbitros, sem fundamento legal para tanto), é óbvio que ele também não deverá agir "como verdadeiro autômato no cumprimento das decisões do árbitro" 524 .

Cabe ao juiz togado, antes de dar cumprimento à decisão arbitral de urgência: analisar os requisitos formais da arbitragem em questão, especialmente quanto à existência de cláusula compromissória e se a decisão emana de árbitros devidamente nomeados ${ }^{525}$; verificar a regularidade e os limites da convenção, o atendimento à ordem pública e aos bons costumes, a suficiência da documentação apresentada para o processamento e efetivação da medida ${ }^{526}$; e se, por acaso, a decisão emanou de quem não podia ser árbitro, carece de fundamentação ou foi proferida por

${ }^{524}$ Cf. CARMONA, Carlos Alberto. Arbitragem e Processo..., p. 326.

${ }^{525}$ Cf. PITOMBO, Eleonora Coelho. Arbitragem e o Poder Judiciário..., p. 111.

${ }^{526}$ Cf. AMARAL, Paulo Osternack. A concessão de medidas urgentes..., p. 30. 
prevaricação, concussão ou corrupção passiva ${ }^{527}$, não podendo, no entanto, fazer qualquer apreciação meritória (a análise deverá ser sempre restrita à questão formal).

A ausência de jurisdição do juízo comum para alterar, revisar ou modificar a decisão arbitral de urgência advém da redação do artigo 18 da Lei de Arbitragem, o qual preceitua que "o árbitro é juiz de fato e de direito, e a sentença que proferir não fica sujeita a recurso ou a homologação pelo Poder Judiciário",528.

Em virtude disso, o juiz estatal não poderá adentrar no mérito da decisão arbitral que deferiu tutela de urgência, tampouco analisar a sua conveniência, ficando restrito e limitado a sua analise formal ${ }^{529}$.

Caso o juiz togado não encontre qualquer defeito ou vício formal no ofício originário do processo arbitral ou na petição da parte interessada, ele deverá determinar o cumprimento da tutela de urgência deferida pelo(s) árbitro(s). Ou seja, executará a medida urgente, utilizando-se de seu poder de força.

O cumprimento da decisão arbitral de urgência pelo juiz estatal seguirá as mesmas regras de direito processual aplicáveis à execução de uma medida liminar deferida em um processo judicial (execução provisória) ${ }^{530}$.

${ }^{527}$ Cf. FICHTNER, José Antonio; MONTEIRO, André Luís. Medidas urgentes no processo..., p. 71.

${ }^{528}$ No mesmo sentido: AMARAL, Paulo Osternack. A concessão de medidas urgentes..., p. 30.

529 CARlos Alberto CARMONA corrobora esse entendimento, mencionando que "recebido o ofício e os documentos, o juiz verificará se a convenção arbitral é regular e se os dados recebidos permitem-lhe avaliar (sempre formalmente) se a solicitação preenche os requisitos que levarão ao seu cumprimento." (Arbitragem e Processo..., pp. 325/326). O autor reitera esse entendimento na obra "O processo arbitral" in Revista de Arbitragem e Mediação, v. 1, n. ${ }^{\circ}$ 1, jan/abr 2004. São Paulo: RT, 2004, p. 30. Na mesma linha, VINíCIUS DE ANDRADE PRADO aduz que resta "ao juiz togado analisar apenas alguns aspectos formais da decisão arbitral." (Medidas cautelares... p. 197). CLÁVIO DE MELO VALENÇA FILHO também sustenta que "após análise formal, sem juízo de oportunidade, deve o juízo estatal deprecado ordenar a execução da medida." (Tutela judicial de urgência e a lide..., p. 28). PAUlO OSTERnACK AMARAL diz que "não poderá o Estado-juiz apreciar a conveniência da decisão concessiva de medida urgente, sob pena de usurpação de competência do juízo arbitral." (A concessão de medidas urgentes..., p. 30). Por fim, SIDNEI BENETI ensina que " 8 a) O juízo estatal deverá examinar os requisitos formais em Juízo de deliberação e exarar o 'Cumpra-se'. (...). 10ª ) Alegações de fundo relativas ao cabimento da medida e da própria arbitragem não poderão ser decididas pelo juízo estatal, devendo ser submetidas ao árbitro ou, se formuladas ao juízo estatal, devendo ser remetidas àquele." (Arbitragem e tutelas de urgência..., p. 105). Em igual sentido, o artigo 28..$^{\circ}$ da Lei n. $.^{\circ} 63 / 11$ de Portugal, que veda ao juízo estatal a revisão do mérito da decisão arbitral liminar: "Artigo 28. ${ }^{\circ}$ Fundamentos de recusa do reconhecimento ou da execução coerciva. (...) 2 - Qualquer decisão tomada pelo tribunal estadual ao abrigo do $n .^{\circ} 1$ do presente artigo tem eficácia restrita ao pedido de reconhecimento ou de execução coerciva de providência cautelar decretada pelo tribunal arbitral. O tribunal estadual ao qual seja pedido o reconhecimento ou a execução de providência cautelar, ao pronunciar-se sobre esse pedido, não deve fazer uma revisão do mérito da providência cautelar". 
Assim, em se tratando do cumprimento de decisão arbitral que deferiu tutela antecipada em favor da parte, o juiz estatal, nos termos do artigo 273, $\S 3 .^{\circ}$, do Código de Processo Civil, deverá observar as normas previstas nos artigos 475-O, $461, \S \S 4 .^{\circ}$ e $5 .^{\circ}$, e $461-A$ desse mesmo $\operatorname{Codex}^{531}$.

I.é., caso a parte vencida não cumpra a tutela de urgência deferida no processo arbitral e executada perante a justiça comum, o juízo estatal poderá fixar penalidades para a hipótese de inadimplemento, notadamente em se tratando de obrigação de fazer ou não fazer, podendo arbitrar multa à parte renitente e, também, majorar eventual multa anteriormente fixada pela decisão arbitral de urgência, em caso de recalcitrância da parte, bem como determinar outras medidas coercitivas cabíveis, sempre visando à efetividade ${ }^{532}$.

Nessa linha, é válida a menção dos acórdãos prolatados pelo Tribunal de Justiça de São Paulo nos autos do agravo de instrumento n. ${ }^{\text {os }}$ 903414641.2005.8.26.0000 e 0099516-23.2005.8.26.0000, por meio dos quais se fixou multa diária de $\mathrm{R} \$ 50.000,00$ (cinqüenta mil reais), enquanto persistisse o descumprimento de decisão liminar proferida em cumprimento de sentença arbitral que determinou obrigação de não fazer à parte (deixar de transmitir jogos de futebol da Liga da UEFA) e, depois de

\footnotetext{
${ }^{530}$ Quanto ao tema, PAULO HENRIQUE DOS SANTOS LUCON ensina que "a execução da tutela antecipada em nada difere da execução da sentença: ambas são fundadas em título provisório". Para ele, a execução provisória é um fenômeno essencialmente único, embora tenha nos dois casos citados fundamentos jurídicos distintos, já que diferente o objeto em que se apóia. Esse é o motivo estrutural pelo qual o artigo 273 , $33 .^{\circ}$, do CPC submete a execução da tutela antecipada às normas do art. 588, II e III, do CPC (atual art. 475-O do CPC). (in Eficácia das decisões e execução provisória. São Paulo: RT, 2000, pp. 270/282).

${ }^{531}$ C. A. AlvaRo DE OliveIRA leciona que a efetivação da tutela antecipada "'observará, no que couber e conforme sua natureza, as normas previstas nos arts. 588,461 , $\S 4^{\circ}$ e $5^{\circ}$, e $461-\mathrm{A}^{\prime}$ (art. 273 , $\S 3^{\circ}$, redação da Lei $\left.\mathrm{n}^{\circ} 10.444 / 2002\right)$. De notar que, embora essa regra não tenha sofrido alteração, a referência ao art. 588 nela contida deve ser lida como concernente ao art. 475-O, em face das modificações pela Lei $\mathrm{n}^{\circ} 11.232$, de 22.12.2005." (Comentários ao Código de..., pp. 6/7).

${ }^{532}$ Quanto ao tema, SIDNEI BENETI assevera que, uma vez exarado o "cumpra-se" pelo juízo estatal no ofício recebido da arbitragem, o magistrado passará "a decidir, doravante, eventuais incidentes na execução (requisição de força policial, arrombamento, prisão etc.)." (Arbitragem e tutelas de urgência..., p. 105). No que tange à imposição de multa ou de outras medidas, C. A. ALVARO DE OLIVEIRA aduz ser "salutar, ainda, porque intensifica a efetividade da providência, a remissão aos $\S \S 4^{\circ}$ e $5^{\circ}$ (redação da Lei $n^{\circ} 10.444 / 2002$ ) do art. 461, a permitir ao juiz, quando da antecipação da tutela, a pedido da parte ou de ofício, a imposição de multa diária à contraparte, se for suficiente ou compatível com a obrigação, fixando prazo razoável para o cumprimento do preceito, e ainda de outras medidas conducentes ao mesmo resultado, desde que compatíveis com a medida, tais como busca e apreensão, remoção de pessoas e coisas, desfazimento de obras e impedimento de atividades nocivas (enumeração meramente exemplificativa), inclusive com a requisição de força policial, se necessário. A menção ao art. 461-A (acrescido pela Lei $\mathrm{n}^{\circ}$ 10.444/2002) sublinha a aplicação dessas mesmas medidas, no que couber, quando se tratar de antecipação de efeitos de sentença com força executiva lato sensu" (OLIVEIRA, Carlos Alberto Alvaro de. Comentários ao Código de..., p. 7).
} 
verificado o descumprimento da liminar, determinou novas medidas práticas para a efetivação da obrigação de não fazer, ordenando "que técnicos acompanhem Oficiais de Justiça com a missão de neutralizarem equipamentos que permitam a transmissão dos jogos, inclusive realizando reparos para impedir a recepção e remessa de sinais, nas antenas, além de ofício para que empresa licenciada pela Embratel possa interromper a retransmissão, via satélite, dos sinais emitidos para transmissão dos jogos da Liga da UEFA”, bem como que fosse oficiado o Ministério Público para a apuração do crime de desobediência, com base no art. 461 do CPC, o qual permite a tutela específica para que se execute obrigação de fazer ou de não fazer ${ }^{533}$.

Portanto, caberá ao juiz togado adotar as providências necessárias e destinadas à execução forçada (poder de imperium) da tutela de urgência deferida em arbitragem, já que o árbitro não possui o poder de executio ${ }^{534}$.

Em um dos poucos trabalhos a fazer referência sobre o assunto, SIDNEI BENETI sustenta que não cabe condenação em honorários advocatícios no procedimento iniciado pelo árbitro, por meio de ofício, para que o Poder Judiciário cumpra a tutela de urgência deferida em arbitragem ${ }^{535}$.

\footnotetext{
533 “Dá-se provimento, em parte, ao Agln. 406.570.4/5, interposto por Topsports, fixando-se multa diária para sancionar o não cumprimento da ordem judicial [art. 461, $5^{\circ}$, do CPC]." (TJ/SP, 4. ${ }^{a}$ Câm. Dir. Priv., A.I. n. ${ }^{\circ}$ 0099516-23.2005.8.26.0000 - antigos n. ${ }^{\text {ss }}$ 406.570-4/5-00 e 994.05.071846-6, Rel. Des. Ênio Zuliani, j. 18/08/05, v.u.); e "Tutela específica do art. 461, do CPC - Medidas de apoio previstas no $§ 6^{\circ}$, do art. 461, do CPC, que são necessárias para que a parte obrigada a não realizar a transmissão de jogos, cuja licença não lhe pertence, cumpra o que se decidiu em Acórdão do Tribunal Estadual - Provimento para deferir as providências, exceto a prisão dos representantes legais, por não se ter evidenciado a real intenção de escarnecera Corte, pela resistência imotivada" (TJ/SP, 4. ${ }^{a}$ Câm. Dir. Priv., A.I. n. ${ }^{\circ}$ 0099516-23.2005.8.26.0000 - antigos n. ${ }^{\text {os }}$ 416.598-4/0-00 e 994.05.099516-0, Rel. Des. Ênio Zuliani, j. 29/09/2005, v.u.).

${ }^{534} \mathrm{Na}$ mesma linha: AMARAL, Paulo Osternack. A concessão de medidas urgentes..., p. 30. TALAMINI, Eduardo. Tutela relativa aos deveres de fazer e de não fazer..., p. 459, e FIGUEIRA JR, Joel Dias. Arbitragem, jurisdição..., p. 223.

535 “ $12^{a}$ ) Não há sucumbência no cumprimento judicial da decisão cautelar incidental arbitral, de maneira que não se fixam honorários advocatícios pelo juízo estatal.” (Arbitragem e tutelas de urgência..., p. 105). Quanto ao tema, ressalta-se que o STJ já pacificou o entendimento de que é cabível a condenação da parte vencida no pagamento de honorários advocatícios em sede de cumprimento definitivo de sentença: "A Corte Especial do STJ, no julgamento do recurso especial submetido ao rito dos recursos repetitivos, assentou que, para efeitos do art. 543-C do CPC: 1.1. São cabíveis honorários advocatícios em fase de cumprimento de sentença, haja ou não impugnação, depois de escoado o prazo para pagamento voluntário a que alude o art. 475-J do CPC, que somente se inicia após a intimação do advogado, com a baixa dos autos e a aposição do 'cumpra-se' (...). (REsp 1134186/RS, Rel. Ministro Luis Felipe Salomão, Corte Especial, julgado em 01/08/2011, DJe 21/10/2011)." (STJ, 4. ${ }^{a}$ T., AgRg no AREsp 189.681/SP, Rel. Min. Luis Felipe Salomão, j. 04/09/2012, v.u.). Mas no que tange à condenação em honorários no cumprimento provisório de sentença, ainda há divergência entre a 3. ${ }^{\mathrm{a}} \mathrm{e}$ a $4{ }^{\mathrm{a}}$ Turmas. Enquanto a $3{ }^{\mathrm{a}}{ }^{\mathrm{T}}$ Turma do STJ entende ser cabível o arbitramento de honorários de sucumbência em cumprimento provisório de sentença ("É firme a orientação desta Corte no sentido de ser cabível a estipulação de honorários advocatícios em sede de execução provisória. Precedentes." - AgRg no
} 
Corroboramos essa tese em parte, pois se a parte vencida permanecer recalcitrante e se fizer necessária a participação da parte beneficiária da tutela de urgência para o cumprimento da decisão arbitral perante o juízo estatal, nesse caso, a parte que continua se negando a cumprir a decisão arbitral de urgência deve, sim, ser condenada nos ônus sucumbenciais, inclusive nos honorários advocatícios da parte contrária (a qual terá obrigatoriamente que ser representada por advogado no procedimento judicial para o cumprimento da decisão arbitral de urgência), em virtude da necessidade da utilização do Poder Judiciário para tanto ${ }^{536}$.

Caso o juiz togado encontre algum vício formal no ofício oriundo do processo arbitral, ele deverá devolver o ofício ao árbitro, informando-o acerca do motivo da recusa de cumprimento.

Isso porque, ao atender e dar cumprimento a qualquer solicitação do árbitro, o juiz deverá tomar as mesmas cautelas que lhe são exigidas pelo artigo 209 do CPC para o cumprimento de carta precatória por outro juiz ${ }^{537}$.

AREsp 48.712-PR. Ainda: AgRg nos EDcl no Ag 1.375.149-SC; AgRg no AREsp 5.733-PR; REsp 978.545MG, AgRg no Ag 1.078.114-RS; AgRg nos EDcl no Ag 1.375.149-SC), a 4. ${ }^{a}$ Turma, ao revés, pontifica que não ("A controvérsia acerca do cabimento dos honorários advocatícios em execução provisória veio a ser apreciada pela Quarta Turma do Superior Tribunal de Justiça que concluiu pela impossibilidade de sua cobrança (REsp 1.252.470/RS)" - AgRg no REsp 1.291.652-PR. Ainda: REsp 1.028.855-SC; AgRg no AREsp 189.515-PR; AgRg no AREsp 190.152-PR; AgRg no AgRg no AREsp 14.152-PR; e REsp 1.252.470-RS). O tema aguarda julgamento pela Corte Especial, conforme a notícia "Interrompido julgamento sobre honorários advocatícios em cumprimento provisório de sentença", publicada no website do STJ em 23/10/2012.

${ }^{536}$ Como visto na nota anterior, embora ainda haja divergência entre a $3 .^{a}$ e a $4 .{ }^{a}$ Turma do STJ quanto ao cabimento de honorários advocatícios em sede de cumprimento provisório de sentença (que seria o caso da execução de uma decisão arbitral de urgência, pois ainda passível de reforma ao final), entendemos que, caso seja necessário o pedido de cumprimento da tutela de urgência arbitral perante o Poder Judiciário, deve prevalecer o entendimento da 3 . $^{a}$ Turma, pelo cabimento da condenação da parte contrária no pagamento de honorários advocatícios, especialmente porque a parte prejudicada na arbitragem, em virtude do descumprimento da decisão arbitral de urgência, terá que se valer do Poder Judiciário e terá, para tanto, que ser representada por advogado. A situação é bastante distinta do cumprimento provisório de sentença em um processo judicial, em que a execução provisória é uma mera opção da parte. Isso porque, no caso do não cumprimento voluntário da decisão arbitral de urgência, a parte prejudicada será obrigada a acessar a justiça comum, devendo a parte contrária, portanto, ser condenada nos ônus da sucumbência.

${ }^{537}$ Cf. AMARAL, Paulo Osternack. A concessão de medidas urgentes..., pp. 29/30. Em igual sentido: CARMONA, Carlos Alberto. Arbitragem e Processo..., p. 326; e FICHTNER, José Antonio; MONTEIRO, André Luís. Medidas urgentes no processo..., p. 71. 
Na hipótese de o cumprimento da tutela de urgência arbitral ser feito por meio de ofício enviado pelo juízo arbitral ao juízo estatal, não caberá qualquer defesa por parte do executado, pois, como visto acima, não se trata de uma ação, mas, sim, de mera solicitação de auxílio feita por parte do árbitro ao juiz togado, para que este, que é o detentor do monopólio do poder de imperium, execute a decisão já proferida pelo árbitro.

O juízo estatal, portanto, proferirá simples ato de expediente, ou um mero "cumpra-se" no ofício recebido do juízo arbitral, insuscetível de defesa ou de recurso, especialmente porque a jurisdição está sendo exercida na arbitragem.

Assim, a parte executada poderá, no máximo, suscitar questões relativas aos requisitos formais do ofício enviado pelo juízo arbitral (uma vez que, como visto acima, o juiz togado poderá fazer apenas a análise formal - um juízo de delibação - da comunicação recebida do juízo arbitral). Qualquer questão de fundo eventualmente levantada pela parte executada deverá ser remetida pelo juiz togado ao juízo arbitral, no qual a jurisdição está sendo exercida, não podendo aquele se imiscuir no

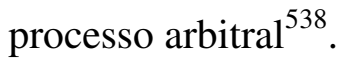

Entretanto, caso a própria parte tome a iniciativa de efetivar a tutela de urgência arbitral, iniciando uma execução provisória da decisão liminar proferida pelo(s) árbitro(s), não há dúvida de que caberá a apresentação de impugnação ao cumprimento da decisão perante o juízo estatal ${ }^{539}$, sendo certo que, da decisão proferida pelo juiz togado na eventual impugnação apresentada pela parte recalcitrante, caberá o recurso previsto na legislação processual civil ${ }^{540}$.

\footnotetext{
${ }^{538}$ Nessa mesma linha: “9a) Alegações referentes a requisitos formais na execução da requisição deverão ser deduzidas perante o Juízo estatal e por este decididas, cabendo recurso segundo o sistema processual geral. $10^{\mathrm{a}}$ ) Alegações de fundo relativas ao cabimento da medida e da própria arbitragem não poderão ser decididas pelo juízo estatal, devendo ser submetidas ao árbitro ou, se formuladas ao juízo estatal, devendo ser remetidas àquele." (BENETI, Sidnei. Arbitragem e tutelas de urgência..., p. 105).

539 Nesse sentido: "O processo de execução implica, por seu turno, a abertura de novas oportunidades de ataque à sentença arbitral, seja por meio impugnação apresentada pelo executado, após a realização da penhora; de embargos, atualmente privilégio da Fazenda; ou, ainda, de exceção de pré-executividade". (VALENÇA FILHO, Clávio de Melo. Sentença arbitral e..., pp. 36/37).

${ }^{540}$ Nessa mesma linha, SIDNEI BENETI afirma que "alegações referentes a requisitos formais na execução da requisição deverão ser deduzidas perante o Juízo estatal e por este decididas, cabendo recurso segundo o sistema processual vigente" (Arbitragem e tutelas de urgência..., p. 105). Exemplo prático é o agravo de instrumento n. ${ }^{\circ}$ 0114241-80.2006.8.26.0000 - n. ${ }^{\text {os }}$ antigos 994.06.114241-0 e 433.010-4/3-00 - ao qual foi negado provimento pelo Tribunal de Justiça de São Paulo, mantendo-se a execução de medidas cautelares
} 
Até mesmo por isso, entendemos ser mais recomendável que a parte favorecida aguarde a expedição de ofício pelo(s) árbitro(s), pelo tribunal arbitral ou pela instituição arbitral, solicitando o auxílio do Poder Judiciário para a efetivação da tutela de urgência arbitral, do que a própria parte tomar a iniciativa de iniciar uma execução provisória da decisão liminar proferida na arbitragem.

E o que deverá ocorrer caso o juiz togado permaneça inerte ou se recuse a executar a tutela de urgência deferida em arbitragem sem a indispensável motivação? Nessa hipótese, as partes da arbitragem deverão ser imediatamente comunicadas acerca do ocorrido, não devendo o árbitro insistir no cumprimento da solicitação, sob pena de violar o seu dever de imparcialidade, previsto no art. 13 , § 6. ${ }^{\circ}$, da Lei 9.307/96 $6^{541}$.

As partes, então, deverão buscar a modificação da decisão judicial por meio dos recursos cabíveis, perante o próprio Poder Judiciário ${ }^{542}$.

Exemplo prático ocorreu na arbitragem n. ${ }^{\circ}$ 16/2009 do Centro de Arbitragem e Mediação da Câmara de Comércio Brasil-Canadá.

Nesse caso, os árbitros deferiram tutela de urgência para suspender a exigibilidade de contratos de mútuo que eram objeto de execução extrajudicial em curso perante o juízo da 5. ${ }^{\text {a } V a r a ~ C i ́ v e l ~ d o ~ F o r o ~ R e g i o n a l ~ d e ~ P i n h e i r o s-S P ~} P^{543}$, enviando, por ofício, cópia da decisão liminar ao juízo estatal, conforme a reprodução abaixo:

deferidas em decisão arbitral, inclusive o bloqueio on line de valores e de bens móveis e imóveis (TJ/SP, 5. ${ }^{a}$ Câm. Dir. Privado, A.I. n. ${ }^{\circ}$ 0114241-80.2006.8.26.0000, Rel. Des. Silvério Ribeiro, j. 22/03/2006, v.u.).

${ }^{541}$ Cf. AMARAL, Paulo Osternack. A concessão de medidas urgentes..., p. 30. Nessa linha, NeIL ANDREWS sustenta que "the neutral arbiter must preserve his appearence of impartiality." (trad. livre: "o árbitro neutro deve preservar a sua aparência de imparcialidade".) (Arbitration and mediation in England..., p. 111).

${ }_{542}^{54}$ Cf. FICHTNER, José Antonio; MONTEIRO, André Luís. Medidas urgentes no processo..., p. 72.

${ }^{543}$ Eis os termos da decisão arbitral de urgência: “(...) C) É concedida medida liminar em favor de (...) para o fim de suspensão imediata da exigibilidade dos contratos de mútuo firmados entre a (...) e a (...), até final decisão deste Tribunal Arbitral acerca dos pleitos que são objeto da presente arbitragem, especialmente em relação aos contratos de mútuo firmados entre as partes acima, nos quais se encontra fundada a execução (Processo $n^{o}$. 011.09.107065-2, ordem/controle $n^{\circ}$ 956/2009). (...)". 


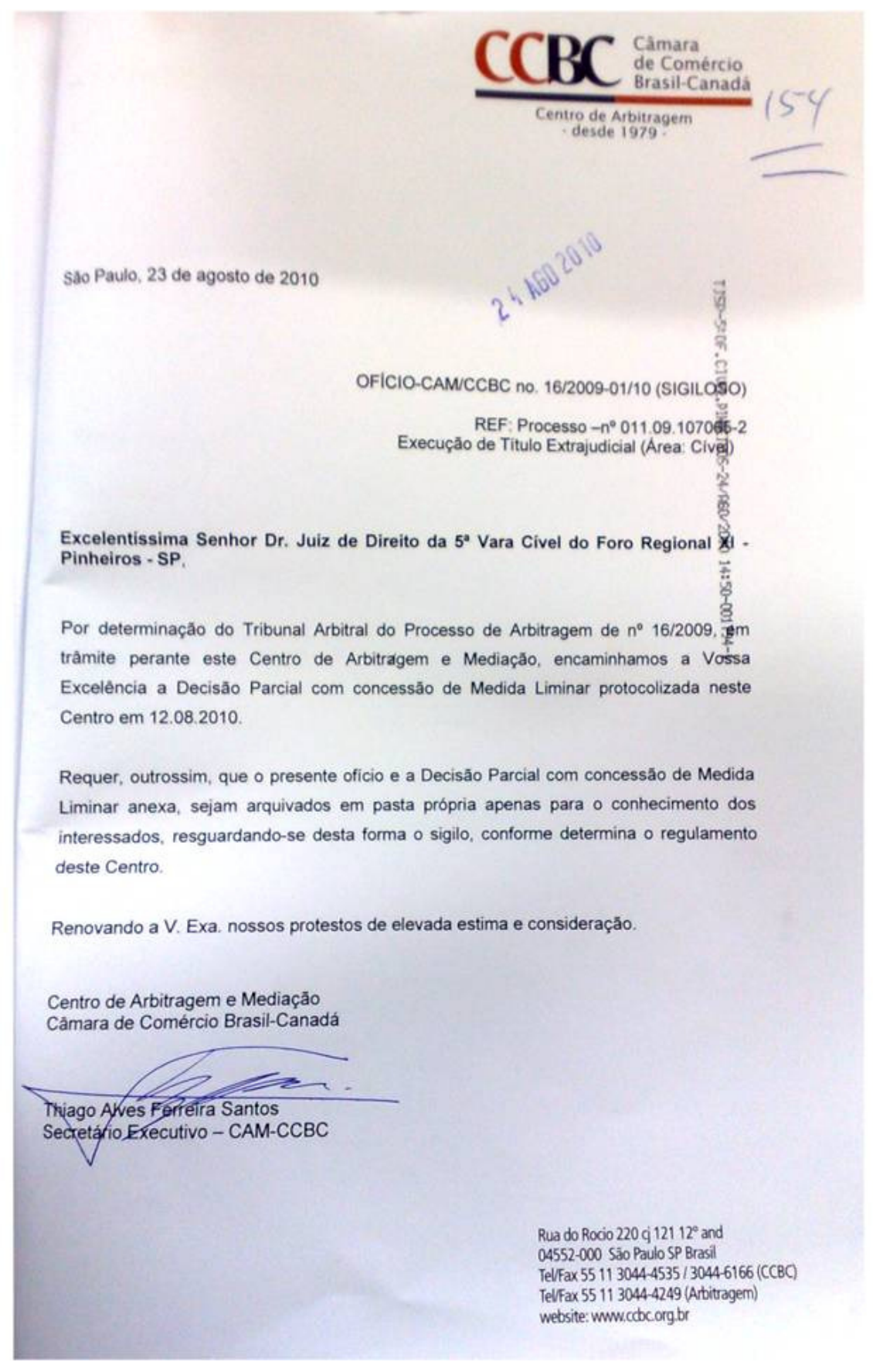

Ocorre que, ao invés de suspender a ação de execução de títulos extrajudiciais, em atenção à decisão arbitral que suspendeu a exigibilidade dos contratos de mútuo executados, o juízo estatal questionou o mérito da decisão arbitral, vinculando a eventual suspensão da execução à garantia do juízo ${ }^{544}$.

\footnotetext{
${ }^{544}$ Eis os termos da decisão do juízo estatal: "Vistos. O artigo 739-A do CPC estipula como regra geral que os embargos não terão efeito suspensivo. O parágrafo primeiro, contudo, permite ao juiz que este, atribua referido efeito a pedido do embargante desde que relevantes seus fundamentos, que o prosseguimento da execução possa causar ao executado grave dano de difícil ou incerta reparação. Contudo, para que o juiz possa fazer esta análise, é preciso que a execução esteja garantida por penhora, situação que não é a presente.
} 
Em virtude disso, a parte prejudiciada interpôs o agravo de instrumento n. ${ }^{\circ}$ 0010190-42.2011.8.26.0000, o qual foi provido pela 11. ${ }^{\text {a }}$ Câmara de Direito Privado do Tribunal de Justiça de São Paulo, para o fim de reformar a decisão de Primeiro Grau que havia se recusado a suspender a execução de títulos extrajudiciais, em cumprimento à decisão liminar arbitral que havia suspendido, liminarmente, a exigência dos contratos de mútuo executados ${ }^{545}$.

Nesse caso, o Tribunal de Justiça de São Paulo determinou o imediato cumprimento da decisão liminar arbitral, concedendo, inclusive, efeito suspensivo ao recurso e, ao final, reformou a decisão recalcitrante de Primeira Instância.

Alguns doutrinadores ainda vislumbram, para a hipótese, a possibilidade da impetração de mandado de segurança contra esse ato do juiz estatal, pois ele seria ilegal e realizado com abuso de autoridade ${ }^{546}$. O mandado de segurança, nessa hipótese, deve ser impetrado perante a instância imediatamente superior à do juiz togado

De fato, embora o valor do crédito exequendo já atingia a quantia de $\mathrm{R} \$ 829.950,85$ quando da propositura da ação - 15/04/2008 - até o presente momento a garantia gira em torno de R\$3.403,50. Não se pode, destarte, considerar que o juízo esteja garantido. Portanto, se os embargos não suspenderam a execução, a decisão que reconheceu a prejudicialidade externa e suspendeu o andamento dos embargos em razão da instauração de compromisso arbitral. Pelos motivos expostos, determino o prosseguimento da presente execução. Observo que o pedido de suspensão poderá ser reapreciado caso os executados indiquem bem a penhora aptos a garantir o juizo. No mais, cumpra-se a determinação contida no segundo parágrafo da r. Decidão (sic) de fls. 128. Int. Cumpra-se”. E após a oposição de embargos de declaração, tendo em vista que o decisum sequer mencionou a decisão liminar arbitral, que suspendeu a exigibilidade dos contratos de mútuo executados, o juiz togado manteve a sua decisão, nos seguintes termos: "Vistos. 1) Fls. 128, segunda parte: já foi cumprido. 2) Fls. 130/131: requisite-se a transferência. Dou por penhorados tais valores, insuficientes para assegurar a satisfação do crédito em execução. Intime-se, de todo modo, a executada, pela imprensa, na pessoa de seus advogados, cientificando-a da constrição judicial. 3) Fls. 146/148: indefiro a desconsideração da personalidade jurídica, pois inexistem dados suficientes revelando o abuso da personalidade jurídica, em suma, não há elementos revelando o desvio de finalidade ou a confusão patrimonial. 4) Fls. 187/191: rejeito os embargos de declaração, porquanto a decisão, examinando a questão posta, não é contraditória, omissa nem obscura. De mais a mais, a própria decisão do Tribunal Arbitral, embora sem aderir a tal posicionamento (fls. 178, item 29), refere-se a um precedente do STJ que, em caso semelhante, condicionou a suspensão da execução à penhora (fls. 175/176, itens 19/22), quer dizer, à garantia da satisfação do crédito em execução, inexistente, por enquanto, no caso vertente. 5) Manifeste-se a exeqüente, em dez dias, dando andamento à execução, sob pena de arquivamento. 6) Intimem-se.”.

${ }^{545}$ Eis a ementa do acórdão: “Agravo de Instrumento - Contrato de compra e venda de ações, compromisso de investimentos e outras avenças com cláusula arbitral instituindo a competência para dirimir a lide instaurada entre as partes - Processamento perante o Juízo do Foro Regional de Pinheiros de execução de títulos extrajudiciais oriundos de contratos de mútuo, com cheques a estes vinculados - Contratos de mútuo que constituem os títulos executivos extrajudiciais, com relação de acessoriedade em relação ao contrato com cláusula arbitral - Suspensão da execução até a solução arbitral final, independentemente de garantia por penhora - Recurso de agravo de instrumento provido." (Rel. Des. Luis Fernando Nishi, j. 28/04/2011, v.u.).

${ }_{546}$ Tal como: FIGUEIRA JR., Joel Dias. Arbitragem, jurisdição..., p. 224; e AMARAL, Paulo Osternack. A concessão de medidas urgentes..., pp. 30/31. 
que realizou o ato tido como coator (permanecer inerte ou recusar-se, sem motivo, a executar a tutela de urgência deferida em arbitragem).

Há quem sustente, também, que o árbitro ou a parte prejudicada poderá requerer as providências correicionais cabíveis contra o juiz estatal que permanece inerte ou se recusa, injustificadamente, a efetivar a tutela de urgência deferida pelo árbitro ${ }^{547}$.

De qualquer forma, para se evitar surpresas e os inúmeros problemas que podem advir da execução de tutelas de urgência deferidas em arbitragem com o auxílio e a cooperação do juízo comum, o ideal seria a regulamentação da questão de forma clara e incisiva.

Já existe algo nesse sentido no Poder Judiciário brasileiro, mas ainda de maneira muito incipiente, como, por exemplo, o Ofício Circular n. ${ }^{\circ}$ 69/99 do Corregedor Geral da Justiça do Estado do Paraná, o qual estabelece que o juízo cível responsável pela distribuição da Justiça Estadual do Paraná é o competente para efetivar tutelas de urgência e/ou coercitivas deferidas por árbitros ${ }^{548}$.

Outra sugestão bastante oportuna, seria a criação de varas e/ou juízes especializados na execução e cumprimento de tutelas de urgência arbitrais (e também de mérito $)^{549}$, “de forma a estreitar as relações e a cooperação entre os juízos

${ }^{547}$ Cf. AMARAL, Paulo Osternack. A concessão de medidas urgentes..., p. 31. Nesse sentido: CARMONA, Carlos Alberto. Arbitragem e Processo..., p. 326, e VALENÇA FILHO, Clávio de Melo. Tutela judicial de urgência e a lide..., p. 28.

${ }^{548}$ Sobre o tema, ver: SILVA, Jonny Paulo da. "A Regulamentação Paranaense Acerca da Atuação do Juiz de Direito no Processo Arbitral, no que diz Respeito à Condução de Testemunhas e Execução de Medidas Coercitivas e Cautelares" in Revista Brasileira de Arbitragem, n. ${ }^{\circ}$ 3. São Paulo: IOB Thomson, 2004, pp. 217/219.

549 Quanto ao assunto, o Tribunal de Justiça do Estado do Paraná foi o precursor, tendo determinado, por meio do Ofício Circular n. ${ }^{\circ}$ 69/1999, que o juízo cível responsável pela distribuição é o competente para apreciar pedidos de tutelas de urgência ou de condução coercitiva de testemunhas, oriundos de arbitragem, que sejam apresentados perante o Poder Judiciário. Já o Tribunal de Justiça do Estado de Minas Gerais, por meio da Resolução n. ${ }^{\circ}$ 679/2011, de 24/11/2011, atribuiu às varas empresariais de Belo Horizonte a competência para processar e julgar ações que envolvam matéria arbitral, ressalvando, no entanto, a competência das varas da Fazenda Pública Estadual ou da Fazenda Pública Municipal, nos casos em que uma das partes seja ente da Administração Pública direta ou indireta do Estado de Minas Gerais ou do Município de Belo Horizonte, respectivamente. Igualmente, o Tribunal de Justiça do Estado do Rio de Janeiro, através da Resolução n. ${ }^{\circ}$ 20/2010, determinou que a distribuição de processos relacionados à arbitragem seja concentrada em 7 (sete) varas empresariais de Primeiro Grau. Em São Paulo, por sua vez, a Resolução n. ${ }^{\circ}$ 538/2011, do Tribunal de Justiça do Estado de São Paulo, criou a Câmara Reservada de Direito Empresarial, 
arbitral e estatal, evitando-se também que o desconhecimento e até o preconceito de alguns juízes togados interfiram no correto cumprimento de tutelas de urgência emanadas de árbitros" $" 550$.

Quanto ao tema, cumpre-se ressaltar que o Projeto de Lei n. ${ }^{\circ}$ 8.046/2010, em trâmite na Câmara dos Deputados, que institui um novo Código de Processo Civil, prevê a criação da chamada "carta arbitral".

Na lição de José Antônio Fichtner, SERgio Nelson MANNHEIMER e ANDRÉ Luís MONTEIRO, a carta arbitral "pode ser definida como o instrumento de cooperação formal entre o árbitro e o Poder Judiciário para fins de cumprimento forçado das decisões proferidas no processo arbitral" ${ }^{\prime 551}$.

Ou seja, o projeto do novo Código de Processo Civil prevê a criação de um instrumento oficial de comunicação entre o juízo arbitral e o juízo estatal, sanando a lacuna existente atualmente, em "novidade que vem ao encontro dos legítimos interesses dos arbitralistas"

Apenas a título de curiosidade, esclarece-se que a carta arbitral é mencionada em quatro dispositivos distintos do projeto do novo Código de Processo Civil, quais sejam: os artigos 69 , $\S 1 .^{\circ}$ e $2 .^{\circ}, 164$, IV, 206 , IV e $236^{553}$.

a qual é competente para julgar litígios de direito empresarial, dentre eles a arbitragem, podendo a parte pugnar pela incompetência de outra Câmara não especializada. Verifica-se, pois, a tendência de criação de varas empresariais ou especializadas que podem contribuir ainda mais com a arbitragem.

${ }^{550}$ Cf. PITOMBO, Eleonora Coelho. Arbitragem e o Poder Judiciário..., p. 112.

551 In Cinco pontos sobre a arbitragem..., pp. 318/319. Nessa mesma linha, DonALDo ARMELIN aduz que "institui-se, com ela [a carta arbitral], um veículo de comunicação entre os órgãos da jurisdição estatal e da arbitral, implementando uma lacuna existente a respeito." (ARMELIN, Donaldo. "Arbitragem e o novo Código de Processo Civil" in Revista de Arbitragem e Mediação, ano 8, vol. 28. WALD, Arnoldo (coord.). São Paulo: RT, jan/mar de 2011, pp. 131/137, p. 134).

${ }_{552}$ Cf. ARMELIN, Donaldo. Arbitragem e o novo Código..., p. 134.

553 “Art. 69. Os pedidos de cooperação jurisdicional devem ser prontamente atendidos, prescindem de forma específica e podem ser executados como: I - auxílio direto; II - reunião ou apensamento de processo; III - prestação de informações; IV - atos concertados entre os juízes cooperantes. $1^{\circ}$. As cartas de ordem, precatória e arbitral seguirão o regime previsto neste Código. $\S 2^{\circ}$. A carta arbitral atenderá, no que couber, aos requisitos da citação por mandado e será instituída [rectius: instruída] com a convenção de arbitragem, com a prova da nomeação do árbitro e com a prova da aceitação da função pelo árbitro.”; “Art. 164. Os atos processuais são públicos. Correm, todavia, em segredo de justiça os processos: (...) IV - que dizem respeito ao cumprimento de carta arbitral, desde que a confidencialidade estipulada na arbitragem seja comprovada perante o juízo.”; “Art. 206. Será expedida carta: (...) IV - arbitral, para que o órgão jurisdicional nacional pratique ou determine o cumprimento, na área de sua competência territorial, de ato solicitado por árbitro."; e 


\section{EM ARBITRAGENS ESTRANGEIRAS}

Com relação à execução das tutelas de urgência deferidas em arbitragem, a dúvida fica ainda maior na hipótese de o processo arbitral estar em trâmite no exterior (i.é., sediada fora do país) e a medida urgente deva ser executada no Brasil.

Nesses casos, surgem questionamentos acerca da forma de a tutela de urgência ser apresentada aqui para cumprimento e quais as expectativas de sua efetivação, conforme o nosso direito ${ }^{554}$.

Embora haja poucos escritos sobre o assunto, a doutrina pátria sustenta que a tutela de urgência deferida em arbitragem conduzida fora do território nacional deve, necessariamente, ser homologada pelo Superior Tribunal de Justiça para que possa ser executada no Brasil ${ }^{555}$.

Tal fato se dá porque o Supremo Tribunal Federal (quando ainda detinha competência para homologar sentenças estrangeiras), no julgamento do

\footnotetext{
“Art. 236. O juiz recusará cumprimento à carta precatória ou arbitral, devolvendo-a com despacho motivado: I - quando não estiver revestida dos requisitos legais; II - quando faltar-lhe competência em razão da matéria ou da hierarquia; III - quando tiver dúvida acerca de sua autenticidade. Parágrafo único. No caso de incompetência em razão da matéria ou da hierarquia, o juiz deprecado, conforme o ato a ser praticado, poderá remeter a carta ao juiz ou ao tribunal competente.".

${ }^{554}$ Nesse mesmo sentido: "Algo, porém, certo quanto a tais expectativas é o relativo ceticismo na prática internacional da arbitragem com respeito à receptividade das cortes estatais quanto a medidas cautelares ou provisionais decretadas no exterior, mormente quando tais medidas possam ter efeitos coativos e que impliquem, por exemplo, a venda de bens perecíveis, ordens para fazer ou se abster de fazer algo, ou o arresto ou penhora de bens." (GARCEZ, José Maria Rossani. Medidas cautelares e de antecipação..., p. 223). Sobre o tema, ver: MANGE, Flávia Foz. O Ordenamento Jurídico Brasileiro e a Ordem Internacional: Admissibilidade de Medidas de Urgência nos Litígios Comerciais Internacionais. Dissertação de mestrado apresentada à Faculdade de Direito da Universidade de São Paulo - janeiro de 2008. PIERO BERNARDINI também enumera diversas dúvidas quanto ao auxílio do Poder Judiciário de um país para a execução de uma decisão arbitral estrangeira: "Pode o juízo estatal se recusar a fornecer tal assistência? Quais os limites da intervenção do juízo estatal? Ele verificará apenas a observância dos requisitos formais pela decisão arbitral ou ele iniciará um novo procedimento sumário? O juízo estatal reconhecerá uma decisão arbitral revogando uma decisão liminar judicial anterior? Pode o juízo estatal fornecer auxílio para executar medidas ordenadas pelo árbitro que não são contempladas no seu ordenamento jurídico? O juízo estatal proferirá a sua própria decisão ou ele executará a decisão proferida pelo árbitro? Podem os meios de recurso ser abertos contra a decisão executória do juízo estatal? Obviamente, a maioria dessas questões será respondida pela legislação do próprio país do juízo estatal." (The Powers of the Arbitrator..., p. 28, tradução livre).

555 "As medidas cautelares ou as sentenças interlocutórias que os árbitros possam determinar em procedimentos arbitrais conduzidos fora do território nacional para serem executadas coativamente no Brasil terão de passar pelo órgão do Poder Judiciário que detenha competência jurisdicional para efeitos de homologação e eventual execução." (GARCEZ, José Maria Rossani. Medidas cautelares e de antecipação..., p. 228).
} 
agravo regimental na carta rogatória CR 7613 AgR/Argentina, equiparou a decisão interlocutória estrangeira que defere tutela de urgência à sentença estrangeira ${ }^{556}$.

Ao assim proceder, isto é, ao equiparar a decisão interlocutória estrangeira que defere uma tutela de urgência à sentença estrangeira, o STF faz com que seja aplicado o disposto no artigo 35 da Lei de Arbitragem brasileira, nos termos do qual, "para ser reconhecida e executada no Brasil, a sentença arbitral estrangeira está sujeita, unicamente, à homologação do Supremo Tribunal Federal" ${ }^{557}$.

Aludido dispositivo legal repetiu a regra prevista no artigo 105, I, “i”, da Constituição Federal, que preceitua que compete ao Superior Tribunal de Justiça a homologação de sentenças estrangeiras, sem distinguir entre sentença judicial ou sentença arbitral ${ }^{558}$.

Exatamente por isso é que as tutelas de urgência proferidas em arbitragens em curso fora do Brasil deverão passar pelo órgão do Poder Judiciário que detenha competência para a sua homologação para que possam aqui ser executadas coativamente $^{559}$, sendo necessário o procedimento de homologação de sentença estrangeira para qualquer tipo de tutela de urgência deferida em arbitragem estrangeira, seja ela tutela cautelar, antecipada ou específica (CPC, art. 461, § $\left.3^{\mathrm{o}}\right)^{560}$.

\footnotetext{
556 "Protocolo de Las Leñas: homologação mediante carta rogatória. O Protocolo de Las Lenas ('Protocolo de Cooperação e Assistência Jurisdicional em Matéria Civil, Comercial, Trabalhista, Administrativa' entre os países do Mercosul) não afetou a exigência de que qualquer sentença estrangeira - à qual é de equiparar-se a decisão interlocutória concessiva de medida cautelar - para tornar-se exequível no Brasil, há de ser previamente submetida à homologação do Supremo Tribunal Federal, o que obsta à admissão de seu reconhecimento incidente, no foro brasileiro, pelo juízo a que se requeira a execução; (...)" (STF-Pleno, CR 7613 AgR/AT - Argentina, Rel. Min. Sepúlveda Pertence, julgamento em 03/04/1997, D.J. 09/05/1997, p. 18.154, RF 342/302, grifamos).

557 THEOTONIO NEGRÃo, José Roberto F. GOUVÊA e LuIS GuILHERME A. BondIOLI esclarecem que "após a Em. Const. 45, de 8.12.04, a competência para a homologação de sentença estrangeira passou ao Superior Tribunal de Justiça (CF 105-I-i)." (in Código de Processo Civil e legislação processual em vigor, 42. edição. São Paulo: Saraiva, 2010, p. 560). Nesse mesmo sentido: "A competência para o reconhecimento de sentenças estrangeiras é do Superior Tribunal de Justiça desde a edição da Emenda Constitucional de $\mathrm{n}^{\circ} 45$ no final do ano de 2004." (RIBEIRO, Rafael Pellegrini. "O reconhecimento e a execução de sentenças arbitrais estrangeiras no direito brasileiro". Arbitragem no Brasil - aspectos jurídicos relevantes. JOBIM, Eduardo; MACHADO, Rafael Bicca (coord.). São Paulo: Quartier Latin, 2008, pp. 417/435, p. 423).

${ }^{558}$ Cf. CARREIRA ALVIM, José Eduardo. "Reconhecimento e execução de sentença arbitral estrangeira". In Arbitragem doméstica e internacional: estudos em homenagem ao prof. Theóphilo de Azeredo Santos. FERRAZ, Rafaella (coord.). Rio de Janeiro: Forense, 2008, p. 176.

${ }^{559}$ Cf. GARCEZ, José Maria Rossani. Medidas cautelares e de antecipação..., pp. 223 e 228.

${ }^{560}$ Cf. CARREIRA ALVIM, José Eduardo. Reconhecimento e execução de sentença..., p. 178. Com relação ao projeto do novo Código de Processo Civil (P.L. n. ${ }^{\circ}$ 8.046/2010, em trâmite na Câmara dos Deputados),
} 
Ressalte-se que, nos termos do artigo 34, parágrafo único, da Lei de Arbitragem brasileira, o critério adotado para se verificar se a decisão é ou não estrangeira foi o do ius solis ${ }^{561}$.

Dessa maneira, pouco importa a nacionalidade dos árbitros e das partes, ou quais foram as regras aplicadas à arbitragem, se a decisão for proferida no exterior, ela será considerada uma decisão estrangeira. Da mesma forma, se a decisão for proferida no território brasileiro, ela será nacional, mesmo que proferida por árbitro ou tribunal estrangeiro, segundo regras processuais e materiais alienígenas ${ }^{562}$.

embora os artigos 27, III, e 34 e seguintes tenham inovado, prevendo uma nova modalidade de cooperação internacional, além da carta rogatória e da homologação de sentença estrangeira, qual seja: o auxílio direto, o artigo 41 do P.L. n. ${ }^{\circ}$ 8.046/2010 prevê, expressamente, que "a cooperação jurídica internacional para o reconhecimento e execução de decisões estrangeiras será cumprida por meio de carta rogatória ou ação de homologação de sentença estrangeira", mantendo a sistemática atualmente em vigor. Contudo, o projeto do novo CPC trouxe regras específicas quanto à homologação de decisões estrangeiras, prevendo expressamente a possibilidade de homologação de decisões interlocutórias, bem como a possibilidade do deferimento de pedidos de urgência e de execução provisória no procedimento de homologação, nos termos dos artigos 914 e 915, in verbis: "Art. 914. As decisões estrangeiras somente terão eficácia no Brasil após homologadas. $\S 1^{\circ}$ São passíveis de homologação todas as decisões, interlocutórias ou finais, bem como as não judiciais que, pela lei brasileira, teriam natureza jurisdicional. § $2^{\circ}$ As decisões estrangeiras poderão ser homologadas parcialmente. $\S 3^{\circ} \mathrm{A}$ autoridade judiciária brasileira poderá deferir pedidos de urgência, assim como realizar atos de execução provisória, nos procedimentos de homologação de decisões estrangeiras. (...)"; "Art. 915. São passíveis de homologação as decisões estrangeiras concessivas de medidas de urgência, interlocutórias e finais. $\S 1^{\circ} \mathrm{O}$ juízo sobre a urgência da medida compete exclusivamente à autoridade jurisdicional requerente. $\S 2^{\circ}$ A decisão que denegar a homologação da sentença estrangeira revogará a tutela de urgência".

${ }_{561}$ Referido critério preceitua que as consequências jurídicas do ato ou do fato dependem exclusivamente do lugar onde ele ocorreu, e foi adotado pelo art. 34, § único, da Lei de Arbitragem brasileira o qual estipula que: "considera-se sentença arbitral estrangeira a que tenha sido proferida fora do território nacional". LuIS FERNANDO GUERRERO aponta que "a Lei de Arbitragem brasileira adota o mesmo critério da Lei Espanhola de Arbitragem e da Convenção de Nova Iorque", bem como que a Lei n. ${ }^{\circ}$ 9.307/96 "não faz diferença entre arbitragem interna e internacional, diferenciando apenas arbitragem nacional de arbitragem estrangeira." (Arbitragem e jurisdição: premissa..., p. 20). Sobre o tema, ver: BRAGHETTA, Adriana. A Importância da Sede da Arbitragem. Visão a partir do Brasil. vol. I. Rio de Janeiro: Renovar, 2010.

${ }_{562}$ Conforme CARREIRA ALVIM, José Eduardo. Reconhecimento e execução de sentença..., p. 175; CARVALHO, Ana Cristina Azevedo Pontes de. As inovações da Convenção de Nova Iorque..., p. 55; e RIBEIRO, Rafael Pellegrini. O reconhecimento e a execução de sentenças..., pp. 419/420, com críticas quanto ao critério exclusivo do ius solis. Por meio do REsp n. ${ }^{\circ} 1.231 .554 /$ RJ, julgado em 24/05/2011, o STJ confirmou a aplicação do critério do ius solis para determinar a nacionalidade da arbitragem. Eis o resumo da ementa: "Processual Civil. Recurso especial. Ação de execução de sentença arbitral. Nacionalidade. Determinação. Critério territorial. (...). 2. A execução, para ser regular, deve estar amparada em título executivo idôneo, dentre os quais, prevê o art. 475-N a sentença arbitral (inciso IV) e a sentença estrangeira homologada pelo STJ (inciso VI). 3. A determinação da internacionalidade ou não de sentença arbitral, para fins de reconhecimento, ficou ao alvedrio das legislações nacionais, conforme o disposto no art. $1^{\circ}$ da Convenção de Nova Iorque (1958), promulgada pelo Brasil, por meio do Decreto Federal n. ${ }^{\circ}$ 4.311/2002, razão pela qual se vislumbra no cenário internacional diferentes regulamentações jurídicas acerca do conceito de sentença arbitral estrangeira. 4. No ordenamento jurídico pátrio, elegeu-se o critério geográfico (ius solis) para determinação da nacionalidade das sentenças arbitrais, baseando-se exclusivamente no local onde a decisão for proferida (art. 34, parágrafo único, da Lei no 9.307/96). 5. Na espécie, o fato de o requerimento para instauração do procedimento arbitral ter sido apresentado à Corte Internacional de Arbitragem da Câmara de Comércio Internacional não tem o condão de alterar a nacionalidade dessa sentença, que permanece brasileira. 6 . Sendo a sentença arbitral em comento de nacionalidade brasileira, constitui, nos 
Nos termos do artigo 36 da Lei de Arbitragem brasileira, o procedimento para a homologação de sentença estrangeira (e, por conseguinte, também da decisão arbitral de urgência estrangeira) seguirá o disposto nos artigos 483 e 484 do CPC, “e, no que couber, a Res. 9 do STJ, de 4.5.05",563, além das regras contidas na Convenção de Nova Iorque.

$\mathrm{O}$ artigo 483, caput, do CPC, estabelece que a sentença estrangeira somente terá eficácia no Brasil depois de homologada pelo Superior Tribunal de Justiça, mencionando em seu parágrafo único que a homologação obedecerá ao que dispuser o regimento interno do STJ.

A Resolução n. 9 do STJ (que "dispõe, em caráter transitório, sobre competência acrescida ao Superior Tribunal de Justiça pela Emenda Constitucional n. ${ }^{\circ}$ 45/2004”) prevê, em seu artigo 5. , I a IV, os requisitos para a homologação de decisão estrangeira no Brasil:

\footnotetext{
“Art. 5. Constituem requisitos indispensáveis à homologação de sentença estrangeira:

I - haver sido proferida por autoridade competente;

II - terem sido as partes citadas ou haver-se legalmente verificado a revelia.;

III - ter transitado em julgado; e

IV - estar autenticada pelo cônsul brasileiro e acompanhada de tradução por tradutor oficial ou juramentado no Brasil”.
}

Por sua vez, o artigo 484 do CPC prevê que "a execução farse-á por carta de sentença extraída dos autos da homologação e obedecerá às regras estabelecidas para a execução da sentença nacional da mesma natureza" (no caso, a execução da tutela de urgência da mesma natureza), cabendo alertar que, como a carta de

termos dos arts. 475-N, IV, do CPC e 31 da Lei da Arbitragem, título executivo idôneo para embasar a ação de execução da qual o presente recurso especial se origina, razão pela qual é desnecessária a homologação por esta Corte. 7. Recurso especial provido para restabelecer a decisão proferida à e-STJ fl. 60." (3. ${ }^{\text { Turma, }}$ Rel. Min. Nancy Andrighi, DJe 01/06/2011, v.u.). Sobre o critério para a determinação da nacionalidade da sentença arbitral, ver ainda: STJ, SEC 894-UY e SEC 611-US.

${ }^{563}$ Cf. NEGRÃO, Theotonio; GOUVÊA, José Roberto F.; e BONDIOLI, Luis Guilherme A. Código de Processo Civil e legislação processual em vigor, 42. ${ }^{a}$ edição. São Paulo: Saraiva, 2010, p. 1184. Em igual sentido, RAFAel PellegRini RIBEIRO pontifica que, no procedimento de homologação, "devem ser

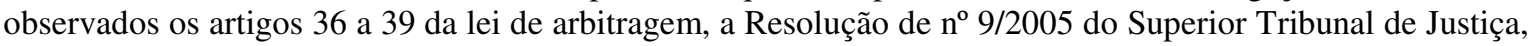
os artigos 483 e 484 do Código de Processo Civil e principalmente o disposto na Convenção de Nova Iorque." (in O reconhecimento e a execução de sentenças..., p. 423). 
sentença foi suprimida em razão da reforma operada pela Lei n. ${ }^{\circ} 11.232 / 05$, a execução será instruída com as peças referidas no art. 475-O, § 3. ${ }^{\circ}$, incisos I a V, do CPC ${ }^{564}$.

O procedimento de homologação de sentença (e, portanto, também de decisão arbitral urgente estrangeira, já que equiparada à sentença estrangeira pelo STF) pelo STJ compreende o pedido da parte interessada mediante petição inicial que deverá conter os requisitos da lei processual (artigo 3. ${ }^{\circ}$ da Res. n. ${ }^{\circ}$ 9/05 do STJ) ${ }^{565}$.

A parte contrária, então, deverá ser citada para, querendo, contestar o pedido homologatório no prazo de 15 (quinze) dias (artigo 8. ${ }^{\circ}$, caput, da Resolução n. ${ }^{\circ}$ 9/05 do STJ) ${ }^{566}$, cuja defesa somente poderá versar sobre autenticidade dos documentos, inteligência da decisão e observância dos requisitos legais (artigo 9. ${ }^{\circ}$, caput, da Resolução n. ${ }^{\circ}$ 9/05 do STJ) ${ }^{567}$.

Caso haja contestação ao pedido homologatório, "o processo será distribuído para julgamento pela Corte Especial, cabendo ao Relator os demais atos relativos ao andamento e à instrução do processo" (artigo 9. ${ }^{\circ}, \S 1 .^{\circ}$, da Resolução n. ${ }^{\circ}$ 9/05 do Superior Tribunal de Justiça).

Em regra, as sentenças estrangeiras são homologadas por inteiro, mas a Resolução n. ${ }^{\circ}$ 9/05 do STJ admite a homologação parcial (artigo 4. $\left.{ }^{\circ}, \S 2 .^{\circ}\right)^{568}$,

\footnotetext{
${ }^{564}$ Nesse sentido: CARREIRA ALVIM, José Eduardo. "Reconhecimento e execução de sentença..., p. 176. 565 “Art. $3^{\circ}$ A homologação de sentença estrangeira será requerida pela parte interessada, devendo a petição inicial conter as indicações constantes da lei processual, e ser instruída com a certidão ou cópia autêntica do texto integral da sentença estrangeira e com outros documentos indispensáveis, devidamente traduzidos e autenticados".

566 "Art. $8^{\circ}$ A parte interessada será citada para, no prazo de 15 (quinze) dias, contestar o pedido de homologação de sentença estrangeira ou intimada para impugnar a carta rogatória".

567 “Art. $9^{\circ} \mathrm{Na}$ homologação de sentença estrangeira e na carta rogatória, a defesa somente poderá versar sobre autenticidade dos documentos, inteligência da decisão e observância dos requisitos desta Resolução".

${ }^{568}$ Em caso interessante, a Corte Especial do STJ homologou, em parte, sentença arbitral estrangeira em virtude de algumas das questões nela constantes já terem sido decididas de forma definitiva no Brasil. Assim, foi indeferida a homologação apenas dos temas já decididos no país, sob pena de ofensa à coisa julgada. Eis a ementa desse acórdão: "Sentença arbitral estrangeira contestada. Pretensão homologatória a ser deferida em parte. Requisitos da lei atendidos. Vícios de negação inexistentes. Ampla competência para dirimir conflitos entre os contratantes de joint venture. Sendo lícito o negócio jurídico realizado no Brasil, por partes de legítimo contrato de joint venture, não se lhe pode extrair as consequiências jurídicas da quebra do acordado. Por mais razão, não se pode afastar a convenção arbitral nele instituída por meio de cláusula compromissória ampla, em que se regulou o Juízo competente para resolver todas as controvérsias das partes, incluindo aí a extensão dos temas debatidos, sob a alegação de renúncia tácita ou de suposta substituição do avençado. Uma vez expressada a vontade de estatuir, em contrato, cláusula compromissória ampla, a sua destituição deve vir
} 
admitindo também, expressamente, "tutela de urgência nos procedimentos de homologação de sentenças estrangeiras" (artigo 4. $\left..^{\circ}, \S 3 .^{\circ}\right)$.

Isto é, caso a tutela de urgência não possa aguardar sequer o trâmite do pedido de homologação, sem que haja prejuízo para o direito tutelado, é possível a obtenção de uma liminar no STJ para a execução imediata da medida urgente estrangeira no Brasil.

Há julgados concedendo o exequatur, antes da oitiva da parte contrária, a cartas rogatórias visando à efetivação de tutela de urgência em matéria criminal $^{569}$, assim como também há jurisprudência em sentido contrário, negando o pedido liminar deduzido em sede de homologação de sentença estrangeira ${ }^{570}$.

através de igual declaração expressa das partes, não servindo, para tanto, mera alusão a atos ou a acordos que não tinham o condão de afastar a convenção das partes. Ademais, o próprio sentido do contrato de joint venture assinado pelas partes elimina o argumento de que uma delas quis abdicar da instituição de juízo arbitral no estrangeiro. A revelia não importa em falta de citação, mas, ao contrário, a pressupõe. O laudo arbitral lavrado por Corte previamente prevista na cláusula compromissória obedece aos requisitos para sua internalização em território pátrio, máxime porque não ofende os ditames dos arts. $3^{\circ}, 5^{\circ}$ e $6^{\circ}$ da Resolução n. ${ }^{\circ} 9$ desta Corte, devendo, por isso, ser homologado. Havendo a Justiça brasileira, definitivamente, resolvido controvérsia quanto a um dos temas do pedido de homologação da sentença arbitral, deve a pretensão ser negada quanto a isso por obediência à coisa julgada. Homologação deferida em parte, com a exclusão dos itens 7 e 10 da decisão arbitral." (STJ, Corte Especial, SEC 1/EX, Rel. Min. Maria Thereza de Assis Moura, j. 19/10/2011, DJe 01/02/2012, v.u.).

569 “Carta Rogatória. Diligências. Busca e apreensão. Quebra de sigilo bancário. Concessão do exeqüatur. (...) 6. A título de argumento obter ditcum, fora formulado pedido de busca e apreensão pelo juízo rogante, reclamando, na espécie, o contraditório diferido, sob pena de frustrar-se o ato de cooperação internacional, consoante o art. $8^{\circ}$, parágrafo único, do Resolução 09, de 04 de maio de 2005, deste sodalício (Precedente da Suprema Corte: HC 90.485 - SP, Relator Ministro Cezar Peluso, Segunda Turma, DJ de 08 de junho de 2007). 7. A Resolução/STJ n. ${ }^{\circ}$ 09/2005, nos parágrafos do seu art. 13, prevê a possibilidade de o interessado exercer o seu direito de defesa por meio de embargos e/ou agravo regimental contra qualquer decisão proferida no cumprimento de carta rogatória. É que as medidas cautelares, em nosso sistema processual, podem ser determinadas inaudiatur et altera pars; daí o contraditório postecipado. Sob este enfoque, a doutrina pátria assenta em lição clássica o seguinte: Entre nós, as medidas cautelares são, em regra, determinadas sem audiência do titular do direito restringido, de ofício ou em atenção a requerimento do Ministério Público, do ofendido ou representação da autoridade policial. As perícias são realizadas também sem participação do investigado ou de seu advogado. A observância do contraditório, nesses casos, é feita depois, dando-se oportunidade ao suspeito ou réu de contestar a providência cautelar ou de combater, no processo, a prova pericial realizada no inquérito. Fala-se em contraditório diferido ou postergado (FERNANDES, Antonio Scarance. Processo Penal Constitucional, São Paulo: Revista dos Tribunais, 1999 , p. 60). (...)" (STJ. Corte Especial, EDcl na CR 438/BE, Rel. Min. Luiz Fux, j. 01/08/2008, DJe 20/10/2008, v.u.); e "Carta Rogatória. Exequatur. Medida cautelar penal. Diligências para identificação e apreensão de bens. Proveito de infração penal. Ciência prévia do paciente. Inadmissibilidade. Risco de frustração das diligências. Caso de contraditório diferido, retardado ou postergado, mediante embargos ou agravo. Garantia de exercício pleno do direito de defesa. Ilegalidade inexistente. HC indeferido. Inteligência do art. $5^{\circ}$, LVI da CF e da Resolução no 9/2005, do STJ. É legítima, em carta rogatória, a realização liminar de diligências sem a ciência prévia nem a presença do réu da ação penal, quando estas possam frustrar o resultado daquelas."

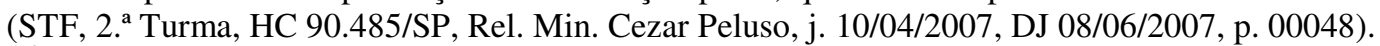

570 "Homologação de sentença estrangeira. Arresto de bens. Pedido de antecipação de tutela. Ausência de elementos que justifiquem a medida. Agravo regimental não provido.” (STJ, Corte Especial, AgRG na SE 
Em caso interessante, quando ainda era competente para a homologação de sentenças estrangeiras, o Supremo Tribunal Federal concedeu liminar na ação cautelar n. ${ }^{\circ}$ 13/PR, para o fim de suspender a execução de tutela antecipada deferida por juízo estatal brasileiro em ação de cobrança ajuizada por empresa brasileira, enquanto não homologada sentença arbitral estrangeira que reconheceu um crédito em favor de empresa estrangeira, a qual era ré na ação judicial em curso no país e pretendia efetivar a compensação entre os valores discutidos nos processos ${ }^{571}$. Nesse caso, o STF acabou, por meio de ação cautelar, concedendo efeito suspensivo a um procedimento de homologação de sentença arbitral ainda sequer iniciado, impedindo o levantamento de valor em ação judicial em curso no país até final decisão do futuro procedimento de homologação de sentença arbitral estrangeira.

Ainda quanto ao tema, as tutelas de urgência deferidas em arbitragens estrangeiras em curso nos Estados-Partes do Mercosul, na Bolívia ou no Chile podem ser homologadas no Brasil mediante carta rogatória, nos termos do artigo 19 do Protocolo de Las Leñas ${ }^{572}$, o que possibilita a concessão do exequatur independentemente da citação do requerido ${ }^{573}$.

5327/DF, Rel. Min. Ari Pargendler, j. 05/12/2011, DJe 01/02/2012, v.u.). Quanto ao tema, ver: DIAS, André Petzhold. "Tutelas de urgência e sentença estrangeira" in Direito Processual Civil, vol. 2. CARVALHO, Milton Paulo de; e CASTRO, Daniel Penteado de (Coord.). São Paulo: Quartier Latin, 2011, pp. 122/140.

571 "Decisão - Liminar - Ação cautelar - Laudo arbitral estrangeiro - Homologação - Ação de cobrança cumulada com perdas e danos - Tutela antecipada - Suspensão." (STF, AC n. ${ }^{\circ}$ 13/PR, Min. Marco Aurélio, j. 08/05/2003, DJU 14/05/2003, p. 00019, in Revista de Direito Bancário, do Mercado de Capitais e da Arbitragem, Ano 6, n. ${ }^{\circ}$ 22. WALD, Arnoldo (coord.). São Paulo: RT, outubro-dezembro de 2003, p. 423).

${ }^{572} \mathrm{O}$ "Acordo de Cooperação e Assistência Jurisdicional em Matéria Civil, Comercial, Trabalhista e Administrativa entre os Estados Partes do Mercosul, a República da Bolívia e a República do Chile" - conhecido como Protocolo de Las Leñas - foi promulgado no Brasil pelo Decreto Federal n. ${ }^{\circ}$ 6.891, de 02 de julho de 2009, estalecendo os seus artigos 18 e 19 que: "Capítulo V - Reconhecimento e Execução de Sentenças e de Laudos Arbitrais. Artigo $18^{\circ}$ As disposições do presente Capítulo serão aplicáveis ao reconhecimento e à execução das sentenças e dos laudos arbitrais pronunciados nas jurisdições dos Estados Partes em matéria civil, comercial, trabalhista e administrativa, e serão igualmente aplicáveis às sentenças em matéria de reparação de danos e restituição de bens pronunciadas em jurisdição penal. Artigo $19^{\circ} \mathrm{O}$ reconhecimento e execução de sentenças e de laudos arbitrais solicitado pelas autoridades jurisdicionais poderá tramitar-se por via de cartas rogatórias e transmitir-se por intermédio da Autoridade Central, ou por via diplomática ou consular, em conformidade com o direito interno. Não obstante o assinalado no parágrafo anterior, a parte interessada poderá tramitar diretamente o pedido de reconhecimento ou execução de sentença. Em tal caso, a sentença deverá estar devidamente legalizada de acordo com a legislação do Estado em que se pretenda sua eficácia, salvo se entre o Estado de origem da sentença e o Estado onde é invocado, se houver suprimido o requisito da legalização ou substituído por outra formalidade".

573 "Protocolo de Las Leñas: homologação mediante carta rogatória. O Protocolo de Las Leñas ('Protocolo de Cooperação e Assistência Jurisdicional em Matéria Civil, Comercial, Trabalhista, Administrativa' entre os países do Mercosul) (...) inovou, entretanto, a convenção internacional referida, ao prescrever, no art. 19, que a homologação (dito reconhecimento) de sentença provinda dos Estados partes se faça mediante rogatória, o que importa admitir a iniciativa da autoridade judiciária competente do foro de origem e que o exequatur se defira independentemente da citação do requerido, sem prejuízo da posterior manifestação do requerido, por 


\section{A homologação da decisão arbitral estrangeira que deferiu}

uma tutela de urgência somente poderá ser negada pelo Superior Tribunal de Justiça caso se verifique alguma das hipóteses previstas nos artigos 38 e 39 da Lei de Arbitragem ${ }^{574}$, no artigo 6. ${ }^{\circ}$ da Resolução n. ${ }^{\circ}$ 9/05 do STJ $^{575}$ ou no artigo V da Convenção de Nova Iorque ${ }^{576}$.

meio de agravo à decisão concessiva ou de embargos ao seu cumprimento." (STF-Pleno, CR 7613 AgR/AT Argentina, Relator Ministro Sepúlveda Pertence, julgamento em 03/04/1997, D.J. 09/05/1997, p. 18.154).

574 "Art. 38. Somente poderá ser negada a homologação para o reconhecimento ou execução de sentença arbitral estrangeira, quando o réu demonstrar que: I - as partes na convenção de arbitragem eram incapazes; II - a convenção de arbitragem não era válida segundo a lei à qual as partes a submeteram, ou, na falta de indicação, em virtude da lei do país onde a sentença arbitral foi proferida; III - não foi notificado da designação do árbitro ou do procedimento de arbitragem, ou tenha sido violado o princípio do contraditório, impossibilitando a ampla defesa; IV - a sentença arbitral foi proferida fora dos limites da convenção de arbitragem, e não foi possível separar a parte excedente daquela submetida à arbitragem; V - a instituição da arbitragem não está de acordo com o compromisso arbitral ou cláusula compromissória; VI - a sentença arbitral não se tenha, ainda, tornado obrigatória para as partes, tenha sido anulada, ou, ainda, tenha sido suspensa por órgão judicial do país onde a sentença arbitral for prolatada". Sobre as hipóteses de indeferimento da homologação, ver: CARVALHO, Ana Cristina Azevedo Pontes de. As inovações da Convenção de Nova Iorque..., pp. 55/58; e RIBEIRO, Rafael Pellegrini. O reconhecimento e a execução de sentenças..., pp. 425/432. Este último autor esclarece que "os incisos do artigo 38 da lei de arbitragem são prova inequívoca de que o legislador brasileiro inspirou-se na Convenção de Nova Iorque, que à época não tinha sido ainda ratificada pelo Brasil", pois "todos os seis casos arrolados no artigo 38 estãoprevistos de forma similar e harmônica ao artigo V da Convenção de Nova Iorque." (Idem, p. 425).

"Art. 39. Também será denegada a homologação para o reconhecimento ou execução da sentença arbitral estrangeira, se o Supremo Tribunal Federal constatar que: I - segundo a lei brasileira, o objeto do litígio não é suscetível de ser resolvido por arbitragem; II - a decisão ofende a ordem pública nacional. Parágrafo único. Não será considerada ofensa à ordem pública nacional a efetivação da citação da parte residente ou domiciliada no Brasil, nos moldes da convenção de arbitragem ou da lei processual do país onde se realizou a arbitragem, admitindo-se, inclusive, a citação postal com prova inequívoca de recebimento, desde que assegure à parte brasileira tempo hábil para o exercício do direito de defesa".

575 "Art. 6. ${ }^{\circ}$ Não será homologada sentença estrangeira ou concedido exequatur a carta rogatória que ofendam a soberania ou a ordem pública".

576 “Artigo V - 1. O reconhecimento e a execução de uma sentença poderão ser indeferidos, a pedido da parte contra a qual ela é invocada, unicamente se esta parte fornecer, à autoridade competente onde se tenciona $\mathrm{o}$ reconhecimento e a execução, prova de que: a) as partes do acordo a que se refere o Artigo II estavam, em conformidade com a lei a elas aplicável, de algum modo incapacitadas, ou que tal acordo não é válido nos termos da lei à qual as partes o submeteram, ou, na ausência de indicação sobre a matéria, nos termos da lei do país onde a sentença foi proferida; ou b) a parte contra a qual a sentença é invocada não recebeu notificação apropriada acerca da designação do árbitro ou do processo de arbitragem, ou lhe foi impossível, por outras razões, apresentar seus argumentos; ou c) a sentença se refere a uma divergência que não está prevista ou que não se enquadra nos termos da cláusula de submissão à arbitragem, ou contém decisões acerca de matérias que transcendem o alcance da cláusula de submissão, contanto que, se as decisões sobre as matérias suscetíveis de arbitragem puderem ser separadas daquelas não suscetíveis, a parte da sentença que contém decisões sobre matérias suscetíveis de arbitragem possa ser reconhecida e executada; ou d) a composição da autoridade arbitral ou o procedimento arbitral não se deu em conformidade com o acordado pelas partes, ou, na ausência de tal acordo, não se deu em conformidade com a lei do país em que a arbitragem ocorreu; ou e) a sentença ainda não se tornou obrigatória para as partes ou foi anulada ou suspensa por autoridade competente do país em que, ou conforme a lei do qual, a sentença tenha sido proferida. 2. O reconhecimento e a execução de uma sentença arbitral também poderão ser recusados caso a autoridade competente do país em que se tenciona o reconhecimento e a execução constatar que: a) segundo a lei daquele país, o objeto da divergência não é passível de solução mediante arbitragem; ou b) o reconhecimento ou a execução da sentença seria contrário à ordem pública daquele país". 
Isto é, nas hipóteses de não restar comprovada a convenção de arbitragem $^{577}$, de ausência de citação válida ${ }^{578}$, de ofensa a ordem pública ${ }^{579}$ etc.

Nas legislações estrangeiras, também é comum a previsão expressa da impossibilidade da homologação de decisão arbitral que ofenda a ordem pública do país local ${ }^{580}$, valendo-se mencionar a lição de JULIAN M. LEW, LOUKAS A.

${ }^{577}$ O STF, à época em que ainda era competente para a homologação de sentença estrangeira, exigia a prova da convenção de arbitragem, conforme acórdão da SEC 6753/UK (Pleno, Rel. Min. Maurício Corrêa, DJ 04/102002, p. 96, v.u.). O STJ, agora o tribunal competente para a homologação de sentença estrangeira, continua seguindo essa mesma linha, conforme os arestos da SEC 967/GB (Rel. Min. José Delgado, j. 15/02/2006, DJ 20/03/2006); da SEC 866/EX (Corte Especial, Rel. Min. Felix Fischer, j. 17/05/2006, v.u.); da SEC 885/US (Corte Especial, Rel. Min. Francisco Falcão, j. 02/08/2010); e da SEC 978/GB (Corte Especial, Rel. Min. Hamilton Carvalhido, j. 17/12/2008).

${ }^{578} \mathrm{Na}$ SEC 833/US (STJ, Corte Especial, Relator para acórdão Min. Luiz Fux, j. 16/08/2006, maioria), o Superior Tribunal de Justiça indeferiu a homologação de sentença arbitral estrangeira ante a ausência de comprovação da regular citação da parte contrária. O mesmo ocorreu na SEC 542/US (STJ, Corte Especial, Rel. Min. Luiz Fux, j. 20/09/2006, v.u.), em que se exigiu a citação via carta rogatória, por se tratar de processo perante a justiça comum. A Convenção de Nova Iorque, que dispõe sobre o reconhecimento e a execução de sentenças arbitrais estrangeiras, e que foi promulgada no Brasil por meio do Decreto Federal n. ${ }^{\circ}$ 4.311/2002, também prevê, em seu artigo V, "1", "b", a possibilidade da recusa do reconhecimento e da execução de sentença arbitral estrangeira em virtude de falha na citação.

579 Levantamento feito pelo escritório TOZZINI, FREIRE ADVOGADOS apurou que 25 sentenças arbitrais estrangeiras já foram submetidas ao STJ, tendo 18 sido confirmadas e 7 rejeitadas, sendo certo que, segundo o advogado desse escritório, ANTONIO BARBUTO NETO, "para tentar derrubar a sentença internacional desfavorável, as empresas brasileiras sempre alegam violação à ordem pública", o que torna muito relevante para as arbitragens comerciais internacionais o conceito de "ordem pública" (cf. matéria intitulada "STJ sinaliza entendimento sobre ordem pública", publicada no jornal "Valor Econômico", caderno "Legislação e Tributos", edição de 01/11/2011). RAFAEL PELLEGRINI RIBEIRO ressaltando a dificuldade de conceituação de "ordem pública", afirma que "a aplicação de exceção da ordem pública deve ser acompanhada com grande dose de razoabilidade para que não ocorram distorções." (O reconhecimento e a execução de sentenças..., p. 431). Quanto ao tema, no julgamento da Sentença Estrangeira Contestada n. ${ }^{\circ}$ 5.493-US (2011/0125467-4), a Corte Especial do STJ proferiu importante decisão em que aponta o que entende por "ordem pública", ao homologar sentença americana de alteração de nome e sobrenome (algo não permitido pela legislação pátria, salvo em situações excepcionais, tais como casamento, constrangimento causado pelo nome etc.), pontificando que tal decisão estrangeira não feriria a ordem pública nacional. No acórdão relatado pelo Exmo. Min. FELIX FISCHER, ele afirma que o fato de uma questão ter sido decidida com base em regra não prevista no ordenamento jurídico nacional (e, sim, em ordenamento estrangeiro), não ofende, por si só, a ordem pública nacional (STJ, Corte Especial, SEC n. ${ }^{\circ}$ 5.493-US, Rel. Min. Felix Fischer, j. 21/09/11, DJe 06/10/11, v.u.). Segundo ARNOLDO WALD, a decisão proferida pelo STJ na SEC 802, relatada pelo Min. JOSÉ DELGADO, fixou o entendimento de que a ordem pública abarca os valores básicos da cultura nacional, não se confundindo com a totalidade da legislação pátria ou com a interpretação a ela dada pelo Poder Judiciário (in "A jurisprudência do Superior Tribunal de Justiça em relação às sentenças arbitrais". Revista de Arbitragem e Mediação, ano 3, vol. 8. WALD, Arnoldo (coord.). São Paulo: RT, 2006, pp. 07/16).

${ }^{580}$ Por exemplo, o artigo 103, (3), do Arbitration Act 1996 da Inglaterra: "Article 103 - Refusal of recognition or enforcement. (...) (3) Recognition or enforcement of the award may also be refused if the award is in respect of a matter which is not capable of settlement by arbitration, or if it would be contrary to public policy to recognise or enforce the award." (trad. livre: "Artigo 103 - Recusa do reconhecimento ou execução (...) (3) O reconhecimento ou a execução de sentença arbitral também poderá ser recusado se a decisão versar sobre matéria não sujeita à arbitragem, ou se for contrário a ordem pública reconhecer e executar a decisão"); o artigo 1514 do CPC francês: "Arte. 1514. Les sentences arbitrales sont reconnues ou exécutées en France si leur existence est établie par celui qui s'en prévaut et si cette reconnaissance ou cette exécution n'est pas manifestement contraire à l'ordre public international." (trad. livre: As sentenças arbitrais são reconhecíveis ou executadas na França se a sua existência é estabelecida por alguém de confiança e se esse reconhecimento 
Mistelis e STEFAN MiCHAEL KRÖLL no sentido de que "the courts are unlikely to enforce an order which is not permitted in their own jurisdiction." (tradução livre: "as cortes dificilmente executarão uma ordem que não é permitida em sua própria jurisdição.”) ${ }^{581}$.

Verifica-se, portanto, que o juízo para o reconhecimento de decisões arbitrais estrangeiras é de delibação, uma vez que são analisados apenas e tãosomente os requisitos extrínsecos da decisão, e nunca o seu mérito ${ }^{582}$.

Assim, não configurada quaisquer das hipóteses previstas nos artigos 38 e 39 da Lei de Arbitragem brasileira, no artigo V da Convenção de Nova Iorque ou no artigo $6 .^{\circ}$ da Resolução n. ${ }^{\circ}$ 9/05 do STJ, este deverá, obrigatoriamente, conceder o pedido de homologação ${ }^{583}$.

ou essa execução não for manifestamente contrária à ordem pública internacional.”); o artigo 1059, (2), 2, b, da ZPO alemã: "Section 1059 Application for setting aside (...) (2) An arbitral award may be set aside only if: (...) 2. the court finds that (...) b) recognition or enforcement of the award leads to a result which is in conflict with public policy (ordre public)." (trad. livre: "Seção 1059 Pedido de revogação (...) (2) Uma decisão arbitral somente poderá ser afastada se: (...) 2. A corte entender que: (...) b) o reconhecimento ou a execução da decisão conduzirá a um resultado que ofende a política pública (ordem pública).”); e os artigos 54..$^{\circ}$ e 56. ${ }^{\circ}, 1$, "b”, “ii”, da Lei n. ${ }^{\circ}$ 63/2011 de Portugal: "Artigo 54. ${ }^{\circ}$ Ordem pública internacional - A sentença proferida em Portugal, numa arbitragem internacional em que haja sido aplicado direito não português ao fundo da causa pode ser anulada com os fundamentos previstos no artigo $46 .^{\circ}$ e ainda, caso deva ser executada ou produzir outros efeitos em território nacional, se tal conduzir a um resultado manifestamente incompatível com os princípios da ordem pública internacional."; "Artigo 56. Fundamentos de recusa do reconhecimento e execução 1 - O reconhecimento e a execução de uma sentença arbitral proferida numa arbitragem localizada no estrangeiro só podem ser recusados: (...) b) Se o tribunal verificar que: (...) ii) $\mathrm{O}$ reconhecimento ou a execução da sentença conduz a um resultado manifestamente incompatível com a ordem pública internacional do Estado português". Quanto ao tema, cumpre-se frisar, ainda, que a Convenção de Nova Iorque de 1958, que dispõe sobre o reconhecimento e a execução de sentenças arbitrais estrangeiras, também prevê, em seu artigo V, "2", "b", a possibilidade da recusa do reconhecimento e da execução de sentença arbitral estrangeira que ofenda a ordem pública do Estado-Parte: “Artigo V (...) 2. O reconhecimento e a execução de uma sentença arbitral também poderão ser recusados caso a autoridade competente do país em que se tenciona o reconhecimento e a execução constatar que: (...) b) o reconhecimento ou a execução da sentença seria contrário à ordem pública daquele país".

${ }^{581}$ In Comparative International..., p. 610.

${ }^{582}$ Cf. RIBEIRO, Rafael Pellegrini. O reconhecimento e a execução de sentenças..., p. 423. Em igual sentido: GUERRERO, Luis Fernando. Arbitragem e jurisdição: premissa..., p. 22.

${ }^{583}$ Nesse sentido: "Homologação de sentença arbitral estrangeira. Caução. Desnecessidade. Lei 9.307/96. Aplicação imediata. Constitucionalidade. Utilização da arbitragem como solução de conflitos. Ausência de violação à ordem pública. Impossibilidade de análise do mérito da relação de direito material. Ofensa ao contraditório e à ampla defesa. Inexistência. Regra da exceção do contrato não cumprido. Fixação da verba honorária. Art. 20, § $4^{\circ}$ do CPC. Pedido de homologação deferido. I - Não é exigível a prestação de caução para o requerimento de homologação de sentença estrangeira. Precedentes do Supremo Tribunal Federal. II A sentença arbitral e sua homologação é regida no Brasil pela Lei n ${ }^{\circ}$ 9.307/96, sendo a referida Lei de aplicação imediata e constitucional, nos moldes como já decidido pelo Supremo Tribunal Federal. III Consoante entendimento desta Corte, não viola a ordem pública brasileira a utilização de arbitragem como meio de solução de conflitos. IV - $\underline{\mathrm{O} \text { controle judicial da homologação da sentença arbitral estrangeira está }}$ limitado aos aspectos previstos nos artigos 38 e 39 da Lei $n^{\circ} 9.307 / 96$, não podendo ser apreciado o mérito da relação de direito material afeto ao objeto da sentença homologanda. Precedentes. V - Não resta configurada a ofensa ao contraditório e à ampla defesa se as requeridas aderiram livremente aos contratos que continham 
Esclarece-se que, nos termos da lição de RAFAEL PELLEGRINI

RIBEIRO, uma decisão arbitral de urgência estrangeira pode ter o seu reconhecimento e a sua homologação rejeitados ex officio, isto é, sem a apresentação de defesa pela parte contrária, nas hipóteses previstas no artigo 39 da Lei de Arbitragem brasileira ou no artigo V, “2”, da Convenção de Nova Iorque (ofensa à ordem pública nacional ou se objeto do litígio não for passível de ser resolvido por arbitragem) ${ }^{584}$.

Se o pedido for negado, somente o próprio Superior Tribunal de Justiça poderá reapreciá-lo, seja por meio de agravo regimental, seja por meio de novo pedido de homologação pela parte, corrigindo o equívoco formal apontado na decisão

expressamente a cláusula compromissória, bem como tiveram amplo conhecimento da instauração do procedimento arbitral, com a apresentação de considerações preliminares e defesa. VI - A Eg. Corte Especial deste Tribunal já se manifestou no sentido de que a questão referente à discussão acerca da regra da exceção do contrato não cumprido não tem natureza de ordem pública, não se vinculando ao conceito de soberania nacional. Ademais, o tema refere-se especificamente ao mérito da sentença homologanda, sendo inviável sua

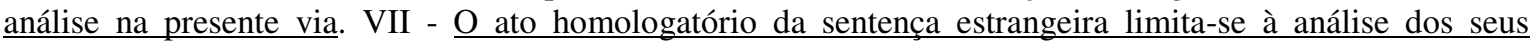
requisitos formais. Isto significa dizer que o objeto da delibação na ação de homologação de sentença estrangeira não se confunde com aquele do processo que deu origem à decisão alienígena, não possuindo conteúdo econômico. É no processo de execução, a ser instaurado após a extração da carta de sentença, que poderá haver pretensão de cunho econômico. VIII - Em grande parte dos processos de homologação de sentença estrangeira - mais especificamente aos que se referem à sentença arbitral - o valor atribuído à causa corresponde ao conteúdo econômico da sentença arbitral, geralmente de grande monta. Assim, quando for contestada a homologação, a eventual fixação da verba honorária em percentual sobre o valor da causa pode mostrar-se exacerbada. IX - Na hipótese de sentença estrangeira contestada, por não haver condenação, a fixação da verba honorária deve ocorrer nos moldes do art. $20, \S 4^{\circ}$ do Código de Processo Civil, devendo ser observadas as alíneas do $\S 3^{\circ}$ do referido artigo. Ainda, consoante o entendimento desta Corte, neste caso, não está o julgador adstrito ao percentual fixado no referido $\S 3^{\circ}$. X - Pedido de homologação deferido." (STJ, Corte Especial, SEC 507/GB, Rel. Min. Gilson Dipp, j. 18/10/2006, grifos nossos). Em igual sentido: “(...) II. A atuação jurisdicional do e. STJ no processo de homologação de sentença arbitral estrangeira encontra balizas nos artigos 38 e 39 da Lei de Arbitragem (Lei 9.307/96). Se não houver transgressão aos bons costumes, à soberania nacional e à ordem pública, não se discute a relação de direito material subjacente à sentença arbitral. (...) VI - Constatada a presença dos requisitos indispensáveis à homologação da sentença estrangeira (Resolução n. ${ }^{\circ}$ 9/STJ, arts. $5^{\circ}$ e $6^{\circ}$ ), é de se deferir o pedido. Sentença Arbitral homologada." (STJ, Corte Especial, SEC 6335/EX, Rel. Min. Felix Fischer, j. 21/03/2012, v.u., g.n.). Ainda: STJ, Corte Especial, SEC 4837/EX, Rel. Min. Francisco Falcão, j. 15/08/2012, v.u.; SEC 3709/EX, Rel. Min. Teori Albino Zvascki, j. 14/06/2012, v.u.; SEC 4439/EX, Rel. Min. Teori Albino Zvascki, j. 24/11/2011, v.u.; SEC 4415/US, Rel. Min. Aldir Passarinho Júnior, j. 29/06/2010, v.u.; SEC 3035/FR, Rel. Min. Fernando Gonçalves, j. 19/08/2009, v.u.; SEC 3661/GB, Rel. Min. Paulo Gallotti, j. 28/05/2009, v.u.; SEC 3660/GB, Rel. Min. Arnaldo Esteves Lima, j. 28/05/2009, v.u.; SEC 894/UY, Rel. Min. Nancy Andrighi, j. 20/08/2008, v.u.; SEC 1302/KR, Rel. Min. Paulo Gallotti, j. 18/06/2008, v.u.; SEC 1210/GB, Rel. Min. Fernando Gonçalves, j. 20/06/2007, v.u.; SEC 760/US, Rel. Min. Felix Fischer, j. 19/06/2006, v.u.; SEC 866/GB, Rel. Min. Felix Fischer, j. 17/05/2006, v.u.; SEC 874/CH, Rel. Min. Francisco Falcão, j. 19/04/2006, v.u.; e SEC 802/US, Rel. Min. José Delgado, j. 17/08/2005, v.u. Quanto ao pedido de homologação, frise-se ainda que o parágrafo único do artigo 24 do Projeto de Lei n. ${ }^{\circ}$ 8.046/2010, em trâmite na Câmara dos Deputados, que institui um novo Código de Processo Civil, prevê que "a pendência da causa perante a jurisdição brasileira não impede a homologação de sentença judicial ou arbitral estrangeira”.

${ }^{584}$ In $\mathrm{O}$ reconhecimento e a execução de sentenças..., p. 428. 
anterior, nos termos do artigo 40 da Lei de Arbitragem brasileira ${ }^{585}$, salvo o cabimento de eventual recurso extraordinário para o Supremo Tribunal Federal ${ }^{586}$.

Na hipótese de tutela de urgência que importe atos de disponibilidade de bens ou qualquer outro ato que possa gerar prejuízo às partes (atos coercitivos), a sua execução no Brasil, por uma parte estrangeira, além de depender da homologação pelo Superior Tribunal de Justiça, também ficará subordinada à prestação de caução pelo exequente.

Para atos coercitivos, a prestação de caução em execuções transnacionais está prevista na Lei-Modelo da UNCITRAL ${ }^{587}$, além de advir, no Brasil, do artigo 835 do CPC, o qual estabelece que "o autor, nacional ou estrangeiro, que residir fora do Brasil ou dele se ausentar na pendência da demanda, prestará, nas ações que intentar, caução suficiente às custas e honorários de advogado da parte contrária, se não tiver no Brasil bens imóveis que lhe assegurem o pagamento" ${ }^{, 588}$.

Frise-se que as partes oriundas dos países do Mercosul, da Bolívia ou do Chile não precisarão prestar caução para executar, no Brasil, tutela de urgência deferida em arbitragem em curso fora do território nacional, em virtude do disposto nos artigos $3 .^{\circ}$ e $4 .^{\circ}$ do Protocolo de Las Leñas, que, no que tange ao acesso à

585 “Art. 40. A denegação da homologação para reconhecimento ou execução de sentença arbitral estrangeira por vícios formais, não obsta que a parte interessada renove o pedido, uma vez sanados os vícios apresentados". Quanto ao tema, RAFAEL PELLEGRINI RIBEIRO anota "que o artigo 40 da lei de arbitragem possibilita a renovação do pedido ao interessado que teve seu pedido de homologação de sentença arbitral estrangeira denegado pelo Superior Tribunal de Justiça por vícios formais." (O reconhecimento e a execução de sentenças..., p. 433).

${ }^{586}$ Cf. CARREIRA ALVIM, José Eduardo. Reconhecimento e execução de sentença..., p. 179.

${ }^{587}$ Nos termos do artigo 26 (6): "6. The arbitral tribunal may require the party requesting an interim measure to provide appropriate security in connection with the measure." (trad. livre: "6. O tribunal arbitral pode exigir que a parte que pleiteia uma medida liminar preste a caução apropriada em relação à medida.").

${ }^{588}$ Cf. GARCEZ, José Maria Rossani. Medidas cautelares e de antecipação..., p. 228, mencionando o autor, ainda, que o Arbitration Act 1996 inglês também prevê a necessidade de caução para a execução de medidas cautelares que importem "venda de artigos perecíveis ou outros atos que afetem a propriedade ou a disponibilidade dos bens de uma das partes." (Idem, ibidem). Eis os termos do artigo 103 do Arbitration Act 1996 da Inglaterra: "103 Refusal of recognition or enforcement. (...) (5) Where an application for the setting aside or suspension of the award has been made to such a competent authority as is mentioned in subsection $(2)(f)$, the court before which the award is sought to be relied upon may, if it considers it proper, adjourn the decision on the recognition or enforcement of the award. It may also on the application of the party claiming recognition or enforcement of the award order the other party to give suitable security." (tradução livre: "Quando um pedido de revogação ou suspensão da decisão for feito para tal autoridade competente como mencionado na subseção (2)(f), a corte perante a qual a decisão é executada poderá, se considerar apropriado, adiar a decisão de reconhecimento ou de execução da decisão. Ela também poderá no procedimento da parte que pleiteia reconhecimento ou execução da decisão ordenar à outra parte que dê a garantia adequada."). 
Justiça, equipara o membro de Estado-Parte do Mercosul, da Bolívia e do Chile ao cidadão brasileiro $^{589}$.

Enfim, pode-se concluir que, no Brasil, é o próprio Poder Judiciário quem, após realizar os exames necessários à concessão do exequatur, autoriza a execução das tutelas de urgência arbitrais estrangeiras, assim como o faz com as decisões judiciais proferidas em outras jurisdições, nos termos do art. 105, I, 'i' da Constituição ${ }^{590}$.

Diante da burocracia envolvida no procedimento acima narrado, é válida a menção da opinião de PIERO BERNARDINI, segundo a qual, em determinadas ocasiões, talvez seja mais efetivo que a parte apresente o seu pedido liminar diretamente perante o juízo estatal em que deverá ser executado, do que aguardar a sua análise pelo árbitro e o posterior procedimento de homologação da decisão $\operatorname{arbitral}^{591}$.

\section{Julian M. Lew, Loukas A. Mistelis e Stefan Michael}

KRÖLL também fazem essa ressalva, especialmente nos casos em que a tutela de urgência deva ser deferida sem a oitiva da parte contrária, recomendando o acesso direto da parte ao Poder Judiciário do país em que a medida deva ser executada, desde que o ordenamento jurídico de tal país permita a concessão de uma medida urgente inaudita altera parte ${ }^{592}$.

Com relação à execução de tutelas de urgência arbitrais estrangeiras em outros países, ressalta-se que, em Portugal, a nova lei de arbitragem portuguesa (Lei n. ${ }^{\circ}$ 63, de 14 de dezembro de 2011), em vigor desde 14/03/2012,

\footnotetext{
589 “Capítulo III - Igualdade do Tratamento Processual. Artigo $3^{\circ}$ Os nacionais, os cidadãos e os residentes permanentes ou habituais de um dos Estados Partes gozarão, nas mesmas condições dos nacionais, cidadãos e residentes permanentes ou habituais de outro Estado Parte, do livre acesso à jurisdição desse Estado para a defesa de seus direitos e interesses. O parágrafo anterior aplicar-se-á às pessoas jurídicas constituídas, autorizadas ou registradas de acordo com as leis de qualquer dos Estados Partes. Artigo $4^{\circ}$ Nenhuma caução ou depósito, qualquer que seja sua denominação, poderá ser imposta em razão da qualidade de nacional, cidadão ou residente permanente ou habitual de outro Estado Parte. O parágrafo precedente aplicar-se-á às pessoas jurídicas constituídas, autorizadas ou registradas conforme as leis de qualquer dos Estados Partes". No mesmo sentido: GARCEZ, José Maria Rossani. Medidas cautelares e de antecipação..., pp. 228/229.

${ }^{590}$ Em igual sentido: FICHTNER, José Antonio; MONTEIRO, André Luís. Medidas urgente..., p. 47.

${ }^{591}$ In The Powers of the Arbitrator..., p. 29.

${ }^{592}$ In Comparative International..., p. 614.
} 
estabelece em seu artigo 27.', “1”, que a tutela de urgência deferida em arbitragem estrangeira pode ser executada diretamente perante o tribunal estadual competente ${ }^{593}$.

Nesse mesmo sentido, a nova lei de arbitragem da CidadeEstado de Hong Kong (“Hong Kong Arbitration Ordinance (Cap. 609)”), em vigor desde 01/06/2011, trouxe como principal inovação a abolição da dualidade de regimes para arbitragens domésticas ou estrangeiras ${ }^{594}$, estabelecendo, na seção 61, que a execução de uma decisão arbitral de urgência estrangeira pode ser executada da mesma forma que uma decisão arbitral de urgência local, dependendo apenas de uma autorização do juízo local ${ }^{595}$.

Em outros países, assim como ocorre no Brasil, a execução de uma decisão arbitral de urgência estrangeira segue as mesmas normas que regulam a homologação de uma sentença arbitral estrangeira ${ }^{596}$.

\footnotetext{
593 “Artigo 27..$^{\circ}$ Reconhecimento ou execução coerciva 1 - Uma providência cautelar decretada por um tribunal arbitral é obrigatória para as partes e, a menos que o tribunal arbitral tenha decidido de outro modo, pode ser coercivamente executada mediante pedido dirigido ao tribunal estadual competente, independentemente de a arbitragem em que aquela foi decretada ter lugar no estrangeiro, sem prejuízo do disposto no artigo $28^{\circ}$ ". Todavia, a sentença arbitral estrangeira depende de homologação pela justiça local, nos termos do art. 55 da Lei n. ${ }^{\circ}$ 63/11: "Do reconhecimento e execução de sentenças arbitrais estrangeiras. Artigo 55. ${ }^{\circ}$ Necessidade do reconhecimento. Sem prejuízo do que é imperativamente preceituado pela Convenção de Nova Iorque de 1958, sobre o reconhecimento e a execução de sentenças arbitrais estrangeiras, bem como por outros tratados ou convenções que vinculem o Estado português, as sentenças proferidas em arbitragens localizadas no estrangeiro só têm eficácia em Portugal, seja qual for a nacionalidade das partes, se forem reconhecidas pelo tribunal estadual português competente, nos termos do disposto no presente capítulo desta lei".

${ }^{594}$ Cf. D'AGOSTINO, Justin; FREEHILLS, Herbert Smith. New Hong Kong Arbitration Ordinance comes into effect. http://kluwerarbitrationblog.com/blog/2011/06/01/new-hong-kong-arbitration-ordinance-comesinto-effect/ Acessado em 01/12/2012.

595 "Section 61. Enforcement of orders and directions of arbitral tribunal (1) An order or direction made, whether in or outside Hong Kong, in relation to arbitral proceedings by an arbitral tribunal is enforceable in the same manner as an order or direction of the Court that has the same effect, but only with the leave of the Court. (2) Leave to enforce an order or direction made outside Hong Kong is not to be granted, unless the party seeking to enforce it can demonstrate that it belongs to a type or description of order or direction that may be made in Hong Kong in relation to arbitral proceedings by an arbitral tribunal. (3) If leave is granted under subsection (1), the Court may enter judgment in terms of the order or direction. (4) A decision of the Court to grant or refuse to grant leave under subsection (1) is not subject to appeal. (5) An order or direction referred to in this section includes an interim measure."(tradução livre: "Seção 61. Execução de ordens e direções do tribunal arbitral (1) Uma ordem ou direção proferida, tanto dentro ou fora de Hong Kong, em relação ao processo arbitral por um tribunal arbitral é executável da mesma maneira que uma ordem ou direção da Corte que tenha o mesmo efeito, mas apenas com a permissão da Corte. (2) Permissão para executar uma ordem ou direção proferida fora de Hong Kong não deverá ser deferida, a não ser que a parte que busca a sua execução possa demonstrar que a medida pertença a um tipo ou descrição de ordem ou direção que possa ser proferida em Hong Kong em um processo arbitral por um tribunal arbitral. (3) Se a autorização for deferida nos termos da subseção (1), a Corte pode proferir o julgamento nos termos da ordem ou da direção. (4) A decisão da Corte de deferir ou indeferir a permissão prevista da subseção (1) não é sujeita a recurso. (5) Uma ordem ou direção referida nesta seção inclui uma medida liminar.”).

${ }^{596}$ Cf. LEW, Julian M., MISTELIS, Loukas A., KRÖLL, Stefan M. Comparative International..., p. 611.
} 
Na Alemanha, o § 1061 do $\mathrm{CPC}$ alemão $(Z P O)$ regula a homologação de sentenças arbitrais estrangeiras ${ }^{597}$.

Já na Itália, o Código de Processo Civil italiano traz o "Capítulo VII - Dos laudos estrangeiros" (no Livro IV - Dos procedimentos especiais, Título VIII - Da arbitragem), composto pelos artigos 839 (Reconhecimento e execução dos laudos estrangeiros) e 840 (Oposição - que trata das formas de impugnação da decisão que homologa ou não a decisão arbitral estrangeira).

Na Inglaterra, por sua vez, a "Parte III" do Arbitration Act de 1996 regula o reconhecimento e a execução de sentenças arbitrais estrangeiras, estando subdivida na "execução das decisões com base na Convenção de Genebra" (artigo 99) e no "reconhecimento e execução de decisões com base na Convenção de Nova Iorque" (artigos 100 a 104).

Na França, também há a necessidade do reconhecimento da sentença arbitral e da obtenção do exequatur, nos termos dos artigos 1514 e 1516 do Código de Processo Civil francês ${ }^{598}$. Tais artigos estão inseridos no "Capítulo III - O reconhecimento e a execução de sentenças arbitrais estrangeiras ou em matéria de

\footnotetext{
${ }^{597}$ Sendo válida a citação do item (1): "Section 1061 - Foreign awards. (1) Recognition and enforcement of foreign arbitral awards shall be granted in accordance with the Convention on the Recognition and Enforcement of Foreign Arbitral Awards of 10 June 1958 (Bundesgesetzblatt [BGBl.] 1961 Part II p. 121). The provisions of other treaties on the recognition and enforcement of arbitral awards shall remain unaffected." (tradução livre: "Seção 1061 - Sentenças estrangeiras. A homologação e a execução de sentenças arbitrais estrangeiras devem ser concedidas de acordo com a Convenção para Homologação e Execução de Sentenças Arbitrais Estrangeiras de 10 de junho de 1958 (Bundesgesetzblatt [BGBl.] 1961 Part II p. 121). As regras de outros tratados para o reconhecimento e execução de sentenças arbitrais permanecem inalteradas."). 598 "Arte. 1514. Les sentences arbitrales sont reconnues ou exécutées en France si leur existence est établie par celui qui s'en prévaut et si cette reconnaissance ou cette exécution n'est pas manifestement contraire à l'ordre public international." (trad. livre: As sentenças arbitrais são reconhecíveis ou executadas na França se a sua existência é estabelecida por alguém de confiança e se esse reconhecimento ou essa execução não for manifestamente contrária à ordem pública internacional.") e "Arte. 1516. La sentence arbitrale n'est susceptible d'exécution forcée qu'en vertu d'une ordonnance d'exequatur émanant du tribunal de grande instance dans le ressort duquel elle été rendue ou du tribunal de Grande Instância de Paris lorsqu'elle um été à l'étranger rendue. La procédure relative à la demande d'exequatur n'est pas contradictoire. La requête est déposée par la partie la plus diligente au greffe de la juridiction accompagnée de l'original de la sentence et d'un exemplaire de la convention d'arbitrage ou de leurs copies réunissant les conditions requises pour leur authenticité." (trad. livre: "A sentença arbitral não é suscetível de execução forçada que não em virtude de uma ordem de execução (exequatur) emanada do tribunal de grande instância do local em que a decisão foi proferida ou do tribunal de Grande Instância de Paris, quando a decisão foi proferida no exterior. O procedimento relativo ao pedido de exequatur não é passível de contraditório. O requerimento é apresentado pela parte mais diligente ao registro da jurisdição, acompanhado do original da sentença e de um exemplar da convenção de arbitragem ou das cópias que reúnam as condições exigidas para a sua autenticidade.”).
} 
arbitragem internacional” (“Chapitre III - La reconnaissance et l'exécution des sentences arbitrales rendues à l'étranger ou en matière d'arbitrage international'), havendo previsão dos recursos cabíveis no "Capítulo IV - Meios de recursos”, "Seção 2 - Sentenças proferidas no exterior" ("Chapitre IV - Les voies de recours", "Section 2 - Sentences rendues à l'étranger").

Nesses ordenamentos em que não há previsão expressa sobre o procedimento para a execução da decisão arbitral de urgência estrangeira, ainda surgem questionamentos acerca da possibilidade de se reconhecer e de se executar tal decisão e em qual extensão ${ }^{599}$, notadamente em virtude da provisoriedade da decisão liminar.

A realidade é que a falta de regramento específico também atrapalha, e muito, a execução de tutelas de urgência proferidas em arbitragens estrangeiras, especialmente quando a execução se faz necessária em outro país que não o qual corre o processo arbitral. Se pouco já foi debatido e escrito com relação à efetivação de tutelas de urgência em arbitragens internas, menos ainda há a respeito da execução de medidas urgentes arbitrais estrangeiras ${ }^{600}$.

Não há dúvida, portanto, de que a execução de tutelas de urgência deferidas em arbitragens estrangeiras merece um estudo mais aprofundado, bem como necessita de regulamentação específica que vise à sua simplificação e o seu desenvolvimento, com ênfase na cooperação mútua entre árbitros e juízos estatais com relação ao cumprimento de medidas urgentes ${ }^{601}$.

\footnotetext{
${ }^{599}$ Cf. LEW, Julian M., MISTELIS, Loukas A., KRÖLL, Stefan M. Comparative International..., p. 611. Os autores ainda citam dois exemplos: o primeiro, em que a Suprema Corte de Queensland negou a execução de uma decisão arbitral de urgência estrangeira, por entender não ser possível a homologação de uma decisão liminar, ainda não definitiva (caso Resort Condominiums International, Inc v Ray Bolwell and others, XX YBCA 628 - 1995, 29/10/1993); e o segundo, em que uma Corte estadunidense reconheceu a possibilidade da homologação e da execução de uma decisão arbitral de urgência estrangeira, por entender que esta já é vinculante para as partes (caso Yasuda Fire \& Marine Insurance Co of Europe v Continental Casualty Co, 37 F3d 345 - 7th Cir, 1994) (Idem, pp. 612/613).

${ }^{600}$ Quanto ao assunto, JOSÉ MARIA ROSSANI GARCEZ alerta que "a falta de convenções internacionais prevendo a execução transnacional de medidas acautelatórias nas arbitragens não colabora para um sistema efetivo e cooperacional de justiça transnacional", salientando que "o tema não foi referido no Protocolo de Genebra de 1923, ou na Convenção de Genebra de 1927, ou, ainda, na Convenção de Nova Iorque de 1958 , e, ainda, não pode ser resolvido pela simples indicação feita nos arts. 9. ${ }^{\circ}$ e 17 da Lei-Modelo da UNCITRAL" (Medidas cautelares e de antecipação..., pp. 229/230).

${ }^{601}$ Nesse mesmo sentido, os comentários feitos por V. V. VEEDER e SERGEI N. LEBEDEV em Improving the Efficiency of Arbitration Agreement and Awards Application: 40 Years of The New York Convention. The Hague: Kluwer Law International, 1999, pp. 21/24. JULIAN M. LEW, LOUKAS A. Mistelis e STEFAN M.
} 
Nessa esteira, PIERo BERNARDINI sugere que os legisladores de cada país regulem, de forma mais efetiva, a questão do auxílio do Poder Judiciário na execução das decisões arbitrais de urgência, limitando esse controle do juízo estatal, na medida do possível, a questões formais de fato relevantes (e.g.: verificar apenas se as condições legais para a concessão da ordem foram satisfeitas etc. $)^{602}$.

\subsection{CONVENCÃo dE NOVA IORQUE}

A Convenção de Nova Iorque, de 10 de junho de 1958, que dispõe sobre o Reconhecimento e a Execução de Sentenças Arbitrais Estrangeiras, foi recepcionada no Brasil pelo Decreto Federal n. ${ }^{\circ}$ 4.311, de 23 de julho de 2002.

Nos termos do artigo III de referida Convenção, a obrigatoriedade da sentença arbitral estrangeira deve ser garantida pelos Estados-Partes ${ }^{603}$.

Assim, como o Brasil recepcionou e promulgou a Convenção de Nova Iorque, tornando-se um Estado-Parte, há o dever de se assegurar o cumprimento das sentenças arbitrais estrangeiras proferidas em um Estado-Parte em nosso país ${ }^{604}$.

KRÖLL também ressaltam que "o problema real é a falta de uma convenção internacional para regular a execução de medidas liminares ou conservativas ordenadas por um tribunal arbitral que está situado em outro país." (Comparative International..., p. 613, tradução livre).

${ }^{602}$ Cf. BERNARDINI, Piero. The Powers of the Arbitrator..., p. 29. Ainda quanto ao tema, JULIAN M. LEW, LOUKAS A. MiSTELIS e STEFAN MICHAEL KRÖLL anotam que "o assunto está na agenda do grupo de trabalho de arbitragem da UNCITRAL desde 1999" e que "duas minutas de artigos foram propostas; elas prevêem a execução das medidas liminares de forma similar à execução de sentenças, com matérias específicas para a impugnação, de acordo com as particulariedades da medida liminar." (Comparative International..., p. 586, tradução livre). Ressalte-se que, em 2010, as regras de arbitragem da UNCITRAL foram revisadas, tendo o artigo 26, que trata das tutelas de urgência ("interim measures") sido alterado, passando a ter nove incisos, ao invés dos únicos três incisos previstos nas regras de 1976. Contudo, nada foi previsto quanto à execução das medidas de urgência especificamente.

603 “Artigo III - Cada Estado signatário reconhecerá as sentenças como obrigatórias e as executará em conformidade com as regras de procedimento do território no qual a sentença é invocada, de acordo com as condições estabelecidas nos artigos que se seguem. Para fins de reconhecimento ou de execução das sentenças arbitrais às quais a presente Convenção se aplica, não serão impostas condições substancialmente mais onerosas ou taxas ou cobranças mais altas do que as impostas para o reconhecimento ou a execução de sentenças arbitrais domésticas".

${ }^{604}$ Nesse sentido: "Ação de cobrança e de indenização. Contrato de exportação de soja. Homologação de sentença arbitral estrangeira em que apreciada causa de pedir e pedido que abrangem o da presente ação de cobrança. Extinção do processo sem o julgamento do mérito. Necessidade. 1. Ação de cobrança cumulada com pedido de indenização ajuizada por sociedade brasileira exportadora em face de sociedade italiana em razão de problemas na execução de contrato de exportação de soja. 2. Homologação, pela Corte Especial do STJ, antes da prolação do acórdão recorrido, de sentença arbitral estrangeira relativa às mesmas partes com a mesma causa de pedir e o mesmo pedido, englobando a pretensão veiculada na presente ação de cobrança. 3. Não conhecimento de parte do recurso especial com base na Súmula 284 do STF. 4. Ausência de violação 
Outrossim, com a incorporação da Convenção de Nova Iorque pelo Brasil, os Estados-Partes que já haviam incorporado anteriormente referida convenção e haviam feito reserva de reciprocidade (e, por conta disso, até então não reconheciam nem executavam sentenças arbitrais brasileiras), passaram a ser obrigados a homologar e a executar sentenças arbitrais proferidas no Brasil envolvendo partes de outro Estado-Parte $^{605}$.

O problema, no que tange ao tema deste trabalho, é que a decisão arbitral liminar estrangeira não é uma sentença arbitral estrangeira (embora, as vezes, possa ser concedida na forma de sentença parcial). Aliás, a melhor interpretação da Convenção de Nova Iorque afasta a decisão arbitral liminar estrangeira da noção de sentença arbitral estrangeira ${ }^{606}$.

E mais: nos termos do artigo V, "1", "e", da mencionada convenção, o reconhecimento e a execução de uma sentença arbitral estrangeira poderão ser indeferidos se ela ainda não se tornou obrigatória ${ }^{607}$, o que poderia trazer a falsa impressão de que a decisão que defere uma tutela de urgência em uma arbitragem estrangeira não poderia ser homologada ou executada, por ainda não ser definitiva.

ao art. 535 do CPC. 5. Impossibilidade de apreciação, na presente demanda, de aspectos relativos à regularidade do procedimento arbitral, os quais deveriam ter sido suscitados no momento da homologação da sentença arbitral. 6. Inexistência de contrariedade ao art. 515 do CPC, porque, com a extinção, no acórdão recorrido, do processo sem o julgamento do mérito em razão da convenção de arbitragem, não mais pode subsistir, como decorrência lógica, qualquer capítulo da sentença, ainda que não impugnado. 7. Uma vez homologada, a sentença arbitral estrangeira adquire plena eficácia no território nacional. 8. A obrigatoriedade da sentença arbitral estrangeira homologada por esta Corte determina a impossibilidade de ser ela revista ou modificada pelo Poder Judiciário, aplicando-se o disposto no art. $3^{\circ}$ da Convenção de Nova York. 9. A continuidade de processo judicial, em que veiculados causa de pedir e pedido apreciados na sentença arbitral estrangeira homologada, colocaria em risco a obrigatoriedade desta. 10. Recurso especial conhecido em parte e, nesta, desprovido." (STJ, 3. ${ }^{a}$ Turma, REsp n. ${ }^{\circ}$ 1.203.430-PR, Rel. Min. Paulo de Tarso Sanseverino, j. 20/09/2012, DJe 01/10/2012, v.u., grifos nossos). E: “A transação havida entre as partes atribui à decisão do laudo arbitral não os efeitos da coisa julgada, mas sim os do ato jurídico perfeito, tornando estável o direito por ele declarado (direito adquirido). Verifica-se, sem dúvida, nítida influência da Convenção sobre o Reconhecimento e Execução das Sentenças Arbitrais Estrangeiras, Nova York, 1958, art. III, mas que há de se adaptar ao sistema constitucional pátrio, conforme acima interpretado (ver Convenção Interamericana sobre Arbitragem Comercial Internacional, art. $4^{\circ}$, aprovada pelo Decreto-Legislativo n 90, de 1995, que, ao empregar a expressão 'terão força de sentença judicial definitiva', permite a interpretação alcançada neste Acórdão)." (TJ/SP, 5. a Câm. Dir. Priv., A.I. n. ${ }^{\circ}$ 124.217-4/0, Rel. Des. Rodrigues de Carvalho, j. 16/09/1999). ${ }^{605}$ Cf. CARVAlHO, Ana Cristina Azevedo Pontes de. As inovações da Convenção de Nova Iorque..., p. 59. ${ }^{606}$ Cf. GARCEZ, José Maria Rossani. Medidas cautelares e de antecipação..., p. 230.

607 “Artigo V - 1. O reconhecimento e a execução de uma sentença poderão ser indeferidos, a pedido da parte contra a qual ela é invocada, unicamente se esta parte fornecer, à autoridade competente onde se tenciona o reconhecimento e a execução, prova de que: (...) e) a sentença ainda não se tornou obrigatória para as partes ou foi anulada ou suspensa por autoridade competente do país em que, ou conforme a lei do qual, a sentença tenha sido proferida". 
Essa confusão, no entanto, deve ser afastada, pois o fato de uma decisão arbitral de urgência estrangeira ser provisória, não torna o seu cumprimento facultativo. Não devem ser confundidos, portanto, os conceitos de provisoriedade e de obrigatoriedade. Ainda que provisória, a decisão arbitral liminar estrangeira já é exigível (obrigatória) de plano ${ }^{608}$.

E, conforme visto no "item 27" acima, como no Brasil a decisão interlocutória estrangeira foi equiparada à sentença estrangeira pelo Supremo Tribunal Federal (quando ainda detinha competência para homologar sentenças estrangeiras) $)^{609}$, as regras da Convenção de Nova Iorque devem ser aplicadas ao procedimento de homologação da decisão arbitral liminar estrangeira, especialmente enquanto esse tema não receber regulamentação própria.

Das regras previstas na Convenção de Nova Iorque, destacase que cabe à parte prejudicada comprovar eventual irregularidade na decisão arbitral estrangeira para que esta não seja homologada (artigo V, "1", letras “a" a "e").

Dessa feita, para que uma decisão arbitral de urgência estrangeira não seja homologada pelo STJ no Brasil, a parte prejudicada deverá comprovar uma das irregularidades previstas no dispositivo da Convenção de Nova Iorque supracitado ${ }^{610}$, prevalecendo o entendimento previsto nas principais convenções internacionais em matéria

\footnotetext{
${ }^{608}$ Lecionando sobre o assunto com relação às sentenças arbitrais, ANA CRISTINA AZEVEDO PONTES DE CARVALHO diz que "não se confunde obrigatoriedade com exeqüibilidade, e as sentenças arbitrais proferidas em países onde ainda se preveja alguma forma de homologação são obrigatórias a partir do momento em que forem intimadas as partes acerca de seu respectivo conteúdo. Obrigatório, portanto, tem o sentido de vinculante (...)" (As inovações da Convenção de Nova Iorque..., pp. 55/56).

${ }^{609}$ No julgamento do agravo regimental na carta rogatória CR 7613 AgR/Argentina.

${ }^{610}$ Nesse sentido: "Sentença arbitral estrangeira. Homologação. Regularidade do procedimento arbitral. Art. 38 da lei 9.307/96. Convenção de Nova Iorque, Art. V. Compromisso arbitral e constituição de advogado: observância das normas de procedimento aplicáveis à espécie. 1. A lei aplicável para disciplinar a representação das partes no procedimento arbitral, bem como a forma como podem manifestar seu ingresso no referido procedimento, é a lei a que as partes se submeteram ou, na falta dela, à do país onde a sentença arbitral foi proferida, cumprindo à parte demandada o ônus de demonstrar a violação a esses preceitos normativos. É o que dispõem a Lei 9.307/96 (art. 38, II) e a Convenção de Nova Iorque (art. V, 1, a). Não demonstrou a requerida, no caso, qualquer violação nesse sentido, não tendo havido, no momento oportuno previsto na lei de regência, qualquer alegação de irregularidade no procedimento arbitral, seja quanto à sua representação, seja quanto à forma de sua intervenção, seja quanto ao exercício do contraditório e da defesa. 2. Pedido de homologação deferido." (STJ, Corte Especial, SEC 3709/EX, Relator Ministro Teori Albino Zavascki, j. 14/06/2012, DJe 29/06/2012, v.u.).
} 
de reconhecimento e execução de decisões arbitrais no sentido de que há uma presunção de que a decisão arbitral seja válida e que, por conseguinte, deve ser reconhecida ${ }^{611}$.

Somente as irregularidades previstas no artigo V, "2", letras "a" e "b", da Convenção de Nova Iorque (quais sejam: o objeto da arbitragem não ser passível de ser solucionado por arbitragem, segundo a lei local; e ofensa à ordem pública) podem ser reconhecidas de ofício, sem provocação da outra parte, pelo STJ.

Por fim, diante da dificuldade na homologação e na execução de tutelas de urgência proferidas em arbitragens estrangeiras, cumpre-se destacar a sugestão feita por V. V. VEEDER e SERGEI N. LEBEDEV, no sentido de que a Convenção de Nova Iorque deva ser aditada para constar, de forma clara e expressa, que as medidas arbitrais de urgência estrangeiras também podem ser reconhecidas e passíveis de execução nos países signatários, com regramento específico para o assunto ${ }^{612}$.

Com isso, ou seja, com o esclarecimento e a ampliação do critério atualmente previsto no artigo V, "1", “e”, da Convenção de Nova Iorque, o reconhecimento e a execução de tutelas de urgência arbitrais se tornariam mais simples e efetivos nas arbitragens internacionais ${ }^{613}$.

${ }^{611}$ Cf. RIBEIRO, Rafael Pellegrini. O reconhecimento e a execução de sentenças..., p. 425.

${ }^{612}$ in Improving the Efficiency of Arbitration Agreement and Awards..., p. 26.

${ }^{613}$ Cf. GARCEZ, José Maria Rossani. Medidas cautelares e de antecipação..., p. 230. 


\section{CAPÍTULO XII}

\section{ACCÃO PARA SUSPENDER O PROCESSO ARBITRAL OU ESTATAL:}

\section{ANTI-SUIT INJUNCTION}

A anti-suit injunction, cuja tradução literal seria "liminar contra-processo" ${ }^{\circ 14}$, surgiu, em princípio, em apoio à arbitragem, visando a evitar o seu questionamento perante o Poder Judiciário local. Todavia, posteriormente, as anti-suit injunctions passaram a ser utilizadas para ameaçar a eficácia da arbitragem, buscando impedir a sua instituição ou, até mesmo, desconstituir os atos nela praticados.

\section{Como leciona SABRINA RIBAS BOLFER:}

"essas medidas podem ser utilizadas tanto a favor da arbitragem, quando um juiz estatal proíbe uma das partes na arbitragem de ingressar em uma jurisdição estatal, em violação da cláusula compromissória; quanto contra, quando o juiz proíbe um signatário de uma convenção de arbitragem de procurar o tribunal arbitral, sob o fundamento que a cláusula de arbitragem é nula, inexistente ou insuscetível de ser executada" ${ }^{\prime 15}$.

Dessa forma, uma anti-suit injunction pode ser conceituada como a ordem dada a uma das partes, pelo juízo estatal ou pelo juízo arbitral, proibindo o ajuizamento ou a continuação de uma ação específica perante o juiz togado, perante a jurisdição de outro Estado ou perante uma corte arbitral ${ }^{616}$.

\footnotetext{
${ }^{614}$ Nessa esteira, SABRINA RIBAS BolFER afirma que: "Anti-suit injunction é um termo em inglês que deriva das palavras anti (anti, contra), suit (processo) e injunction, que significa injunção, ordem, medida. Poder-seia traduzir, para o português como sendo uma ordem antiprocesso." (BOLFER, Sabrina Ribas. Anti-suit injuctions e Arbitragem Comercial Internacional. Dissertação de mestrado apresentada à Faculdade de Direito da Pontifícia Universidade Católica do Paraná em julho de 2005, p. 6).

${ }_{615}^{615}$ BOLFER, Sabrina Ribas. Anti-suit injuctions..., citação do resumo.

${ }^{616}$ EMMANUEL GAILLARD conceitua a anti-suit injunction da seguinte forma: "une anti-suit injunction est un ordre donné à un plaideur par les juridictions d'un Etat de ne pas saisir les juridictions d'un autre Etat ou un tribunal arbitral, ou, s'il l'a déjà fait, de se désister de l'action en cause." (trad. livre: "uma anti-suit injunction é uma ordem dada a uma parte pela jurisdição de um Estado de não ingressar na jurisdição de um outro Estado ou de um tribunal arbitral, ou, se já o fez, de desistir da ação em questão.”) (GAILLARD, Emmanuel. "Anti-Suit Injunctions et Reconnaissance des Sentences Annulées au Siège: Une Évolution Remarquable de la Jurisprudence Américaine" in Journal Du Droit International, n. ${ }^{\circ}$ 04. Paris: Jurisclasseur, oct-nov-dec., 2003, p. 1.106).
} 
As anti-suit injunctions são mais comuns no âmbito do Direito Internacional Privado, especialmente em arbitragens comerciais internacionais ${ }^{617}$, embora elas também possam, perfeitamente, ser ajuizadas no Brasil ${ }^{618}$.

Quando as anti-suit injunctions são utilizadas em favor da arbitragem, o árbitro de um processo arbitral regularmente instaurado ou o juiz togado pode proferir uma decisão determinando que a parte se abstenha de ajuizar ação judicial que atente contra a arbitragem ou determinando que a parte deixe de prosseguir com eventual demanda já em curso $^{619}$.

Frise-se que, mesmo sem possuir o poder de imperium, o árbitro poderá proferir tal decisão. E caso a parte contrária se recuse a cumpri-la, o árbitro poderá decretar a reparação do dano causado pela desobediência ou solicitar o auxílio do Poder Judiciário para o cumprimento forçado da decisão ${ }^{620}$.

$\mathrm{Na}$ hipótese em que a parte renitente está buscando judicialmente desconstituir uma convenção arbitral válida e livremente pactuada entre as partes, as anti-suit injunctions funcionam como importantes mecanismos em favor da arbitragem, tendo em vista que, como leciona THIAGO MARINHO NUNES, elas objetivam "impedir o desenrolar de um processo judicial de má-fé" ${ }^{621}$.

Por outro lado, quando utilizadas contra a arbitragem, as antisuit injunctions materializam-se por meio de ações judiciais distribuídas perante o Poder

\footnotetext{
${ }^{617}$ Cf. BOLFER, Sabrina Ribas. Anti-suit injuctions..., resumo.

${ }^{618}$ SABRINA RIBAS BOLFER cita alguns exemplos de anti-suit injunctions ajuizadas no Brasil objetivando evitar uma arbitragem, mencionando os seguintes casos: MBV Commercial and Export Management Establishment v. Resil Indústria e Comércio Ltda.; Celso Varga v. Câmara de Comércio Brasil-Canadá (TJ/SP, AC n. ${ }^{\circ}$ 296.036-4/4); CAOA v. Renault (TJ/SP, AI n. ${ }^{\circ}$ 124.217-4/0 e AI n. ${ }^{\circ}$ 285.411-4/0); e Energética Rio Pedrinho S.A. v. COPEL Distribuição S.A. (TJ/PR, AI n. ${ }^{\circ} 174.874-9 / 02$ e AI n. $\left.{ }^{\circ} 174.879-9\right)$ (Anti-suit injuctions..., pp. 91/96).

${ }^{619}$ Cf. BOLFER, Sabrina Ribas. Anti-suit injuctions..., p. 19.

${ }^{620}$ Em igual sentido: BOLFER, Sabrina Ribas. Anti-suit injuctions..., p. 128.

621 "Arbitragem Institucional, Anti-suit Injunctions e Princípio da Autonomia" in Revista Brasileira de Arbitragem, n. ${ }^{\circ}$ 16. São Paulo: IOB/CBAr, out/dez 2007, p. 136.
} 
Judiciário buscando a suspensão do andamento de um processo arbitral ou, até mesmo, a desconstituição de atos processuais efetivados pelo(s) árbitro(s) ${ }^{622}$.

Nesses casos, elas servem para evitar a instituição de uma arbitragem (com fulcro, quase sempre, em suposta irregularidade da convenção arbitral pactuada entre as partes) ou para paralisar o andamento do processo arbitral, impedindo a marcha de uma arbitragem já instaurada ${ }^{623}$.

Na Alemanha, nos termos do $§ 1032$, “1”, da ZPO, uma ação judicial deve ser extinta pela Corte caso as partes tenham pactuado uma convenção arbitral $^{624}$. No entanto, admite-se expressamente a ação judicial prévia a arbitragem para a verificação da admissibilidade ou não do processo arbitral (a anti-suit injunction), o que não impede, no entanto, o início da arbitragem, conforme o disposto no $§ 1032$, “2" e "3", do CPC alemão $(Z P O)^{625}$.

Em Portugal, o artigo 5. . "4", da Lei n. ${ }^{\circ}$ 63/2011 proibiu a utilização da anti-arbitration injunction, exatamente para evitar a interferência do Poder Judiciário nos processos arbitrais ${ }^{626}$.

${ }^{622}$ Cf. NUNES, Thiago Marinho. "A prática das Anti-Suit Injunctions no Procedimento Arbitral e seu Recente Desenvolvimento no Direito Brasileiro". Revista Brasileira de Arbitragem, n. ${ }^{\circ}$ 5. São Paulo: IOB/CBAr, jan/mar de 2005, pp. 15/51, esp. p. 16.

${ }^{623}$ Nesse mesmo sentido: BOLFER, Sabrina Ribas. Anti-suit injuctions..., p. 61.

624 "Section 1032 Arbitration agreement and substantive claim before court (1) A court before which an action is brought in a matter which is the subject of an arbitration agreement shall, if the respondent raises an objection prior to the beginning of the oral hearing on the substance of the dispute, reject the action as inadmissible unless the court finds that the arbitration agreement is null and void, inoperative or incapable of being performed." (trad. livre: "Seção 1032 Convenção arbitral e ação perante o juízo estatal (1) A Corte perante a qual uma ação é distribuída sobre assunto que é objeto de uma convenção arbitral deve, se o contestante levantar uma objeção antes do início da oitiva oral do objeto da disputa, rejeitar a ação como inadmissível, a não ser que a Corte considere a convenção arbitral nula e inválida, inoperante e incapaz de ser aperfeiçoada.").

625 "(2) Prior to the constitution of the arbitral tribunal, an application may be made to the court to determine whether or not arbitration is admissible. (3) Where an action or application referred to in subsection 1 or 2 has been brought, arbitral proceedings may nevertheless be commenced or continued, and an arbitral award may be made, while the issue is pending before the court." (trad. livre: "(2) Antes da constituição do tribunal arbitral, um pedido pode ser apresentado à Corte para determinar se a arbitragem é ou não admissível. (3) Quando uma ação ou pedido referidos nos itens ' 1 ' ou ' 2 ' for apresentado, o procedimento arbitral poderá, mesmo assim, ser iniciado ou prosseguir, e uma decisão arbitral poderá ser proferida, enquanto o assunto estiver pendente perante a Corte.").

${ }^{626}$ Conforme lição de JOSÉ MIGUEL JÚDICE: “b) Anti-arbitration injunctions proibidas (art. $5^{\circ}, \mathrm{n}^{\circ} 4$ ) - esta proibição surge como corolário da recepção do efeito negativo do princípio 'kompetenz-kompetenz' e visa reforçar os objetivos de separação deste meio alternativo em relação à justiça estatal, matéria muito sensível na União Européia, em especial depois do 'Relatório Heidelberg'." (in O Projecto de Nova Lei..., p. 242). Eis os termos do aludido dispositivo legal: "Artigo 5. ${ }^{\circ}$ Efeito negativo da convenção de arbitragem. 1 - O tribunal 
O principal problema das anti-suit injunctions está no abuso de sua utilização ${ }^{627}$, especialmente quando buscam impedir a instituição de uma arbitragem regular, o que pode acarretar problemas no desenvolvimento do processo arbitral e, também, uma indesejada judicialização da arbitragem.

A doutrina destaca que o abuso no uso da anti-suit injunction é o principal meio de se prejudicar e inviabilizar uma arbitragem ${ }^{628}$, ressaltando THIAGO MARINHO NUNES que as anti-suit injunctions abusivas "rasgam não só a Lei de Arbitragem como os princípios mais basilares nela instituídos"629.

PIERo Bernardini anota que, nos Estados Unidos, já há uma preocupação muito grande do Poder Judiciário com a excessiva procura da justiça comum por partes de uma arbitragem, o que pode, até mesmo, inviabilizar o processo arbitral ${ }^{630}$. O

estadual no qual seja proposta acção relativa a uma questão abrangida por uma convenção de arbitragem deve, a requerimento do réu deduzido até ao momento em que este apresentar o seu primeiro articulado sobre o fundo da causa, absolvê-lo da instância, a menos que verifique que, manifestamente, a convenção de arbitragem é nula, é ou se tornou ineficaz ou é inexequível. 2 - No caso previsto no número anterior, o processo arbitral pode ser iniciado ou prosseguir, e pode ser nele proferida uma sentença, enquanto a questão estiver pendente no tribunal estadual. 3 - O processo arbitral cessa e a sentença nele proferida deixa de produzir efeitos, logo que um tribunal estadual considere, mediante decisão transitada em julgado, que o tribunal arbitral é incompetente para julgar o litígio que lhe foi submetido, quer tal decisão seja proferida na acção referida no n. $^{\circ} 1$ do presente artigo, quer seja proferida ao abrigo do disposto no n. ${ }^{\circ} 9$ do artigo $18 .^{\circ}$, e nas subalíneas $i$ ) e iii) da alínea $a$ ) do n. ${ }^{\circ} 3$ do artigo $46 .^{\circ} .4$ - As questões da nulidade, ineficácia e inexequibilidade de uma convenção de arbitragem não podem ser discutidas autonomamente em acção de simples apreciação proposta em tribunal estadual nem em procedimento cautelar instaurado perante o mesmo tribunal, que tenha como finalidade impedir a constituição ou o funcionamento de um tribunal arbitral".

${ }^{627}$ Cf. BOLFER, Sabrina Ribas. Anti-suit injuctions..., resumo e pp. 62/63.

${ }^{628}$ Nesse sentido, EMMANUEL GAILLARD anota que "le anti-suit injunction est le moyen ideal de tenter de faire échec au bom déroulement de l'arbitrage." (tradução livre: "a anti-suit injunction é o meio ideal de tentar fazer falhar o bom desenrolar da arbitragem.”) (Anti-Suit Injunctions et Reconnaissance..., p. 1.107). Na mesma linha, SABRINA RIBAS BOLFER aduz que "esse abuso ocorre quando verificada a existência de uma cláusula compromissória válida, a parte reticente à arbitragem ingressa diante de suas jurisdições estatais, requerendo uma anti-suit injunction a fim de tornar a arbitragem inoperante." (Anti-suit injuctions..., p. 62). Por fim, NEIL ANDREWS aponta que "a party to an arbitration agreement can also slow down the process by bringing a pre-emptive case in the courts. In practice it takes a long time for the courts to renounce jurisdiction in favour of an arbitrator." (trad. livre: "uma parte de uma convenção arbitral também pode protelar o processo por meio de um caso preventivo nas cortes. Na prática, leva-se bastante tempo para as cortes renunciarem a jurisdição em favor do árbitro.”) (Arbitration and Mediation in England..., p 126).

${ }^{629}$ NUNES, Thiago Marinho. "Arbitragem Institucional, Anti-suit Injunctions e Princípio da Autonomia" in Revista Brasileira de Arbitragem, n. ${ }^{\circ}$ 16. São Paulo: IOB/CBAr, out/dez 2007, p. 137.

630 "Where the courts appear to have been concerned with the possibility that a party could frustrate the arbitral process by repeated resort to the courts." (tradução livre: "Onde os juízos estatais parecem estar preocupados com a possibilidade de a parte poder frustrar o processo arbitral mediante a procura repetida das cortes.") (The Powers of the Arbitrator..., p. 27). Até mesmo por conta disso, PIERO BERNARDINI afirma que, nos E.U.A., é controvertida a possibilidade de a parte pleitear uma tutela de urgência perante o Poder Judiciário quando há convenção de arbitragem firmada pelas partes (idem, ibidem). 
mesmo ocorre na Inglaterra, onde as anti-suit injunctions, na maioria das vezes, são utilizadas para impedir processos judiciais infundados contra a arbitragem ${ }^{631}$.

Exatamente por isso, nos E.U.A., a desobediência a uma ordem judicial de não ingressar em juízo, ou mesmo o abuso no uso da anti-suit injunction, pode caracterizar o contempt of court $^{632}$ e dar azo a pesadas multas ou, até mesmo, a pena de prisão ${ }^{633}$.

Portanto, sem sombra de dúvida, é a utilização excessiva e abusiva das anti-suit injunctions que deve ser coibida, para se evitar, como dito acima, a judicialização da arbitragem.

Nessa linha, até mesmo o apoio do Poder Judiciário ao processo arbitral deve ser buscado sempre com moderação ${ }^{634}$, sob pena, também, de se judicializar a arbitragem.

Por fim, ainda quanto ao tema, ARNOLDO WALD salienta que, no Brasil, uma das decisões mais importantes para a arbitragem quanto ao conflito de decisões arbitral e judicial é aguardada no julgamento do Conflito de Competência n. ${ }^{\circ}$ 111.230/DF, pela 2. ${ }^{a}$ Seção do Superior Tribunal de Justiça, o qual deverá decidir, pela primeira vez na seção, a competência do STJ para dirimir a divergência existente entre um tribunal arbitral e o Poder Judiciário ${ }^{635}$.

${ }^{631}$ Cf. ANDREWS, Neil. Arbitration and mediation in England..., pp. 108 e 126/128. Quanto ao assunto, NEIL ANDREWS menciona a sua preocupação com uma decisão proferida pela European Court of Justice (Corte Européia de Justiça) em 10/02/2009, no caso Allianz SpA etc v West Tankers, no qual referida corte estabeleceu que as cortes inglesas não mais poderiam proferir anti-suit injunctions para proibir uma parte de uma arbitragem de continuar com um processo judicial nas cortes dos Estados-Membros da zona jurisdicional da União Européia, o que configura um grande empecilho à eficiência do sistema inglês de arbitragem comercial (Idem, ibidem).

632 Tradução livre: desacato ou desobediência a um tribunal.

${ }^{633}$ Cf. GAILLARD, Emmanuel. Anti-Suit Injunctions et Reconnaissance..., p. 1.107. NEIL ANDREWS estatui que, na Inglaterra, o árbitro não possui poderes para punir uma parte por contempt of court (multas, ordem de prisão e penhora de bens), ressalvando, no entanto, que ele pode aplicar outras sanções internas à parte para fazer com que ela cumpra as decisões arbitrais (Arbitration and mediation in England..., p. 116).

${ }^{634}$ Cf. BOLFER, Sabrina Ribas. Anti-suit injuctions..., p. 3.

${ }^{635}$ WALD, Arnoldo. "Competência do STJ para dirimir conflito entre juiz e árbitro". Revista Consultor Jurídico de 31/08/12. http://www.conjur.com.br/2012-ago-31/arnoldo-wald-competencia-stj-dirimir-conflitoentre-juiz-arbitro. Acessado em 04/09/2012. 


\section{CAPÍTULO XIII - CONCLUSÕES}

A arbitragem pode ser conceituada como um meio alternativo de solução de litígios civis ou comerciais, atuais ou futuros, sobre direitos patrimoniais disponíveis, por meio de um árbitro ou de árbitros privados, escolhidos pelas partes, cujas decisões produzem os mesmos efeitos jurídicos produzidos pelas sentenças proferidas pelos órgãos do Poder Judiciário.

Somente as pessoas capazes de contratar podem se valer da arbitragem e apenas para solucionar conflitos relacionados a direitos patrimoniais disponíveis. Diante disso, conflitos envolvendo questões não patrimoniais, tais como questões de estado, de direito de família etc. não podem ser objeto de um processo arbitral.

Quando representa e defende direitos indisponíveis de toda a coletividade, atuando na sua condição de entidade pública, o Estado não pode participar de uma arbitragem. No entanto, as sociedades de economia mista, as empresas estatais, as autarquias e os demais entes da Administração Pública podem participar de arbitragens que versem sobre assuntos ligados à atividade econômica em sentido estrito ou a atos de natureza contratual ou privada, sendo possível, nesses casos, a concessão de tutelas de urgência mesmo em uma arbitragem envolvendo o Poder Público.

A origem da arbitragem, como meio de composição de litígios, é bem anterior à jurisdição pública.

No Brasil, a promulgação da Lei n. ${ }^{\circ}$ 9.307/96 possibilitou a efetiva utilização da arbitragem em maior escala e com mais segurança, especialmente porque ela eliminou dois dos grandes obstáculos até então existentes em nossa legislação, quais sejam: a ausência de regulamentação da cláusula compromissória e a necessidade de homologação da sentença arbitral.

A arbitragem encontra-se em pleno crescimento no Brasil, tendo em vista que: (i) superou a desconfiança inicial das partes e dos operadores do Direito; (ii) teve a sua constitucionalidade reconhecida pelo Supremo Tribunal Federal; e (iii) torna-se cada vez mais utilizada e abrangente, notadamente diante da morosidade e da falta de especificidade do Poder Judiciário. 
O Poder Judiciário brasileiro tem acompanhado a evolução da arbitragem no Brasil, proferindo um grande número de decisões que refletem bom conhecimento sobre a matéria e que privilegiam as decisões arbitrais.

Ao longo do tempo, quatro foram as teorias desenvolvidas e sistematizadas acerca da natureza jurídica da arbitragem: (i) a teoria publicista ou processualista; (ii) a teoria contratual ou privatista; (iii) a teoria mista (contratualpublicista); e (iv) a teoria autônoma (esta, nem sempre mencionada).

A teoria publicista ou processualista adota a tese da jurisdicionalidade da arbitragem, considerando que o árbitro recebe das partes o poder jurisdicional, o qual fica subtraído ao juízo estatal, o que possibilita ao árbitro a apreciação e a concessão de tutelas de urgência. A nosso ver, no Brasil, o legislador fez uma clara opção pela teoria publicista da arbitragem, nos termos, especialmente, dos artigos 18 e 31 da Lei n. ${ }^{\circ}$ 9.307/96, os quais equiparam o árbitro ao juiz e estabelecem que a decisão proferida pelo árbitro produz os mesmos efeitos, entre as partes e seus sucessores, de uma sentença proferida pelo Poder Judiciário.

A teoria contratual ou privatista considera a arbitragem como criação da autonomia da vontade, associando-a a idéia de negócio jurídico e, mais especificamente, a um contrato, sendo, portanto, de natureza privada. De acordo com os adeptos dessa teoria, não há exercício de poderes jurisdicionais pelo(s) árbitro(s), razão pela qual este(s) não poderia(m) apreciar e conceder tutelas de urgência, as quais deveriam ser sempre buscadas perante o Poder Judiciário.

A teoria mista adota parte dos fundamentos da teoria contratual e parte dos elementos da teoria publicista. De acordo com essa teoria, a arbitragem seria contratual na sua origem e jurisdicional no seu resultado. E, por possuir a arbitragem finalidade jurisdicional, os defensores dessa teoria também entendem que o árbitro possui poderes para apreciar e conceder tutelas de urgência no processo arbitral, notadamente se não houver qualquer vedação a respeito na convenção arbitral. 
A teoria autônoma considera que as arbitragens internacionais teriam fundamento e se desenvolveriam com base em regras próprias, adotadas pelas partes, sem vinculação com qualquer sistema jurídico, seja com os sistemas jurídicos dos países das partes envolvidas, seja com o sistema jurídico do país da sede do órgão arbitral julgador. Sob a ótica dessa teoria, a decisão arbitral internacional é um ato autônomo, não vinculado a qualquer jurisdição.

$\mathrm{O}$ enquadramento da arbitragem como atividade jurisdicional depende seja dado um novo enfoque ao conceito tradicional de jurisdição, adequando-se a técnica à realidade e buscando-se uma visão mais ampla e teleológica da jurisdição, que, ao final, é a resolução dos conflitos e a pacificação social. De todo o modo, flexibilizando-se o conceito tradicional de jurisdição, notadamente a parte que a tem como atividade exclusiva do Estado, conclui-se que o árbitro possui poder jurisdicional. Isso porque, considerando-se a sentença como o elemento fundamental da jurisdição, pois é o que põe fim à controvérsia, sendo este o objetivo final do Estado soberano, podemos verificar a presença de jurisdição na arbitragem, uma vez que a sentença nela proferida não fica sujeita a recurso ou a homologação e também coloca fim à lide trazida aos árbitros, pacificando de forma definitiva o conflito social. Além disso, os artigos 18, 26 e 31 da Lei de Arbitragem brasileira e o artigo 475-N, IV, do CPC equiparam a sentença arbitral à sentença judicial, uma vez que ambas constituem título executivo judicial, bem como possuem os mesmos requisitos e os mesmos efeitos, notadamente o de produzir coisa julgada. Por fim, a arbitragem se desenvolve com a garantia do devido processo legal, sendo inegável que o Estado cedeu ao árbitro parte de seu poder de decidir uma lide.

O árbitro não possui todos os poderes que compõem a jurisdição estatal, mas apenas alguns deles, havendo um "fracionamento" da jurisdição no que tange à arbitragem e aos poderes do árbitro.

Ao se analisar os poderes do árbitro e os elementos da jurisdição, depreende-se que o árbitro tem o poder de conhecimento (cognitio), o poder de documentação, o poder de julgamento (iudicium), mas possui o poder de coerção (coertio) de forma restrita e não possui o poder de execução forçada (executio), uma vez que ele não tem o poder de império para fazer valer coativamente as suas decisões, o qual é componente privativo do Estado. 
A falta de imperium não afeta o caráter jurisdicional da arbitragem, tendo em vista que o próprio Estado coloca à disposição do(s) árbitro(s) o poder de executio que detém para que a decisão arbitral seja respeitada e cumprida.

Como a própria legislação reservou privativamente ao Estado o poder de imperium, tal poder não pode ser concedido aos árbitros pelas partes na convenção de arbitragem, sob pena de ofensa à ordem pública. Exatamente por isso, seria ingênuo pensar que a arbitragem poderia sobreviver sem o auxílio e o suporte do Poder Judiciário nos termos da lei atual, pois o poder de imperium deve, obrigatoriamente, ser buscado perante o juiz estatal.

A relação entre o juízo arbitral e o estatal é de cooperação, e não de subordinação. O Poder Judiciário é órgão de cooperação, de suporte e de assistência às atividades do juízo arbitral, não sendo aquele órgão de interferência ou de fiscalização da justiça privada, não possuindo o juiz togado poderes para revisar ou para se imiscuir no processo conduzido pelos árbitros.

A arbitragem e o Poder Judiciário devem ser vistos como órgãos de realização da justiça com funções complementares, e não concorrentes.

É possível se estabelecer uma comparação entre as tutelas de urgência atuais e os interditos do processo romano. Isso porque, já nos interditos do direito romano, era possível a obtenção de ordem liminar, até mesmo sem a presença da parte contrária e mediante cognição sumária das alegações do autor. No direito romano antigo, portanto, já eram conhecidas a cognição sumária e as tutelas de urgência.

No direito pátrio, quanto às tutelas de urgência atuais, tanto na prática forense, como na Academia, distingue-se a medida cautelar da tutela antecipada, pontificando-se, em linhas gerais, que os provimentos cautelares são medidas instrumentais ao processo, que visam a assegurar a utilidade de seu provimento final, enquanto a antecipação da tutela, por sua vez, tem como escopo antecipar a entrega do próprio bem da vida pretendido, oferecendo ao demandante, desde logo, no todo ou em parte, aquilo que pretende obter como resultado final do processo. 
Não obstante as diferenças conceituais, os provimentos cautelares e as antecipações de tutela fundadas no inciso I do artigo 273 do Código de Processo Civil têm evidentes elementos comuns, capaz de integrá-las em um único gênero: o gênero das "tutelas de urgência", do qual elas seriam espécies. Isso porque os dois institutos (a medida cautelar e a tutela antecipada) têm como objetivo comum neutralizar ou, ao menos, minorar os efeitos prejudiciais do decurso do tempo sobre os direitos. Além disso, essas duas tutelas de urgência também têm em comum a sumariedade na cognição e a provisoriedade da decisão que a defere. E ambas são fungíveis (art. 273, § 7. o, do CPC).

O Projeto de Lei do Senado n. ${ }^{\circ}$ 166, de 2010 (agora Projeto de Lei n. ${ }^{\circ}$ 8.046/2010, em trâmite na Câmara dos Deputados), que institui um novo Código de Processo Civil, prevê a extinção do livro das ações cautelares, regulando as tutelas de urgência em um só título, juntamente com as tutelas da evidência, o que também demonstra o viés sistemático para a criação de um único gênero de tutelas de urgência (ao invés da dicotomia existente atualmente entre tutela antecipada e medida cautelar).

Se mesmo no processo civil (o qual é sujeito a muito mais formalismos e ao princípio da adequação mais rigoroso) as medidas cautelares e as tutelas antecipadas são fungíveis, sendo irrelevantes para o deslinde do caso concreto as diferenças ontológicas existentes entre elas, com muito mais razão essa mesma diretriz deve ser adotada na arbitragem. Especialmente porque, na arbitragem, as partes são livres para adotar as regras que entenderem convenientes para o deslinde da controvérsia, devendo zelar, tão somente, para que não sejam violados os princípios do contraditório, do devido processo legal, da igualdade das partes, da imparcialidade do árbitro e de seu livre convencimento, bem como para que não haja ofensa à ordem pública.

Não devem ser aplicadas de forma indiscriminada ao processo arbitral as regras do processo comum, sabidamente formalistas e morosas. Pelo contrário, as eventuais lacunas do procedimento adotado pelas partes ou previsto no regulamento da câmara arbitral não deverão, obrigatoriamente, ser preenchidas pelos dispositivos do Código de Processo Civil, podendo ser resolvidas pelo(s) próprio(s) árbitro(s), com base em princípios gerais do processo. 
As discussões acerca da concessão de uma tutela jurisdicional justa e tempestiva, bem como sobre a necessidade da aceleração do processo, têm sido destaque no Brasil e no restante do mundo, sendo antiga a preocupação com a razoável duração do processo.

O processo, como forma de solução de conflitos que se exterioriza por uma sequiência de atos processuais, é dinâmico e, por conseguinte, tem o fator tempo como um de seus elementos característicos naturais. Com efeito, não existe processo que não consuma ao menos algum tempo, razão pela qual se pode afirmar, sem qualquer dúvida, que o tempo é um dos componentes indissociáveis do processo. E, diante do fator tempo (que não é eliminável, pois é inerente a qualquer processo), surge o conflito entre celeridade-efetividade e segurança jurídica.

A excessiva duração do processo ofende a garantia do devido processo legal, sendo certo que o processo só cumpre a sua função quando permite a concessão, ao titular da pretensão, da tutela a que este faz jus, em tempo de efetivamente preservar o seu direito, tendo em vista a evidente e íntima relação entre a efetividade da tutela jurisdicional e a duração temporal do processo.

Da inevitável duração de um processo é que surge a necessidade das tutelas de urgência, que não podem aguardar, muitas vezes, sequer a citação da parte contrária (ou, no caso deste trabalho, sequer a instauração do juízo arbitral ou o término da arbitragem), sob pena de dano grave ou de difícil reparação à parte, ou, até mesmo, de perecimento do bem da vida em questão. Ou seja, as tutelas de urgência surgiram para contornar a dificuldade que era trazida pela ausência de efetividade das tutelas jurisdicionais deferidas de forma intempestiva, as quais poderiam sujeitar à parte a um processo e a uma sentença praticamente inúteis. Elas trazem um efeito relevante que é o de redistribuir os ônus do tempo da duração do processo entre as partes, colocando em situação mais favorável a parte que possui o melhor direito prima facie.

Em se tratando de um processo em trâmite perante o Poder Judiciário, a fim de se evitar um dano irreparável ou de difícil reparação, ou para garantir o resultado útil e prático do processo durante o inevitável tempo (ainda que mínimo) que ele 
deverá tramitar, o juiz tem à sua disposição as medidas cautelares (artigos 798 e seguintes do CPC) e a possibilidade de antecipação da tutela (artigo 273 do CPC). E assim como no processo judicial, não há dúvida de que, no processo arbitral, ainda que este seja notoriamente mais célere, também haverá situações em que será necessário tomar providências urgentes para garantir a eficácia do provimento arbitral ou, até mesmo, para preservar o bem da vida em discussão, diante dos prejuízos que o tempo de duração do processo poderá causar ao direito da parte.

O artigo 22, § 4. ${ }^{\circ}$, da Lei n. ${ }^{\circ}$ 9.307/96, que trata das tutelas de urgência no processo arbitral, não possui uma redação clara sobre o assunto, o que causou certa insegurança no início de sua vigência (notadamente porque a legislação pátria anterior, que regulava o instituto da arbitragem, vedava expressamente a concessão de medidas urgentes pelo árbitro, tendo a Lei n. ${ }^{\circ}$ 9.307/96 modificado essa posição). Contudo, passados mais de 16 (dezesseis) anos da promulgação de tal lei, já se pacificou na doutrina e na jurisprudência a possibilidade de o árbitro decretar medidas cautelares e de antecipar os efeitos da tutela na arbitragem.

Não há necessidade de a convenção de arbitragem prever, expressamente, poderes específicos para que os árbitros possam conceder tutelas de urgência, pois tais poderes decorrem da sistemática da Lei de Arbitragem brasileira e da própria investidura dos árbitros pelas partes para solucionarem o litígio.

A convenção de arbitragem não pode retirar dos árbitros o poder geral de cautela e o poder de antecipar tutela, uma vez que tais poderes são inerentes à própria jurisdição arbitral. Isto é, quando as partes concedem ao árbitro poderes para solucionar uma controvérsia, concedem também a ele o poder geral de cautela e o poder de antecipar os efeitos da tutela final indispensáveis, muitas vezes, ao pleno exercício da jurisdição arbitral. Ao árbitro é outorgada a jurisdição (ainda que privada), recebendo este todos os poderes necessários para apreciar e julgar o conflito existente entre as partes. Apenas o poder de imperium é reservado em caráter de exclusividade ao Estado.

O fato de a tutela de urgência ser provisória, podendo ser reformada ou modificada a qualquer tempo, também acarreta a impossibilidade de o poder 
cautelar ficar a cargo do Poder Judiciário, e não do árbitro, pois é este quem conduzirá o processo arbitral e a sua instrução.

A autonomia da vontade das partes não pode chegar ao ponto de dividir a jurisdição (quanto ao mérito, a jurisdição seria arbitral, e quanto às tutelas de urgência, que também envolvem a análise do mérito, ainda que de forma sumária, a jurisdição seria estatal), pois o poder do árbitro para apreciar e conceder tutelas de urgência decorre da própria Lei de Arbitragem, bem como do conceito constitucional de jurisdição, a qual é outorgada ao árbitro pelas partes quando optam pela arbitragem.

Nos ordenamentos jurídicos estrangeiros, há basicamente três posições distintas: (i) a primeira, dos países que reservam ao Estado o poder de apreciar e determinar tutelas de urgência, vedando a sua concessão em sede de arbitragem (como, por exemplo, a Argentina, a Itália e a Áustria); (ii) a segunda, dos países que conferem ao(s) árbitro(s) o poder de apreciar e conceder tutelas de urgência (e.g., a Alemanha, a Bélgica, a Suíça, a França e Portugal); e (iii) a terceira, dos países que autorizam as partes a conceder ao(s) árbitro(s), se assim o desejarem, poderes para apreciar e conceder tutelas de urgência (como, por exemplo, a Holanda e a Inglaterra).

Vários países incorporaram em sua legislação interna a Lei Modelo da UNCITRAL ("United Nations Commission on International Trade Law" Comissão das Nações Unidas para o Direito Comercial Internacional), na sua íntegra ou em grande parte, para regular as arbitragens internacionais, tais como: o Canadá, o Chipre, a Rússia, a Austrália, a Bulgária, o México, a Escócia, o Peru, a Nigéria, a Tunísia, a Ucrânia, o Egito, Hong-Kong, Cingapura e diversos estados dos Estados Unidos da América, sendo certo que o artigo 17, (1), da referida Lei Modelo autoriza a concessão de tutelas de urgência pelo(s) árbitro(s), a não ser que pactuado de outra forma pelas partes.

Os regulamentos das principais câmaras arbitrais internacionais prevêem a possibilidade de o árbitro apreciar e deferir tutelas de urgência, tal como o artigo 26 das Regras de Arbitragem da UNCITRAL e o artigo 28 do regulamento de arbitragem e de ADR da International Chamber of Commerce - ICC ("Câmara do Comércio Internacional - CCI"). 
Nas arbitragens internacionais, caberá ao árbitro analisar se as regras eleitas pelas partes contemplam o poder do árbitro para apreciar e deferir tutelas de urgência. Em sendo positiva a resposta, o árbitro deverá verificar, ainda, se referido poder não conflita com as regras de direito do país local onde eventual medida urgente deverá ser executada.

Embora a arbitragem seja um meio de resolução de conflitos que tem como uma de suas principais vantagens a celeridade (juntamente com o sigilo e a especificidade), certamente haverá casos em que as partes poderão necessitar de uma tutela de urgência antes mesmo de instituída a arbitragem, ou seja, durante o lapso de tempo entre a violação do direito e a aceitação do encargo pelo(s) árbitro(s). Quando isso ocorrer (e houver a necessidade de uma tutela de urgência para evitar dano irreparável ou de difícil reparação, ou, até mesmo, para antecipar a entrega do bem da vida em jogo), caberá ao Poder Judiciário apreciar a medida urgente que se fizer necessária.

Tendo em vista as peculiaridades envolvendo a instituição de uma arbitragem e, especialmente, em se tratando de uma medida indispensável para evitar o perecimento do direito da parte, deve-se abrir uma exceção e se aceitar que o pedido de antecipação de tutela pré-arbitral seja feito em procedimento autônomo, em outros autos, que não os da própria arbitragem (pois ainda não instituída), perante o juízo estatal.

Tendo em vista que o pedido de tutela de urgência préarbitral deverá ser deduzido por meio de uma ação perante o Poder Judiciário (ainda que preparatória à futura arbitragem), tal ação será disciplinada pelo Código de Processo Civil, aplicando-se as regras de fixação de competência, os requisitos da petição inicial, as regras sobre o valor da causa etc. e sendo perfeitamente possível, e até mesmo recomendável, a exigência da prestação de caução pela parte para que a tutela de urgência pré-arbitral seja deferida e efetivada pelo juízo estatal.

Caso a solução do litígio por meio da arbitragem esteja prevista em uma cláusula compromissória vazia e se faça necessário o ajuizamento da ação judicial regulada pelo artigo $7 .^{\circ}$ da Lei de Arbitragem brasileira, ante a recusa da parte contrária em firmar o compromisso arbitral, é possível a cumulação do pedido de tutela de 
urgência ao processo de instauração forçada da arbitragem, notadamente se o periculum in mora não permitir a análise final de referida demanda sem o prejuízo do direito a ser tutelado liminarmente.

Algumas câmaras arbitrais trazem em seus regulamentos previsão específica autorizando o acesso ao Poder Judiciário em determinadas circunstâncias, inclusive, para a obtenção de medidas cautelares ou antecipatórias, o que reforça o cabimento da tutela de urgência prévia à instituição da arbitragem perante o Judiciário.

O fato de uma parte se valer do Poder Judiciário para obter uma tutela de urgência, enquanto não instaurada a arbitragem, não significa, de forma alguma, renúncia à jurisdição arbitral. Nesse caso, a convenção de arbitragem (seja a cláusula compromissória, seja o compromisso arbitral) permanecerá válida.

Caso a arbitragem já esteja devidamente instaurada, a parte não poderá se valer do Poder Judiciário, devendo dirigir o pedido de tutela de urgência diretamente ao(s) árbitro(s), pois, nesse caso, toda e qualquer medida urgente incidental somente poderá ser apreciada pela jurisdição privada arbitral.

A única exceção a essa regra é a hipótese de uma tutela de urgência que não poderia aguardar sequer um dia e não se faz possível a reunião do(s) árbitro(s) em tempo hábil, por motivos pessoais ou profissionais. Nesse caso, diante da impossibilidade de o árbitro analisar a tutela de urgência, a parte está autorizada a se valer do Poder Judiciário para a sua apreciação, até mesmo para se evitar o perecimento do direito da parte e para que não sejam violados princípios constitucionais básicos de acesso à justiça e de apreciação de lesão ou ameaça a direito.

Com relação à indicação da lide e da ação principal (CPC, art. 801, inc. III), cumpre à parte autora informar ao juízo estatal que a ação cautelar ou o pedido de antecipação de tutela é preparatório de futura arbitragem a ser instaurada perante o juízo arbitral previsto na convenção de arbitragem. 
Tendo em vista a incidência das regras do Código de Processo Civil à ação cautelar prévia à instituição da arbitragem perante o Poder Judiciário e ao pedido de antecipação de tutela pré-arbitral, aplica-se ao caso o disposto no artigo 806 do Estatuto Processual, segundo o qual "cabe à parte propor a ação, no prazo de trinta dias, contados da data da efetivação da medida cautelar, quando esta for concedida em procedimento preparatório". Contudo, como a ação principal não será dirigida ao juízo estatal, mas, sim, ao juízo arbitral (será a própria arbitragem), o prazo de trinta dias deve ser interpretado de forma distinta da corriqueiramente havida na justiça estatal. Não se poderá exigir da parte a instituição da arbitragem no prazo legal de trinta dias, contados da efetivação da medida liminar, pois a instauração da arbitragem depende da aceitação do encargo pelo(s) árbitro(s) (nos termos do artigo 19 da Lei n. ${ }^{\circ}$ 9.307/96), ato que poderá levar muito mais do que trinta dias em virtude de motivos alheios à vontade da parte (e.g.: impugnação da nomeação do árbitro, recusa do árbitro etc.), não podendo a parte, por conseguinte, ser prejudicada por conta disso. Assim, caberá ao beneficiário da tutela de urgência pré-arbitral comprovar, dentro do prazo legal de trinta dias previsto no artigo 806 do CPC, que tomou as providências necessárias para dar início à arbitragem.

Para se evitar eventuais percalços na prática, a recomendação é a de que a parte tome todas as medidas possíveis para o início da arbitragem: seja apresentando o pedido expresso perante a câmara arbitral eleita, seja enviando notificação à(s) parte(s) contrária(s) acerca de sua intenção de dar início à arbitragem, seja tomando qualquer outra medida efetiva que transpareça a sua vontade clara de iniciar o processo arbitral dentro do prazo de trinta dias da efetivação da liminar.

Na hipótese de cláusula compromissória vazia, caso a parte contrária se recuse a assinar o compromisso arbitral após ter sido devidamente notificada para tanto, caberá à parte que se valeu da tutela de urgência pré-arbitral ajuizar a ação prevista no art. 7. $^{\circ}$ da Lei n. ${ }^{\circ}$ 9.307/96 dentro desse prazo de trinta dias, comprovando, assim, que tomou as medidas cabíveis para a instituição do processo arbitral dentro do prazo legal, sob pena de extinção da tutela de urgência pré-arbitral. 
A tutela de urgência pré-arbitral deferida pela justiça comum não perde o seu objeto ou a sua eficácia, tampouco deve ser automaticamente revogada pelo juízo togado, pela simples instauração da arbitragem.

Uma vez instituída a arbitragem, os autos da ação que discute a tutela de urgência pré-arbitral devem ser remetidos ao juízo arbitral, para que este possa reapreciar e analisar o pedido liminar da melhor forma possível.

Mesmo que a tutela de urgência prévia à instituição da arbitragem tenha caráter satisfativo e já tiver sido cumprida perante o juízo estatal, ainda assim os autos deverão ser remetidos ao juízo arbitral, após a sua instauração, para a ratificação ou não da liminar, sendo certo que, em caso de sua reforma ou revogação, a parte que se favoreceu da medida urgente deverá ressarcir a parte contrária dos prejuízos por ela sofridos.

Quanto ao recurso contra a decisão proferida na ação que discute uma tutela de urgência pré-arbitral que estiver pendente de julgamento perante um Tribunal, este deverá ser julgado prejudicado se a arbitragem for instituída antes de seu julgamento, com a remessa dos autos ao juízo arbitral. Isso porque, assim que instituída a arbitragem, cessa a jurisdição do juízo estatal com relação ao pedido de tutela de urgência pré-arbitral, mesmo que de um Tribunal, devendo este também remeter à questão (e os autos do processo) para a análise do(s) árbitro(s) assim que a arbitragem for instituída.

Uma possibilidade mencionada pela doutrina para solucionar o problema da apreciação de tutelas de urgência antes da instituição da arbitragem é o chamado "procedimento pré-arbitral". Por meio desse procedimento, as partes poderão, na própria convenção de arbitragem (seja na cláusula compromissória, seja no compromisso arbitral), excluir do Poder Judiciário inclusive a apreciação das tutelas de urgência, atribuindo tal encargo, antes da instituição da arbitragem, a um árbitro especial ou a um órgão arbitral específico, o qual terá competência para decidir, em caráter provisório, a tutela de urgência que a ele for submetida, cabendo ao juízo arbitral definitivo, após a sua devida instituição, confirmar ou revogar tal decisão. 
Algumas câmaras arbitrais adotam regulamentos próprios voltados às tutelas de urgência pré-arbitrais, nos quais há previsão da imediata nomeação de um terceiro, o qual terá poderes para analisar e conceder medidas urgentes antes da instauração da arbitragem definitiva. Exemplos delas são: (i) A American Arbitration Association - AAA; (ii) a WIPO - World Intellectual Property Organization (“OMPI Organização Mundial de Propriedade Intelectual"); (iii) a Corte Internacional de Arbitragem da CCI; e (iv) a Câmara de Arbitragem do Mercado - CAM.

A grande vantagem do procedimento pré-arbitral com relação à tutela de urgência prévia à instituição da arbitragem perante o Poder Judiciário é que a decisão que aprecia a medida urgente será proferida por um árbitro da própria câmara arbitral que será responsável pela condução da futura arbitragem, tratando-se de pessoa com expertise no assunto e habituado com o processo arbitral, o que faz com que referida decisão seja menos apta à posterior revisão pelos árbitros do que uma decisão proferida de forma urgente e precária pelo juízo comum (o qual, muitas vezes, sequer tem condições de apreciar todos os argumentos e os documentos trazidos pela parte, diante do volume de trabalho diário).

O procedimento pré-arbitral deve ter sido expressamente aceito e regulado pelas partes para ser utilizado, uma vez que, no silêncio, prevalece o direito de elas se socorrerem ao Poder Judiciário.

No Brasil, a convenção de arbitragem deve, obrigatoriamente, ser estipulada por escrito para que tenha validade. A exigência de a convenção de arbitragem ser escrita também existe na Alemanha, na Itália, em Portugal, na França, na Inglaterra, na Argentina, dentre outros países.

A cláusula compromissória guarda plena autonomia em relação ao contrato ou ao documento em que estiver inserida (artigo $8 .^{\circ}$, caput, da Lei de Arbitragem brasileira), permanecendo válida ainda que o contrato ou o documento seja considerado nulo. 
Cumpre ao(s) próprio(s) árbitro(s) decidir(em) acerca da validade da cláusula compromissória (artigo 8. ${ }^{\circ}, \S$ único, da Lei de Arbitragem - princípio da kompetenz-kompetenz).

Caberá ao árbitro emergencial, ao árbitro de apoio ou ao terceiro ordenador, responsável pela apreciação da tutela de urgência pré-arbitral, verificar a regularidade da convenção de arbitragem, analisando (i) se esta prevê o procedimento pré-arbitral, (ii) se tal procedimento foi devidamente aceito e regulado pelas partes, (iii) se as partes foram regularmente representadas ao pacturem a convenção de arbitragem etc.. Caso verifique a existência de alguma irregularidade na convenção de arbitragem, ele não poderá analisar e conduzir o procedimento pré-arbitral, por ausência de poderes jurisdicionais, evitando-se, assim, a futura anulação da decisão arbitral de urgência.

O árbitro pode (e mais: deve) revisar a decisão provisória e precária proferida pelo Poder Judiciário que apreciou o pedido de tutela de urgência préarbitral, assim que a arbitragem for regularmente instaurada, tendo o juízo arbitral poder para manter, alterar ou revogar a medida liminar deferida pelo juiz togado.

Até mesmo eventual sentença proferida em ação cautelar préarbitral pode ser revista e alterada pelos árbitros, ainda que tal sentença tenha restado irrecorrida no juízo estatal ou reconhecido alguma matéria de ordem pública (tal como, por exemplo, a prescrição, agora cognoscível de ofício pelo juiz), considerando que a controvérsia analisada é de competência (melhor: de jurisdição) dos árbitros.

É perfeitamente possível a instauração de uma arbitragem cautelar preparatória, tal como, por exemplo, para a exibição de documentos ou para a produção antecipada de prova, especialmente se houver consenso entre as partes e estas já tiverem optado, por meio de cláusula compromissória ou de compromisso arbitral, pela solução do litígio por meio de arbitragem. Nesse caso, duas serão as opções: ou se confirma, posteriormente, a instauração da arbitragem com os árbitros que participaram da arbitragem cautelar preparatória; ou, diversamente, não se confirma. 
As partes interessadas na produção antecipada de uma prova podem instaurar uma arbitragem cujo objeto seja única e exclusivamente a produção e a homologação de tal prova, comprometendo-se a resolver eventual litígio posterior, se necessário, também por meio de arbitragem. No entanto, havendo urgência na produção da prova e ainda não se encontrando instaurada a arbitragem, a parte poderá se valer do Poder Judiciário para produzi-la, ainda que exista cláusula compromissória arbitral no contrato a que diz respeito tal prova.

Nas arbitragens internacionais, as medidas para a preservação das provas ("measures for the preservation of evidence") também são admitidas.

Para o pedido de concessão de medida cautelar incidental em uma arbitragem, não há necessidade da instauração de um novo processo arbitral, bastando que a parte interessada na referida medida cautelar incidental faça o pedido por meio de petição endereçada ao(s) árbitro(s) da arbitragem já em curso. Isso porque a arbitragem prescinde de formalismos excessivos, sendo possível, portanto, a adoção de um procedimento mais informal, direto e célere para o pleito de medidas cautelares incidentais em um processo arbitral.

Se a tutela de urgência incidental for de extrema urgência, não podendo aguardar sequer a manifestação da parte contrária, ou na hipótese de haver fundado receio de que a parte contrária possa impedir a sua efetivação, caso tome conhecimento de seu conteúdo, o árbitro poderá apreciar o pedido inaudita altera parte, hipótese em que o contraditório será postergado, mas deverá ser garantido, com a oitiva da parte contrária a posteriori.

Uma vez apreciado o pedido de tutela de urgência pelo árbitro, deferido este ou não, a instrução do processo arbitral deverá ser feita de maneira conjunta, de forma a aproveitar tanto o pedido principal, como o pedido cautelar incidental. E assim se dá para se evitar a duplicação inútil de atividade, em atenção ao princípio da economia processual, e, especialmente, tendo em vista a corriqueira similitude fática da matéria tratada tanto no pedido principal como no pedido de tutela de urgência. 
Uma diferença significativa da tutela de urgência pleiteada perante o juízo arbitral com relação à medida requerida perante o juízo estatal é que a decisão do árbitro que a concede ou a indefere não fica sujeita a recurso, tendo em vista a ausência de previsão na Lei de Arbitragem brasileira. Tal diferença torna ainda mais relevante, na arbitragem, a provisoriedade das tutelas de urgência e a própria instrução do processo arbitral. Na arbitragem, caberá à parte trazer os elementos necessários, em sede de instrução do processo arbitral, para possibilitar eventual revisão da decisão pelo(s) árbitro(s), tendo em vista que a tutela de urgência é passível de revisão a qualquer tempo diante de novos fatos e de novas evidências.

Ante a ausência de recurso cabível, a decisão arbitral liminar deverá ser imediatamente cumprida pela parte, sob pena de ser executada perante a justiça estatal.

A sentença arbitral que apreciar os pedidos principais das partes também deverá confirmar, modificar ou revogar a decisão relativa à tutela de urgência, uma vez que estas têm como uma de suas principais características a provisoriedade, dependendo de decisão futura para a sua confirmação.

Se forem instauradas duas arbitragens para a apreciação do mesmo pedido de tutela de urgência perante câmaras arbitrais distintas, as partes terão de se valer do Poder Judiciário para verificar a correta interpretação da convenção arbitral, não cabendo conflito de competência ao Superior Tribunal de Justiça.

Levando-se em conta que o árbitro é o juiz de fato e de direito de um processo arbitral (artigo 18 da Lei de Arbitragem brasileira), consideramos ser perfeitamente possível e admissível a concessão de tutelas de urgência de ofício também por parte do árbitro, ressalvando-se, no entanto, a necessidade de se respeitar a excepcionalidade mencionada neste trabalho, sob pena de ofensa ao devido processo legal, à ordem pública e a própria imparcialidade do árbitro. 
Quanto às medidas coercitivas para a instrução do processo, assim como o juiz, o árbitro também poderá tomá-las de ofício, em virtude de seu poderdever de instrução do processo.

Tendo em vista que o árbitro não possui o poder de imperium para conduzir coercitivamente uma testemunha ou para buscar e apreender livros e documentos, na hipótese de renitência da parte ou da testemunha em cumprir tais determinações, o árbitro poderá, de ofício, requerer a execução de tais providências coercitivas junto ao Poder Judiciário.

No plano das arbitragens internacionais, a atuação de ofício do árbitro é ainda mais limitada e restrita, tendo em vista que os regulamentos das principais câmaras de arbitragem internacionais vinculam a concessão de eventual tutela de urgência ao pedido expresso da parte.

A decisão proferida pelo árbitro que aprecia uma tutela de urgência, concedendo-a ou a indeferindo, em regra, não pode ser impugnada por meio de recurso, tendo em vista a ausência de previsão na Lei de Arbitragem brasileira (embora as partes possam prever na convenção de arbitragem essa possibilidade - algo que é raro e vai contra o que se espera de uma arbitragem: celeridade e especialidade do julgador). Diante disso, a decisão arbitral de urgência somente poderá ser impugnada judicialmente: (i) por meio da ação prevista no artigo 33, caput, da Lei n. ${ }^{\circ}$ 9.307/96; ou (ii) por meio de impugnação ao cumprimento da decisão, caso esta não tenha sido espontaneamente cumprida e a parte beneficiada pela tutela de urgência tenha buscado a sua execução perante a justiça comum. Em qualquer das hipóteses, a decisão arbitral de urgência somente poderá ser contestada se estiver eivada de alguma das nulidades previstas no artigo 32 da mesma lei, não podendo a parte vencida, de forma alguma, desafiar o mérito da decisão.

Aplicam-se as normas do Código de Processo Civil tanto à ação prevista no artigo 33, caput, da Lei de Arbitragem, como à impugnação ao cumprimento da decisão, por se tratar de objeções que tramitarão perante o juízo comum. 
A regra é que a execução da decisão arbitral não se suspende, mesmo se contestada por impugnação ou por ação visando à decretação de nulidade (anulação) da decisão arbitral perante o Poder Judiciário. Embora seja possível, em caso de decisão arbitral teratológica ou, ainda, de dano grave e irreversível pelo cumprimento da decisão, a concessão de efeito suspensivo à impugnação ou o deferimento de tutela antecipada na ação de nulidade (anulação) para o fim de suspender os efeitos da decisão arbitral de urgência. No entanto, assim como ocorre hoje nos cumprimentos de decisões judiciais, a suspensão da execução deve ser sempre a exceção.

Assim como ocorre em um processo judicial, poderá o árbitro determinar que a parte beneficiária preste caução a fim de que uma tutela de urgência seja deferida em seu favor no processo arbitral.

Embora a caução não seja obrigatória para o deferimento de uma tutela de urgência, sendo uma faculdade do árbitro exigi-la ou não, nas situações em que a concessão da tutela de urgência envolva evidente risco patrimonial à parte contrária, ou mesmo risco de irreversibilidade da medida, é recomendável que o árbitro exija a prestação de caução pela parte beneficiada.

Na hipótese de o árbitro não ter fixado caução, entendemos que o juiz togado poderá fazê-lo quando do cumprimento judicial de mencionada decisão arbitral, para evitar que a parte contrária não seja devidamente ressarcida na hipótese de reforma da decisão liminar.

$\mathrm{O}(\mathrm{s})$ árbitro(s) também poderá(ão) substituir a tutela de urgência concedida a uma parte por caução ou outra garantia menos gravosa a ser prestada pela parte no processo arbitral, respeitando, assim, o critério do menor gravame.

A parte requerente deverá ser informada e ouvida acerca da substituição da medida, mesmo sendo sabido que a substituição poderá ser feita pelo julgador independentemente de provocação da parte requerente, uma vez que a execução da liminar corre por conta e risco desta. Com a oitiva da parte requerente sobre a troca da 
medida, restará afastada qualquer ilação sobre a sua eventual irresponsabilidade pela execução da liminar.

Caso não haja qualquer previsão distinta no regulamento escolhido pelas partes na arbitragem, por meio de uma interpretação sistemática das próprias tutelas de urgência e da potencialidade danosa que trazem consigo (uma vez que, na maioria das vezes, são deferidas inaudita altera parte e com base em cognição sumária), aplica-se a responsabilidade objetiva prevista em nosso ordenamento processual civil também aos processos arbitrais.

Embora a responsabilidade do beneficiário da tutela de urgência seja objetiva, caberá a outra parte comprovar a efetiva ocorrência de danos em virtude da efetivação da tutela de urgência, pois não há responsabilidade sem prejuízo.

Caso seja reformada a decisão que concedeu a tutela de urgência e ela tenha sido executada com a cobrança de multa diária (astreintes), o valor recebido pela parte favorecida a título de multa também deverá ser devolvido à parte contrária, por força da responsabilidade objetiva do demandante e para se evitar enriquecimento sem causa.

Mesmo na hipótese de concessão de tutela de urgência de ofício, a própria parte será responsável pelos prejuízos causados pela efetivação da medida. Os árbitros ou o tribunal arbitral também poderão ser responsabilizados, especialmente nos casos em que a parte que não pleiteou a tutela de urgência noticiar ao juízo arbitral que não tem interesse na medida, mas apenas na tutela jurisdicional de mérito, para ter certeza de que seu direito é válido.

Se a decisão que houver concedido a tutela de urgência for revogada ou reformada, as partes deverão ser restituídas ao status quo ante, sendo possível a liquidação dos prejuízos causados à parte contrária nos próprios autos da arbitragem.

Quanto à eventual responsabilidade do(s) árbitro(s), também se aplicam subsidiariamente as regras previstas em nosso ordenamento jurídico relativas à 
responsabilidade do juiz, especialmente porque, conforme o disposto no artigo 18 da Lei de Arbitragem brasileira, o árbitro é legalmente considerado "juiz de fato e de direito". Assim, o árbitro responderá pelos prejuízos causados à parte se agir com dolo ou má-fé na apreciação e na concessão de uma tutela de urgência, violando, por conseguinte, os deveres prescritos nos artigos $13, \S 6 .^{\circ}$, e 14, $\S 1 .^{\circ}$, da Lei de Arbitragem brasileira.

Se a arbitragem contar com mais de um árbitro, somente aquele(s) que comprovadamente agir(em) com dolo ou má-fé pode(m) ser responsabilizado(s), sendo certo que a responsabilidade poderá ser tanto cível como criminal.

$\mathrm{O}(\mathrm{s})$ árbitro(s) também pode(m) ser responsabilizado(s) pela revogação judicial da decisão arbitral que havia deferido eventual tutela de urgência, uma vez que é dever contratual do(s) árbitro(s) para com as partes de proferir uma decisão válida. Há duas situações distintas quanto à responsabilidade do(s) árbitro(s) em caso de anulação da decisão arbitral: (i) quando a decisão arbitral é anulada com base nos incisos I, II, VI, VII ou VIII do artigo 32 da Lei de Arbitragem brasileira, o árbitro ou o painel de árbitros é civilmente responsável pelos prejuízos advindos da tutela de urgência que havia deferido, incluindo-se também a obrigação de ressarcir às partes as custas, as despesas, os honorários do(s) árbitro(s) e do advogado, devidamente atualizados, em virtude do encerramento da jurisdição arbitral; (ii) quando a anulação da decisão arbitral se dá com fulcro nos incisos III, IV ou V do artigo 32 da Lei n. ${ }^{\circ}$ 9.307/96, a responsabilidade do árbitro ou do painel arbitral fica restrita à prolação de nova decisão arbitral, sanando os vícios indicados na decisão judicial (obrigação de fazer), sob pena de, não o fazendo, aí sim, se converter essa obrigação em perdas e danos, com a responsabilização do(s) árbitro(s) no pagamento de compensação pecuniária.

Não é possível compelir quem não tenha firmado a convenção de arbitragem a participar de uma arbitragem ou a se sujeitar aos seus efeitos, sendo vedado ao(s) árbitro(s) conceder tutelas de urgência que envolvam bens ou direitos de terceiros, que não participam da arbitragem. Contudo, o árbitro pode conceder tutelas de urgência que envolvam providências simples a serem tomadas por órgãos públicos ou privados (terceiros), tais como, por exemplo, uma anotação em registro imobiliário ou a retirada do nome da parte de um cadastro de inadimplentes. 
No Brasil, as teorias criadas nas arbitragens internacionais para envolver ou atingir terceiros ainda são vistas com desconfiança, exigindo-se, por cautela, o consenso inequívoco da parte para que esta figure em uma arbitragem e para que esteja sujeita aos efeitos da decisão arbitral.

Caso uma decisão arbitral de urgência venha a atingir, de alguma forma, bens ou direitos de terceiro, este terá de se valer do mesmo remédio previsto para a hipótese similar em processos judiciais, qual seja: dos embargos de terceiro, a serem opostos perante o juiz togado.

Nas hipóteses de cumprimento espontâneo da decisão arbitral de urgência pela parte ou de ausência da necessidade de execução da medida, o Poder Judiciário sequer intervirá na relação, pois não haverá a necessidade de utilização do poder de imperium para fazer valer a decisão.

Caso haja recusa da parte em cumprir por livre e espontânea vontade a tutela de urgência imposta pelos árbitros, a decisão deverá ser executada perante o juízo comum, devendo tal pedido, se oriundo da corte arbitral, ser feito mediante simples comunicação entre juízos, como no caso de uma carta precatória. Se o pedido for oriundo da própria parte interessada, deverá ser feito por meio de petição, a qual deverá ser instruída com as peças referidas no artigo 475-O, § 3., incisos I a V, do CPC, além da cópia da convenção de arbitragem e da comprovação de que o(s) árbitro(s) que proferiu(iram) a decisão aceitou(aram) o encargo, seguindo o procedimento de uma execução provisória. Tal petição deverá ser distribuída para uma das varas que seriam competentes para julgar a questão posta na arbitragem, determinando o juiz togado sorteado o cumprimento da decisão arbitral de urgência pela parte renitente.

O juízo estatal não poderá questionar o mérito da decisão que deferiu a tutela de urgência em arbitragem, devendo fazê-la cumprir, em atenção à indispensável boa relação entre juiz togado e árbitro. No entanto, o juiz togado poderá (e deverá) analisar os requisitos formais da arbitragem. 
O cumprimento da decisão arbitral de urgência pelo juiz estatal seguirá as mesmas regras de direito processual aplicáveis à execução de uma medida liminar deferida em um processo judicial (execução provisória).

Em se tratando de cumprimento de decisão arbitral que deferiu tutela antecipada em favor da parte, o juiz estatal, nos termos do artigo 273 , § 3 . $^{\circ}$, do CPC, deverá observar as normas previstas nos artigos 475-O, 461, §§ 4. ${ }^{\circ}$ e $5 .^{\circ}$, e $461-\mathrm{A}$ desse mesmo Codex, podendo: (i) fixar penalidades para a hipótese de inadimplemento (notadamente em se tratando de obrigação de fazer ou não fazer); (ii) arbitrar multa à parte renitente; (iii) majorar eventual multa anteriormente fixada pela decisão arbitral de urgência, em caso de recalcitrância da parte; e (iv) determinar outras medidas coercitivas cabíveis, sempre visando à efetividade.

Não cabe condenação em honorários advocatícios no procedimento iniciado pelo árbitro, por meio de ofício, para que o Poder Judiciário cumpra a tutela de urgência deferida em arbitragem. No entanto, caso a parte vencida permaneça recalcitrante e se faça necessária a participação da parte beneficiária da tutela de urgência para o cumprimento da decisão arbitral perante o juízo estatal, caberá a condenação da parte que continua se negando a cumprir a decisão arbitral de urgência nos ônus sucumbenciais, inclusive nos honorários advocatícios da parte contrária (a qual terá obrigatoriamente que ser representada por advogado no procedimento judicial para o cumprimento da decisão arbitral de urgência).

Caso o juiz togado encontre algum vício formal no ofício oriundo do processo arbitral, ele deverá devolver o ofício ao árbitro, informando-o acerca do motivo da recusa de cumprimento.

Na hipótese de o cumprimento da tutela de urgência arbitral ser feito por meio de ofício enviado pelo juízo arbitral ao juízo estatal, não caberá qualquer defesa por parte do executado, pois não se trata de uma ação, mas, sim, de mera solicitação de auxílio feita por parte do árbitro ao juiz togado, para que este, que é o detentor do monopólio do poder de imperium, execute a decisão já proferida pelo árbitro. O juízo estatal, portanto, proferirá simples ato de expediente, ou um mero "cumpra-se" no ofício 
recebido do juízo arbitral, insuscetível de defesa ou de recurso, especialmente porque a jurisdição está sendo exercida na arbitragem. O executado poderá, no máximo, suscitar eventual irregularidade formal no ofício enviado pelo juízo arbitral.

Caso a própria parte tome a iniciativa de efetivar a tutela de urgência arbitral, iniciando uma execução provisória da decisão liminar proferida pelo(s) árbitro(s), não há dúvida de que caberá a apresentação de impugnação ao cumprimento da decisão perante o juízo estatal, sendo certo que, da decisão proferida pelo juiz togado na eventual impugnação apresentada pela parte recalcitrante, caberá o recurso previsto na legislação processual civil.

Caso o juiz togado permaneça inerte ou se recuse a executar a tutela de urgência deferida em arbitragem sem a indispensável motivação, as partes da arbitragem deverão ser imediatamente comunicadas acerca do ocorrido, não devendo o árbitro insistir no cumprimento da solicitação, sob pena de violar o seu dever de imparcialidade previsto no artigo $13, \S 6^{\circ}$, da Lei n. ${ }^{\circ}$ 9.307/96. As partes, então, deverão buscar a modificação da decisão judicial por meio dos recursos cabíveis, perante o próprio Poder Judiciário.

A tutela de urgência deferida em arbitragem conduzida fora do território nacional deve, necessariamente, ser homologada pelo Superior Tribunal de Justiça para que possa ser executada no Brasil, tendo em vista que o Supremo Tribunal Federal (quando ainda detinha competência para homologar sentenças estrangeiras), no julgamento do agravo regimental na carta rogatória CR 7613 AgR/Argentina, equiparou a decisão interlocutória estrangeira que defere tutela de urgência à sentença estrangeira, aplicando-se, por conseguinte, o disposto no artigo 35 da Lei de Arbitragem brasileira, segundo o qual, "para ser reconhecida e executada no Brasil, a sentença arbitral estrangeira está sujeita, unicamente, à homologação do Supremo Tribunal Federal”.

Nos termos do art. 34, parágrafo único, da Lei de Arbitragem brasileira, o critério adotado para se verificar se a decisão é ou não estrangeira foi o do ius solis. Dessa maneira, pouco importa a nacionalidade dos árbitros ou das partes, bem como quais foram as regras aplicadas à arbitragem, se a decisão for proferida no exterior, ela será 
considerada uma decisão estrangeira. Da mesma forma, se a decisão for proferida no território brasileiro, a sentença arbitral será nacional, mesmo que proferida por árbitro ou tribunal estrangeiro, segundo regras processuais e materiais alienígenas.

O procedimento para a homologação de sentença estrangeira (e, por conseguinte, também da decisão arbitral de urgência estrangeira), nos termos do artigo 36 da Lei de Arbitragem brasileira, seguirá o disposto nos artigos 483 e 484 do CPC, na Resolução n. ${ }^{\circ}$ 9/05 do STJ e nas regras contidas na Convenção de Nova Iorque.

Em regra, as sentenças estrangeiras são homologadas por inteiro, mas a Resolução n. ${ }^{\circ}$ 9/05 do STJ admite a homologação parcial (artigo 4. ${ }^{\circ}, \S 2 .^{\circ}$ ), admitindo também, expressamente, a concessão de tutela de urgência nos procedimentos de homologação (artigo $4 .^{\circ}, \S 3 .^{\circ}$ ).

As tutelas de urgência deferidas em arbitragens estrangeiras em curso nos Estados-Partes do Mercosul, na Bolívia ou no Chile podem ser homologadas no Brasil mediante carta rogatória, nos termos do artigo 19 do Protocolo de Las Leñas, o que possibilita a concessão do exequatur independentemente da citação do requerido.

A homologação da decisão arbitral estrangeira que deferiu uma tutela de urgência somente poderá ser negada pelo Superior Tribunal de Justiça caso se verifique alguma das hipóteses previstas nos artigos 38 e 39 da Lei de Arbitragem, no artigo 6. ${ }^{\circ}$ da Resolução n. ${ }^{\circ}$ 9/05 do STJ ou no artigo V da Convenção de Nova Iorque. Ou seja, o juízo para o reconhecimento de decisões arbitrais estrangeiras é de delibação, uma vez que são analisados apenas os requisitos extrínsecos da decisão, e nunca o seu mérito. Não configurada quaisquer dessas hipóteses, o STJ deverá, obrigatoriamente, conceder o pedido de homologação.

Uma decisão arbitral de urgência estrangeira pode ter o seu reconhecimento e a sua homologação rejeitados ex officio nas hipóteses previstas no art. 39 da Lei de Arbitragem brasileira ou no art. V, “2”, da Convenção de Nova Iorque (ofensa à ordem pública ou se objeto do litígio não for passível de ser resolvido por arbitragem). 
Se o pedido for negado, somente o próprio Superior Tribunal de Justiça poderá reapreciá-lo, seja por meio de agravo regimental, seja por meio de novo pedido de homologação pela parte, corrigindo o equívoco formal apontado na decisão anterior, nos termos do artigo 40 da Lei de Arbitragem brasileira, salvo o cabimento de eventual recurso extraordinário para o Supremo Tribunal Federal.

$\mathrm{Na}$ hipótese de tutela de urgência que importe atos de disponibilidade de bens ou qualquer outro ato que possa gerar prejuízo às partes (atos coercitivos), a sua execução no Brasil, por uma parte estrangeira, além de depender da homologação pelo Superior Tribunal de Justiça, também ficará subordinada à prestação de caução pelo exequente. As partes oriundas dos países do Mercosul, da Bolívia ou do Chile não precisarão prestar caução para executar, no Brasil, tutela de urgência deferida em arbitragem em curso fora do território nacional, em virtude do disposto nos artigos $3 .^{\circ}$ e $4 .^{\circ}$ do Protocolo de Las Leñas, que, no que tange ao acesso à Justiça, equipara o membro de Estado-Parte do Mercosul, da Bolívia e do Chile ao cidadão brasileiro.

A Convenção de Nova Iorque, de 10 de junho de 1958, que dispõe sobre o Reconhecimento e a Execução de Sentenças Arbitrais Estrangeiras, foi recepcionada no Brasil pelo Decreto Federal n. ${ }^{\circ} 4.311$, de 23 de julho de 2002, estabelecendo em seu artigo III que a obrigatoriedade da sentença arbitral estrangeira deve ser garantida pelos Estados-Partes.

Uma anti-suit injunction pode ser conceituada como a ordem dada a uma das partes, pelo juízo estatal ou pelo juízo arbitral, proibindo o ajuizamento ou a continuação de uma ação específica perante o juiz togado, perante a jurisdição de outro Estado ou perante uma corte arbitral.

As anti-suit injunctions podem ser utilizadas em favor ou contra a arbitragem. Quando utilizadas em favor da arbitragem, o árbitro de um processo arbitral regularmente instaurado ou o juiz togado pode proferir uma decisão determinando que a parte se abstenha de ajuizar ação judicial que atente contra a arbitragem ou determinando que a parte deixe de prosseguir com eventual demanda já em curso. Quando utilizadas contra a arbitragem, as anti-suit injunctions materializam-se por meio de ações 
judiciais distribuídas perante o Poder Judiciário buscando a suspensão do andamento de um processo arbitral ou, até mesmo, a desconstituição de atos processuais efetivados pelo(s) árbitro(s).

O principal problema das anti-suit injunctions está no abuso de sua utilização, especialmente quando buscam impedir a instituição de uma arbitragem regular, o que pode acarretar problemas no desenvolvimento do processo arbitral e, também, uma indesejada judicialização da arbitragem. Mesmo o apoio à arbitragem deve ser buscado com moderação perante o Judiciário, sob pena, também, da judicialização do processo arbitral. 


\section{CAPÍTULOXIV}

\section{BIBLIOGRAFIA}

ALlORIO, Enrico. Problemas de Derecho Procesal, Tomo I. Tradução de Santiago Sentis Melendo. Buenos Aires: Ediciones Jurídicas Europa América S.A., 1963.

ALMEIDA, João Alberto de. Processo Arbitral. Belo Horizonte: Del Rey, 2002.

ALVES, Rafael Francisco. “O devido processo legal na arbitragem”. Arbitragem no Brasil - Aspectos jurídicos relevantes. JOBIM, Eduardo; MACHADO, Rafael Bicca (coord.). São Paulo: Quartier Latin, 2008, pp. 381/416.

AMARAL, Paulo Osternack. "A concessão de medidas urgentes em processo arbitral envolvendo o poder público". Revista de Processo - RePro, ano 33, n. ${ }^{\circ}$ 157. São Paulo: RT, março de 2008, pp. 18/50.

ANDREWS, Neil. "Arbitration and mediation in England". Revista de Processo - RePro,

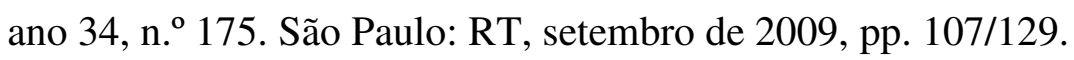

ARENHART, Sergio Cruz. "Breves observações sobre o procedimento arbitral" in: http://jus.com.br/revista/texto/7161/breves-observacoes-sobre-o-procedimento-arbitral. Acessado em 09/06/2012

MARINONI, Luiz Guilherme. Processo de conhecimento, vol. II,

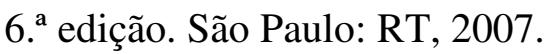

ARMELIN, Donaldo. "Tutela de urgência e arbitragem". Tutelas de Urgência e Cautelares - Estudos em Homenagem a Ovídio A. Baptista da Silva. São Paulo: Saraiva, 2010, pp. 360/378.

. "Arbitragem. Antecipação dos efeitos da tutela. Ação de instituição de arbitragem procedente. Eficácia imediata, embora pendente apelação sem efeito suspensivo. Competência do Tribunal Arbitral para a concessão de antecipação dos efeitos da tutela". Revista de Arbitragem e Mediação, vol. 6. WALD, Arnoldo (coord.). São Paulo: RT, jul/set de 2005, pp. 217/227. 
ARMELIN, Donaldo. "Notas sobre Sentença Parcial e Arbitragem". Revista de Arbitragem e Mediação, ano 5, vol. 18. WALD, Arnoldo (coord.). São Paulo: RT, jul/set de 2008, pp. 274/300.

"Arbitragem e o novo Código de Processo Civil". Revista de Arbitragem e Mediação, ano 8, vol. 28. WALD, Arnoldo (coord.). São Paulo: RT, jan/mar de 2011, pp. 131/137.

ASSIS, Araken de. Manual da Execução. São Paulo: RT, 2009.

ATHENIENSE, Aristóteles. "As medidas coercitivas no juízo arbitral”. Revista de Direito Bancário, do Mercado de Capitais e da Arbitragem, vol. 19. WALD. Arnoldo (coord.). São Paulo: RT, jan/mar de 2003, pp. 313/316.

AULETTA, Ferruccio. “Cognizione sommaria e giudizio arbitrale”. Diritto dell'arbitrato (a cura di Giovanni Verde). Torino: Giappichelli, pp. 493/508.

AYOUB, Luiz Roberto. Arbitragem: o acesso à justiça e a efetividade do processo, 1. a edição. Rio de Janeiro: Lumen Juris, 2005.

AZEVEDO, André Gomma de. “A arbitragem no Brasil após 5 anos da Lei n 9.307/96: novos desafios para a sua plena eficácia”. Estudos em arbitragem, mediação e negociação. AZEVEDO, André Gomma de (Org.). Brasília: Brasília Jurídica, 2002, pp. $183 / 216$.

BAPTISTA DA SILVA, Ovídio A. "A Antecipação de Tutela, na Recente Reforma Processual". A Reforma do Código de Processo Civil. TEIXEIRA, Sálvio de Figueiredo (coord.). São Paulo: Saraiva, 1996.

"Antecipação de Tutela e Responsabilidade Objetiva". Revista dos Tribunais, n. ${ }^{\circ}$ 748. São Paulo: RT, fevereiro de 1998, pp. 32/46. 
BARBOSA MOREIRA, José Carlos. "Tutela de Urgência e Efetividade do Direito". Temas de direito processual, 8. ${ }^{a}$ Série. São Paulo: Saraiva, 2004, pp. 89/105. . "La Nuova Legge Brasiliana Sull'Arbitrato". Temas Fundamentais de Direito Processual, 1. a edição, Sexta Série. São Paulo: Saraiva, 1997, pp. 273/290. "Estrutura da Sentença Arbitral". Revista Sintese de Direito Civil e Processual Civil, n. ${ }^{\circ}$ 16. São Paulo, março/abril de 2002, pp. 05/12. . "As reformas do Código de Processo Civil: condições de uma avaliação objetiva". Temas de direito processual, 6. a série. São Paulo: Saraiva, 1997.

BARBOSA, Rui. Oração aos Moços, 5. edição popular anotada por KURY, Adriano da Gama. Rio de Janeiro: Edições Casa de Rui Barbosa, 1999. www.casaruibarbosa.gov.br/ dados/DOC/artigos/rui_barbosa/FCRB_RuiBarbosa_Oracao_aos_mocos.pdf. Acessado em 09/07/2011.

BASILIO, Ana Tereza Palhares; FONTES, André R. C. "Notas introdutórias sobre a natureza jurídica da arbitragem". Revista de Arbitragem e Mediação, ano 4, vol. 14. WALD, Arnoldo (coord.). São Paulo: RT, jul/set de 2007, pp. 48/51.

BEDAQUE, José Roberto dos Santos. "Estabilização das tutelas de urgência". Estudos em homenagem a Ada Pellegrini Grinover. YARSHELL, Flávio Luiz; MORAES, Maurício Zanoide de (org.). São Paulo: DPJ, 2005, pp. 660/683.

Tutela Cautelar e Tutela Antecipada: Tutelas Sumárias e de Urgência (tentativa de sistematização), 5. a edição. São Paulo: Malheiros, 2009.

Código de Processo Civil Interpretado. MARCATO, Antônio Carlos (coord.). São Paulo: Atlas, 2004.

BENETI, Sidnei. “Arbitragem e tutelas de urgência”. Revista do Advogado - Arbitragem e Mediação, ano XXVI, n. ${ }^{\circ}$ 87. São Paulo: AASP, setembro de 2006, pp. 100/108. 
BERMUDES, Sérgio. “Medidas coercitivas e cautelares no processo arbitral”. Reflexões sobre Arbitragem: in memoriam do Desembargador Cláudio Vianna de Lima. MARTINS, Pedro A. Batista; GARCEZ, José Maria Rossani (Coord.). São Paulo: LTr, 2002, pp. $276 / 282$.

BERNARDINI, Piero. "The Powers of the Arbitrator". Conservatory and Provisional Measures in International Arbitration. Paris: International Chamber of Commerce - ICC The International Court of Arbitration, 1993, pp. 21/30.

BETTI, Emilio. Diritto processuale civile italiano. 11. a edição. Roma: Società Editrice de Foro Italiano, 1936.

BOISSESÓN, Matthieu de. Droit francais de l'arbitrage: interne et international. Paris: GLN Joly, 1990.

BOLFER, Sabrina Ribas. Anti-suit injuctions e Arbitragem Comercial Internacional. Dissertação de mestrado apresentada à Faculdade de Direito da Pontifícia Universidade Católica do Paraná em julho de 2005.

BRAGHETTA, Adriana. A Importância da Sede da Arbitragem. Visão a partir do Brasil. vol. I. Rio de Janeiro: Renovar, 2010.

CALAMENDREI, Piero. Introduzione allo studio sistemático dei provvedimenti cautelari. Opere Giuridiche, Morano, 1983.

CALMON DE PASSOS, José Joaquim. Comentários ao Código de Processo Civil, V. III, 8. a edição. Rio de Janeiro: Forense, 2001.

Comentários ao Código de Processo Civil, Tomo I, Vol. X. São Paulo: RT, 1984.

CÂMARA, Alexandre Freitas. Arbitragem - Lei $n .^{\circ}$ 9.307/96, 5. ${ }^{a}$ edição. Rio de Janeiro: Lumen Juris, 2009. 
CÂMARA, Jacintho Arruda; SUNDFELD, Carlos Ari. “O cabimento da arbitragem nos contratos administrativos". Revista de Direito Administrativo, n. ${ }^{\circ}$ 248. São Paulo: Atlas/FGV, mai/ago de 2008, pp. 117/126.

CAPRASSE, Olivier. "A arbitragem e os grupos de sociedades". Revista de Direito Bancário, do Mercado de Capitais e da Arbitragem, Ano 6, n. ${ }^{\circ} 21$. WALD, Arnoldo $^{2}$ (coord.). São Paulo: RT, jul/set de 2003, pp. 339/386.

CARMONA, Carlos Alberto. Arbitragem e Processo: Um Comentário à Lei n. ${ }^{\circ}$ 9.307/96, 3. ${ }^{\text {a }}$ edição. São Paulo: Atlas, 2009.

Arbitragem e processo, 1. a edição. São Paulo: Malheiros, 1998.

"O processo arbitral". Revista de Arbitragem e Mediação, vol. 1. WALD, Arnoldo (coord.). São Paulo: RT, jan/abr de 2004, pp. 21/31.

. A Arbitragem no processo civil brasileiro. São Paulo: Malheiros, 1993. . “Árbitros e Juízes: guerra ou paz?”. Aspectos Fundamentais da Lei de Arbitragem. MARTINS, Pedro A. Batista; LEMES, Selma M. Ferreira; CARMONA, Carlos Alberto (coord.). Rio de Janeiro: Forense, 1999, pp. 421/433.

- "Das boas relações entre os juízes e os árbitros". Revista do Advogado, n. ${ }^{\circ}$ 51. São Paulo: AASP, outubro de 1997, pp. 17/24. . “Ensaio sobre a Sentença Arbitral Parcial”. Revista Brasileira de Arbitragem, n. ${ }^{\circ}$ 18. São Paulo: IOB/CBAr, abr/jun de 2008, pp. 07/26.

. “Arbitragem e jurisdição". Revista de Processo - RePro, n. ${ }^{\circ}$ 58. São Paulo: RT, 1990, pp. 33/40.

- "Flexibilização do Procedimento Arbitral". Revista Brasileira de Arbitragem, n. ${ }^{\circ}$ 24. São Paulo: IOB/CBAr, out/nov/dez de 2009, pp. 07/21. 
CARNEIRO, Athos Gusmão. "Arbitragem. Cláusula Compromissória. Cognição e Imperium. Medidas Cautelares e Antecipatórias. Civil Law e Common Law". Revista Brasileira de Arbitragem, n. ${ }^{\circ}$ 3. São Paulo: IOB/CBAr, jul/set de 2004, pp. 42/59.

CARNEIRO, Paulo Cezar Pinheiro. "Aspectos processuais da nova Lei de Arbitragem". Arbitragem - lei brasileira e a praxe internacional, 2. a edição. CASELLA, Paulo Borba (coord.). São Paulo: LTr, 1999.

CARNELUTTI, Francesco. Diritto e Processo. Napoli: Morano Editore, 1958.

Instituzioni del processo civile italiano, 5. ${ }^{\text {a }}$ edição. Roma: Foro Italiano, 1956.

Sistema de direito processual civil, vol. I. Traduzido por Hiltomar Martins Oliveira. São Paulo: Classic Book, 2000.

. Derecho Procesal Civil y Penal. Buenos Aires: Ediciones Jurídicas, 1971.

CARREIRA ALVIM, José Eduardo. Tratado geral da arbitragem - Interno. Belo Horizonte: Mandamentos Editora, 2000.

. "Reconhecimento e execução de sentença arbitral estrangeira". Arbitragem doméstica e internacional: estudos em homenagem ao prof. Theóphilo de Azeredo Santos. FERRAZ, Rafaella (coord.). Rio de Janeiro: Forense, 2008, pp. 173/187.

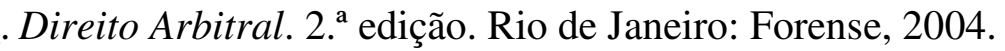

. Comentários à Lei de Arbitragem, 2. a edição. Rio de Janeiro: Lumen Juris, 2004. . Elementos de Teoria Geral do Processo, 7. a edição. Rio de Janeiro: Forense, 1997. 
CARVAlHO, Ana Cristina Azevedo Pontes de. "As inovações da Convenção de Nova Iorque de Arbitragem em face da Lei de Arbitragem brasileira". Arbitragem no Brasil aspectos jurídicos relevantes. JOBIM, Eduardo; MACHADO, Rafael Bicca (coord.). São Paulo: Quartier Latin, 2008, pp. 45/72.

CHIAVASSA, Tércio. Tutelas de Urgência Cassadas: a Recomposição do Dano. São Paulo: Quartier Latin, 2004.

CHIOVENDA, Giuseppe. Instituições de direito processual civil, vol. II. Tradução J. Guimarães Menegale. São Paulo: Saraiva, 1943.

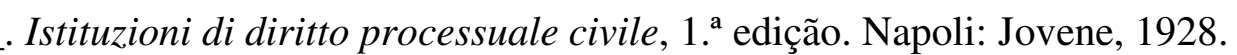

CLAY, Thomas. "As Medidas Cautelares Requeridas ao Árbitro”. Revista de Arbitragem e Mediação, ano 5, vol. 18. WALD, Arnoldo (coord.). São Paulo: RT, jul/set de 2008, pp. $311 / 332$.

COLOMBO, Manuela Correia Botelho. "Medidas de Urgência no Processo Arbitral Brasileiro". Revista de Processo - RePro, ano 35, n. ${ }^{\circ}$ 183. São Paulo: RT, maio de 2010, pp. $257 / 287$.

COMOGLIO, Luigi Paolo; FERRI, Corrado; TARUFFO, Michele. Lezioni sul processo civile. Bologna: Il Mulino, 1998.

CORREIA, André de Luizi. Acórdão comentado: "Contrato de suprimento de gás canalizado entre a Petrobras e a CEG. Recusa da Petrobras em manter o suprimento de volumes não previstos em contrato. Arbitragem instaurada pela concessionária e ação judicial movida pelo Estado do Rio de Janeiro, ambas visando à manutenção do suprimento. Pedido de suspensão da ação, até a solução da questão pelo Tribunal Arbitral. Acórdão do TJRJ que indeferiu o pedido, sem, no entanto, negar a arbitrabilidade dos conflitos oriundos dos contratos de suprimento de gás. Petróleo Brasileiro S.A. (Petrobras) x Estado do Rio de Janeiro - AgIn 2008.002.05857 - TJRJ rel. Des. Wagner Cinelli de Paula Freitas". Revista de Arbitragem e Mediação, ano 5, vol. 19. WALD, Arnoldo (coord.). São Paulo: RT, out/dez de 2008. 
COSTA, Almir Alegres. Competência dos Tribunais Arbitrais com relação a medidas coercitivas e cautelares. http://www.viajus.com.br/viajus.php?pagina=artigos\&id=1905. Acessado em 02/06/2011.

COSTA, Nilton César Antunes da. Poderes do Árbitro. São Paulo: RT, 2002.

COUTINHO, Cristiane Maria Henrichs de Souza. Arbitragem e a Lei n. 9 307/96. Rio de Janeiro: Forense, 1999.

COUTURE, Eduardo. Fundamentos del derecho procesal civil. Buenos Aires: Depalma editor, 1958.

CRETELLA NETO, José. Curso de Arbitragem. Rio de Janeiro: Forense, 2004.

CRUZ E TUCCI, José Rogério. Tempo e processo: uma análise empírica das repercussões do tempo na fenomenologia processual (civil e penal). São Paulo: RT, 1997.

CUESTA SAENZ, José Maria de la. "Introduccion al arbitraje de consumo". Revista de Derecho Privado, s/n. . . Madrid, Feb. 1997, pp. 121/129.

DAVID, René. L'arbitrage Dans Le Commerce International, 1. a’ edição. Paris: Económica, 1981.

DELGADO, José Augusto. "Arbitragem no Brasil - evolução histórica e conceitual". Arbitragem no Brasil - aspectos jurídicos relevantes. JOBIM, Eduardo; MACHADO, Rafael Bicca (coord.). São Paulo: Quartier Latin, 2008, pp. 221/247.

DIAS, André Petzhold. "Tutelas de urgência e sentença estrangeira". Direito Processual Civil, vol. 2. CARVALHO, Milton Paulo de; CASTRO, Daniel Penteado de (coord.). São Paulo: Quartier Latin, 2011, pp. 122/140.

DIDIER JR., Fredie. Curso de Direito Processual Civil, 7. edição. Salvador: Jus Podivum, 2007. 
DINAMARCO, Cândido Rangel. A instrumentalidade do processo. 12. ${ }^{a}$ edição. São Paulo: Malheiros, 2005.

. Instituições de direito processual civil. v. I. São Paulo: Malheiros, 2001.

Instituições de direito processual civil. v. III. São Paulo: Malheiros, 2001.

. "O Regime jurídico das medidas urgentes". A nova era do Processo

Civil. São Paulo: Malheiros, 2003.

A Reforma do Código de Processo Civil, 5. ${ }^{\text {a }}$ edição. São Paulo:

Malheiros, 2001.

A reforma da reforma. São Paulo: Malheiros, 2002.

DITTRICH, Lotario. "Il Provvedimento D'urgenza ex art. 700 C.P.C.". Il Processo Cautelare. Padova: Cedam, 2004.

DOLLINGER, Jacob; TIBURCIO, Carmen. Direito internacional privado - Arbitragem

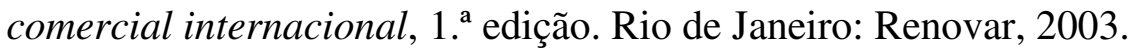

FAZZALARI, Elio. L'Arbitrato. Torino: UTET, 1997. . Istituzioni di Diritto Processuale, 7. a edição. Padova: Cedam, 1994.

FICHTNER, José Antonio; MONTEIRO, André Luís. "Medidas urgentes no processo arbitral brasileiro". Revista Trimestral de Direito Civil, vol. 35. Rio de Janeiro: Padma, julho/setembro de 2008, pp. 43/73.

; MANNHEIMER, Sergio Nelson; MONTEIRO, André Luís. “Cinco pontos sobre a arbitragem no Projeto do novo Código de Processo Civil". Revista de

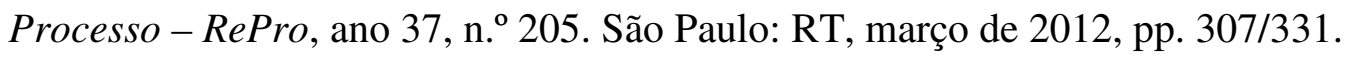


FIGUEIRA JÚNIOR, Joel Dias. Arbitragem, jurisdição e execução. 2. a edição. São Paulo: RT, 1999.

FONTES, André R. C.; BASILIO, Ana Tereza Palhares. "Notas introdutórias sobre a natureza jurídica da arbitragem". Revista de Arbitragem e Mediação, ano 4, vol. 14. WALD, Arnoldo (coord.). São Paulo: RT, jul/set de 2007, pp.48/51.

FRONTINI, Paulo Salvador. "Arbitragem e execução da sentença arbitral. Apontamentos sobre os reflexos da Lei $n^{o}$ 11.232/2005 no âmbito do cumprimento forçado da sentença arbitral". Revista do Advogado - Arbitragem e Mediação, ano XXVI, n. ${ }^{\circ}$ 87. São Paulo: AASP, setembro de 2006, pp. 76/86.

FURTADO, Paulo; BULOS, Uladi L. A Lei de Arbitragem Comentada. São Paulo: Saraiva, 1997.

GAILLARD, Emmanuel. “Anti-Suit Injunctions et Reconnaissance des Sentences Annulées au Siège: Une Évolution Remarquable de la Jurisprudence Américaine”. Journal Du Droit International, n. ${ }^{\circ}$ 04. Paris: Jurisclasseur, oct/nov/dec, 2003.

GAJARDONI, Fernando da Fonseca. "A arbitragem nos tribunais estatais - 10 anos de jurisprudência". Revista do Advogado - Arbitragem e Mediação, ano XXVI, n. ${ }^{\circ}$ 87. São Paulo: AASP, setembro de 2006, pp. 52/60.

"Aspectos fundamentais de processo arbitral e pontos de contato com a jurisdição estatal". Revista de Processo - RePro, ano 27, n. ${ }^{\circ}$ 106. São Paulo: RT, abril/junho de 2002, pp. 189/216.

GAMA E SOUZA JÚNIOR, Lauro da. "Comentário ao acórdão: Agravo de Instrumento 18187/2003 - 1. ${ }^{a}$ Câm. Cív. - Tribunal de Justiça do Rio de Janeiro - Relatora Desembargadora Valéria G. da Silva Maron”. Revista de Arbitragem e Mediação, vol. 4. WALD, Arnoldo (coord.). São Paulo: RT, jan/mar de 2005, pp. 262/266. 
GARCEZ, José Maria Rossani. Arbitragem nacional e internacional. Belo Horizonte: Del Rey, 2007.

"Medidas cautelares e de antecipação de tutela na arbitragem". Arbitragem doméstica e internacional: estudos em homenagem ao prof. Theóphilo de Azeredo Santos. FERRAZ, Rafaella e MUNIZ, Joaquim Paiva. (Coord.). Rio de Janeiro: Forense, 2008, pp. 213/230.

. "Escolha da Lei Substantiva da Arbitragem". Revista de Arbitragem e Mediação, vol. 4. WALD, Arnoldo (coord.). São Paulo: RT, jan/mar de 2005, pp. 49/61.

GIUSTI, Gilberto. "O árbitro e o juiz: da função jurisdicional do árbitro e do juiz". Revista Brasileira de Arbitragem, n. ${ }^{\circ}$ 5. São Paulo: IOB/CBAr, 2005, pp. 06/13.

GOMES, Luiz Felipe Azevedo. A intervenção do Estado na arbitragem, ano XXIV, s/nº. Porto Alegre: Ajuris, março de 1997.

GONÇALVES, Carlos Roberto. Responsabilidade civil, 6. ${ }^{a}$ edição. São Paulo: Saraiva, 1995.

GONNET, Gabriella Rampazzo. Commentario breve al Codice di Procedura Civile, 3. a edição. CARPI, Federico; e TARUFFO, Michele (coord.). Padova: Cedam, 1994.

GORON, Lívio Goellner. "Repensando as Tutelas de Urgência e as Fronteiras entre Medidas Cautelares e Antecipatórias". Revista Dialética de Direito Processual, n. 103. São Paulo: Dialética, 2011, pp. 67/87.

GRAU, Eros Roberto. “Arbitragem e contrato administrativo". Revista Trimestral de Direito Público, n. ${ }^{\circ}$ 32, abr/jun de 2000, pp. 14/20.

"Da arbitrabilidade de litígios envolvendo sociedades de economia mista e da interpretação de cláusula compromissória”. Revista de Direito Bancário, do Mercado de Capitais e da Arbitragem, vol. 18, ano 5. WALD, Arnoldo (coord.). São Paulo: RT, outubro/dezembro de 2002. 
GRINOVER, Ada Pellegrini. "Parecer - Arbitragem: ação anulatória e embargos do devedor". Revista Brasileira de Arbitragem, n. ${ }^{\circ}$ 18. São Paulo: IOB/CBAr, abril/junho de 2008, pp. 154/181.

. "Parecer - Arbitragem e Litisconsórcio Necessário". Revista Brasileira de Arbitragem, n. ${ }^{\circ}$ 10. São Paulo: IOB/CBAr, jul/set de 2006, pp. 07/38.

. Teoria Geral do Processo, 6. ${ }^{a}$ edição (Cooperação: CINTRA, Antonio Carlos de Araújo; e DINAMARCO, Cândido Rangel). São Paulo: Malheiros, 1987.

GUERRERO, Luis Fernando. "Arbitragem e jurisdição: premissa à homologação da sentença arbitral estrangeira". Revista de Processo - RePro, ano 33, n. ${ }^{\circ}$ 159. São Paulo: RT, maio de 2008, pp. 09/34.

. "Tutela de Urgência e Arbitragem". Revista Brasileira de Arbitragem,

n. ${ }^{\circ}$ 24. São Paulo: IOB/CBAr, out/nov/dez de 2009, pp. 22/44.

GUILHERME, Luiz Fernando do Vale de Almeida. "O uso da medida cautelar no procedimento arbitral". Arbitragem - Estudos em homenagem ao Prof. Guido Fernando Silva Soares, In Memorium. LEMES, Selma M. Ferreira; CARMONA, Carlos Alberto; MARTINS, Pedro Batista (coord.). São Paulo: Atlas, 2007, pp. 136/147.

HANOTIAU, Bernard. "A experiência da cautelar pré-arbitral na CCI'. Revista de Direito Bancário, do Mercado de Capitais, da Arbitragem, ano 5, n. ${ }^{\circ}$ 17. WALD, Arnoldo (coord.). São Paulo: RT, julho/setembro de 2002, pp. 325/328.

. Complex Arbitrations. The Hague: Kluwer Law, 2005.

HERNANDES NETO, Antonio Marcos. "Noções Gerais de Arbitragem Comercial Internacional e sua Aplicação para Solução de Conflitos em Investimentos Estrangeiros". Cadernos da Escola de Direito e Relações Internacionais - UniBrasil, n. ${ }^{\circ}$ 12, vol. 1, Curitiba, pp. 278/288. 
HOFFMAN, Paulo. “Arbitragem: algumas dúvidas processuais práticas quando o juízo estatal é chamado a intervir". Arbitragem no Brasil - Aspectos jurídicos relevantes. JOBIM, Eduardo; MACHADO, Rafael Bicca (Coord.). São Paulo: Quartier Latin, 2008, pp. $301 / 326$.

JÚDICE, José Miguel. "O Projecto de Nova Lei de Arbitragem Voluntária em Portugal". Revista Brasileira de Arbitragem, n. ${ }^{\circ}$ 23. São Paulo: IOB/CBAr, jul/set 2009, pp. 240/246.

KRÖLL, Stefan Michael; LEW, Julian M.; MISTELIS, Loukas A. Comparative International Commercial Arbitration. Haia, Londres, Nova Iorque: Kluwer Law International, 2003, pp. 585/625.

LACERDA, Belizário Antônio de. Comentários à lei de arbitragem. Belo Horizonte: Del Rey, 1998.

LACERDA, Galeno. "Tutela Antecipatória e Tutela Interdital". Estudos de Direito Processual e Homenagem a Luiz Machado Guimarães. BARBOSA MOREIRA, José Carlos (coord.), 1. a edição. Rio de Janeiro: Forense, 1977.

OLIVEIRA, Carlos Alberto Alvaro de. Comentários ao Código de Processo Civil. Volume VIII, Tomo II, 8. a edição. Rio de Janeiro: Forense, 2007.

LA CHINA, Sergio. Arbitrato: Il sistema e l'esperieza, Milano: Giuffrè, 1995.

LACROIX, Carlos A. Filartiga. El primer arbitraje. www.cacb.org.br/.../El\%20Primer\%20 Arbitraje.doc. Acessado em 08/06/2012.

LEMES, Selma Maria Ferreira. O Termo de Arbitragem e suas peculiaridades. Disponível na Internet: http://www.mundojuridico.adv.br. Acessado em 28/09/2010.

. "Os princípios jurídicos da Lei de Arbitragem". Aspectos fundamentais da Lei de Arbitragem. MARTINS, Pedro A. Batista; LEMES, Selma M. Ferreira; CARMONA, Carlos Alberto (coord.). Rio de Janeiro: Forense, 1999, pp. 73/111. 
LEMES, Selma Maria Ferreira. "A inteligência do art. 19 da Lei de Arbitragem (instituição da arbitragem) e as medidas cautelares preparatórias". Revista de Direito Bancário, do Mercado de Capitais e da Arbitragem, ano 6, n. ${ }^{\circ}$ 20. WALD, Arnoldo (coord.). São Paulo: RT, abril/junho de 2003, pp. 411/423.

"Medidas cautelares prévias à instituição da arbitragem - Logos Engenharia S/A x Construtora Gomes Lonrenço Ltda. AgIn 1.0024.08.074006-1/001(1), TJMG, rel. Des. Márcia de Paoli Balbino". Revista de Arbitragem e Mediação, ano 6, vol. 20. WALD, Arnoldo (coord.). São Paulo: RT, jan/mar de 2009, pp. 231/252.

- "A arbitragem e a jurisprudência paulista". Dez anos da lei de arbitragem - aspectos atuais e perspectivas para o instituto. Rio de Janeiro: Lumen Juris, 2007, pp. 171/182.

Arbitragem na Administração Pública - Fundamentos jurídicos e Eficiência econômica. São Paulo: Quartier Latin, 2007.

LEMOS, Eduardo. Arbitragem \& Conciliação. Brasília: Editora Consulex, 2001.

LEW, Julian M.; MISTELIS, Loukas A.; KRÖLL, Stefan Michael. Comparative International Commercial Arbitration. Haia, Londres, Nova Iorque: Kluwer Law International, 2003, pp. 585/625.

LIEBMAN, Enrico Tullio. "Unità del processo cautelare". Problemi del processo civile. Napoli: Morano, 1962.

Manual de Direito Processual Civil, 3. a edição, Vol. I. DINAMARCO, Cândido Rangel (trad. it.). São Paulo: Malheiros, 2005.

LIMA, Cláudio Vianna de. "Notícia da Arbitragem no Direito Positivo Brasileiro". Revista Forense, n. ${ }^{\circ} 334$, abr/jun de 1996, pp. 43/55. 
LIMA, Flávio Pereira; MIRANDA, Daniel Calhman. "A Extensão da Cláusula Compromissória a Partes Não Signatárias no Direito Brasileiro". Arbitragem no Brasil, volume I. São Paulo: Impressão Régia, 2010, pp. 13/26.

LIMA, Leandro Rigueira Rennó. “O Procedimento Cautelar Pré-Arbitral da CCI”. Revista Brasileira de Arbitragem, n. ${ }^{\circ}$ 18. São Paulo: IOB/CBAr, abr/mai/jun de 2008, pp. 60/79.

LOBO, Carlos Augusto da Silveira. "O procedimento cautelar pré-arbitral da CCI'. Arbitragem doméstica e internacional. FERRAZ, Rafaella; MUNIZ, Joaquim de Paiva (coord.). Rio de Janeiro: Forense, 2008, pp. 55/63.

LOPES, João Batista. Tutela Antecipada no Processo Civil Brasileiro, 4. ${ }^{a}$ edição. São Paulo: Saraiva, 2003.

“As 'antigas novidades' do processo civil brasileiro e a efetividade da

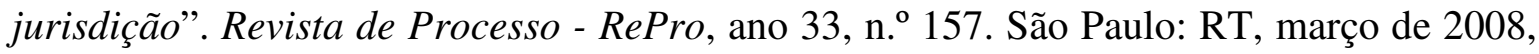
pp. 09/17.

LUCON, Paulo Henrique dos Santos. Eficácia das decisões e execução provisória. São Paulo: RT, 2000.

. Duração razoável e informatização do processo judicial. Vitória: Panóptica, ano 1, n. ${ }^{\circ}$, maio/junho de 2007, pp. 368/384. Disponível em: www.panoptica. org/maio_junto2007/N.8_016_Lucon.p.368-384.pdf. Acessado em 03/07/2011.

MAGALHÃES, José Carlos de. "A tutela antecipada no processo arbitral". Revista de Arbitragem e Mediação, vol. 4. WALD, Arnoldo (coord.). São Paulo: RT, jan/mar de 2005, pp. 11/20.

"Sentença arbitral estrangeira. Incompetência da justiça brasileira para anulação. Competência exclusiva do STF para apreciação da validade de homologação". Revista de Arbitragem e Mediação, vol. 1. WALD, Arnoldo (coord.). São Paulo: RT, jan/abr de 2004, pp. 135/148. 
MANNHEIMER, Sergio Nelson; FICHTNER, José Antonio; MONTEIRO, André Luís. "Cinco pontos sobre a arbitragem no Projeto do novo Código de Processo Civil". Revista de Processo - RePro, ano 37, n. . 205. São Paulo: RT, março de 2012, pp. 307/331.

MARCATO, Antônio Carlos. Código de Processo Civil Interpretado, 2. ${ }^{a}$ edição. São Paulo: Atlas, 2005.

MARINONI, Luiz Guilherme. A Antecipação da Tutela, 8. a edição. São Paulo: Malheiros, 2004.

Teoria Geral do Processo. São Paulo: RT, 2006.

Efetividade do processo e tutela de urgência. Porto Alegre: Fabris,

1994.

; ARENHART, Sérgio Cruz. Processo de conhecimento, vol. II,

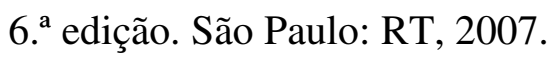

MARTINS, Pedro A. Batista. Apontamentos sobre a lei de arbitragem. Rio de Janeiro: Forense, 2008.

. "Panorâmica sobre as provas na arbitragem". Arbitragem no Brasil Aspectos jurídicos relevantes. JOBIM, Eduardo; MACHADO, Rafael Bicca (Coord.). São Paulo: Quartier Latin, 2008, pp. 328/357.

"Apontamentos sobre a arbitragem no Brasil". Revista do Advogado, n. ${ }^{\circ}$ 51. São Paulo: AASP, outubro de 1997, pp. 36/45.

. "A arbitragem e o mito da sentença parcial". Arbitragem - Estudos em Homenagem ao Prof. Guido Fernando Silva Soares, In Memoriam. LEMES, Selma M. Ferreira; CARMONA, Carlos Alberto; MARTINS, Pedro Batista (coord.). São Paulo: Atlas, 2007, pp. 267/284. 
MARTINS, Pedro A. Batista. "Da Ausência de Poderes Coercitivos e Cautelares do Árbitro". Aspectos fundamentais da Lei de Arbitragem. MARTINS, Pedro A. Batista; LEMES, Selma M. Ferreira; CARMONA, Carlos Alberto (coord.). Rio de Janeiro: Forense, 1999, pp. 357/382.

MENTHON, François de. Le rôle de l'arbitrage dans l'evolution judiciaire. Tese apresentada à Université de Paris - Faculté de Droit. Paris: Editions Spes, 1926.

MIRANDA, Daniel Calhman; LIMA, Flávio Pereira. “A Extensão da Cláusula Compromissória a Partes Não Signatárias no Direito Brasileiro". Arbitragem no Brasil, volume I. São Paulo: Impressão Régia, 2010, pp. 13/26.

MISTELIS, Loukas A.; KRÖLL, Stefan Michael; LEW, Julian M. Comparative International Commercial Arbitration. Haia, Londres, Nova Iorque: Kluwer Law International, 2003, pp. 585/625.

MONIZ DE ARAGÃO, Egas Dirceu. “Medidas Cautelares Inominadas". Revista Brasileira de Direito Processual, n. ${ }^{\circ}$ 57. Rio de Janeiro: Forense, janeiro/março de 1998, pp. 33/90.

"Alterações no Código de Processo Civil: tutela antecipada, perícia".

Reforma do Código de Processo Civil. TEIXEIRA, Sálvio de Figueiredo (coord.). São Paulo: Saraiva, 1996.

MONTEIRO, André Luís; MANNHEIMER, Sergio Nelson; FICHTNER, José Antonio. “Cinco pontos sobre a arbitragem no Projeto do novo Código de Processo Civil". Revista de Processo - RePro, ano 37, n. ${ }^{\circ}$ 205. São Paulo: RT, março de 2012, pp. 307/331.

; FICHTNER, José Antonio. “Medidas urgentes no processo arbitral brasileiro". Revista Trimestral de Direito Civil, vol. 35. Rio de Janeiro: Padma, julho/setembro de 2008, pp. 43/73. 
MONTORO, Marcos André Franco. Flexibilidade do procedimento arbitral. Tese de doutorado apresentada à Faculdade de Direito da Universidade de São Paulo em 2010.

MORAIS, Jose Luis Bolzan de. Mediação e Arbitragem: alternativas à jurisdição! Porto Alegre: Livraria do Advogado, 1999.

MORTARA, Ludovico. Commentario del Codice e della Legge di Procedura Civile, v. III, Milano: Casa Editrice Dottor Francesco Vallardi, 1923.

MOTULSKY, Henry. La nature juridique de l'arbitrage. In Ecrits, t. II, Dalloz, 1974.

MUNIZ, Petrônio R. G. "A tutela antecipada no procedimento pré-arbitral”. Arbitragem Estudos em Homenagem ao Prof. Guido Fernando Silva Soares, In Memorian. LEMES, Selma M. Ferreira; CARMONA, Carlos Alberto; MARTINS, Pedro Batista (coord.). São Paulo: Atlas, 2007, pp. 285/302. . "A arbitragem e a história naval brasileira". Prática Jurídica, n. 26. Brasília: Editora Consulex, maio de 2004.

MURIEL, Marcelo. “A Arbitragem frente ao Judiciário Brasileiro”. Revista Brasileira de Arbitragem, v. 1. São Paulo: IOB/CBAr, jan/mar de 2004, pp. 27/39.

NALINI, José Renato. Ética Geral e Profissional. São Paulo: RT, 1997.

NEGRÃO, Theotonio; GOUVÊA, José Roberto F. e BONDIOLI, Luis Guilherme A. Código de Processo Civil e legislação processual em vigor, 42. a edição. São Paulo: Saraiva, 2010.

NERY JR., Nelson. Princípios do processo civil na Constituição Federal, 8. ${ }^{a}$ edição. São Paulo: RT, 2004.

; NERY, Rosa Maria de Andrade. Código de processo civil comentado e legislação extravagante. São Paulo: RT, 2007. 
NEVES, Celso. Estrutura fundamental do processo civil. Rio de Janeiro: Forense, 1995.

NORMAND, Jacques. "Les mesures provisoires et l'arbitrage". Les mesures provisoires en droit belge, français et italien. VAN COMPERNOLLE, Jacques; TARZIA, Giuseppe (org.). Bruxelas: Bruylant, 1998, pp. 461/471.

NUNES, Thiago Marinho. “A prática das Anti-Suit Injunctions no Procedimento Arbitral e seu Recente Desenvolvimento no Direito Brasileiro". Revista Brasileira de Arbitragem, n. ${ }^{\circ}$ 5. São Paulo: IOB/CBAr, jan/mar de 2005, pp. 15/51.

. "Arbitragem Institucional, Anti-suit Injunctions e Princípio da Autonomia". Revista Brasileira de Arbitragem, n. ${ }^{\circ}$ 16. São Paulo:IOB/CBAr, out/dez 2007.

OLIVEIRA, Carlos Alberto Alvaro de; LACERDA, Galeno. Comentários ao Código de Processo Civil. Volume VIII, Tomo II, 8. a edição. Rio de Janeiro: Forense, 2007.

OLIVEIRA JÚNIOR, Waldemar Mariz de. Participação e processo. GRINOVER, Ada Pellegrini; DINAMARCO, Cândido Rangel; WATANABE, Kazuo (Coord). São Paulo: RT, 1988.

OPORTO, Silvia Fazzinga. VASCONCELLOS, Fernando. Arbitragem Comercial Internacional. http://sisnet.aduaneiras.com.br/lex/doutrinas/arquivos/080306t.pdf. Acesso em 02/06/2012.

OPPETIT, Bruno. Etudes offertes à Pierre Bellet. Paris: Litec, 1991, pp. 415/425, tradução de VALENÇA FILHO, Clávio de Melo; e LEMOS, Bruno. “Justiça Estatal e Justiça Arbitral'. Revista Brasileira de Arbitragem, n. ${ }^{\circ}$ 25. São Paulo: IOB/CBAr, jan/mar de 2010, pp. 184/195.

PALACIO, Lino Enrique. Manual de Derecho Procesal Civil, v. II. Abeledo-Perrot, 1990.

PARIZATTO, João Roberto. Arbitragem: Comentários à Lei 9.307, de 23-9-96. São Paulo: Editora de Direito, 1997. 
PAULA, Paulo Afonso Garrido de. Código de Processo Civil Interpretado. MARCATO, Antônio Carlos (coord.). São Paulo: Atlas, 2004.

PINTO, José Emilio Nunes. "Anotações Práticas sobre a Produção de Prova na Arbitragem". Revista Brasileira de Arbitragem, n. ${ }^{\circ}$ 25. São Paulo: IOB/CBAr, jan/mar de 2010, pp. 07/28.

"A arbitrabilidade de controvérsias nos contratos com o estado e empresas estatais". Revista Brasileira de Arbitragem. n. ${ }^{\circ}$ 01. São Paulo: IOB/CBAr jan/mar de 2004, pp. 09/26.

PITOMBO, Eleonora Coelho. "Arbitragem e o Poder Judiciário: Aspectos Relevantes". Aspectos práticos da arbitragem. GUILHERME, Luiz Fernando do Vale de Almeida (Coord.). São Paulo: Quartier Latin, 2006, pp. 105/124.

PIZZOL, Patrícia Miranda. Código de Processo Civil Interpretado. MARCATO, Antônio Carlos (coord.). São Paulo: Atlas, 2004.

PONTES DE MIRANDA, Francisco Cavalcanti. Comentários ao Código de Processo Civil, Tomo XV, 2. ${ }^{a}$ edição. Rio de Janeiro: Forense, 1979.

. Tratado de Direito Privado, Tomo II, 2. a edição. São Paulo: RT, 1983.

PRADO, Vinícius de Andrade. "Medidas cautelares no procedimento arbitral". Estudos em arbitragem, mediação e negociação. AZEVEDO, André Gomma de (org.). Brasília: Brasília Jurídica, 2002, pp. 185/200.

PROTO PISANI, Andrea. Lezioni di diritto processuale civile. 3. ${ }^{\mathrm{a}}$ edição. Napoli: Jovene, 1999.

PUCCI, Adriana Noemi. “Juiz \& Árbitro”. Aspectos Atuais da Arbitragem. Rio de Janeiro: Forense, 2001. 
RIBEIRO, Rafael Pellegrini. "O reconhecimento e a execução de sentenças arbitrais estrangeiras no direito brasileiro". Arbitragem no Brasil - Aspectos jurídicos relevantes. JOBIM, Eduardo; MACHADO, Rafael Bicca (coord.). São Paulo: Quartier Latin, 2008, pp. $417 / 435$.

RICCI, Edoardo Flávio. Lei de Arbitragem Brasileira. São Paulo: RT, 2005.

RIVAS, Adolfo Armando. "El Arbitraje según el Derecho Argentino". Revista de Processo - RePro, ano 12, n. ${ }^{\circ}$ 45. São Paulo: RT, jan/mar de 1987, pp. 70/93.

ROMERO, Eduardo Silva. "International Arbitration involving State Parties. Observations on the applicable law in State Contract Arbitration". Revista de Arbitragem e Mediação, vol. 6. WALD, Arnoldo (coord.). São Paulo: RT, 2005, pp. 176/195.

ROSA, Pérsio Thomaz Ferreira. "A arbitragem e o Poder Judiciário: questão pontual sobre a harmonia entre as duas jurisdições". Revista Fórum CESA, ano 4, n. ${ }^{\circ}$ 10, janeiro/março de 2009.

RUBELLIN-DEVICHI, Jacqueline. L'Arbitrage. Nature Juridique. Droit Interne et Droit International Privé. Paris: LGDJ, 1965.

RUBINO SAMMARTANO, Mauro. Il Diritto dell'Arbitrato (Interno), 2. a edição. Padova: Cedam, 1994.

SALLES, Carlos Alberto de. A Arbitragem na solução de controvérsias contratuais da administração pública. Tese de livre-docência defendida perante a Faculdade de Direito da Universidade de São Paulo em 2011.

SALVANESCHI, Laura. "Mesures provisoires et arbitrage en droit italien". Les mesures provisoires en droit belge, français et italien. VAN COMPERNOLLE, Jacques; TARZIA, Giuseppe (org.). Bruxelas: Bruylant, 1998, pp. 447/460.

SATTA, Salvatore. Direito processual civil, vol. II (trad. Luiz Autuori). Borsoi, 1973. 
SICA, Heitor Vitor Mendonça. Preclusão Processual Civil, 2. edição. São Paulo: Atlas, 2008.

SILVA, Eduardo Silva da. Arbitragem e Direito de Empresa. São Paulo: RT, 2003.

SILVA, João Marçal Rodrigues Martins da. A Extensão dos Efeitos da Cláusula de Arbitragem para Partes Não Signatárias. Monografia apresentada à Faculdade de Direito da Pontifícia Universidade Católica do Rio de Janeiro em 2012.

SILVA, João Paulo Hecker da. Tutela de Urgência e Tutela da Evidência nos Processos Societários. Tese de doutorado apresentada à Faculdade de Direito da Universidade de São Paulo em abril de 2012.

SILVA, Jonny Paulo da. "A Regulamentação Paranaense Acerca da Atuação do Juiz de Direito no Processo Arbitral, no que diz Respeito à Condução de Testemunhas e Execução de Medidas Coercitivas e Cautelares". Revista Brasileira de Arbitragem, n. 3. São Paulo: IOB/CBAr, 2004, pp. 217/219.

SIMÃO, José Fernando. "A natureza jurídica da arbitragem”. Novos Rumos da Arbitragem no Brasil. GUILHERME, Luiz Fernando do Vale de Almeida (coord.). São Paulo: Fiuza, 2004, pp. 225/236.

STRENGER, Irineu. Comentários à Lei Brasileira de Arbitragem. São Paulo: LTr, 1998.

SUNDFELD, Carlos Ari; CÂMARA, Jacintho Arruda. "O cabimento da arbitragem nos contratos administrativos". Revista de Direito Administrativo, n. ${ }^{\circ}$ 248. São Paulo: Atlas/FGV, mai/ago de 2008, pp. 117/126.

SZKLAROWSKY, Leon Frejda. Evolução histórica da arbitragem. In http://jus.com.br/ revista/texto/6842/evolucao-historica-da-arbitragem. Acessado em 02/06/2012

TARZIA, Giuseppe. Il Processo Cautelare. Padova: Cedam, 2004. 
TARZIA, Giuseppe. "Medidas cautelares atípicas: uma análise comparativa". LUCON, Paulo Henrique dos Santos (trad.). Revista de Processo - RePro, n. ${ }^{\circ}$ 9. São Paulo: RT, jul/set de 2000, pp. 206/222.

. Il Nuovo Processo Cautelare. Padova: Cedam, 1993.

. "Considerazioni Comparative sulle Misure Provisiorie nel Processo

Civile”. Rivista di Diritto Processuale, n. ${ }^{\circ}$ 2. Padova: Cedam, abril/junho de 1985.

. "Il Giusto Processo di Esecuzione". Rivista di Diritto Processuale.

2001, pp. 329/350.

. "O contraditório no processo executivo". Revista de Processo - RePro,

ano 7, n. 28 (tradução de Thereza Celina de Arruda Alvim). São Paulo: RT, out/dez de 1982, pp. 55/85.

TEPEDINO, Gustavo. “Invalidade da Cláusula Compromissória e seu Controle (também) pela Jurisdição Estatal". Arbitragem no Brasil - Aspectos jurídicos relevantes. JOBIM, Eduardo; MACHADO, Rafael Bicca (Coord.). São Paulo: Quartier Latin, 2008, pp. $153 / 173$.

THEODORO JÚNIOR, Humberto. Curso de direito processual civil, v. I, 9. a edição. Rio de Janeiro: Forense, 1992.

. Curso de Direito Processual Civil, v. III, 34. ${ }^{\text {a }}$ edição. Rio de Janeiro:

Forense, 2005.

Comentários ao Novo Código Civil. vol. III, t. II. TEIXEIRA, Sálvio de Figueiredo (Coord.). Rio de Janeiro: Forense, 2003.

Processo Cautelar, 18. a edição. São Paulo: LEUD, 1999. 
THEODORO JÚNIOR, Humberto. “Arbitragem e Terceiro - Litisconsórcio Fora do Pacto Arbitral - Outras Intervenções de Terceiros". Reflexões sobre arbitragem: in memoriam do Desembargador Cláudio Vianna de Lima. MARTINS, Pedro A. Batista; GARCEZ, José Maria Rossani (Coord.). São Paulo: LTr,, 2002, pp. 227/275.

"A arbitragem como meio de solução de controvérsias". Revista Forense, n. ${ }^{\circ}$ 353. Rio de Janeiro: Forense, jan/fev de 2001, pp. 107/116.

Tutela jurisdicional de urgência - Medidas cautelares e antecipatórias.

Rio de Janeiro: América Jurídica, 2001.

TIBURCIO, Carmen; DOLLINGER, Jacob. Direito internacional privado - Arbitragem

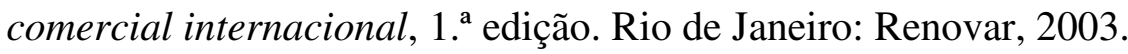

TOMMASEO, Ferruccio. I Provvedimenti D’urgenza. Padova: Cedam, 1983.

VALENÇA FILHO, Clávio de Melo. "Tutela Judicial de Urgência e a Lide Objeto da Convenção de Arbitragem". Revista Brasileira de Arbitragem, n. ${ }^{\circ}$ 7. São Paulo: IOB Thomson, jul/set de 2005, pp. 07/29.

Poder Judiciário e Sentença Arbitral, 1. a edição. Curitiba: Juruá, 2002.

VASCONCELLOS, Fernando; OPORTO, Silvia Fazzinga. Arbitragem Comercial Internacional. http://sisnet.aduaneiras.com.br/lex/doutrinas/arquivos/080306t.pdf. Acesso em $02 / 06 / 2012$.

VEEDER, V. V.; LEBEDEV, Sergei N. Improving the Efficiency of Arbitration Agreement and Awards Application: 40 Years of The New York Convention. The Hague: Kluwer Law International, 1999.

VERÇOSA, Haroldo Malheiros Duclerc. "Doze anos da Lei de Arbitragem: alguns aspectos ainda relevantes". Aspectos da Arbitragem Institucional - 12 anos da Lei 9.307/1996. VERÇOSA, Haroldo Malheiros Duclerc (coord.). São Paulo: Malheiros, 2008, pp. $15 / 32$. 
VERÇOSA, Haroldo Malheiros Duclerc. O Judiciário e a valorização da arbitragem. www.migalhas.com.br/dePeso/16,MI160682,71043-O+Judiciario+e+a+valorizacao+da+ arbitragem. Acessado em 01/08/2012.

VERDE, Giovanni. “Arbitrato e giurisdizione”. L'Arbitro secondo la legge 28/83. Napoli: Jovene Editore, 1985, pp. 161/182.

VIANNA, Duval. Lei de arbitragem: comentários à Lei 9307/96, DOU de 24.09.96. Rio de Janeiro: Esplanada, 1998.

VIEIRA, Antonio Vicente. Eficácia da aplicação da Lei de Arbitragem: a cláusula compromissória. http://jusvi.com/artigos/39120/2. Acessado em 28/09/2010.

VIGORITI, Vicenzo. "Em Busca de um Direito Comum Arbitral: Notas sobre o Laudo Arbitral e sua Impugnação". CARMONA, Carlos Alberto (trad. it.). Revista de Processo RePro, ano 23, n. ${ }^{\circ}$ 91. São Paulo: RT, jul/set de 1998, pp. 11/26.

VILELA, Marcelo Dias Gonçalves. "Reflexões sobre a Tutela Cautelar na Arbitragem". Revista Brasileira de Arbitragem, n. ${ }^{\circ}$ 7. São Paulo: IOB Thomson, jul/set 2005, pp. 30/44.

“Ação Cautelar Inominada Preparatória. Agravo de Instrumento. Efeito Ativo Concedido. Ciência da Posterior Instauração do Juízo Arbitral. Incompetência Superveniente da Justiça Estatal. Remessa dos Autos ao Árbitro para Manutenção ou não da Tutela Concedida". Revista de Arbitragem e Mediação, ano 5, vol. 19. WALD, Arnoldo (coord.). São Paulo: RT, out/dez de 2008, pp. 191/199.

WALD, Arnoldo. “A validade da sentença arbitral parcial nas arbitragens submetidas ao regime da CCI'. Revista de Direito Bancário, do Mercado de Capitais e da Arbitragem, vol. 17. WALD, Arnoldo (coord.). São Paulo: RT, jul/set de 2002, pp. 329/341.

. "Novos rumos para a arbitragem no Brasil". Revista de Direito Bancário, do Mercado de Capitais e da Arbitragem, vol. 14. WALD, Arnoldo (coord.). São Paulo: RT, out/dez de 2001, pp. 321/356. 
WALD, Arnoldo. "A jurisprudência do Superior Tribunal de Justiça em relação às sentenças arbitrais". Revista de Arbitragem e Mediação, ano 3, vol. 8. WALD, Arnoldo (coord.). São Paulo: RT, 2006, pp. 07/16.

WAMBIER, Teresa Arruda Alvim (org.). Aspectos Polêmicos da Antecipação de Tutela. São Paulo: RT, 1997.

WATANABE, Kazuo. "Assistência judiciária e o juizado de pequenas causas". Juizado especial de pequenas causas (Lei 7.244, de 7 de novembro de 1984). WATANABE, Kazuo (coord.). São Paulo: RT, 1985.

YARSHELL, Flávio Luiz. "Brevíssimas notas a respeito da produção antecipada da prova na arbitragem". Revista de Arbitragem e Mediação, ano 4, vol. 14. WALD, Arnoldo (coord.). São Paulo: RT, jul/set de 2007, pp. 52/56.

- "Antecipação de Tutela Específica nas Obrigações de Declaração de Vontade, no Sistema do CPC". Aspectos Polêmicos da Antecipação de Tutela. WAMBIER, Teresa Arruda Alvim (coord.). São Paulo: RT, 1997.

YOSHIKAWA, Eduardo Henrique de Oliveira. Execução Extrajudicial e Devido Processo Legal. São Paulo: Atlas, 2010. - "Limites à Possibilidade de Antecipação da Tutela Jurisdicional de Ofício". Revista Dialética de Direito Processual, n. ${ }^{\circ}$ 104. São Paulo: Dialética, 2011, pp. $24 / 43$.

ZERBINI, Eugênia C. G. de Jesus. "Cláusulas arbitrais: transferência e vinculação de terceiros à arbitragem". Arbitragem no Brasil - Aspectos jurídicos relevantes. JOBIM, Eduardo; MACHADO, Rafael Bicca (coord.). São Paulo: Quartier Latin, 2008, pp. $141 / 151$. 
FONTES: www.stf.jus.br; www.stj.jus.br; www.ibanet.org; www.mundojuridico.adv.br; www.senado.gov.br; www.iidd.com.br; www.ccbc.org.br; www.cbar.org.br; www.fgv.br; www.camaradearbitragemsp.org.br; www.camec.com.br; www.ci.uc.pt; www.aasp.org.br; www.ambito-juridico.com.br; www.adr.org; www.iccwbo.org; www.amcham.com.br; www.viajus.com.br; www.legislation.gov.hk; www.jus.uol.com.br; www.tj.sp.gov.br; www.tjmg.jus.br; www.tjpr.jus.br; www.tjrs.jus.br; www.tjrj.jus.br; www.camarb.com.br; www.dre.pt; www.dis-arb.de; www.dgpj.mj.pt; www.planalto.gov.br; www.abdir.com.br; www.migalhas.com.br; www.infoleg.gov.ar; www.legifrance.gouv.fr; www.uncitral.org; www.sparbitral.com; www2.camara.leg.br; www.altalex.com; www.nai-nl.org/en/; www.finra.org; 


\section{CAPÍTULO XV}

\section{ANEXOS}

\section{RESUMO}

Esta dissertação analisa as questões concernentes às tutelas de urgência antes e durante o processo arbitral (incluindo-se a forma como podem ser pleiteadas, apreciadas e efetivadas), bem como a interação entre os árbitros, o Poder Judiciário e também entre a Câmara de Arbitragem responsável pela condução do processo arbitral (no caso de arbitragem institucional). O trabalho traz uma breve análise sobre a história da arbitragem e acerca de sua natureza jurídica, com um enfoque específico às tutelas de urgência, analisando, igualmente, os regulamentos dos principais centros de arbitragens pátrios e alienígenas, bem como a legislação nacional e estrangeira sobre o tema das tutelas de urgência em arbitragem. Os principais pontos analisados referem-se: (i) às tutelas de urgência prévias à instauração da arbitragem (quando as partes já se comprometeram, por meio de cláusula compromissória ou de compromisso arbitral, a solucionar eventual lide por meio da arbitragem); (ii) às tutelas de urgência no curso de um processo arbitral; (iii) à efetivação das tutelas de urgência, a qual exige a utilização de força e, por conseguinte, depende do auxílio e de interação com o Poder Judiciário; (iv) à efetivação das tutelas de urgência proferidas em arbitragens estrangeiras; e (v) às anti-suit injunctions.

Palavras-chave: arbitragem; tutelas de urgência; medidas cautelares; tutela antecipada; tutelas de urgência prévias à instauração da arbitragem; tutelas de urgência no curso de um processo arbitral; execução de decisão arbitral de urgência 


\section{ABSTRACT}

This dissertation analyses the questions regarding provisional and interim measures previously or during an arbitration proceeding (including the means they can be pleaded, analyzed and enforced), as well as the interaction between the arbitrators, the Judiciary Power and also with the Court of Arbitration responsible for the conduction of the arbitration proceeding (in the case of institutional arbitration). The study brings a brief analysis of the history of arbitration and about its legal nature, with a specific focus on provisional and interim measures, also analyzing the regulations of the main Courts of Arbitration from Brazil and from abroad, as well as the Brazilian and foreign legislation about provisional and interim measures in arbitration. The main topics analyzed are referred to: (i) provisional and interim measures previously to the beginning of the arbitration (when the parties have already committed themselves, through arbitration clause or arbitration agreement, to resolve any conflict through arbitration); (ii) provisional and interim measures during an arbitration proceeding; (iii) the enforcement of provisional and interim measures, which requires the use of force (coercive power) and, therefore, depends on the assistance and the support of the Judiciary Power; (iv) the enforcement of provisional and interim measures rendered on foreign arbitrations; and (v) the anti-suit injunctions.

Key-words: arbitration; provisional and interim measures; interim relief; anticipated relief; provisional and interim measures previously to the beginning of an arbitration; provisional and interim measures during an arbitration proceeding; enforcement of an interim measure rendered in an arbitration. 